Universidade Federal de Santa Catarina - UFSC

Centro de Filosofia e Ciências Humanas - CFH

Programa de Pós-Graduação em História - PPGH

SANDRO DA SILVEIRA COSTA

Os Transportes Motorizados em Florianópolis:

percepções e sensibilidades cotidianas (1920-1941)

FLORIANÓPOLIS

Março 2010 


\section{SANDRO DA SILVEIRA COSTA}

\section{Os Transportes Motorizados em Florianópolis:}

percepções e sensibilidades cotidianas (1920-1941)

Tese apresentada ao Programa de Pós-Graduação em História do Centro de Filosofia e Ciências Humanas da Universidade Federal de Santa Catarina, como exigência parcial para obtenção do grau de Doutor em História Cultural.

Orientação: Prof. ${ }^{a}$ Dra. Cynthia Machado Campos.

\section{FLORIANÓPOLIS}

Março 2010 
“... um sistema de signos verbais ou icônitos é uma reserva de formas que esperam do leitor o seu sentido".

Michel de Certeau 


\section{SUMÁRIO}

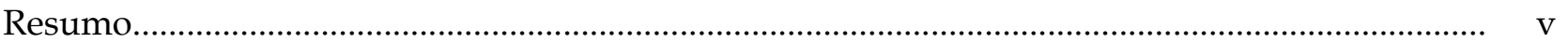

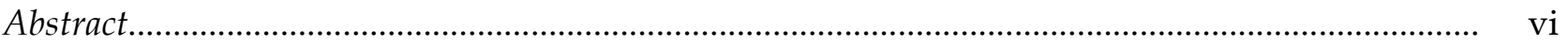

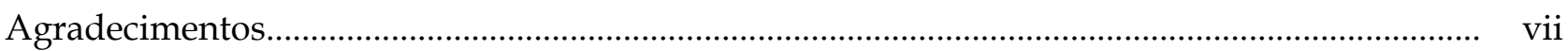

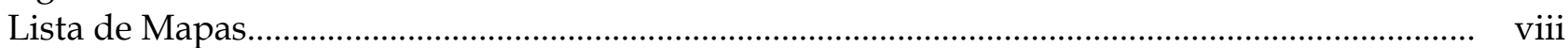

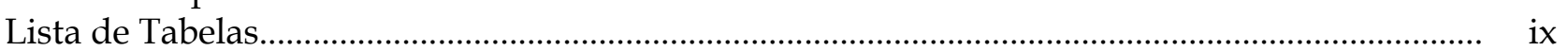

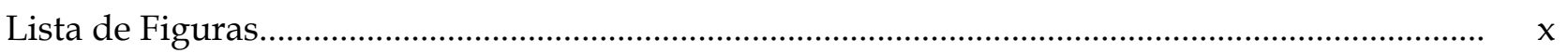

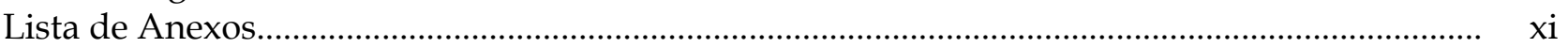

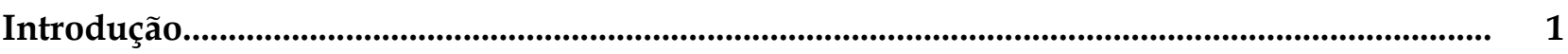

Capítulo 1 - Adaptações e Conflitos: novos personagens no ambiente urbano.......................... 27

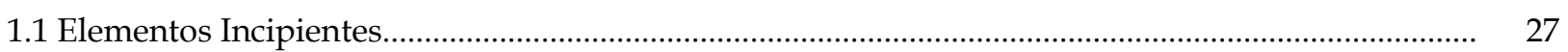

1.2 Os Processos Criminais em Cena 1: vivências cotidianas nas malhas do urbano................................ 34

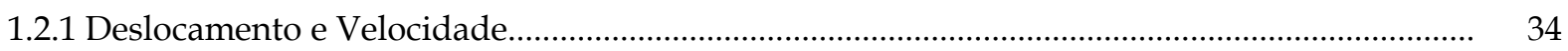

1.2.2 Moeda e Motorização................................................................................................................. 71

1.2.2.1 Aquisição e Recursos........................................................................................................... 71

1.2.2.2 Diversificação e Propriedade............................................................................................. $\quad 76$

Capítulo 2 - Espaço, Poder Público e Disciplinarização....................................................................... 89

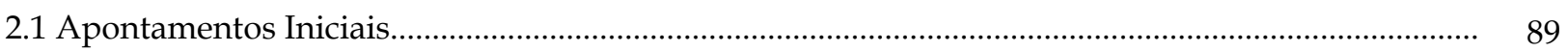

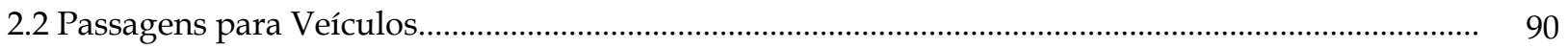

2.3 Os Processos Criminais em Cena 2: legislação e municipalidade.......................................................... 98

Capítulo 3 - Novos Tempos; Outras Legislações: adaptações e reformulação.............................. 135

3.1 Os Processos Criminais em Cena 3: legislação e circulação.................................................................... 135

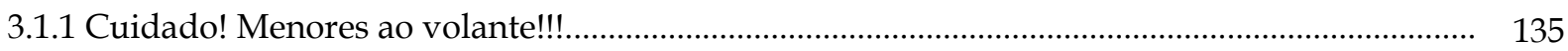

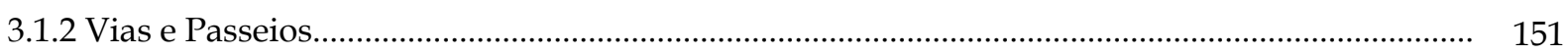

3.1.3 Legislação e Circulação: incrementação e complexidade............................................................ 176

Capítulo 4 - Os Processos Criminais em Cena 4: pedagogia e punição........................................... 196

4.1 Inquéritos e Julgamentos: enquadramento e absolvição.......................................................................... 198

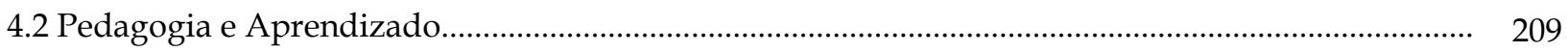

4.3 A Cidade e o Automóvel em dois momentos: retórica e jurisprudência............................................... 227

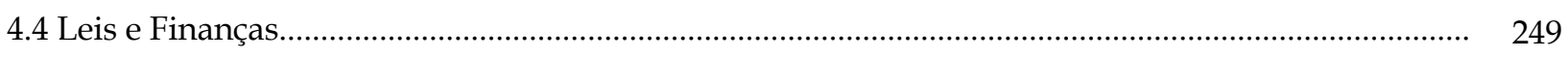

Capítulo 5 - Os Transportes Coletivos: convivência e preterimento............................................ 268

5.1 Os Coletivos na Ótica da Imprensa Local.............................................................................................. 270

5.2 Conflitos e Disputas: os coletivos motorizados pedem passagem....................................................... 289

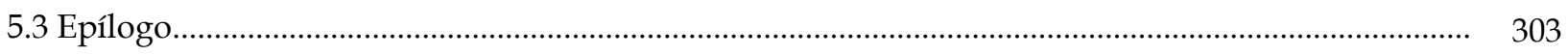

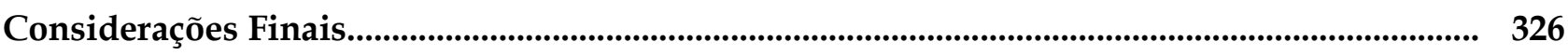

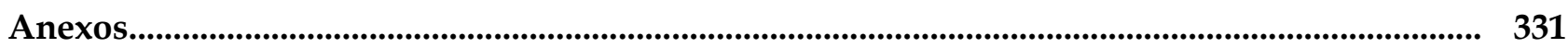

Fontes e Bibliografia Utilizadas e Referenciadas na Tese.......................................................... 359 


\section{RESUMO}

O presente estudo tem como tema principal as percepções e sensibilidades cotidianas expressas pelos habitantes da capital catarinense frente à gradativa introdução do transporte motorizado no perímetro urbano da cidade de Florianópolis, no período compreendido entre os anos de 1920 e 1941. O que propomos é discutir a maneira como, para muitos dos habitantes da capital catarinense, o progresso da cidade representou novas formas de viver no perímetro urbano, ou seja, acostumar-se a andar pelas novas ruas, redefinidas e calçadas para os automóveis e não somente para os transeuntes. Objetivamos discutir, também, o gradativo processo de imposição dos veículos motorizados no espaço central de Florianópolis, envolvendo a adaptação de normas legislativas de trânsito que se tentavam aplicar ao meio urbano da capital catarinense, como forma de disciplinar o fluxo e deslocamento de veículos e transeuntes.

Entendemos que as fontes de maior relevância para a presente investigação são os processos criminais que contemplam episódios de atropelamentos e colisões no perímetro urbano da capital catarinense. A tônica geral que perpassa a análise desses documentos - e das demais fontes pesquisadas - observa que a circulação dos automóveis se impôs gradativamente àquela operada por transeuntes e veículos não motorizados - carroças, bondes puxados por burros, tílburys. Tal imposição foi processada de maneira gradativa no decorrer das décadas de 10 e 20 do século passado, e devemos observar que os transeuntes, ao circularem pelas ruas do perímetro urbano da Capital, operam, muitas vezes, táticas e estratégias específicas, ditadas pelas condicionantes do viver urbano, que conferem caráter imprevisível e circunstancial às atitudes por eles tomadas para se esquivarem das investidas operadas pelos veículos motorizados. Além disso, é importante percebermos que os chauffeurs, condutores dos automóveis, operam, também, artifícios e recursos diversos para, muitas vezes, evitar atropelamentos e colisões.

Os processos e as demais fontes oficiais, jornalísticas e bibliográficas analisadas nesta pesquisa permitem-nos abordar específicas possibilidades de investigação. Objetivamos, pois, estudar maneiras específicas de como os florianopolitanos adaptaram-se à gradativa introdução dos veículos motorizados, pois novas sensibilidades e percepções impunham-se aos antigos hábitos e costumes. Desse modo, este estudo possibilita-nos analisar aspectos importantes da vida de personagens anônimos do cotidiano de Florianópolis, que de outra maneira seriam, a nosso ver, muito difíceis de serem elucidados e trazidos à tona.

Palavras-chave: cotidiano; poder; sensibilidades. 


\section{ABSTRACT}

The present study has as its main theme the everyday perceptions and sensitivities expressed by inhabitants of the capital of Santa Catarina front of the gradual introduction of motorized transport in the urban area of the city of Florianópolis, in the period between the years 1920 and 1941. What is proposed is to discuss how, for many of the inhabitants of the capital of Santa Catarina, the city's progress represented new ways of living in the urban area, or get used to walking on new streets, redefined and paved for cars and not only for pedestrians. Objective is to discuss also the gradual process of taxation of motor vehicles in the central area of Florianópolis, involving the adaptation of law rules of traffic to try to apply the urban capital of Santa Catarina, in order to regulate the flow and movement of vehicles and passersby. We understand that the sources of greatest relevance to this investigation are the criminal cases that include episodes of pedestrians and collisions in the urban capital of Santa Catarina. The general tone that pervades the analysis of these documents - and other research sources - notes that the movement of cars was imposed gradually to that operated by pedestrians and nonmotorized vehicles - wagons, trams pulled by donkeys, tilburys. This charge has been processed in a gradual way, over the decades of 10 and 20 of the last century, and it should be noted that the passers-by to move the urban streets of the capital, operating, often, specific strategies and tactics, dictated by the constraints of urban living, giving unpredictable and incidental to the attitudes taken by them to shirk the investees operated by motorized vehicles. Furthermore, it is important to realize that the chauffeurs, drivers of cars, also operate tricks and resources for many times, avoid collisions and pedestrian accidents.

The procedures and other official sources, journalism and literature analyzed in this study allow to address specific research opportunities. Our intention is, therefore, to study specific ways of how florianopolitans adapted to the gradual introduction of motor vehicles, as new sensitivities and perceptions had to take the old habits and customs. Thus, this study allows us to analyze important aspects of life anonymous character of daily Florianópolis, which otherwise would be, in our view, very difficult to be clarified and brought to surface.

Key-words: power; daily; sensitivities. 


\section{AGRADECIMENTOS}

A realização desta pesquisa tornou-se possível graças à colaboração e incentivo de pessoas que me auxiliaram durante o transcurso de sua elaboração.

Gostaria de dedicar especiais agradecimentos à professora Cynthia Machado Campos, que incentivou-me e orientou-me com muita competência, atenção e carinho.

Agradeço à professora Joana Maria Pedro pela minuciosa atenção dedicada a este texto, sugerindo novas abordagens de investigação e apontando criteriosamente os aspectos da pesquisa que poderiam ser aprofundados. Dedico, também, meus sinceros agradecimentos à professora Maria Stella Martins Bresciani, pela valiosa colaboração prestada à avaliação deste texto.

Agradeço, igualmente, ao professor Arthur César Isaia, pelo incentivo prestado à realização deste trabalho.

À minha esposa, companheira de todas as horas.

Aos meus pais, pelo carinho, incentivo e companheirismo prestados em todos os momentos.

Sandro da Silveira Costa 


\section{LISTA DE MAPAS}

Mapa 01 Área Central e Perímetro Urbano da cidade de Florianópolis - Décadas de 1920 e $1930 \ldots . .28$

Mapa 02 Perímetro Suburbano e Distritos de Florianópolis - Décadas de 1920 e 1930

Mapa 03 Localização das Chácaras dentro do Perímetro Urbano de Florianópolis - final do século XIX e início do XX

Mapa 04 Rua José Veiga (Av. Mauro Ramos) e Encostas do Morro da Cruz - Década de 1920........

Mapa 05 Esquina das ruas Artista Bittencourt e Visconde de Ouro Preto (Cruzamento à Direita) Processo n. 171, 27 dez. 1931

Mapa 06 Largo General Osório (Instituto Estadual de Educação - IEE) e Bairros Adjacentes Década de 1920 


\section{LISTA DE TABELAS}

Tabela 01 Número de cartas expedidas no Estado de Santa Catarina (1911-1929)

Tabela 02 Número de cartas expedidas por município no Estado de Santa Catarina (1911-1922)........

Tabela 03 Preços dos principais gêneros alimentícios no comércio varejista do município de Florianópolis - 1925

Tabela 04 Taxas de serviço de conservação de estradas e de registro e fiscalização de veículos 1936

Tabela 05 Tempo de Prisão e Respectivos Valores Afiançáveis.

Tabela 06 Número de Registro de Veículos Motorizados - 1951.

Tabela 07 Exames para Condutores de Veículos no Estado de Santa Catarina - 1954 - 1960. 


\section{LISTA DE FIGURAS}

Figura 01 Praça XV de Novembro - início do século XX......

Figura 02 Automóveis e Chauffeurs

Figura 03 Carros e Boleeiros

Figura 04 Banco Nacional do Comércio; esquina da rua João Pinto com a Praça XV de Novembro...

Figura 05 Vemos, em primeiro plano, a Alfândega e o Mercado Público e, ao fundo, a ponte Hercílio Luz - início do século XX.

Figura 06 Avenida Central, c. 1908

Figura 07 Voiturette/Barata

Figura 08 Praça XV de Novembro / Praça Fernando Machado (Museu do Saneamento).

Figura 09 Distribuidores da Goodyear em Santa Catarina.

Figura 10 Óleo Essolube - 1940

Figura 11 Rua Trajano (esquina com a rua Felipe Schmidt).

Figura 12 Foto ilustrando o primeiro ônibus de Florianópolis no momento de sua inauguração 1920 (parte frontal)

Figura 13 Caminhão X Carroça - 1928.

Figura 14 Exemplo das lanchas motorizadas na passagem do Estreito entre a Ilha e o Continente, no primeiro quarto do século $\mathrm{XX}$

Figura 15 Trapiche Municipal - data aproximada, 1922.

Figura 16 Abertura do trecho terminal da rua Felipe Schmidt, próximo à ponte Hercílio Luz - 1940.. 296 


\section{LISTA DE ANEXOS}

Anexo 01 Atropelamento - Processo n. 30, 05 mar. 1923. Caixa 03................................................ 332

Anexo 02 Desastre/Colisão - Processo n. 52, 05 nov. 1925. Caixa 05............................................ 333

Anexo 03 Colisão - Processo n. 95, 05 jul. 1926. Caixa 09............................................................. 334

Anexo 04 Atropelamento - Processo n. 239, 21 jan. 1934. Caixa 26.................................................. 335

Anexo 05 Atropelamento - Processo n. 45, 04 ago. 1923. Caixa 06.............................................. 336

Anexo 06 Colisão - Processo n. 171, 27 dez. 1931. Caixa 16...................................................... 337

Anexo 07 Atropelamento - Processo n. 29, 21 nov. 1923. Caixa 03............................................. 338

Anexo 08 Atropelamento - Processo n. 45, 13 abr. 1925. Caixa 05.............................................. 339

Anexo 09 Colisão/Queda - Processo n. 76, 21 mar. 1926. Caixa 07............................................... 340

Anexo 10 Colisão/Atropelamento - Processo n. 77, 25 mar. 1926. Caixa 07.................................... 341

Anexo 11 Atropelamento - Processo n. 62, 03 abr. 1926. Caixa 06............................................. 342

Anexo 12 Atropelamento - Processo n. 173, 20 ago. 1931. Caixa 17........................................... 343

Anexo 13 Colisão / Atropelamento - Processo n. 194, 21 nov. 1932. Caixa 20............................... 344

Anexo 14 Atropelamento - Processo n. 351, 09 ago. 1937. Caixa 38............................................. 345

Anexo 15 Colisão - Processo n. 373, 27 jan. 1938. Caixa 41 …......................................................... 346

Anexo 16 Atropelamento - Processo n. 73, 17 dez. 1926. Caixa 07............................................ 347

Anexo 17 Atropelamento - Processo n. 96, 19 dez. 1928. Caixa 02 .............................................. 348

Anexo 18 Atropelamento - Processo n. 183, 11 jan. 1932. Caixa 19............................................ 349

Anexo 19 Preços para comercialização e/ou venda de automóveis - 1919-1928.................................. 350

Anexo 20 Banco de Dados: Processos criminais envolvendo atropelamentos e colisões em Florianópolis (1923-1941) ....................................................................................... 


\section{INTRODUÇÃO}

O presente estudo tem como tema principal as percepções e sensibilidades cotidianas expressas pelos habitantes da capital catarinense frente à gradativa introdução do transporte motorizado $^{1}$ no perímetro urbano da cidade de Florianópolis ${ }^{2}$, no período compreendido entre os anos de 1920 e $1941^{3}$. O interesse pela temática nasceu das reflexões despertadas pelas leituras relacionadas com o tema, durante a elaboração de minha dissertação de mestrado ${ }^{4}$. O que propomos é discutir dois aspectos principais: a) a maneira como, para muitos dos habitantes da capital catarinense, o progresso da cidade representou novas formas de viver no perímetro urbano, ou seja, acostumar-se a andar pelas novas ruas, redefinidas e calçadas para os automóveis e não somente para os transeuntes; b) o gradativo processo de imposição dos veículos motorizados no espaço urbano de Florianópolis, que envolveram a evolução e/ou adaptação de normas legislativas de trânsito que se tentavam aplicar ao meio urbano da capital catarinense, como forma de disciplinar o fluxo e deslocamento de veículos e de transeuntes. De acordo com Roselane Neckel, “[...] muitos demoraram a internalizar as novas sensibilidades para viver na cidade transfigurada, sendo inúmeros os registros de atropelamento nos processos criminais, nas décadas iniciais do século XX" ${ }^{, 5}$. Em vista disso, é pertinente questionarmos: De que maneira a população da capital catarinense se adaptou à introdução e à circulação dos veículos motorizados? Quais as percepções manifestadas pelos florianopolitanos frente à crescente circulação dos veículos motorizados no perímetro e no espaço central urbano da cidade de Florianópolis?

No início da década de 1920, atestamos, no Estado de Santa Catarina, especialmente em Florianópolis, a implantação de algumas disposições e órgãos regulamentares de trânsito ${ }^{6}$. O Regulamento para o serviço policial do Estado estipula, dentre outros dispositivos, que os condutores de veículos devem dispor da respectiva carta de habilitação e apresentar idade igual ou superior a dezoito anos ${ }^{7}$. Exigências semelhantes foram estipuladas pela Lei n. 1325, de 18 de agosto de 1920, pois registra que o exame de habilitação para os condutores de veículos, a que se refere o Regulamento para o serviço policial do Estado, será exigido somente das pessoas que

\footnotetext{
${ }^{1}$ Neste trabalho, o transporte motorizado é consubstanciado nos automóveis e ônibus, os quais são movidos por motores acionados por combustão interna. Os primeiros envolvem três categorias principais: a) automóveis particulares; b) automóveis de aluguel; e c) automóveis de praça - ver discussão a respeito no transcorrer dos capítulos da tese. Já os ônibus caracterizam veículos motorizados destinados exclusivamente ao transporte de passageiros.

${ }^{2}$ As delimitações relativas ao perímetro urbano e ao espaço central da cidade de Florianópolis são registradas no capítulo primeiro da tese. Vale, porém, o registro de que o perímetro urbano envolve uma dimensão mais ampla, que abarca o espaço urbano central da capital catarinense.

${ }^{3}$ As razões para a delimitação do espaço cronológico proposto serão discutidas a seguir.

${ }^{4}$ COSTA, Sandro da Silveira. Ponte Hercílio Luz: mutações urbanas em uma cidade insular (1890-1960). Dissertação (Mestrado em História). Florianópolis: UFSC, 2002.

${ }^{5}$ NECKEL, Roselane. A República em Santa Catarina: modernidade e exclusão (1889-1920). Florianópolis: UFSC, 2003. p. 82.

${ }^{6}$ No início da década de 1920, atesta-se a inexistência de uma ligação terrestre entre os espaços insular e continental da Ilha de Santa Catarina, o que dificultou a introdução de veículos motorizados na cidade de Florianópolis. Esse quadro alterou-se, gradativamente, a partir de 1926, com a inauguração da ponte Hercílio Luz. Esses aspectos contribuíram para a delimitação do tempo cronológico inicial da pesquisa.

${ }^{7}$ Santa Catarina. Regulamento para o serviço policial do Estado. Florianópolis: Tipografia da Livraria Central, 1920.
} 
conduzirem automóveis de uso particular ou de aluguel. Essa lei estipula, igualmente, que os veículos particulares, exceto os automóveis, poderão ser dirigidos por condutores sem carta, desde que apresentem idade igual ou superior a dezoito anos ${ }^{8}$. Além disso, o Decreto 1465A, de 17 de maio de 1921, cria, anexa à Força Pública, uma seção para serviços especiais de automóveis, composta de "um 1. ${ }^{\text {o }}$ sargento, 4 segundos, 4 terceiros e 3 cabos"

Essas ideias registram o estabelecimento de dispositivos e órgãos de trânsito no Estado e na capital catarinense, recursos que objetivavam disciplinar e organizar o trânsito e a atividade de condutores de veículos. Para a cidade de Florianópolis, esses aspectos assumiram maior relevância, pois somente após a inauguração da ponte Hercílio Luz, em 1926, atestamos a constante introdução de veículos motorizados e a organização de empresas de ônibus e dispositivos regulamentares para o trânsito da capital catarinense ${ }^{10}$. É importante, entretanto, destacarmos como os chauffeurs e, especialmente, os transeuntes adaptaram-se aos meios de locomoção motorizados e às regras e condutas de comportamento no trânsito. Assim, este estudo concentra-se na análise e na investigação dos processos criminais que envolvem atropelamentos e colisões em Florianópolis, no período entre os anos de 1923 e $1941^{11}$. Esses documentos constituem, portanto, as principais fontes para a elaboração do presente texto. Importa destacarmos que a análise dos processos permite-nos perceber as relações estabelecidas entre os habitantes da capital catarinense ${ }^{12}$ e os veículos motorizados, bem como traços específicos da vida cotidiana dos florianopolitanos. Desse modo, destacamos que o estudo e a investigação dos processos de atropelamento e de colisões oferecem importantíssimos elementos de análise para a temática proposta.

Neste ponto, julgamos conveniente narrar um pouco da trajetória de pesquisa que resultou no trabalho de elaboração da presente tese. $O$ trabalho de pesquisa e investigação das fontes foi, efetivamente, iniciado no mês de janeiro de 2004, com a leitura de material bibliográfico. Ao tomarmos contato, nessa época, com o livro intitulado A República em Santa Catarina: modernidade e exclusão (1889-1920), de autoria de Roselane Neckel, professora do Departamento de História da Universidade Federal de Santa Catarina (UFSC), surgiu a ideia de analisarmos os processos criminais anteriormente mencionados para, então, procedermos à

\footnotetext{
${ }^{8}$ Lei n. 1325, de 18 de agosto de 1920. Dispondo sobre o exame de habilitação para condutores de automóveis. In: Coleção de Leis, Decretos, Resoluções e Portarias de 1920. Florianópolis: Imprensa Oficial, 1920. p. 13-14.

${ }^{9}$ Decreto 1465A, de 17 de maio 1921. Criando, na Força Pública, uma seção para serviços especiais de automóveis. (In: Coleção de Leis, Decretos e Resoluções de 1921. Florianópolis: Imprensa Oficial, 1921. p. 46).

${ }^{10}$ Dentre esses dispositivos, destaca-se: Santa Catarina. Instruções Regulamentares para o serviço de trânsito público. Florianópolis: Imprensa Oficial, 1928.

${ }^{11}$ Os processos criminais relativos aos acidentes de trânsito, na cidade de Florianópolis, são disponibilizados, apenas, a partir do ano de 1923, conforme pesquisa realizada junto ao Arquivo Central do Tribunal de Justiça do Estado de Santa Catarina (Br-101, km. 209 - Picadas do Sul Forquilhinha). Nesse local, encontramos, portanto, para cada década do período em apreço, o total de: a) década de 1920: onze processos; e b) década de 1930: sete processos, o que contabiliza dezoito documentos, analisados no transcorrer dos cinco capítulos da tese. Optamos por analisar processos que referenciem atropelamentos e colisões ocorridos no perímetro urbano da capital catarinense - ver capítulo 1 , mapa 01 , p. 28 - haja vista o maior número de ocorrências e sua melhor delimitação geográfica.

${ }^{12}$ Notadamente, chauffeurs, transeuntes, passageiros, as vítimas dos atropelamentos e colisões, e as testemunhas que presenciaram tais episódios.
} 
investigação das percepções dos florianopolitanos quanto à presença e à circulação dos veículos motorizados pelas ruas do perímetro urbano da capital catarinense, a partir da década de 20 do século passado.

Quanto ao trabalho inicial de pesquisa das fontes, analisamos, primeiramente, os processos criminais; procedimento este que foi efetuado de maneira paralela à leitura e ao fichamento dos textos bibliográficos. Após obedecermos aos trâmites legais para a busca de autorização para pesquisar no Arquivo Central do Tribunal de Justiça do Estado de Santa Catarina, escolhemos os meses de março e abril de 2004 para a efetuação dos trabalhos de triagem e de seleção dos documentos processuais que seriam analisados nesta tese. Esse trabalho foi deveras penoso e exaustivo, pois o Tribunal de Justiça do Estado não contava, na época - e ainda hoje -, com um sistema informatizado que permitisse ao pesquisador ter fácil acesso aos documentos que objetivasse estudar. Isso nos levou a olhar, aproximadamente, cem caixas que continham, em média, cada uma, dez processos criminais, dos quais apenas dois ou três se referiam aos episódios de atropelamentos e colisões ocorridos no perímetro urbano da capital catarinense, durante os anos de 1923 e 1954.

É importante esclarecermos que, num primeiro momento, foram encontrados quarenta e oito processos de crimes de atropelamentos e colisões registrados na Primeira Vara Criminal da cidade de Florianópolis, durante o período cronológico supracitado. Na Segunda Vara Criminal, encontramos um processo. Isso totaliza, portanto, quarenta e nove documentos. Desses processos, trinta e quatro enfocam atropelamentos e colisões ocorridos no perímetro e no espaço urbano central da cidade de Florianópolis. Os demais registram essas ocorrências nos bairros e distritos da cidade. Assim, optamos, inicialmente, pela análise e investigação de trinta e quatro processos criminais relativos aos anos de 1923 e 1954. Essa delimitação cronológica considerava, portanto, a adoção, para a cidade de Florianópolis, do seu primeiro plano diretor, que salientava, dentre outros aspectos, a nítida preferência concedida pelo poder público municipal ao transporte rodoviário; aspecto este que obedecia às diretrizes estabelecidas nas esferas estadual e federal. O desenrolar dos trabalhos de pesquisa e a elaboração da tese demonstraram, entretanto, que a análise desse vasto material ${ }^{13}$ e a contemplação de tão amplo período cronológico tornaria inviável um trabalho acurado sobre as fontes. Em vista disso, optamos por investigar os processos criminais relativos às décadas de 1920 e 1930, o que totalizou, como vimos, o total de dezoito documentos.

Após os meses de março e abril de 2004 - com os processos devidamente selecionados -, procedemos ao trabalho de coleta e investigação das demais fontes: relatórios, leis, mensagens de

\footnotetext{
${ }^{13}$ Para as décadas de 1940 e 1950, seriam analisados, respectivamente, o total de: a) oito; e b) sete processos criminais.
} 
governo, artigos de jornal publicados junto à imprensa local, códigos penais e de trânsito, fontes essas pesquisadas junto a órgãos específicos da cidade de Florianópolis. A pesquisa dessas fontes foi norteada, em última análise, pela coleta do material processual levantado junto ao Tribunal de Justiça do Estado de Santa Catarina, durante o período supracitado. Grande parte da pesquisa que originou a presente tese foi efetuada, portanto, durante o primeiro semestre de 2004. Nos períodos subsequentes, procedemos, de maneira gradual, à coleta e à análise de material que julgamos necessário para a complementação e aprofundamento do estudo proposto.

Apresentamos, assim, o projeto de pesquisa que originou este estudo - resultado da investigação das fontes assinaladas anteriormente - ao Programa de Pós-Graduação em História da Universidade Federal de Santa Catarina para a seleção do ano de 2005, ocasião em que objetivemos aprovação. Ingressamos, contudo, formalmente, no programa um ano depois, o que nos forneceu condições para o aprimoramento de trabalhos voltados ao aperfeiçoamento acadêmico e à análise e à elaboração da presente tese. Com este trabalho, esperamos contribuir para a historiografia florianopolitana e catarinense, na medida em que oferecemos ao leitor episódios do cotidiano da cidade de Florianópolis que, de outra maneira, seriam difíceis de ser revelados.

A presente tese é organizada em cinco capítulos, e a análise dos processos criminais é, com efeito, contemplada em todos eles. Desse modo, a tônica geral que perpassa a análise dos documentos supracitados - e das demais fontes pesquisadas - observa que a circulação dos automóveis se impôs, gradativamente, àquela operada por transeuntes e veículos não motorizados - carroças, bondes puxados por burros, tílburys. Tal imposição processou-se de maneira gradativa no decorrer das décadas de 10 e 20 do século passado, e devemos observar que os transeuntes, ao circularem pelas ruas do perímetro urbano da Capital, operam, muitas vezes, táticas e estratégias específicas, ditadas pelas condicionantes do viver urbano, que conferem caráter imprevisível e circunstancial às atitudes por eles tomadas para se esquivarem das investidas operadas pelos veículos motorizados. Além disso, é importante percebermos que os chauffeurs, condutores dos automóveis, operam, também, artifícios e recursos diversos para, muitas vezes, evitar atropelamentos e colisões. Veremos que a tônica que perpassou a circulação dos veículos motorizados pelas ruas do perímetro urbano da Capital, no período em estudo, foi pautada pelas altas velocidades e pelo comportamento afoito dos chauffeurs ao volante; aspectos que foram denunciados pelos artigos dos periódicos locais e que sinalizam para a progressiva e irreversível imposição dos automóveis frente à circulação operada pelos transeuntes.

Diante dessas questões, é importante destacarmos que as regulamentações de trânsito que se tentavam aplicar na capital catarinense, no período em apreço, salientam as intervenções 
urbanas propaladas pelos poderes administrativos locais e estaduais. Contudo, muitas atitudes e práticas expressas por chauffeurs, passageiros e transeuntes, no perímetro urbano de Florianópolis, não correspondiam às tentativas e esforços de se planejar e disciplinar a urbe ${ }^{14}$.

De outro modo, é importante observarmos que a circulação de automóveis, passageiros e pedestres pelas ruas da capital catarinense configurava um processo complexo que envolve transgressões e obediências mútuas, operadas, especialmente, por chauffeurs e transeuntes, às normas e às leis de trânsito, pois circunstâncias variadas, porém imprevisíveis, determinam comportamentos condizentes ou transgressores desses personagens aos regulamentos e dispositivos legais de trânsito. Nesse sentido, podemos considerar que as vivências cotidianas operadas por eles no meio urbano da cidade de Florianópolis, encerram enquadramentos às normas e às leis de trânsito e, igualmente, às investidas operadas pelos veículos motorizados; mas também manifestam transgressões e desobediências, que perfiguram astúcias e comportamentos díspares que compõem, no limite, atitudes e práticas antidisciplinares ${ }^{15}$. A vivência cotidiana opera, portanto, em muitas ocasiões, contrapoderes que não se adequam ou, simplesmente, não são contidos pelas normas e convenções sociais existentes ${ }^{16}$. De maneira análoga, podemos considerar que os pedestres manifestam, em suas andanças pelas ruas, seus desejos e interesses próprios, que, naturalmente, não são determinados pelos ritmos impostos pelo poder advindo das normas e das leis vigentes ou da circulação operada pelos automóveis.

Assim, a ordem reinante, que encerra um conjunto de imposições e regulamentações, deixa margem para as improvisações expressas pelos habitantes do espaço urbano de Florianópolis em inúmeras situações cotidianas. Em última instância, essa ordem serve de suporte para inúmeras produções e vivências operadas no dia a dia ${ }^{17}$. O processo de inserção dos veículos motorizados pelas ruas do perímetro urbano da capital catarinense e a gradativa adaptação da população florianopolitana perante esse processo envolveu, portanto, negociações e embates, sobre os quais, concomitante à presença e à circulação dos automóveis, encontramos registros de percepções da população florianopolitana frente a esses elementos.

É importante destacarmos que os aspectos assinalados anteriormente não são exclusivos do contexto urbano da capital catarinense, uma vez que encontraremos, no transcorrer da presente investigação, exemplos de situações semelhantes ocorridas em outras cidades do país e da Europa Ocidental, que destacam os cenários dos grandes centros urbanos nacionais e europeus, sobretudo quanto às cidades de São Paulo, Rio de Janeiro e Paris. Objetivamos, pois, oferecer uma análise profícua e consubstancial à temática proposta, inserindo a cidade de Florianópolis

\footnotetext{
${ }^{14}$ NECKEL, Roselane. A República em Santa Catarina: modernidade e exclusão (1889-1920). Florianópolis: UFSC, 2003. p. 86.

${ }^{15}$ CERTEAU, Michel de. A invenção do cotidiano 1: artes de fazer. 8. ed. Petrópolis: Vozes, 2002. p. 17.

${ }^{16}$ RAGO, Margareth. Do cabaré ao lar: a utopia da cidade disciplinar: Brasil 1890-1930. 3. ed. Rio de Janeiro: Paz \& Terra, 1997. p. 172.

${ }^{17}$ CERTEAU, Michel de. A invenção do cotidiano 1: artes de fazer... op. cit., p. 49-50.
} 
dentro de um contexto mais amplo, no qual também podemos verificar situações de resistência e de imposição operadas por transeuntes, passageiros, chauffeurs e veículos motorizados. Para os efeitos deste estudo, podemos destacar que a circulação automobilística, nos centros das grandes cidades e, igualmente, na capital catarinense, obedeceu a uma tônica geral, interpretada como promessa de liberdade e conforto, mas que, gradativamente, converteu-se, durante o século XX, num verdadeiro empecilho à circulação dos transeuntes e dos próprios veículos; estes tomados por uma aura ameaçadora uma vez que, cotidianamente, colocavam em risco a vida dos pedestres e usuários das cidades. Destacamos, entretanto, que a aplicação dos padrões de modernidade, considerando-se as devidas proporções urbanísticas e financeiras, operou-se, em Florianópolis, com certo distanciamento temporal e envolveu, conforme verificamos no transcorrer da tese, algumas situações ilustrativas de atropelamentos e colisões atestadas nas grandes cidades brasileiras e europeias.

Os automóveis simbolizam, dentre outros elementos, a modernização e o progresso imprimidos, especialmente, pela sociedade ocidental. Percebemos, igualmente, as relações de poder operadas entre os veículos motorizados e os transeuntes. É importante notarmos que, para os efeitos deste estudo, o poder está sempre presente nas relações humanas, nas quais há, é claro, possibilidades de resistência ${ }^{18}$. O que podemos perceber desses registros é que o poder deve ser analisado como algo que circula, pois, exercido em rede, nunca está localizado aqui ou ali. Assim é que, nas suas malhas, os indivíduos não só circulam, mas estão sempre em posição de exercer o poder e de sofrer sua ação ${ }^{19}$. Nesse sentido, a análise dos processos criminais evidencia que os transeuntes não estão inteiramente sob a influência dos automóveis; pois, em muitas passagens registradas nos episódios de atropelamentos e colisões verificados junto aos processos, eles imprimem atitudes e práticas, disponibilizadas por suas capacidades físicas, direcionadas ao ato de esquivar-se ou fugir frente à circulação automobilística.

Os processos e as demais fontes oficiais, jornalísticas e bibliográficas analisadas nesta pesquisa permite-nos abordar específicas possibilidades de investigação. Objetivamos, pois, estudar maneiras específicas de como os florianopolitanos adaptaram-se à gradativa introdução dos veículos motorizados, pois novas sensibilidades e percepções impunham-se aos antigos hábitos e costumes. Verificamos, igualmente, curiosidades e aspectos diversificados sobre a vida cotidiana dos habitantes da capital catarinense. Desse modo, esse estudo possibilita-nos analisar aspectos importantes da vida de personagens anônimos do cotidiano de Florianópolis que, de outra maneira, seriam, a nosso ver, muito difíceis de serem elucidados e trazidos à tona.

\footnotetext{
${ }^{18}$ FOUCAULT, Michel. Sexo, Poder e Indivíduo. Florianópolis: Nefelibata, 2003. p. 70-72.

${ }^{19}$ FOUCAULT, Michel. Microfísica do Poder. 17 ed. Rio de Janeiro: Graal, 2002. p. 183.
} 
Como metodologia, adotamos o sistema de levantamento e revisão de fontes bibliográficas, bem como o de leitura e de análise de publicações historiográficas, periódicas e de legislações de trânsito e penal que documentam as percepções e o processo de adaptação expressos pelos florianopolitanos, em vista da presença e da circulação dos veículos motorizados no perímetro urbano da cidade de Florianópolis. Pretendemos reunir e interpretar informações colhidas em arquivos, bibliotecas e instituições especializadas. Utilizamos, preferencialmente, as técnicas de fichamento e registro fotográfico para a melhor coleta e organização das informações.

As fontes bibliográficas contemplam publicações referentes ao exercício do poder nas diversas esferas sociais e às relações perpetradas entre os indivíduos para processá-lo ou absolvêlo. Envolvem, igualmente, publicações que analisam o aspecto urbano das grandes cidades brasileiras e internacionais - sobretudo Paris, Rio de Janeiro e São Paulo -, principalmente quanto à evolução da malha viária e dos transportes motorizados. Objetivamos, dessa forma, fornecer embasamento teórico à pesquisa, mediante a relação dessas publicações com as demais fontes e com a temática proposta.

No tocante às fontes oficiais, reservamos especial atenção aos acervos da cidade de Florianópolis, sobretudo ao consultarmos os documentos das seguintes instituições: Tribunal de Justiça do Estado de Santa Catarina (TJ/SC), Arquivo Público Estadual (APSC), Arquivo Histórico da Prefeitura Municipal de Florianópolis (AHPMF), Biblioteca Pública Estadual (BIPESC) e Instituto Brasileiro de Geografia e Estatística (IBGE). Essas fontes compreendem, basicamente, os seguintes tipos de documentos: processos criminais, códigos penais e de trânsito estaduais e nacionais, relatórios, mensagens de governo, leis, decretos e resoluções. Objetivamos, ainda, elaborar um estudo fundamentado sobre as percepções e o processo de adaptação vivenciados pelos florianopolitanos frente à presença e à circulação dos veículos motorizados no perímetro urbano da capital catarinense, no período compreendido entre os anos de 1920 e 1941.

Quanto às fontes jornalísticas, pesquisamos, principalmente, os jornais $O$ Estado, República, A Gazeta, O Dia e Folha Nova. Os registros jornalísticos atestam a posição da imprensa local relacionada à dinâmica operada pela convivência simultânea dos bondes e dos ônibus na cidade de Florianópolis, durante as décadas de 20 e 30 do século passado. Registram, igualmente, muitos dos atropelamentos e das colisões verificados nos processos criminais analisados e o consequente posicionamento da imprensa local sobre esses acontecimentos. Enfatizamos que o estudo das fontes jornalísticas objetiva, portanto, complementar as informações constantes nos processos criminais e nas documentações bibliográfica e oficial, analisadas neste estudo. 
O exame das fontes compreende, também, a documentação de caráter iconográfico. Essa documentação foi colhida, basicamente, no Banco de Imagens da Fundação Franklin Cascaes, no Arquivo Histórico Municipal de Florianópolis e no jornal $O$ Estado. Assim, apresenta inúmeras fotografias que retratam o aprimoramento dos transportes urbanos e da malha viária da cidade de Florianópolis no período em estudo. O que procuramos foi adequá-las ao contexto da pesquisa, como forma de melhor ilustrar a temática proposta.

Quanto ao trabalho com as fontes, realizamos, no primeiro momento, um levantamento preliminar da bibliografia existente. Essa bibliografia engloba tanto obras gerais quanto específicas. As obras gerais têm como objetivo principal fornecer embasamento teórico para a pesquisa, uma vez que abordam temáticas especialmente relacionadas à evolução urbana e ao tráfego motorizado nas cidades, tanto no âmbito nacional como da Europa Ocidental. Abrangem, também, publicações referentes ao exercício do poder nas diversas esferas sociais e às relações e táticas perpetradas entre os indivíduos para processá-lo ou absolvê-lo. Dentre elas, destacamos o livro organizado por Flávio R. Kothe, intitulado Walter Benjamin: sociologia ${ }^{20}$. O autor seleciona textos de autoria de Walter Benjamin; dentre os quais se destacam: Paris, capital do século XIX e A Paris do Segundo Império em Baudelaire. Esses textos analisam as modificações sofridas pela cidade de Paris durante a gestão do prefeito municipal George Eugène Haussmann e suas repercussões paisagísticas e sociais. Registram, igualmente, as impressões de Charles Baudelaire (1821-1867) sobre as modificações aqui referenciadas. Assim, o poeta exprime o olhar do "[...] alegórico a perpassar a cidade [que] é o olhar do estranhamento. É o olhar do flâneur [...]. O flâneur ainda está no limiar tanto da cidade grande quanto da classe burguesa. Em nenhuma delas ele se sente em casa. Ele busca o seu asilo na multidão"21 . Esses textos salientam, igualmente, a visão benjaminiana de modernidade, que enfatiza seus aspectos negativista e utópico. Segundo Walter Benjamin, "[...] a modernidade é o inferno", mas, "enquanto tal, é simultaneamente apocalíptica",22.

O texto de autoria de Max Horkheimer, intitulado Eclipse da Razão ${ }^{23}$, questiona o caráter racional da cultura industrial contemporânea e apregoa que o intenso processo de mecanização, verificado nas sociedades ocidentais, culminou na anulação da identidade individual dos seres humanos. O autor salienta, portanto, que esses aspectos conferem "[...] à moderna sociedade industrialista o seu aspecto niilista"; Horkheimer acredita, porém, que podemos construir um

\footnotetext{
${ }^{20}$ KOTHE, Flávio R. (Org.). Walter Benjamin: sociologia. 2. ed. São Paulo: Ática, 1991. (Col. Grandes Cientistas Sociais, n. 50).

${ }^{21}$ BENJAMIN, Walter. Paris: capital do século XIX. In: KOTHE, Flávio R. (Org.). Walter Benjamin: sociologia. 2. ed. São Paulo: Ática, 1991. p. 39. (Col. Grandes Cientistas Sociais, n. 50).

${ }_{22}^{2}$ ROUANET, Sérgio Paulo e WITTE, Bernd. Por que o moderno envelhece tão rápido? In: ASCHER, Nelson. (Org). Dossiê Walter Benjamin. Revista USP. São Paulo: CCS/USP, n. 15, set./nov. 1992. p. 107. Sobre esses aspectos ver, também: a) BENJAMIN, Walter. Rua de mão única. 3. ' reimpressão. São Paulo: Brasiliense, 2000. v. 2. p. 71-142. (Obras Escolhidas); e b) capitalismo. 2. reimpressão. São Paulo: Brasiliense, 2000. v. 3. p. 104-149. (Obras Escolhidas).

${ }^{23}$ HORKHEIMER, Max. Eclipse da razão. 5. ed. São Paulo: Centauro, 2002. Este livro foi publicado, originalmente, no ano de 1946.
} 
mundo diferente, que objetive atender aos anseios humanos, pois “[...] o único meio de auxiliar a natureza [humana] é libertar o seu pretenso opositor, o pensamento independente"24.

É importante considerarmos que Walter Benjamin e Max Horkheimer são importantes expoentes da Escola de Frankfurt. A par de suas especificidades filosóficas e conceituais, podemos considerar que, para os frankfurtianos, a pretensa objetividade científica, que forneceu as diretrizes fundamentais das sociedades ocidentais, não promoveu a emancipação humana em relação à técnica e ao trabalho escravizante e explorador e não nos conduziu, portanto, à liberdade e à plena realização do espírito humano. A crítica à razão torna-se, por conseguinte, “[...] a exigência revolucionária para o advento de uma sociedade racional, porque o mundo do homem, até hoje, não é 'o mundo humano', mas 'o mundo do capital'",25.

As obras de autoria de Michael Foucault analisam especialmente o exercício do poder nas diversas esferas sociais $^{26}$. Elas propõem, com efeito, a articulação do poder com o saber e investigam os efeitos do poder que, segundo o autor, estão difundidos e enraizados em todas as instâncias da sociedade. Foucault estuda, igualmente, a evolução do sistema prisional nos países europeus - notadamente, na França - durante os séculos XVIII e XIX, e sinaliza, durante esse período, alterações dos objetivos e da aplicação das penas e dos processos criminais ${ }^{27}$. Nesse sentido, o sofrimento físico não caracteriza a punição, que é, a partir do século XIX, aplicada em sistemas prisionais e objetiva corrigir e transformar o comportamento do condenado para reintegrá-lo à sociedade. Assim, a abertura de processos criminais e a aplicação das penas objetivam preservar a humanidade descoberta na figura do criminoso.

Michael de Certeau, no livro $A$ Invenção do Cotidiano - publicado em dois volumes ${ }^{28}$-, refuta a suposta passividade dos indivíduos anônimos frente ao exercício do poder. Defende, portanto, que os cidadãos comuns possuem sensibilidades e anseios próprios e que se utilizam de procedimentos, criatividade e táticas específicas pelas quais elaboram maneiras próprias para sobreviver, modificar e adequar-se à ordem social estabelecida pelo exercício e pela disseminação do poder nas diversas esferas sociais. Assim, as relações de poder que perpassam todos os aspectos e nuanças colocados no cotidiano não impedem o exercício e a prática de ações de personagens anônimos que ali vivem e transitam - ideia partilhada por Michel Foucault. Essa é, pois, a dinâmica que norteará o enfoque conferido aos processos criminais aqui estudados.

\footnotetext{
${ }^{24}$ HORKHEIMER, Max. Eclipse da razão. 5. ed. São Paulo: Centauro, 2002. p. 98 e p. 129.

${ }^{25}$ MATOS, Olgária C. F. A Escola de Frankfurt: luzes e sombras do iluminismo. São Paulo: Moderna, 1993. p. 8.

${ }^{26}$ FOUCAULT, Michel. Microfísica do Poder. 17. ed. Rio de Janeiro: Graal, 2002; __. Vigiar e Punir: nascimento da prisão. 22. ed. Petrópolis: Vozes, 2000; ___. Sexo, Poder e Indivíduo. Florianópolis: Nefelibata, 2003; __ . Ditos e Escritos: estratégia, poder-saber. 1 ed. Rio de Janeiro: Forense Universitária, 2003. v. 4; __. Ditos e Escritos: ética, sexualidade, política. 1 ed. Rio de Janeiro: Forense Universitária, 2004. v. 5.

${ }^{27}$ FOUCAULT, Michael. Vigiar e Punir: nascimento da prisão. 22. ed. Petrópolis: Vozes, 2000.

${ }^{28}$ CERTEAU, Michel de. A invenção do cotidiano 1: artes de fazer. 8. ed. Petrópolis: Vozes, 2002; morar, cozinhar. 5. ed. Petrópolis: Vozes, 2003. A invenção do cotidiano 2:
} 
A obra de autoria de Carlo Ginzburg ${ }^{29}$ é fundamentada, principalmente, no conceito de circularidade cultural $^{30}$. É, igualmente, centrada na corrente micro-histórica. O livro analisa os processos criminais imputados pela Inquisição Papal ao moleiro friulano Domenico Scandella (Menocchio), durante o século XVI. As declarações prestadas por Menocchio registram suas interpretações das escrituras sagradas, especialmente quanto à criação e à origem do universo. Além disso, a análise da documentação utilizada pelo autor fornece-nos aspectos importantes sobre as ideias, os sentimentos, as aspirações e as atividades cotidianas exercidas pela personagem central e pelos indivíduos integrantes da comunidade na qual viviam. Considerarmos esses pontos é importante, pois os processos criminais e demais fontes analisadas, na presente pesquisa, permitem-nos, igualmente, revelar aspectos importantes do cotidiano dos chauffeurs, passageiros, transeuntes e testemunhas das colisões e dos atropelamentos registrados nos processos supracitados. Nesse contexto, devemos observar, também, o livro Os protagonistas anônimos da história: micro-história ${ }^{31}$, de Ronaldo Vainfas. Nele, o autor analisa o surgimento e as características da corrente micro-histórica ${ }^{32}$ e estuda textos característicos dessa corrente historiográfica. É pertinente esclarecermos que não pretendemos elaborar um estudo especificamente micro-histórico. Algumas características dessa corrente historiográfica são, no entanto, apropriadas para a elaboração da presente pesquisa, pois a micro-história dedica-se à análise dos “[...] pequenos enredos", dos "personagens anônimos" e dos "aspectos cotidianos das sociedades passadas" "33. Além disso, a análise da temática e dos objetivos então propostos será permeada pela correlação com a conjuntura nacional e internacional da época ${ }^{34}$.

\footnotetext{
${ }^{29}$ GINZBURG, Carlo. O queijo e os vermes: o cotidiano e as idéias de um moleiro perseguido pela Inquisição. 3. ed. São Paulo: Companhia das Letras, 2003.

${ }^{30}$ Conforme Ronaldo Vainfas, "A cultura popular, segundo Ginzburg, se define antes de tudo pela sua oposição à cultura letrada ou oficial das classes dominantes, o que confirma a preocupação do autor em recuperar o conflito de classes em uma dimensão sociocultural. Mas a cultura popular se define também, de outro lado, pelas relações que mantém com a cultura dominante, filtrada pelas classes subalternas segundo seus próprios valores e condições de vida. É a propósito dessa dinâmica entre os níveis culturais popular e erudito [...], que Carlo Ginzburg propõe o conceito de circularidade cultural". (VAINFAS, Ronaldo. Os protagonistas anônimos da história: micro-história. Rio de Janeiro: Campus, 2002. p. 61).

${ }^{31}$ VAINFAS, Ronaldo. Os protagonistas anônimos da história: micro-história. Rio de Janeiro: Campus, 2002.

${ }^{32}$ VAINFAS, Ronaldo. Os protagonistas anônimos da história... op. cit., p. 11, p. 51, p. 103, p. 120, p. 136, p. 142. Devemos observar, também, o seguinte texto: REVEL, Jacques. A História ao rés do chão (Prefácio). In: LEVI, Giovanni. A herança imaterial: carreira de um exorcista no século XVII. Rio de Janeiro: Civilização Brasileira, 2000. p. 7-37. Destacamos, desse último texto, uma passagem que exemplifica as características da corrente micro-histórica, pois salienta a necessária operação da redução da escala de observação que o historiador deve efetuar na análise e elaboração de um estudo de caráter micro-histórico. Segundo Revel: “[...] a escolha do indivíduo não é considerada contraditória com a do social: torna possível uma abordagem diferente deste último. Sobretudo, permite destacar, ao longo de um destino específico - o destino de um homem, de uma comunidade, de uma obra - a complexa rede de relações, a multiplicidade dos espaços e dos tempos nos quais se inscreve. Usada em pequena escala, torna muitas vezes possível uma reconstituição do vivido inacessível às outras abordagens historiográficas. Propõe-se por outro lado a identificar as estruturas invisíveis segundo as quais esse vivido se articula”. (REVEL, Jacques. A História ao rés do chão (Prefácio). In: LEVI, Giovanni. A herança imaterial: carreira de um exorcista no século XVII... op. cit., p. 17).

${ }^{33}$ VAINFAS, Ronaldo. Os protagonistas anônimos da história... op. cit., p. 13.

${ }^{34}$ Ao analisarmos a evolução do traçado urbano e dos veículos motorizados nas cidades de São Paulo, Rio de Janeiro e Paris, notamos que acerca desse aspecto, Ronaldo Vainfas expõe que “[...] os debates nos últimos anos do século XX apontam para uma possível compatibilidade entre as escalas de investigação macrossocial e microanalítica. As técnicas descritivas da micro-história podem mesmo otimizar a exposição de exemplos e a verticalização de seus significados em textos de história geral, permitindo ao leitor um contato mais estreito com a 'experiência vivida' de certos atores. Sem dúvida que um procedimento desse tipo apresenta maior potencial elucidativo para a exposição de casos do que a simples menção pontual de situações ilustrativas de tal ou qual dinâmica ou estrutura. Nesse caso, tratar-se-ia de uma alternância de escalas, de uma passagem do olhar macrossocial para a observação microanalítica como procedimento metodológico, sem prejuízo da primeira". (VAINFAS, Ronaldo. Os protagonistas anônimos da história... op. cit., p. 150).
} 
Os livros intitulados Urbanismo ${ }^{35}$ e Planejamento Urbano $^{36}$, de Le Corbusier, registram as implicações da modernidade para os grandes centros urbanos europeus e norte-americanos. O autor analisa, nesses textos, os efeitos maléficos dos tradicionais projetos de planejamento urbano que privilegiam a circulação do automóvel em detrimento da circulação humana e que ocasionam "[...] o ajuntamento progressivo e aleatório [de indivíduos e máquinas]"37. Registra, igualmente, suas próprias impressões sobre o trânsito da cidade de Paris durante a década de 20 do século passado. Como urbanista, Le Corbusier propõe a elaboração de novos projetos urbanísticos e a construção de ruas e edificações que privilegiem a circulação do ar e a penetração da luz e das radiações solares.

José Luiz Vieira, no livro A história do automóvel: a evolução da mobilidade (São Paulo: Alaúde Editorial, 2008. (v. 1. da Pré-história a 1908), apresenta muitas informações sobre o universo automotivo. Discute em rápidas abordagens, dentre outras questões, as disputas existentes entre os industriais e principais ramos ligados ao automóvel desde, pelo menos, o último quarto do século XIX. Assim, países como Alemanha, Estados Unidos, França e Itália concorrem entre si para apresentar, nas exposições universais e salões automotivos, novidades e recursos originais, como o pedal do acelerador, a injeção de combustível operada por carburação, maior potência e durabilidade de motores, etc. Nesse contexto, fábricas e indústrias automotivas começaram a ser fundadas e organizadas; dentre as quais, destacamos as seguintes: Renault, Mercedes-Benz, Fiat, Ford, Studebaker, Chrysler.

O autor apresenta, também, que a vitória do automóvel foi conseguida não sem antes haver resistências por aqueles que, habituados ao uso de charretes, carros puxados por cavalos e burros e bondes elétricos, denominavam os novos veículos de "carruagens sem cavalo" "38. Além disso, é válido observarmos que houve incertezas e agruras nas tentativas de se implementar, nos veículos, motores de combustão interna, os quais, pelo menos até as duas primeiras décadas do século XX, tiveram que enfrentar forte concorrência dos motores a vapor ou elétricos. A par dos questionamentos e dúvidas que pairam sobre as informações apresentadas no livro, é importante observarmos os contextos e quadros gerais por ele apresentados, pois nos fornecem uma visão abrangente sobre o universo automotivo verificado, especialmente, nos países europeus e nos Estados Unidos, bem como sobre as disputas ideológicas e conceituais despertadas entre industriais e empresas do ramo.

Nicolau Sevcenko trabalha em âmbito nacional. Nas publicações Orfeu extático na metrópole: São Paulo, sociedade e cultura nos frementes anos 20; e, A capital irradiante:

\footnotetext{
${ }^{35}$ Le Corbusier. Urbanismo. São Paulo: Martins Fontes, 1992.

${ }^{36}$ Le Corbusier. Planejamento Urbano. 3. ed. São Paulo: Perspectiva, 1984. (Col. Debates, n. 37).

${ }^{37}$ Le Corbusier. Urbanismo... op. cit., p. 84.

${ }^{38}$ VIEIRA, José L. A história do automóvel: a evolução da mobilidade. S. Paulo: Alaúde Editorial, 2008. (v. 1. da Pré-história a 1908$)$. p. 129.
} 
técnica, ritmos e ritos do rio $^{39}$, o autor discute, dentre outros aspectos, a formação do quadro urbano-industrial brasileiro nos séculos XIX e XX, sobretudo em São Paulo. Estuda, igualmente, as iniciativas do governo municipal para a remodelação do espaço urbano central da cidade por meio da construção de largas avenidas e da implementação de sistemas de escoamento de água e esgoto sanitário. Nesse ponto, observaremos, no transcorrer da tese, críticas ao seu posicionamento que partilha da ideia de que os modelos de urbanismo adotados na Europa sobretudo a remodelação empreendida por Georges Eugène Haussmann, em Paris - foram, de alguma forma, aplicados nos principais contextos urbanos brasileiros. A fundamentação de nossa crítica observa, pois, que houve, de fato, disputas políticas e ideológicas entre as principais correntes dirigentes do país, na época, especialmente sobre a implementação arbitrária de medidas adotadas em outros contextos urbanos, uma vez que, para a cidade de São Paulo, deviase, por exemplo, estar atento às particularidades do sítio urbano, emoldurado por colinas e vales $^{40}$. Temos, contudo, que Sevcenko observa e analisa, nas publicações então citadas, as ocorrências cotidianas de atropelamentos de pedestres nas ruas da capital paulista e as opiniões expressas pelos transeuntes sobre esses acontecimentos. Percebemos, claramente, a gradual imposição da circulação dos veículos motorizados frente à efetuada por carroças, bondes elétricos e pedestres.

O autor José Geraldo Vinci de Morais discute a formação do quadro urbano-industrial brasileiro e as iniciativas dos governos municipais para a remodelação dos espaços urbanos das capitais dos estados de São Paulo, Rio de Janeiro e Minas Gerais, no livro Cidade e Cultura Urbana na Primeira República ${ }^{41}$. Essas perspectivas, sobretudo quanto à cidade de São Paulo, são analisadas, também, por Maria Stella Martins Bresciani, em três artigos utilizados no presente estudo: a) História e historiografia das cidades: um percurso ${ }^{42}$; b) Imagens de São Paulo: Estética e Cidadania ${ }^{43}$; e c) Nas Ruas, os Caminhos da Cidade ${ }^{44}$. A mesma autora, no livro Palavras da Cidade ${ }^{45}$, seleciona vários textos e artigos que discutem, dentre outros aspectos, o urbanismo e o planejamento urbano como elementos participantes da organização viária e predial de várias cidades brasileiras e latino-americanas ${ }^{46}$. Esses escritos discutem,

\footnotetext{
${ }^{39}$ SEVCENKO, Nicolau. Orfeu extático na metrópole: São Paulo, sociedade e cultura nos frementes anos 20. São Paulo: Companhia das Letras, 1992; ___ . A capital irradiante: técnica, ritmos e ritos do rio. In: ___ . (Org.). História da vida privada no Brasil - República: da Be lle Èpoque à Era do Rádio. 5. ed. São Paulo: Companhia das Letras, 2002. p. 513-619.

${ }^{40}$ Sobre essa discussão, ver CAMPOS, Cândido Malta. Os Rumos da Cidade: Urbanismo e Modernização em São Paulo. São Paulo: Senac, 2002.

${ }^{41}$ MORAES, José Geraldo Vinci de. Cidade e cultura urbana na Primeira República. São Paulo: Atual, 1994.

${ }^{42}$ BRESCIANNI, Maria Stella Martins. História e Historiografia das Cidades: um percurso. In: FREITAS, Marcos Cezar. (Org.). Historiografia brasileira em perspectiva. São Paulo: Contexto, 1998.

${ }^{43}$ BRESCIANNI, Maria Stella Martins. Imagens de São Paulo: Estética e Cidadania. In: Anais do IV Seminário de História da Cidade e do Urbanismo. Rio de Janeiro, v. 1, p. 465-474, nov. 1996.

${ }^{44}$ BRESCIANNI, Maria Stella Martins. Nas Ruas, os Caminhos da Cidade. In: Cadernos de História de São Paulo / A cidade e a rua. São Paulo, n. 2, p. 27-38, jan./dez. 1993.

${ }^{45}$ BRESCIANNI, Maria Stella Martins. (Org.). Palavras da cidade. Porto Alegre: UFRGS, 2001.

${ }^{46}$ Dentre estes textos, destacamos: a) BRESCIANI, Maria Stella Marins. Melhoramentos entre intervenções e projetos estéticos: São Paulo (1850-1950). In: (Org.). Palavras da cidade. Porto Alegre: UFRGS, 2001. p. 351-352; e b) CARIDE, Horacio E. O polvo, a mancha e a
} 
também, as políticas governamentais de saneamento e melhoria das regiões centrais das cidades e as relações entre palavras e imagens textuais expressas pelos meios urbanos, processadas pelos vínculos emocionais estabelecidos entre elas e os cidadãos que os habitam. O texto elaborado por Stella Bresciani, para a coletânea supracitada, intitulado Melhoramentos entre intervenções e projetos estéticos: São Paulo (1850-1950), analisa, dentre outros potos, os sentidos e os significados dos espaços urbanos expressos pelas linguagens especializada, culta e vernacular e oferece especial destaque às impressões cotidianas referenciadas por seus habitantes.

Em outro texto, intitulado $A$ Cidade: objeto de estudo e experiência vivenciada ${ }^{47}$, Bresciani discute a ideia de que o interesse intelectual pelo estudo das cidades procede de questões colocadas no presente. A cidade foge, desse modo, ao controle humano e configura-se, gradualmente, como espaço agigantado, o que sugere que a compreensão de cidade não mais encontra correspondência na imagem da cidade que se tem diante dos olhos.

Nesse artigo, Bresciani estuda, também, a formação do pensamento urbanístico sobre a cidade de São Paulo, reduto de um saber de especialistas que propuseram intervenções sobre o espaço urbano da capital paulista. A proposta do estudo tem, pois, como suporte teórico a concepção do urbanismo como projeto estruturado por dados objetivos, nutrido, também, por imagens idealizadas e utópicas, cujo norte se situa em um lugar idealizado de perfeição; e isso implica, portanto, afirmar a existência de uma distância entre a intenção projetiva da lei e o comportamento que objetiva disciplinar. Salientamos que outro ponto importante desse artigo se refere ao fato de que a autora trabalha com memória e história, pois, segundo ela, “[...] é impossível renunciar [...] a ter em mente dois momentos vivenciados em minha experiência pessoal, momentos intermediados pelo tempo da memória que me traz à lembrança a cidade dos anos 50 e 60, lembranças talvez idealizadas pela escolha que faço, mas certamente pela distância temporal e pelo trabalho de rememorar, seletivo, sempre um pouco excludente" ${ }^{\natural 4}$. A autora também analisa as ideias de Joseph Rykwert. Estudioso das cidades, Rykwert localiza, nos problemas do trânsito, a atual concentração das preocupações das autoridades urbanas e dos usuários da cidade, pedestre ou motorizado. Assim, os constantes engarrafamentos atormentam de tal modo a vida urbana que a engenharia de trânsito terá que repensar o planejamento urbano.

O texto Cidade e História ${ }^{49}$, também de autoria de Maria Stella Bresciani, discute a interdisciplinaridade como elemento constitutivo do urbanismo como campo de saber, bem como a historização de sua denominação e reconhecimento na década inicial do século XX. De acordo

\footnotetext{
megalópole. O urbanismo como representação, Buenos Aires, 1927-1989. In: BRESCIANI, Maria Stella Martins (Org). Palavras da Cidade. Porto Alegre: UFRGS, 2001. p. 41-75.

${ }^{47}$ BRESCIANI, Maria Stella Martins. A Cidade: objeto de estudo e experiência vivenciada. In: Revista Brasileira de Estudos Urbanos e Regionais. São Paulo: ANPUR, v. 6, n. 2, nov. 2004. p. 9-26.

${ }^{48}$ Ibidem, p. 16.

${ }^{49}$ BRESCIANI, Maria S. M. Cidade e História. In: OLIVEIRA, Lúcia L. (Org.). Cidade: história e desafios. R de Janeiro: FGV, 2002. p. 16-35.
} 
com Bresciani, "Quais foram os caminhos que levaram a essa estrutura interdisciplinar dos estudos sobre as cidades? Seríamos nós os responsáveis pela pulverização do objeto cidade, tal como outros temas do domínio da história, submetidos a recortes específicos, quando não ao esfacelamento?" 50 . A proposta da autora direciona-se, justamente, em sentido contrário, pois a intenção é mostrar que, ao se tomar o urbanismo como objeto de estudo em sua configuração acabada, podemos incorrer no anacronismo de tentar localizar o significado de uma ausência ou de se ir em busca de uma origem determinante; ou, ainda, de resvalarmos para a "positivação" ou "naturalização" da questão urbana, "acompanhando sua evolução" através do tempo.

Nesse procedimento, a cidade moderna e o saber que se forma a partir e/ou sobre ela - o urbanismo ou ciência urbana - seriam encarados como fenômenos inerentes à época contemporânea, decorrentes do caráter universal da industrialização iniciada no último quartel do século XVIII. Esse artigo objetiva mostrar, portanto, que a questão urbana é fundamentada pelo debate político, o que indica que sua configuração é moldada por conflitos e tensões. Stella Bresciani acredita, por conseguinte, que o estudo dos espaços urbanos envolve o rompimento com a relação mecânica de causa-efeito, ou com a estreita noção de determinação férrea que, comumente, temos sobre a constituição física ou espacial das cidades. Por outro lado, somente no início do século XX, o urbanismo se configura como saber destinado ao estudo dos espaços urbanos. Aqui, a autora reafirma ser um equívoco conceber o urbanismo como saber pronto e acabado, que oferece toda e qualquer solução aos problemas enfrentados pelos grandes centros urbanos da atualidade. Nesse sentido, o ambiente urbano, como fluxo de contatos, experiências e percepções, não pode ser mensurado pela referência a uma norma objetiva, exterior a ele ${ }^{51}$.

O livro Os rumos da cidade: urbanismo e modernização em São Paulo, do arquiteto Candido Malta Campos ${ }^{52}$, surge como uma importante contribuição para a compreensão do papel de urbanistas e políticos nas transformações do espaço dessa cidade, no período entre os anos de 1870 e 1945. Nesse estudo, o autor investiga a gestação e o conteúdo de projetos urbanísticos e de instrumentos intervencionistas ou reguladores do espaço urbano da capital paulista, como códigos de obras e zoneamentos, normas de parcelamento, taxas de melhoria, etc. Desvenda a diversidade das propostas urbanísticas pensadas para a cidade de São Paulo em meio a diferentes posturas, divergências teóricas e distintas filiações, e a forma como se procurou adequá-las às condições locais. Campos sinaliza como essas disputas políticas envolvem demandas simbólicas, estéticas, higienistas, de valorização imobiliária e interesses políticos e comerciais ${ }^{53}$. Confrontos,

\footnotetext{
${ }^{50}$ BRESCIANI, Maria Stella Martins. Cidade e História. In: OLIVEIRA, Lúcia Lippi. (Org.). Cidade: história e desafios. Rio de Janeiro: FGV, 2002. p. 19.

${ }^{51}$ Ibidem, 30

${ }^{52}$ CAMPOS, Cândido Malta. Os Rumos da Cidade: Urbanismo e Modernização em São Paulo. São Paulo: Senac, 2002.

${ }^{53}$ CORREIA, Telma de Barros. Os Rumos da Cidade: Urbanismo e Modernização em São Paulo. Resenha. São Paulo: Senac, 2002. In: Revista Brasileira de Estudos Urbanos e Regionais. São Paulo: ANPUR, n. 5, maio 2002. p. 119-120.
} 
debates e busca de soluções alternativas, muitas vezes conciliatórias, marcaram a trajetória de projetos e propostas, mas também contrariaram as ideias e ações de urbanistas, políticos e técnicos dos setores de obras públicas.

Outra questão enfatizada refere-se às diferentes formas de apropriação de modelos urbanísticos adotados em contextos internacionais. Nesse sentido, destacamos que, nas primeiras décadas do século XX, modelos de inspiração "haussmanniana" - então privilegiados nas intervenções urbanísticas nas capitais nacionais - chocaram-se com padrões de inspiração "sittiana", defendidos por urbanistas como Vítor Freire e Saturnino de Brito. Demonstramos, também, como a ênfase das propostas urbanísticas foi se deslocando de questões sanitárias para preocupações viárias, num movimento que redefine os padrões estéticos eleitos e sua aplicação nos planos urbanísticos. Evidenciamos que, ao assinalar o descompasso entre planos e intervenções, o autor sinaliza os limites dos projetos teóricos quando das tentativas de sua aplicação prática no espaço urbano da cidade de São Paulo. O eixo central da obra é, portanto, precisamente sublinhar e analisar o vasto campo de lutas - tantas vezes escamoteado em abordagens restritas a aspectos formais - que permeia o pensamento e a prática do urbanismo.

Destacamos, também, o livro de autoria de Marco Antônio Cornacioni Sávio, intitulado $A$ modernidade sobre rodas: tecnologia automotiva, cultura e sociedade (São Paulo: EDUC, 2002). Esse texto é resultado de sua dissertação de mestrado apresentada na PUC-SP, e apresenta ricas informações quanto ao movimento dos automóveis - de praça e de aluguel - que circulavam pela cidade de São Paulo, pelo menos, desde a década de 10 do século passado. O autor trabalha com a noção de artefato técnico, que pode ser entendido como "[...] o conjunto de tecnologias que acaba por mobilizar todo o corpo social num único objetivo, que é o de manter em funcionamento esse gigantesco, artefato [o automóvel] que acabaria por abarcar todas as sociedades humanas" $" 54$.

É necessário, entretanto, chamarmos a atenção para o fato de que esse texto registra termos como "classe social" (p. 20) e "experiência" (p. 32), em desuso entre os historiadores da alçada cultural. O autor registra, pois, que o automóvel assinala "o início de uma nova era", "marcada pela modernização tecnológica e pela urbanização"; é, porém, ponto de crítica a ideia por ele defendida de que esse mesmo contexto "[...] tem como paradigma as grandes cidades da Europa e dos Estados Unidos" "55, a partir das quais nossas elites objetivavam adotar "[...] um modelo social de desenvolvimento"; em síntese, "o mundo europeu" ${ }^{\text {" }}$. Além disso, devemos contestar e relativizar a argumentação colocada pelo mesmo autor, de que o "[...] grande crescimento pelo

\footnotetext{
${ }^{54}$ SÁVIO, Marco Antônio Cornacioni. A Modernidade sobre Rodas. São Paulo: EDUC, 2002. p. 22.

${ }_{55}$ Ibidem, p. 40.

${ }^{56}$ Ibidem, p. 46-47.
} 
qual passou a cidade [de São Paulo] no início do século XX deve-se única e exclusivamente ao café" ${ }^{, 57}$. O livro lança, entretanto, luz sobre outros aspectos, como, por exemplo, as análises em torno da construção de um arcabouço legal para o automóvel na cidade, que veio a ser uma tentativa de regulamentar o uso dessa máquina nas ruas, e a ideia de que o automóvel assumiu o papel difusor de uma nova "ética da velocidade e do movimento" na capital paulista, ligada a um projeto civilizador automotivo, cujo “[...] principal meio de difusão eram os raids, que serviam como meio de propaganda privilegiada para as políticas propostas por Washington Luís, 'o melhor amigo das boas estradas" $" 58$.

No livro organizado por Diléia Zanotto Manfio, intitulado Poesias Completas / Mário de Andrade ${ }^{59}$, destacamos os textos: a) Paulicéa Desvairada (p. 55-115); b) Losango Cáqui (p. $123-$ 158); c) Grã Cão do Outubro (p. 311-325); e d) Lira Paulistana (p. 349-397). Nesses textos, datados, respectivamente, dos anos de 1922, 1926, 1933 e 1945, percebemos, em vários dos poemas que os compõem, que a vida urbana, além de inspirar a produção de discursos, transforma-se em foco dominante da vida social, palco para debates e espaço de decisões. Observamos nesses textos, as imagens mais recorrentes nos discursos da época sobre a capital paulista. Na São Paulo de Mário, a velocidade, verticalidade e a busca generalizada por signos de metropolização aparecem humanizados. Esse olhar sobre a vida urbana, que objetiva humanizar suas transformações, seus ritmos, refere-se, em síntese, a uma maneira de ver e de representar a modernidade paulistana. Nos poemas de Mário de Andrade, está implícita a ideia de que a vida urbana é o meio de acesso à "civilização" que passa, também, pelos signos da modernidade. Mário, em suas obras, interroga-se, entretanto, sobre o significado dessa nova metrópole e a problematiza indefinidamente.

O livro de autoria de Maria Cintra Gordinho, intitulado Transportes no Brasil: a opção rodoviária ${ }^{60}$, analisa a evolução dos meios de transporte existentes no Brasil, no período compreendido entre os séculos XVI e XX. Ela estuda, nessa época, os momentos de impulso e retrocesso dos sistemas ferroviário, hidroviário e rodoviário. O que nos interessa, todavia, para os propósitos do presente estudo, é salientar a consolidação definitiva do transporte rodoviário no Brasil na década de 1950. Nesse período, especialmente durante o governo de Juscelino Kubitschek (1956-1961), a indústria automobilística recebeu expressivo incentivo do governo federal, por meio da implantação de indústrias automobilísticas internacionais e do fomento à pavimentação de estradas e ao parque industrial brasileiro. A análise desses aspectos contribui para a delimitação temporal da presente pesquisa, compreendida entre os anos de 1920 e 1941 . A

\footnotetext{
${ }^{57}$ SÁVIO, Marco Antônio Cornacioni. A Modernidade sobre Rodas. São Paulo: EDUC, 2002. p. 41.

${ }^{58}$ Ibidem, p. 37.

${ }^{59}$ MANFIO, Diléia. (Org.). Poesias Completas / Mário de Andrade. Belo Horizonte: Itatiaia, 2005.

${ }^{60}$ GORDINHO, Margarida Cintra. Transportes no Brasil: a opção rodoviária. São Paulo: Marca D’Água, 2003.
} 
consolidação do transporte rodoviário no Brasil é, igualmente, observada na obra de autoria de Thomas Skidmore, intitulada Brasil: de Getúlio Vargas a Castelo Branco (1930-1964) ${ }^{61}$. Nela, o autor analisa a evolução do quadro político-econômico do Brasil no período e discute, dentre outros aspectos, a política de fomento à indústria automobilística e ao transporte rodoviário, notadamente durante o período de vigência do Estado Novo (1937-1945) e do governo de Juscelino Kubitschek ${ }^{62}$ - ver seção Epílogo, no quinto capítulo da tese.

A bibliografia específica engloba, principalmente, obras de autores catarinenses: Roselane Neckel, Méri Frotscher, Maria Inês Sugai, Joana Maria Pedro, Eliane Veras, Hermetes Reis de Araújo, nas quais podemos perceber uma discussão mais aproximada sobre a evolução do quadro urbano da cidade de Florianópolis, no período em estudo, e sobre os procedimentos e práticas envoltas nos trâmites legais para punir e/ou inocentar chauffeurs frente às ocorrências de atropelamentos e colisões verificadas nos processos criminais analisados. É relevante, ainda, destacarmos que uma análise mais aprofundada das ideias expressas pelo conjunto bibliográfico apontado anteriormente - e sua consequente intercalação às demais fontes estudadas - é realizada no transcorrer dos capítulos da tese.

O livro de autoria da prof. ${ }^{\text {a }}$ Roselane Neckel, intitulado A República em Santa Catarina: modernidade e exclusão (1889-1920) ${ }^{63}$, analisa a implantação do regime republicano em Santa Catarina e os novos hábitos e costumes que foram perpetrados pela imprensa da época como condizentes com a vivência na capital catarinense. Ela estuda, paralelamente, os objetivos e as iniciativas governamentais na implantação de reformas urbanas necessárias à modernização da cidade. Além disso, a obra registra as práticas cultivadas pela população da cidade de Florianópolis como forma de resistir às iniciativas governamentais de ordenação do espaço urbano ou transgredi-las.

Do texto Práticas Proibidas: práticas costumeiras de aborto de infanticídio no século $X I X^{64}$, destacamos, especialmente, o capítulo terceiro, intitulado Aborto e Infanticídio nos Códigos Penais e nos Processos Judiciais: a pedagogia de condutas femininas ${ }^{65}$. Nesse texto, os autores objetivam tecer uma análise pautada na investigação de falas e depoimentos registrados nos processos criminais instaurados contra mulheres na cidade de Florianópolis, durante os anos 1900 e 1950, as quais foram acusadas de terem praticado aborto, infanticídio e sonegação de

\footnotetext{
${ }^{61}$ SKIDMORE, Thomas. Brasil: de Getúlio a Castelo (1930-1964). 12. ed. Rio de Janeiro: Paz e Terra, 2000.

${ }^{62}$ Essas perspectivas são, igualmente, analisadas em duas obras organizadas por Boris Fausto: a) FAUSTO, Boris. (Org.). História Geral da Civilização Brasileira. 9. ed. Rio de Janeiro: Bertrand Brasil, 2001. Tomo III: O Brasil Republicano. v. 3: Sociedade e Política (1930-1964); e b) _ (Org.). História Geral da Civilização Brasileira. 9. ed. Rio de Janeiro: Bertrand Brasil, 2001. Tomo III: O Brasil Republicano. v. 4: Economia e Cultura (1930-1964).

${ }^{63}$ NECKEL, Roselane. A República em Santa Catarina: modernidade e exclusão (1889-1920). Florianópolis: UFSC, 2003.

${ }^{64}$ PEDRO, J. M (Org). Práticas Proibidas: práticas costumeiras de aborto de infanticídio no século XIX. Florianópolis: Cidade Futura, 2003.

${ }^{65}$ PEDRO, Joana Maria; NECKEL, Roselane; HAWERROTH, Eliana Izabel; MACHADO, Vanderlei. Aborto e Infanticídio nos Códigos Penais e nos Processos Judiciais: a pedagogia de condutas femininas. In: PEDRO, Joana Maria. (Org). Práticas Proibidas: práticas costumeiras de aborto de infanticídio no século XIX. Florianópolis: Cidade Futura, 2003. p. 85-109.
} 
cadáver. Nesse sentido, pretendemos “[...] perceber a constituição de subjetividades e o controle dos corpos através da perseguição e de uma 'vontade de saber' por parte das autoridades com respeito a práticas femininas que possibilitavam às mulheres desembaraçarem-se de uma gravidez não desejada, o que significava maior autonomia sobre os corpos" ${ }^{\text {66 }}$. Desse modo, objetivamos perceber como práticas, como o aborto, ou mesmo infanticídio e sonegação de cadáver, foram sendo historicamente problematizadas e criminalizadas. Esses aspectos aplicamse, especialmente, ao quarto capítulo da tese, que tem como título: Os Processos Criminais em Cena 4: pedagogia e punição, pois pretendemos relacioná-los à construção de discursos que se moldavam com relação às falas dos chauffeurs, passageiros, transeuntes e testemunhas, ouvidos nos inquéritos e processos judiciais analisados no presente estudo.

Incluímos, também, algumas considerações da obra das autoras Méri Frotscher e Lea Maria Ferreira Vedana, intitulada Viagens pela cidade: o transporte coletivo em Blumenau ${ }^{67}$, que analisa a evolução do transporte coletivo na cidade de Blumenau, desde o início do século XX até a década de 90 do século passado. As autoras estudam, inicialmente, o surgimento dos primeiros ônibus ${ }^{68}$ e a organização das primeiras empresas de transporte coletivo na cidade, efetuada nas décadas de 1930 e 1940. Elas enfocam, ainda, a expansão e a gradativa complexidade organizacional do transporte coletivo nas décadas de 1950, 1960 e 1970. Analisam, igualmente, a introdução dos primeiros automóveis e a gradual presença e circulação desses veículos pelas ruas da cidade de Blumenau. Além disso, discutem a dinâmica operada pela convivência simultânea dos bondes, ônibus e automóveis nas ruas de Blumenau durante as décadas de 20 e 30 do século passado.

Maria Inês Sugai, em sua dissertação de mestrado, intitulada As Intervenções Viárias e as Transformações do Espaço Urbano: A Via de Contorno Norte-Ilha ${ }^{69}$, analisa a evolução do traçado urbano da cidade de Florianópolis, desde o final do século XIX até a década de 70 do século passado. Ela estuda, também, as iniciativas governamentais para a implantação, nas décadas de 1960 e 1970, da avenida de contorno norte-ilha - futura avenida Beira-mar Norte. Essa iniciativa salienta a intensa presença do tráfego motorizado na cidade de Florianópolis, no período supracitado. Atesta a autora, também, a nítida preferência concedida pelas autoridades municipais e estaduais ao transporte rodoviário, em detrimento do marítimo e do ferroviário.

\footnotetext{
${ }^{66}$ PEDRO, Joana Maria; NECKEL, Roselane; HAWERROTH, Eliana Izabel; MACHADO, Vanderlei. Aborto e Infanticídio nos Códigos Penais e nos Processos Judiciais: a pedagogia de condutas femininas. In: PEDRO, Joana Maria. (Org). Práticas Proibidas: práticas costumeiras de aborto de infanticídio no século XIX. Florianópolis: Cidade Futura, 2003. p. 85.

${ }^{67}$ FROTSCHER, Méri; VEDANA, Lea Maria Ferreira. Viagens pela Cidade: o transporte coletivo de Blumenau. Florianópolis: Insular, 1999.

${ }^{68}$ Ocorrido na década de 10 do século passado. De acordo com as autoras, “[...] no início do século, quando os primeiros ônibus começaram a circular na cidade de Blumenau, as distâncias entre os bairros pareciam ser bem maiores. O primeiro ônibus, adquirido em 1914, [...] fazia o transporte de passageiros do centro da cidade à localidade de Itoupava Seca”. (FROTSCHER, Méri; VEDANA, Lea Maria Ferreira. Viagens pela Cidade: o transporte coletivo de Blumenau... op. cit., p. 15).

${ }^{69}$ SUGAI, Maria Inês. As Intervenções Viárias e as Transformações do Espaço Urbano: A Via de Contorno Norte-Ilha. Dissertação (Mestrado em Arquitetura e Urbanismo). São Paulo: USP, 1994.
} 
Já o texto da prof. ${ }^{\text {a }}$ Eliane Veras ${ }^{70}$ analisa, especialmente, a evolução do transporte coletivo na cidade de Florianópolis, durante os séculos XVII até os dias atuais. Ela descreve e analisa os meios de transporte da cidade de Desterro dos séculos XVII a XIX; o surgimento, em 1920, do primeiro ônibus em Florianópolis e as linhas e itinerários dos coletivos durante as décadas de 1940, 1950 e $1960^{71}$. Num segundo momento do texto, intitulado Novas demandas numa cidade que cresce, analisa a evolução do transporte coletivo a partir da década de 1970, até os dias atuais. Concede, também, especial atenção ao atual Sistema Integrado de Transporte Coletivo de Florianópolis. O livro é rico em informação e em documentação jornalística e iconográfica, mas seu período de abrangência é muito extenso, o que prejudica o seu caráter analítico.

É importante considerarmos que o estudo, aqui apresentado, analisa fontes inéditas: processos criminais e códigos de trânsito locais. A problemática proposta, que analisa as percepções cotidianas expressas pelos florianopolitanos, quanto à implementação e à circulação dos automóveis, no período de 1920 a 1941, envolve o jogo de poder implícito nas relações estabelecidas entre veículos, chauffeurs e pedestres. Essa dinâmica alicerça, com efeito, a elaboração da presente tese. A análise consubstancial, aqui proposta, entre as fontes bibliográficas, periódicas, oficiais, processos criminais e códigos penais e de trânsito, confere ao presente estudo seu caráter inovador e relevante para a historiografia local e catarinense. Entendemos, dessa forma, que ambos os trabalhos não são, de maneira alguma, semelhantes, mas complementares.

As fontes bibliográficas mencionadas anteriormente foram localizadas, basicamente, na Biblioteca Pública do Estado (BIPESC); na Biblioteca da UFSC (BU); no Instituto Histórico e Geográfico de Santa Catarina (IHGSC); e na biblioteca particular do autor. As fontes jornalísticas foram encontradas, sobretudo, na Biblioteca Pública do Estado. Pesquisamos, principalmente, os jornais O Estado, República, A Gazeta, O Dia e Folha Nova. Essas fontes registram, como vimos, a posição da imprensa local sobre a dinâmica operada pela convivência simultânea dos bondes e dos ônibus na capital catarinense, durante as décadas de 20 e 30 do século passado. Além disso, registram muitos dos atropelamentos e das colisões verificados nos processos criminais analisados e o consequente posicionamento da imprensa sobre esses episódios, notadamente quanto às velocidades atingidas pelos automóveis nas ruas do perímetro urbano de Florianópolis.

Os processos criminais registram os atropelamentos e as colisões ocorridos na cidade de Florianópolis, no período compreendido entre os anos de 1923 e 1938. Para a elaboração da

\footnotetext{
${ }^{70}$ VEIGA, Eliane. Transporte Coletivo em Florianópolis: origens e destino de uma cidade à beira-mar. Florianópolis: Insular, 2004.

${ }^{71}$ É importante registrarmos que, na presente tese, não enfatizaremos esses aspectos, pois privilegiamos as impressões cotidianas e as relações de poder expressas pelos florianopolitanos, frente à introdução e circulação dos veículos motorizados pelas ruas do perímetro urbano da capital catarinense.
} 
pesquisa, selecionamos dezoito processos. Eles registram, dentre outros aspectos, as percepções, opiniões e sensibilidades cotidianas expressas pelos florianopolitanos sobre a circulação dos veículos motorizados pelas ruas do perímetro urbano da capital catarinense e constituem as principais fontes para a elaboração do presente estudo. (Anexo 20, p. 351).

Analisamos, também, códigos penais e de trânsito. Os primeiros registram os dispositivos legais aplicados à punição dos responsáveis pelos atropelamentos e colisões ${ }^{72}$. Verificamos, todavia, ocasiões em que expressam claramente as tentativas deliberadas de inocentar os chauffeurs e motoristas supostamente responsáveis pelos acontecimentos supracitados, por meio das quais atestamos a conjugação dos poderes financeiro e judiciário para a concretização desses objetivos. Os códigos de trânsito contemplam publicações compreendidas entre os anos de 1914 e $1940^{73}$ e registram, nesse período, a evolução das normas e dos dispositivos de trânsito aplicados nos âmbitos nacional, estadual e municipal.

As fontes, como relatórios, decretos, projetos de lei, leis e mensagens de governo encontram-se, principalmente, no Arquivo Público do Estado (APSC), na Biblioteca Pública Estadual (BIPESC) e no Arquivo Histórico da Prefeitura Municipal de Florianópolis (AHPMF). Pesquisamos, com efeito, relatórios de autoria da Diretoria de Obras Públicas e da Prefeitura Municipal de Florianópolis. Esses relatórios registram, portanto, a preocupação do poder público municipal com o aspecto urbano e viário da capital catarinense e elucidam as medidas adotadas para a melhoria das vias públicas e da infraestrutura urbana.

Pesquisamos, igualmente, os relatórios de autoria da Chefatura de Polícia da capital catarinense. Esses documentos salientam os registros das cartas expedidas para chauffeurs e cocheiros para a cidade de Florianópolis e outros municípios de Santa Catarina, no período compreendido entre os anos de 1911 e 1929, a partir dos quais podemos ter uma ideia da evolução da circulação dos veículos motorizados pelas ruas das principais cidades catarinenses. Além disso, registramos leis, decretos e decretos-leis que enfocam, sobretudo, a criação, no ano de 1935, da Secretaria de Segurança Pública e a atribuição a esse órgão, a partir do ano de 1938, dos serviços referentes à orientação e fiscalização do trânsito de veículos automotores nas vias públicas estaduais ${ }^{74}$; as taxas cobradas pelo emplacamento de veículos; a criação do serviço de

\footnotetext{
${ }^{72}$ Os códigos penais são encontrados, especialmente, no livro: PIERANGELI, José Henrique. Códigos Penais do Brasil: evolução histórica. 2. ed. São Paulo: Revista dos Tribunais, 2004. Essa publicação apresenta, dentre outros, os textos integrais dos seguintes documentos: a) Decreto n. 847, de 11 de outubro de 1890 (Codigo Penal do Brazil - 1890); b) Decreto n. 22213, de 14 de dezembro de 1932 (Consolidação das Leis Penais - 1932); c) Decreto-lei n. 2848, de 7 de dezembro de 1940 (Código Penal Brasileiro - 1940); d) Decreto-lei n. 3688, de 3 de outubro de 1941 (Lei das Contravenções Penais - 1941).

${ }^{73}$ Dentre elas, destacamos: a) Regulamento para as estradas estaduais a que se refere o Decreto n. 1116 desta data. In: O Dia. Florianópolis, 16 e 17 abr. 1918. p. 2; b) Santa Catarina. Regulamento para o serviço policial do Estado. Florianópolis: Tipografia da Livraria Central, 1920; c) Santa Catarina. Instruções Regulamentares para o serviço de trânsito público. Florianópolis: Imprensa Oficial, 1928; d) Lei n. 123, de 10 de novembro de 1936. Estabelece o plano rodoviário do Estado. In: Coleção de Leis de 1936. Florianópolis: Imprensa Oficial, 1936; e) Decreto-lei n. 3651: dá nova redação ao Código Nacional de Trânsito. Rio de Janeiro, 25 de setembro de 1941. In: Revista Forense: mensário nacional de doutrina, jurisprudência e legislação. Rio de Janeiro, out. 1941. v. LXXXVIII, ano XXXVIII, fascículo 461, n. 88. p. 578-590.

${ }^{74}$ Decreto-lei n. 24, de 7 jan. 1938. Atribuindo à Secretaria de Segurança a orientação e fiscalização do trânsito nas vias públicas. In: Santa Catarina. Coleção de Decretos-Leis de 1938. Florianópolis: Imprensa Oficial do Estado, 1939. p. 6-10.
} 
cadastro das estradas de rodagem estaduais (1936); a criação e ampliação do plano rodoviário do Estado, durante o período compreendido entre os anos de 1937 e 1946.

Por outro lado, as Mensagens de Governo encaminhadas pelo poder público estadual ao Congresso Representativo do Estado atestam os serviços de manutenção e os incentivos financeiros aplicados pelo poder público estadual para a conservação e a incrementação da infraestrutura ferroviária e rodoviária no Estado de Santa Catarina. Nesse sentido, percebemos a preferência concedida pelo poder público estadual à incrementação do transporte rodoviário, especialmente a partir das décadas de 1930 e 1940; processo este que obedece a uma política mais ampla, de cunho federal, visível, sobretudo durante a década de 50 do século passado. É importante destacarmos, ainda, que outros decretos e leis analisados instituem, para o período em estudo, os códigos penais e de trânsito aplicados no Estado de Santa Catarina e, especialmente, na cidade de Florianópolis. Esses documentos objetivaram regulamentar e disciplinar a atividade de condução dos veículos motorizados pelas estradas e ruas estaduais e da capital catarinense.

No Arquivo Histórico da Prefeitura Municipal de Florianópolis, analisamos projetos de lei que instituíram os primeiros serviços de bondes e ônibus na cidade de Florianópolis e que, regulamentam, portanto, a circulação desses veículos nas ruas do seu perímetro urbano. O Plano Diretor foi instituído, legalmente, no ano de 1952 e objetivou ordenar e disciplinar o perímetro urbano da capital do Estado via aplicação de diversos dispositivos: alargamento de ruas; criação de áreas comerciais e residenciais; melhor delimitação dos espaços destinados à circulação dos pedestres e veículos motorizados. A elaboração e a aplicação do Plano Diretor e, logo a seguir, do Código Municipal de Florianópolis (1955) testemunham a necessidade de ordenação do espaço urbano da capital catarinense para atender, de modo especial, ao crescente fluxo de automóveis.

Na Biblioteca Pública e no Arquivo Público do Estado, pesquisamos, igualmente, os anuários e guias catarinenses, no período compreendido entre os anos de 1927 e 1955. Salientamos que esses documentos atestam, durante esse período, o incremento das malhas ferroviária e rodoviária do Estado de Santa Catarina e em sua Capital. Esses documentos são analisados, sobretudo, na seção Epílogo, integrante, como vimos, do quinto capítulo da tese.

No Instituto Brasileiro de Geografia e Estatística (IBGE), pesquisamos recenseamentos populacionais e anuários estatísticos brasileiros. Selecionamos, pois, aspectos sobre o Estado e a capital catarinense. Constam, nesses documentos, informações sobre o contingente populacional urbano e rural e a frota de automóveis e veículos movidos a tração animal existentes no Estado de Santa Catarina e, especialmente, na cidade de Florianópolis. Essas informações referem-se, sobretudo, ao período compreendido entre os anos de 1925 e 1940. 
As fontes iconográficas foram organizadas, principalmente, no Banco de Imagens da Fundação Franklin Cascaes, no Arquivo Histórico Municipal de Florianópolis e no jornal $O$ Estado. Essas fontes registram, com efeito, a evolução dos veículos motorizados e do traçado urbano de Florianópolis. O trabalho com essas fontes objetiva, como mencionamos, adequá-las ao contexto da pesquisa como forma de ilustrar a temática proposta.

Quanto ao aspecto estrutural do trabalho, é importante destacarmos, uma vez mais, que a tese conta com cinco capítulos. No primeiro, intitulado Adaptações e Conflitos: novos personagens no ambiente urbano, analisamos as percepções e as sensibilidades expressas pelos florianopolitanos - especialmente chauffeurs, passageiros, transeuntes e testemunhas dos sinistros - quanto às velocidades atingidas pelos automóveis ao circularem pelas ruas do perímetro urbano da capital catarinense, durante as décadas de 20 e 30 do século passado. Nesse capítulo, foram analisados seis processos criminais que registram as ocorrências de atropelamentos e colisões na cidade de Florianópolis, durante os anos de 1923 e 1934. Desse modo, pretendemos, igualmente, tecer uma investigação sobre a relação de poder estabelecida entre o conjunto automóvel/chauffeur e os pedestres, e as táticas e os procedimentos práticos que estes exercem para se esquivarem e/ou se protegerem das investidas operadas pelos veículos motorizados. Inclusa nesses aspectos, está contemplada uma análise sobre as características do ambiente urbano moderno, notadamente quanto às grandes cidades brasileiras e da Europa Ocidental, na qual procuramos assinalar a circulação e o comportamento dos indivíduos frente à agitação e à aceleração do tempo, características próprias dos grandes centros urbanos do período, que são pautados, igualmente, pela perda de experiências vivenciadas na cidade, evocadas pela memória de temporalidades passadas. Pretendemos, pois, analisar as situações de atropelamentos e colisões verificadas nas ruas do perímetro urbano da capital catarinense, como aspectos inseridos dentro de um contexto mais amplo; obedecemos, para isso, logicamente, a certo distanciamento temporal e espacial.

No segundo capítulo, Espaço, Poder Público e Disciplinarização, foi analisado um processo criminal, datado do ano de 1923. A escolha desse processo é justificada pela relevância em relação aos propósitos levantados para esse capítulo, uma vez que o referido texto processual sinaliza para a clara imposição dos veículos automotores no contexto urbano da Capital, pois envolve o atropelamento de uma pessoa de considerável idade - a vitima, Francisca Ana Alves, tinha, segundo consta, 45 anos - que falece em função dos ferimentos recebidos após o choque com o respectivo automóvel. Assim, efetuamos uma discussão sobre o aprimoramento do aparato legislativo implantado em Santa Catarina e em sua Capital, especialmente durante as décadas de 10 e 20 do século passado; dispositivo este que pretendeu melhor organizar e 
controlar o deslocamento dos veículos - motorizados e/ou operados por força motriz animal pelas vias intermunicipais e, igualmente, pelas ruas do perímetro urbano da cidade de Florianópolis.

A terceira parte é intitulada Novos Tempos; Outras Legislações: adaptações e reformulação. Nesse espaço são analisados oito processos criminais, que abrangem os anos de 1923 e 1938. Objetivamos tecer uma investigação sobre a evolução e/ou adaptação das normas e regulamentos disciplinares de trânsito que se tentaram aplicar nas estradas intermunicipais do Estado e nos logradouros e vias públicas da cidade de Florianópolis, durante as décadas de 20 e 30 do século passado. Procuramos, desse modo, verificar, dentre outros elementos, em que medida as legislações de trânsito aplicadas em Santa Catarina e, especialmente, em sua Capital, atenderam à circulação automobilística e àquela operada por pedestres e veículos não motorizados. É importante assinalarmos, por fim, que os comportamentos e práticas exercidos pelos usuários da cidade - especialmente chauffeurs e transeuntes, alvos preferenciais das investidas operadas pelos veículos motorizados -, estavam, muitas vezes, em dissonância com os objetivos traçados pelas autoridades governamentais locais, voltadas para o controle e fiscalização de comportamentos indevidos ou transgressores no trânsito, por meio da instituição de normas e dispositivos disciplinares de trânsito. Operam-se, desse modo, choques e conflitos entre as normas instituídas e as vivências cotidianas praticadas pelos florianopolitanos.

No quarto capítulo, que tem como título Os Processos Criminais em Cena 4: pedagogia e punição, analisamos sete processos criminais que registram ocorrências de atropelamentos e colisões durante os anos de 1923 e 1934. O que pretendemos, nesse capítulo, foi elaborar uma análise sobre os procedimentos e falas proferidas pelos envolvidos nas ocorrências de atropelamentos e colisões: chauffeurs, transeuntes, passageiros, testemunhas, junto aos inquéritos policiais e processos judiciais. Além desses personagens, analisamos as falas de juízes, promotores e advogados de defesa e acusação presentes nas etapas processuais supracitadas. $\mathrm{O}$ que pretendemos foi investigar essas falas como elementos discursivos que envolvem, naturalmente, tendências e pontos de vista diferenciados sobre um mesmo aspecto, como, por exemplo, posicionamentos quanto às velocidades e a comportamentos dos chauffeurs ao volante. As falas proferidas nos inquéritos policiais e nos processos judiciais são, pois, espaços discursivos. Assim, o que pretendemos foi tentar perceber de que maneira os processos foram conduzidos. Desse modo, objetivamos tecer uma análise pautada na investigação de discursos, que expressam intencionalidades e propósitos específicos, voltados para a condenação ou não daqueles entendidos como responsáveis pelas ocorrências de atropelamentos e colisões. Assim, pretendemos realçar o caráter eminentemente político envolto em cada fala ou depoimento 
prestado, em que o ato de "ouvir dizer" a respeito de determinado sinistro ou ocorrência revela seu caráter pedagógico e instrutivo quanto aos comportamentos considerados indevidos no trânsito. Além disso, na última seção desse capítulo, atemo-nos à análise do teor discursivo de falas e de pareceres que dão conta das tentativas de proceder-se à deliberada intenção de punir os transeuntes e inocentar os chauffeurs pelos sinistros ocorridos, o que realça um claro jogo político que envolve a conjugação de interesses em torno dos poderes judiciário e financeiro.

$\mathrm{Na}$ última parte, intitulada Os Transportes Coletivos: convivência e preterimento, analisamos os textos e artigos dos periódicos locais do período, com o objetivo de tecermos uma investigação sobre a circulação simultânea dos ônibus e bondes pelas ruas do perímetro urbano de Florianópolis ${ }^{75}$. Pretendemos, desse modo, verificar a dinâmica do processo de inserção dos coletivos motorizados e os embates discursivos presentes nos periódicos locais sobre a progressiva circulação desses veículos em detrimento dos bondes, operados a força motriz animal. Inclusos nesta análise, estão a busca e a investigação de posicionamentos da imprensa local, contrários ou favoráveis à manutenção de um ou outro serviço, o que atesta que a circulação dos veículos motorizados - no caso, os ônibus - pelas ruas da cidade de Florianópolis foi, em síntese, conflituosa e problemática, conforme asseveram, igualmente, os posicionamentos de órgãos governamentais locais, no período em estudo.

A última parte do quinto capítulo constitui um Epílogo no qual elaboramos uma discussão sobre o processo inicial de implementação dos semáforos nos principais cruzamentos de ruas da cidade de Florianópolis, a partir da década de $1950^{76}$. Efetuamos essa discussão por meio da análise de artigos de jornal e do Primeiro Plano Diretor da capital catarinense, datado de 1952/55. Objetivamos constatar que, nesse período, é considerável o adensamento do fluxo de veículos motorizados pelas ruas do perímetro urbano da Capital; processo este que atesta a preferência concedida ao transporte rodoviário, em detrimento do marítimo e ferroviário. Esse aspecto obedece, em síntese, àquele traçado pela esfera federal, no qual verificamos especial atenção e fomento ao transporte rodoviário e ao incremento da indústria automobilística nacional, especialmente durante o período de governo de Juscelino Kubitschek (1956-1961). Pretendemos, desse modo, relacionar os contextos nacional, estadual e local frente à preferência concedida ao rodoviarismo, e objetivamos, por fim, inserir o contexto florianopolitano num cenário mais amplo. Devemos, entretanto, ter em mente que o palco principal apresentado no

\footnotetext{
${ }_{75}^{75}$ Nesta parte, será analisado, também, o Processo n. 183, de 11 de janeiro de 1932. Caixa 19. Ver Anexo 20 , p. 351.

${ }^{76} \mathrm{O}$ período de abrangência da tese envolve, conforme mencionado, os anos de 1920 e 1941 . Entretanto, é importante tecermos uma análise quanto aos debates e discussões para a implementação dos semáforos nos cruzamentos das vias centrais da cidade de Florianópolis a partir da década de 1950, pois tal aspecto ratifica a intensificação do fluxo automotivo no espaço urbano da Capital - especialmente nos espaços acima referenciados -, o que nos ajuda a compreender o gradual processo de inserção dos veículos motorizados na cidade de Florianópolis. Além disso, as iniciativas para a implementação desses recursos obedecem determinações federais, esplanadas, formalmente, no Primeiro Código Nacional de Trânsito, instituído em 1941 - ver seção Epílogo -, que teorizou uma série de práticas e posturas que deviam ser gradualmente observadas nas ruas e no trânsito automotivo das cidades brasileiras, a partir desse período.
} 
transcorrer da tese constitui-se, em síntese, no perímetro urbano da capital catarinense e nas vivências cotidianas operadas por seus habitantes.

O período cronológico da investigação proposta abrange os anos de 1920 e 1941, ou seja, vimos que, durante o início da década de 20 do século passado, foram instituídos importantes órgãos e normas disciplinares de trânsito ${ }^{77}$, que objetivavam não somente disciplinar a circulação de pedestres, mas também de veículos não motorizados e, principalmente, dos automóveis, que à época constituíam novos elementos no ambiente urbano de Florianópolis. Assinala, portanto, o momento de nítidas intervenções das autoridades estaduais e municipais para disciplinar e organizar o trânsito no Estado e na capital catarinense. É importante considerarmos a inexistência, até 1926 - data de inauguração da ponte Hercílio Luz -, de qualquer ligação terrestre entre as partes insular e continental da cidade de Florianópolis. Esse aspecto contribuiu para a presença pouco marcante dos veículos motorizados na cidade até as primeiras décadas do século XX e, também, para a delimitação do período inicial do presente estudo.

Assim, a cronologia estabelecida nesta tese obedece, em síntese, aos anos abarcados pelos processos criminais, que envolvem o período compreendido entre os anos de 1923 e 1938 . O presente estudo envolve, todavia, o período entre os anos de 1920 e 1941, pois, além dos elementos já apontados, que delimitam o período inicial de investigação, é válido destacarmos que, no início da década de 40 do século passado, adotaram-se novos dispositivos penais e de trânsito, vigentes para todo o território nacional. Dentre eles, destacamos: a) o primeiro Código Nacional de Trânsito, instituído no ano de 1941; b) o Novo Código Penal e o primeiro Código de Processo Penal brasileiros ${ }^{78}$. Os dispositivos arrolados objetivavam, respectivamente, padronizar a circulação dos veículos motorizados em todo o território nacional e atualizar a aplicação de penas e a organização dos processos criminais elaborados em todo o País. Percebemos, como visto, nova fase na organização do trânsito e dos dispositivos penais em todo o território nacional. Além disso, é importante observarmos que, a partir do mês de outubro de 1940, o emplacamento de veículos para todo o território do estado de Santa Catarina é efetuado anualmente, o que atesta o crescimento do fluxo dos veículos automotores pelas rodovias

\footnotetext{
${ }^{77}$ Notadamente: a) Santa Catarina. Regulamento para o serviço policial do Estado. Florianópolis: Tipografia da Livraria Central, 1920; b) Lei n. 1325 , de 18 de agosto de 1920. Dispondo sobre o exame de habilitação para condutores de automóveis. In: Coleção de Leis, Decretos, Resoluções e Portarias de 1920. Florianópolis: Imprensa Oficial, 1920; c) Decreto n. 1465A, de 17 de maio de 1921. Criando na Força Pública uma seção para serviços especiais de automóveis. In: Coleção de Leis, Decretos e Resoluções de 1921. Florianópolis: Imprensa Oficial, 1921. ${ }^{78}$ Esses códigos foram instituídos, respectivamente, nos anos de 1940 e 1941, todavia, entraram em vigor no dia $1 .^{\circ}$ de janeiro de 1942 . Assim, é válido observarmos que: a) o Código Penal Brasileiro de 1940 foi instituído pelo Decreto-lei n. 2848, de 07 de dezembro de 1940 . O artigo 361 do referido código estipula que este documento “[...] entrará em vigor no dia 1. e janeiro de 1942". (PIERANGELI, José Henrique. Códigos Penais do Brasil: evolução histórica. 2. ed. São Paulo: Revista dos Tribunais, 2004. p. 497); e b) No Decreto-lei n. 3689 , de 03 de outubro de 1941 (Código de Processo Penal - 1941. Rio de Janeiro, 1941), o artigo 810 estabelece que "Art. 810 - Esse Código entrará em vigor no dia 1º de janeiro de 1942". Outrossim, o artigo 1. expõe que "Art. $1^{\circ}$ - O processo penal reger-se-á, em todo o território brasileiro, por este Código". Dessa forma, padronizaram-se a organização e a apresentação dos processos e inquéritos policiais abertos no País. Instituíram-se, então, na década de 1940, novas regras que disciplinavam a atividade policial na investigação de delitos e crimes. Além disso, percebemos a atuação do Estado brasileiro na disciplinarização e organização da atividade policial no País.
} 
estaduais e, igualmente, pelas ruas do perímetro urbano da capital catarinense ${ }^{79}$. Esses elementos são analisados, especialmente, no capítulo terceiro da tese.

No Epílogo, disposto no capítulo quinto, tomamos a liberdade de estender um pouco mais o corte cronológico proposto para esta investigação, pois objetivamos, nessa parte, analisar o contexto da inserção das primeiras sinaleiras nos cruzamentos das principais vias do espaço central da cidade de Florianópolis, operado a partir da década de 1950. Além disso, a partir dos anos de 1952/1955, atestamos, na capital catarinense, a aplicação do primeiro Plano Diretor da cidade. Assim, esse documento evidencia a nítida preferência concedida pelas autoridades municipais e estaduais ao transporte rodoviário e ao incremento do fluxo de automóveis. $\mathrm{Na}$ década de 1950, era, portanto, notória e significativa a presença dos veículos motorizados no perímetro urbano da Capital; processo este que obedece à conjuntura nacional, norteada pelo expressivo fomento à rodoviação e ao incremento da indústria automotiva no País.

É importante esclarecermos que o corte cronológico, proposto nesta tese, encerra somente caráter didático. Nesse aspecto, a pesquisa tencionou, como vimos, investigar as percepções cotidianas e o gradual processo de adaptação da população florianopolitana frente à circulação dos veículos motorizados nas ruas do perímetro urbano da capital catarinense. A análise dos processos criminais e demais fontes oficiais, jornalísticas e bibliográficas enfatiza posicionamentos da população florianopolitana quanto à presença e circulação dos veículos motorizados. Além disso, a temática e os procedimentos metodológicos propostos constituem específicos caminhos de investigação e salientam aspectos importantes sobre o cotidiano de personagens anônimos da capital catarinense que, de outra maneira, seriam difíceis de ser revelados. Desse modo, é válido observarmos que “[...] o historiador trabalha com versões, e não com fatos", uma vez que "a verdade está longe de ser um dado positivo, e é sempre uma construção, marcada, portanto, pela relatividade, não só por não ser a verdade absoluta, mas também por necessitar um esforço de exegese das relações que a tecem" ${ }^{\text {"80 }}$.

\footnotetext{
${ }^{79}$ Ver Santa Catarina.Coleção de Decretos-Leis, Decretos, Resoluções e Portarias, jun. 1940. p. 203-204.

${ }^{80}$ NEVES, Margarida de Souza. História, memória e memorialística. Esboços - Revista do Programa de Pós-Graduação em História da UFSC. Florianópolis: UFSC, n. 11, 2004. p. 14. (Dossiê Cidade e Memória). Ver, também, a respeito: JÚNIOR, Durval Muniz de Albuquerque. História: a arte de inventar o passado: ensaios de teoria da História. Bauru: EDUSC, 2007.
} 


\section{Capitulo 1 - Adaptações e Conflitos: novos personagens no ambiente urbano}

\subsection{Elementos Incipientes}

No presente capítulo, o leitor entrará em contato com situações de atropelamentos e colisões verificadas no perímetro urbano da cidade de Florianópolis, durante as décadas de 20 e 30 do século passado ${ }^{81}$. Nosso intento é, precisamente, analisar as percepções e sensibilidades expressas pelos habitantes da capital catarinense ${ }^{82}$ frente à gradativa circulação do transporte motorizado no espaço urbano da cidade de Florianópolis, por meio da investigação de processos criminais pesquisados junto ao Arquivo Central do Tribunal de Justiça do Estado de Santa Catarina $^{83}$, no período entre os anos de 1923 e $1941^{84}$.

Assim, neste texto, é importante percebermos como os chauffeurs e, especialmente, os transeuntes adaptaram-se aos meios de locomoção motorizados e às novas condutas de comportamento no trânsito, e que envolvem, inegavelmente, relações de poder que se estabelecem, de maneira simultânea, entre a circulação dos automóveis ${ }^{85}$ e dos transeuntes em questão $^{86}$. Veremos, no transcorrer do texto, que a adaptação à nova tecnologia motorizada e às regras de trânsito que foram, gradualmente, implementadas na cidade para oferecer melhor organização à circulação dos automóveis envolveu, inegavelmente, embates e conflitos com antigos hábitos e práticas expressos pela população florianopolitana da época. Desse modo, a integração dos veículos motorizados à dinâmica cotidiana da cidade ocorreu de forma lenta e conflituosa, pois novos hábitos, especialmente a adaptação à velocidade e ao ritmo de deslocamento imprimidos pelos automóveis, entram em conflito com antigas percepções de tempo e espaço já arraigadas no cotidiano dos habitantes da capital catarinense, acostumados que estavam ao deslocamento de veículos tracionados por força motriz animal, que se caracterizava por ser efetuado de forma mais lenta e cadenciada.

\footnotetext{
${ }^{81} \mathrm{O}$ perímetro urbano da capital catarinense consubstancia-se como espaço preferencial de análise porque entendemos que é nele que se processa, com maior intensidade, o fluxo de veículos motorizados. Além disso, o centro é o núcleo original, o ponto de partida nodal de uma aglomeração urbana. O centro é, pois, o marco zero de uma cidade, o local onde tudo começou, o seu núcleo de origem. Desse modo, o centro é um espaço privilegiado no tempo. É importante observarmos que o perímetro urbano engloba o "espaço central" (centro) de uma cidade, mas envolve uma dimensão mais ampla, contemplando, também, ruas, avenida e logradouros adjacentes ou limítrofes ao "centro urbano". No presente estudo, analisamos, portanto, os episódios de atropelamentos e colisões ocorridos no perímetro urbano da cidade de Florianópolis - que engloba, dentre outras, as ruas Esteves Júnior, Visconde de Ouro Preto e as avenidas Rio Branco e Herć́lio Luz. Consideramos ruas do espaço central (centro) da cidade de Florianópolis aquelas situadas próximas ou adjacentes à Praça XV de Novembro, destacando-se as ruas Artista Bittencourt, Felipe Schmidt, Trajano, Arcipreste Paiva. Ver mapa 01, p. 29.

${ }^{82} \mathrm{Na}$ parte introdutória da tese, estão expressos os personagens que representam, para os efeitos deste estudo, os habitantes da capital catarinense.

${ }^{83}$ O Arquivo Central do Tribunal de Justiça do Estado de Santa Catarina está localizado, como vimos, no município de São José (BR - 101 - km 209 - Picadas do Sul - Forquilhinha).

${ }^{84}$ Os processos criminais relativos aos acidentes de trânsito na cidade de Florianópolis são disponibilizados, como vimos, apenas a partir do ano de 1923, conforme pesquisa realizada junto ao Arquivo Central do Tribunal de Justiça do Estado de Santa Catarina. Além disso, encontramos, para cada década do período em apreço, o total de: a) década de 1920: onze processos; e b) década de 1930: sete processos, o que contabiliza dezoito documentos, analisados no decorrer dos cinco capítulos da tese. Para maiores esclarecimentos quanto ao período cronológico estipulado na pesquisa, ver introdução.

${ }^{85}$ Deve-se ter em mente que se trata, sempre, do conjunto automóvel/chauffeur.

${ }^{86}$ As relações de poder são, aqui, analisadas a partir das ideias trabalhadas por Michel Foucault, que sinalizam para o fato de que o poder está disseminado, de maneira capilar, pelas diversas esferas sociais e institucionais.
} 


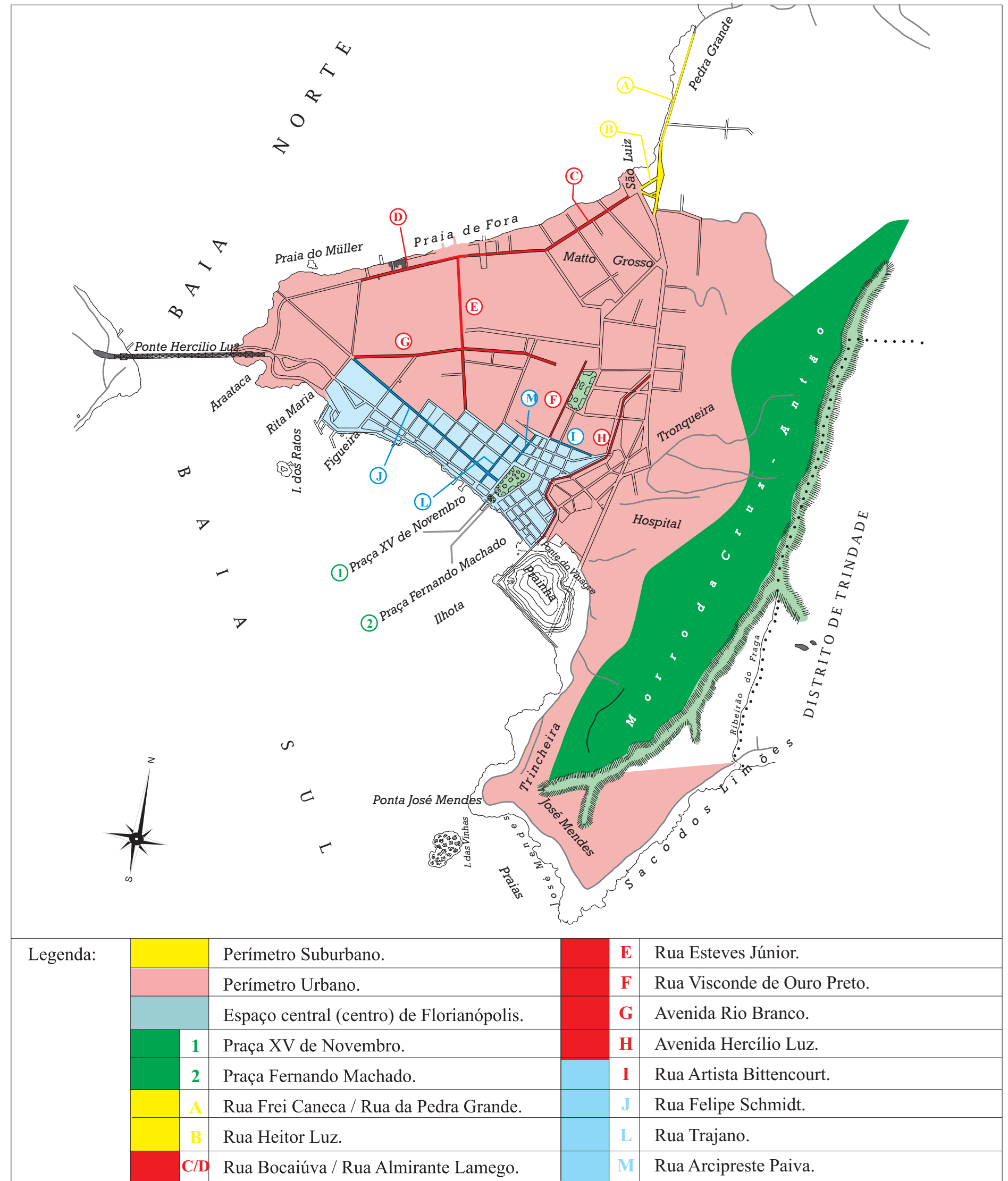

(*) Mapa do perímetro urbano da cidade de Florianópolis - 1940. Fontes: a) Centro Administrativo do Estado de Santa Catarina - Secretaria de Planejamento/Diretoria de Estatística e Cartografia - Florianópolis - Santa Catarina; e b) Guia do Estado de Santa Catarina: Suplemento para o ano de 1937. Florianópolis: Livraria Central de Alberto Entres, 1937.

Criação e Diagramação: Duplic Digital Copiadora-Florianópolis - Santa Catarina.

Adaptações feitas pelo autor, com base nas informações constantes no guia supracitado.

Objetivamos, também, relacionar o processo de adaptação da população florianopolitana frente à introdução dos veículos motorizados com situações semelhantes atestadas em outras cidades do País e da Europa Ocidental, a fim de inseri-lo, pois, em um contexto mais amplo e diversificado. Além disso, é importante destacarmos que a análise dos processos criminais 
permite-nos verificar muitos vestígios da vida cotidiana dos florianopolitanos. Nesse sentido, entendemos que o estudo dos processos de atropelamentos e colisões oferece-nos riquíssimos elementos de análise para a temática proposta.

Julgamos, em primeira mão, conveniente observar, entretanto, que a capital catarinense, desde sua fundação, no século XVII, até as primeiras décadas do século passado, não dispunha de ligação terrestre entre o espaço insular e continental ${ }^{87}$. As comunicações entre Ilha e Continente faziam-se por via marítima, e o transporte de cargas e de passageiros, especialmente no perímetro urbano de Florianópolis, efetuava-se por carroças e bondes movidos a tração animal. A partir dessas explanações, consideramos necessário esclarecer que é difícil precisar o momento exato da introdução dos primeiros veículos motorizados na capital catarinense; podemos, todavia, afirmar que, no período anterior à inauguração da ponte Hercílio Luz (1926), era reduzido o número de automóveis na cidade de Florianópolis. As tabelas 01 e 02, a seguir, apontam elementos importantes para melhor compreendermos este processo.

Tabela 01: Número de cartas expedidas no Estado de Santa Catarina (1911-1929)

\begin{tabular}{c|c|c|c}
\hline Anos & Cartas para Chauffeurs & Cartas para Boleeiros/ Cocheiros & Número Total de Cartas Expedidas \\
\hline $1911\left(^{*}\right)$ & ---- & 09 & 09 \\
1914 & 16 & $111(* *)$ & 19 \\
1922 & 77 & 27 & 188 \\
1929 & 87 & 150 & 36 \\
\hline Total & 180 & 332 & \\
\hline
\end{tabular}

(*) Os dados para este ano compreendem o total de cartas de boleeiros expedido entre os dias 12/04 e 15/05.

(**) Número correspondente ao total de carteiras extraídas para carros, carroças e carretas no Estado de Santa Catarina, no ano de 1922.

Fontes: a) 1911: Santa Catarina. Relatório Apresentado ao Exmo. Sr. Coronel Vidal José de Oliveira Ramos, digníssimo Governador do Estado pelo Desembargador Sílvio de Sá Gonzaga, Chefe de Polícia, em 1. ${ }^{\circ}$ de junho de 1911. Florianópolis: Gab. Tip. d' O Dia, 1911; b) 1914: Santa Catarina. Relatório Apresentado ao Exmo. Sr. Secretário Geral do Estado pelo Chefe de Polícia Ulysses Gerson Alves da Costa. Florianópolis, 14 maio de 1915; c) 1922: Estado de Santa Catarina. Relatório Apresentado ao Exmo. Sr. Dr. Joë Luiz M. Colaço, Secretário do Interior e Justiça pelo Desembargador Antero de Assis, Chefe de Polícia. Florianópolis, 1922; d) Santa Catarina. Relatório da Chefatura de Polícia Apresentado ao Exmo. Sr. Dr. Secretário do Interior e Justiça. Florianópolis, 1929.

Tabela 02: Número de cartas expedidas por município no Estado de Santa Catarina (1911-1922)

\begin{tabular}{|c|c|c|c|c|c|c|c|c|c|}
\hline \multirow{3}{*}{ Municípios } & \multicolumn{3}{|c|}{ Cartas para Chauffeurs } & \multicolumn{3}{|c|}{ Cartas para Boleeiros/ Cocheiros $(*)$} & \multicolumn{3}{|c|}{$\begin{array}{c}\text { Número Total de Cartas Expedidas por } \\
\text { Município }\end{array}$} \\
\hline & \multicolumn{3}{|c|}{ Anos } & \multicolumn{3}{|c|}{ Anos } & \multicolumn{3}{|c|}{ Anos } \\
\hline & 1911 & 1914 & 1922 & $1911(* *)$ & 1914 & 1922 & 1911* & 1914 & 1922 \\
\hline Florianópolis & --- & 15 & 28 & 07 & 02 & 36 & 07 & 17 & 64 \\
\hline São José & --- & --- & --- & 02 & 01 & 05 & 02 & 01 & 04 \\
\hline Palhoça & --- & --- & --- & 01 & --- & 02 & 01 & --- & 02 \\
\hline Biguaçú & --- & --- & --- & --- & --- & 02 & --- & --- & 02 \\
\hline Santo Amaro & --- & --- & --- & --- & --- & 01 & --- & --- & 01 \\
\hline Lages & --- & 01 & 03 & --- & --- & 01 & --- & 01 & 04 \\
\hline Blumenau & --- & --- & 14 & --- & --- & 40 & --- & --- & 54 \\
\hline Itajaí & --- & --- & 07 & --- & --- & 05 & --- & --- & 12 \\
\hline Joinvile & --- & --- & 25 & --- & --- & 19 & --- & --- & 44 \\
\hline $\begin{array}{l}\text { Total de Cartas } \\
\text { Expedidas }\end{array}$ & --- & 16 & 77 & 10 & 03 & 111 & 10 & 19 & 188 \\
\hline
\end{tabular}

(*) Número correspondente ao total de carteiras extraídas para carros, carroças e carretas, respectivamente, para os anos de 1911 , 1914 e 1922. (**) Os dados para este ano compreendem o total de cartas de boleeiros expedido entre os dias 12/04 e 15/05.

Fontes: a) 1911: Santa Catarina. Relatório Apresentado ao Exmo. Sr. Coronel Vidal José de Oliveira Ramos, digníssimo Governador do Estado pelo Desembargador Sílvio de Sá Gonzaga, Chefe de Polícia, em 1. ${ }^{\circ}$ de junho de 1911. Florianópolis: Gab. Tip. d' O Dia, 1911; b) 1914: Santa Catarina. Relatório Apresentado ao Exmo. Sr. Secretário Geral do Estado pelo Chefe de Polícia Ulysses Gerson Alves da Costa. Florianópolis, 14 maio de 1915; c) 1922: Santa Catarina. Relatório Apresentado ao Exmo. Sr. Dr. Joë Luiz M. Colaço, Secretário do Interior e Justiça pelo Desembargador Antero de Assis, Chefe de Polícia. Florianópolis, 1922.

\footnotetext{
${ }^{87}$ Essa ligação foi efetivada com a construção da Ponte Hercílio Luz, inaugurada no dia 13 de maio de 1926 . (A inauguração oficial da Ponte Hercílio Luz. O Estado. Florianópolis, 13 maio 1926. p. 1).
} 
As tabelas registradas anteriormente apontam aspectos importantes sobre o processo inicial de inserção dos veículos motorizados no Estado e na capital catarinense. A tabela 01 aponta que, no ano de 1911, não houve, no Estado de Santa Catarina, qualquer registro de cartas extraídas para chauffeurs, embora, no mesmo ano, tenha havido a expedição de nove cartas para boleeiros e cocheiros, conforme aponta o relatório apresentado ao Governador do Estado, pelo Chefe de Polícia, desembargador Sílvio de Sá Gonzaga. Nesse ponto, é importante observarmos que, para os efeitos deste estudo, consideramos, frente à variada nomenclatura encontrada nas fontes pesquisadas, que a denominação chauffeur corresponde àquele indivíduo que conduz e/ou dirige veículos motorizados, especialmente automóveis particulares, de aluguel e de praça. As denominações boleeiro, cocheiro, dentre outras, referem-se àqueles indivíduos que conduzem veículos operados a tração animal, como carros, carretas, tílburys. Importa, ainda, esclarecermos que, na vasta maioria dos documentos pesquisados, a expressão "carro" corresponde, especialmente, ao veículo operado a tração animal, e apenas a denominação "automóvel" identifica veículos automotores, especialmente aqueles de propriedade particular. É essa, precisamente, a classificação que adotamos nesta pesquisa.

Nos anos de 1914, 1922 e 1929, a mesma tabela aponta que foi expedido, respectivamente, no Estado de Santa Catarina, o total de dezesseis, setenta e sete e oitenta e sete cartas para chauffeurs; e três, cento e onze e vinte sete cartas para boleeiros e cocheiros. Observamos que houve, de fato, um crescimento significativo e constante do número de cartas extraídas para os condutores de veículos motorizados. Outro aspecto que julgamos importante é o fato de que, no ano de 1914, foram expedidas, no Estado de Santa Catarina, apenas três cartas para condutores de veículos tracionados por força motriz animal, o que aponta um claro decréscimo, se comparado ao total de nove cartas extraídas para boleeiros e cocheiros, verificado no ano de 1911. Isso pode ser considerado um indício de que a circulação de veículos tracionados por força motriz animal, no Estado de Santa Catarina estava, se não em declínio, mas em clara competição com a circulação dos veículos motorizados ${ }^{88}$; embora tenha havido um crescimento significativo desse número nos anos de 1922 e 1929, com, respectivamente, cento e onze e vinte e sete cartas extraídas. Acreditamos que o total de cento e onze cartas expedidas para boleeiros e cocheiros, no ano de 1922, deve-se, especialmente, à expressa obrigatoriedade para que os condutores de veículos retirassem a respectiva carta de habilitação, conforme estipula, de modo especial, o artigo 113 do Regulamento para o serviço policial do Estado, de 1920, pois o mesmo registra que

\footnotetext{
${ }^{88}$ No ano de 1914, o Decreto n. 846, de 29 de dezembro, expede o "Regulamento das estradas estaduais e respectivo imposto de trânsito". O artigo 18 desse regulamento registra que "Art. 18 - Com exceção dos automóveis, nenhum veículo poderá transportar carga superior a 1.000 quilos". (Regulamento das estradas estaduais e respectivo imposto de trânsito a que se refere o Decreto n. 846 , de 29 dez. 1914 . In: Leis, Decretos, Resoluções e Portarias de 1914. Florianópolis: Gab. Tip. d' O Dia, 1915. p. 187-210). Isso atesta, já em 1914, a circulação simultânea, nas estradas estaduais, dos automóveis e veículos operados com tração animal.
} 
“Art. 113 - Os condutores de veículos quando em serviço deverão estar munidos da respectiva carta de habilitação" ${ }^{\Perp 9}$.

É importante observarmos que, no ano de 1914, o "Regulamento das estradas estaduais e respectivo imposto de trânsito", a que se refere o Decreto n. 846, de 29 de dezembro, não menciona textualmente, em nenhum dos seus cinquenta artigos, a obrigatoriedade para a retirada de "cartas de habilitação", como fator condicionante para que os condutores de veículos automotores ou não - tivessem permissão para trafegarem, com os seus veículos, pelas estradas estaduais. Outro elemento que consideramos importante é o fato de que esse regulamento não se refere ao trânsito de veículos nas estradas municipais, mas, apenas, naquelas de caráter estadual, pois o artigo 46 estipula que “[...] O presente Regulamento irá sendo aplicado às diversas estradas estaduais, à proporção que o Governo for criando, nelas, postos especiais e subvertendoas ao regimento nele estabelecido" 90 . Assim, é bastante plausível considerarmos que está suficientemente justificado o baixo número de cartas extraídas para "boleeiros e cocheiros", verificado em Santa Catarina, durante os anos de 1911 e 1914.

Elementos importantes são, igualmente, apresentados pela tabela 02, que lista o "Número de cartas expedias por município no Estado de Santa Catarina”, nos anos de 1911, 1914 e 1922. Em primeiro lugar, não verificamos, para o ano de 1911, nos nove municípios listados, qualquer registro de cartas extraídas para chauffeurs. No ano de 1914, apenas os municípios de Florianópolis e Lages apresentam, respectivamente, o registro de quinze e uma cartas expedidas para os condutores de veículos motorizados. Por outro lado, é válido salientarmos que, no ano de 1922, foi expedido, para a cidade de Florianópolis, o total de vinte e oito cartas para chauffeurs e trinta e seis cartas para boleeiros e cocheiros. Outra observação relevante é, com efeito, o fato de que, no ano de 1922, foi expedida, para a cidade de Florianópolis, maior quantidade de cartas para boleeiros e cocheiros (36), em relação às extraídas para chauffeurs (28). Igualmente, é válido destacarmos que, nesse mesmo ano, o Estado de Santa Catarina contava com trinta e três municípios $^{91}$, dos quais apenas cinco apresentaram registro das cartas expedidas para chauffeurs. Desses, os municípios de Florianópolis, Joinvile e Blumenau apresentaram o maior número de registros, com, respectivamente, vinte e oito, vinte e cinco e quatorze cartas expedidas para os condutores de veículos motorizados.

\footnotetext{
${ }^{89}$ Santa Catarina. Regulamento para o serviço policial do Estado. Florianópolis: Tipografia da Livraria Central, 1920.

${ }^{90}$ Regulamento das estradas estaduais e respectivo imposto de trânsito a que se refere o Decreto n. 846, de 29 dez. 1914. In: Leis, Decretos, Resoluções e Portarias de 1914... op. cit. Além disso, é importante observarmos que o Regulamento para o serviço policial do Estado, de 1920, contempla a circulação de veículos nas ruas de caráter municipal, pois o parágrafo quinto do artigo 120, estipula que, dentre as "obrigações comuns a todos os cocheiros, carroceiros e motoristas" está a de "\# 5. - Caminhar nas ruas da cidade a trote curto, sem precipitar a carreira dos animais, nem o movimento dos carros e automóveis". (Santa Catarina. Regulamento para o serviço policial do Estado... op. cit.).

${ }^{91}$ CABRAL, Oswaldo Rodrigues. História de Santa Catarina. 4. ed. Florianópolis: Lunardelli, 1994. p. 368-373. Nesse rumo, observemos que cinco anos após, em 1927, o Estado de Santa Catarina contava com trinta e cinco municípios. Ver Santa Catarina. Relatório apresentado ao Exm. ${ }^{\circ}$ Sr. Dr. Adolfo Konder, Governador do Estado, pelo Dr. Cid Campos, Secretário do Interior e Justiça, em 24 de maio de 1928. Florianópolis: Tip. São José, 1928.
} 
Além disso, no relatório apresentado ao Governador do Estado pelo Chefe de Polícia, desembargador Sílvio de Sá Gonzaga, no ano de 1911 (ver tabela 02), não encontramos, no registro intitulado Quadro dos Individuos que tiveram carta de boleeiro a contar de 28 de setembro de 1910 a 15 de maio de 1911, nenhuma menção aos termos chauffeur ou automóvel. Assim, para o ano de 1911, não existe, de acordo com esse documento, nenhum município do Estado que apresente registro de cartas expedidas para chauffeurs. Por outro lado, no relatório apresentado ao Exmo. Sr. Secretário Geral do Estado pelo Chefe de Polícia, Ulysses Gerson Alves da Costa, no ano de 1915 (ver tabela 02), encontramos, no registro correspondente ao Quadro dos Individuos que tiraram carta de cocheiro ou chauffeur durante o ano de 1914, menção aos termos supracitados, onde constatamos, ainda, que apenas os municípios de Florianópolis e Lages apresentaram registro de expedição de cartas para chauffeurs, com, respectivamente, quinze e uma cartas extraídas, conforme se observa na tabela $02^{92}$. É curioso observarmos, também, que, ao compararmos os dados relativos aos anos de 1911, 1914 e 1922, houve, para essa última data, significativo aumento do número de cartas extraídas para chauffeurs e, especialmente, para boleeiros e cocheiros, nas três principais cidades do Estado, quais sejam: Florianópolis, Blumenau e Joinvile ${ }^{93}$. Desse modo, o número de cartas extraídas para os condutores de veículos operados com tração animal, no ano de 1922, está, inclusive, presente em todos os nove municípios listados. Acreditamos que esse aumento significativo do número de registros de habilitação se deve, especialmente, à expressa obrigatoriedade para que os condutores de veículos estivessem regularmente habilitados, conforme estipula, como visto, o artigo 113 do Regulamento para o serviço policial do Estado.

Nesse ponto, é válido esclarecermos que, durante as pesquisas para a elaboração do presente estudo, procedemos à investigação e à procura de material relativo aos registros (placas) de veículos motorizados ou operados a tração animal, e de seus respectivos proprietários - nesse caso, textos e documentos referentes aos livros de matrículas de condutores de veículos ${ }^{94}$. Essa investigação obedeceu ao período cronológico contemplado na tese (1920-1941). Para não nos alongarmos em demasia sobre as etapas e procedimentos de pesquisa do material anteriormente referido, julgamos suficiente mencionar que, nos meses de março e abril de 2007 e janeiro de 2009, procedemos à pesquisa desse material em várias instituições e órgãos do Estado de Santa

\footnotetext{
${ }^{92}$ Assim, devemos observar que já no ano de 1913 verificamos a circulação dos automóveis nas ruas do perímetro urbano da capital catarinense, pois o artigo do jornal $O$ Dia, de 11 de janeiro daquele ano, considera que "Estanislau Logowcki previne ao público que recebeu um esplêndido automóvel para trabalhar na praça, aos seguintes preços: até 5 passageiros por hora $10 \$ 000$ [dez mil réis]; volta ao morro [da Cruz] 10\$000; até a Catedral, ida e volta, 5\$000”. (Automóvel. O Dia. Florianópolis, 11 jan. 1913. p. 2).

93 Informação inferida conforme os dados apresentados pela tabela 02 , em discussão.

${ }^{94}$ No ano de 1920, foi instituído, como vimos, em Santa Catarina, o Regulamento para o Serviço Policial do Estado. Esse regulamento estipula, no artigo 118, que "Art. 118 - Na Delegacia Auxiliar de Polícia haverá um livro de matrícula de todos os condutores de veículos do Estado, que será feito conjuntamente com a expedição da carta de habilitação". (Santa Catarina. Regulamento para o serviço policial do Estado. Florianópolis: Tipografia da Livraria Central, 1920).
} 
Catarina; de sua Capital, e da cidade do Rio de Janeiro sem, contudo, obtermos êxito ${ }^{95}$. As informações obtidas nas instituições pesquisadas nos fazem crer que o material relativo aos registros de veículos automotores ou operados por tração animal, e de seus respectivos proprietários foi, provavelmente, incinerado ou extraviado, pois essas instituições não o dispõem ou, no máximo, contemplam documentação recente, datada a partir das décadas de 1970 e 1980 .

Outro elemento importante é aquele registrado pelo artigo do jornal $O$ Estado, de 18 mar. 1920, que considera que "Continua, com regularidade, o registro de carregadores e condutores de veículos. Acham-se registrados [até] agora cerca de 500 carregadores e condutores de veículos"96. Os elementos analisados, até aqui, indicam-nos, claramente, que, durante a década de 1910 e o início do decênio seguinte, o processo de introdução e circulação dos veículos motorizados pelas ruas e estradas estaduais e, especialmente, do espaço central da capital catarinense, era incipiente ${ }^{97}$. Ressaltamos, entretanto, que o artigo do jornal O Estado, referido anteriormente, salienta que o registro de carregadores e condutores de veículos "continua com regularidade". Nesse sentido, o crescimento do número de veículos de praça e de aluguel ${ }^{98}$, na cidade de Florianópolis, atestará, dentre outros fatores, a necessidade da organização do Regulamento para o serviço policial do Estado, instituído, como visto, no ano de $1920^{99}$.

\footnotetext{
${ }^{95}$ As instituições pesquisadas foram: a) Instituto de Planejamento Urbano de Florianópolis (IPUF); b) Secretaria Municipal dos Transportes e Terminais (SMTT); c) Secretaria Municipal de Urbanismo e Serviços Públicos (SUSP); d) Arquivo Público do Estado; e) Biblioteca Pública; f) Arquivo Histórico da Prefeitura Municipal de Florianópolis; g) Almoxarifado da Polícia Civil de Santa Catarina (cidade de São José - Grande Florianópolis); h) Detran (Florianópolis); e i) consulta ao site da Biblioteca Nacional (Rio de Janeiro), no qual registramos informações às seguintes Divisões: Obras Gerais; Obras Raras; Coordenadoria de Acervo Especializado; Sistema Nacional de Bibliotecas Públicas; Divisão de Informações (presta atendimento à pesquisadores, professores e estudantes que estejam vinculados à instituições de ensino e pesquisa localizadas fora do Estado do Rio de Janeiro).

${ }^{96}$ Registro de condutores de veículos. O Estado. Florianópolis, 18 mar. 1920. p. 1. Nesse ponto, é importante referenciarmos o texto de autoria de Ana Maria da Silva Moura, intitulado Cocheiros e Carroceiros: homens livres no Rio de senhores e escravos. Nesse livro, a autora analisa a dinâmica cotidiana da cidade do Rio de Janeiro durante a segunda metade do século XIX, e procura elucidar elementos que contribuíram para a gradual organização da infraestrutura urbana da capital carioca. Nesse sentido, esclarece diferenças havidas entre "carroceiro" e "cocheiro". Segundo a autora, o primeiro não tem a "[...] obrigatoriedade quanto ao quê, ao quanto, ao onde empregar seus veículos porque o patrão é ele próprio. Seus pontos de concentração e circulação são ditados pelo que lhe aparece como mais vantajoso para venda de produtos ou para pegar cargas. Tendo sua licença de carroceiro e cumprindo as regras de trânsito, condições elementares, não sofre a pressão do fiscal da freguesia como o cocheiro de aluguel, que possuí rígida regulamentação de trabalho"; "Os carroceiros são os pioneiros da formação da infra-estrutura de abastecimento e serviços urbanos por via terrestre, que vão abrir caminho e ligar os mercados da cidade". Por outro lado, os "[...] cocheiros de aluguel também participam do transporte e abastecimento da cidade, mas não ao nível individual e artesanal. No setor de abastecimento e transporte de cargas estão vinculados diretamente ao comércio [...] atacadista. A grande maioria, porém, está ligada à prestação de serviços urbanos de coches e carruagens para passageiros que, surgidos desde [a década] de 50 [do século XIX], proliferaram pelas décadas seguintes através das cocheiras de aluguel". (MOURA, Ana Maria da Silva. Cocheiros e Carroceiros: homens livres no Rio de senhores e escravos. São Paulo: Hucitec, 1988. p. 43-44 e p. 51-52. (Col. Estudos Históricos)). E possível pensarmos que essa dinâmica está presente, também, na cidade de Florianópolis, pois os carroceiros e carregadores ambulantes desempenhavam, ao que tudo indica, semelhante papel numa cidade que, até o início do século XX, não contava, como visto, com uma ligação terrestre entre Ilha e Continente. O transporte de mercadorias efetuava-se, sobretudo, por meio de carroças e bondes movidos a tração animal, guiados por carroceiros ou transportadores ambulantes. Veremos à frente e, especialmente no capítulo segundo da tese, que a figura do cocheiro integrou, também, o cotidiano da cidade de Florianópolis, dedicada, sobremaneira, ao transporte de passageiros dentro do espaço urbano da capital catarinense. Além disso, veremos também que, na cidade de Florianópolis, as atividades desempenhadas por carroceiros e cocheiros eram regulamentadas por posturas municipais ou regulamento policial.

${ }^{97}$ Nesse ponto, devemos observar, também, que, no ano de 1927, existiam, aproximadamente, 131 veículos motorizados para passageiros na cidade de Florianópolis. Esse número contempla o total de automóveis, auto-ônibus e motociclos. (IBGE. Anuário Estatístico do Brasil, ano II, Rio de Janeiro, 1936. p. 151).

${ }^{98}$ Sobre os veículos de praça e de aluguel que circulavam, por exemplo, na cidade de São Paulo, vejamos o que diz Marco Antônio Cornacioni Sávio. Assim, no livro A Modernidade Sobre Rodas: tecnologia automotiva, cultura e sociedade, o autor observa, a esse respeito, que "Havia dois tipos de serviços distintos para a utilização dos automóveis. De um lado estavam os automóveis de praça, que representavam o grosso dos chauffeurs da cidade e, de outro, os automóveis de aluguel, ligado às garagens e que serviam a um público mais requintado. O serviço, no entanto, não diferia muito entre os prestadores, o que lhes garantia um tratamento igualitário pela população". (SÁVIO, Marco Antônio Cornacioni. A Modernidade sobre Rodas. São Paulo: EDUC, 2002. p. 67). Observamos, pois, certa afinidade às ideias, expostas acima pela autora Ana Maria da Silva Moura, a respeito dos condutores e veículos que circulavam pela capital federal. Essa dinâmica também é encontrada na cidade de Florianópolis, corroborada pelo estudo aplicado aos processos criminais, disposto no transcorrer de toda a tese.

${ }^{99}$ Esse documento foi instituído no ano de 1919, pelo seguinte decreto: Decreto n. 1305, de 15 dez. 1919. Reorganizando o serviço policial do Estado e baixando regulamento para este fim. (In: Coleção de Leis, Decretos e Resoluções - 1919. Florianópolis: Imprensa Oficial, 1922. p. 94).
} 


\subsection{Os Processos Criminais em Cena 1: vivências cotidianas nas malhas do urbano}

\subsubsection{Deslocamento e Velocidade}

$\mathrm{Na}$ seção anterior, vimos que os veículos automotores representaram, durante as décadas iniciais do século passado, novos elementos que vieram integrar o contexto urbano da capital catarinense. Frente a esse quadro, discutimos, nesta seção, os seguintes questionamentos: De que maneira podemos perceber a circulação automobilística nas ruas de uma cidade de pequeno porte, como então se apresentava a capital catarinense durante as décadas de 20 e 30 do século passado? Que embates e negociações estiveram envolvidos na circulação e convivência simultânea de transeuntes, chauffeurs e veículos motorizados pelas ruas da cidade de Florianópolis? Podemos considerar que novos ritmos e deslocamentos imprimidos pela tecnologia motorizada entram em choque com antigas percepções de tempo e de velocidade expressas pela população florianopolitana da época. Esse processo ocorreu, pois, de maneira gradual e conflituosa. Nesse sentido, que disputas e sensibilidades estão envolvidas quanto à percepção da velocidade e do deslocamento expressos pela tecnologia motorizada? Como são negociadas as relações de poder que se estabelecem entre homens (transeuntes e chauffeurs) e máquinas (automóveis)? Que elementos nos fornecem os processos criminais, anteriormente referidos, para a elucidação dos questionamentos propostos?

Tentando responder a essas questões, devemos considerar que nossa incursão aos processos criminais que registram episódios de atropelamentos e colisões pelas ruas do perímetro urbano da cidade de Florianópolis inicia-se por meio da análise do processo número (n.) $30^{100}$, de 05 de março de $1923^{101}$, que registra o atropelamento do transeunte Manoel Antônio, 35 anos ${ }^{102}$. É importante considerarmos que as referências aos processos criminais atuam como pano de fundo para abordarmos assuntos e temáticas respectivas. Assim, em suas observações tomadas na abertura do inquérito policial, a vítima considera que "hoje, às treze horas", atravessava a

\footnotetext{
Com relação ao incremento, nesta época, da circulação de veículos de praça na cidade de Florianópolis, o artigo do jornal $O$ Estado, de 25 de maio de 1920, destaca que "A fim de regularizar convenientemente o movimento de veículos nesta Capital, o Sr. Capitão João de Oliveira Carvalho, baixou ontem uma resolução estabelecendo determinadas obrigações para os guias e condutores de veículos, não só quanto à velocidade com ao uso de sinais e avisos à distância". Corroborando com essas considerações, o artigo observa, à frente, que "Devido ao notável aumento do número de veículos de praça nesta Capital, esta providência já de há tempos vinha se tornando de urgente e inadiável necessidade". (Regulamentando o trânsito de Veículos. O Estado. Florianópolis, 25 maio 1920. p. 1). Esses elementos corroboram, portanto, a necessidade, já assinalada, da futura organização do Regulamento para o serviço policial do Estado.

${ }^{100}$ A numeração dos processos obedece àquela conferida pelo Tribunal de Justiça do Estado de Santa Catarina.

${ }^{101}$ As datas referem-se àquelas registradas na abertura (portaria) dos processos.

${ }^{102}$ É importante observarmos que as notas da imprensa local noticiavam, pelo menos desde o ano de 1913, acidentes e colisões envolvendo automóveis. Assim, o artigo do jornal O Dia, de 16 de março de 1913, observa que "Ontem, às sete horas e quarenta minutos da noite, quando descia da Pedra Grande, o bonde n. 18 ao chegar pelas imediações da casa [...] do Sr. Major Luiz Carvalho, chocou-se com o automóvel de propriedade do nosso amigo Júlio Nicolau de Moura, que conduzia uma família. Ao chocar-se os dois veículos, o condutor do bonde, Jacinto Ezequiel, caiu sobre os bancos, ferindo bastante o rosto, sendo o cocheiro cuspido fora do bonde, e o chauffeur sofrendo grande abalo". (Na Pedra Grande: choque de um automóvel com um bonde - condutor ferido. Grande susto. O Dia. Florianópolis, 16 mar. 1913. p. 1). Analisando essas ideias, percebemos que o acontecimento foi noticiado em primeira página. De outra forma, os termos cocheiro e chauffeur identificam, respectivamente, o condutor do bonde - operado com tração animal - e do automóvel. Observamos, também, que danos físicos foram ocasionados ao condutor do respectivo bonde. Veremos, a seguir, por ocasião da análise dos processos criminais, maiores detalhes quanto à convivência simultânea havida entre veículos, chauffeurs, passageiros e transeuntes.
} 
Praça XV de Novembro, “quando, inesperadamente, viu atrás ${ }^{103}$ de si um automóvel que subia a mesma praça", portanto "tratou de correr a fim de se livrar do carro; porém não conseguiu porque houve um choque que o atirou ao chão ferindo-lhe em diversas partes do corpo" ${ }^{\text {104 }}$. (Figura 01, p. 35 e Anexo 01, p. 332).

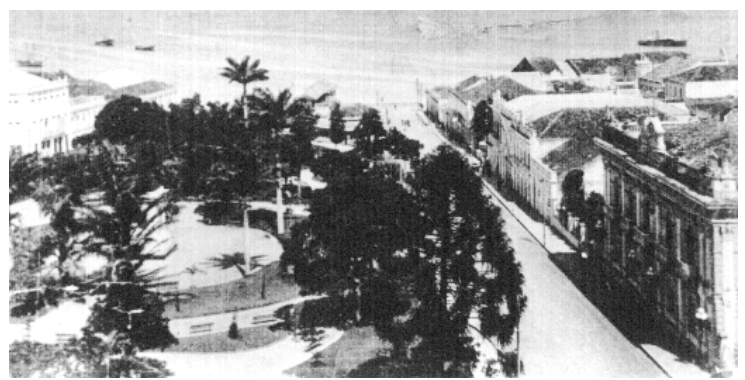

Figura 01 - Praça XV de Novembro - início do século XX. Vemos, em primeiro plano, no canto direito da ilustração, o Palácio do Governo (atual Palácio Cruz e Souza); à época, sede do governo estadual. Fonte: Banco de Imagens da Fundação Franklin Cascaes / Casa da Memória (Núcleo Audiovisual).

Dessa passagem, é relevante destacarmos que o transeunte, no momento em que percebeu a aproximação do automóvel, objetivava "correr a fim de se livrar do carro"; não obteve, entretanto, êxito porque "houve um choque que o atirou ao chão ferindo-lhe em diversas partes do corpo". Nessa situação, percebemos dois aspectos principais: a) a circulação do automóvel tornou-se preferencial e preponderante à circulação dos transeuntes. Vale observarmos que a testemunha em questão considerou como inesperada a presença do veículo motorizado que a atropelou; ou seja, nesse processo, o elemento surpresa foi, conforme relatou a vítima, representado pelo aparecimento inesperado do automóvel; aspecto este que constitui, sem dúvida, uma situação ilustrativa que permeou outros episódios de atropelamentos e colisões verificados não apenas na cidade de Florianópolis, mas também em outras cidades do país e do mundo; e b) o transeunte tenta esquivar-se do veículo que se aproxima - executa, portanto, ação de resistência frente à presença do automóvel, embora sem resultados positivos. Assim, podemos afirmar que se evidencia uma relação de poder entre a circulação automobilística e a efetuada pelos pedestres. Assim, o poder é exercido de múltiplas formas, intrínseco às sujeições que existem e funcionam no corpo social ${ }^{105}$.

É importante registrarmos que a circulação dos automóveis, nas cidades, foi alvo de regulamentações expedidas, sobretudo, pelos respectivos poderes públicos municipais e

\footnotetext{
${ }^{103}$ Optamos, neste trabalho, por proceder à atualização ortográfica dos textos de época. De maneira análoga, foram adotadas, neste texto, as normas de editoração referentes à grafia atualizada dos nomes de pessoas, publicações (livros e periódicos), ruas, edifícios, associações, etc. Apenas as fontes listadas ao final deste trabalho conservam a grafia original da época correspondente em que foram publicadas.

${ }^{104}$ Processo n. 30, 05 mar. 1923. Caixa 03.

${ }^{105}$ FOUCAULT, Michel. Microfísica do Poder. 17 ed. Rio de Janeiro: Graal, 2002. p. 181. É importante registrarmos que, conforme observa Michel Foucault, "Eu emprego muito pouco a palavra poder, e se eu o faço algumas vezes, é para abreviar a expressão que eu utilizo sempre: relações de poder". Foucault entende, portanto, o poder não como algo pronto, condicionado por "[...] uma estrutura política, um governo, ou uma classe social dominante", mas que é estabelecido nas relações humanas, "quaisquer que sejam - quer se trate de comunicar verbalmente [...] ou que se trate de relações amorosas, institucionais ou econômicas". (FOUCAULT, Michel. Sexo, Poder e Indivíduo. Florianópolis: Nefelibata, 2003. p. 70-71). O estudo genealógico do poder é operado por Michel Foucault, especialmente, a partir de publicações como Vigiar e Punir (1975); História da Sexualidade I: A vontade de saber (1976) e Microfisica do Poder (1979), quando o autor introduz, nas análises históricas, a questão do poder como um instrumento capaz de explicar a produção dos saberes. Nesse sentido, o próprio Foucault expõe que é "[...] preciso se livrar do sujeito constituinte, livrar-se do próprio sujeito, isto é, chegar a uma análise que possa dar conta da constituição do sujeito na trama histórica. É isto que eu chamaria de genealogia, isto é, uma forma de história que dê conta da constituição dos saberes, dos discursos, dos domínios de objeto, etc., sem ter que se referir a um sujeito, seja ele transcendente com relação ao campo de acontecimentos, seja perseguindo sua identidade vazia ao longo da história”. (FOUCAULT, Michel. Microfísica do Poder... op. cit., p. 07).
} 
estaduais. Essas regulamentações foram implantadas gradualmente, com o objetivo oferecer condições de tráfego aos pedestres e veículos motorizados. As ideias apontadas esclarecem que a imposição dos automóveis não impediu o exercício de resistência efetuado pelos transeuntes, pois, conforme Michel de Certeau, procedimentos minúsculos e cotidianos “[...] jogam com os mecanismos de disciplina e não se conformam com ela a não ser para alterá-los"106. Desse modo, entendemos que o processo de inserção dos veículos motorizados pelas ruas do perímetro urbano da capital catarinense e a gradativa adaptação da população florianopolitana frente a esse processo envolveram negociações e embates, nos quais, concomitante à presença e à circulação dos automóveis, encontramos registros de percepções e resistências da população florianopolitana frente a esses elementos. Assim, devemos considerar que a circulação de automóveis e transeuntes pelas ruas da capital catarinense sofre mútua influência, pois interesses diversos colocados por homens e máquinas participam, em grande medida, como elementos que determinaram as regras e normas de circulação e convivência diárias no trânsito.

O atropelamento descrito pelo processo em discussão é similar aos ocorridos em outras cidades do Estado e do País. Nicolau Sevcenko analisa, na cidade de São Paulo dos anos 1920, o pedestre em meio ao movimento incessante de veículos. Conforme as notas da imprensa da época, "No dia 31 de dezembro, às vinte horas, [...] achava-me na Praça da República e dirigiame para a Rua Sete de Abril. Quase ao entrar nesta, percebi que em minha direção se encaminhava um automóvel com bastante velocidade". Continuando seu registro, o transeunte afirma: "Tratei de desviar-me" do referido automóvel, "mas em vão, pois por todos os lados para que me encaminhava, era perseguido pelo automóvel, e por um requinte de perversidade, o chauffeur não diminuía a marcha da máquina"; e, nessa situação, viu-se "por isso forçado a correr até galgar o passeio da praça, escapando de ser colhido pelo automóvel por verdadeiro milagre". E conclui afirmando: "Quantos desastres desses não se dão nessa cidade a todo momento e que são atribuídos ao acaso, quando muitos se dão de caso pensado, por perversidade dos chauffeurs" $" 107$. As mesmas ideias são partilhadas por Le Corbusier, nas seguintes palavras:

Chega 1. ${ }^{\circ}$ de outubro. No crepúsculo das seis horas nos Champs-Élysées, foi a loucura, de repente. Depois do vazio, a retomada furiosa do trânsito. Depois cada dia acentuou ainda mais a agitação. Saímos de casa, e, passando o umbral, sem transição; eis-nos tributários da morte: os carros passam. Vinte anos atrás levam-me de volta à minha juventude de estudante; o meio da rua nos pertencia: lá cantávamos, lá conversávamos... o ônibus a cavalo circulava vagarosamente. Nesse $1 .^{\circ}$ de outubro de 1924, nos Champs-Élysées, assiste-se ao acontecimento, ao renascimento titânico dessa coisa nova, cujo ímpeto fora quebrado por três meses de férias: o trânsito. Carros e mais carros, rápido, muito rápido! Recebemos energia, seríamos tomados pelo entusiasmo, pela alegria [...] da força. O cândido e

\footnotetext{
${ }^{106}$ CERTEAU, Michel de. A invenção do cotidiano 1: artes de fazer. 8. ed. Petrópolis: Vozes, 2002. p. 41.

107 SEVCENKO, Nicolau. Orfeu extático na metrópole: São Paulo, sociedade e cultura nos frementes anos 20. São Paulo: Companhia das Letras, 1992. p. 75. Observamos ao leitor que utilizaremos apenas as ideias expressas por Sevcenko que, entendemos, estiverem em consonância aos propósitos do presente estudo. Além disso, vale lembrarmos que, para a elaboração do texto Orfeu extático na metrópole..., o autor trabalha, especialmente, com artigos do jornal $O$ Estado de São Paulo (OESP), aspecto que, entendemos, não invalida sua contribuição para as historiografias paulistana e brasileira.
} 
ingênuo gozo de estar no meio da força, do poder. O perigo agora é sentido por todos. Notemos de passagem que, em poucos anos, já esquecemos a alegria de viver (a boa alegria secular de se deixar levar tranqüilamente pelas pernas); mergulhamos numa atitude de animal acuado, do salve-se quem puder cotidiano ${ }^{108}$.

Essas citações permitem-nos considerar que chauffeurs e automóveis exerceram poder frente aos transeuntes, os quais se tornaram inferiorizados frente à imposição dos veículos motorizados. Salientamos, entretanto, que os transeuntes se utilizam de táticas, habilidades e procedimentos práticos - muitas vezes exigidos pela própria presença dos automóveis -, para se esquivarem desses veículos. Além disso, é importante considerarmos que a circulação automobilística exige a presença da figura humana (chauffeur); esse personagem adota, todavia, comportamentos e papéis muitas vezes distintos. Assim estabelecem, entre si, diferentes possibilidades de convívio dentro do cenário urbano. De outro modo, podemos referenciar que, com o incremento do transporte motorizado nas ruas e avenidas das cidades, a utilização de bicicletas, bondes e carroças obedeceu ao padrão afirmado pelos automóveis. $\mathrm{O}$ exemplo dos personagens supracitados, vítimas e testemunhas anônimas depondo em nome dos transeuntes, esclarece, no entanto, que situações aflitivas como essas se tornaram características do cotidiano para aqueles que circulavam pela cidade - como atestam, para o caso da cidade de Florianópolis, os episódios de atropelamentos e colisões relatados nos processos criminais, em análise -, o que os forçava a desenvolver, em contrapartida, uma agilidade mecânica correspondente à ameaça que os sobressaltava, como recurso compensatório e medida de defesa ${ }^{109}$.

Podemos destacar, nessa passagem, a noção de experiência referenciada por Walter Benjamin, pois é, na crítica mais radical e profunda às ilusões progressistas, que cabe analisarmos suas observações sobre o declínio da experiência no mundo moderno. Assim, a “[...] experiência (Erfahung) não se confunde para ele com a experiência vivida (Erlebnis); enquanto a primeira é um traço cultural enraizado na tradição, a segunda situa-se num nível psicológico imediato, não tendo absolutamente a mesma significação"110. A Erfahung corresponde, portanto, à experiência no sentido estrito do termo; pois, nesse caso, entram em conjunção, na memória, certos conteúdos do passado individual com outros do passado coletivo. Desse modo, os “[...] cultos, com seus cerimoniais, suas festas [...], produziam reiteradamente a fusão desses dois

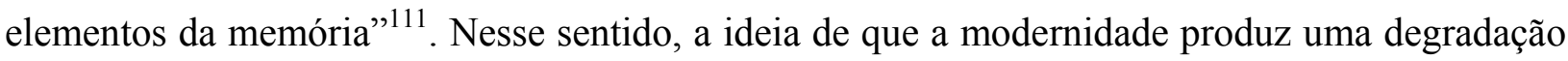
ou perda da experiência está fortemente presente nos escritos de Walter Benjamin; perda esta que está estreitamente ligada “[...] à transformação em autômato: os gestos repetitivos, mecânicos e carentes de sentido dos trabalhadores à volta com a máquina reaparecem nos gestos

\footnotetext{
${ }^{108}$ LE CORBUSIER. Urbanismo. São Paulo: Martins Fontes, 1992. p. VIII e IX.

${ }^{109}$ SEVCENKO, Nicolau. Orfeu extático na metrópole... op. cit., p. 75.

${ }^{110}$ LOWI, Michael. Redenção e Utopia: o judaísmo libertário na Europa Central. São Paulo: Companhia das Letras, 1989. p. 100.

111 BENJAMIN, Walter. Sobre alguns temas em Baudelaire. In:__. Charles Baudelaire: um lírico no auge do capitalismo. 2. ${ }^{a}$ reimpressão. São Paulo: Brasiliense, 2000. v. 3. p. 107. (Obras Escolhidas).
} 
de autômatos dos transeuntes na multidão"112. Tanto uns como outros "[...] não conhecem mais a Erfahung mas apenas a Erlebnis, e em particular a Chokerlebnis, a experiência vivida do choque, que provoca neles um comportamento reativo, de autômatos 'que liquidaram completamente sua memória' ${ }^{\natural 113}$. Enriquecendo essa análise, Walter Benjamin afirma que

\begin{abstract}
A evolução se produz em muitos setores, e fica evidente, entre outras coisas, no telefone, onde o movimento habitual da manivela do antigo aparelho cede lugar à retirada do fone do gancho. Entre os inúmeros gestos de comutar, inserir, acionar, etc., especialmente o 'click' do fotógrafo trouxe consigo muitas conseqüências. Uma pressão do dedo bastava para fixar um acontecimento por tempo ilimitado. $\mathrm{O}$ aparelho como que aplicava ao instante um choque póstumo. Paralelamente às experiências ópticas desta espécie, surgiam outras táteis, como as ocasionadas pela folha de anúncio dos jornais, e mesmo pela circulação na cidade grande. O mover-se através do tráfego implicava uma série de choques e colisões para cada indivíduo. Nos cruzamentos perigosos, inervações fazem-no estremecer em rápidas seqüências, como descargas de uma Bateria. Se em Poe, os passantes ainda lançam olhares ainda aparentemente despropositados em todas as direções ${ }^{114}$, os pedestres modernos são obrigados a fazê-lo para se orientar pelos sinais de trânsito. A técnica submeteu, assim, o sistema sensorial a um treinamento de natureza complexa. Com essas palavras obtemos uma compreensão mais nítida acerca da natureza absurda da uniformidade com que Poe pretende estigmatizar a multidão. Uniformidade da indumentária, do comportamento e, não menos importante, a uniformidade dos gestos ${ }^{115}$.
\end{abstract}

As ideias expressas esclarecem que os habitantes das grandes cidades europeias, ao tomarem contato com novas tecnologias surgidas, sobretudo, a partir do final do século XIX e início do século seguinte, são obrigados a adequar o movimento de seus corpos aos ritmos por elas impostos. A técnica condiciona o sistema sensorial do indivíduo e exige o agenciamento do olhar como elemento indissociável do viver urbano. É, portanto, “[...] evidente que o olho do habitante das metrópoles está sobrecarregado com funções de segurança", pois quem "vê sem ouvir, é muito mais... inquieto do que quem ouve sem ver. Eis algo característico da cidade grande"; e, dessa forma, as "relações recíprocas dos homens nas cidades grandes... distinguem-se

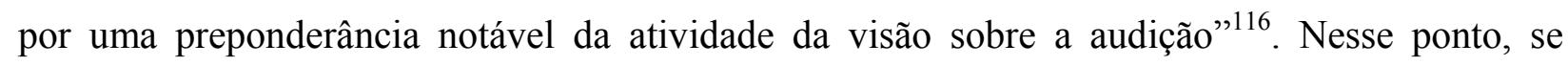
considerarmos que as imagens emergentes da mémoire involontaire se distinguem pela aura que possuem, então a fotografia - como referenciada na citação anterior - tem um papel decisivo no declínio da aura. Assim, o que "[...] torna insaciável o prazer do belo é a imagem do mundo primitivo", que Charles Baudelaire (1821-1867) chama de "velado por lágrimas de nostalgia"117; ““Ó, fostes em idos tempos / minha irmã ou minha mulher' - esta confissão de Goethe é o tributo que o belo, como tal, pode exigir", pois enquanto "a arte tiver em mira o belo e o 'reproduzir' [...], fá-lo-á ascender das profundezas do tempo"; porém na "reprodução técnica isso não mais se verifica" ${ }^{118}$. A circulação por meio do tráfego motorizado exigia, igualmente, que os transeuntes

\footnotetext{
${ }^{112}$ LOWI, Michael. Redenção e Utopia: o judaísmo libertário na Europa Central. São Paulo: Companhia das Letras, 1989. p. 100.

${ }^{113}$ Idem.

${ }^{114}$ Walter Benjamin se refere ao texto $O$ homem na multidão, de autoria de Edgard Allan Poe. Ver POE, Edgard Allan. O homem na multidão. Disponível em: $<$ http://www.alfredo-braga.pro.br/biblioteca/homemnamultidao.html $>$.

${ }^{115}$ BENJAMIN, Walter. Sobre alguns temas em Baudelaire. In:

São Paulo: Brasiliense, 2000. v. 3. p. 124-125. (Obras Escolhidas).

${ }^{116}$ Ibidem, p. 142.

${ }^{117}$ Ibidem, p. 139.

${ }^{118}$ BENJAMIN, W. "Sobre alguns temas em Baudelaire". In: . Charles Baudelaire: um lírico no auge do capitalismo. 2. ' reimpressão. . Charles Baudelaire: um lírico no auge do capitalismo... op. cit., p. 139.
} 
se comportassem, em diversas situações cotidianas, como indivíduos autômatos, pois “[...] o mover-se através do tráfego implicava uma série de choques e colisões para cada indivíduo".

Esses aspectos são, igualmente, vivenciados pelos florianopolitanos ao circularem cotidianamente pelas ruas do perímetro urbano da capital catarinense, durante as décadas de 20 e 30 do século passado. É esse, precisamente, o aspecto que verificamos em muitas situações de atropelamentos e colisões apresentadas pelos processos criminais e demais fontes pesquisadas neste estudo. É importante observarmos que o trecho do processo n. 30, citado anteriormente, está intimamente relacionado às ideias expostas acima, pois o que percebemos é que a vítima de atropelamento, Manoel Antônio, defronta-se com o automóvel ao mesmo tempo como sujeito e objeto, e sofre integralmente as investidas operadas por esse veículo. Por outro lado, devemos lembrar que, para os efeitos deste estudo, a circulação simultânea de pedestres e automóveis pelas ruas da capital catarinense é entendida como um processo que apresenta mútua influência de ambos os lados, pois os indivíduos que transitam a pé pelo perímetro urbano de Florianópolis trilham itinerários e esboçam gestos próprios, muitas vezes condicionantes das atitudes dos chauffeurs ao conduzirem os veículos motorizados. Chauffeurs e pedestres são, portanto, personagens que integram o mesmo espaço urbano, desempenham nele diferentes papéis que apontam para um saber-fazer que sinaliza sua apropriação ${ }^{119}$; mas, em diversas circunstâncias colocadas pelo cotidiano, são obrigados a negociar estratégias e posturas comportamentais que tornem possível sua mútua convivência dentro do espaço representado pela urbe.

Outro cenário igualmente interessante para os propósitos do presente texto nos é apresentado pelas ideias expostas no processo n. 52, datado de 05 de novembro de 1925 , que referenciam o desastre sofrido pelo automóvel n. 86, guiado pelo chauffeur amador Max Muller, 25 anos, ocorrido na Avenida Hercílio Luz. O acusado registra o episódio da seguinte maneira: ${ }^{120}$ "no dia cinco do corrente, às onze horas da manhã, foi ao ponto dos automóveis e tomou o auto n. 86 para ir ao Tiro Alemão" ${ }^{\prime 12}$. Nessa ocasião, Max Muller encontra no ponto de automóveis da Capital, seu amigo Hans Lepell e o convida para acompanhá-1o ${ }^{122}$; entretanto, “após ter saído do Tiro Alemão"123, Max Muller "encontra na rua Blumenau ${ }^{124}$ o seu amigo Emílio Brosig que, nessa ocasião, guiava o auto n. 102; dali, saíram ambos e, ao passarem pela Avenida Hercílio Luz, o [acusado] notou um forte estampido, tendo nesta ocasião [manobrado] a

\footnotetext{
${ }^{119}$ CERTEAU, Michel de; GIARD, Luce; MAYOL, Pierre. A invenção do cotidiano 2: morar, cozinhar. 5. ed. Petrópolis: Vozes, 2003. p. 55. ${ }^{120} \mathrm{O}$ "Auto de perguntas e declarações" prestadas por Max Muller foi formulado no dia 09 de novembro de 1925.

${ }^{121}$ Processo n. 52, 05 nov. 1925. Caixa 05. Na antiga rua José Veiga, atual Avenida Mauro Ramos, existiam, à época, pelo menos três entidades importantes, quais sejam: a) o Schützenerein Zu Florianópolis, vulgarmente chamado "Sociedade dos Atiradores do Tiro Alemão"; b) o Tiro de Guerra 40, formado por futuros reservistas do exército nacional, e c) a associação filantrópica Asilo de Mendicidade Irmão Joaquim. Ver, a respeito, SILVA, Adolfo Nicolich. Ruas de Florianópolis: resenha histórica. Florianópolis: Fundação Franklin Cascaes, 1999 . p. 112.

${ }_{122}$ Processo n. 52, 05 nov. 1925. Caixa 05.

${ }^{123} \mathrm{O}$ desastre aconteceu quando o chauffeur amador Max Muller e os demais ocupantes do veículo sinistrado saíram do Tiro Alemão, e, tomando o veículo n. 86, percorreram algumas ruas até que houve o acidente, ocorrido na Avenida Hercílio Luz.

${ }^{124}$ A rua Blumenau corresponde à atual rua Victor Konder. SILVA, A. Nicolich. Ruas de Florianópolis: resenha histórica ... op. cit., p. 135.
} 
direção do auto, virando em seguida"125. Continuando com suas declarações, o acusado afirma que "só soube saírem feridos Hans Lepell e Jorge Sandmann ${ }^{126}$ após ir ao Hospital de Caridade, pois não viu [o que aconteceu após o incidente] porque estava sem sentidos devido ao abalo produzido pelo desastre" ${ }^{\text {,127. }}$.

Nesse ponto, salientamos que a condução de veículos motorizados exige adaptações sensoriais e percepções mais apuradas - comparando-se com aquelas exigidas pela condução dos veículos tracionados por força motriz animal - sobre o meio circundante. Os automóveis igualmente proporcionam maior isolamento dos chauffeurs e passageiros frente ao ambiente externo. Choques e colisões automobilísticas ocasionavam, em certas situações - conforme atesta o exemplo registrado pelo processo em discussão -, graves ferimentos a passageiros e transeuntes, ou mesmo o falecimento destes. A condução da tecnologia motorizada assume, portanto, certo grau de frieza e impessoalidade, pois coloca, lado a lado, máquinas e homens.

Por outro lado, devemos avaliar, também, a postura dos chauffeurs ao guiarem os veículos motorizados, ou seja, a figura humana - como agente acionador da máquina - também exerce um papel importante para a coibição ou não de acidentes ou colisões, embora devamos lembrar que o automóvel era um elemento que estava sendo gradualmente inserido na cidade de Florianópolis e, ao representar uma nova tecnologia, exercia fascínio e sedução para aqueles que o dirigiam, os quais fomentavam conduções em alta velocidade ou performance em pleno perímetro urbano - como veremos, com maior riqueza de detalhes, logo a seguir.

O papel do transeunte também merece destaque no cenário urbano, pois, para os efeitos deste estudo, representa o personagem que circula a pé pelas ruas do perímetro urbano da cidade de Florianópolis. Nesse sentido, podemos considerar - parafraseando Freud e Benjamin - que para "[...] o organismo vivo [- no caso aqui considerado, o transeunte -], proteger-se contra os estímulos é uma função quase mais importante do que recebê-los: o organismo está dotado de reservas de energias próprias e, acima de tudo, deve estar empenhado em preservar as formas específicas de conversão de energia nele operantes contra a influência uniformizante e, por conseguinte, das imensas energias ativas no exterior" ${ }^{\prime 28}$. Assim salientamos, uma vez mais, que os transeuntes não estão colocados como agentes passivos no cenário urbano, prontos para

\footnotetext{
${ }^{125}$ Processo n. 52, 05 nov. 1925. Caixa 05. É importante observarmos que Max Muller assumiu o volante do automóvel n. 86 “próximo ao Teatro Álvaro de Carvalho", no percurso de ida ao Tiro Alemão. Essa informação é confirmada no "Auto de perguntas e declarações” prestado por Hans Lepell, passageiro do mesmo automóvel, no dia 19 de novembro de 1925. Processo n. 52, 05 nov. 1925. Caixa 05.

${ }^{126}$ Jorge Sandmann é chauffeur profissional, proprietário do automóvel n. 86, e falece no Hospital de Caridade no mesmo dia do sinistro, em decorrência dos ferimentos que recebeu por ocasião do desastre. Curioso, portanto, é o fato de que em nenhuma das passagens do referido processo é identificada, claramente, a natureza do automóvel n. 86 - se estritamente particular, de praça ou de aluguel. Pelos dados apontados no processo, inferimos, porém, que tal veículo era de praça. Por outro lado, os registros processuais analisados neste estudo apontam que apenas os indivíduos de muito boa condição financeira adquiriam automóveis particulares e dispunham de chauffeurs para servir-lhes - ver, também, neste capítulo, seção Aquisição e Recursos.

${ }^{127}$ Processo n. 52, 05 nov. 1925. Caixa 05.

${ }^{128}$ Freud, Sigmund. Jenseits dês Lustprinzips (3. ed. Viena, 1923. p. 34s) apud BENJAMIN, Walter. Sobre alguns temas em Baudelaire. In: . Charles Baudelaire: um lírico no auge do capitalismo. 2. ${ }^{a}$ reimpressão. São Paulo: Brasiliense, 2000. v. 3. p. 109. (Obras Escolhidas).
} 
receber choques provocados por máquinas e veículos; mas, ao contrário, operam resistências minúsculas e silenciosas - ditadas pelas circunstâncias impostas pelo cotidiano, que lhes permitem negociar espaços e locais próprios, dentro do espaço meio urbano de Florianópolis ${ }^{129}$.

Os atropelamentos e colisões ocorridos nas ruas da capital catarinense eram noticiados, com certa frequência, pelos registros jornalísticos locais ${ }^{130}$. O artigo do jornal $O$ Estado, de 05 de novembro de 1925, registra o sinistro em questão, confirmando o que foi declarado pelas palavras prestadas pelo acusado e, igualmente, fornece esclarecimentos sobre o ocorrido:

Hoje, às doze horas, mais ou menos, deu-se na rua José Veiga, nesta cidade, um lamentável desastre de automóvel, ao qual resultou a morte de uma pessoa, saindo duas outras feridas. Àquela hora, subiam a rua José Veiga, em direção à Pedra Grande, os carros n. 102 (guiado pelo chauffeur Emílio Brosig) e n. 86 (guiado pelo chauffeur Max Müller). Neste último carro, ao lado do chauffeur Müller, ia o proprietário do referido automóvel, Sr. Jorge Sandmann e mais um passageiro de nome Hans Lepell, natural de Hamburgo. Ambos os carros iam com regular velocidade ${ }^{131}$ e, a certa altura, antes de fazer a curva no trecho final da Av. Hercílio Luz, o Sr. Emílio Brosig, que ia guiando o automóvel 102, ouviu um estampido seco. Imediatamente brecou o seu carro e viu que o auto 86 tinha virado. Emílio Brosig correu para o local do desastre e encontrou o carro n. 86 sem a pneumática de uma das rodas traseiras e meio tombado. O chauffeur Max Müller estava [...] desacordado e Jorge Sandmann havia sido projetado para fora do carro, muito ferido, em estado grave, estando também ferido Hans Lepell. Tomadas as primeiras providências, foram Jorge Sandmann e Hans Lepell conduzidos para o Hospital de Caridade, onde Jorge veio a falecer momentos depois. A polícia abriu inquérito, ouvindo o chauffeur do carro n. 102, Emílio Brosig, deixando de inquirir o Sr. Max Müller, por estar este completamente perturbado e incapaz de poder adiantar quaisquer declarações no momento ${ }^{132}$.

Os registros destacam que os veículos envolvidos no desastre imprimiam "regular velocidade". É importante salientarmos que os casos de atropelamentos e colisões, verificados nos processos criminais, registram, com certa frequência, as altas velocidades atingidas pelos automóveis. A circulação dos veículos motorizados, especialmente durante as primeiras décadas do século XX, foi operada, muitas vezes, como forma de ostentação e poder. Os chauffeurs eram, em sua maioria, jovens - como exemplifica o processo em questão -; eram, portanto, mais facilmente propícios a ceder aos apelos propagandísticos que difundiam as ideias de conforto e velocidade proporcionada pelos veículos motorizados. Frente ao exposto, é importante esclarecermos que, durante as décadas de 1920 e 1930, os chauffeurs eram, de fato, indivíduos muito jovens. Vale destacarmos que, do total de onze processos analisados para a década de 1920 - ver, deste capítulo, nota 84 -, nada menos que nove documentos envolvem veículos motorizados conduzidos por chauffeurs com idades igual ou menor do que 25 anos. (Ver Anexo 20, p. 351). Entendemos, pois, que esses dados não são suficientes para estabelecermos uma

\footnotetext{
${ }^{129}$ CERTEAU, Michel de. A invenção do cotidiano 1: artes de fazer. 8. ed. Petrópolis: Vozes, 2002. p. 102.

130 É importante observarmos que, na presente tese, são analisados dezoito processos criminais. Desses, encontramos oito episódios de atropelamentos ou colisões referenciados na imprensa local, conforme pesquisa realizada nos artigos jornalísticos disponíveis na Biblioteca Pública do Estado, o que estabelece o percentual de 44,4\%. Aspecto curioso é o fato de que, em 1926, ano de inauguração da Ponte Hercílio Luz, verificamos o maior número de registros de ocorrências de atropelamentos e colisões, perfazendo o total de três artigos encontrados.

${ }^{131}$ Essa informação foi confirmada pelo acusado Max Muller, pois, em suas declarações datadas de 09 de novembro de 1925 , ele afirma que os dois automóveis "vinham em marcha regular". (Processo n. 52, 05 nov. 1925. Caixa 05). Nesse caso, é coerente pensarmos que Max Muller possivelmente orientado pela figura de seu advogado - alegou ser regular a velocidade de ambos os automóveis, pois ele objetivava sua absolvição junto ao processo criminal contra ele movido.

${ }^{132}$ Desastre de automóvel: o carro 86 virou. O Estado. Florianópolis, 05 nov. 1925. p. 1.
} 
estatística aproximada do percentual de jovens chauffeurs que, à época, conduziam veículos motorizados, mas sinalizam, sem dúvida, uma tendência que observamos durante as décadas de 1920 e 1930, uma vez que o automóvel constitui, nesse período, um elemento novo no meio urbano de Florianópolis - se comparado à circulação dos carros tracionados por força motriz animal: bondes, carroças, tílburys - e, como tal, era guiado, em sua maioria, por indivíduos de pouca idade, e que, em certos casos, estavam aprendendo a guiar e tomar conhecimento da tecnologia motorizada.

Os automóveis configuravam novos ingredientes do ambiente urbano e, desse modo, fascinavam aqueles que podiam adquiri-los ou guiá-los. Nesse sentido, Emílio Brosig ${ }^{133}$, chauffeur do automóvel n. 102, afirma que o veículo n. 86 imprimia, no momento do desastre, alta velocidade; pois, "ao passar pela Avenida Hercílio Luz guiando o automóvel particular n. 102, de propriedade do senhor Jorge Boetter ${ }^{134}$, isto hoje, pelas onze horas da manhã”, observou "que atrás vinha em vertiginosa velocidade pela mesma avenida o auto $\mathrm{n}$. 86, de propriedade do senhor Jorge Sandmann, guiado pelo senhor Max Muller, que vinha ao lado daquele"135. Continuando seu depoimento, Emílio Brosig reafirma o que foi anteriormente declarado, pois salienta que o chauffeur Max Muller, "tentando passar pela sua frente", foi, "em dado momento, com a corrida que vinha, ido de encontro ao meio-fio virando o referido veículo, que ficou completamente avariado"136. (Anexo 02, p. 333).

Por meio das informações apontadas no processo, entendemos ser plausível argumentar que o chauffeur Max Muller imprimia, no momento do ocorrido, considerável velocidade ao automóvel n. 86 - devemos sublinhar que a noção de velocidade é, em síntese, uma construção discursiva e, como tal, depende da ótica ou da intenção de quem a ela se refere -, pois a gravidade do desastre resultou no falecimento do passageiro Jorge Sandmann, uma vez que, de acordo com Emílio Brosig, ele, após o incidente, parou “o seu automóvel” e, se dirigindo ao local do desastre, observou que se achavam feridos os indivíduos de nome Hans Lepell, Jorge Sandmann e o chauffeur Max Muller ${ }^{137}$. Desse modo, eles "foram imediatamente conduzidos no seu auto para o Hospital de Caridade ${ }^{138}$ e, logo que chegaram nesse hospital, veio a falecer,

\footnotetext{
${ }^{133}$ Emílio Brosig é solteiro e tem vinte anos de idade. Confirmamos, novamente, a tendência de que, nas décadas iniciais do século XX, os chauffeurs eram, em sua maioria, jovens.

${ }^{134}$ Nesse ponto, é válido destacarmos o registro da testemunha Aristides de Aguiar Júnior, 34 anos, Cabo do Batalhão da Força Pública do Estado, pois a mesma afirma, no dia 07 de novembro de 1925, que Emílio Brosig é "chauffeur amador". Além disso, a identificação da testemunha Emílio Brosig, por ocasião de seu depoimento prestado no dia 21 de janeiro de 1926, registra que esta tem "20 anos de idade", é "solteiro" e "empregado no comércio". (Processo n. 52, 05 nov. 1925. Caixa 05). Ele guiava, como visto, o automóvel n. 102, de propriedade de Jorge Boetter, ou seja, existiam indivíduos de considerável situação financeira, proprietários de automóveis, que dispunham de chauffeurs amadores para conduzirem os seus veículos - ver, a respeito, neste capítulo, seções Aquisição e Recursos e Diversificação e Propriedade.

${ }^{135}$ Processo n. 52, 05 nov. 1925. Caixa 05.

${ }^{136}$ Idem.

${ }^{137}$ Idem.

${ }^{138}$ A testemunha Aristides de Aguiar Júnior, Cabo da Força Pública do Estado, afirma que o chauffeur Emílio Brosig “conduziu os feridos” para a Delegacia de Florianópolis, e "daquela para o Hospital de Caridade"; e "soube meia hora depois deste fato que Jorge Sandmann veio a falecer em consequência dos ferimentos recebidos, tendo os outros dois [indivíduos] ficado em tratamento, um no Hospital de Caridade e o outro em sua residência”. (Processo n. 52, 05 nov. 1925. Caixa 05). Tais aspectos são confirmados por Hans Lepell, passageiro do automóvel n. 86.
} 
vítima do desastre, o proprietário do auto n. 86, de nome Jorge Sandmann" ${ }^{\text {139 }}$. Esses aspectos concordam com o parágrafo sétimo do artigo 121 do Regulamento para o serviço policial do Estado, o qual registra que, dentre "Art. 121 - As obrigações especiais dos cocheiros e motoristas, de carros e automóveis de praça”, eles devem “\# 7. - Participar incontinente ao delegado auxiliar ou a quem estiver no serviço na delegacia, o transporte de pessoas enfermas, a fim de serem aplicadas as medidas higiênicas que no caso couberem"140.

Assim, podemos referenciar, ao que tudo indica, que os chauffeurs ou condutores de veículos e/ou automóveis procediam, em determinadas ocasiões, de maneira coerente às normas disciplinares de trânsito. Veremos, contudo, que as transgressões e as desobediências a tais normas também faziam parte do cotidiano para aqueles que circulavam pelas ruas da capital catarinense, durante as primeiras décadas do século XX. Desse modo, a circulação e a convivência simultânea de veículos e transeuntes, operadas nas ruas da cidade de Florianópolis, configuravam processos complexos que envolviam, a todo o momento, obediências e transgressões às normas disciplinares de trânsito. Dado o exposto, podemos considerar que aqueles que circulam cotidianamente pela cidade de Florianópolis - sejam eles chauffeurs, passageiros ou transeuntes - utilizam e/ou reapropriam, muitas vezes, os códigos e referências urbanas locais de acordo com seus desejos e necessidades específicos. Os pedestres, de maneira especial, utilizam-se das ruas para fazer "caminhar as florestas de seus desejos e interesses"141, pois as ordenações urbanas vigentes - expressas, por exemplo, em códigos ou leis de trânsito perfiguram um conjunto de imposições estimuladoras das invenções e improvisações operadas na esfera cotidiana da urbe ${ }^{142}$. Devemos, então, observar que Michel de Certeau trabalha com a noção de homem ordinário ${ }^{143}$, personagem que escapa silenciosamente às ordenações legais reinantes em determinado tempo e lugar. Essa figura inventa o cotidiano, operando astúcias e táticas de resistência, pelas quais altera os objetos e os códigos sociais e, igualmente, reapropria o espaço e os costumes a seu jeito.

A velocidade de deslocamento dos automóveis envolvidos no desastre é referenciada pelas palavras do Primeiro Sargento do Segundo Batalhão de Infantaria da Força Pública do Estado, Elzínio Maurício Wanderley, expressas no dia do sinistro, pois afirma que, no dia do ocorrido, "estava em sua casa [quando] ouviu um estampido, e chegando à janela para verificar do que se tratava, viu o automóvel n. 86 que se achava virado" "144. A presente testemunha se dirigiu ao local do acidente e, naquele instante, "viu o chauffeur e proprietário do referido automóvel que

\footnotetext{
${ }^{139}$ Processo n. 52, 05 nov. 1925. Caixa 05.

${ }^{140}$ Santa Catarina. Regulamento para o serviço policial do Estado. Florianópolis: Tipografia da Livraria Central, 1920.

${ }^{141}$ CERTEAU, Michel de. A invenção do cotidiano 1: artes de fazer. 8. ed. Petrópolis: Vozes, 2002. p. 49-50.

142 Ibidem, p. 50.

${ }^{143}$ Ibidem, p. 57.

${ }^{144}$ Processo n. 52, 05 nov. 1925. Caixa 05.
} 
estava caído, gravemente ferido, bem como o chauffeur chamado Max Müller e o passageiro Hans Lepell, que também saíram gravemente feridos"145. Prosseguindo com suas considerações, a testemunha afirma que "soube que os referidos automóveis vinham com excesso de velocidade, supondo [...] que este desastre fosse devido à velocidade que os mesmos traziam" "146 - a noção de velocidade aqui mencionada não deve ser entendida como aspecto comprobatório ou verídico, mas tão somente como elemento referencial.

Essa testemunha registra, em novas declarações prestadas no dia 26 de dezembro de 1925 , outros detalhes sobre o ocorrido, pois aponta que, "por ocasião do desastre", estava em casa, quando foi "chamado por uma senhora que morava em sua companhia que lhe informou haver se dado um desastre de automóvel nas proximidades", e "ao sair viu [um] chauffeur caído sobre o guidão do automóvel, ferido, e outro que lhe disseram ser dono do automóvel, caído no chão, gravemente ferido" 147 . Nesse ponto, percebemos que os chauffeurs e os passageiros dos automóveis também eram colocados, em certas situações, em posição de desvantagem frente à circulação imprimida pelos automóveis. O choque sofrido pelo automóvel em questão resultou nos ferimentos apresentados pelo passageiro, Hans Lepell, e pelos chauffeurs Max Muller e Jorge Sandmann - o primeiro, condutor do veículo; e o segundo, o proprietário, que faleceu, como vimos, momentos depois, no Hospital de Caridade.

$\mathrm{O}$ estudo das relações de poder que se estabelecem entre pedestres e veículos motorizados ou entre estes e os chauffeurs e passageiros que neles circulam envolve, naturalmente, a velocidade de deslocamento dos automóveis ${ }^{148}$; e devemos considerar, uma vez mais, que o poder está em todos os lugares, difundido e enraizado em toda e qualquer atividade humana ${ }^{149}$. Por outro lado, devemos entender o poder não como elemento de dominação global ou centralizada, que se difunde pelos diversos setores da vida social de modo homogêneo, mas que

\footnotetext{
${ }^{145}$ Processo n. 52, 05 nov. 1925. Caixa 05.

${ }^{146}$ Idem.

${ }^{147}$ Idem.

${ }^{148}$ Em depoimento prestado no dia 26 de dezembro de 1925, a testemunha Aristides de Aguiar Júnior afirma que "voltando do Quartel onde estivera de serviço, passando pela Avenida Hercílio Luz, encontrou-se com o Sargento Wanderley, que lhe determinou tomasse conta de uns civis que se achavam feridos, [vítimas de um] desastre de automóvel; [e] dirigindo-se ao local viu o automóvel n. 86 quebrado e duas pessoas feridas e ensangüentadas, e viu outra que lhe parecia também ferida, estando todas rodeadas de muitos populares". Além disso, a testemunha afirma, no mesmo depoimento, que "ouviu dizer que o automóvel vinha em grande disparada e que tinha havido um esbarro". Ainda em outra passagem desse depoimento, Aristides de Aguiar Jr. afirma, em resposta ao Promotor Público, que "ignora que o chauffeur [Max Muller] e os passageiros do auto viessem embriagados, e que ignora que o acusado presente tenha carta de chauffeur visada pela Polícia". (Processo n. 52, 05 nov. 1925. Caixa 05). No dia 13 de fevereiro de 1926, o Capitão Delegado de Polícia de Florianópolis, Cantídio Quintino Régis, assina o ofício n. 36, em reposta ao documento anterior, de autoria do Juiz da Segunda Vara da Capital. Esse ofício registra que, "Em resposta ao seu ofício de ontem datado, sob n. 15, tenho a informar-lhe que Max Müller é chauffeur desde 25 de outubro de 1923, data essa que fez exame". (Processo n. 52, 05 nov. 1925. Caixa 05). Isso confirma, claramente, que Max Muller tinha carta de chauffeur há, pelo menos, dois anos. O acusado tinha, à época em que tirou a sua habilitação, 23 anos de idade, fato que corrobora com a tendência de que os chauffeurs eram indivíduos jovens. Outro aspecto importante é o fato de que a testemunha Aristides de Aguiar Júnior "ouviu dizer que o automóvel vinha em grande disparada", ou seja, podemos considerar que as pessoas que estavam presentes ao ocorrido informaram à referida testemunha que o chauffeur Max Muller imprimia alta velocidade ao automóvel n. 86. Isso sinaliza para o fato de que o ato de "ouvir" sobre as ocorrências de atropelamentos e colisões desempenhava um papel importante como forma de se obter informações sobre os sinistros, servindo, inclusive, de instrumento de contribuição para a abertura de inquéritos policiais, que serviriam à apuração dos aspectos envolvidos nos episódios de atropelamentos e colisões verificados no espaço central da Capital (vimos que o artigo do jornal $O$ Estado, de 05 de novembro de 1925, confirma a abertura de inquérito policial para a presente ocorrência de atropelamento). Outras informações quanto ao papel pedagógico embutido nas falas das testemunhas e no transcorrer de inquéritos e processos criminais, serão encontradas no quarto capítulo da tese, intitulado Os Processos Criminais em Cena 4: pedagogia e punição.

${ }^{149}$ FOUCAULT, Michel. Microfísica do Poder. 17 ed. Rio de Janeiro: Graal, 2002. p. 142.
} 
possui uma existência própria e formas específicas ao nível mais elementar. Os atropelamentos e encontros existentes entre automóveis e transeuntes, verificados cotidianamente em Florianópolis, envolvem, claramente, uma relação de poder, pois concordamos com a ideia de que o poder não está localizado em nenhum ponto específico da vida cotidiana, mas funciona como uma rede de dispositivos a que nada ou ninguém escapa, pois não existe exterior possível $^{150}$.

Desse modo, a análise dos episódios de atropelamentos verificada até o presente momento, sinalizando a mútua circulação entre pedestres e veículos motorizados pelas ruas do espaço central da cidade de Florianópolis, permite-nos considerar que o poder se expande por toda a sociedade, assume as formas mais regionais e particulares e toma corpo em técnicas de dominação específicas. A natureza do poder, aqui discutida, intervém de maneira direta na esfera cotidiana dos habitantes da capital catarinense, pois atinge a esfera mais concreta desses indivíduos - o seu corpo - e, dessa forma, situa-se ao nível do próprio corpo social, uma vez que penetra na vida cotidiana. Desse modo, o poder é operado nos espaços microssociais; espaços estes que apenas podem ser observados ao estudarmos determinado contexto espacial e sociocultural no que tange aos aspectos individual e particular ${ }^{151}$.

Os episódios de atropelamentos e colisões analisados até aqui salientam, também, que os passageiros dos automóveis e, especialmente, os transeuntes, utilizam-se de suas percepções físicas para se esquivarem ou se protegerem da circulação automobilística verificada nas ruas da capital catarinense. Desse modo, podemos considerar que essa circulação não coloca face a face nem homens nem leis naturais, mas sistemas de forças naturais humanizadas pela intenção dos motoristas, e homens transformados em forças naturais pela energia física da qual eles se tornam os mediadores $^{152}$. Evidenciamos que não se trata, portanto, da operação de um agente - o veículo motorizado - sobre um objeto inerte e indefeso - o transeunte ou passageiro -, pois automóveis e pedestres estabelecem, entre si, uma relação de mútua influência: aqueles circulando, preferencialmente, nas ruas e avenidas da cidade de Florianópolis, e operando, muitas vezes, investidas frente à circulação dos transeuntes; e estes utilizando-se de táticas e estratégias para sobreviverem ilesos, ou com leves danos físicos, por ocasião das investidas dos automóveis.

\footnotetext{
${ }^{150}$ MACHADO, Roberto. Introdução: Por uma genealogia do poder. In: FOUCAULT, Michel. Microfísica do Poder. 17 ed. Rio de Janeiro: Graal, 2002. p XIV

${ }^{151}$ É pertinente esclarecermos que não se pretende elaborar um estudo especificamente micro-histórico. Algumas características dessa corrente historiográfica são, no entanto, apropriadas para a confecção da presente investigação, pois a micro-história dedica-se, como visto, à análise dos "pequenos enredos", dos "personagens anônimos" e dos "aspectos cotidianos das sociedades passadas". (VAINFAS, Ronaldo. Os protagonistas anônimos da história: micro-história. Rio de Janeiro: Campus, 2002. p. 13). Sobre maiores esclarecimentos quanto às especificidades e características da corrente micro-histórica, ver a) REVEL, Jacques. Microanálise e construção do social. In: _. Jogos de escalas: a experiência da microanálise. Rio de Janeiro: FGV, 1998. p. 15-38; b) CERUTTI, Simona. Processo e experiência: indivíduos, grupos e identidades em Turim no século XVII. In: REVEL, Jacques. Jogos de Escalas: a experiência da microanálise... op. cit., p. 173-201; c) A História ao rés-do-chão (Prefácio). In: LEVI, Giovanni. A herança imaterial: carreira de um exorcista no século XVII. Rio de Janeiro: Civilização Brasileira, 2000. p. 7-37; d) LIMA, Henrique Espada. A micro-história italiana: Escalas, Indícios e Singularidades. 1. ed. Rio de Janeiro: Civilização Brasileira, 2006.

${ }^{152}$ LATOUR, Bruno. Jamais fomos modernos: ensaio de antropologia simétrica. Rio de Janeiro: Ed. 34, 1994. p. 54-55.
} 
No ano de inauguração da ponte Hercílio Luz (1926), o processo n. 95, de 05 de julho, registra, nessa data, a colisão ocorrida entre o automóvel n. 32, guiado pelo chauffeur Aniceto Machado de Souza, e o carro de praça conduzido pelo boleeiro Onofre de Aquino, na esquina da Avenida Rio Branco com a rua Esteves Júnior. As declarações prestadas pelo acusado, Aniceto Machado de Souza, 25 anos, atestam que, "hoje, pelas dezenove horas subia a rua Esteves Júnior guiando o automóvel 132, pois estava fazendo um frete com os seus colegas chauffeurs, Clemente Rovere, José Soares, Euclydes de Souza e Izidoro de Souza"153. O veículo em questão se deslocava à "velocidade de trinta quilômetros a hora" e "ao chegar à esquina da Avenida Rio Branco encontrou o carro de praça conduzido pelo boleeiro Onofre de Aquino; que desse encontro resultou ter o seu automóvel quebrado a lança do referido carro e a cabeça de um dos cavalos" "154. Em consequência desse choque, o automóvel 132 "virou, ficando completamente quebrado, [em vista disso,] os passageiros Euclydes de Souza e Izidoro de Souza, receberam graves ferimentos na cabeça e foram levados para o Hospital de Caridade, onde se acham" ${ }^{\prime 155}$. Nesse depoimento, o acusado afirma, também, que "antes de chegar à referida esquina da Avenida Rio Branco, não fonfonou, não tendo o referido boleeiro também fonfonado; que é chauffeur e fez exame nesta delegacia de polícia em 24 de dezembro de $1925^{\prime 156}$. Tais aspectos são confirmados pela testemunha Clemente Rovere, passageira do referido auto, que no dia 05 de julho, observa que "o chauffeur Aniceto Machado, que guiava o automóvel, ao chegar à esquina não fonfonou, mas também não ouviu se o boleeiro fez o mesmo" ${ }^{\text {"157. }}$.

Do exposto, destacamos aspectos importantes: a) o veículo guiado pelo chauffeur Aniceto Machado de Souza é de praça, "pois estava fazendo um frete como os seus colegas", e o condutor exerce a profissão de chauffeur, regularmente matriculado desde 24 de dezembro de 1925; b) o referido chauffeur tem a idade de 25 anos. Esse fato atesta, novamente, a ideia de que, nas décadas de 1920 e 1930, os chauffeurs eram, em sua maioria, indivíduos jovens, e, em muitos casos, estavam aprendendo a dirigir ou eram habilitados há pouco tempo ${ }^{158}$; c) o automóvel 132, "ao chegar à esquina da Avenida Rio Branco", chocou-se com "o carro de praça conduzido pelo boleeiro Onofre de Aquino"; e "desse encontro resultou ter o seu automóvel quebrado a lança do referido carro e a cabeça de um dos cavalos". Nesse ponto, percebemos, claramente, que se estabelece uma nítida diferenciação entre "automóvel" e "carro": aquele operado com tração mecânica, conduzida pelo chauffeur; e este movido com tração animal, conduzido pela figura do boleeiro (Figuras 02 e 03, p. 47); d) outro ponto que devemos destacar

\footnotetext{
${ }^{153}$ Processo n. 95, 05 jul. 1926. Caixa 09.

${ }_{155}^{154}$ Idem.

${ }^{155}$ Idem.

${ }^{156}$ Idem.

${ }^{157}$ Idem.

${ }^{158} \mathrm{O}$ referido chauffeur prestou exame para condução de automóveis no mês de dezembro de 1925; era habilitado há, pelo menos, seis meses.
} 
é o fato de que o acusado afirma que o automóvel que guiava imprimia a "velocidade de trinta quilômetros a hora".

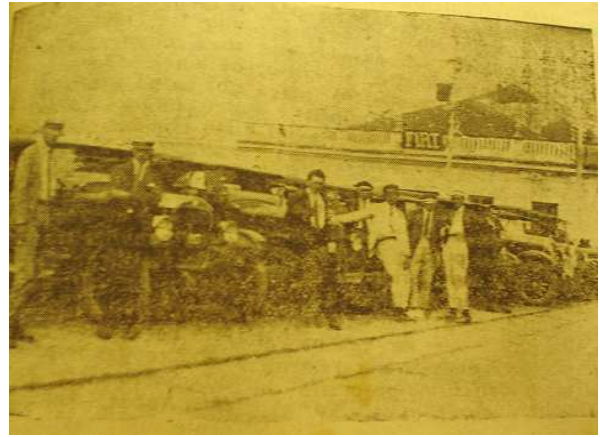

Figura 02 - Automóveis e Chauffeurs. Fonte: Aos nossos melhores amigos - Gente do povo, de mãos calejadas e coração nobilíssimo. Folha Nova. Florianópolis, 17 nov. 1927. p. 3.

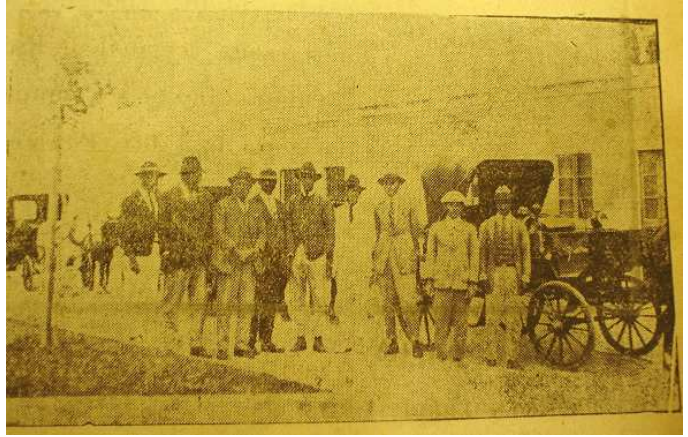

Figura 03 - Carros e Boleeiros. Fonte: Aos nossos melhores amigos - Gente do povo, de mãos calejadas e coração nobilíssimo. Folha Nova. Florianópolis, 17 nov. 1927. p. $3 .^{159}$

Corroborando com essas informações, o passageiro Clemente Rovere afirma que, na ocasião do sinistro, “o declarante, com seus colegas Izidoro de Souza, Euclydes de Souza e José Soares fretaram para passear o auto n. 132, guiado pelo chauffeur Aniceto Machado de Souza" e "subiram a rua Esteves Júnior em velocidade de quarenta quilômetros a hora, mais ou menos"160. Da mesma maneira, o passageiro José Soares afirma que "ele declarante fretou com seus colegas" o automóvel n. 132 e "nestas condições subiram a rua Esteves Júnior em velocidade de quarenta quilômetros a hora" ${ }^{\prime 161}$.

É importante esclarecermos que não podemos estipular, com precisão, a velocidade com a qual se deslocava o referido automóvel na ocasião do sinistro, mas podemos inferir que a velocidade de trinta ou quarenta quilômetros por hora, conforme referenciada nos registros citados, é superior àquela permitida pelo Regulamento para o serviço policial do Estado, de 1920; pois, sobre as velocidades estipuladas para o tráfego de veículos pelas ruas da capital catarinense, o artigo 120 desse regulamento estipula, dentre outros dispositivos, que

Art. 120 - São obrigações comuns a todos os cocheiros, carroceiros e motoristas: \# $3 .^{\circ}$ - Dirigir os animais sem castigos imoderados; \# 4. ${ }^{\circ}$ - Guiar com prudência os animais, carros, bondes, automóveis, para evitar prejuízos aos transeuntes ou passageiros; \# 5. ${ }^{\circ}$ - Caminhar nas ruas da cidade a trote curto, sem precipitar a carreira dos animais, nem o movimento dos carros ou automóveis; \# $8 .^{\circ}$ - Diminuir a marcha nas proximidades das esquinas para evitar encontros com outros veículos ${ }^{162}$.

Além disso, sabemos com segurança que, no ano de 1923, não era permitido aos automóveis atingirem, no perímetro urbano de Florianópolis, velocidade maior do que vinte quilômetros por hora, pois o artigo 36 das Instruções Regulamentares para o serviço de trânsito público, de 1928, estipula que “[...] Nas ruas e praças da Capital, os automóveis e auto-

\footnotetext{
${ }^{159}$ Sobre discussões a respeito do exercício da profissão de cocheiro na capital federal, no início do século XX, ver RIO, João do. Velhos Cocheiros (Crônica). In:

${ }^{160}$ Processo n. 95, 05 jul. 1926. Caixa 09.

${ }^{161}$ Idem.

${ }^{162}$ Santa Catarina. Regulamento para o serviço policial do Estado. Florianópolis: Tipografia da Livraria Central, 1920.
} 
caminhões não poderão passar de vinte quilômetros a hora, de marcha, e os carros terão a velocidade máxima de um animal a trote" ${ }^{\Perp 163}$. Assim, é plausível considerarmos que o comportamento de chauffeurs, passageiros e transeuntes no meio urbano de Florianópolis não se adequou integralmente às normas legais vigentes - aspecto que verificamos, de modo especial, durante os primeiros decênios do século $\mathrm{XX}$-, pois a internalização de novas sensibilidades desencadeada, em parte, pela percepção da velocidade de deslocamento dos automóveis no espaço urbano foi operada de maneira gradual e envolveu conflitos e adaptações caracterizados, especialmente, pela sedução exercida pela tecnologia motorizada para aqueles que a guiavam e, também, pelas tentativas de adaptação dos órgãos e legislações locais vigentes quanto à contemplação de regras e de normas de circulação que pudessem atender - pelo menos em parte - à circulação dos veículos motorizados pelas ruas do perímetro urbano da capital catarinense.

Evidenciamos, portanto, que a circulação cotidiana de automóveis e transeuntes pelas ruas do perímetro urbano da cidade de Florianópolis era operada, muitas vezes, conforme circunstâncias e situações variadas, que não obedeciam ou simplesmente não eram vigiadas pelos poderes administrativos locais. Nesse sentido, as práticas e usos cotidianos da cidade operavam reapropriações das normas estabelecidas legalmente. Os florianopolitanos - chauffeurs, transeuntes e passageiros - efetuavam trajetórias múltiplas e imprevisíveis, que caracterizavam maneiras diferentes e específicas de circular ou vivenciar a cidade. Essas práticas configuravam resistências - operadas, muitas vezes, de maneira não intencionada - às normas e regras de trânsito que se tentavam aplicar na capital catarinense e, por certo, não obedeciam a receitas predefinidas para sua aplicação ou resultado. $\mathrm{O}$ uso da cidade é, pois, um processo heterogêneo que envolve mobilidades táticas e estratégias de defesa frente às circunstâncias impostas pelo cotidiano. Envolve, também, imprevisibilidades, circunstâncias variadas; não previamente definidas, que permitem àqueles que habitam a urbe nela sobreviverem com relativo sucesso e resultados positivos ${ }^{164}$.

Outro aspecto importante, registrado pelas declarações do acusado, é o fato de que "em consequência do choque havido entre os dois veículos", o automóvel n. 132 "virou, ficando completamente quebrado, [e] os passageiros Euclydes de Souza e Izidoro de Souza, receberam graves ferimentos na cabeça e foram levados para o Hospital de Caridade”. Percebemos, nesse ponto, que os passageiros e, também, os transeuntes eram, em determinadas situações, colocados em posição de inferioridade frente à circulação imprimida pelos automóveis ${ }^{165}$. Esse aspecto não

\footnotetext{
${ }^{163}$ Santa Catarina. Instruções Regulamentares para o serviço de trânsito público. Florianópolis: Imprensa Oficial, 1928. p. 10.

${ }^{164}$ CERTEAU, Michel de. A invenção do cotidiano 1: artes de fazer. 8. ed. Petrópolis: Vozes, 2002. p. 16.

${ }^{165}$ A posição de inferioridade dos transeuntes e passageiros frente à circulação dos automóveis se torna evidente ao observarmos que no processo em questão, o passageiro Euclydes de Souza faleceu no Hospital de Caridade no dia 06 de julho de 1926, em decorrência dos ferimentos provocados pelo acidente com o veículo n. 132, conforme informações constantes no "Auto de exame cadavérico", anexo ao presente processo.
} 
impedia, portanto, que eles resistissem a tais investidas, por isso esquivavam-se a fim de protegerem-se ou, mesmo, fazendo uso da palavra, em seus depoimentos e falas, para denunciar comportamentos indevidos no trânsito.

Nesse ponto, devemos considerar que a circulação automobilística nos centros urbanos brasileiros impôs-se, em muitas situações, àquela operada pelos transeuntes. Atentos, inclusive, a outras passagens já colocadas na tese sobre esse aspecto, é importante esclarecermos que os chauffeurs adotavam, cotidianamente, posturas agressivas ao volante, tomavam os espaços das ruas e avenidas e preteriam a circulação dos transeuntes. Essas considerações são importantes para tecermos um gancho com aquilo que estamos estudando, pois uma análise pormenorizada nos permite considerar que a prática da condução de automóveis pelas ruas dos grandes centros urbanos brasileiros e, em especial, da capital catarinense envolve posturas diferenciadas, adotadas, especialmente, por chauffeurs e transeuntes, a partir das quais os primeiros adotam, em especial, práticas agressivas ao volante, tentando impor sua maneira de circular e atuar na cena urbana. Essa prática era incitada, no caso dos chauffeurs, pelo fato de, entre outros aspectos, estarem acomodados nos automóveis, os quais lhes proporcionavam relativo conforto e isolamento da rua, mantendo-os "longe" e apartados do convívio mais direto com a cotidianidade urbana. Vimos, entretanto, que os transeuntes adotavam táticas para se esquivarem da presença e da circulação dos veículos motorizados. Faziam-se, portanto, presentes na cena urbana.

Retomemos, pois, as falas dos personagens envolvidos na cena de colisão havida entre o automóvel n. 132 e o carro de praça n. 30. As declarações prestadas por Onofre de Aquino, no dia 05 de julho de 1926, expõem que, "hoje, pelas dezenove horas, descia a Avenida Rio Branco em marcha lenta e fonfonando porque ia fazer a curva para entrar na rua Esteves Júnior” e que, "no momento em que ia fazer a referida curva, subia em grande velocidade e sem fonfonar o automóvel n. 132, guiado pelo chauffeur Aniceto Machado de Souza", e que ele "esbarrou com tanta violência no seu carro que quebrou a lança do mesmo e a cabeça de um dos cavalos"166.

Observamos que Onofre de Aquino considera "excessiva" a velocidade de trinta ou quarenta quilômetros horários, atingida pelo veículo motorizado, pois assinala, ainda, que o automóvel n. 132 "esbarrou com tanta violência no seu carro que quebrou a lança do mesmo e a cabeça de um dos cavalos", e que "atribui o desastre ao descuido, ao relaxamento do chauffeur e principalmente ao excesso de velocidade" que imprimia ao veículo na ocasião do sinistro ${ }^{167}$. Além disso, ele aponta que Aniceto M. de Souza subia a rua Esteves Júnior "sem fonfonar", aspecto que corrobora o que foi declarado pelo próprio chauffeur na ocasião do seu depoimento.

\footnotetext{
${ }^{166}$ Processo n. 95, 05 jul. 1926. Caixa 09.

${ }^{167}$ Idem.
} 
A alta velocidade atingida pelo veículo motorizado em questão, conforme assinala o boleeiro Onofre de Aquino, foi novamente por ele referenciada ao registrar, em outra passagem de suas declarações, que "o referido automóvel, logo que se chocou com o seu carro, capotou, cuspindo todos os que nele iam ao chão, tal era a velocidade em que ia, [e] que dessa queda resultou saírem gravemente feridos os chauffeurs Euclydes de Souza e Izidoro de Souza, ambos passageiros do automóvel", e "que sabe que iam outros chauffeurs no referido [veículo], mas que nada sofreram"168. Ratificando essas ideias, a testemunha Marcolino José Espíndola, "54 anos, jardineiro", afirma, em depoimento prestado no dia 05 de julho de 1926, que, "hoje, pelas dezenove horas, achava-se na rua Esteves Júnior em frente ao Palacete do Bispado e, portanto, bem próximo à esquina da Avenida Rio Branco, que viu quando passou o automóvel 132 em velocidade assustadora ${ }^{169}$; que não sabe quem o guiava", mas ouviu "um grande ruído e correu para ver do que se tratava"; observou, também, em outra passagem do seu depoimento, que "o chauffeur que conduzia o automóvel [...] não fonfonou atribuindo o desastre ao excesso de velocidade com que ia o referido chauffeur ${ }^{\prime 170}$. (Anexo 03, p. 334).

É importante considerarmos, uma vez mais, que, durante as primeiras décadas do século XX, o automóvel se constitui como novo elemento no meio urbano de Florianópolis. A presença e o deslocamento de veículos motorizados - arriscamos afirmar - eram mesmo pouco conhecidos para boa parcela da população - especialmente para aquela que vivia nos distritos ou áreas rurais do município (ver notas 175 e 176, p. 51-52 e Mapas 02 e 03, p. 53-54) -, acostumada que estava à dinâmica imprimida pela circulação das carroças ou bondes tracionados por força motriz animal ${ }^{171}$.

Outro aspecto que julgamos relevante é o fato de que as normas e as legislações de trânsito que, à época, tentavam-se aplicar na cidade de Florianópolis a fim de oferecer melhores condições de tráfego para bondes, carroças e veículos automotores, bem como para a circulação

\footnotetext{
${ }^{168}$ Processo n. 95, 05 jul. 1926. Caixa 09.

${ }^{169}$ A velocidade atingida pelo automóvel n. 132, no momento do choque com o carro guiado por Onofre de Aquino, parece ter sido um aspecto que chamou a atenção de todos aqueles que presenciaram o sinistro, pois a testemunha Henrique Raupp Júnior, 45 anos, advogado, afirma, em declarações prestadas no dia 07 de julho de 1926, que, "no dia 05 do corrente, mais ou menos, às sete horas da noite, estava ele no jardim de sua casa, que fica na esquina da rua Esteves Júnior com a Avenida Rio Branco, quando ouviu o ruído forte de um automóvel que vinha em vertiginosa correria do lado de baixo da rua Esteves Júnior em direção ao centro da cidade; que se passaram alguns segundos quando notou o aparecimento do automóvel na esquina da Avenida Rio Branco, ouvindo imediatamente um forte ruído e, em seguida, o tombamento do mesmo automóvel na esquina oposta ao seu jardim, ao mesmo tempo em que ouviu um dos passageiros gritar "minha nossa senhora!", fazendo-se, então, momentâneo silêncio; que o tombamento tivera por causa o encontro com o carro do boleeiro Onofre que, na mesma ocasião, vinha de cima da Avenida Rio Branco, dobrando a esquina, como quem queria se dirigir para a Praia de Fora". Continuando suas observações, Henrique Raupp Júnior afirma que "Onofre ia em passo lento com o seu carro, devendo-se a culpa do desastre ser exclusivamente atribuído ao chauffeur do automóvel que vinha em correria vertiginosa rua acima”. (Processo n. 95, 05 jul. 1926. Caixa 09). Do exposto, percebemos que a testemunha em questão confirmou as ideias registradas pelo boleeiro Onofre de Aquino e pela testemunha Marcolino José Espíndola, pois ela afirma que o referido boleeiro "ia em passo lento" e o automóvel n. 132 "vinha em vertiginosa correria", devendo-se "a culpa do desastre ser exclusivamente atribuído ao "excesso de velocidade" "atingido pelo automóvel em questão. Vale observarmos o trecho do depoimento de Henrique Raupp Júnior quando ele afirma que o automóvel guiado por Aniceto Machado "vinha em vertiginosa correria do lado de baixo da rua Esteves Júnior em direção ao centro da cidade".

${ }^{170}$ Processo n. 95, 05 jul. 1926. Caixa 09

${ }^{171} \mathrm{Na}$ capital catarinense, a desativação completa do serviço de bondes ocorreu na década de 1930; e, durante todo o período em que esteve em atividade, este serviço foi operado por tração animal. Ver Os bondes de Florianópolis. O Estado. Florianópolis, 10 jan. 1925 . p. 5. Maiores detalhes a respeito serão encontrados nos capítulos terceiro e quinto da tese.
} 
dos transeuntes, entravam, muitas vezes, em conflito ou dissonância frente aos objetivos e anseios expressos por boleeiros, chauffeurs e transeuntes. Podemos afirmar, em vista disso, que as normas e legislações de trânsito que eram aplicadas ao meio urbano da capital catarinense, no período em estudo, não atenderam somente aos interesses dos órgãos responsáveis por sua elaboração. A aplicação prática dessas regras exigiu, inegavelmente, avanços, recuos e readaptações frente às exigências impostas pelo cotidiano da cidade, expressas, em parte, pelas necessidades colocadas por chauffeurs, passageiros e pedestres, personagens anônimos da população florianopolitana. Assim, algumas de suas falas e percepções foram trazidas à tona por meio do trabalho de investigação proposto neste estudo. Desse modo, é válido considerarmos que o uso cotidiano do espaço urbano de uma cidade - no caso específico, da cidade de Florianópolis - é caracterizado por diversos sentidos e apropriações. Os itinerários traçados pelos transeuntes, de modo especial, encerram, em várias ocasiões, sonhos de viajar diante de uma certa vitrine ou mesmo “[...] considerações alegres, serenas ou amargas sobre o seu próprio destino, inúmeros 'segmentos de sentido' que podem ir um tomando o lugar do outro conforme se vai caminhando, sem ordem e sem regra", despertadas "ao acaso dos encontros, suscitadas pela atenção flutuante aos 'acontecimentos' que sem cessar, se vão produzindo da rua"172. Desse modo, o cotidiano da cidade encerra inúmeras práticas e acontecimentos que, simplesmente, não são contidos pelo poderes normativos em voga e que, por isso, oferecem à cidade seu caráter fluído e mutante, impossível, muitas vezes, de ser equacionado ou disciplinado ${ }^{173}$.

A presente pesquisa objetiva analisar as percepções dos florianopolitanos quanto às ocorrências de atropelamentos e colisões verificadas no perímetro urbano da cidade de Florianópolis, durante as décadas de 1920 e 1930. O trecho das declarações da testemunha Henrique Raupp Júnior, destacado anteriormente - ver nota 169 -, indica, todavia, que a rua Esteves Júnior e a Avenida Rio Branco não integravam, à época, o centro da cidade. De qualquer modo, para os efeitos deste estudo, essas vias contemplam aquelas que fazem parte do perímetro urbano da capital catarinense, pois devemos observar que o Guia do Estado de Santa Catarina, de 1937, estipula que o perímetro suburbano de Florianópolis compreende as seguintes regiões: a) Estação Agronômica; b) Penitenciária da Pedra Grande; e c) Três Pontes (atual bairro do Itacorubi ${ }^{174}$. Registra esse documento, igualmente, que os distritos correspondem, dentre outras, às seguintes localidades: a) Trindade; b) Saco dos Limões; e c) Lagoa [da Conceição] ${ }^{175}$. (Mapa

\footnotetext{
${ }^{172}$ CERTEAU, Michel de; GIARD, Luce; MAYOL, Pierre. A invenção do cotidiano 2: morar, cozinhar. 5. ed. Petrópolis: Vozes, 2003. p. 44. ${ }^{173}$ BRESCIANI, Maria Stella Martins. Cidade e História. In: OLIVEIRA, Lúcia Lippi (Org.). Cidade: história e desafios. Rio de Janeiro: FGV, 2002. p. 30.

${ }^{174}$ Guia do Estado de Santa Catarina: Suplemento para o ano de 1937. Florianópolis: Livraria Central de Alberto Entres, 1937.

${ }^{175}$ Guia do Estado de Santa Catarina: Suplemento para o ano de 1937... op. cit. No ano de 1939, o Relatório da Prefeitura Municipal de Florianópolis também identificava essas regiões como distritos da Capital, além de outras; quais sejam: "Ribeirão"; "Santo Antônio [de Lisboa]"; "Rio Vermelho"; "Canasvieiras"; "Cachoeira [do Bom Jesus]", e "Ratones". (RAMOS, Mauro. Relatório da Prefeitura Municipal de Florianópolis. Apresentado ao Sr. Interventor Federal no Estado. Florianópolis, 1940. p. 48-49).
} 
02, p. 53). Esse mesmo documento destaca, ainda, que "o perímetro urbano é a área da cidade compreendida entre o Morro do Antão [da Cruz], mar, José Mendes, até confrontar a praia, e entroncamento das ruas Bocaíuva e Visconde de Taunay" ${ }^{\prime 16}$. (Mapa 01, p. 28).

A análise do acidente discutido no presente processo pode ser aprofundada ao destacarmos, novamente, as impressões registradas pelo boleeiro Onofre de Aquino e pela testemunha Marcolino José Espíndola, que consideram que o chauffeur do automóvel n. 132 "não fonfonou" e que o desastre foi provocado, "muito principalmente" em virtude do "excesso de velocidade" imprimido pelo veículo ${ }^{177}$. Notamos que esses personagens consideram excessiva a velocidade de trinta ou quarenta quilômetros horários - não permitida, como vimos, pelo regulamento policial em vigor para o tráfego de veículos dentro do perímetro urbano de Florianópolis. Nesse ponto, devemos lembrar, novamente, que a ideia ou noção de velocidade assume caráter negociável e/ou relativista; é entendida, portanto, de diferentes maneiras, conforme as visões, anseios e valores expressos pelo indivíduo. Devemos, por conseguinte, tomar as falas registradas anteriormente como elementos referenciais, que envolvem diferentes posicionamentos e dimensões políticos, e não propriamente como afirmações contundentes ou comprobatórias.

Durante as décadas de 1920 e 1930, a alta velocidade atingida pelos automóveis parece, entretanto, ter sido um aspecto marcante nas ruas do espaço central da capital catarinense conforme referenciam os artigos dos periódicos locais, como é exemplificado a seguir. De acordo com as notas jornalísticas da época, os chauffeurs imprimiam, com certa regularidade, correrias loucas por suas ruas e avenidas. Vale salientarmos que a ocorrência de atropelamentos e colisões, provocada, muitas vezes, pelo excesso de velocidade dos automóveis, não foi motivo suficiente para coibir comportamentos desenfreados ao volante. O artigo do jornal $O$ Estado, de 06 de julho de 1926, registra o sinistro analisado neste processo e salienta a frequência das excessivas velocidades atingidas pelos automóveis nas ruas da capital catarinense:

\footnotetext{
${ }^{176}$ Guia do Estado de Santa Catarina: Suplemento para o ano de 1937... op. cit. É importante observar que à rua Bocaiúva, seguem, em direção à Pedra Grande, as ruas Heitor Luz e Frei Caneca. No período em estudo estipulado neste capítulo, estas vias encontram-se, portanto, fora dos limites do perímetro urbano da cidade de Florianópolis - (ver mapa 01, p. 28). Outro aspecto que devemos destacar é o processo de urbanização das chácaras e terrenos baldios existentes nas regiões próximas ao centro urbano, que foi operado com maior nitidez a partir do final do século XIX e início do século XX, havendo, igualmente, um período de intensa urbanização durante as décadas de 1950 e 1960 . Nesse sentido, destacamos as palavras de Maria Inês Sugai ao afirmar que as chácaras representavam "[...] o complemento da abastança dos grandes senhores dos sobrados.... Apesar de situadas fora do centro urbano, ocupando extensas áreas, não tinham dimensão suficiente e nem constituíam uma propriedade de produção agrícola [pois] seus proprietários exerciam quase sempre atividades urbanas. As chácaras localizavam-se nos arredores de Desterro. Na Ilha, as chácaras localizavam-se na península central, nas Freguesias mais próximas, como Trindade e na Lagoa, e ao redor do Morro da Cruz, como no Saco dos Limões e José Mendes, pelo sul, e Pedra Grande e Agronômica, pelo norte. Havia chácaras também no Continente, como em Coqueiros e São Miguel. Os estudos existentes conduzem a três evidências: a) a maior parte das chácaras localizava-se na península central ou muito próxima dela; b) as chácaras situadas na Agronômica e Saco dos Limões, distam no máximo 4 km da Praça do Palácio; no entanto, a maior parte situava-se à distância de $2 \mathrm{~km}$ da Praça, bastante próximas, portanto, da área urbana; e c) $70 \%$ das chácaras [...] localizavam-se na área norte da Praça do Palácio, definindo um interesse de ocupação na direção da Praia de Fora, voltada para a Baía Norte. As chácaras foram sendo implantadas na direção norte, acompanhando os caminhos abertos no século XVIII e que ligavam a Vila de Desterro (na orla sul) às duas fortificações situadas ao norte da península. A localização dessas edificações militares teve importante papel no direcionamento de eixos de ocupação na península central. Esses antigos caminhos deram origem a muitas ruas que constituem atuais vias de ligação norte-sul na área central, como a atual Rua Esteves Júnior, situada no caminho que ligava a Vila do Desterro ao Forte de São Francisco e, também, as ruas Visconde de Ouro Preto, Almirante Alvim e Victor Konder, criadas a partir dos antigos caminhos que iam da Vila ao Forte de São Luiz". (SUGAI, Maria Inês. As Intervenções Viárias e as Transformações do Espaço Urbano: A Via de Contorno Norte-Ilha. Dissertação (Mestrado em Arquitetura e Urbanismo). São Paulo: USP, 1994). Ver nota 81, p. 27 e mapa 03, p. 54.

${ }^{177}$ Processo n. 95, 05 jul. 1926. Caixa 09.
} 
Mapa 02: Perímetro Suburbano e Distritos de Florianópolis - Décadas de 1920 e 1930 (*) $^{*}$

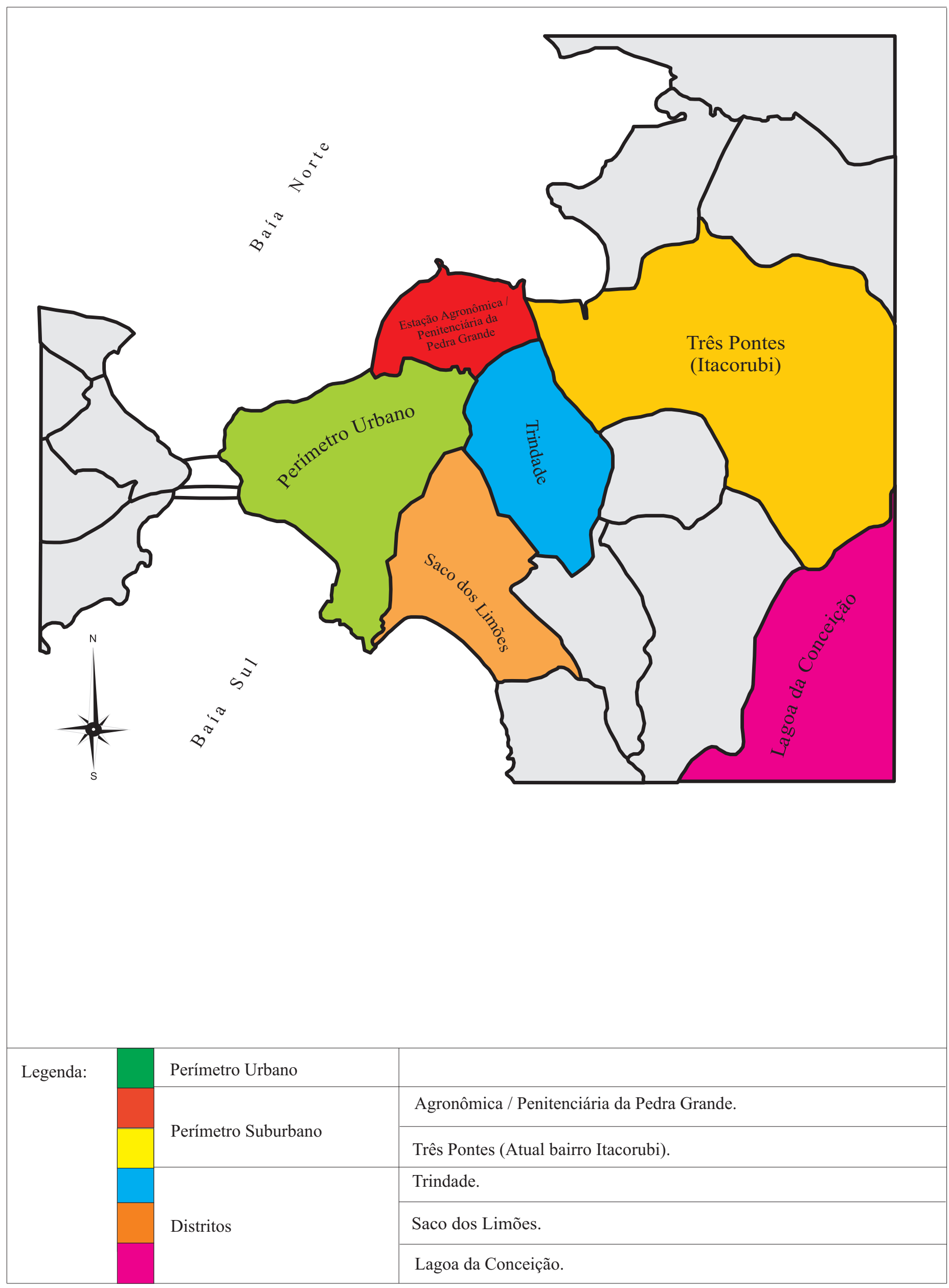




\section{Mapa 03: Localização das Chácaras dentro do Perímetro Urbano de Florianópolis - final do século XIX e início do XX (*)}

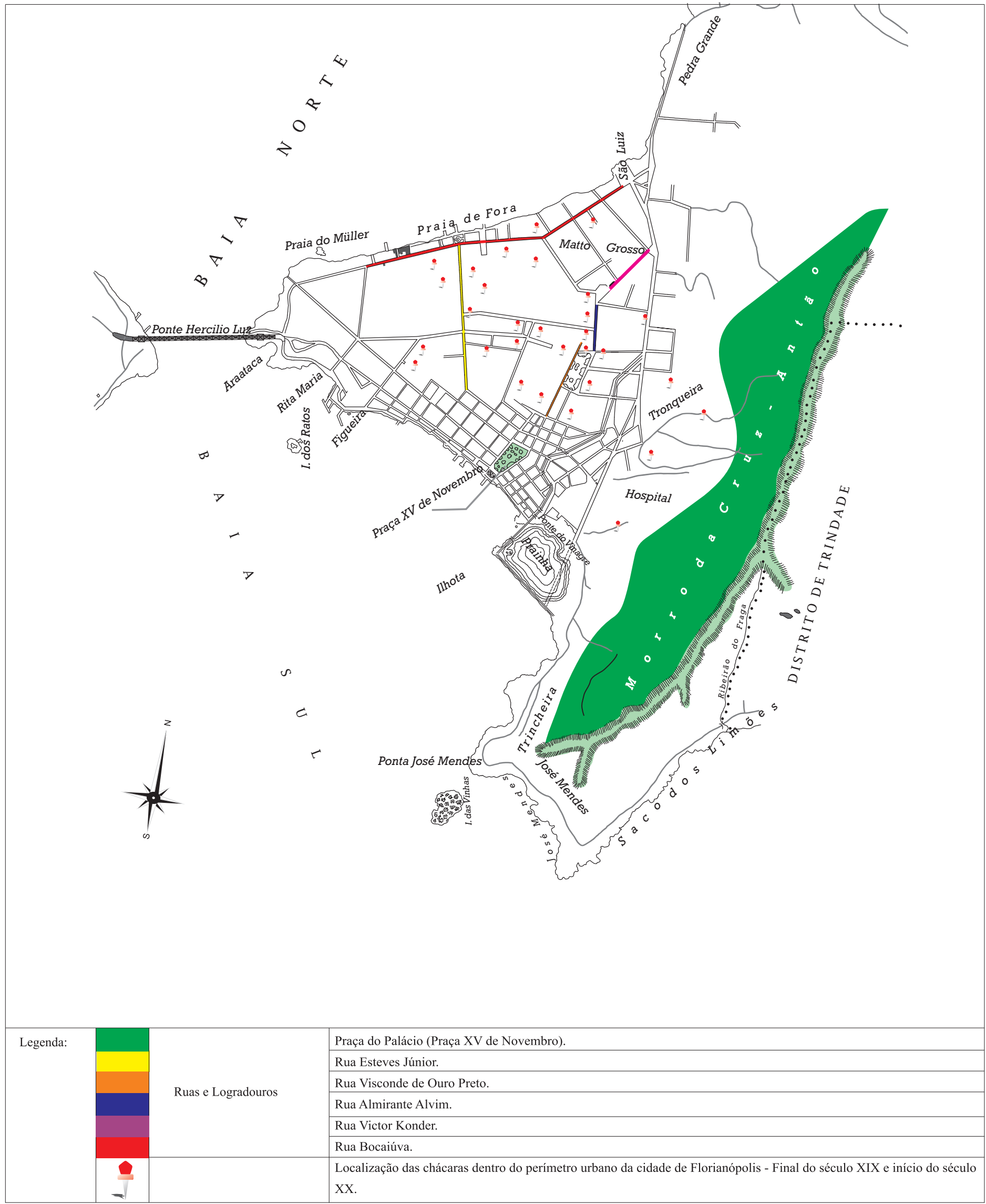

(*) Mapa do perímetro urbano da cidade de Florianópolis - 1940. Fonte: Centro Administrativo do Estado de Santa Catarina - Secretaria de Planejamento/Diretoria de Estatística e Cartografia - Florianópolis - Santa Catarina. Criação e Diagramação: Duplic Digital Copiadora - Florianópolis - Santa Catarina.

Adaptações feitas pelo autor, conforme informaçoes constantes nos textos: a) SUGAI, Maria Inês. As Intervenções Viárias e as Transformações do Espaço Urbano: A Via de Contorno Norte-Ilha. Dissertação (Mestrado em Arquitetura Urbanismo). São Paulo: USP, 1994 ; e b)VEIGA, Eliane Veras da. Florianópolis: memória urbana. Florianopolis: UFSC e Fundação Franklin Cascaes, 1993. Devemos observar, no mapa, a maior concentração de chácaras existentes na área norte da Praça XV de Novembro. Nesse mapa estão registrados trinta chácaras e terrenos localizados em áreas que serão posteriormente ocupadas por ruas, logradouros, praças, edifícios; ocupação esta que decorre, especialmente, de processos de desapropriações ou partilhas de heranças familiares. 
Desastre e morte - mais uma vez a imprudência redundou em prejuízos lamentáveis e conseqüências fatais. Inúmeras vezes temos clamado contra o modo excessivamente intolerável de certos condutores de veículos, que, abusando da liberdade mais que ampla que lhes têm sido dada pela polícia, vivem em correrias loucas pelas ruas da cidade, e, ao mesmo tempo, 'contra-a-mão'. Ontem, porém, o caso assumiu maiores proporções, com o lamentável acontecimento ocorrido à rua Esteves Júnior, esquina da Avenida Rio Branco. Mais ou menos às dezenove horas, deu-se, ali, um violentíssimo encontro entre o auto n. 132, guiado pelo chauffeur Aniceto Machado, e o carro de praça n. 30, guiado por Onofre de Aquino. No momento da colisão, Aniceto brecou violentamente o carro, que imediatamente tombou. Como conseqüência, ficaram feridos o chauffeur Aniceto [...] e os passageiros Euclydes e Izidoro de Souza que foram transportados, primeiramente para a Farmácia Popular; e daí para o Hospital de Caridade ${ }^{178}$.

A análise das ideias apontadas permite-nos considerar que os chauffeurs guiavam os veículos motorizados de maneira inconsequente, imprimindo "correrias loucas pelas ruas da cidade, e, ao mesmo tempo, 'contra-a-mão"'. Desse modo, a nota da imprensa local referencia que a imprudência era, mesmo, algo corriqueiro nas ruas do perímetro urbano da Capital, pois assinala, "mais uma vez”, que a “imprudência redundou em prejuízos lamentáveis e conseqüências fatais", produzindo "um violentíssimo encontro entre o auto n. 132 e o carro de praça n. 30". Além disso, sugere que não havia policiamento ostensivo nas ruas da cidade de Florianópolis como forma de coibir ou fiscalizar o desrespeito às normas de trânsito referentes, sobretudo, aos limites de velocidade permitidos para o tráfego de veículos nas ruas do espaço central da cidade, pois os chauffeurs, conforme apontados no artigo jornalístico em questão, abusavam "da liberdade mais que ampla que lhes têm sido dada pela polícia", e efetuavam com os seus veículos, “correrias loucas” pelas ruas da capital catarinense ${ }^{179}$.

Corroborando com esses elementos, destacamos que, no ano de 1928, o artigo do jornal República, de 1. ${ }^{\circ}$ de maio, registra que "a velocidade excessiva de que abusam certos chauffeurs é, na maioria das vezes, a verdadeira causa de muitos acidentes"; e assinala, inclusive, que "esses abusos originam, naturalmente, os mais graves desastres" ${ }^{\prime 180}$. Assim, podemos destacar que, ao estabelecerem conotações europeizadas, modernas e célebres, cocheiros e chauffeurs acentuam sua identificação pessoal com a nova potestade; e diferenciam-se, assim, dos demais cidadãos, sejam eles pedestres, sejam passageiros ${ }^{181}$. É importante observarmos que a discussão quanto às altas velocidades imprimidas pelos chauffeurs aos veículos motorizados está presente na quase totalidade dos processos criminais analisados. É, como vimos, alvo de comentários e

\footnotetext{
${ }^{178}$ Os autos, sempre os autos! O Estado. Florianópolis, 06 jul. 1926. p. 1.

${ }^{179}$ Ideias nessa direção são apontadas pela "Mensagem apresentada à Assembléia Legislativa do Estado", em 29 de julho de 1928 , pois nessa ocasião, é assinalado "[...] o crescente movimento [de veículos] que vai tendo esta Capital e o número insuficientíssimo de inspetores de veículos: dois, apenas, sendo um [cedido?]”. (KONDER, Adolfo. Presidente do Estado de Santa Catarina. MENSAGEM apresentada á Assembléia Legislativa. Florianópolis, 29 jul. 1928. p. 46). A situação no Estado à época era, ao que parece, semelhante, ao considerarmos o que registra o Relatório datado de 1931, encaminhado ao Interventor Federal em Santa Catarina pelo Secretário dos Negócios do Interior e Justiça, pois aponta que "O Estado não dispõe de uma organização completa de natureza exclusivamente civil para o policiamento de prevenção e repressão. Na Capital, a Chefatura com o Gabinete de Identificação e Médico Legal; nos municípios, as Delegacias de Polícia a cargo de um Delegado leigo (cargo não remunerado, nem especializado), é tudo". (Santa Catarina. Relatório apresentado ao Exmo. Sr. General Ptolomeu de Assis Brasil, Interventor Federal, pelo Dr. Manoel Pedro Silveira, Secretário de Estado dos Negócios do Interior e Justiça. Florianópolis, nov. 1931. p. 11-12).

${ }^{180}$ Desastres de automóveis. República. Florianópolis, 1. ${ }^{\circ}$ maio 1928. p. 1.

${ }^{181}$ SEVCENKO, Nicolau. A capital irradiante: técnica, ritmos e ritos do rio. In:

da Belle Èpoque à Era do Rádio. 5. ed. São Paulo: Companhia das Letras, 2002. p. 527. (Org.). História da vida privada no Brasil - República:
} 
observações da imprensa local, uma vez que as altas velocidades atingidas pelos automóveis encerram elementos característicos do cotidiano da cidade de Florianópolis, vivenciados diretamente por chauffeurs, passageiros e por aqueles que circulavam a pé pelas ruas do perímetro urbano da capital catarinense.

Podemos afirmar, por outro lado, que, no decorrer do século XX, a circulação do automóvel nas ruas da capital catarinense, assim como nas ruas dos grandes centros urbanos do Brasil e da Europa Ocidental, tornou-se preferencial à circulação de bondes, carroças e transeuntes. Conforme referencia André Gorz no texto $A$ ideologia social do carro a motor (ComCiência, São Paulo: SBPC, 2004), a presença e a gradativa massificação do automóvel fomentaram a ilusão de que os chauffeurs têm preferência à circulação dos pedestres e veículos não motorizados. O automóvel conduz ao “[...] egoísmo cruel e agressivo do motorista” que em várias situações verificadas no cotidiano, "está figuramente matando 'os outros', que aparecem meramente como um obstáculo físico à sua velocidade", e esse "egoísmo competidor e agressivo" caracteriza "a chegada do comportamento social burguês, e tem existido desde que dirigir tornou-se lugar comum". ${ }^{182}$ Percebemos, ainda, que, nesse texto, o autor problematiza e discute a prioridade concedida à circulação dos automóveis nos espaços urbanos das grandes cidades, durante o século XX. O referido autor registra, também, que o uso indiscriminado do automóvel fomenta a ilusão de que cada indivíduo pode beneficiar-se desse recurso "às custas de todos os demais" seres humanos e analisa, igualmente, o fato de que as grandes cidades foram adaptadas ou planejadas para atender à circulação dos veículos motorizados, mediante a implementação de largas ruas e avenidas. A circulação dos pedestres assumiu, dessa forma, posição secundária. $\mathrm{O}$ autor conclui, entretanto, o artigo apregoando a utilização do transporte coletivo e observa que a utilização dos automóveis não é eminentemente necessária para promover a locomoção das pessoas pelas estradas e vias públicas das cidades.

No presente capítulo, investigamos a dinâmica operada pela convivência simultânea de automóveis e pedestres pelas ruas do espaço central da capital catarinense durante as décadas de 1920 e 1930. Os episódios de atropelamentos e colisões, verificados na cidade de Florianópolis, atestam o constante e diário embate estabelecido entre automóveis, chauffeurs e transeuntes pelo direito ao tráfego nas vias públicas da capital catarinense. Vimos, igualmente, que as leis e regras de trânsito, estabelecidas com o objetivo de disciplinar a circulação de pedestres e veículos, não apresentavam resultados práticos totalmente eficientes, pois os florianopolitanos não se adequavam integralmente a essas regras. Além disso, as normas de trânsito tentavam equacionar

\footnotetext{
${ }^{182}$ GORZ, André. A ideologia social do carro a motor. ComCiência: revista eletrônica de jornalismo científico - Transportes. São Paulo: SBPC/Labjor, n. 53, abr. 2004. Disponível em: http://www.comciencia.br/200404/reportagens/02.shtml.
} 
interesses diversos - expressos por legisladores e usuários cotidianos da cidade -, o que ocasionava conflitos e inadaptabilidades, especialmente para aqueles que circulavam diariamente pelas ruas da cidade de Florianópolis. Constatamos, portanto, que as regras e normas de trânsito foram elaboradas e adaptadas de maneira lenta e gradual, uma vez que objetivam conciliar velhos e antigos hábitos expressos pelos florianopolitanos, especialmente quanto ao costume no contato com a circulação de bondes e carroças, e à novidade representada pela tecnologia motorizada.

As observações dispostas nos dois parágrafos precedentes nos permitem considerar que a utilização do automóvel, nos grandes centros urbanos nacionais, e, também, na cidade de Florianópolis, preteriu - a par de toda a regulamentação urbana e viária existente - àquela operada pelos transeuntes e veículos não motorizados. Assim, o uso do espaço viário urbano foi, de certa forma, apropriado pelos chauffeurs e motoristas que, diante do pretenso privilégio concedido à tecnologia motorizada, acharam-se no direito de bem usufruir das ruas e das avenidas, vedando-as à apropriação cotidiana dos transeuntes. Dessa forma, é plausível pensarmos que os motoristas e chauffeurs, ao se utilizarem do espaço público em seus automóveis e veículos, fazem-no conforme seus próprios interesses, uma vez que cada um em particular imprime a velocidade desejada ou estaciona em locais que melhor lhe convier. Assim, podemos considerar que chauffeur e condutor configuram-se, de modo especial, como personagens que, apartados do compromisso com a preservação do espaço do transeunte, imprimem altas velocidades nas ruas e avenidas, e colocam, muitas vezes, a vida dos transeuntes - e a sua própria -, em constante risco.

Podemos, assim, afirmar que as situações envoltas nos episódios de atropelamentos e colisões caracterizaram não apenas a cidade de Florianópolis, mas, principalmente, os grandes centros urbanos do país. Verificamos, em passagens anteriores, a situação do trânsito na cidade de São Paulo, e constatamos que os episódios de atropelamentos e colisões que ocorreram na capital paulista tornaram-se, especialmente a partir da década de 1920, características do cotidiano para aqueles que circulavam pela cidade, o que os forçava a desenvolver, em contrapartida, uma agilidade mecânica correspondente à ameaça que representavam as investidas dos veículos automotores.

O maior montante de recursos financeiros em circulação, advindo, em grande parte, dos lucros verificados na economia cafeeira, viabilizou a concentração de investimentos estrangeiros e nacionais na área central da capital paulista, direcionada, em especial, à construção e ao aperfeiçoamento de instituições bancárias, portos e obras de infraestrutura. $\mathrm{O}$ comércio se desenvolveu, o número de fábricas e a oferta de serviços urbanos aumentaram. As populações 
das cidades do Rio de Janeiro e de São Paulo cresceram rapidamente com a chegada contínua de imigrantes estrangeiros. Entre 1900 e 1920, a população de São Paulo saltou de 240.000 para 579.000 habitantes e a do Rio, de 800.000 para $1.150 .000^{183}$. Como não havia uma infraestrutura urbana capaz de acolher tal aumento demográfico, essas cidades começaram a apresentar um processo de inchamento, em função do seu crescimento desordenado. A especulação urbana se generalizou, o que agravou, sensivelmente, as condições de vida dos estratos sociais populares. Nesse processo, constatamos que, paralelamente, houve o alargamento de ruas e de avenidas existentes no espaço central da capital paulista, com o objetivo de atender, dentre outros aspectos, ao crescente fluxo de automóveis ${ }^{184}$.

De outro modo, a concentração de investimentos, na área central da cidade de São Paulo, acentuou a tendência de aglomeração das atividades urbanas nessa região; e a crescente prosperidade da elite paulistana, advinda, especialmente, dos lucros e investimentos proporcionados pela economia cafeeira, fomentou a aquisição de automóveis, processo que se acelerou consideravelmente durante a década de $1920^{185}$. Esses elementos contribuíram para o adensamento do tráfego motorizado e para a intensificação dos congestionamentos verificados, especialmente, no espaço central da capital paulista. Dessa forma, das aleias do Anhangabaú à Praça da Sé, o entorno do "triângulo" central ${ }^{186}$ foi transformado em um grande parking-lot ao ar livre $^{187}$. Além disso, as linhas de bonde, estabelecidas no leito das ruas, e a intensa movimentação de pedestres agravavam o problema da circulação viária e automobilística. Assim, o "círculo exterior" - formado pelo alargamento das ruas Líbero Badaró, Benjamin Constant e Boa Vista - proposto pelo prefeito Victor Freire, em 1911, para descongestionar o tráfego motorizado no "triângulo" central ainda não havia sido concluído, pois era necessário finalizar o

\footnotetext{
${ }^{183}$ IBGE. Anuário Estatístico do Brasil, Rio de Janeiro, 1999. v. 59.

${ }^{184}$ Corroborando com estas ideias, Maria Stella Bresciani, ao estudar os melhoramentos e intervenções urbanas da cidade de São Paulo, entre os anos de 1850 e 1950, afirma que: "A circulação de veículos no 'triângulo central' e a expansão da área urbanizada passam a compor um item no elenco das preocupações administrativas na década de 1880 . Obras de melhoramento incluem 'a abertura de avenidas circulares' para 'facilitar o tráfego da cidade, evitando a congestão das ruas centrais'; a construção de um viaduto (o do Chá inaugurado em 1898), para ultrapassar o obstáculo físico do vale do Anhangabaú (1881 e 1886). O viaduto passa a constituir um ícone entre os 'melhoramentos da capital paulista"'. (Grifos da autora). (BRESCIANI, Maria Stella Marins. Melhoramentos entre intervenções e projetos estéticos: São Paulo (1850-1950). In: (Org.). Palavras da cidade. Porto Alegre: UFRGS, 2001. p. 351-352). Incrementando tal discussão, Marco Antônio Cornacioni Sávio observa que a "[...] chegada do primeiro veículo automotor ao país, mais especificamente, a São Paulo" corresponde a "um Decauville de 6 cavalos, trazido e registrado em 1900 por Henrique Santos-Dumont, irmão do ilustre cientista aeronáutico Alberto Santos-Dumont, uma importante figura do novo mundo técnico-científico que se formava desde os meados do século XIX, na Europa". Outra figura emblemática da época, ao menos para a política e o cotidiano da capital paulista, Antônio Prado - prefeito da cidade entre 1899 e 1910 -, era partidária do Partido Republicano Paulista (PRP), com forte atuação e tendências progressistas e modernizantes. Antônio Prado simpatizava com a nova tecnologia motorizada, pois, segundo consta, foi o "responsável pelo segundo veículo automotor na cidade de São Paulo". (SÁVIO, Marco Antônio Cornacioni. A Modernidade sobre Rodas. São Paulo: EDUC, 2002. p. 14 e p. 31). A partir desses primeiros passos e, claro, contando com forte apoio dos poderes públicos da Capital e do Estado paulistano, delineou-se, progressivamente, na cidade, uma cultura em torno da utilização e do apelo propagandístico difundido pelo automóvel, cultura esta que se solidificou, em definitivo, no decorrer dos anos 1920. (Ibidem, p. 34). Devemos observar, aqui, que a tabela 02: Número de cartas expedidas por municipio no Estado de Santa Catarina (1911-1922), disposta neste capítulo (seção Elementos Incipientes), aponta que, já em 1914, são observados veículos automotores circulando pelas ruas das cidades de Florianópolis e Lages. Considerando esses apontamentos, temos que há, ao menos, um intervalo estimado de doze anos entre a circulação dos primeiros automóveis na cidade de São Paulo e na capital do Estado de Santa Catarina.

${ }_{185}^{185}$ CAMPOS, Cândido Malta. Os Rumos da Cidade: Urbanismo e Modernização em São Paulo. São Paulo: Senac, 2002. p. 259.

${ }_{186}$ Região do atualmente chamado centro velho, que se localiza entre as ruas Líbero Badaró, XV de Novembro e Boa Vista. O nome, originalmente, está relacionado a três igrejas localizadas na região, a saber: a) Sé; b) São Sebastião e c) São Bento. Ver SÁVIO, Marco Antônio Cornacioni. A Modernidade sobre Rodas. São Paulo: EDUC, 2002. p. 53.

${ }^{187}$ CAMPOS, Cândido Malta. Os Rumos da Cidade: Urbanismo e Modernização em São Paulo... op. cit., p. 259.
} 
viaduto interligando a rua Boa Vista ao Largo do Palácio. Poucas ruas e avenidas radiais - São João, Brigadeiro Luís Antônio - ofereciam certo desafogo às pressões do tráfego ${ }^{188}$. Nesse sentido, podemos referenciar que atropelamentos e colisões eram verificados com certa frequência nas ruas do espaço central da cidade de São Paulo, durante os anos 1920 e 1930. Tais ocorrências atestam que os pedestres estavam, constantemente, em alerta; pois, nas cidades sobretudo nas capitais dos estados -, cria-se um campo de batalha diário entre os transeuntes e os novos veículos automotores. A convivência simultânea de pedestres e chauffeurs coloca, entretanto, lado a lado, personagens que expressam posições e comportamentos diferentes no cenário urbano, mas elas exercem, igualmente, poder e influência de maneira mútua e transformam os espaços centrais das cidades em autênticos palcos de negociações. Essas posturas evidenciam, com efeito, diferentes possibilidades de convívio verificadas no cotidiano da urbe. Nesse ponto, é importante deixarmos claro que é essa, precisamente, a situação que verificamos no cenário urbano da capital catarinense, por ocasião da análise dos processos criminais analisados neste texto.

As situações apontadas anteriormente também foram verificadas em contextos urbanos internacionais. Na cidade de Paris, por exemplo, verificamos, durante a década de 1920, algumas situações referentes aos atropelamentos de pedestres e aos danos físicos a eles causados pelas investidas dos automóveis. No Apêndice à Edição brasileira do livro Urbanismo, de autoria de Le Corbusier, atestamos, na parte intitulada Os acidentes da Rua, episódios de atropelamentos de pedestres nas ruas da capital francesa. Assim, o autor registra que "[...] um acidente bastante grave abriu, ontem, a série habitual dos danos imputáveis ao trânsito", pois no "bulevar Voltaire, um táxi dirigido pelo motorista Jean Guilhem, morador de Asnières, atropelou ao passar e atirou ao chão a Sra. Joséphine Cardine, de setenta e cinco anos, moradora na cité Popincourt n. ${ }^{\circ} 18$, e duas crianças, Jean, de doze anos, e Georgette Zussy, oito anos, que se encontravam no meiofio"189. Em outra passagem desse texto, constatamos o registro de que a "[...] Sra. Cardine, com fratura no crânio, foi transportada para o hospital Saint-Antoine. Quanto às crianças [...], foram levadas de volta à casa dos pais, na rua de la Folie-Méricourt, n. ${ }^{\circ}$ 26”; e, por fim, “[...] na praça Saint-Michel, um rapaz entregador, Robert Sorthivir, quinze anos, entra com um triciclo de transporte de mercadorias no trilho do bonde e fica preso entre duas viaturas que se cruzam. Com a perna direita fraturada, foi transportado à Santa Casa"190.

Esses episódios atestam, em parte, o que foi trabalhado por nós no presente texto: os encontros diários entre veículos e transeuntes sinalizam, em determinadas ocasiões, a fragilidade

\footnotetext{
${ }^{188}$ CAMPOS, Cândido Malta. Os Rumos da Cidade: Urbanismo e Modernização em São Paulo. São Paulo: Senac, 2002. p. $259-260$.

${ }^{189}$ LE CORBUSIER. Os Acidentes da Rua. In:

${ }^{190}$ Ibidem, p. 298. Urbanismo. São Paulo: Martins Fontes, 1992. p. 297.
} 
destes últimos, pois sofrem, integralmente, as investidas operadas pelos veículos. A transeunte mencionada no primeiro trecho, Joséphine Cardine, de setenta e cinco anos, foi "atropelada e atirada ao chão" pelo táxi que trafegava pelo bulevar Voltaire. Na outra ocasião, o rapaz de nome Robert Sorthivir, de quinze anos, que guiava um triciclo de transporte de mercadorias - o condutor tinha pouca idade - "entra no trilho do bonde e fica preso entre duas viaturas que se cruzam"; disso, resulta ficar fraturada a sua perna direita. É interessante, igualmente, atentarmos para o fato de que o noticiário, que se reporta ao atropelamento de Joséphine Cardine, salienta que esse acontecimento é "bastante grave" e que ele "abriu, ontem, a série habitual dos danos imputáveis ao trânsito". Por essa passagem, percebemos que esse periódico considera que a circulação dos veículos causava, habitualmente, danos físicos aos transeuntes e, desse modo, podemos considerar que os atropelamentos e colisões, verificados na época (1925) na capital francesa, ocorriam com certa frequência, atestados durante considerável espaço temporal ${ }^{191}$.

Desse modo, é perfeitamente possível fazermos uma analogia com os episódios de atropelamentos e colisões verificados nas ruas do espaço central da capital catarinense durante as décadas de 1920 e 1930, pois o processo em discussão registra, no ano de 1926, a colisão entre o automóvel n. 132, guiado pelo chauffeur Aniceto Machado de Souza, e o carro de praça guiado

\footnotetext{
${ }^{191}$ A seguir, destacamos, do mesmo texto, outras duas passagens que fornecem, ao leitor, um panorama mais claro sobre a situação do trânsito na cidade de Paris durante as décadas de 1910 e 1920. Assim, temos:

(1) Trânsito - os carros no teto: "O problema do trânsito em Paris é um dos exemplos mais claros da tacanhez de espírito e da impotência de ação de que sofremos no tocante a tudo quanto se refere à organização dos serviços públicos. Passantes e veículos caminham e rodam cada vez mais comprimidos no centro da capital; o afluxo aumenta todos os dias; tornou-se a tese cotidiana de lamentações para jornalistas e homens de negócios, para os parisienses e os suburbanos, e de todo esse concerto de lamúrias não parece sair nenhuma idéia prática, nenhuma fórmula de realização. Sabiam que cerca de quinhentas mil pessoas passam nas horas de afluência pela Paris congestionada? Saibam que os estorvos do trânsito fazem todos perder um tempo enorme; tomemos 20 minutos por dia, pois elas passam aí várias vezes, são cerca de 200.000 horas diárias perdidas ou perto de 60 milhões por ano! Elevem os espíritos, meus caros concidadãos, à altura das necessidades da vida moderna. Estão diante de uma grande dificuldade. Encarem-na de frente, e considerem que não sairão dela sem um esforço considerável.” (LE CORBUSIER. Os Acidentes da Rua. In: LE CORBUSIER. Urbanismo... op. cit., p. 296).
}

(2) Há carros demais e ruas de menos: "Foi distribuído ontem na Prefeitura, o relatório de Émile Massard, sobre os trabalhos do Congresso da Estrada em Sevilha, e sobre os diferentes meios de melhorar o trânsito... Vale a pena reter as conclusões do relatório: já em 1910, Massard escrevera: 'Em Paris, a superfície circulante (dos carros) é maior do que a superfície circulável (das ruas)'. Logo, já naquela época, se todos os veículos saíssem simultaneamente, não se poderiam mover. Ora, em 1910, havia 54.000 automóveis na França; hoje [1925], há 361.000 e anuncia-se que esse número será dobrado dentro de cinco anos. Mas terão as ruas aumentado a superfície? Não, sem dúvida. É essa a questão. Por ora, o único meio de se melhorar o trânsito é obter o máximo de rendimento dos sistemas adotados e aplicar o mais estritamente possível os regulamentos. Mas isso será insuficiente. Ante o enorme e contínuo desenvolvimento do 'automobilismo', é preciso pensar em criar novas vias para as novas máquinas. É a questão das estradas que se coloca e também a das passagens de carros sob as ruas. As novas estradas poderão ser subterrâneas ou aéreas nas cidades. De qualquer modo, cumprirá construí-las". (LE CORBUSIER. Os Acidentes da Rua. In: op. cit., p. 297).

Os registros anteriores atestam aspectos interessantes: os transeuntes e veículos circulavam de modo "comprimido" pelas ruas do centro da capital francesa, onde o fluxo de veículos "aumenta todos os dias". Além disso, os estorvos do trânsito faziam todos "perder um tempo enorme" nos engarrafamentos ou mesmo como resultado de colisões e atropelamentos. Outra constatação importante é o fato de que, já no ano de 1910, "a superfície circulante (dos carros) em Paris é maior do que a superfície circulável (das ruas). Além disso, verificamos que, na França, o fluxo de automóveis aumentava consideravelmente, pois se previa que a frota de 361.000 automóveis do país seria dobrada no espaço de cinco anos, sem que, para isso, tivesse ocorrido o aumento correspondente da superfície das ruas. Desse modo, cumpria-se a necessidade de se construir novas estradas, "subterrâneas" (túneis e metrô) "ou aéreas" (viadutos) nas cidades francesas. Por outro lado, essas soluções - especialmente quanto à construção de vias e estradas aéreas - foram implementadas na capital paulista durante os últimos anos do século XIX. Os exemplos mais evidentes são, como visto, a abertura de avenidas circulares, para facilitar o tráfego pelas ruas centrais da cidade e a construção e inauguração do viaduto do Chá (1898). Ver, a respeito: Bresciani, Maria Stella Martins. Melhoramentos entre intervenções e projetos estéticos: São Paulo (18501950). In:__ (Org). Palavras da cidade. Porto Alegre: UFRGS, 2001. A cidade de Florianópolis, por seu turno, apenas contará, em 1952/1955, com o seu primeiro plano diretor. Esse estudo urbanístico proporcionou uma leitura detalhada do sistema viário da capital catarinense, e constatou, dentre outros aspectos, os crescentes congestionamentos verificados da área central da cidade. Como solução, foi proposta a construção de uma via-tronco que, atravessando a ponte Hercílio Luz, interligaria de maneira mais eficiente - na visão dos autores do plano - as partes continental e insular da cidade. Entretanto, apenas durante as décadas de 1960 e 1970 , a solução definitiva para os congestionamentos de veículos na cidade foi acenada, com a construção da avenida de contorno norte-ilha, precursora da atual avenida Beira-mar Norte. Maiores detalhes sobre esse assunto serão discutidos no quinto capítulo da tese. 
pelo boleeiro Onofre de Aquino; dentre outros elementos, resultou que, em consequência desse choque, o automóvel n. 132 "virou, ficando completamente quebrado, [assim,] os passageiros Euclydes de Souza e Izidoro de Souza, receberam graves ferimentos na cabeça e foram levados para o Hospital de Caridade". Em vista disso, percebemos que os episódios de atropelamentos e colisões, verificados em cidades, como Florianópolis e, mesmo em centros urbanos mais populosos ou densamente edificados - como São Paulo e Paris -, produzem efeitos semelhantes aos transeuntes que circulam, a pé, pelas ruas dos seus respectivos espaços centrais, quais sejam: danos físicos, a obrigatoriedade de circularem com concentração, reflexos rápidos e atenção máxima por suas ruas e avenidas, dentre outros. Assim, corroborando com essas ideias, podemos referenciar, novamente, as palavras de Le Corbusier, ao observar que

\begin{abstract}
O século XIX abriu uma era de cálculo, de ciência experimental e aplicada. As máquinas surgiram em massa; seu número cresceu de tal modo que tumultuaram e modificaram os costumes [e] a economia. Já fez cem anos, com efeito, que a primeira locomotiva puxou um comboio de vagões numa estrada de ferro que ia de uma cidade a outra, introduzindo, assim, nas relações e nos transportes, uma mudança na direção - de fato uma velocidade que cresceria incessantemente, estendendo seus efeitos ao conjunto das atividades humanas. Essas atividades estiveram equilibradas durante milênios na base de quatro quilômetros por hora determinados pelo passo do homem, do cavalo ou do boi. Doravante, temos de opor a essa cadência os cinqüenta a cem quilômetros por hora dos veículos nas estradas planas e dos navios $[\ldots]^{192}$; enfim, as velocidades sem medidas do telégrafo, do telefone, do rádio. As conseqüências não iriam tardar: uma intensa agitação que tomou conta dos homens e de seus pensamentos. Ritmo novo, destruidor de hábitos seculares e criador de novas atitudes ${ }^{193}$.
\end{abstract}

Vimos que os elementos por ele apontados - especialmente quanto às novas velocidades imprimidas pelos automóveis e os novos comportamentos e ritmos praticados por chauffeurs, pedestres e passageiros diante da presença e deslocamento da tecnologia motorizada - fizeram parte do cotidiano da cidade de Florianópolis durante as décadas iniciais do século XX especialmente se considerarmos aqui, as devidas proporções espaciais, urbanísticas e populacionais. Essa é, porém, apenas uma das facetas que caracteriza a convivência simultânea operada por veículos - motorizados ou não -, chauffeurs, boleeiros e pedestres no cotidiano das cidades, pois o presente estudo analisa textos e registros nos quais é possível vislumbrarmos o cenário urbano da capital catarinense como palco de lutas e imposições expressas por transeuntes e por aqueles que guiavam os veículos. Desse modo, nas circunstâncias colocadas pelo cotidiano da cidade de Florianópolis, podemos assinalar que chauffeurs e pedestres exprimem, de modo

\footnotetext{
192 José Luiz Vieira observa, por exemplo, que "No dia 17 de janeiro de 1899, em Achéres, Yvelines, perto de Paris, Camile Jenatzy, conhecido como o Diabo Vermelho por causa da cor de sua barba, cobre um quilometro a $66 \mathrm{~km} / \mathrm{h}$ num CGA dogcart (carrinho aberto, de dois lugares). No mesmo dia, à tarde, Gaston de Chasseloup-Laubat bate seu recorde. Dez dias depois, Jenatzy atinge $80 \mathrm{~km} / \mathrm{h}$, e Chasseloup, em seu Jeantaud aerodinamizado, novamente quebra seu recorde. Em 29 de abril, Jenatzy volta à carga e faz $105 \mathrm{~km} / \mathrm{h}$ em seu veículo elétrico La Jamais Contente, tornando-se a primeira pessoa a ultrapassar a barreira dos cem quilômetros horários”. (Grifo do autor). (VIEIRA, José Luiz. A história do automóvel: a evolução da mobilidade. São Paulo: Alaúde Editorial, 2008. (v. 1. da Pré-história a 1908). p. 242). Controvérsias à parte, esclarecedor é o fato de que, já naquela época, atingiam-se, com os veículos motorizados - elétricos, a vapor ou de combustão interna -, consideráveis velocidades. Mais do que isso, as corridas e disputas automobilísticas feitas à época - algumas, inclusive, de abrangência internacional - sinalizam para a concorrência havida entre os principais países e indústrias produtores de automóveis, que lutavam, portanto, para impor-se em um cenário novo e muito promissor. Entre os principais países produtores de automóveis, à época, destacam-se os seguintes: França, Alemanha e Estados Unidos. Sobre essa dinâmica, veremos maiores detalhes, no capítulo terceiro da tese, intitulado Novos Tempos; Outras Legislações: adaptações e reformulação.

${ }^{193}$ LE CORBUSIER. Planejamento Urbano. 3 ed. São Paulo: Perspectiva, 1984. p. 25-26. (Col. Debates, n. 37).
} 
especial, dois personagens distintos que assinalam diferentes anseios e expectativas, mas que se utilizam de habilidades específicas que lhes permitem conviver - com ganhos e perdas para uns e outros - em um mesmo espaço urbano ${ }^{194}$.

Durante a década de 1930, os episódios de atropelamentos e colisões continuaram ocorrendo no perímetro urbano da capital catarinense. Na presente seção, procedemos, como visto, à discussão sobre as disputas e sensibilidades expressas pelos florianopolitanos quanto à percepção da velocidade e deslocamento imprimidos pelos automóveis. Efetuamos, igualmente, uma análise sobre as relações de poder que se estabelecem entre a circulação de chauffeurs, transeuntes e veículos motorizados, verificada no espaço urbano supracitado. Assim, no ano de 1934, o processo n. 239, de 21 de janeiro, fornece-nos - como os demais processos aqui analisados - elementos importantes para a elucidação dos questionamentos anteriormente enunciados. Esse processo registra o atropelamento da menor Alice Grumiché. Nele, o Cabo da Força Pública, Leopoldo João dos Santos, observa que "hoje, às vinte e trinta horas, achava-se em frente ao Cine Palace à rua Arcipreste Paiva, quando viu um automóvel particular, de propriedade do senhor Arlindo Pinto da Luz, e guiado pelo chauffeur Hélio Souza Silva ${ }^{195}$, o qual trazia velocidade excessiva" $" 196$. A testemunha afirma, igualmente, que "ao defrontar o dito cinema, atropelou uma menor que por ali passava, atirando-a ao solo"; "que tratando-se de um desastre efetuou a prisão do chauffeur em apreço nos seguintes termos: 'o senhor está preso, acompanhe-me à Chefatura de Polícia",197. No momento do desastre, "o chauffeur Hélio Souza brecou imediatamente o seu auto, podendo o mesmo ter evitado o atropelamento se subisse com velocidade moderada"198. (Anexo 04, p. 335).

A análise das ideias apontadas permite-nos destacar aspectos importantes. O senhor Arlindo Pinto da Luz, proprietário do automóvel, não o conduzia no instante do atropelamento, fato que confirma a tendência, referenciada anteriormente, de que, nas primeiras décadas do século XX, apenas os indivíduos que apresentavam muito boa condição financeira adquiriam automóveis - especialmente particulares - e dispunham de empregados para servir-lhes. A vítima possuía apenas seis anos de idade $^{199}$. Observamos, pois, que ela não dispunha de

\footnotetext{
${ }^{194}$ CERTEAU, Michel de; GIARD, Luce; MAYOL, Pierre. A invenção do cotidiano 2: morar, cozinhar. 5. ed. Petrópolis: Vozes, 2003. p. 200. ${ }^{195} \mathrm{O}$ referido chauffeur tinha dezoito anos. Esse aspecto concorda com o artigo 10 das Instruções Regulamentares para o serviço de trânsito público, de 1928, que estabelece que "Art. 10 - Nenhum menor de 18 anos poderá guiar veículos na via pública, sob pena de multa de $20 \$ 000$ ". (Santa Catarina. Instruções Regulamentares para o serviço de trânsito público. Florianópolis: Imprensa Oficial, 1928. p. 17). Esse elemento também confirma a tendência, inúmeras vezes apontada neste estudo, de que os chauffeurs eram, em sua maioria, indivíduos muito jovens.

${ }^{196}$ Processo n. 239, 21 jan. 1934. Caixa 26. É importante destacarmos que, no ano de 1934, vigoravam, para todo o Estado de Santa Catarina, as Instruções Regulamentares para o serviço de trânsito público, de 1928, pois, de acordo com o registro do presente processo, "O Decreto 2075, de 28 de junho de 1927, que aprovou as instruções para a Inspetoria de Veículos do Estado, proibiu terminantemente que os motoristas conduzam automóveis com alta velocidade, no centro da cidade, impondo multa aos transgressores". (Processo n. 239, 21 jan. 1934. Caixa 26).

${ }^{197}$ Processo n. 239, 21 jan. 1934. Caixa 26.

${ }^{198}$ Idem.

${ }^{199}$ O "Auto de exame de corpo de delito", datado de 21 de janeiro de 1934, anexo ao presente processo, assinala que "examinado uma menina de cor branca, com seis anos de idade, constataram o seguinte: uma ferida contusa na região frontal do lado esquerdo, de bordos irregulares, medindo quatro centímetros de extensão, interessando a pele e o tecido celular subcutâneo; uma contusão na região ocipital; uma contusão na região do terço inferior da perna esquerda, em sua face anterior”. (Processo n. 239, 21 jan. 1934. Caixa 26).
} 
condições físicas apropriadas para se esquivar do automóvel; aspecto corroborado pela hipótese de que o chauffeur Hélio Souza Silva conduzia o veículo com "velocidade excessiva”, conforme apontam as ideias expressas pelo Cabo Leopoldo João dos Santos, registradas anteriormente.

É importante destacarmos que as declarações prestadas pelas testemunhas confirmam, unanimemente, a "velocidade excessiva" atingida pelo automóvel no momento do atropelamento. Nesse sentido, a fala prestada por Alexandre Gevaerd, no dia 21 de janeiro de 1934, referencia que, "Hoje, às vinte e trinta horas, achava-se ele declarante na esquina da Praça XV de Novembro com a rua Tenente Silveira, quando a sua atenção foi despertada por um automóvel que subia a respectiva praça, lado do Palácio, com velocidade bastante excessiva” e "que quando o dito automóvel defrontava o Cine Palace, colheu uma criança que em conseqüência da queda recebeu diversos ferimentos; que o chauffeur apesar de ter brecado o seu automóvel, não pode evitar o desastre, tal a velocidade que levava"200.

Corroborando com essas declarações, o Cabo da Força Pública, Leopoldo João dos Santos, expôs, em novo depoimento, datado de 16 de fevereiro de 1934, que "ele depoente estava em frente ao Cine Palace, sito à rua Arcipreste Paiva, quando o automóvel n. 246 subindo em alta velocidade, isto é, em quarenta à cinqüenta quilômetros por hora, atropelou, na referida rua, bem em frente ao local em que se encontrava o depoente, uma menor cujo o nome o depoente não sabe"; e continuando suas alegações, a testemunha considerou que "o acusado podia ter evitado o atropelamento se normal fosse a velocidade de seu automóvel", e "que o automóvel de que se trata não buzinou ao aproximar-se do local do desastre"201.

Ideias semelhantes podem ser verificadas no depoimento prestado pelo Primeiro Sargento Músico da Força Pública, Paulo José dos Santos, no dia 16 de fevereiro de 1934; pois, nessa oportunidade, esclareceu que, "no dia e hora referidos na denúncia, estando ele depoente em frente à Catedral, viu passar da Praça XV de Novembro em linha reta para a rua Arcipreste Paiva o auto 246, guiado pelo acusado Hélio Souza Silva, em alta velocidade"; tendo, "ao defrontar o Cine Palace, atropelado uma menor, que foi atirada ao solo; Que não se lembra de ter ouvido o automóvel em questão fonfonar antes do local do acidente" e que "o acusado não pôde evitar o atropelamento devido exatamente a velocidade em que ia naquela ocasião"202.

\footnotetext{
${ }^{200}$ Processo n. 239, 21 jan. 1934. Caixa 26.

${ }^{201}$ Idem.

${ }^{202}$ Processo n. 239, 21 jan. 1934. Caixa 26. A testemunha Paulo José dos Santos afirma em depoimento prestado no dia 21 de janeiro de 1934 data de ocorrência do atropelamento da menor -, que "quando [...] chegou ao local para efetuar a prisão do 'chauffeur' Hélio Souza, este já tinha sido preso em flagrante pelo Cabo da Força Pública, Leopoldo João dos Santos, que o conduziu imediatamente à esta Delegacia”. (Processo n. 239, 21 jan. 1934. Caixa 26). O que queremos observar é que, na ocasião do atropelamento referido neste processo, estiveram presentes ao local do sinistro, duas autoridades policiais, uma das quais já havia efetuado a prisão em flagrante do acusado Hélio Souza Silva. Assim, podemos inferir que, já durante a metade da década de 1930, observamos - pelo menos no espaço central da capital catarinense - considerável presença policial, aspecto este que será incrementado nos anos seguintes; pois, dentre outros fatores, será criada, no ano de 1935, a Secretaria de Segurança Pública do Estado de Santa Catarina, órgão que, a partir do ano de 1938, efetuará a "orientação e físcalização do trânsito nas vias públicas". (Lei n. 12, de 12 de novembro de 1935. Cria a Secretaria de Segurança Pública. In: Santa Catarina. Coleção de Leis, Decretos, Resoluçóes e Portarias de 1935. Florianópolis: Livraria Central de Alberto Entres, 1936. p. 13-14 e Decreto-lei n. 24, de 7 jan. 1938 . Atribuindo à Secretaria de Segurança a orientação e fiscalização do trânsito nas vias públicas. In: Santa Catarina. Coleção de Decretos-Leis de 1938.
} 
É importante observarmos que as referidas testemunhas tiveram a sua atenção despertada pela passagem do automóvel, e esse episódio, segundo elas, decorreu especialmente da excessiva velocidade imprimida pelo veículo na ocasião do atropelamento. Esses elementos sugerem-nos que, no transcorrer da década de 1930, os automóveis faziam parte do cotidiano dos habitantes da cidade de Florianópolis e apenas circunstâncias específicas - colisões, atropelamentos, ou deslocamentos em alta velocidade - chamavam a atenção dos transeuntes ou daqueles que se encontravam em passeios públicos ou estabelecimentos comerciais da cidade. Essa é apenas uma inferência, mas, entendemos, plausível de ser considerada ${ }^{203}$.

As declarações referenciadas apontam, como visto, para a alta velocidade atingida pelo automóvel no instante do atropelamento. A alta velocidade imprimida pelos veículos motorizados, mencionada nos processos, parece, todavia, ter sido aspecto frequente; pois, como visto, foi constatado que os registros jornalísticos da época já salientavam a imprudência e a velocidade excessiva com que os chauffeurs conduziam os automóveis. O artigo do jornal $O$ Estado, de 22 de janeiro de 1934, registra, por exemplo, o atropelamento atestado pelo processo em discussão da seguinte forma:

Ontem, cerca das vinte e quinze horas, o automóvel $246 \mathrm{P}^{204}$, de propriedade do Sr. Arlindo Pinto da Luz e guiado pelo motorista Hélio Souza, subia com grande velocidade da Praça XV para a rua Arcipreste Paiva, quando ao chegar em frente ao Cine Palace, atropelou e derrubou por terra a menor Alice, filha do Sr. Eurico Grumiché, residente à rua Itajaí, s/n. A cena foi rápida e brutal pois não se concebe que, num ponto como aquele, onde o movimento de pedestres era intenso, um chauffeur ousasse fazer passar seu carro com tal velocidade. Brecando pouco além o veículo, o motorista foi preso em flagrante pelo Cabo Leopoldo dos Santos, sendo conduzido à Chefatura de Polícia ${ }^{205}$.

A análise das ideias apontadas permite-nos considerar que os pedestres eram, em muitas situações colocadas pelo cotidiano, frágeis e vulneráveis frente às altas velocidades atingidas pelos automóveis, especialmente no perímetro urbano da cidade de Florianópolis. Percebemos, igualmente, a relação de poder operada entre os veículos motorizados e os transeuntes, pois entendemos que, quando se fala de poder, as pessoas pensam imediatamente em uma estrutura política, um governo, um estrato social dominante; mas, de fato, nas relações humanas, o poder está sempre presente. Há, entretanto, nas relações de poder, forçosamente possibilidades de resistência - de resistência violenta, de fuga, de astúcia, de táticas que revertam a situação -, sem as quais não haveria absolutamente relações de $\operatorname{poder}^{206}$.

\footnotetext{
Florianópolis: Imprensa Oficial do Estado, 1939. p. 6-10). Maiores detalhes a respeito serão encontrados no capítulo terceiro da tese, notadamente na seção Legislação e Circulação: incrementação e complexidade.

${ }^{203}$ A testemunha Alexandre Gevaerd afirmou, no dia 16 de fevereiro de 1934, que ela "não pôde ver o desastre por achar-se virado de costas para o local em que o auto apanhou a vítima". Entretanto, nesta mesma ocasião, a presente testemunha afirmou que "teve sua atenção voltada para um automóvel que passava em alta velocidade, cerca de quarenta a cinqüenta quilômetros por hora". (Processo n. 239, 21 jan. 1934. Caixa 26). Esse aspecto confirma o que Alexandre Gevaerd disse por ocasião de seu depoimento prestado no dia 21 de janeiro de 1934 , anteriormente referido. (Processo n. 239, 21 jan. 1934. Caixa 26). Esses elementos corroboram a hipótese considerada por nós, anteriormente.

${ }^{204}$ A letra $P$ indica que se trata de veículo Particular.

${ }^{205}$ Um automóvel: atropela e fere uma menina. O Estado. Florianópolis, 22 jan. 1934. p. 8.

206 FOUCAULT, Michel. Sexo, Poder e Indivíduo... op. cit., p. 70-72;

Janeiro: Forense Universitária, 2004. v. 5. p. 276-277.

Ditos e Escritos: ética, sexualidade, política. 1 ed. Rio de
} 
Por outro lado, devemos considerar que a experiência social da metropolização se funda na supremacia da tecnologia moderna. Além disso, o crescimento das cidades era um fenômeno em gestação e os automóveis configuravam um fato novo, a partir do qual os atropelamentos se tornam diários, especialmente envolvendo anciãos e crianças ${ }^{207}$. Desse modo, é válido observarmos que a circulação dos veículos motorizados no meio urbano é caracterizada, dentre outros aspectos, pelas altas velocidades que os chauffeurs imprimem aos seus automóveis, pois é improvável que eles adotassem comportamentos sempre exemplares no trânsito e obedecessem, na totalidade de suas andanças pela cidade, às regras e às normas legais vigentes. Esse aspecto já foi por nós discutido. É verificado não somente na cidade de Florianópolis, mas, principalmente, em centros urbanos mais expressivos, como São Paulo e Rio de Janeiro. Nesse ponto, é válido, porém, observarmos, para a cidade de São Paulo, os poemas de Mário de Andrade, especialmente aqueles intitulados Losango Cáqui (1926) e Grã-cão do outubro $(1927)^{208}$.

Nesses poemas, o autor exprime, claramente, seus sentimentos e impressões sobre o cotidiano da capital paulista e faz referência, dentre outros assuntos, à intensa urbanização, ao incessante tráfego de automóveis e à atmosfera moderna que tomava conta da cidade de São Paulo. Assim, podemos observar que a vida urbana, além de inspirar a produção de discursos, transforma-se em foco dominante da vida social, local de difusão de ideias, palco para debates e espaço de decisões. A cidade, a um só tempo, seduz e transforma mentalidades. Ela está, pois, na origem de uma eclosão de discursos que espelham, com força particular, o impacto urbano sobre o imaginário e sobre as novas formas coletivas nascentes, especialmente citadinas ${ }^{209}$.

A velocidade também participa dessa lógica, uma vez que surge em inúmeras referências discursivas ao tráfego urbano, à circulação de automóveis e de bondes, à pressa dos transeuntes; enfim, a um novo ritmo que se quer ver impresso na cidade. $\mathrm{O}$ automóvel aparece, então, como metáfora por excelência da modernidade e da urbanidade. Os "automóveis, cinema, asfalto" compõem uma imagem imediata e coletivamente reconhecida como sendo ligada à vida moderna. Assim, a relação de Mário de Andrade com a modernidade urbana é, entretanto, outra. Na São Paulo de Mário, os valores fortes da época: a velocidade, a verticalidade, a busca generalizada por signos de metropolização, aparecem humanizados, pois, segundo o poeta,

[...] Careço de marchar cabeça levantada, / Olhar altivo para frente... /

Mas eu queria olhar à esquerda... / Bonita casa colonial/

Cheinha mesmo de paisagens! $!^{10}$

\footnotetext{
${ }^{207}$ SEVCENKO, Nicolau. Orfeu extático na metrópole... op. cit., p. 74.

${ }^{208}$ O Poema Losango Cáqui engloba uma reunião de vários poemas produzidos por Mário de Andrade, publicados no ano de 1926. Para esta passagem da tese, analisaremos os poemas $I X$ e $X$, intitulados, respectivamente, "Careço de marchar cabeça levantada" e "TABATINGÜERA". No poema Grã-cão do outubro, composto de cinco partes, analisaremos a última, intitulada "Dor", publicada em outubro de 1933. Ver MANFIO, Diléia. (Org.). Poesias Completas / Mário de Andrade. Belo Horizonte: Itatiaia, 2005.

${ }^{209}$ SCHPUN, Mônica Raisa. Luzes e sombras da cidade - São Paulo na obra de Mário de Andrade. In: Revista Brasileira de História, v. 23, n. 46, São Paulo, 2003. (Dossiê Experiências Urbanas).

${ }^{210}$ ANDRADE, Mário. Poema "IX - Careço marchar cabeça levantada", de Losango Cáqui. In: MANFIO, Diléia. (Org.). Poesias Completas / Mário de Andrade... op. cit. p. 130.
} 
Referindo-se à violência do processo de urbanização, Mário traz, todavia, à cena discursiva um de seus possíveis contrapontos:

[...] Mas a taba cresceu... Tigüeras agressivas, / Pra traz! Agora o asfalto anda em Tabatingüera. / Mal se esgueira um pagé entre locomotivas / E o forde assusta os manés lentos do Anhangüera ${ }^{211}$.

Aqui, notamos as percepções de Mário quanto ao aspecto assustador da modernidade paulistana. Enfim, o prédio Martinelli, cartão postal da urbanização paulistana, não poderia estar ausente dessa leitura da cidade e de seus rumos:

[...] A cidade está mais agitada e meidia. / As ruas devastam minha virgindade /

E os cidadãos talvez marquem encontro nos meus lábios. /

E agora apontai-me, janelas do Martinelli, / Calçadas, ruas, ruas ladeiras rodantes, viadutos, /

Onde estão os judeus de consciência lívida? / Os tortuosos japoneses que flertam São Paulo? /

Os ágeis brasileiros do Nordeste? Os coloridos? / Onde estão os coloridos italianos? /

Onde estão os turcomanos? ${ }^{212}$

Em todos os exemplos dados, por trás do esforço empregado em reforçar os traços de transformação e de ruptura, insinua-se a vida pacata e provinciana da cidade, e se descortina uma realidade muito menos homogênea, marcada pela convivência de ritmos, equipamentos e paisagens díspares. Assim, essa convivência torna-se, particularmente, visível nas referências feitas a elementos da paisagem natural da cidade, colocadas em confronto com a nova paisagem arquitetônica e urbanística. Esse olhar sobre a vida urbana que tende a humanizar suas transformações e seus ritmos refere-se, em síntese, a uma maneira de ver e de representar a modernidade paulistana. Em vista disso, podemos considerar que a cidade é objeto de múltiplos discursos e olhares, que não se hierarquizam, mas que se justapõem, compõem ou se contradizem, sem, por isso, serem uns mais verdadeiros ou importantes que outros ${ }^{213}$.

A cidade se impõe para o historiador como um domínio estimulante, pois ela não é apenas um fato colocado pelo saber técnico; mas, antes, um espaço envolto e edificado por elementos heterogêneos, nos quais coexistem medidas e esquadrinhamentos urbanísticos, mesclados às influências impostas por mitos, lembranças, esquecimentos e referenciais mentais diversos, expressos por seus habitantes. Ela é, em síntese, um espaço que permite diversos olhares e percepções e, como tal, passível de questionamentos e reinvenções ${ }^{214}$.

Por outro lado, nos poemas aqui analisados, está explícita a ideia de que a vida urbana é o meio de acesso à "civilização" que passa, também, pelos signos da modernidade. No romance modernista Macunaíma (1928), por exemplo, se tanto os hábitos e objetos “civilizados” quanto os equipamentos urbanos impressionam o herói, o que o assusta mesmo são os elementos da

\footnotetext{
211 ANDRADE, Mário. Poema "X - TABATINGÜERA”, de Losango Cáqui. In: MANFIO, Diléia. (Org.). Poesias Completas / Mário de Andrade. Belo Horizonte: Itatiaia, 2005. p. 130.

${ }^{212}$ ANDRADE, Mário. "Dor" (15.X.33), poema de Grã cão do outubro. In: MANFIO, Diléia. (Org.). Poesias Completas / Mário de Andrade... op. cit., p. 318.

${ }^{213}$ CASTORIADIS, Cornélius. A Instituição Imaginária da Sociedade. Rio de Janeiro: Paz e Terra, 1982. p. 154 e p. $167-168$.

${ }^{214}$ BRESCIANI, Maria Stella Martins. Cidade e História. In: OLIVEIRA, Lúcia Lippi (Org.). Cidade: história e desafios. Rio de Janeiro: FGV, 2002. p. 32.
} 
modernidade, a Máquina: “máquina-automóvel”, “máquina revolver”, “máquina smith-wesson”; mas também "máquina negócios", "máquina telefone”, "máquina relógio", etc. Ao contrário dos futuristas europeus que celebram, sem hesitar, a cidade, a urbanização, as máquinas e a tecnologia em geral, Mário, em suas obras, interroga-se, contudo, sobre o significado dessa nova metrópole, problematizando-a indefinidamente. O dilaceramento do poeta resulta, efetivamente, das tensões sociais que o rodeiam. De um lado, sua linhagem social o compromete com um passado hierárquico; por outro, ele compreende o valor do novo, o efeito espetacular da industrialização, o papel empreendedor dos imigrantes, a democratização da vida urbana. E muitos dos poemas produzidos por Mário de Andrade captam esse paradoxo.

Nesta altura do texto, é importante enfatizarmos os conceitos de modernidade e modernização. O primeiro corresponde a uma visão de mundo e pressupõe valores culturais inter-relacionados: secularização política e moral, progressivo aperfeiçoamento cultural e material, fé na razão e no progresso científico, e racionalidade empresarial. O segundo está, pois, intimamente relacionado ao conceito de modernidade, mas corresponde, especificadamente, aos processos de evolução e de aperfeiçoamento tecnológicos. Quanto ao termo modernidade, Bern Witte o discute a partir das interpretações de Charles Baudelaire e Walter Benjamin. De acordo com o autor, podemos

[...] dizer que o que é moderno hoje estará envelhecido ou fora de moda amanhã. Por isso, os teóricos da modernidade criaram este conceito em analogia ao conceito de moda, e o primeiro que o fez foi Baudelaire. Ele é o inventor da palavra e da coisa, la modernité. Baudelaire diz que não há nada melhor do que esta palavra para exprimir [a] eterna volatilização dos fenômenos. Em Baudelaire, a modernité não é mais do que uma ampliação do conceito de arte. Esta palavra deve dar expressão à idéia de que também o que há de volátil, o fenômeno cotidiano, deve ser incluído na arte. É isso que Baudelaire denomina modernité. A única lei que continua válida para Benjamin é a de que sempre e a qualquer preço é necessário o novo, que por sua vez se torna antiquado, com a mesma velocidade. Entendido de outra forma, o conceito de modernidade é limítrofe, é um conceito-limiar, dentro do qual está fixado o fato de que não existe [...] quaisquer leis de validade geral nem quaisquer valores eternos do estético. Em Benjamin, podemos ler que 'a modernidade tem que estar sob o signo do suicídio'. Esta frase que, evidentemente, também é interpretável biograficamente tem uma coerência sistemática, a saber, ela alude como signo para o fato de que é impossível que o ser humano se torne criativamente ativo na modernidade. 'As resistências que a modernidade opõe ao élan produtivo natural do homem estão em discordância com as suas forças'. A produção da mente ou do espírito tem como meta a efetividade e, com isso, a durabilidade. Mas efetividade e durabilidade são impossibilitadas pelo princípio da modernidade. Pois o que acaba de ser criado é imediatamente envelhecido e é vitima do desprezo e do esquecimento ${ }^{215}$.

As considerações anteriores podem ser aprofundadas ao destacarmos que Walter Benjamin analisa o aspecto urbano de Paris no início do século XX. Nesse sentido, referencia a vida de uma cidade pacata, onde ainda havia "[...] afeição pelas passagens, [e] onde o flâneur escapava ao olhar do veículo, que não tolera a concorrência dos pedestres"; havia, com efeito, "o transeunte que se perde na multidão; mas também havia ainda o flâneur, que precisa de espaço

\footnotetext{
${ }^{215}$ ROUANET, Sérgio Paulo e WITTE, Bernd. Por que o moderno envelhece tão rápido? In: ASCHER, Nelson. (Org). Dossiê Walter Benjamin. Revista USP. São Paulo: CCS/USP, n. 15, set./nov. 1992. p. 104-105.
} 
para agir e que não quer privar-se de sua privatização. Ocioso, caminhava como se fosse uma personalidade: assim era o seu protesto contra a divisão do trabalho, que transforma as pessoas em especialistas", e "assim ele também protestava contra a operosidade e a eficiência"216. Desse modo, “[...] por volta de 1840 fazia parte do bom-tom [...] levar tartarugas a passear pelas passagens. O flâneur gostava de deixar que o seu ritmo fosse ditado por elas", pois se "[...] dependesse dele, o progresso teria de aprender esse pas. Mas não foi ele quem nisso teve a última palavra: foi Taylor, que transformou em palavra-de-ordem o 'abaixo a flânerie"",217. É, precisamente, contra essas ideias que Walter Benjamin interpreta a "vida anterior", evocada por Baudelaire, como uma referência a uma era primitiva e edênica, em que "[...] a experiência autêntica ainda existia e as cerimônias do culto e as festividades permitiam a fusão do passado individual com o passado coletivo" 218 . Benjamin percebe o espaço urbano parisiense como trabalhado "[...] pela memória voluntária, que escapa [...] à rigidez organizada desta, sendo invadida por lapsos de esquecimento e lembranças desconcertantes, arrancadas do fundo [...] da memória involuntária fugidia" e pouco "apropriada a se deixar envolver por explicações ou seqüências objetivas" ${ }^{219}$. Essa noção de experiência não corresponde, portanto, ao cenário das grandes cidades, notadamente agitado e catastrófico.

Em outras palavras, podemos considerar que, na modernidade, não há a possibilidade de se efetuar algo duradouro, que seja transmitido para as gerações futuras. Assim, a moda, os valores culturais, os avanços tecnológicos são elaborados para atender a interesses imediatos. Desse modo, os costumes e valores religiosos tradicionais de uma certa comunidade ou sociedade são desprezados, e valorizam-se, por exemplo, a ação transformadora e a nova forma de se vestir e de se comportar em público, ou seja, a modernidade anula a experiência. No poema $O$ gosto do

\footnotetext{
${ }^{216}$ BENJAMIN, Walter. A Paris do Segundo Império em Baudelaire. In: KOTHE, Flávio R. (Org.). Walter Benjamin: sociologia. 2. ed. São Paulo: Ática, 1991. p. 81. (Col. Grandes Cientistas Sociais, n. 50). Esse esforço de rememoração do passado tem por tarefa, segundo Benjamin, a construção de constelações que ligam o presente ao passado. Essas constelações, esses momentos "[...] arrancados da continuidade histórica vazia, são mônadas, ou seja, são concentrados da totalidade histórica. Os momentos privilegiados do passado, diante dos quais o adepto do materialismo histórico faz uma pausa, são aqueles que constituem uma interrupção messiânica dos acontecimentos". LOWY, Michael. Walter Benjamin: aviso de incêndio: uma leitura das teses "Sobre o conceito de história". São Paulo: Boitempo, 2005. p. 131. Assim, podemos considerar que, para Benjamin, articular o passado historicamente significa "[...] apoderar-se de uma lembrança tal como ela lampeja num instante de perigo" (tese VI, p. 65). O momento de perigo para o sujeito histórico - para Benjamin, as classes oprimidas - é aquele em que surge a imagem autêntica do passado, e Benjamim enxerga, nas multidões dominadas, núcleos de resistência, núcleos estes que outrora formaram as massas revolucionárias de 1848 e os partidários da Comuna de Paris dos anos 1870/71. Em outras palavras, em um momento de perigo supremo, apresenta-se uma constelação salvadora que liga o presente ao passado. Ainda é válido destacarmos que Walter Benjamin introduz, na tese VII, um novo conceito: a Einfühlun, cujo equivalente mais próximo é a empatia. O termo empatia se identifica com o cortejo dos dominadores e sua origem encontra-se, segundo Benjamin, na acedia, que é o "[...] sentimento melancólico da todo-poderosa fatalidade, que priva as atividades humanas de qualquer valor. Conseqüentemente, ela leva a uma submissão total à ordem das coisas que existem" (p. 71). E é exatamente contra esse historicismo servil que Benjamin propõe "escovar a história a contrapelo", pois deixada à própria sorte "[...] a história somente produzirá novas guerras, novas catástrofes, novas formas de barbárie e opressão” (p. 74). Nos trechos destacados, as páginas entre parênteses correspondem ao livro (LOWY, M. Walter Benjamin: uma leitura das teses "Sobre o conceito de história". São Paulo: Boitempo, 2005).

${ }^{217}$ BENJAMIN, W. A Paris do Segundo Império em Baudelaire. In: KOTHE, Flávio R. (Org.). Walter Benjamin: sociologia... op. cit., p. 81.

${ }^{218}$ LOWY, Michael. Walter Benjamin: aviso de incêndio: uma leitura das teses "Sobre o conceito de história"... op. cit., p. 29.

219 BENJAMIN, Walter. "Sobre alguns temas em Baudelaire"; "O Flâneur". In: . Charles Baudelaire: um lírico no auge do capitalismo... op. cit. apud BRESCIANI, Maria Stella Martins. A Cidade: objeto de estudo e experiência vivenciada. In: Revista Brasileira de Estudos Urbanos e Regionais. São Paulo: ANPUR, v. 6, n. 2, nov. 2004. p. 15. No presente estudo, objetivamos trabalhar esses elementos no contexto da cidade de Florianópolis, pois devemos observar, uma vez mais, que a vida cotidiana de uma cidade é emoldurada por circunstâncias e vivências diversas, operadas por seus habitantes - representados, aqui, pelos florianopolitanos, que ao circularem cotidianamente pelas ruas do perímetro urbano da capital catarinense, efetuam trilhas móveis, que obedecem, antes de tudo, aos seus próprios anseios, memórias e percepções despertadas por suas vivências no cenário urbano em questão.
} 
nada, de autoria de Charles Baudelaire, destacarmos a seguinte frase: “A adorável Primavera já perdeu seu odor!"220. Sobre essa passagem, podemos enfatizar que "O desmoronamento da experiência que Baudelaire havia compartilhado é confessado na palavra perdeu. O odor é, pois, o refúgio inacessível da mémoire involontaire"; não há, portanto, "nenhum consolo para quem não pode mais fazer qualquer experiência",221.

As ideias apontadas nos permitem afirmar que os veículos motorizados simbolizam, dentre outros elementos, a modernidade e o progresso imprimidos, especialmente, pela sociedade ocidental, pois a rápida circulação pelas ruas da cidade, proporcionada pelos automóveis, encurta as distâncias, acelera o tempo e classifica o deslocamento operado pelos pedestres e veículos não motorizados como lento, inoperante e pertencente ao passado arcaico e obsoleto. Desse modo, podemos registrar as ideias expressas por Bruno Latour que, ao analisar a temporalidade moderna, observa: "De onde vem a idéia de um tempo que passa? Da própria Constituição moderna. Os modernos têm a particularidade de compreender o tempo que passa como se ele realmente abolisse o passado antes dele", pois "não se sentem distantes da Idade Média por alguns séculos, mas separados dela por [...] cortes epistemológicos", ou seja, "rupturas epistêmicas que são tão radicais que não sobrou nada mais deste passado dentro deles - que nada mais desse passado deve sobreviver neles". Assim, "já que tudo aquilo que acontece é para sempre eliminado, os modernos têm realmente a sensação de uma flecha irreversível do tempo, de uma capitalização, de um progresso" ${ }^{, 22}$. Por outro lado, é importante considerarmos que o progresso, tal como é imaginado e ativado nas sociedades burguesas, dispara em nós a obsessão do moderno. Desse modo, a ideia de Progresso torna-se, portanto, obsessiva e é transformada em um motivo embriagante que se desliga da atenção e da realidade ${ }^{223}$.

Essas ideias exigem um questionamento. De que maneira podemos perceber esses elementos na cidade de Florianópolis no período estudado? Os padrões de modernidade urbana, como as grandes avenidas, o ritmo rápido e incessante dos veículos motorizados, a organização de amplo sistema de água e esgotos, e o embelezamento das regiões centrais das cidades eram referenciados no continente europeu, sobretudo no eixo Paris-Londres. No Brasil, esses padrões eram almejados principalmente no Rio de Janeiro, capital política e centro econômico do país, na época - embora, veremos, tais anseios estiveram envoltos em várias disputas ideológicas, conceituais e políticas, contrárias ou mesmo a favor das tentativas de sua aplicação prática. Tratando-se de Florianópolis, cujos avanços no campo econômico, cultural e urbanístico eram

\footnotetext{
${ }^{220}$ BAUDELAIRE, Charles. Poema "LXXXIII - O gosto do nada". In: Obra Prima de Cada Autor, n. 52).

${ }^{221}$ BENAMIN, W. "Sobre alguns temas em Baudelaire". In: _ . Charles Baudelaire: um lírico no auge do capitalismo... op. cit., p. 135.

${ }^{222}$ LATOUR, Bruno. Jamais fomos modernos: ensaio de antropologia simétrica. Rio de Janeiro: Ed. $34,1994$. p. 68.

${ }^{223}$ GONÇALVES FILHO, José Moura. Memória e Sociedade. Memória e ação cultural. Revista do Arquivo Municipal. São Paulo: Departamento do Patrimônio Histórico Municipal, 1992. p. 29.
} 
também incipientes, os modelos e padrões de modernidade eram inspirados no Rio de Janeiro, mas também, como parâmetro mais distante, no continente europeu. Assim, a modernidade em Florianópolis refletia-se de maneira ainda mais distante. A aplicação dos padrões de modernidade, considerando-se as devidas proporções urbanísticas e financeiras, operou-se, em Florianópolis, com certo distanciamento temporal e envolveu, sobretudo, a participação dos órgãos governamentais e veículos jornalísticos locais, que difundiram a noção de uma cidade ordenada, salubre e higienizada ${ }^{224}$.

É importante assinalarmos, entretanto, que as notas jornalísticas e as demais fontes pesquisadas: processos criminais, mensagens de governo, leis e relatórios, códigos penais e de trânsito, registram as percepções e impressões dos florianopolitanos perante o gradual processo de incrementação do transporte motorizado pelas ruas do perímetro urbano da capital catarinense. Assim, no presente estudo, os processos de modernidade e modernização são identificados, de modo especial, pela crescente circulação automobilística pelas ruas no espaço físico supracitado. Esse aspecto relaciona-se, também, ao incremento da velocidade atingida pelos automóveis, pois, no período em estudo, atestamos o gradual aperfeiçoamento de veículos, o que implica no encurtamento das distâncias e dos percursos efetuados na capital catarinense.

O gradual incremento dos transportes motorizados em Florianópolis foi, portanto, alvo das percepções dos seus habitantes, registradas, sobretudo, nos processos criminais que envolvem atropelamentos e colisões, no período em estudo. Nesse sentido, concebemos que os processos de modernidade e modernização, como entendidos neste texto, atingiram diretamente a população florianopolitana, pois os textos processuais registram as percepções cotidianas expressas pelos habitantes da cidade de Florianópolis quanto à circulação automobilística pelas ruas da cidade; habitantes estes que configuram homens comuns, obscuros heróis do efêmero, atores e agentes da história ${ }^{225}$.

Além disso, é importante considerarmos que a temática e os procedimentos metodológicos, propostos nesta pesquisa, constituem específicos caminhos de investigação e salientam aspectos importantes sobre o cotidiano de personagens anônimos da capital catarinense. Esses aspectos são, portanto, analisados pelo estudo dos processos criminais e demais fontes utilizadas. Assim,

\footnotetext{
${ }^{224}$ Maiores esclarecimentos quanto à "atmosfera" de modernidade que, à época, permeava o ambiente urbano da capital catarinense, ver COSTA, Sandro da Silveira. Ponte Hercílio Luz: mutações urbanas em uma cidade insular (1890-1960). Dissertação (Mestrado em História). Florianópolis: UFSC, 2002. Nesse texto, procuro arguir, dentre outros elementos, que as características da modernidade, apontadas acima, são aplicáveis ao contexto urbano de uma cidade de menor porte, como a capital catarinense, pois eram divulgadas pelos órgãos governamentais locais, difundindo a ideia de uma cidade organizada e civilizada, em pé de igualdade com outros centros urbanos brasileiros e europeus. Assim, importante é destacarmos que a cidade moderna, desejada, realizada ou não, existiu como elaboração simbólica na concepção de quem a projetou a quis concretizar. Em outras palavras, podemos considerar que Florianópolis, apesar de não ser uma cidade moderna como Paris ou Rio de Janeiro, era considerada como tal nos discursos da imprensa e do governo. A representação imaginária da cidade moderna ganhava força de realidade, pois "aqui e ali, ainda se contorcem vilas de aspecto colonial ladeadas de casas quadradas e incompatíveis a uma cidade moderna que se quer salubre e confortável” (Saneamento de Florianópolis. República. Florianópolis, 08 set. 1919. p. 1). Além disso, vimos que a introdução da tecnologia motorizada nas cidades de São Paulo e Florianópolis operou-se, respectivamente, dentro de um curto espaço temporal que engloba, grosso modo, quinze anos.

${ }_{225}$ CERTEAU, Michel de; GIARD, Luce; MAYOL, Pierre. A invenção do cotidiano 2: morar, cozinhar. 5. ed. Petrópolis: Vozes, 2003 . p. 342.
} 
podemos considerar que o campo de interesse sobre a cidade, pela sua propria complexidade e pluridimensionalidade, dá margem a diferentes modalidades e enfoques historiográficos, uma vez que a apreensão de um objeto tão multifacetário como o urbano implica, necessariamente, na adoção de perspectivas privilegiadas ${ }^{226}$. Nesse sentido, sempre haverá, a nosso ver, sob o rótulo "história urbana", várias modalidades historiográficas, eventualmente constituindo saberes específicos $^{227}$.

Vale observarmos que, neste texto, objetivamos relacionar e/ou pôr em contato aspectos específicos do cotidiano da cidade de Florianópolis com situações e contextos verificados em outras cidades do país e da Europa Ocidental. Investigamos, desse modo, as percepções e as sensibilidades que os florianopolitanos expressaram quanto à gradativa introdução dos veículos motorizados pelas ruas do perímetro urbano da capital catarinense. Procuramos, todavia, elucidar, também, situações semelhantes verificadas em outros contextos e ambientes urbanos. Objetivamos, com isso, tecer uma análise particular sobre o contexto urbano da cidade de Florianópolis durante as décadas de 20 e 30 do século passado.

Desse modo, não podemos pensar que a História escreve a si mesma, que os fatos se impõem ao historiador; e também não podemos achar que o fazer histórico é possível sem os elementos - fontes - que nos remetem a determinado contexto ou situação temporal e, consequentemente, histórica. Evidenciamos, pois, que não podemos escrever a história sem documentos, nem sem as ferramentas e conceitos que a cultura historiográfica nos proporciona $^{228}$. Assim, tecer, costurar, escrever, como qualquer evento humano, por mais particular e específico que seja, estabelece uma relação dinâmica e intrínseca entre fontes e interpretação. Enfatizamos que o passado, como a História, é uma invenção do presente, embora ancorada nos signos por ele deixados; passado este que está longe de estar morto, pois é "revelado" ou "trazido à tona" pelo trabalho do historiador ${ }^{229}$.

\subsubsection{Moeda e Motorização}

\subsubsection{Aquisição e Recursos}

Vimos em passagens anteriores deste estudo que durante as décadas de 20 e 30 do século passado, os automóveis representaram novos personagens que vieram integrar o cenário urbano da capital catarinense. Desse modo, é plausível considerarmos que apenas os indivíduos que apresentavam muito boa condição financeira podiam adquiri-los e, paralelamente, manter

\footnotetext{
${ }^{226}$ SILVA, Luís Octávio. História Urbana: uma área de conhecimento. Revista de Ciências Humanas. Florianópolis: EDUFSC, n. 29 , abr. 2001. p. 52.
227 Idem.

${ }^{228}$ JÚNIOR, Durval M. de Albuquerque. História: a arte de inventar o passado: ensaios de teoria da História. Bauru: EDUSC, 2007. p. 32.

${ }^{229}$ Ibidem, p. 31 e p. 33.
} 
profissionais responsáveis pela condução desses veículos - os chauffeurs. Esse cenário corresponde, em grande medida, àqueles indivíduos que eram proprietários de veículos particulares. Veremos, entretanto, a seguir, na seção Diversificação e Propriedade, que os próprios chauffeurs eram, muitas vezes, os proprietários dos veículos os quais utilizavam em sua profissão. Por hora, analisamos o processo criminal n. 30, de 05 de março de 1923 - por nós já referenciado -, pois entendemos tratar-se de um episódio de atropelamento que exemplifica, de modo especial, o fato de os automóveis particulares serem adquiridos, sobremaneira, pelos indivíduos que apresentavam muito boa condição financeira junto às sociedades florianopolitana e catarinense da época ${ }^{230}$. Além disso, é importante não nos reportarmos, com frequência, aos processos já analisados, para que o presente texto não se torne cansativo. Assim, a opção pela análise do processo n. 30, nesta altura do texto, é justificada pela sua clara relevância no que tange aos propósitos registrados na presente seção.

Notamos que o referido processo envolve o atropelamento do transeunte Manoel Antônio, 35 anos de idade, que, na data de 05 de março de 1923, atravessava a Praça XV de Novembro, quando viu atrás de si um automóvel que subia a mesma praça e, em vista disso, "tratou de correr a fim de se livrar do carro; porém não conseguiu porque houve um choque que o atirou ao chão ferindo-lhe em diversas partes do corpo" ${ }^{\text {,231 }}$. O que nos interessa salientar é, precisamente, o fato de que esse processo expõe registros que atestam a recente presença dos veículos motorizados na capital catarinense. O acusado Hermínio Ramos, preso em flagrante, assevera que "não é chauffeur matriculado e apenas está aprendendo a guiar automóvel"232. Além disso, declara que "é verdade que hoje depois das três horas da tarde subia a Praça XV de Novembro guiando o automóvel do Dr. Ângelo ${ }^{233}[\ldots]^{, 234}$. Corroborando com essas afirmações, a testemunha Adeodato Lélis de Assunção afirma, no dia doze de março, que "quem guiava o automóvel era um moço de nome Hermínio Ramos", e que ele "não tem carta de chauffeur"235.

Dessas citações, podemos destacar dois aspectos: a) o chauffeur não dispunha de carteira de habilitação, de forma que houve, à primeira vista, descumprimento do artigo primeiro da Lei 1325, de 18 de agosto de 1920, que estabelece que "Art. 1. ${ }^{\circ}$ - O exame de habilitação para os condutores de veículos, a que se refere o Regulamento para o serviço policial do Estado ${ }^{236}$, será exigido somente das pessoas que conduzirem automóveis de uso particular ou de aluguel e

\footnotetext{
${ }^{230}$ Outros processos criminais analisados neste texto, contemplam, também, situações onde os proprietários dos automóveis particulares eram, via de regra, indivíduos que apresentavam destacada posição socioeconômica na sociedade catarinense da época. Dentre esses processos, apontamos o de número 239, de 21 de janeiro de 1934, sobre o atropelamento da menor Alice Grumiché, analisado na seção Deslocamento e Velocidade.

${ }^{231}$ Processo n. 30, 05 mar. 1923. Caixa 03.

${ }^{232}$ Idem.

${ }^{233}$ O chauffeur Hermínio Ramos era "solteiro, com vinte e um anos de idade completos, natural deste Estado, enfermeiro do Dr. Ângelo Dias".

(Processo n. 30, 05 mar. 1923. Caixa 03).

${ }^{234}$ Processo n. 30, 05 mar. 1923. Caixa 03.

${ }^{235}$ Idem.

${ }^{236}$ Santa Catarina. Regulamento para o serviço policial do Estado. Florianópolis: Tipografia da Livraria Central, 1920.
} 
quaisquer outros veículos de aluguel ou frete"237; e b) o automóvel pertence ao médico Dr. Ângelo Dias, mas era guiado por seu enfermeiro, Hermínio Ramos. Esse aspecto aponta para a tendência de que, nas primeiras décadas do século XX, apenas os indivíduos que apresentavam muito boa condição financeira adquiriam automóveis particulares e dispunham de empregados para servir-lhes ${ }^{238}$.

Nesse ponto, é válido observarmos que o chauffeur foi um personagem comum no cotidiano da cidade de Florianópolis, durante as décadas de 1920 e 1930; e corresponde, de maneira geral, ao jovem profissional responsável por dirigir automóveis de natureza estritamente particular, de propriedade de indivíduos dotados de destacada situação financeira e que podiam, portanto, adquiri-los. Havia, porém, também os chauffeurs encarregados de conduzir veículos de aluguel ou de praça, e muitos desses veículos eram de propriedade de terceiros, os quais também ostentavam, via de regra, boa situação financeira junto à sociedade florianopolitana da época.

Outro aspecto que julgamos relevante é o fato de que, dentre os dezoito processos criminais analisados na tese, apenas três referenciam episódios de atropelamentos ou colisões ocasionados por chauffeurs que guiavam automóveis de cunho particular, no sentido de que esses personagens, ao que parece, atendiam exclusivamente aos interesses de seus respectivos patrões $^{239}$. Esses veículos não eram, portanto, utilizados como táxis, ou seja, para o transporte diário de passageiros ou cargas. Assim, grande parte dos processos criminais analisados - quinze ao total - referenciam atropelamentos e colisões que envolveram veículos ou automóveis de praça, de aluguel ou mesmo veículos de cunho particular que eram de propriedade dos próprios chauffeurs, motoristas ou de órgãos públicos e militares. (Anexo 20, p. 351).

Uma elucidação coerente para esse dado pode ser encontrada ao observarmos que os veículos de praça ou de aluguel circulavam com maior frequência pelas ruas do perímetro urbano da Capital e, desse modo, sujeitos ao maior risco de estarem envolvidos em colisões e atropelamentos. Por outro lado, é possível considerarmos que, durante as décadas de 1920 e 1930, o número de veículos de cunho estritamente particular era significativo; não transparente neste estudo em decorrência, dentre outros aspectos, das razões apontadas anteriormente ${ }^{240}$.

\footnotetext{
${ }^{237}$ Lei n. 1325, de 18 ago. de 1920. Dispondo sobre o exame de habilitação para condutores de automóveis. In: Coleção de Leis, Decretos, Resoluções e Portarias de 1920. Florianópolis: Imprensa Oficial, 1920. p. 13.

${ }^{238}$ De acordo com o "Relatório Apresentado ao Exmo. Sr. Dr. Joë Luiz M. Colaço, Secretário do Interior e Justiça pelo Desembargador Antero de Assis, Chefe de Polícia”, datado de 1922, Ângelo Dias tirou carteira de habilitação para conduzir automóveis no dia 19 do mês de agosto de 1922, na cidade de Florianópolis. Esse documento registra, igualmente, que, ao menos, outro "ilustre" personagem da cidade de Florianópolis obteve habilitação para conduzir automóveis naquele ano. Assim, o "Dr. Fulvio Aduci" - governador do Estado em 1930 - retirou habilitação no dia 17 do mês de janeiro. Essa observação sinaliza, ao menos, que pessoas de destacada posição social ou financeira se davam ao luxo de obter e, até mesmo, guiar os veículos que adquiriam. Ver, a respeito, "Relatório das carteiras extraídas para condutores de veículos, relativo ao ano de 1922". In: Santa Catarina. Relatório Apresentado ao Exmo. Sr. Dr. Joë Luiz M. Colaço, Secretário do Interior e Justiça pelo Desembargador Antero de Assis, Chefe de Polícia... op. cit., p. 27-33.

${ }^{239}$ Esses processos são: a) Década de 20: Processo n. 30, 05 mar. 1923. Caixa 03; Processo 96, 19 dez. 1928. Caixa 02; e b) Década de 30: Processo n. 239, 21 jan. 1934. Caixa 26. (Anexo 20, p. 351).

${ }^{240}$ Vimos, em passagens anteriores deste texto, que diante da vasta documentação pesquisada para a elaboração do presente estudo, não foram encontrados textos ou menções relativos aos registros (placas) de veículos motorizados ou operados a tração animal, bem como de seus respectivos proprietários. Desse modo, é difícil estipularmos uma estatística aproximada sobre o número de veículos particulares, de praça, ou de
} 
Nesse ponto, devemos observar que as transgressões às normas de trânsito caracterizavam, em muitas ocasiões, as práticas exercidas pelos habitantes da capital catarinense. O chauffeur em apreço, no momento em que guiava o automóvel do Dr. Ângelo Dias, não apresentava a respectiva carta de habilitação, conforme registrado pelas suas declarações, anteriormente referidas. Assim, corroborando com esses elementos, a testemunha Cândido José dos Santos, vinte anos, expôs, em depoimento prestado no dia 24 de agosto de 1923, que "estando no Trapiche Municipal, viu naquela ocasião um grupo de populares na Praça XV de Novembro"; que "procurando se aproximar do dito grupo deparou com o carro de propriedade do Dr. Ângelo, que era guiado pelo denunciado" 241 . Continuando seu depoimento, a testemunha considerou que “o denunciado não possuía carta de motorista dada pela Polícia, de acordo com o regulamento ${ }^{242}$, e que tinha por hábito guiar o referido auto por sua alta recreação e sem o consentimento do proprietário de quem era empregado, servindo de enfermeiro" ${ }^{243}$. Nessa passagem do texto, destacamos, uma vez mais, que transgressões e obediências às normas e aos dispositivos de trânsito faziam parte do cotidiano para aqueles que circulavam a pé, ou em seus veículos. A absorção de novos ritmos e vivências - incitadas, em grande medida, pela presença e circulação dos automóveis - é operada, pois, de forma lenta e gradual, com avanços e recuos perante os antigos hábitos e práticas exercidos pelos florianopolitanos.

Desse modo, para transformar Florianópolis em uma cidade moderna e aprazível campanha fomentada, especialmente, pelos periódicos locais da época - não bastava apenas modificar seu cenário urbano, e estabelecer, por exemplo, regras e locais próprios para a circulação de veículos e pedestres, mas era necessário, igualmente, alterar comportamentos e maneiras de viver. Além dos cuidados com a limpeza e salubridade dos espaços públicos, vários hábitos da população deveriam ser abandonados. Caminhar descalço pelas ruas, proferir palavras e expressões em voz alta foram hábitos combatidos pelos artigos de jornal da época, uma vez que os entendiam como práticas não condizentes com a vivência em uma Capital. Assim, os artigos dos periódicos locais lançavam, cotidianamente, campanhas contrárias a essas práticas. Nesse

aluguel que, à época, foram licenciados na capital catarinense. Para oferecermos um exemplo, o "Relatório Apresentado ao Exmo. Sr. Dr. Joë Luiz M.Colaço, Secretário do Interior e Justiça pelo Desembargador Antero de Assis, Chefe de Polícia", no ano de 1922, registra, para aquele ano, o Número de cartas expedidas por município no Estado de Santa Catarina, sem fazer qualquer menção à natureza dos veículos licenciados ver seção Elementos Incipientes -, embora registre os nomes dos indivíduos em que as respectivas cartas foram licenciadas. Vale observarmos que para aquele ano foram licenciados, nos nove municípios listados, 188 veículos, entre carros e automóveis - ver tabela 02 , p. 29 -, e todos os respectivos proprietários pertenciam ao sexo masculino. Ver Santa Catarina. Relatório Apresentado ao Exmo. Sr. Dr. Joë Luiz M. Colaço, Secretário do Interior e Justiça pelo Desembargador Antero de Assis, Chefe de Polícia... op. cit., p. 27-33. A não menção à natureza dos veículos licenciados foi, aliás, a tônica que encontramos em todos os documentos similares pesquisados. É importante assinalarmos que à época (1922), a chefatura de polícia era o órgão diretamente responsável pela organização e físcalização do tráfego de veículos na capital catarinense maiores detalhes sobre esse aspecto serão encontrados no capítulo terceiro da tese -, e os textos pesquisados não apresentam registros das placas dos veículos e, paralelamente, de seus respectivos proprietários.

${ }^{241}$ Processo n. 30, 05 mar. 1923. Caixa 03.

${ }^{242}$ Santa Catarina. Regulamento para o serviço policial do Estado. Florianópolis: Tipografia da Livraria Central, 1920.

${ }^{243}$ Processo n. 30, 05 mar. 1923. Caixa 03. Muitas dessas informações podem ter sido fornecidas à testemunha pelos populares que, naquela hora, encontravam-se junto ao automóvel do Dr. Ângelo Dias, pois Cândido José dos Santos afirma, em declarações prestadas no dia 12 de março de 1923, que, "na tarde do dia 05 do corrente, em frente à Farmácia Popular, conforme lhe disseram, o automóvel pertencente ao Dr. Ângelo e guiado por um moço de nome Hermínio, atropelou um homem de cor, cujo nome não sabe”. (Processo n. 30, 05 mar. 1923. Caixa 03) 
sentido, é importante considerarmos que a introdução dos veículos motorizados e sua crescente circulação pelas ruas da capital catarinense são igualmente consideradas ${ }^{244}$, de acordo com a imprensa e os órgãos governamentais locais, essenciais para o progresso da cidade e para a ordenação e civilidade dos comportamentos e condutas sociais dos seus habitantes.

Por outro lado, a introdução e gradual circulação dos veículos motorizados, especialmente pelas ruas dos centros urbanos europeus e norte-americanos, evidenciam, também, a ação laboriosa do extrato burguês. Assim, o automóvel foi originalmente concebido como veículo destinado a atender às exigências desse estrato social, que, como visto, foi capaz de adquirir e utilizar o veículo motorizado como meio particular de transporte. A circulação do automóvel assumiu, gradualmente, papel privilegiado nas ruas das cidades e implicou alterações no ritmo da circulação imprimida pelos transeuntes.

Corroborando com essas ideias, assinalamos que, na esfera da capital catarinense, os periódicos locais expunham um universo complexo e abrangente, em que transparece a urbe desejada pelas elites. A imprensa parece assumir, como sua missão, a propagação de hábitos considerados adequados à vivência em uma Capital, pois muitos artigos tematizam sobre padrões de boa ou má conduta para a população. Assim, é possível entendermos “[...] a presença de artigos jornalísticos em torno de comportamentos adequados e inadequados, subjacentes à reorganização do aparato policial-judiciário, incumbido de identificar e punir aqueles que tivessem posturas indesejáveis" 245 - como exemplificam os processos criminais analisados. A difusão de imagens alardeadas por princípios morais e higienistas evidencia, portanto, o caráter normatizador da imprensa no período ${ }^{246}$.

É importante observarmos que, para os efeitos deste estudo, os próprios aparatos policial e jurídico não são aplicados à população sem sofrerem, contudo, adaptações e influências colocadas pelas práticas cotidianas expressas pelos habitantes da cidade de Florianópolis. Assim, as regras e normas legais, judiciárias e de trânsito são, também, palco e reflexo de negociações e embates diante dos antigos hábitos operados pelos florianopolitanos no cotidiano da urbe. Desse modo, não devemos tomar os textos ou as práticas que proclamam o ideal como o "[...] reflexo de uma situação, mas sim como a formulação de uma exigência, e é nessa qualidade que eles fazem parte do real"; esse, bem entendido, como encerrado na esfera do discurso ${ }^{247}$. Veremos, a seguir, situações apontadas pelos processos criminais em que os próprios chauffeurs são os

\footnotetext{
${ }^{244}$ Dentre outros elementos, quais sejam: calçamento e alargamento de ruas; ajardinamento de canteiros e praças; implementação dos sistemas de iluminação elétrica (1908-1910) e esgoto sanitário (1906-1913). Observamos, portanto, a concretização de atividades que promovem a higienização e disciplinarização do espaço central da cidade de Florianópolis. Sobre esses aspectos, ver a) VEIGA, Eliane Veras da. Florianópolis: memória urbana. Florianópolis: UFSC e Fundação Franklin Cascaes, 1993; b) NECKEL, Roselane. A República em Santa Catarina: modernidade e exclusão (1889-1920). Florianópolis: UFSC, 2003.

${ }^{245}$ NECKEL, Roselane. A República em Santa Catarina: modernidade e exclusão (1889-1920)... op. cit., p. 71.

${ }^{246}$ Ibidem, p. 72.

${ }^{247}$ FOUCAULT, Michel. Microfísica do Poder. 17 ed. Rio de Janeiro: Graal, 2002. p. 87.
} 
proprietários dos veículos que dirigem. Esse elemento vem, ao certo, corroborar para a gradual complexidade que a circulação cotidiana de carros e automóveis assumiu pelas ruas da capital catarinense, durante as décadas de 20 e 30 do século passado.

\subsubsection{Diversificação e Propriedade}

Ainda no ano de 1923, outro cenário nos é apresentado pelo processo n. 45, de 04 de agosto, que registra o atropelamento do jardineiro Pedro Mansolli, 59 anos, na Avenida Hercílio Luz, ocasionado pelo choque com o automóvel n. 88, guiado pelo chauffeur Braz de Souza, solteiro, dezenove anos, proprietário do referido veículo. Assim, o "Auto de perguntas e declarações" prestado pelo acusado, datado de 04 de agosto de 1923, registra que ele declarou que "é chauffeur do auto n. 88 , de propriedade própria" ${ }^{248}$. Pelo exposto, percebemos que havia ocasiões em que os veículos motorizados eram de propriedade de indivíduos jovens, de pouca idade. Essa não era, todavia, a regra geral. Vale salientarmos que as observações referidas no processo em discussão, destacadas anteriormente, não se referem aos automóveis particulares, mas aos veículos de aluguel ou de praça ${ }^{249}$. Cabe ressaltarmos que não encontramos, nesse processo e nos demais documentos pesquisados, registros que atestem a maneira como foi adquirido o referido automóvel. Além disso, não podemos afirmar se o mesmo veículo já havia sido integralmente adquirido pelo chauffeur em apreço até a data correspondente ao sinistro verificado no presente processo. Alguns aspectos podem, entretanto, ser apontados para esclarecer a maneira como os próprios chauffeurs se tornavam proprietários dos automóveis que guiavam: a) herança familiar; b) os veículos adquiridos pelos chauffeurs não eram novos - dados os custos para sua aquisição -, mas utilizados por outras pessoas que, ao se desfazerem de seus veículos, colocavam-nos à venda ou permuta; c) outro aspecto importante que devemos destacar é o fato de que o chauffeur que consegue adquirir o próprio automóvel - que utiliza, via de regra, em sua profissão -, não é um indivíduo pobre ou totalmente desprovido de recursos financeiros. Por outro lado, não podemos afirmar que esse indivíduo pertença aos estratos mais favorecidos da sociedade florianopolitana. Assim, esse personagem pertence aos estratos sociais médios; e, inclusive, tem residência fixa na cidade ${ }^{250}$. De outro modo, podemos inferir que dificilmente um

\footnotetext{
${ }^{248}$ Processo n. 45, 04 ago. 1923. Caixa 06.

${ }^{249}$ Não fica claro, pelas informações contidas no processo, se o referido automóvel era de praça ou de aluguel. Obedecendo aos critérios já adotados nesta pesquisa, podemos considerar que tal veículo não era de natureza estritamente particular, pois o "Auto de perguntas e declarações" prestadas por Braz de Souza, no dia 04 de agosto de 1923, aponta que ele conduzia, na ocasião do atropelamento, "um passageiro de nome João Cascaes pela Avenida Hercílio Luz, quando vinha em direção à cidade”. (Processo n. 45, 04 ago. 1923. Caixa 06).

${ }^{250}$ O presente processo registra que o chauffeur Braz de Souza é "solteiro, com dezenove anos de idade, natural deste Estado" e "residente nesta cidade à Rua José Veiga, número vinte e nove, sabendo ler e escrever". A rua José Veiga corresponde, grosso modo, à atual Av. Mauro Ramos. O atropelamento descrito no presente processo ocorreu no ano de 1923. Nessa data, a referida avenida não está localizada, exatamente, no espaço central da cidade de Florianópolis, ou seja, o chauffeur em apreço não residia no centro da cidade, local preferencialmente destinado à habitação dos estratos sociais mais abastados. Braz de Souza apresentava, todavia, residência fixa na capital catarinense, o que, sem dúvida, o distinguia dos estratos sociais mais desfavorecidos da cidade de Florianópolis, compostos por mendigos, pessoas maltrapilhas ou, mesmo, por aquelas que habitavam as encostas dos morros próximos à cidade. (Ver mapa 04, p. 78). O chauffeur Braz de Souza também sabia "ler e escrever". Esse fato também o distingue daqueles indivíduos pobres ou miseráveis que, especialmente durante as décadas de 1920 e 1930 , não teriam condições
} 
chauffeur teria condições de adquirir um automóvel por meio, única e exclusivamente, de seu trabalho como chauffeur ou taxista, pois, como vimos, os automóveis, especialmente aqueles zero quilômetros, apresentavam, à época (1920/1923), alto custo de aquisição.

Diante dos elementos elucidados, devemos observar que, no ano de 1920, o preço líquido para compra do veículo Voiturette (barata), incluído os custos de importação da praça de São Paulo, era de 3:400\$000 (três contos, quatrocentos mil réis) ${ }^{251}$. Da mesma forma, no ano de 1923, o preço do novo veículo Ford, modelo Double-Phaeton, incluído, igualmente, os custos de importação da praça de São Paulo, era de 4:450\$000 (quatro contos, quatrocentos e cinquenta mil réis $)^{252}$. Para termos uma ideia do alto valor de aquisição dos automóveis zero quilômetro na época, é importante que o comparemos aos preços dos principais gêneros alimentícios consumidos na cidade de Florianópolis no ano de 1925, apresentados pela tabela 03, a seguir. Assim, temos:

Tabela 03: Preços dos principais gêneros alimentícios no comércio varejista do município de Florianópolis - 1925

\begin{tabular}{l|c|c|l|c|c}
\hline \multicolumn{1}{c|}{ Produtos } & Unidade & Valor Oficial -1 Kg. $\left.*^{*}\right)$ & Produtos & Unidade & Valor Oficial -1 Kg. $\left.*^{*}\right)$ \\
\hline Arroz & Kg. & $\$ 800^{\mathrm{a}}$ & Farinha de Trigo & $\mathrm{Kg}$. & $\$ 760$ \\
Açúcar & Kg. & $\$ 750^{\mathrm{b}}$ & Feijão & $\mathrm{Kg}$. & $\$ 805^{\mathrm{d}}$ \\
Café & $\mathrm{Kg}$. & $2 \$ 500^{\mathrm{c}}$ & & $\mathrm{Kg}$. & \\
\hline
\end{tabular}

(*) Comércio atacadista. Valores referentes à média anual, por quilo, dos produtos exportados.
a) arroz britado de $2 .^{\mathrm{a}}$
b) açúcar branco cristal.
c) café torrado de 2 . $^{\mathrm{a}}$
d) feijão preto superior.

Fonte: VIANNA, Antonio Vicente Bulcão. Presidente do mesmo Congresso, no exercício do cargo de Governador do Estado de Santa Catarina. MENSAGEM apresentada ao Congresso Representativo do Estado. Florianópolis, 22 jul. 1926.

Considerando, do presente quadro, o maior valor atribuído à aquisição do quilo do café $2 \$ 500$ (dois mil e quinhentos réis) -, temos que o valor para a aquisição do automóvel Voiturette, no ano de 1920, é suficiente para a compra de 1360 quilos do produto. Do mesmo modo, o valor para a aquisição do veículo Ford Double-Phaeton, no ano de 1923, é suficiente para a compra de 1780 quilos do produto (café), referenciado na tabela 3. (Ver Anexo 19, p. 350). Além desses indicativos, é importante considerarmos que o exemplo dado pelo presente processo, no qual o próprio chauffeur declara ser o proprietário do automóvel que utiliza em sua profissão, evidencia, dentre outros elementos, o grande significado que o automóvel assumiu, na

\footnotetext{
apropriadas para melhor adquirir tais habilidades. Além disso, o registro "saber ler e escrever", presente nos dezoito processos verificados nas décadas de 1920 e 1930, para a presente tese, atesta a relevância dessas habilidades para aqueles que, nessa época, habitavam a capital catarinense ou outras cidades do Estado. Sobre as discussões e inferências quanto ao destaque que os chauffeurs ostentavam junto aos demais "trabalhadores urbanos" das cidades de São Paulo e Rio de Janeiro, ver, respectivamente, a) SÁVIO, Marco Antônio Cornacioni. A Modernidade sobre Rodas. São Paulo: EDUC, 2002. p. 66-67; e b) RIO, João do. A Alma encantadora das ruas: crônicas. São Paulo: Cia. das Letras, 2008. p. 64-65. ((Org.). Raúl Antelo).

${ }^{251}$ Ford - Depósito permanente para todo o Estado de Santa Catarina - Joinvile. O Estado. Florianópolis, 07 jan. 1920.

${ }^{252}$ Hoepcke, Irmão \& Cia. Seção de Máquinas - Florianópolis: Ford, auto universal - o novo modelo Double-Phaeton. O Estado. Florianópolis, 08 jan. 1923. p. 4.
} 
Mapa 04: Rua José Veiga (Av. Mauro Ramos) e Encostas do Morro da Cruz - Década de 1920 (*)

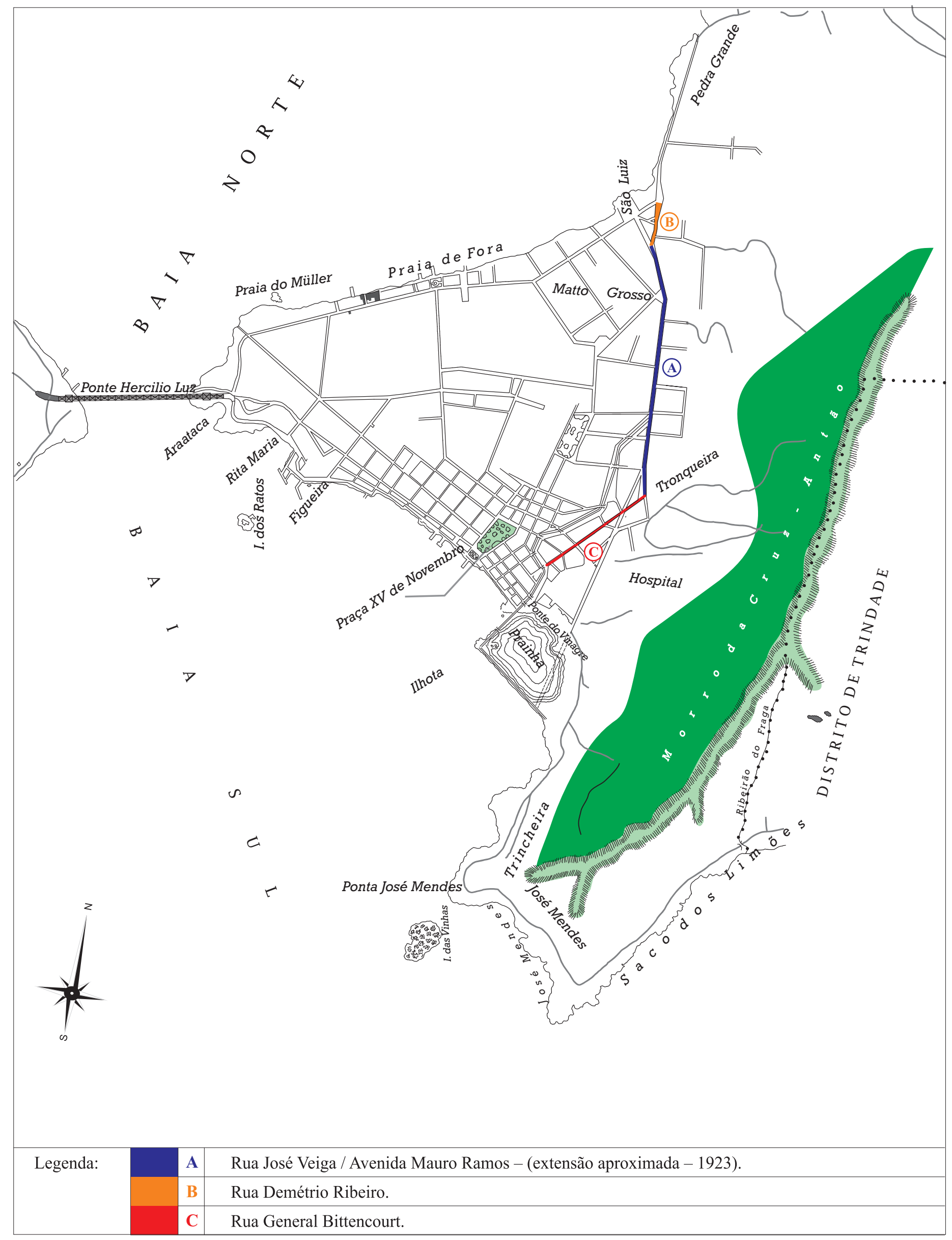

(*) Mapa do perímetro urbano da cidade de Florianópolis - 1940. Fonte: Centro Administrativo do Estado de Santa Catarina - Secretaria de Planejamento/Diretoria de Estatística e Cartografia-Florianópolis - Santa Catarina.

Criação e Diagramação: Duplic Digital Copiadora - Florianópolis - Santa Catarina

Adaptações feitas pelo autor, com base nas informações constantes no processo n. 45, de 04 de agosto de 1923. Caixa 06. 
época, para aqueles que o possuíam, pois representava um símbolo de status e/ou reconhecimento individual, especialmente dentro dos ambientes ou espaços por eles cotidianamente frequentados $^{253}$. Esse é um elemento que, sem dúvida, justificava o esforço em adquiri-lo; esforço este presente, também, entre os integrantes dos estratos médios da população florianopolitana da época, como então se apresentava o chauffeur em questão.

As declarações prestadas pelo acusado, constantes no "Auto de perguntas e declarações" a ele dirigidas, registram o atropelamento descrito no presente processo da seguinte maneira: "hoje às sete horas da noite, quando conduzia um passageiro de nome João Cascaes pela Avenida Hercílio Luz", em "direção à cidade", encontrou-se "com Pedro Mansolli que vinha em direção contrária e que procurava atravessar pela frente do automóvel, e que o fez com tanta infelicidade que o pára-lama atirou Pedro Mansolli ao chão, passando por sobre as pernas dele, uma das rodas de trás" ${ }^{254}$. (Anexo 05, p. 336). Do exposto, podemos constatar que à época da ocorrência do referido atropelamento (1923), os automóveis possuíam "pára-lama”, com o evidente objetivo de evitar ou minimizar possíveis danos causados por colisões ou atropelamentos. Desse modo, é notório o fluxo de veículos motorizados pelas ruas da Capital no início da década de 1920, mesmo em período anterior à inauguração da Ponte Hercílio Luz. Além disso, o automóvel em questão "atirou Pedro Mansolli ao chão" e passou com uma das rodas traseiras por cima da perna direita da vítima, o que ocasionou a ela ferimentos consideráveis. Insistimos nesse ponto porque os automóveis, dada a sua forma de introdução nas cidades, duplamente aureolado pelo prestígio da mais moderna tecnologia europeia e do mais vistoso objeto de consumo conspícuo, foram utilizados de forma a acentuar a sua mística e se impor como uma moldura mecânica sofisticada do poder, mesmo quando eram guiados por chauffeurs ou empregados de companhias ${ }^{255}$.

Devemos observar que a Avenida Hercílio Luz, concluída no ano de 1922, "se estende em duas alamedas marginais ao grande coletor denominado 'Fonte da Bulha",256. Sobre esse

\footnotetext{
${ }^{253}$ SÁVIO, Marco Antônio Cornacioni. A Modernidade sobre Rodas. São Paulo: EDUC, 2002. p. 66-67.

${ }^{254}$ Processo n. 45, 04 ago. 1923. Caixa 06.

${ }^{255}$ É válido observarmos que, no Estado de Santa Catarina e, especialmente, na cidade de Florianópolis, o Regulamento para o serviço policial do Estado estipulou, a partir do ano de 1920, regras claras para permitir a circulação, em serviço, de chauffeurs e boleeiros. Vimos, anteriormente, as obrigações estipuladas para a aquisição da carta de habilitação e regras básicas para a circulação de veículos pelas ruas da capital catarinense. Outras regras eram, entretanto, estipuladas ao se dirigir automóveis e demais veículos, uma vez que objetivavam oferecer segurança aos condutores e transeuntes. Os artigos 121 e 124 do referido regulamento estipulam, em seus diversos itens e parágrafos, que:

“Art. 121 - São obrigações especiais dos cocheiros e motoristas, de carros e automóveis de praça: \# 1. ${ }^{\circ}$ - Apresentar-se vestido com asseio e decência; \# 2. ${ }^{\circ}$ - Não dormir dentro do veículo, quando em descanso e nem fumar em serviço; \# $4 .^{\circ}$ - Tratar com polidez e atenciosa deferência o passageiro, evitando toda e qualquer alteração com o mesmo; \# 5. ${ }^{\circ}$ - Conduzir o passageiro ao lugar de destino sem atrasar a marcha do veículo, nem atravessar outros quarteirões senão os necessários para lá chegar; \# 9. ${ }^{\circ}$ - Não estacionar fora dos pontos marcados pela Delegacia Auxiliar nem chamar passageiros"; "Art. 124 - Todo veículo de condução ou transporte, qualquer que seja o seu destino, deve oferecer a maior segurança e achar-se em estado de completo asseio". (Santa Catarina. Regulamento para o serviço policial do Estado. Florianópolis: Tipografia da Livraria Central, 1920).

Observamos, pelo exposto, que os chauffeurs e boleeiros eram obrigados a obedecer regras explícitas quanto à segurança que deveriam oferecer aos passageiros e transeuntes. Conforme verificamos no processo em questão, essas regras, muitas vezes, não eram, todavia, obedecidas à risca, pois traziam perigo aos transeuntes e ocasionavam-lhes sustos e ferimentos, decorrentes dos atropelamentos que sofriam. As tentativas de se disciplinar o trânsito de veículos pelas ruas das cidades e, em especial, na capital catarinense, eram alvo de transgressões, adaptações ou desobediências por parte daqueles que as deveriam cumprir, não excluindo, neste ponto, a circulação de transeuntes, que, igualmente, tentava esquivar-se das investidas operadas pelos carros e veículos motorizados.

${ }^{256}$ HORN, Raulino Júlio Adolfo. (Coron. ${ }^{\text {el }}$ ). Presidente do mesmo Congresso, no exercício do cargo de Governador do Estado de Santa Catarina. MENSAGEM apresentada ao Congresso Representativo do Estado. Florianópolis, 16 ago. 1922. p. 46.
} 
aspecto, observamos que o jornal República ao referenciar, no ano de 1922, a inauguração dessa avenida, salienta que ela "liga as duas baías, norte e sul, canalizando as águas da fonte da Bulha" e "se desdobra em majestosas retas e belas curvas, com a sua arborização verdejante"257. Em vista disso, é possível considerarmos que a referida avenida dispunha de duas vias, paralelas ao canal denominado Fonte da Bulha, destinadas a atender aos sentidos de ida e vinda dos veículos. Não nos é possível afirmar, na época referenciada no processo, os sentidos de subida e descida vigentes para o trânsito de veículos na Avenida Hercílio Luz ${ }^{258}$. Podemos, entretanto, inferir que o chauffeur em questão não poderia tentar passar com o seu automóvel "em qualquer dos lados" da via onde trafegava - como então registra as impressões do passageiro do automóvel n. 88, João Cascaes, tomadas no dia 17 de agosto de $1923^{259}$-, pois existiam determinações legais que estipulavam a correta maneira de se dirigir veículos pelas ruas da capital catarinense. Assim, por exemplo, o chauffeur ou condutor deveria "guiar com prudência os animais, carros, bondes, automóveis, para evitar prejuízos aos transeuntes ou passageiros"260.

A declaração prestada pela vítima, Pedro Mansolli, natural da Itália, registra aspectos interessantes. Segundo o depoente, "hoje às sete horas, mais ou menos da noite, vinha para sua casa e chegando à Avenida Hercílio Luz, foi de encontro à sarjeta da mesma, produzindo-lhe os ferimentos feitos pelo automóvel guiado pelo chauffeur Braz de Souza"; e que "só viu o automóvel quando levou o encontro [com este], visto que o mesmo auto não deu sinal como é de costume, pois se ele escutasse o apito, teria se defendido do choque e não teria ficado ferido" 261 . Nesse ponto, gostaríamos de destacar três aspectos. O primeiro refere-se ao fato de que os chauffeurs eram obrigados, por lei ou códigos policiais e de trânsito, a acionar a buzina quando encontrassem, pela frente, algum outro veículo ou transeunte, de modo a não lhes obstruir ou dificultar a passagem com os seus automóveis ${ }^{262}$. O chauffeur em apreço, conforme as informações aqui apontadas, não procedeu, entretanto, de maneira condizente às determinações legais. Assim, podemos referenciar que, em situações diversas, atestamos desobediências às normas e às sinalizações de trânsito, o que nos permite considerar que as intenções legais e governamentais, que objetivavam disciplinar a circulação de pedestres e veículos pelas ruas da cidade de Florianópolis, especialmente em seu espaço central, chocavam-se com os ritmos e comportamentos expressos por chauffeurs, passageiros e transeuntes.

\footnotetext{
${ }^{257}$ A inauguração da Avenida Hercílio Luz. República, Florianópolis, 07 set. 1922.

${ }^{258}$ Salientamos que, no presente processo, não foi encontrada qualquer menção aos sentidos de subida e descida de veículos na Avenida Hercílio Luz.

${ }^{259}$ Processo n. 45, 04 ago. 1923. Caixa 06.

${ }^{260}$ Santa Catarina. Regulamento para o serviço policial do Estado. Florianópolis: Tipografia da Livraria Central, 1920.

${ }^{261}$ Processo n. 45, 04 ago. 1923. Caixa 06.

${ }^{262}$ O parágrafo décimo do artigo 121 do Regulamento para o serviço policial do Estado observa que "\# $10 .^{\circ}$ - O motorista do automóvel" deve fazer "uso da buzina todas as vezes que tiver de dobrar alguma esquina ou tiver na sua frente, algum outro veículo, transeunte, ou outro qualquer móvel, ou semovente, que lhe impeça ou dificulte o trânsito". (Santa Catarina. Regulamento para o serviço policial do Estado...op. cit.).
} 
Quanto ao segundo aspecto, destacamos que a vítima afirma conhecer, conforme sua declaração, a obrigatoriedade do emprego da buzina na situação de iminente atropelamento. Devemos observar, portanto, que o depoimento concedido pela vítima foi, provavelmente, embasado conforme suas próprias impressões quanto ao atropelamento que sofreu, pois foi tomado no mesmo dia da ocorrência do sinistro; este verificado no período noturno. Diante disso, não nos é possível afirmar que o depoimento em questão foi tomado com acompanhamento de advogados, pois os elementos apresentados pelas declarações prestadas pela vítima não nos fornecem tais pistas. É possível, entretanto, que as testemunhas que presenciaram o ocorrido, tenham concedido informações à vítima quanto ao procedimento irregular do chauffeur. Desse modo, devemos considerar o registro de Pedro Xavier dos Reis, quarenta anos, que, em alegações prestadas no dia 08 de agosto de 1923, afirma que, "no dia 04 do corrente, às sete horas da noite, mais ou menos, quando passava pela Avenida Hercílio Luz, viu um automóvel parado e cercado por diversas pessoas" e "tratando de indagar o que foi, soube que o mesmo automóvel, guiado pelo chauffeur Braz de Souza, tinha atropelado e ferido um velho de origem italiana, e que as pessoas que estavam ali presentes comentavam a falta de cuidado e a imprudência do chauffeur" 263 .

As ideias expostas registram que as pessoas que estavam em volta dos agentes envolvidos diretamente no acidente, destacaram a "falta de cuidado e a imprudência" cometida pelo chauffeur Braz de Souza, o que sugere que o atropelamento foi, provavelmente, por ele causado. Além disso, não podemos descartar a hipótese de que algumas dessas pessoas tenham informado à vítima sobre a obrigatoriedade do chauffeur fazer uso da buzina na iminência do atropelamento em questão; mas não podemos, igualmente, desconsiderar a ideia de que foi a própria vítima que, em suas declarações, registrou, por conhecimento próprio, o fato de que os chauffeurs devem fazer uso da buzina quando encontram, à sua frente, algum transeunte.

Devemos considerar, ainda, que a vítima tinha cinquenta e nove anos de idade e, nessas condições, é muito provável que ela jamais tenha conduzido automóvel pelas ruas da capital catarinense $^{264}$. Consideramos, por isso, de extrema importância o trecho de seu depoimento, descrito anteriormente, pois sugere-nos que os transeuntes, mesmo aqueles que não conduziam veículos motorizados, conheciam, ao menos, as regras básicas que norteavam a circulação dos automóveis pelas ruas da Capital, o que lhes permitia protestar ou mesmo vigiar o comportamento dos chauffeurs, quando em movimento com os seus veículos. Nesse sentido, a

\footnotetext{
${ }^{263}$ Processo n. 45, 04 ago. 1923. Caixa 06.

${ }^{264}$ É importante observarmos, uma vez mais, que, durante as décadas de 1920 e 1930, os chauffeurs eram, em sua maioria, jovens e estavam, muitas vezes, "aprendendo a guiar automóvel". Além disso, vimos que durante a década de 1910 e o início do decênio seguinte, o processo de introdução e circulação dos veículos motorizados pelas ruas do perímetro urbano da capital catarinense era incipiente, o que nos permite considerar que a vítima em questão jamais tenha guiado veículos motorizados.
} 
circulação de automóveis e de pedestres pelas ruas de Florianópolis configurava um processo complexo que envolvia transgressões, mas também observações coerentes quanto às normas e às leis de trânsito, operadas por transeuntes, chauffeurs, passageiros ou testemunhas dos sinistros. Assim, circunstâncias variadas determinavam comportamentos condizentes ou transgressores aos regula mentos e aos dispositivos legais de trânsito, operados por aqueles que circulavam pela cidade de Florianópolis.

No terceiro ponto, é importante considerarmos que a vítima também afirma que, se pudesse ouvir "o apito do automóvel, teria se defendido do choque e não teria ficado ferido". Essas ideias permitem-nos considerar que os transeuntes operavam resistências às investidas dos automóveis, pois delineavam táticas e comportamentos diversos, com o objetivo de adequar-se ou defender-se dessas investidas, pois as táticas são operadas ocasionalmente, ou seja, não existem regras predefinidas que se possam utilizar para sua efetuação, uma vez que "[...] aproveitam as 'ocasiões' e delas dependem" ${ }^{265}$. A efetuação de táticas pressupõe mobilidade e improvisação, pois “[...] consegue estar onde ninguém espera. É astúcia. Em suma, a tática é a arte do fraco" 266 . Os transeuntes operavam, pois, recursos diversos - em seus discursos e atitudes práticas - para constatar irregularidades ou desobediências às regras e às leis de trânsito e, bem assim, para assegurar a sua integridade física diante da circulação dos veículos motorizados.

A testemunha Carlos Magalons, Praça da Força Pública, esclarece, igualmente, aspectos importantes sobre o ocorrido, pois "viu o automóvel n. 88 passar em frente a uma verdura na Avenida Hercílio Luz e tomando seguimento, encontrou-se o mesmo automóvel com um senhor de idade o qual parecia-lhe ser italiano", que "seguia em direção contrária àquela tomada pelo automóvel" ${ }^{267}$. Essas passagens sugerem-nos que as vítimas de atropelamentos ou colisões, via de regra, percebiam a presença e a circulação dos automóveis. Corroborando com essas ideias, vimos que a testemunha Pedro Xavier dos Reis observou que "viu um automóvel parado e cercado por diversas pessoas" e, diante dessa situação, indagou sobre o ocorrido.

Em vista disso, podemos considerar que os florianopolitanos, sejam eles vítimas, sejam testemunhas de atropelamentos ou de colisões, estavam atentos à presença do automóvel e percebiam sua aproximação ou deslocamento, reconhecendo-o quando do seu deslocamento pelas ruas do perímetro urbano da cidade de Florianópolis. Esse é um aspecto importante, pois sinaliza, dentre outros elementos, que o crescimento do tráfego de veículos motorizados na capital catarinense foi operado de maneira gradual. Nesse sentido, devemos observar que o automóvel, nos dias atuais, está completamente inserido no cotidiano da cidade de Florianópolis

\footnotetext{
${ }^{265}$ CERTEAU, Michel de. A invenção do cotidiano 1: artes de fazer. 8. ed. Petrópolis: Vozes, 2002. p. 100.

${ }^{266}$ Ibidem, p. 101.

${ }^{267}$ Processo n. 45, 04 ago. 1923. Caixa 06. As declarações da presente testemunha foram prestadas no dia 17 de agosto de 1923.
} 
- e, especialmente, no contexto das grandes cidades brasileiras e/ou internacionais -, pois, dentre outros aspetos, não o percebemos em nossas práticas e vivências operadas no dia a dia. Outro elemento importante que verificamos nas declarações prestadas por Carlos Magalons é o fato de que "o automóvel não deu sinal como é de costume e que o fato aconteceu por que o chauffeur

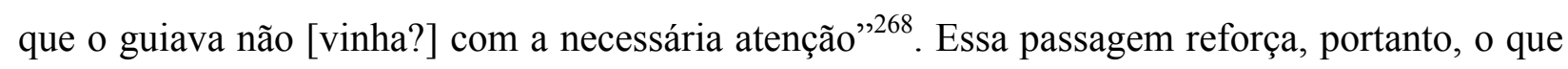
foi declarado anteriormente pela vítima. Além disso, reforça o que foi declarado "pelas pessoas que estavam presentes" ao sinistro, pois "comentavam a falta de cuidado e a imprudência do mesmo chauffeur", conforme as ideias expostas nas declarações prestadas por Pedro Xavier dos Reis, anteriormente analisadas.

O que percebemos é que os transeuntes observavam - ou diziam observar -, com certa frequência, os dispositivos e as leis de trânsito e emitiam opiniões quanto à maneira imprudente com que os chauffeurs conduziam os veículos motorizados pelas ruas da cidade de Florianópolis. Essa é, todavia, apenas uma faceta da complexa relação que envolvia a circulação de veículos e transeuntes, pois chauffeurs e pedestres operavam, igualmente, desobediências e transgressões às regulamentações de trânsito. Além disso, podemos perceber que a vítima em questão tentou proteger-se da investida do automóvel, porém não houve tempo suficiente para evitar o atropelamento, pois a ausência da buzina impediu-a de identificar, com antecedência, a proximidade do veículo. O que objetivamos destacar é, contudo, o fato da confiança posta na inteligência e na inventividade do mais fraco, na atenção à sua mobilidade tática, por meio da qual se esboça uma concepção política do agir e das negociações estabelecidas com forças proporcionalmente maiores, representadas pela circulação dos veículos motorizados ${ }^{269}$.

No ano de 1931, o processo n. 171, de 27 de dezembro, registra a colisão de dois automóveis "no cruzamento das ruas Artista Bittencourt e Visconde de Ouro Preto"270. Assim, o acusado Oscar John, que guiava o automóvel n. 99, declarou no dia 28 de dezembro de 1931, que “ontem, às vinte e três e meia horas, conduzia o seu auto, em companhia de dois amigos, pela rua Artista Bittencourt; que ao se aproximar da esquina dessa rua com a Visconde de Ouro Preto, fonfonou, dando assim sinal; que seu auto tinha os faróis acesos ${ }^{\text {"271 }}$. Dessa passagem, podemos inferir que o chauffeur em questão era o proprietário do veículo que dirigia; aspecto que nos permite considerar que essa prática pôde ser verificada na cidade de Florianópolis durante o decorrer das décadas de 1920 e 1930, e que se estendeu pelos decênios seguintes. Continuando as suas declarações, o acusado afirmou que, "assim que ia fazer a curva para entrar na rua Visconde de Ouro Preto, pelo centro da rua, encontrou-se com um outro auto que vinha em

\footnotetext{
${ }^{268}$ Processo n. 45, 04 ago. 1923. Caixa 06.

${ }^{269}$ CERTEAU, Michel de. A invenção do cotidiano 1: artes de fazer. 8. ed. Petrópolis: Vozes, 2002. p. 19.

${ }^{270}$ Processo n. 171, 27 dez. 1931. Caixa 16.

${ }^{271}$ Idem.
} 
sentido contrário; que o referido auto também ia tomar a rua Artista Bittencourt, e que transitando pela 'mão' do depoente, fez com que ambos se chocassem"272.

Analisando essas informações, podemos destacar aspectos importantes. Em primeiro lugar, é válido esclarecermos que Oscar John era "natural deste Estado, com trinta anos de idade, fillho de Carlos Frederico John, solteiro, de cor branca, empregado no comércio, sabendo ler e escrever, residente nesta Capital à rua Esteves Júnior, número seis” ${ }^{\text {273 }}$. Vimos, também, que o automóvel que conduzia era, provavelmente, de sua propriedade. Oscar John tinha trinta anos de idade, o que nos permite afirmar que ostentava uma idade relativamente avançada. Não figurava, portanto, entre aqueles jovens chauffeurs que verificamos nos processos anteriormente analisados. Oscar John era chauffeur amador, pois, conforme sua descrição, "era empregado no comércio". O automóvel que conduzia não era, portanto, de praça ou de aluguel, mas de natureza particular. Percebemos, igualmente, que os chauffeurs ostentavam, naquela época, razoável condição financeira. Essa condição pode ser atribuída ao personagem Oscar John, pois residida “nesta Capital à rua Esteves Júnior, número seis”,274, ou seja, o chauffeur em apreço possuía residência fixa na cidade, em local privilegiado - dentro dos limites do perímetro urbano da Capital -, uma vez que a rua Esteves Jr. era habitada, dentre outros personagens, por médicos, advogados, comerciantes, como ilustra o processo 95, de 05 de julho de 1926, já analisado.

Outro aspecto que julgamos importante é o fato de que o chauffeur, "ao se aproximar da esquina da rua Artista Bittencourt com a Visconde de Ouro Preto, fonfonou, dando assim sinal; que seu auto tinha os faróis acesos". Essa passagem parece indicar-nos, à primeira vista, que Oscar John procedeu de maneira correta ao, segundo afirma, utilizar-se da buzina na proximidade da referida esquina e manter acesos os faróis do seu automóvel, pois essas atitudes estão de acordo com o que estipulam os artigos 43 e 46 das Instruções Regulamentares para o serviço de trânsito público, que estabelecem que "Art. 43 - Nenhum veículo poderá usar buzinas, tímpanos, gláxons, etc., depois da meia noite, salvo quando dobrar uma esquina ou nos cruzamentos de ruas"; e "Art. 46 - À noite os veículos não poderão transitar sem lanternas acesas e colocadas lateralmente" 275 . É válido, porém, observarmos que as declarações prestadas pelo acusado se encaixam, perfeitamente, às determinações legais apontadas anteriormente; e, nesse sentido, podemos considerar que as afirmações alegadas pelo chauffeur Oscar John podem ter sido devidamente instruídas por advogados ou, o que, talvez, é menos provável, formuladas pelo próprio acusado, para inocentar-se das acusações da referida colisão que sobre ele incidiram.

\footnotetext{
${ }^{272}$ Processo n. 171, 27 dez. 1931. Caixa 16.

${ }^{273}$ Idem.

${ }^{274}$ Idem.

${ }^{275}$ Santa Catarina. Instruções Regulamentares para o serviço de trânsito público. Florianópolis: Imprensa Oficial, 1928. p. 10.
} 
Por outro lado, não podemos descartar a hipótese de que o chauffeur Oscar John tenha, de fato, obedecido às determinações legais de trânsito vigentes à época. O que queremos considerar é o fato de que, nas várias circunstâncias colocadas pelo cotidiano, chauffeurs, passageiros e transeuntes operavam - mesmo que, às vezes, de maneira inconsciente - transgressões e obediências às normas ou às leis de trânsito. Em outras palavras, essas atitudes faziam parte das vivências e práticas cotidianas esboçadas por tais personagens no meio urbano de Florianópolis. Desse modo, podemos pensar, por um lado, que o comportamento de chauffeurs, passageiros e transeuntes era, ao mesmo tempo, obediente e transgressor às normas de circulação pelas ruas da capital catarinense; elementos estes que dependiam das circunstâncias colocadas pelo viver cotidiano.

Assinalamos, ainda, que o chauffeur Otaviano dos Santos Botelho, envolvido no acidente, é "natural deste Estado, com vinte e quatro anos de idade, casado, chauffeur profissional"276. Essa passagem permite-nos confirmar a tendência, registrada em várias passagens anteriores deste texto, que aponta que os chauffeurs eram, em sua maioria, personagens muito jovens, que figuravam no cotidiano da cidade de Florianópolis. Assim, Otaviano dos Santos Botelho expôs, em declarações prestadas no dia 28 de dezembro de 1931, que "às onze e meia horas da noite, de ontem, conduzia o seu automóvel pela rua Visconde de Ouro Preto, trazendo um passageiro que sabe ser Cabo da Armada Nacional e chamar-se Carlos Lopes Reis" e "que ao se aproximar da esquina dessa rua com a Artista Bittencourt, intensificou a luz dos faróis do seu carro, para dar sinal, fonfonando em seguida" ${ }^{277}$. Nessa ocasião, "ouviu o fonfonar de um veículo; que procurou colocar o seu auto bem na 'mão'; que assim que chegou na curva, procurou desviar-se do outro veículo que vinha transitando na mão do depoente", e foi "então impossível ter evitado que o seu automóvel fosse apanhado pelo outro" e que "o auto que batera no seu era guiado pelo chauffeur amador Oscar John"278.

As declarações prestadas pela testemunha Carlos Lopes Reis, no dia 27 de dezembro de 1931, corroboram o que foi referenciado pelo chauffeur em questão, pois asseverou que "viajava no automóvel n. 218, de aluguel, pela rua Visconde de Ouro Preto, com destino à Praça XV de Novembro" (Anexo 06, p. 337) e "que ao aproximar-se da esquina daquela rua com a Artista Bittencourt, o chauffeur do carro em que viajava o declarante, Otaviano dos Santos Botelho, fonfonou e intensificou a luz dos faróis do mesmo, indo com o seu auto na respectiva mão"279.

Apesar dos procedimentos que indicam coerência aos elementos constantes nos dispositivos e nas normas disciplinares de trânsito vigentes à época, a testemunha Horst

\footnotetext{
${ }^{276}$ Processo n. 171, 27 dez. 1931. Caixa 16.

${ }^{277}$ Idem.

${ }^{278}$ Idem.

${ }^{279}$ Idem .
} 
Wehling, passageira do automóvel guiado pelo chauffeur Oscar John, afirmou que, "ao aproximarem-se da esquina das ruas Artista Bittencourt com a Visconde de Ouro Preto, chamou a atenção de Oscar John para a luz projetada por um farol de automóvel"280. A testemunha esclareceu, também, que “como Oscar John vinha transitando com o seu carro 'contra-mão', procurou um metro antes da esquina tomar o lado direito" e "que nesse momento chega ao local outro veículo, não dando tempo de se desviarem, resultando ir o auto guiado por John de encontro ao outro, atingindo a parte traseira" 281 . Horst Wehing afirmou, ainda, que "notando estar Oscar John muito alcoolizado; pediu que conduzisse o carro em pequena velocidade, isso assim que embarcou no auto" 282 .

As declarações prestadas por envolvidos e testemunhas do acidente sugerem-nos que foram obedecidos alguns dispositivos de trânsito. Interessa observarmos, entretanto, que o chauffeur Oscar John efetuou, ao que parece, condutas desapropriadas ao trânsito de veículos, pois, de acordo com a testemunha Horst Wehling, o chauffeur "vinha transitando com o seu carro "contra-mão", procurando "um metro antes da esquina tomar o lado direito". Devemos observar que o chauffeur que transitava pela rua Artista Bittencourt e pretendia atingir a rua Visconde de Ouro Preto deveria dobrar o cruzamento à direita (Mapa 05, p. 87). Além disso, os artigos terceiro e oitavo das Instruções Regulamentares para o serviço de trânsito público, de 1928 estipulam, respectivamente, que "Art. 3. - Todo veículo deve caminhar, quando possível, junto à guia do passeio direito, só podendo deixar esse lado quando tiver de passar por outro veículo"; “Art. 8. - Quando dobrar uma esquina à direita deverá conservar-se junto ao passeio da mão direita"283. Devemos considerar, também, que a mesma testemunha afirmou, como vimos, que Oscar John estava "muito alcoolizado",284 e que "pediu que conduzisse o carro em pequena velocidade, isso assim que embarcou no auto". Assim, os aspectos analisados permitemnos inferir que a circulação dos veículos motorizados pelas ruas da capital catarinense envolveu gradual processo de adaptação de chauffeurs, passageiros e transeuntes.

\footnotetext{
${ }^{280}$ Processo n. 171, 27 dez. 1931. Caixa 16

${ }^{281}$ Idem.

${ }^{282}$ Idem.

${ }^{283}$ Santa Catarina. Instruções Regulamentares para o serviço de trânsito público. Florianópolis: Imprensa Oficial, 1928. p. 5-6.

${ }^{284} \mathrm{O}$ "Auto de exame de embriaguez" é incluso nesse processo. O exame registra os seguintes quesitos: "Primeiro; estava embriagado?; Segundo: qual a bebida que produziu a embriaguez?; Terceiro: qual o período da embriaguez?". As respostas indicam que "ao primeiro, sim, alcoolismo fisiológico agudo; ao segundo, álcool comum, chamado aguardente; ao terceiro, segundo período". Como referência, podemos destacar que "O I.M.L do Estado do Paraná, órgão oficial para o diagnóstico da embriaguez alcoólica [no Brasil] desde 1970 passou a adotar a tabela contida no livro do Prof. Ernani Simas Alves - Medicina Legal e Deontologia, v. II, a qual é baseada na Associação Médica Americana, porém com algumas alterações". A tabela registra que o segundo estágio de embriaguez alcoólica considera o percentual de 0,6 a $1,5 \mathrm{ml}$ de álcool por litro de sangue e caracteriza-se por "[...] leve euforia, menos inibições e aparente confiança. As reações se retardam em até $40 \%$. Nesta fase notam-se alterações psíquicas, neurológicas, sensoriais, pequenas confusões, atenção perturbada”. (FILHO, Dilermando Brito. Toxicologia Humana e Geral. 2. ed. Rio de Janeiro/São Paulo: Atheneu, 1988. p. 92-93). É importante observarmos que se considerou possível o estado de embriaguez do chauffeur Oscar John, e que, a título de curiosidade, o atual código de trânsito brasileiro, baixado pela Lei Federal 9503 , de 23 de setembro de 1997, estipula no artigo 165, que "Dirigir sob a influência de álcool, em nível superior a seis decigramas por litro de sangue, ou de qualquer substância entorpecente ou que determine dependência física ou psiquiátrica" caracteriza "infração gravíssima" e estipula a seguinte penalidade: "multa (cinco vezes) e suspensão do direito de dirigir". Nesse caso, o referido artigo estabelece como medida administrativa a "retenção do veículo até a apresentação de condutor habilitado e recolhimento do documento de habilitação". Código de Trânsito Brasileiro - CTB, 23 set. 1997. (Disponível em: <www.br.com.br/portalbr/calandra.nsf\#http://www.br.com.br/portalbr/calandra.nsf>).
} 
Mapa 05: Esquina das ruas Artista Bittencourt e Visc. de Ouro Preto (cruzamento à direita) - Processo n. 171, 27 dez. $1931\left(^{*}\right)$

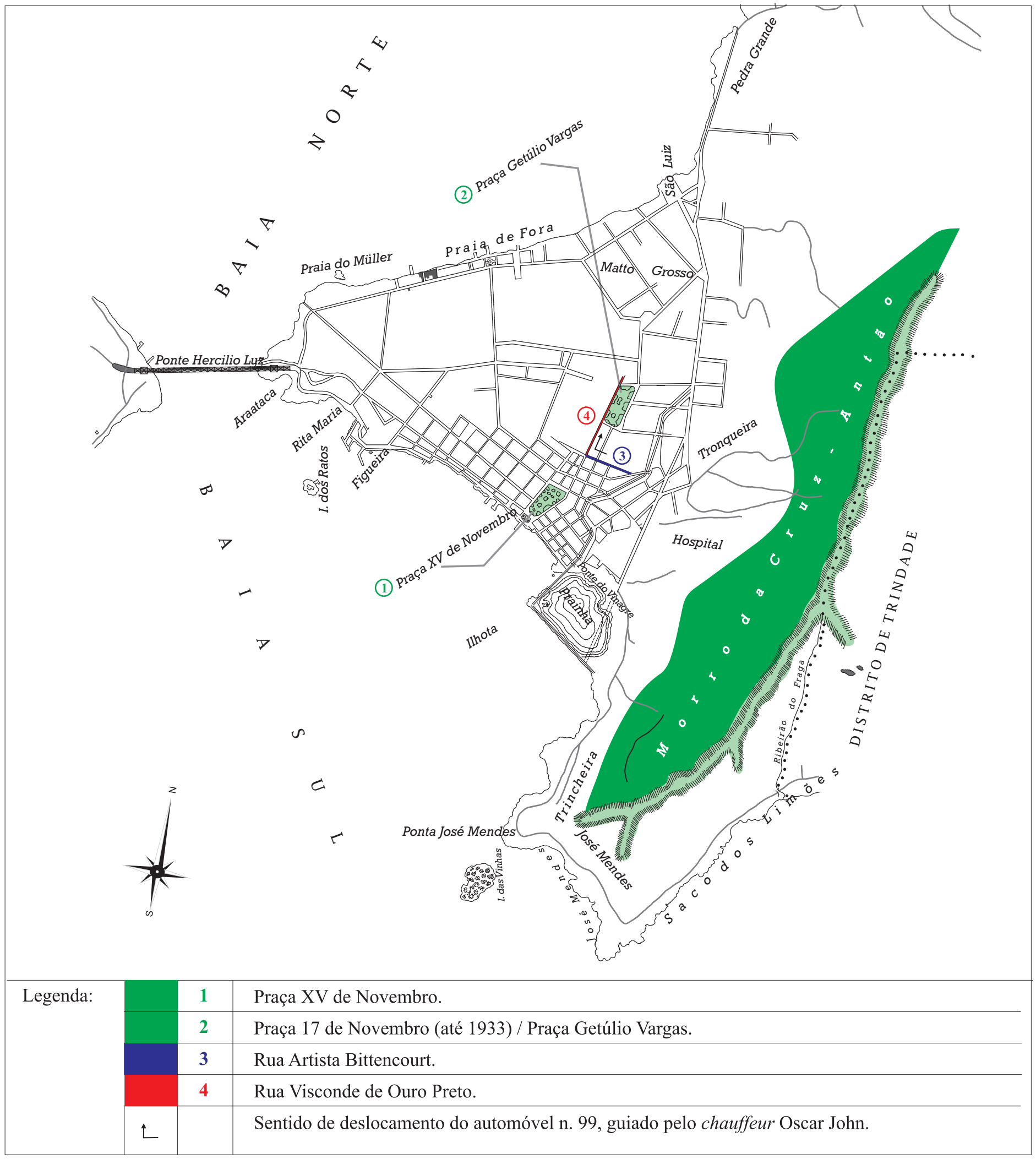

(*) Mapa do perímetro urbano da cidade de Florianópolis - 1940. Fonte: Centro Administrativo do Estado de Santa Catarina - Secretaria de Planejamento/Diretoria de Estatística e Cartografia-Florianópolis - Santa Catarina.

Criação e Diagramação: Duplic Digital Copiadora-Florianópolis - Santa Catarina.

Adaptações feitas pelo autor, conforme informações constantes no processo n. 171, de 27 de dezembro de 1931. Caixa 16.

Nesse sentido, entendemos que o comportamento desses personagens, integrantes do cotidiano da cidade, foi condicionado, dentre outros elementos, pela presença e circulação dos automóveis pelas ruas do perímetro urbano de Florianópolis. De outro modo, é importante observarmos que, para os efeitos deste estudo, a vivência operada pelos chauffeurs, passageiros e transeuntes no espaço urbano da capital catarinense envolve, inegavelmente, trajetórias e comportamentos diversos e, ao mesmo tempo singulares, pois cada personagem, imerso no cotidiano urbano, comporta-se de maneira a "obedecer" trilhas móveis, nem sempre ditadas por 
normas ou regras de trânsito preestabelecidas. A obediência a essas regras é elemento igualmente característico do viver urbano. Os comportamentos e vivências que se verificam, diariamente, no espaço urbano de Florianópolis contemplam, todavia, num processo continuamente interativo, obediências e transgressões às normas estabelecidas para o bom comportamento de pedestres e chauffeurs, em meio ao tráfego motorizado. Esse estar na cidade se traduz no registro das imagens cotidianas e contém uma lógica que é, precisamente, a do mapa espaço-cidade e a do ritmo de tempo urbano - formada pelos trajetos de cada personagem, durante os quais trabalham com suas próprias memórias e imaginações ${ }^{285}$. Vimos, porém, que as práticas e vivências cotidianas expressas por chauffeurs, passageiros e transeuntes denunciam os limites impostos por leis ou regulamentos de trânsito e apontam, em inúmeras situações cotidianas, transgressões e desobediências de toda a ordem.

Neste capítulo, vimos, também, que a análise dos mecanismos de poder não objetiva demonstrar que esses são, ao mesmo tempo, anônimos e sempre vencedores; mas se trata de demarcar os modos de ação e as possibilidades de resistência e de contra-ataque ${ }^{286}$. Assim, as estratégias de poder permitem aos indivíduos exercerem certa margem de liberdade. Nesse ponto, salientamos, uma vez mais, que as atividades cotidianas assumem atitudes e práticas que se processam de maneira não linear, obediente, muitas vezes, às circunstâncias postas pelo cotidiano e que se diluem no interior das determinações legais em voga ${ }^{287}$ - veremos, a propósito, no capítulo seguinte, os embates e discussões políticos e governamentais em torno das tentativas de se aplicarem normas e padrões urbanísticos e de trânsito no espaço urbano da cidade de Florianópolis; esforços estes que foram parcialmente implementados, não sem antes observarem-se resistências e reclames diversos, apontados por correntes políticas divergentes ou, mesmo, nas notas jornalísticas locais. De outro modo, as vivências operadas no meio urbano da capital catarinense, expressas por chauffeurs, passageiros e pedestres, configuram aspectos específicos do seu cotidiano, e compõem cenários ricos em possibilidades de análise e investigação. Nesse sentido, podemos considerar que qualquer evento histórico é fruto do entrelaçamento de tantos outros eventos de natureza diferenciada, que apenas é possível ao historiador visualizá-lo parcialmente, mas que não o impede de entregar-se à responsabilidade de tecer e esquadrinhar histórias ricas em temáticas e cenários específicos ${ }^{288}$.

\footnotetext{
${ }^{285}$ BRESCIANI, Maria Stella Martins. A Cidade: objeto de estudo e experiência vivenciada. In: Revista Brasileira de Estudos Urbanos e Regionais. São Paulo: ANPUR, v. 6, n. 2, nov. 2004. p. 13.

${ }^{286}$ FOUCAULT, Michel. Microfísica do Poder. 17 ed. Rio de Janeiro: Graal, 2002. p. 225 e p. 241.

${ }^{287}$ CERTEAU, Michel de. A invenção do cotidiano 1: artes de fazer. 8. ed. Petrópolis: Vozes, 2002. p. $103-104$.

${ }^{288}$ JÚNIOR, Durval M. de Albuquerque. História: a arte de inventar o passado: ensaios de teoria da História. Bauru: EDUSC, 2007. p. 29.
} 


\section{Capítulo 2 - Espaço, Poder Público e Disciplinarização}

\subsection{Apontamentos Iniciais}

No presente texto, objetivamos tecer uma discussão sobre a evolução do aparato legislativo implantado no Estado de Santa Catarina e na cidade de Florianópolis, especialmente durante as décadas de 10 e 20 do século passado; dispositivo este que pretendeu melhor organizar e controlar o deslocamento dos veículos - motorizados e/ou operados por força motriz animal pelas vias intermunicipais e, igualmente, pelas ruas do perímetro urbano da cidade de Florianópolis.

Diante desse quadro, devemos observar os seguintes questionamentos: Como o espaço público da capital catarinense foi gradualmente disciplinado - devendo-se considerar, naturalmente, os conflitos, embates e nuanças expressos pelos interventores da urbe (agentes detentores do saber e do poder de intervir, transformar e edificar a cidade segundo normas legais e jurídicas) e os usuários cotidianos da cidade (boleeiros, transeuntes, chauffeurs, passageiros), inerentes a esse processo - para acondicionar o tráfego de veículos operados por força motriz animal e, posteriormente, aquele representado pelos automóveis? Até que ponto as regras e as normas de trânsito implementadas na cidade de Florianópolis, especialmente a partir da década de 20 do século passado, apresentaram alterações e/ou adaptações frente às legislações que norteavam, pelo menos desde o final do século $\mathrm{XIX}^{289}$, a circulação dos carros e carroças operados por força motriz animal, para, dentre outros objetivos, atender à circulação dos automóveis? Em que medida a legislação de trânsito aplicada no Estado de Santa Catarina e, especialmente, em sua Capital, atendeu, de maneira concomitante, à circulação automobilística e àquela operada por pedestres e veículos não motorizados? De que modo foram organizados os órgãos fiscalizadores do trânsito no âmbito da capital catarinense no período em estudo? Esses são, em síntese, os questionamentos que procuramos equacionar neste capítulo. Vale observarmos que os processos criminais, analisados no capítulo anterior, foram selecionados em função de sua maior relevância para a discussão das temáticas então propostas. Assim, adotamos a mesma dinâmica em relação às temáticas abordadas neste capítulo, especialmente na seção $O s$ Processos Criminais em Cena 2: legislação e municipalidade.

A partir dessas questões, é importante destacarmos que as regulamentações de trânsito que se tentavam aplicar na capital catarinense no período em estudo (décadas de 1910 e 1920) salientam as intervenções urbanas propaladas pelos poderes administrativos locais e estaduais.

\footnotetext{
${ }^{289}$ Conforme registradas pelos códigos de posturas municipais dos anos de 1889 e 1896, analisados a seguir.
} 
Essas regulamentações suscitam, porém, transgressões e desobediências efetuadas pelos florianopolitanos, como verificamos, especialmente, no transcorrer do terceiro capítulo da tese. Desse modo, concomitante ao movimento que objetivava reconstruir o espaço urbano e reformular as condutas sociais, a circulação dos transeuntes delineava trilhas móveis e imprevisíveis, registrando o descompasso entre as práticas disciplinares e as improvisações cotidianas. Assim, resgatar essas nuanças significa apreender que muitas atitudes e sensibilidades não correspondiam às tentativas de se planejar e ordenar a cidade ${ }^{290}$. De outro modo, vimos que a circulação de automóveis e de pedestres pelas ruas da capital catarinense configurava, notadamente, um processo complexo que envolvia transgressões e obediências mútuas, operadas por chauffeurs e transeuntes, às normas e às leis de trânsito, pois circunstâncias variadas, porém, imprevisíveis, determinavam comportamentos condizentes ou transgressores desses personagens aos regulamentos e aos dispositivos legais de trânsito; e que esses mesmos dispositivos foram elaborados, muitas vezes, como recursos para atender às exigências colocadas pela própria circulação cotidiana de veículos e pedestres.

\subsection{Passagens para Veículos}

Nesta seção, objetivamos analisar que, já durante a década de 10 do século passado, verificamos, entre os principais dispositivos da legislação estadual relativos ao trânsito, nítida preocupação quanto à circulação de veículos automotores e/ou operados por força motriz animal. Salientamos, entretanto, que no início da década de 20 do século passado, atestamos, no Estado de Santa Catarina, especialmente em Florianópolis, a implantação de algumas disposições e órgãos regulamentares de trânsito. O Regulamento para o serviço policial do Estado, instituído, conforme referenciado no capítulo anterior, no ano de 1920, estipula, dentre outros dispositivos, que os condutores de veículos devem dispor da respectiva carta de habilitação e apresentar idade igual ou superior a dezoito anos ${ }^{291}$.

Além desses elementos, o referido documento estabelece as obrigações comuns "a todos os cocheiros, carroceiros e motoristas", pois eles devem trazer, estando em serviço, a carteira de habilitação; guiar com prudência os animais, carros, bondes e automóveis ${ }^{292}$, para evitar prejuízos aos transeuntes e passageiros; caminhar nas ruas da cidade a trote curto, sem precipitar o ritmo de deslocamento dos animais e o movimento dos carros ou automóveis; manter acesas as lanternas, quando trafegarem no período noturno; guardar a ordem quanto às ruas de subida e de

\footnotetext{
${ }^{290}$ NECKEL, Roselane. A República em Santa Catarina: modernidade e exclusão (1889-1920). Florianópolis: UFSC, 2003. p. 86.

${ }^{291}$ Artigos 113 e 115 (alínea “a”). In: Santa Catarina. Regulamento para o serviço policial do Estado. Florianópolis: Tipografia da Livraria Central, 1920.

${ }^{292}$ É importante observarmos que, nessa passagem, a expressão “automóveis” é registrada posteriormente, pois os condutores devem guiar, em primeira mão, "os animais, carros e bondes”. Isso sugere que, no ano de 1920, os automóveis ainda não dispunham de posição privilegiada frente aos demais veículos, ao circularem pelas ruas de Florianópolis; posição esta que conquistarão, de maneira progressiva, durante os anos seguintes.
} 
descida; e diminuir a marcha nas proximidades das esquinas para evitar choques ou encontros com outros veículos ${ }^{293}$. Analisando, especialmente, as obrigações comuns "a todos os cocheiros, carroceiros e motoristas", observamos a determinação para que os condutores e motoristas estejam devidamente habilitados para a condução de veículos automotores ou tracionados por força motriz animal. Além disso, percebemos preocupações em prover-se segurança ao tráfego de transeuntes e passageiros. Outro elemento que julgamos importante é o registro de que os condutores deveriam "guardar a ordem quanto às ruas de subida e descida". Apontamentos nesse sentido são expressos pelo artigo 136 do Regulamento para o serviço policial do Estado, pois registra que "[...] Pela delegacia auxiliar, serão expedidos editais, designando as ruas de subida e descida $[\ldots]^{, 294}$.

Constatamos, portanto, que já havia, dentro do regulamento policial em questão, menções à expedição de normas que visavam a determinar quais os sentidos que os chauffeurs e boleeiros deveriam seguir ao guiar os veículos nas ruas da Capital. Esclarecemos, ainda, que não nos foi possível encontrar os “editais" supracitados. Destacamos, porém, que o processo n. 194, de 21 de novembro de 1932, analisado no capítulo terceiro da tese, apresenta, textualmente, o teor do “Edital”, datado de 18 de julho de 1927, expedido pelo delegado de polícia do município de Florianópolis $^{295}$ - ver página 172. Esse edital registra os locais permitidos para a prática e aprendizagem da condução de automóveis ${ }^{296}$. Além disso, o texto do processo n. 194 também sinaliza que "o mesmo edital foi publicado na mesma data, no jornal República, órgão oficial, para o devido conhecimento público, durante alguns dias e fixado no lugar de costume na Prefeitura Municipal, como é de praxe ${ }^{, 297}$. Como observamos, era prática costumeira fixar editais dessa natureza na Prefeitura Municipal, e podemos perfeitamente inferir que os "editais" que designariam "as ruas de subida e descida", registrados no artigo 136 do Regulamento policial do Estado, foram, muito provavelmente, fixados, também, no local supracitado.

Artigos ou determinações expressas que estipulassem os sentidos de ida e vinda nas estradas e ruas estaduais, ou mesmo naquelas circunscritas ao perímetro urbano da capital catarinense, fizeram-se presentes, com maior nitidez, apenas quando da publicação das Instruções Regulamentares para o serviço de trânsito público, datadas do ano de $1928^{298}$. Esse aspecto permite-nos considerar, uma vez mais, que o processo de introdução e de circulação dos veículos motorizados pelas ruas da Capital foi efetuado de maneira gradual.

\footnotetext{
${ }^{293}$ Ver Santa Catarina. Regulamento para o serviço policial do Estado. Florianópolis: Tipografia da Livraria Central, 1920.

${ }^{294}$ Santa Catarina. Regulamento para o serviço policial do Estado... op. cit.

${ }^{295}$ A autoridade policial referida é, conforme registra o próprio edital, o "encarregado do expediente da Delegacia Auxiliar". (Processo n. 194, 21 nov. 1932. Caixa 20).

${ }^{296}$ Processo n. 194, 21 nov. 1932. Caixa 20.

${ }^{297}$ Idem.

${ }^{298}$ Santa Catarina. Instruções Regulamentares para o serviço de trânsito público. Florianópolis: Imprensa Oficial, 1928.
} 
Exigências semelhantes foram estipuladas pela Lei Estadual n. 1325, de 18 de agosto de 1920, pois registra, como já referenciado no capítulo anterior, que "Art. $1 .^{\circ}-\mathrm{O}$ exame de habilitação para os condutores de veículos, a que se refere o art. 113, do Regulamento para o serviço policial do Estado, será exigido somente das pessoas que conduzirem automóveis de uso particular ou de aluguel"299. Essa lei estipula, igualmente, no parágrafo primeiro desse artigo, que “\# 1." - Os veículos de uso privado, exceto os automóveis, poderão ser dirigidos por condutores sem carta, desde que [...] tenham idade igual ou superior a dezoito anos"300.

Ainda no início da década de 20 do século passado, foram implantados órgãos fiscalizadores do trânsito no Estado de Santa Catarina, conforme registra o artigo primeiro do Decreto Estadual 1465A, de 17 de maio de 1921, que cria, anexa à Força Pública, uma "seção para serviços especiais de automóveis", composta de "um 1. ${ }^{\circ}$ sargento, 4 segundos, 4 terceiros e 3 cabos”301. Essa seção ocupava-se, especialmente, da manutenção dos veículos automotores que circulavam pelas ruas da capital catarinense, pois o artigo segundo desse decreto estabelece que “Art. 2. ${ }^{\circ}$ - As praças para obterem a graduação de que trata o art. 1. ${ }^{\circ}$, serão submetidas a exame prático de mecânica, por uma comissão presidida pelo chefe das oficinas da Força Pública"302.

Assim, percebemos, já no início da década de 1920, o estabelecimento de dispositivos legais de cunho estadual que se ocupavam, especialmente, do atendimento e da fiscalização à circulação operada pelos veículos motorizados. Desse modo, a especialização de leis e dos serviços, destinados ao atendimento das necessidades e das exigências colocadas pela circulação

\footnotetext{
${ }^{299}$ Lei n. 1325, de 18 ago. 1920. Dispondo sobre o exame de habilitação para condutores de automóveis. In: Coleção de Leis, Decretos, Resoluções e Portarias de 1920. Florianópolis: Imprensa Oficial, 1920. p. 13-14.

${ }^{300}$ Lei 1325 , de 18 ago. 1920. Dispondo sobre o exame de habilitação para condutores de automóveis. In: Coleção de Leis, Decretos, Resoluções e Portarias de 1920... op. cit, p. 13. É válido observarmos que, no início do século XX, leis e regulamentos de trânsito eram aplicados, igualmente, em outras cidades brasileiras, notadamente naquelas de grande porte, como, por exemplo, São Paulo e Rio de Janeiro. Para a cidade de São Paulo, destacamos o Ato (Municipal) n. 146, de 26 fev. 1903. (Primeira Lei - Regulamenta o trânsito de automóveis na cidade de São Paulo). Essa lei "Manda observar o regulamento sobre a circulação de automóveis", e, dentre seus diversos artigos, destacamos:

“Art. $1^{\circ}$ - Para que qualquer carro automóvel possa transitar pelas ruas e estradas do Município, é necessário que o respectivo proprietário se ache de posse de um alvará de licença especial, concedido pela Prefeitura; Art. 2. ${ }^{\circ}$ - A denominação automóvel, a que se refere o presente regulamento, compreende todos os veículos munidos de motor mecânico, qualquer que seja a natureza deste; Art. $3{ }^{\circ}-\mathrm{O}$ requerimento dirigido pelo Prefeito, para obtenção do alvará de licença, deverá mencionar o nome e o domicílio do proprietário, o nome do fabricante e o tipo de veículo assim como deverá especificar os limites do peso, da velocidade deste e da força do motor"; Art. 5. - No alvará de licença mencionar-seá o número de matrícula de cada automóvel, que será apenso em taboleta ou pintado em caracteres visíveis na parte posterior do carro, sem o que não será permitido o trânsito de tal veículo; Art. $6^{\circ}-$ A ninguém é permitido conduzir automóvel sem que se ache munido de uma carta de habilitação, concedida pela Prefeitura, depois do exame, no qual o peticionário mostre conhecer todos os organismos do aparelho e a forma de o manobrar, assim como possua os requisitos necessários de prudência, sangre frio e visualidade; Art. $8 .^{\circ}-$ Nos lugares estreitos, ou onde haja acumulação de pessoas a velocidade será a de um homem a passo. Em caso algum, poderá a velocidade ir além de 30 quilômetros por hora em campo raso, de 20 quilômetros nos pontos habitados e de 12 quilômetros nas ruas centrais da cidade, velocidades que deverão ser reduzidas sempre que isso se torne necessário, segundo o número de pessoas no veículo em trânsito". (Ato n. 146, de 26 fev. 1903. (Primeira Lei Regulamenta o trânsito de automóveis na cidade de São Paulo)". In: História do Detran. Disponível em:

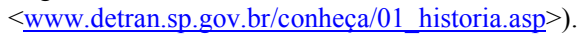

Observamos que os artigos destacados estipulam regras específicas quanto à autorização para condução de veículos e as velocidades estipuladas para as regiões central, periférica e distrital da cidade de São Paulo. Nesse ponto, afirmamos que nenhum artigo da presente lei estipulou idades mínimas para dirigir veículos automotores; entretanto, registra-se, claramente, que para que "qualquer carro automóvel possa transitar pelas ruas e estradas do Município, é necessário que o respectivo proprietário se ache de posse de um alvará de licença especial, concedido pela Prefeitura". Além disso, especificam-se os veículos automotores, que compreendem "todos os veículos munidos de motor mecânico, qualquer que seja a natureza deste". Essa classificação também foi por nós adotada no presente texto. A lei em apreço testemunha, claramente, o processo de circulação automobilística na cidade de São Paulo, mas é, antes de tudo, um sintoma da necessidade de regularizar-se o trânsito de carros e automóveis que, pelo menos desde o início do século XX, atestava alguma densidade, especialmente pelas ruas centrais da capital paulista.

${ }^{301}$ Decreto 1465A, de 17 maio 1921. Criando, na Força Pública, uma seção para serviços especiais de automóveis. (In: Coleção de Leis, Decretos e Resoluções de 1921. Florianópolis: Imprensa Oficial, 1921. p. 46).

${ }^{302}$ Idem.
} 
automobilística, permite-nos considerar seu relativo grau de complexidade que, ao que parece, já assumia à época. Essas normas registram, por outro lado, o estabelecimento de dispositivos e órgãos de trânsito no Estado e na capital catarinense, recursos que objetivavam disciplinar e organizar o trânsito e a atividade de condutores de veículos. Para a cidade de Florianópolis, esses aspectos assumiram maior relevância, pois somente após a inauguração da ponte Hercílio Luz, em 1926, atestamos maior incremento à introdução de veículos motorizados e à organização e/ou adaptação de dispositivos regulamentares para disciplinar o trânsito da capital catarinense ${ }^{303}$. Por outro lado, devemos lembrar, uma vez mais, que, para os efeitos deste estudo, os órgãos e leis de trânsito implementados na cidade de Florianópolis sinalizam, igualmente, como um sintoma das necessidades e das exigências colocadas por novos elementos e personagens - automóveis e chauffeurs - no cenário urbano da Capital.

Neste ponto, é válido observarmos que, nos anos de 1914 e 1918, foram organizados e publicados os "regulamentos para as estradas estaduais" de Santa Catarina, que objetivaram organizar e/ou disciplinar, de maneira incipiente no Estado, o trânsito de veículos automotores ou operados a tração animal pelas ruas e estradas intermunicipais ${ }^{304}$. Nesses regulamentos, são registrados artigos referentes aos impostos cobrados "em postos especiais, localizados nos pontos mais convenientes das estradas construídas pelo Estado, sendo o seu produto escriturado como renda especial [...] para ser exclusivamente aplicado na conservação e reconstrução das ditas estradas"305. Além dessas preocupações, os regulamentos supracitados estipulam, igualmente, em seus capítulos e artigos, preocupações quanto: a) às "obrigações dos proprietários marginais"; b) "ao trânsito" de veículos operados a tração animal, como carros, carroças, tilburys, ou mecânicos: automóveis; c) às multas aplicadas às infrações cometidas contra os dispositivos existentes nos referidos regulamentos. Observamos, portanto, entre os anos de 1914 e 1918, a circulação simultânea, especialmente nas estradas de cunho intermunicipal, de automóveis e de veículos operados a tração animal.

Devemos assinalar que, no regulamento datado do ano de 1914, o artigo 12, por exemplo, estipula, dentre outros dispositivos, que

Art. 12 - Os proprietários dos terrenos marginais das estradas são obrigados:

\# 1. ${ }^{\circ}$ - A limpar cuidadosamente as valas e sarjetas laterais da estrada nos meses de junho a dezembro de cada ano, lançando os detritos a uma distância nunca menor de cinco metros para dentro de seus terrenos; si, porém, se der obstrução em outra qualquer época são obrigados a limpá-las em quinze dias;

\footnotetext{
${ }^{303}$ Dentre esses dispositivos, destacamos: Santa Catarina. Instruções Regulamentares para o serviço de trânsito público. Florianópolis: Imprensa Oficial, 1928.

${ }^{304}$ Nesse ponto, é importante destacarmos o artigo segundo do Regulamento para as estradas estaduais, de 1918, que estipula que "Art. 2. - São $^{\circ}$ estradas estaduais as que, pela sua extensão ou importância, devam ser submetidas à fiscalização imediata das autoridades estaduais". (Regulamento para as estradas estaduais a que se refere o Decreto 1116 desta data. In: O Dia. Florianópolis, 16 e 17 abr. 1918. p. 2).

${ }^{305}$ Ver, especialmente, artigo primeiro, no Regulamento das estradas estaduais e respectivo imposto de trânsito a que se refere o Decreto n. 846 , de 29 dez. 1914. In: Leis, Decretos, Resoluções e Portarias de 1914. Florianópolis: Gab. Tip. d’ O Dia, 1915.
} 
\# 2. ${ }^{\circ}$ - A remover dentro de doze horas úteis, as árvores, pedras ou quaisquer outros objetos que, de seus terrenos desabem sobre o leito da estrada, valas e sarjetas;

\# $3 .^{\circ}$ - A conservar perfeitamente desmatados e limpos 15 metros de seus terrenos, em cada lado da estrada;

\# 4. ${ }^{\circ}$ - A não plantar árvores de alto crescimento a menos de 15 metros de distância das valas e $\operatorname{sarjetas}^{306}$.

Nas passagens destacadas, percebemos a nítida preocupação das autoridades estaduais em determinar a limpeza e a desobstrução dos terrenos marginais às estradas. Embora não esteja disposto textualmente, podemos concluir, com certa propriedade, que, dentre os objetivos centrais das medidas aqui estipuladas, encontramos o de prover boas condições ao tráfego de veículos tracionados por força motriz animal, ou mesmo àqueles de natureza automotiva. Estabelecem, pois, normas que objetivam assegurar, para tanto, a desobstrução do "leito da estrada" e das "valas e sarjetas".

A circulação e a convivência simultânea dos automóveis e dos veículos tracionados por força motriz animal pelas estradas estaduais, verificadas já durante a década de 10 do século passado, podem ser melhor elucidadas ao observarmos as tabelas 01 e 02 , dispostas no capítulo primeiro da tese, pois elas registram, especialmente para os anos de 1914 e 1922, a expedição de carteiras de habilitação para chauffeurs e boleeiros. A tabela 02, por exemplo, intitulada Número de cartas expedidas por município no Estado de Santa Catarina (1911-1922), registra que, no ano de 1914, foram expedidas para as cidades de Florianópolis e Lages o total respectivo de quinze e uma cartas para chauffeurs. No mesmo ano, a tabela correspondente aponta, para as cidades de Florianópolis e São José, a expedição de, respectivamente, duas e uma cartas para boleeiros. Neste ponto, vale observarmos que, no ano de 1922, todos os nove municípios, listados pela tabela 02, apresentavam registros crescentes do número de cartas extraídas para boleeiros, ao compararmos os dados correspondentes ao ano de 1914. Ao mesmo tempo, apenas cinco desses municípios apresentavam, no ano de 1922, registros crescentes do número de cartas extraídas para chauffeurs, ao compararmos com os dados dispostos para o mesmo ano precedente ${ }^{307}$. Esses elementos reforçam a ideia de que os veículos motorizados e aqueles operados por força motriz animal circulavam, simultaneamente, pelas ruas de cunho estadual e, também, naquelas circunscritas ao perímetro urbano da capital catarinense.

Com base nos dados analisados, é possível inferirmos que a convivência simultânea de veículos automotores e daqueles tracionados por força motriz animal, especialmente pelas vias e estradas de cunho estadual, processou-se já em período anterior, pois é importante considerarmos

\footnotetext{
${ }^{306}$ Decreto n. 846, de 29 dez. 1914. Expedindo o Regulamento das estradas estaduais e respectivo imposto de trânsito. (In: Leis, Decretos, Resoluções e Portarias de 1914. Florianópolis: Gab. Tip. d’O Dia, 1915. p. 86).

${ }^{307}$ Ver, a respeito: a) 1914: Santa Catarina. Relatório Apresentado ao Exmo. Sr. Secretário Geral do Estado pelo Chefe de Polícia Ulysses Gerson Alves da Costa. Florianópolis, 14 maio de 1915; b) 1922: Santa Catarina. Relatório Apresentado ao Exmo. Sr. Dr. Joë Luiz M. Colaço, Secretário do Interior e Justiça pelo Desembargador Antero de Assis, Chefe de Polícia. Florianópolis, 1922.
} 
que a organização de regulamentos para a fiscalização e a organização do tráfego de automóveis e de veículos não motorizados pelas estradas estaduais atesta, especialmente, a necessidade de oferecer respostas a problemas já postos, decorrentes, em parte, da crescente circulação desses veículos pelas estradas aqui referidas, conforme verificado anteriormente.

Além desses aspectos, fica evidente, já na década de 1910, a preferência concedida ao tráfego de veículos diversos: carros, carroças, tilburys, automóveis em detrimento à circulação dos transeuntes. Esse aspecto é registrado, de maneira especial, pelo Regulamento para as estradas estaduais, datado de 16 e 17 de abril de 1918, que estipula, dentre outros dispositivos, que dentre as "obrigações dos proprietários marginais", destacamos: "Art. 30 - Todos os proprietários, inquilinos, arrendatários ou possuidores de terrenos marginais às estradas", são "obrigados a limpar e a conservar permanentemente, as valas e sarjetas laterais, lançando os restos de vegetação, a lama e os detritos, delas extraídas, a uma distância nunca inferior a cinco metros para dentro do terreno"; “Art. 35 - Todas as árvores, pedras ou quaisquer objetos que dos terrenos caírem ou rolarem sobre o leito da estrada ou valas, serão por seus ocupantes removidos dentro de 12 horas"; “Art. 36 - É igualmente vedado colocar, nos leitos ou valas, material de qualquer espécie, veículos, detritos ou quaisquer outros objetos, senão durante o tempo indispensável para que sejam transportados para o interior dos terrenos"; "Art. 42 - Quando se houver de construir ou reconstruir cercas, muros, ou taipas laterais às estradas, proceder-se-á de modo a não as estreitar”; e “Art. 44 - As infrações de qualquer das disposições deste Capítulo será punida com a multa de $10 \$$ a $50 \$ 000 " 308$. Além disso, devemos assinalar que, "para a boa conservação das estradas serão observadas"309, dentre outros aspectos, que "Art. 15 - Todos os buracos ou depressões, que se formarem no leito da estrada, serão imediatamente aterrados" 310 .

Analisando esses artigos, ficam evidenciadas, em primeiro lugar, claras similitudes com os artigos e parágrafos destacados do regulamento datado do ano de 1914, anteriormente registrado. Assim, embora as disposições textuais de ambos os textos sejam ligeiramente diferentes, o que observamos são as proximidades de conteúdo e de mensagem nelas expressos. Desse modo, devemos observar a preocupação em se evitar a obstrução dos leitos das ruas e estradas estaduais, como o claro objetivo de permitir ou facilitar a livre circulação de veículos. Percebemos, portanto, a partir dos anos de 1914 e 1918, as preocupações das autoridades governamentais para beneficiar o trânsito de automóveis e de veículos operados a tração animal nas estradas estaduais. Além disso, devemos ponderar que a própria circulação dos veículos,

\footnotetext{
${ }^{308}$ Regulamento para as estradas estaduais a que se refere o Decreto 1116 desta data. In: O Dia. Florianópolis, 16 e 17 abr. 1918. p. 2 . Esse regulamento foi baixado pelo Decreto n. 1116, de 10 abr. 1918: aprovando o regulamento para as estradas de rodagem estaduais. (In: Santa Catarina. Colecção de Leis, Decretos e Resoluções de 1918. Florianópolis: Imprensa Oficial, 1919. p. 161).

${ }^{309}$ Observar artigo 13. (In: Regulamento para as estradas estaduais a que se refere o Decreto 1116, 1918... op. cit, p. 2).

${ }^{310}$ Regulamento para as estradas estaduais a que se refere o Decreto $1116,1918 \ldots$ op. cit, p. 2.
} 
sejam eles automotores, sejam tracionados por força motriz animal, condiciona as iniciativas tomadas pelos poderes públicos locais e estaduais para a elaboração de normas e dispositivos legais de trânsito; processo este que envolve, inegavelmente, conflitos e disputas políticas e ideológicas para a sua efetivação e resultados práticos.

É importante destacarmos o que estipula o artigo 28 do regulamento datado de 1918, pois nele se registra que "[...] Os serviços de conservação serão assiduamente fiscalizados pelos auxiliares técnicos da Diretoria de Obras Públicas, pelos Agentes de Terras, e outros profissionais designados pelo Secretário Geral dos Negócios do Estado"311. Não nos cabe, aqui, fazermos um estudo aprofundado sobre os serviços de fiscalização das estradas estaduais, durante o período compreendido entre os anos de 1914 e 1920. É importante, todavia, assinalarmos que, conforme observado anteriormente, foram estipuladas medidas práticas para a boa conservação das estradas estaduais. Além disso, existiam órgãos e agentes designados pelo Estado para os serviços de fiscalização das obras de melhoria e de conservação dessas estradas, ou seja, a esfera estadual, ao que parece, fazia-se presente para prover o bom gerenciamento das estradas e vias intermunicipais e essa presença era, senão, uma resposta às exigências colocadas pela circulação cotidiana de veículos pelas estradas catarinenses de cunho intermunicipal.

Durante a década de 10 do século passado, a circulação e a convivência simultâneas dos automóveis e veículos operados por força motriz animal pelas estradas estaduais tornaram-se evidentes, pois, ainda no ano de 1918, o artigo 48 do Regulamento para as estradas estaduais a que se refere o Decreto 1116 , de 10 de abril, estipula que "[...] Ninguém poderá conduzir veículos pelas estradas sem estar devidamente habilitado com a carta de boleeiro ou motorista". Além disso, a habilitação era vedada aos menores de 18 anos, pois o indivíduo deveria “Art. 51 juntar provas de que é maior de dezoito anos, de bom comportamento" ${ }^{\text {312 }}$. Percebemos, por outro lado, que a categoria "veículos" envolvia aqueles tracionados por força motriz animal e, também, os de natureza automotiva. Em vista disso, podemos considerar que esse elemento sinaliza para o fato de que, ao final da década de 1910, não tínhamos - pelo menos em âmbito legislativo exata clareza sobre a denominação que se deveria empregar para referir-se, de modo especial, aos veículos automotores; aspecto este que será, gradualmente, equacionado por ocasião da elaboração do Regulamento para o serviço policial do Estado (1920) e das Instruções Regulamentares para o serviço de trânsito público (1928).

As determinações estipuladas no artigo 48, supracitado, envolviam, ao que parece, todos os condutores que circulavam pelas vias e estradas estaduais, pois “Art. 50 - Nos municípios, onde

\footnotetext{
${ }^{311}$ Regulamento para as estradas estaduais a que se refere o Decreto 1116 desta data. In: O Dia. Florianópolis, 16 e 17 abr. 1918 . p. 2. ${ }^{312}$ Idem.
} 
não houver serviço organizado de exames de boleeiros ou motoristas, os candidatos poderão habilitar-se perante os delegados de polícia"313. A habilitação era, entretanto, como visto, vedada aos menores de dezoito anos. O que percebemos é que os condutores de veículos automotores ou tracionados por força motriz animal deveriam estar legalmente habilitados para terem o direito de guiar os seus veículos. Além disso, a habilitação para dirigir parece ter alcançado um significativo grau de importância; pois, mesmo nos municípios em que não havia serviços específicos destinados à sua obtenção, ela era intermediada pelas autoridades policiais locais.

Assim, os elementos registrados pelos artigos 48 e 51, anteriormente referidos, foram ratificados, de modo especial, pelo Regulamento para o serviço policial do Estado, de 1920. A partir dos anos de 1920 e 1921, a obrigatoriedade para a obtenção da carta foi, todavia, exigida apenas daqueles indivíduos que conduziam veículos automotores, conforme estipula, como visto, a Lei Estadual n. 1325, de 18 de agosto de 1920. O que observamos, entre os anos de 1918 e 1920, são mudanças referentes às normas de trânsito, notadamente quanto ao direito de conduzir automóveis; pois, a partir do início da década de 20 do século passado, apenas aqueles que conduziam veículos automotivos eram obrigados a serem legalmente habilitados para tal prática. Esse aspecto vigorou, pelo menos, até o ano de 1928, por ocasião da publicação das Instruções Regulamentares para o serviço de trânsito público ${ }^{314}$.

É importante destacarmos que o objetivo central do presente estudo é analisar e investigar a(s) maneira(s) como os florianopolitanos se adaptaram à circulação dos veículos automotores pelas ruas do perímetro urbano da cidade de Florianópolis. Nesse sentido, objetivamos tecer uma investigação circunscrita ao âmbito da capital catarinense - observando, naturalmente, as correlações com outros centros urbanos nacionais e da Europa Ocidental -, e não propriamente relacionada ao Estado de Santa Catarina. É válido, entretanto, mencionarmos novamente o registro já referenciado, que atesta, em período um pouco anterior à década de 1920, o estabelecimento de regulamentos específicos que apresentavam, textualmente, como principal objetivo, o ato de organizar e disciplinar o tráfego de veículos pelas estradas estaduais de Santa Catarina. Ressaltamos, todavia, que, para os efeitos deste estudo, apenas no início da década de 20 do século passado, atestamos, especialmente em Florianópolis, a nítida implantação de disposições e de órgãos regulamentares de trânsito que se ocuparam não apenas dos veículos operados a tração animal, mas, principalmente, dos novos elementos componentes da cena urbana: os automóveis.

\footnotetext{
${ }^{313}$ Regulamento para as estradas estaduais a que se refere o Decreto 1116 desta data. In: O Dia. Florianópolis, 16 e 17 abr. 1918. p. 2.

${ }^{314} \mathrm{O}$ artigo primeiro desse texto aponta que "Art. $1^{\circ}$ - Os condutores de veículos de qualquer natureza deverão estar munidos, quando em serviço, da respectiva caderneta de habilitação". (Santa Catarina. Instruções Regulamentares para o serviço de trânsito público. Florianópolis: Imprensa Oficial, 1928. p. 06).
} 


\subsection{Os Processos Criminais em Cena 2: legislação e municipalidade}

Nesta parte, objetivamos discutir até que ponto as regras e as normas de trânsito implementadas na cidade de Florianópolis, especialmente a partir das décadas de 10 e 20 do século passado, apresentaram alterações e/ou adaptações em relação às legislações que norteavam, pelo menos desde o final do século XIX, a circulação dos carros e carroças operados por força motriz animal, para, dentre outros objetivos, atender à circulação dos automóveis? Nesse sentido, procedemos a uma análise dos textos dos códigos de posturas municipais datados dos anos de 1889, 1896 e 1898. Esses textos serviram, igualmente, para tecermos uma análise paralela sobre os aspectos técnico e moral envolvidos na adoção de normas legais relativas à adequação de ruas e edificações para, dentre outros aspectos, prover melhores condições ao tráfego de veículos.

De outro modo, analisamos, também, as percepções expressas pelos órgãos governamentais locais a respeito das tentativas colocadas em prática para prover o saneamento e a higienização do perímetro urbano da capital catarinense; situação esta que será relacionada aos contextos dos principais centros urbanos do País, no período. Essas tentativas disciplinadoras dos ambientes urbanos em questão objetivaram, em síntese, adequá-los às posturas civilizatórias propagadas pelas elites locais, posturas essas observadas, especialmente, naquelas facções ligadas ao viés republicano, uma vez que almejavam - ao menos em teoria - o progresso material e moral da sociedade brasileira da época, vedado aos seus estratos sociais inferiores.

Neste ponto, é importante destacarmos que procedemos, igualmente, a uma análise do processo criminal n. 29, datado de 21 de novembro de 1923, que referencia o atropelamento da transeunte Francisca Ana Alves, quarenta anos, ocorrido nas proximidades da Praça XV de Novembro. Essa análise serviu como pano de fundo para adentrarmos na investigação sobre o fato de que os pedestres que circulavam pelas ruas do perímetro urbano da cidade de Florianópolis, durante as décadas de 20 e 30 do século passado, eram, também, alvo dos atropelamentos provocados pelos veículos movidos a tração animal - que, naturalmente, suscitavam resistências e tensões -; elementos estes que já integravam o ambiente urbano da cidade de Florianópolis, pelo menos desde o final do século XIX, conforme demonstramos por meio da análise do conteúdo dos artigos dos códigos de posturas da capital catarinense datados, como vimos, dos anos de 1889, 1896 e 1898.

A cena de atropelamento que nos permitiu iniciar nossa discussão é registrada, portanto, pelo processo n. 29, de 21 de novembro de 1923. Esse texto referencia o atropelamento da transeunte Francisca Ana Alves, ocorrido no dia 16 do mesmo mês e ocasionado - conforme 
registrado no presente processo - pelo chauffeur Antônio Vieira, 23 anos, que guiava o automóvel de aluguel n. 55 na Praça XV de Novembro.

O Capitão da Força Pública do Estado, Frogílio Mello, evidencia outros detalhes do ocorrido ao afirmar, no "Auto de prisão em flagrante", que "hoje, às quatro e meia horas da tarde, prendeu em flagrante o chauffeur do auto n. 55", pois ele, "ao subir a Praça XV de Novembro, em frente ao Banco Nacional do Comércio" (Figura 04, p. 100), atingiu com o automóvel em questão "uma mulher que subia na mesma direção atirando-a ao chão e passando por sobre ela as rodas do mesmo veículo"315. (Anexo 07, p. 338) ${ }^{316}$.

Informações relevantes sobre o sinistro são, igualmente, registradas pelo depoimento da testemunha Cecílio Ladislau da Cunha, pois ela considera que, "ontem pelas quatro e meia horas da tarde, mais ou menos, em frente ao Banco Nacional do Comércio, viu o automóvel n. 55, cujo chauffeur chama-se Antônio Vieira, subir a Praça XV de Novembro e atropelar uma mulher que atravessava a rua em direção ao Jardim"317. Cecílio Ladislau da Cunha afirma, também, que o automóvel "passou as rodas por cima da mesma mulher" e que "foi uma das pessoas que ajudou a levantar a [vítima] que estava bastante ensangüentada"318. É possível afirmarmos, assim, que o atropelamento em questão tenha assumido gravidade considerável à transeunte, pois ela faleceu no dia seguinte ao sinistro. Além disso, o "Auto de perguntas e declarações" prestado por Francisco Malaquias Silva, cunhado da vítima, esclarece que ela "faleceu, hoje, às cinco horas da madrugada no Hospital de Caridade, proveniente dos ferimentos que recebeu, ontem, quando foi pisada pelo automóvel n. 55 na Praça XV de Novembro"319.

Assim, num primeiro momento, percebemos, claramente, que, como vimos no capítulo anterior, os transeuntes eram, muitas vezes, colocados em posição de inferioridade perante a circulação automobilística. Mas essa é, sem dúvida, apenas uma das facetas que compunha o viver urbano; pois, para aqueles que circulavam cotidianamente pela cidade de Florianópolis -

\footnotetext{
${ }^{315}$ Processo n. 29, 21 nov. 1923. Caixa 03.

${ }^{316}$ Esse processo foi escolhido para ser analisado neste capítulo, pois nele percebemos que a presença do automóvel é bastante emblemática perante a circulação da transeunte, que, veremos, falece no hospital, em razão do atropelamento que sofreu - ver também artigo do jornal República, que referencia o sinistro em questão, disposto a seguir. Além disso, o episódio de atropelamento nele explanado ocorreu nas imediações da Praça XV de Novembro, local que, melhor do que qualquer outro, representa o "espaço central" da cidade de Florianópolis. A prisão em flagrante do chauffeur Antônio Vieira vem, em nossa visão, corroborar para a escolha do referido processo, que, entendemos, reúne, portanto, elementos ilustrativos para que se proceda à análise das tentativas de disciplinarização do espaço urbano que, à época - primeira metade da década de 1920 -, recaíram com maior nitidez sobre o espaço urbano da capital catarinense, sobretudo quanto à circulação de veículos motorizados e à atividade de condução desses automóveis.

${ }^{317}$ Processo n. 29, 21 nov. 1923. Caixa 03

${ }^{318}$ Idem.

${ }^{319}$ Processo n. 29, 21 nov. 1923. Caixa 03. Nesse sentido, é importante observarmos como o artigo do jornal República, de 17 de novembro de 1923, registra o atropelamento descrito no processo em questão:

"Francisca Ana Alves, uma pobre velhinha de 45 anos de idade ao atravessar ontem, pelas dezesseis horas, à Praça XV de Novembro, de frente ao Banco Nacional do Comércio, foi atropelada pelo auto n. 55, guiado por Antônio Vieira, vulgo Antônio Pança. A vítima, que recebeu grandes ferimentos, foi medicada na Farmácia Popular. A polícia tomou conhecimento do fato, comparecendo à farmácia o Sr. Desemb. Antero de Assis, chefe de polícia, e comissário Haroldo Leis. Francisca Alves foi recolhida, por ordem da polícia, ao Hospital de Caridade, sendo o seu estado gravíssimo. Antônio Vieira acha-se preso na cadeia pública. O sr. Major Fernando Machado, delegado de Polícia, abriu o respectivo inquérito, já tendo sido interrogadas várias testemunhas". (Vítima de um auto. República. Florianópolis, 17 nov. 1923. p. 2).

Analisando as informações, podemos perceber que, já no início da década de 1920, o aparado policial e legal operava no sentido de prender infratores de trânsito e abrir inquéritos respectivos. Sobre a atuação dos aparatos policial e jurídico como forma de investigar crimes de atropelamentos e colisões nas ruas do espaço central de Florianópolis, durante as décadas de 1920 e 1930, ver, a seguir, o quarto capítulo da tese.
} 
assim como para aqueles que transitavam pelos grandes centros urbanos do país e da Europa Ocidental -, estratégias e táticas estavam implícitas em suas atitudes e comportamentos, que lhes permitiam esboçar resistências e tensões, muitas vezes mudas e imperceptíveis, às investidas colocadas pela presença e pela circulação da tecnologia motorizada.

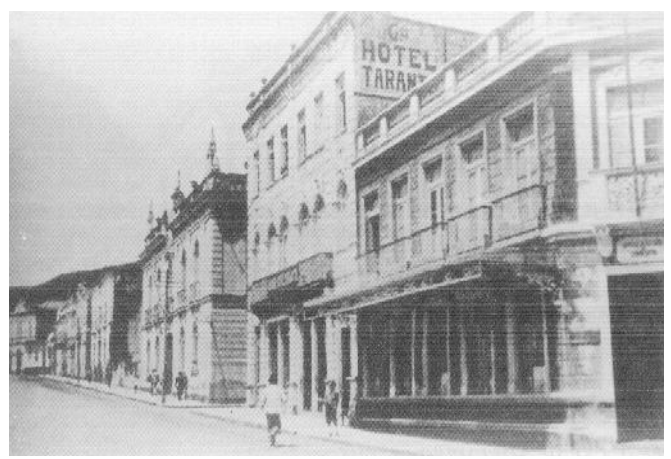

Figura 04 - Banco Nacional do Comércio; esquina da rua João Pinto com a Praça XV de Novembro (canto direito da foto, ao lado do Hotel Taranto). Fonte: SILVA, Adolfo Nicolich da. Ruas de Florianópolis: resenha histórica. Florianópolis: Fundação Franklin Cascaes, 1999. p. 39.

Nesse sentido, podemos considerar que os automóveis eram veículos pesados e se deslocavam em velocidades inéditas em pleno espaço urbano. As velocidades de vinte, trinta ou quarenta quilômetros horários, atingidas pelos veículos motorizados pelas ruas centrais das cidades, durante as décadas iniciais do século $\mathrm{XX}$, eram consideravelmente superiores às velocidades de quatro ou cinco quilômetros por hora, correspondente àquelas atingidas pelos pedestres $^{320}$. Desse modo, o automóvel se tornou, progressivamente, um símbolo de poder e condicionou - em muitas situações postas no dia a dia - os comportamentos e ritmos de deslocamento operados pelos pedestres e habitantes das cidades ${ }^{321}$. Por outro lado, devemos observar que os próprios pedestres determinavam, em diversas circunstâncias colocadas pelo cotidiano, a maneira como chauffeurs e boleeiros deveriam guiar, respectivamente, veículos automotores e aqueles tracionados por força motriz animal.

É importante observarmos que, por um lado, a velocidade das máquinas e automóveis exigia uma redobrada precaução ao se atravessar ruas e pontes, por outro ela se incorpora, gradativamente, ao próprio subconsciente das pessoas e, inevitavelmente, como toda a manifestação de adesão aos condicionamentos modernos, assumia um sinal de distinção daqueles que mais ostensivamente os exibiam ${ }^{322}$. Os chauffeurs assumiam, muitas vezes, uma postura agressiva ao volante; pois, ao terem o privilégio de guiar tecnologia e máquinas inéditas, julgavam-se no direito de se apossarem das ruas dos espaços centrais das cidades, muitas vezes, as únicas pavimentadas, para imprimir altas velocidades aos veículos que conduziam. Num país como o Brasil, aonde os automóveis chegaram, sobremaneira, como produtos importados de

\footnotetext{
${ }^{320}$ Ver, especialmente, Le Corbusier. Planejamento Urbano. 3. ed. São Paulo: Perspectiva, 1984. p. 26. (Col. Debates, n. 37).

${ }^{321}$ SEVCENKO, Nicolau. A capital irradiante: técnica, ritmos e ritos do rio. In: ___. (Org.). História da vida privada no Brasil - República: da Belle Èpoque à Era do Rádio. 5. ed. São Paulo: Companhia das Letras, 2002. p. 558.

322 Ibidem, p. 550.
} 
requinte e de alto luxo, eles, gradativamente, tornaram-se instrumentos de ostentação, prestígio e poder $^{323}$, e refletiram relações que aglutinam e colocam em choque chauffeurs e transeuntes, uma vez que exemplificam - a par de suas mobilidades e táticas - uma relação posta no cotidiano entre aqueles que, de certa forma, usufruem o poder: os chauffeurs, que são os condutores dos veículos motorizados, e aqueles que são, mais diretamente, atingidos por ele: os pedestres e transeuntes que circulavam pelas ruas das cidades. Desse modo, a análise do processo aqui referenciado endossa a ideia de que os automóveis, em muitas ocasiões, atormentavam os pedestres, pois a vítima de atropelamento, Francisca Ana Alves, sofreu "diversos ferimentos na cabeça e no corpo", e faleceu no dia seguinte ao sinistro, em razão do atropelamento que sofreu.

Devemos salientar que as ideias expostas nos parágrafos anteriores foram expressas com maior nitidez pelo historiador Nicolau Sevcenko que, em seu texto A capital irradiante: técnica, ritmos e ritos do rio (v. 3, 1998. (Col. História da vida privada no Brasil)), analisa o posicionamento de destaque da cidade do Rio de Janeiro no cenário nacional, durante o final do século XIX e início do século XX. Nesse contexto, investiga os movimentos e ritmos que compunham o cotidiano carioca da época e enfatiza, dentre outros aspectos, a presença dos veículos motorizados pelas ruas do perímetro urbano da capital fluminense; presença esta que, na visão do autor, ocasionou agitações e turbulências cotidianas, pois alterou o ritmo de deslocamento dos transeuntes e provocou neles alterações motoras e psíquicas a fim de que pudessem enfrentar a agitação diária das ruas e passagens urbanas.

Esse ponto de vista é, igualmente, defendido pelo mesmo autor em outro texto de sua autoria, intitulado Orfeu extático na metrópole: São Paulo, sociedade e cultura nos frementes anos 20 (Companhia das Letras, 1992). Nesse estudo, Nicolau Sevcenko investiga, sobretudo, fontes e textos literários e jornalísticos a partir dos quais analisa a transformação que a metropolização da cidade de São Paulo impôs às percepções e, às vivências cotidianas de sua população. O autor também realiza o mapeamento do imaginário coletivo paulistano e salienta os seguintes elementos: a) tecnológicos: aviões, automóveis, linhas telefônicas, telégrafo; b) culturais - se assim podemos defini-los -: exposições universais, músicas e manifestações populares, como carnaval, passeata; c) elementos relacionados ao trabalho diário: as jornadas de trabalho nas fábricas, greves; dentre outros.

Desse modo, a cidade de São Paulo, tomada como metrópole nacional da época, envolve e aglutina as novas práticas e tendências que a constituem como centro cultural e social, em que as vivências suscitadas no espaço urbano, alimentadas por uma nova percepção do tempo - agora muito mais dinâmico e acelerado -, podem ser inferidas por meio das diversas notas e passagens 
da imprensa local analisadas pelo autor, sobretudo aquelas registradas no periódico O Estado de São Paulo. Assinalamos esses apontamentos porque percebemos certo grau de exagero nas proposições defendidas pelo autor, sobretudo quanto ao ritmo dos automóveis, considerado altamente acelerado e desmedido e que configurava ameaças potencialmente perigosas à integridade física dos transeuntes ${ }^{324}$. Nosso posicionamento vai ao encontro da ideia de que os veículos motorizados suscitavam, sim, novos ritmos e vivências cotidianas, por isso os transeuntes deveriam obedecer a regras e normas de circulação urbana para que pudessem dividir o espaço central das cidades com os automóveis; e, sem dúvida, em diversas ocasiões, a circulação automobilística os forçava a imprimir uma agilidade mecânica e automatizada, concernente ao ritmo imposto pelos veículos motorizados.

Devemos, entretanto, observar, como vimos, que os próprios transeuntes adaptavam-se aos novos ritmos e vivências cotidianas e se utilizavam de táticas e de procedimentos práticos que assumiam, muitas vezes, um caráter emergencial diante das circunstâncias que envolviam as investidas dos veículos motorizados ou mesmo em relação às ocorrências de atropelamentos e colisões; e que, por outro lado, os próprios chauffeurs, ao conduzirem os veículos, tinham suas posturas e atitudes ao volante modificadas ou condicionadas pelo próprio deslocamento de pedestres pelas ruas das cidades.

Assim, podemos considerar que pedestres e chauffeurs exercem, mutuamente, operações disjuntivas, que são produtoras de acontecimentos diferenciados e, também, imprevisíveis, as quais dão lugar a espaços e atitudes a partir das quais os lances e as práticas exercidos são - ou devem ser - proporcionais às situações encontradas no cotidiano ${ }^{325}$; e é nesse sentido que podemos referenciar, portanto, que as regras organizadoras dos lances e posturas emergenciais e imprevisíveis constituem, também, uma memória: armazenamento e classificação, de esquemas e de ações que articulam novos lances conforme as ocasiões ${ }^{326}$.

Por outro lado, podemos fazer uma analogia entre os condicionamentos operados pelos comportamentos dos transeuntes perante o ritmo de deslocamento dos automóveis, e entre os comportamentos dos trabalhadores fabris diante do ritmo incessante e ininterrupto de relógios e máquinas. Assim, destacamos do texto Tempo, Disciplina do Trabalho e Capitalismo Industrial, de Edward Pawmer Thompson ${ }^{327}$, a ideia de que, a partir do final de século XVIII e durante todo o século seguinte, desenvolveu-se, de maneira progressiva, a noção de que o trabalho fabril condiciona o empregado à monotonia e à alienação diante de suas atividades diárias na unidade

\footnotetext{
${ }^{324}$ Sobre essas observações, ver, especialmente: SEVCENKO, Nicolau. Orfeu extático na metrópole: São Paulo, sociedade e cultura nos frementes anos 20. São Paulo: Companhia das Letras, 1992. p. 73-88.

${ }^{325}$ CERTEAU, Michel de. A invenção do cotidiano 1: artes de fazer. 8. ed. Petrópolis: Vozes, 2002. p. 83.

${ }^{326}$ Ibidem, p. 83-84.

327 THOMPSON, Edward Pawmer. Tempo, Disciplina de Trabalho e Capitalismo Industrial. In: Companhia das Letras, 1998. p. 267-304. . Costumes em Comum. São Paulo:
} 
produtiva. Desse modo, o trabalhador especializado - personagem que se tornou cada vez mais comum durante todo o século XIX - assumia, quase que invariavelmente, um comportamento autômato, dependente do ritmo das máquinas; tornava-se, portanto, alienado perante as etapas de produção que implicavam na configuração final de determinado produto.

Esse contexto foi, segundo o autor, construído historicamente, uma vez que, durante o final do século XVIII e o início do século XIX, ainda podíamos encontrar, com certa frequência, a manutenção de "[...] ritmos e mecanismos de trabalho 'naturais' semelhantes, acompanhando outras ocupações rurais ou industriais", pois "deve-se cuidar das ovelhas na época do parto e protegê-las dos predadores; as vacas devem ser ordenhadas; deve-se cuidar do fogo e não deixar que se espalhe pelas turfas", etc $^{328}$. Nesses contextos, parece haver "[...] pouca separação entre 'o trabalho' e a 'vida"”, pois as "relações sociais e o trabalho são misturados - o dia de trabalho se alonga ou se contrai segundo a tarefa" e não há "grande senso de conflito entre o trabalho e o passar do dia"329. Em vista disso, a noção de tempo que surge nesses contextos "[...] tem sido descrita como orientação pelas tarefas"; procedimento este que envolve o "descaso pelo tempo do relógio" e que suscitou ações e práticas de resistência diante da imposição das máquinas e ao seu ritmo de trabalho ${ }^{330}$.

Durante o final do século XVIII e início do século XIX, ainda podíamos constatar certa irregularidade quanto aos ciclos semanal ou anual de trabalho efetuados, sobretudo, pelos trabalhadores rurais da Inglaterra. Assim, segundo "[...] as exigências gerais das tarefas semanais, quinzenais [ou mesmo anuais], o dia de trabalho podia ser prolongado ou reduzido"331. Em outras palavras, o padrão de trabalho sempre alternava momentos de atividade intensa e de ociosidade quando os homens detinham o controle de sua vida produtiva. Por fim, podemos notar que "[...] a irregularidade do dia e da semana de trabalho estava estruturada, até as primeiras décadas do século XIX, no âmbito da irregularidade mais abrangente do ano de trabalho, pontuado pelos seus feriados e feiras tradicionais" ${ }^{\prime 32}$.

A padronização de horários e ritmos de trabalho fabril somente é nitidamente visível quando da "introdução da indústria em grande escala movida a máquinas"333. Assim, o que pretendemos abordar não são apenas mudanças na técnica de manufatura que exigem maior sincronização do trabalho e maior exatidão na rotina do tempo, mas também como esses elementos são vivenciados na sociedade capitalista industrial nascente. Isso envolve, inegavelmente, a percepção do tempo em seu condicionamento tecnológico e a sua medição

\footnotetext{
${ }^{328}$ THOMPSON, Edward Pawmer. Tempo, Disciplina de Trabalho e Capitalismo Industrial. In:

${ }^{329}$ Ibidem, p. 271-272.

${ }^{330}$ Ibidem, p. 271.

${ }^{331}$ Ibidem, p. 280.

${ }^{332}$ Ibidem, p. 285.

${ }^{333}$ Ibidem, p. 280. 
como meio de exploração da mão de obra. Desse modo, já em 1755, encontramos, no texto Conselho amigável dos pobres, de autoria do reverendo J. Clayton, publicado na cidade inglesa de Manchester, que o "[...] trabalhador não deve flanar na praça do mercado, nem perder tempo fazendo compras" 334 . Além disso, "Clayton reclama que 'as igrejas e as ruas [estão] apinhadas de inúmeros espectadores' nos casamentos e funerais, 'os quais apesar da miséria de sua condição faminta [...] não têm escrúpulos em desperdiçar as melhores horas do dia só para admirar o espetáculo"335. Essas passagens são ilustrativas para salientarmos a preocupação envolvida com a nascente produção industrial em larga escala, pautada pelo máximo aproveitamento do tempo em prol do acúmulo de lucro e riqueza. Em suma, notamos que se estava configurando a ideia fundamental do tempo como prerrogativa essencial para o desenvolvimento capitalista, pois o mesmo texto registra que "[...] a mesa do chá é 'esse vergonhoso devorador de tempo e dinheiro" "336; e era exatamente nas fábricas têxteis e nas oficinas, que se impunha a nova disciplina de tempo.

Mas o que dizer da internalização da disciplina? Neste ponto, devemos observar que, a partir da metade do século XIX e com maior nitidez durante as décadas seguintes, os teólogos moralistas puritanos "[...] ofereciam a cada homem o seu próprio relógio moral interior" 337 . Assim, "Richard Baxter, em seu Cristian directory [Guia cristão], apresenta muitas variações sobre o tema de redimir o tempo", pois enfatiza que se devia "empregar todo o tempo para o dever" ${ }^{\prime 338}$. Nesse contexto, a perda de tempo é intolerável, porque irrecuperável o que envolve, inegavelmente, a ética puritana e/ou metodista que é permeada pela ideia de que se deve proceder ao máximo aproveitamento possível do tempo, “[...] esse único tempo, que lhes é dado [por Deus] para a salvação de suas almas”339. Enfatizamos que está esboçado um discurso que permeia uma justificativa ideal, e mesmo irrefutável, para a melhor e mais proveitosa obtenção de lucro e riqueza.

Esse fundamento moral é, aliás, amplamente discutido no clássico texto de autoria de Max Weber, intitulado A Ética Protestante e o Espírito do Capitalismo ${ }^{340}$. Esse estudo foi, originalmente, publicado entre os anos de 1904 e 1905 e nele está expressa, com riqueza de detalhes, a questão de que o trabalho e o aproveitamento do tempo, em atividades produtivas, envolvem a ideia de vocação. Assim, esse elemento foi concebido ao homem burguês ${ }^{341}$ por

\footnotetext{
${ }^{334}$ THOMPSON, Edward Pawmer. Tempo, Disciplina de Trabalho e Capitalismo Industrial. In: Costumes em Comum... op. cit., p. 292.

${ }^{335} \mathrm{Idem}$.

${ }^{336}$ Idem.

${ }^{337}$ Ibidem, p. 295.

${ }^{338}$ BAXTER, Richard. Cristian directory apud THOMPSON, Edward Pawmer. Tempo, Disciplina de Trabalho e Capitalismo Industrial. In: $\overline{339}$ Idem.

${ }^{340}$ WEBER, Max. A Ética Protestante o e Espírito do Capitalismo. 12. ed. São Paulo: Pioneira, 2001.

${ }^{341}$ Nesse livro, Weber estuda as origens do capitalismo burguês com sua organização racional do trabalho e enfoca, sobretudo, as implicações religiosas na configuração do moderno capitalismo. Desse modo, as origens desse sistema econômico devem ser buscadas nos primórdios dos
} 
meio da figura divina, pois, como indivíduo predestinado, passou a obrar em vida com o objetivo de atingir a salvação de sua alma ${ }^{342}$. A par da profícua discussão exposta no livro, o autor, ao final dele, textualiza que, desde " [...] que o ascetismo começou a remodelar o mundo e a nele se desenvolver, os bens materiais foram assumindo uma crescente e inexorável força sobre os homens, como nunca antes na História"; Weber acrescenta, porém, que "[...] hoje em dia - ou definitivamente, quem sabe - seu espírito religioso safou-se da prisão. O capitalismo vencedor, apoiado numa base mecânica, não carece mais de seu abrigo"; e, no "[...] setor de seu mais alto desenvolvimento, nos Estados Unidos, a procura da riqueza, despida de sua roupagem éticoreligiosa", tende, portanto, cada vez mais, a "associar-se com paixões puramente mundanas"343.

Thompson, em seu texto, salienta, ainda, que os teólogos metodistas empregaram regras rígidas quanto ao máximo aproveitamento do tempo. Dentre essas regras, o costume de levantar cedo era assumido com extrema seriedade. Esse costume foi, igualmente, apropriado pelos evangélicos. Assim, "Hannah More contribuiu com versos imortais em seu 'Early rising' [Acordar cedo]", dos quais destacamos: “Assassino calado, oh preguiça, / Pare de aprisionar minha mente, / E que eu não perca outra hora / Contigo, oh sono perverso"344. Por outro lado, dentro do movimento metodista, desenvolveu-se a doutrina de santificação de John Wesley que, apesar de se afastar da doutrina ortodoxa (anglicana), origina-se nela. Assim, a doutrina de Wesley defende que o indivíduo pode, nesta vida, com a devida graça trabalhando em seu ser, obter a santificação, que envolve a ideia de libertação pelo pecado. A isso, deveria ser acrescido o sentimento de estado de graça, através da prática de boas obras ${ }^{345}$.

É importante considerarmos que muitos autores discutidos no texto de Thompson sobretudo quanto aos teólogos metodistas - são igualmente analisados no estudo de Max Weber. Esse aspecto demonstra que Thompson, ao elaborar Costumes em Comum, estava dialogando, em muitas passagens, com o texto de Weber. Assim, os elementos discutidos anteriormente, contribuíram, entretanto, para inculcar sem dúvida, no proletariado fabril, a ideia de que se devia trabalhar com pontualidade e disciplina. Desse modo, formaram-se, gradualmente, novos hábitos de trabalho e se impôs uma nova disciplina de tempo. Nesse sentido, na "[...] sociedade capitalista madura, todo o tempo deve ser consumido, negociado, utilizado", pois "é uma ofensa que a força de trabalho meramente 'passe o tempo",346.

tempos modernos, especialmente junto nos "extratos sociais ascendentes da classe média industrial inferior", formados, em sua maioria, por calvinistas e puritanos ingleses, franceses e flamengos. WEBER, Max. A Ética Protestante o e Espírito do Capitalismo... op. cit., p. 67-90. É importante registrarmos que esse "homem burguês", "calvinista ou puritano" corresponde, na visão weberiana, a uma tipologia ideal.

${ }_{342}$ Percebe-se, portanto, que Weber analisa a religião - calvinista, em especial - enquanto "ação social", vista por ele enquanto "tipo ideal".

${ }^{343}$ WEBER, Max. A Ética Protestante o e Espírito do Capitalismo. 12. ed. São Paulo: Pioneira, 2001. p. 131.

${ }^{344}$ MORE, H., Works, II, 1830, p. 42 apud THOMPSON, Edward P. Tempo, Disciplina de Trabalho e Capitalismo Industrial. In: Costumes em Comum... op. cit., p. 296.

${ }^{345}$ THOMPSON, Edward P. Tempo, Disciplina de Trabalho e Capitalismo Industrial. In: Costumes em Comum. São Paulo: Companhia das Letras, 1998. p. 296; WEBER, Max. A Ética Protestante o e Espírito do Capitalismo... op. cit., p. 99.

${ }^{346}$ THOMPSON, Edward P. Tempo, Disciplina de Trabalho e Capitalismo Industrial. In: Costumes em Comum... op. cit., p. 298. 
Uma observação que julgamos importante e que se aplica aos objetivos centrais do presente estudo diz respeito ao fato de que "[...] o registro histórico não acusa simplesmente uma mudança tecnológica neutra e imutável, mas também a exploração e a resistência à exploração; e

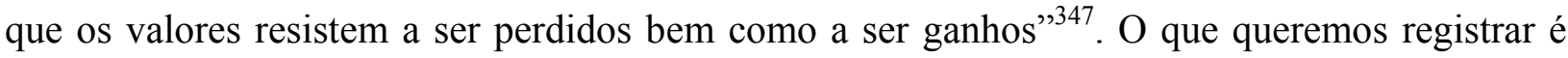
que, para os efeitos do presente estudo, a gradual introdução e circulação dos veículos motorizados pelas ruas do perímetro urbano da capital catarinense suscitou, naturalmente, resistências por parte da população florianopolitana, acostumada que estava ao ritmo de deslocamento operado pelos veículos movidos a tração animal, que se processava de maneira mais lenta e cadenciada.

Em vista disso, a nova tecnologia motorizada entrou em choque com antigos hábitos e costumes praticados pela população florianopolitana, e esse aspecto acarretou resistências e tensões num duplo viés: a) é quase certo que houve resistências, por exemplo, para abandonar a circulação nos antigos tílburys e carroças ou mesmo aceitar proibições quanto à prática de jogos e de brincadeiras pelas ruas da cidade para ceder espaço aos veículos motorizados; pois, especialmente a partir do ano de 1928, foram "[...] rigorosamente proibidos nas vias públicas da Capital os jogos de fute-bola, diavolô, peteca, amarelinha, bocha, ou quaisquer outros que possam perturbar o sossego público, e o trânsito de veículos e pedestres"; ${ }^{348}$ e b) é bastante plausível inferirmos que a população florianopolitana, pelo menos nos primeiros anos da introdução dos automóveis na capital catarinense, expressou, de maneira paralela, cautela e entusiasmo na aceitação dos automóveis como veículos preferenciais para o deslocamento pelas ruas do perímetro urbano - e, mesmo, nos bairros e distritos - da cidade de Florianópolis.

De outro modo, as análises anteriormente registradas, especialmente quanto aos comportamentos condicionados do operariado fabril inglês e sobre a máxima utilização do tempo em favorecimento às atividades de produção em larga escala, podem ser apropriadamente utilizadas para fazermos uma comparação com o ritmo imprimido pelos automóveis, pois o comportamento dos boleeiros e chauffeurs ao volante evidencia, conforme nos lembra Max Horkheimer, que diferentes graus de liberdade estão envolvidos no ato de conduzir uma

\footnotetext{
347 THOMPSON, Edward P. Tempo, Disciplina de Trabalho e Capitalismo Industrial. In:____. Costumes em Comum... op. cit., p. 301.

${ }^{348}$ Santa Catarina. Instruções Regulamentares para o serviço de trânsito público... op. cit., p. 13-14. A esse respeito, já em 1921, o artigo do jornal $O$ Estado, de 20 de julho, chamava a atenção para o aspecto de que as "nossas autoridades policiais prestariam, sem dúvida, um grande serviço à população se acabassem de vez com as partidas de 'foot-ball' nas praças e ruas desta Capital”, pois os “"campos' improvisados aumentam dia a dia”, e onde já "se joga livremente nas ruas Saldanha Marinho, Anita Garibaldi, na Avenida Hercílio Luz, na Praça General Osório e no Largo 13 de Maio...". Adiante, é observado que "Não é, porém, só o jogo e os riscos de levar uma 'bolada' o que preocupa as famílias residentes naquelas ruas", pois o que "mais lhes aborrecem são os impropérios, as obscenidades preferidas pelos jogadores no ardor da luta, sempre disputada e entusiástica". Dado o exposto, a nota registra, por fim, que se espera que "as nossas autoridades policiais deligenciem para que acabem com os perigos dos matchs em plena rua". (É preciso acabar com os 'matchs' nas ruas. O Estado. Florianópolis, 20 jul. 1921. p. 2). Essa nota jornalística não coloca, em nenhum momento, conflitos entre chauffeurs e pedestres pelo direito à ocupação e ao uso do espaço urbano. Podemos, porém, observar que, pelo menos desde o início da década de 1920, são lançados artigos na imprensa local, chamando a atenção para o incômodo e o inconveniente que "as partidas de 'foot-ball'” causavam aos moradores das ruas então citadas, pois, segundo sugerido, perturbavam o sossego público. Pelo que percebemos, a atuação policial, nesse ramo, não mostrou a eficiência esperada pela nota jornalística em questão; pois, em 1928, "os jogos de fute-bola" e outras brincadeiras, efetuados nas "vias públicas da Capital", ainda constituíam prática comum, precisando, naquele momento, ser novamente disciplinados, especialmente frente "ao trânsito de veículos e pedestres".
} 
carruagem ou dirigir um automóvel. Devemos considerar que o automóvel é mais rápido e eficiente e é mais facilmente manobrável. Salientamos, contudo, que “[...] o acréscimo de liberdade trouxe uma mudança no seu caráter. É como se as leis, normas e instruções que devemos cumprir dirigissem o carro e não nós. Existem limites para a velocidade, advertências para dirigir mais devagar; parar e manter-se dentro de certas faixas" e sentidos atribuídos para cada rua ou avenida. Devemos, portanto, encarar como necessário o ato de "[...] manter os olhos na estrada e ficar pronto para reagir a cada instante com o movimento certo"349.

Nesse sentido, ao conduzirmos um automóvel, devemos obedecer a leis e a normas específicas. Assim, nossa espontaneidade é, pois, substituída por uma disposição de espírito que nos obriga a descartarmo-nos de qualquer emoção ou ideia que possa diminuir nossa atenção ao volante. Desse modo, concebemos que automóveis e máquinas condicionam - em muitas situações verificadas no cotidiano das cidades e fábricas - os respectivos ritmos e comportamentos expressos por chauffeurs, transeuntes e trabalhadores fabris, e lhes forçam a adotar posturas automatizadas e/ou desnaturalizadas.

Outras referências e apontamentos críticos sobre o condicionamento das atitudes expressas por chauffeurs e motoristas podem ser encontrados no texto de autoria de Richard Sennett, intitulado Carne e Pedra: o corpo e a cidade na civilização ocidental (2. ed. Rio de Janeiro: Record, 2001). Nessa publicação, o autor objetiva tecer análises sobre a história da cidade, contada a partir da "experiência corporal do povo: como mulheres e homens se moviam; o que viam e ouviam; os odores que atingiam suas narinas; onde comiam; seus hábitos de vestir e de banhar-se; e de que forma faziam amor, desde a Atenas antiga à Nova York atual”350. No capítulo 10: Individualismo Urbano: a Londres de E. M. Foster (p. 259-286), Sennett destaca e analisa o livro de Foster, Howard End (“Juntar apenas"). Demonstra, desse modo, que o respectivo autor faz uma reflexão sobre a rápida transformação de Londres, durante a revolução urbana, e aponta que "[...] a velocidade era o fato mais importante da vida moderna" 351 . O que Foster procura evocar é essa apatia dos sentidos, que está presente, mesmo escondida, na conduta cotidiana tipicamente urbana ${ }^{352}$. Assim, individualismo e velocidade, juntos, amortecem o corpo moderno; não permitem que ele se vincule ao meio exterior.

Aprofundando essa discussão, Sennett observa que muitos recursos e tecnologias modernas: elevadores, luz elétrica, etc., promoveram a gradativa quebra do vínculo dos homens com o meio exterior; quebra esta, iniciada, pelo menos, desde o século XVIII e potencializada nos cem anos seguintes. Assim, o elevador (1846) possibilitou que os indivíduos, em poucos

\footnotetext{
${ }^{349}$ HORKHEIMER, Max. Eclipse da razão. 5. ed. São Paulo: Centauro, 2002. p. 102-103.

${ }^{350}$ SENNETT, Richard. Carne e Pedra: o corpo e a cidade na civilização ocidental. 2. ed. Rio de Janeiro: Record, 2001. p. 15.

${ }^{351}$ FOSTER, E.M., Howard End apud SENNETT, Richard. Carne e Pedra: o corpo e a cidade na civilização ocidental... op. cit., p. 264.

${ }^{352}$ SENNETT, Richard. Carne e Pedra: o corpo e a cidade na civilização ocidental... op. cit., p. 265.
} 
segundos, se afastassem da rua e de tudo o que existe nela. A energia elétrica dirimiu a importância da luz solar como meio de estabelecer vínculos entre o interior e o exterior das construções $^{353}$. Nesse sentido, Richard Sennett sinaliza para o perigo que representa o individualismo moderno, uma vez que torna as pessoas desconectadas dos lugares em que circulam e se movem, fazendo-as perder a noção de "destino compartilhado" ${ }^{354}$. Por fim, o autor sinaliza para a necessidade de que nosso entendimento a respeito do corpo precisa mudar a fim e que os habitantes dos grandes conglomerados urbanos ${ }^{355}$ resgatem o respeito mútuo e, desse modo, consigam "aceitar a dor do próximo" e "captar a diferença alheia",356.

Neste momento do texto, podemos observar - retomando a análise do processo n. 29, de 21 de novembro de 1923 - que os elementos e circunstâncias envolvidos no sinistro, registrado no processo supracitado, são ilustrativos para lançarmos o seguinte questionamento: os transeuntes que circulavam, cotidianamente, pelas ruas do perímetro urbano da cidade de Florianópolis não entravam, igualmente, em choque com os veículos movidos a tração animal, sofrendo atropelamentos e colisões diários? Bom, devemos esclarecer que, como vimos, nosso intento é, precisamente, analisar as percepções e as sensibilidades expressas pelos habitantes da capital catarinense diante da gradativa circulação do transporte motorizado no perímetro urbano da cidade de Florianópolis, por meio da investigação de processos criminais. Em vista disso, neste texto, buscamos perceber como os chauffeurs, passageiros e, especialmente, os transeuntes adaptaram-se aos meios de locomoção motorizados e às novas condutas de comportamento no trânsito. Parece-nos, contudo, razoável considerar que os florianopolitanos entravam, sim, em choque com os carros e veículos operados por força motriz animal, como carroças, bondes e tílburys, que já circulavam pelas ruas da capital catarinense em época precedente ao aparecimento dos veículos motorizados.

Desse modo, em pesquisa realizada na Biblioteca Pública do Estado, encontramos os códigos de posturas municipais de Florianópolis relativos aos anos de 1889, 1896 e 1898. À primeira vista, salta-nos aos olhos a similitude dos conteúdos registrados nessas publicações. Eles abordam temáticas diversas: a) alinhamento e nivelamento de ruas; b) conservação de estradas e caminhos; c) higiene e saúde pública; d) saneamento; e) condutores e trânsito de

\footnotetext{
${ }^{353}$ SENNETT, Richard. Carne e Pedra: o corpo e a cidade na civilização ocidental. 2. ed. Rio de Janeiro: Record, 2001. p. $280-281$.

${ }^{354}$ Ibidem, p. 264.

${ }^{355}$ Discutindo, nesse livro, o exemplo da cidade de Nova York nas décadas de 1960 e 1970, Sennett observa que Robert Moses, ao iniciar seus trabalhos de intervenção urbana naquela cidade, durante os anos 1920 e 1930, encarava a malha urbana de forma arbitrária, desconhecendo obrigações de "manter ou melhorar o que seus antecessores haviam feito"; e "assim, ele construiu pontes, parques e auto-estradas". Desse modo, Moses "favoreceu tanto a locomoção individual nos automóveis que, segundo alguns, chegou a ameaçar a viabilidade de tudo o que já existia". (SENNETT, Richard. Carne e Pedra: o corpo e a cidade na civilização ocidental... op. cit., p. 292-293).

${ }^{356}$ SENNETT, Richard. Carne e Pedra: o corpo e a cidade na civilização ocidental... op. cit., p. $292-293$; p. 300 e p. 305.
} 
carros, carroças e animais; f) disposições sobre o serviço de bondes, etc. Em todas as três publicações, observamos a clara similaridade existente nos conteúdos dispostos pelos vários títulos e capítulos por elas apresentados. Estes, salvo pequenas alterações, são similares e tratam de temas correlatos. É importante percebermos que, em nenhum dos artigos das publicações supracitadas, há menção aos termos automóvel ou chauffeur, ou seja, essas publicações tratam, nos capítulos correspondentes, apenas do trânsito de veículos operados por força motriz animal. Assim, por exemplo, o capítulo correspondente ao "trânsito de carros, carroças e animais", disposto no código de posturas do ano de 1889, trata, especialmente, da obrigatoriedade de "todos os carros, carroças e qualquer veículo particular ou de aluguel, empregados em serviços da cidade", serem matriculados anualmente ${ }^{357}$. Esse mesmo código também registra, no artigo 147, que "[...] em nenhum caso, serão admitidos a matrícula aos menores de dezoito anos"358.

Esses elementos são suficientes para inferirmos sobre a ocorrência de atropelamentos e de colisões provocados por veículos operados a tração animal, já durante os últimos decênios do século XIX. Vale registrarmos que, já na última década do oitocentos, havia a obrigatoriedade para que todos os condutores de "carros, carroças, ou outros quaisquer veículos de boléia" estivessem regularmente matriculados na "secretaria de polícia", conforme estipula o artigo 145 do código de posturas aqui já referido ${ }^{359}$. Assim, o que percebemos é que, já no final do século XIX, havia determinações legais que estipulavam a obrigatoriedade para que todos os condutores, maiores de dezoito anos, estivessem regulamente matriculados; condições exigidas para conceder-se o direito à condução dos veículos. Esses elementos continuaram a ser exigidos no século seguinte, conforme observamos na seção anterior, por ocasião das análises efetuadas nos artigos e conteúdos apresentados pelos regulamentos estaduais de 1914 e 1918.

Outro elemento que julgamos importante é o fato de que muitos dos artigos dispostos nos códigos de posturas dos anos de 1889, 1896 e 1898 são, igualmente, similares àqueles registrados pelo Regulamento para o serviço policial do Estado (1920), notadamente quanto às exigências e à obrigatoriedade para que os condutores de veículos estivessem regularmente habilitados; e quanto às "obrigações comuns a todos os cocheiros, carroceiros e motoristas", que deveriam, dentre outros elementos, "apresentar-se vestido com asseio e decência"; "tratar com polidez e atenciosa deferência o passageiro, evitando toda e qualquer alteração com o mesmo"; "guiar com prudência os animais, carros, bondes, automóveis, para evitar prejuízos aos transeuntes e passageiros" ${ }^{360}$. Aqui, é possível percebermos que os "transeuntes" e os

\footnotetext{
${ }^{357}$ Câmara Municipal da Cidade do Desterro. Código de Posturas. Lei n. 1238, de 22 out. 1888. Desterro: Tipografia da Regeneração, 1889. p. 28. Ver, especialmente, dessa publicação, o artigo 141.

${ }^{358}$ Câmara Municipal da Cidade do Desterro. Código de Posturas. Lei n. 1238, de 22 out. 1888... op. cit, p. 29.

${ }^{359}$ Idem.

${ }^{360}$ Para não nos alongarmos em demasia sobre esses aspectos, é suficiente ver os artigos 113, 115, 120 e 121 - e parágrafos correspondentes - do Regulamento para o serviço policial do Estado, de 1920. (Santa Catarina. Regulamento para o serviço policial do Estado. Florianópolis: Tip.
} 
"passageiros" determinavam, também, o ritmo de deslocamento dos veículos e que não devemos, portanto, adotar posturas unilaterais, nas quais apenas os chauffeurs e boleeiros, ao guiarem automóveis e carros, tinham o pleno direito ao uso e deslocamento pelas ruas do perímetro urbano de Florianópolis. Devemos atentar para o fato de que, nessas passagens, observamos, também, os termos "motoristas" e “automóveis". Notamos, portanto, que o Regulamento para o serviço policial do Estado objetiva atender, também, ao trânsito de veículos motorizados ${ }^{361}$. É este, precisamente, o principal avanço dessa publicação em relação ao conteúdo apresentado pelos códigos de posturas municipais de Florianópolis, anteriormente referenciados. Podemos, igualmente, constatar esse avanço ao observarmos os conteúdos dos "regulamentos das estradas estaduais", datados dos anos de 1914 e 1918, referenciados na seção anterior.

Em outras palavras, podemos afirmar, com certa propriedade, que, entre o final do século XIX e as primeiras décadas do século seguinte, houve, ao que parece, uma apropriação dos elementos dispostos nos capítulos e artigos dos códigos de posturas municipais supracitados para a elaboração dos "regulamentos das estradas estaduais" dos anos de 1914 e 1918; e, especialmente, do Regulamento para o serviço policial do Estado, de 1920, com o objetivo de regularizar, dentre outros aspectos, a circulação do automóvel, que se coloca, portanto, como novo elemento presente nas vias intermunicipais e nas ruas do perímetro urbano da capital catarinense, a partir daquele período.

É importante observarmos, ainda, que o parágrafo oitavo do artigo 149 do código de posturas de 1889 registra que "Art. 149 - Todo o cocheiro de carro de praça ou de aluguel é obrigado: \# 8. ${ }^{\circ}$ - A conservar as lanternas acesas desde o anoitecer até se recolher à cocheira"362. Notamos que havia, já em 1889, determinações para a condução de veículos no período noturno e marcações acerca do local em que, ao final do expediente de trabalho, deveriam ser recolhidos, ou seja, à cocheira. Elementos idênticos são registrados pelo parágrafo oitavo do artigo 156 do código de posturas de 1896. Entretanto, o artigo 126 do Regulamento para o serviço policial do Estado discrimina "carros ou automóveis de aluguel em cocheira ou garagem",363. Assim, percebemos que há menção a dois tipos de veículos de aluguel: os carros, que são tracionados por força motriz animal, e os automóveis, operados com tração mecânica; e que eles eram acondicionados em "cocheira" ou "garagem". Em vista disso, novos elementos - automóveis e

da Livraria Central, 1920). Conteúdos similares são encontrados junto aos artigos 145, 146, 147, 149 e 150 do código de posturas de 1889 e aos artigos 152, 153, 154, 156 e 157, do código de posturas de 1896. Ver, a respeito: a) Câmara Municipal da Cidade do Desterro. Código de Posturas. Lei n. 1238, de 22 out. 1888... op. cit; e b) Santa Catarina. Código de Posturas Municipais de Florianópolis. Florianópolis: Tipografia da República, 1896.

${ }^{361}$ O Regulamento para o serviço policial do Estado abrange também, como visto, o trânsito em âmbito municipal - ver capítulo primeiro -, diferente, por exemplo, do Regulamento das estradas estaduais e respectivo imposto de trânsito a que se refere o Decreto n. 846 , de 29 dez. 1914 , que trata do trânsito nas estradas de cunho estadual. Daí porque o nosso objetivo em chocar as informações registradas no regulamento policial de 1920 com aquelas referenciadas nos códigos de posturas municipais aqui discutidos.

${ }^{362}$ Câmara Municipal da Cidade do Desterro. Código de Posturas. Lei n. 1238, de 22 out. 1888. Desterro: Tip. da Regeneração, 1889. p. 29.

${ }^{363}$ Santa Catarina. Regulamento para o serviço policial do Estado. Florianópolis: Tipografia da Livraria Central, 1920. 
garagens - estavam começando a fazer parte do cenário urbano de Florianópolis no início do século passado. Atestamos, novamente, neste ponto, as inovações apresentadas pelo Regulamento policial do Estado, de 1920, anteriormente referidas.

É importante destacarmos que, ao menos a partir da publicação do código de posturas municipais do ano de 1889, são dispostos, textualmente, vários artigos e determinações que, dentre outros aspectos, objetivavam disciplinar a circulação de veículos e pedestres pelas ruas do perímetro urbano da capital catarinense. Desse modo, na parte intitulada "Dos carros, carroças e mais veículos", destacamos que

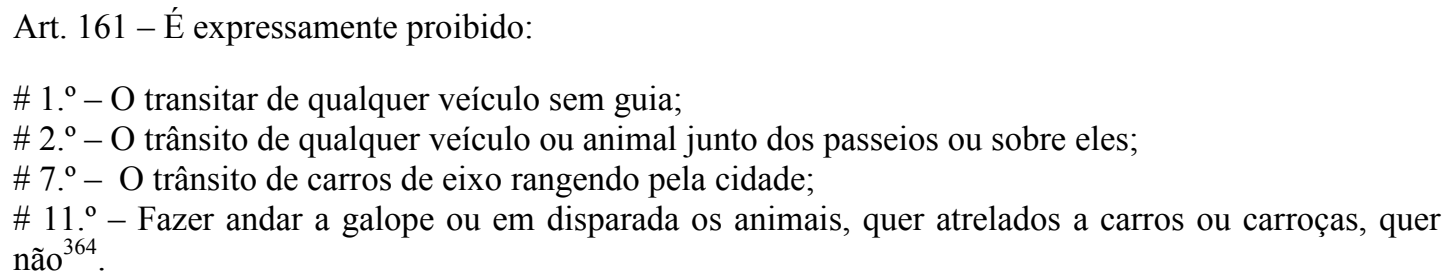

O texto registrado permite-nos assinalar algumas observações. Em primeiro lugar era proibido aos condutores dos veículos, já no final do século XIX, transitarem sem a referida guia ou mesmo, como visto, sem estarem devidamente habilitados para tal prática. Outro ponto que julgamos importante destacar é que foram estipulados locais apropriados para a circulação de veículos, animais e pedestres, especialmente dentro do perímetro urbano da capital catarinense; pois, à circulação dos primeiros, eram destinadas as ruas; já os pedestres deveriam transitar - ao menos em teoria - pelos passeios públicos (calçadas). Observamos, portanto, a designação de locais específicos destinados ao tráfego de veículos e transeuntes.

Além disso, era proibido o "trânsito de carros de eixo rangendo pela cidade", ou seja, podemos considerar que, à época, havia preocupações por parte da administração municipal em proporcionar relativo sossego e tranquilidade àqueles que circulavam, cotidianamente, pelas ruas e passeios públicos da cidade de Florianópolis - então Desterro. Assim, visando a alcançar tais objetivos, proibia-se, igualmente, que os condutores de veículos ou aqueles indivíduos montados em animais os conduzissem em altas velocidades pelas ruas do espaço urbano da capital catarinense. Nesse ponto, podemos aventar, também, a existência de preocupação relativa a evitarem-se choques entre veículos ou atropelamentos causados aos transeuntes.

Dentre as preocupações assinaladas pela administração municipal para disciplinar o espaço público da cidade de Florianópolis a fim de melhor organizar o tráfego de veículos e pedestres, encontramos o que determina os artigos 162 e 165 do Código de Posturas de 1889. Assim, destacamos que, “Art. 162 - Aos carroceiros ou condutores de carroças, carrinhos de mão e

\footnotetext{
${ }^{364}$ Câmara Municipal da Cidade do Desterro. Código de Posturas. Lei n. 1238, de 22 out. 1888. Desterro: Tipografia da Regeneração, 1889. p. 31-32.
} 
outros veículos empregados no trânsito de carga, materiais, etc. no perímetro da cidade", fica designada "Art. 165 - A parte da rua do Príncipe [atual rua Conselheiro Mafra], ${ }^{365}$ entre a Alfândega e a continuação da rua Trajano, para ponto de estação de tais veículos, que deverão se conservar sempre alinhados"366 (Figura 05, p. 112). Observamos, portanto, desde o final do século XIX, a adoção de medidas específicas destinadas a prover melhor organização e acondicionamento à circulação de veículos, animais e transeuntes pelas ruas e logradouros do perímetro urbano da cidade de Florianópolis.

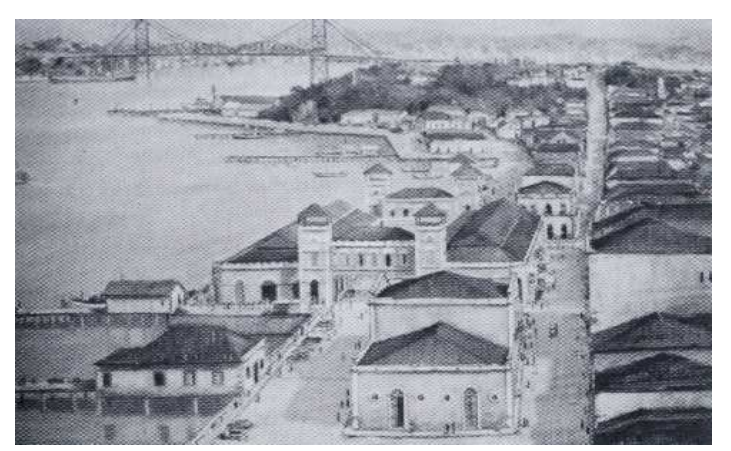

Figura 05 - Vemos, em primeiro plano, a Alfândega e o Mercado Público e, ao fundo, a ponte Hercílio Luz - início do século XX. A paisagem disposta em primeiro plano é, portanto, bem próxima ao local designado pelo código de posturas de 1889 para "ponto de estação" de "carroças, carrinhos de mão e outros veículos". Fonte: Pintura de Aldo Beck apud VEIGA, Eliane Veras da. Florianópolis: memória urbana. Florianópolis: UFSC / Fundação Franklin Cascaes, 1993. p. 309.

Neste ponto, devemos fazer uma importante observação, pois, para os efeitos deste estudo, os códigos e normas de trânsito teorizados para a capital catarinense envolviam ou procuravam amalgamar interesses diversos: daqueles responsáveis por sua elaboração teórica e aplicação prática - legisladores, políticos, engenheiros -, bem como das próprias atitudes e usos expressos pelo homem comum no cotidiano da cidade. Assim, os costumes e as práticas cotidianos exercidos pela população florianopolitana nas ruas, logradouros e locais públicos da capital catarinense foram elementos que, de uma ou outra forma, influenciaram, direta ou indiretamente, na elaboração e na aplicação de leis e códigos de trânsito, instituídos pelos poderes públicos municipal e estadual para o âmbito da cidade de Florianópolis. Nesse sentido, o artigo 161 do código de posturas de 1889, descrito anteriormente, pode ser interpretado como uma tentativa de se disciplinarem antigas práticas exercidas pelos habitantes da capital catarinense, uma vez que proíbe, por exemplo, em seus parágrafos segundo e sétimo, “Art. 161 - \# 2. ${ }^{\circ}$ - O trânsito de qualquer veículo ou animal junto dos passeios ou sobre eles", e “\# 7. - O trânsito de carros de eixo rangendo pela cidade". Além disso, essas passagens permitem-nos vislumbrar que tais práticas eram, mesmo, exercidas durante muito tempo pelos habitantes da cidade, e que frente ao novo regime político em voga - o código de posturas referido foi publicado no ano de 1889 precisaram, ao menos em caráter teórico, ser disciplinadas por meio de regras e dispositivos regulamentares de trânsito, dispostos e organizados no referido código de posturas.

\footnotetext{
${ }^{365}$ Ver: VEIGA, Eliane Veras da. Florianópolis: memória urbana. Florianópolis: UFSC/Fundação Franklin Cascaes, 1993. p. 364.

${ }^{366}$ Câmara Municipal da Cidade do Desterro. Código de Posturas. Lei n. 1238, de 22 out. 1888. Desterro: Tipografia da Regeneração, 1889. p. 32-33.
} 
Os códigos de posturas municipais referentes à capital catarinense aqui discutidos registram, também, artigos e parágrafos relativos ao calçamento e ao nivelamento das ruas e travessas da cidade. Assim, da publicação de 1889, podemos observar que "as praças ou largos compreenderão um espaço nunca menor de vinte e dois metros em quadro",367. Além disso, "as ruas e travessas terão a largura de $13,{ }^{\mathrm{m}}$ e 20 , dando-se às que novamente se abrirem a direção dos pontos cardeais, quando a isso não se oponha o maior nivelamento retilíneo" ${ }^{\text {,368 }}$. Essas medidas, ao que parece, eram provisórias, pois os artigos 12 e 13 registram, respectivamente, que "Art. 12 - As praças, ruas e travessas das cidades e povoações do município, bem assim as estradas ora existentes e as que se abrirem, terão a direção, o nivelamento e as proporções indicadas nas respectivas plantas"; porém, “Art. 13 - Enquanto não forem levantadas e adotadas as plantas respectivas, serão observadas as disposições” registradas anteriormente ${ }^{369}$. Além disso, o artigo 15 registra, claramente, que “[...] Nenhuma edificação ou reedificação, qualquer que seja, começará no espaço compreendido nas plantas das [...] freguesias e povoações, ou no determinado pela Câmara, sem que preceda o alinhamento e nivelamento, ${ }^{\text {,370 }}$.

Destacamos que, nas pesquisas realizadas para a elaboração do presente estudo, não nos foi possível encontrar tais plantas. Não nos cabe, todavia, neste espaço, tecermos comentários aprofundados sobre o nivelamento ou alinhamento das ruas, praças e travessas existentes na cidade de Florianópolis (Desterro) ao final do século XIX. O que objetivamos é ressaltar que, já naquela época, havia preocupações das autoridades municipais com a organização das ruas e logradouros da cidade. Além disso, é válido destacarmos que “Art. 14 - Os proprietários de quadra ou rua, que for ou tiver sido concertada pela Câmara, segundo o nivelamento por ela marcado, uma vez feitas as respectivas sarjetas, ficam obrigados a calçar os passeios das frentes de seus terrenos ou casas, na conformidade do mesmo nivelamento" ${ }^{371}$. Esses calçamentos deveriam ser efetuados com "lajes lavradas e esquadrejadas, tijoleiras de cimento, ou pedras cobertas de cimento" 372 . Essa obrigação era exigida, igualmente, dos "proprietários que tiverem as suas frentes calçadas de pedra bruta" ${ }^{373}$. Esses elementos assumiam, de certa forma, caráter emergencial, pois o parágrafo segundo do artigo 14 estipula que “\# 2. ${ }^{\circ}$ - O prazo de seis meses será concedido para o cumprimento desta obrigação, contando da data do edital em que a Câmara anunciar estar pronta a quadra ou rua na forma do referido nivelamento"374.

\footnotetext{
${ }^{367}$ Ver artigo 13, parágrafo primeiro. In: Câmara Municipal da Cidade do Desterro. Código de Posturas. Lei n. 1238 , de 22 out. 1888 . Desterro: Tipografia da Regeneração, 1889. p. 07.

${ }^{368}$ Texto descrito no parágrafo segundo, artigo 13. In: Câmara Municipal da Cidade do Desterro. Código de Posturas. Lei n. 1238 , de 22 out. 1888 ... op. cit, p. 07.

${ }^{369}$ Câmara Municipal da Cidade do Desterro. Código de Posturas. Lei n. 1238, de 22 out. 1888... op. cit, p. 07.

${ }^{370}$ Idem.

${ }^{371}$ Idem.

${ }^{372}$ Ver artigo 14. In: Câmara Municipal da Cidade do Desterro. Código de Posturas. Lei n. 1238, de 22 out. $1888 \ldots$ op. cit, p. 07.

${ }^{373}$ Ver art. 14, parág. primeiro. In: Câmara Municipal da Cidade do Desterro. Código de Posturas. Lei n. 1238 , de 22 out. 1888 ... op. cit, p. 07.

${ }^{374}$ Câmara Municipal da Cidade do Desterro. Código de Posturas. Lei n. 1238, de 22 out. 1888... op. cit, p. 07.
} 
Julgamos conveniente observar, ainda, que os textos destacados referem-se a uma publicação datada do ano de 1889, ou seja, as preocupações quanto ao nivelamento e ao calçamento das ruas, assim como quanto aos demais capítulos e artigos dessa publicação, envolvem, ao que parece, claros interesses políticos atinentes à "necessidade" de oferecer-se à capital do Estado um conjunto de leis e regulamentações urbanas que assinalassem a passagem para o novo regime político ${ }^{375}$. Nesse sentido, podemos considerar que as autoridades municipais almejaram elaborar uma legislação para a cidade do Desterro - ao menos em seu caráter retórico ${ }^{376}$ - com o objetivo de tentar "apagar" os elementos e características do que entendiam ser o passado "imperial" e "atrasado" da cidade. Essas preocupações são, igualmente, expressas quanto ao "Trânsito de carros, carroças e animais", pois o artigo 141 estipula, dentre outros aspectos, que “[...] Todos os carros, carroças e qualquer veículo particular ou de aluguel, empregados em serviços da cidade, serão numerados e arrolados todos os anos nos meses de janeiro a fevereiro" e "seus proprietários serão obrigados a mandar apresentá-los no referido prazo ao empregado encarregado de proceder à numeração e arrolamentos, exceto os carros e máquinas de companhias de bondes e estradas de ferro, que serão franqueadas ao empregado municipal para o dito fim"377. Constatamos, portanto, que, pelo menos a partir daquele momento, a numeração e o emplacamento eram exigidos dos mais variados tipos de veículos e eram aplicados, inclusive, aos "carros e máquinas das companhias de bondes e estradas de ferro". Além disso, é importante assinalarmos que “Art. 143 - Os carros, carroças e outros veículos que forem encontrados sem numeração, findo o prazo estipulado no artigo 141, serão apreendidos pelos fiscais, e conservados em depósito, até que seus proprietários paguem a respectiva multa e o imposto a que estejam obrigados",378.

Neste espaço, não nos cabe julgar se tais determinações eram ou não cumpridas - seja pela falta de fiscalização eficiente, seja conforme observamos no capítulo anterior, por táticas adotadas pelos chauffeurs e transeuntes para, dentre outros aspectos, driblar ou desobedecer às determinações legais -, mas atentar para a preocupação da Câmara Municipal, textualizada em códigos e dispositivos legais, em dotar a capital catarinense de regras que visavam à disciplinarização de condutas e comportamentos "condizentes" com o novo regime político em

\footnotetext{
${ }^{375}$ Observemos que a aprovação do Código de Posturas da cidade de Florianópolis, datado de 1896, cujos artigos e parágrafos são, em grande parte, similares ao texto de 1889, envolveu, igualmente, interesses políticos, notadamente para registrar, sob o ponto de vista da administração pública municipal, um novo momento para a capital catarinense, que, a partir do ano de 1894, passou a ser denominada Florianópolis. Esse ato coroou, simbolicamente, a vitória das elites republicanas no Estado. Sobre a mudança do nome da cidade de Florianópolis, ver Santa Catarina. Lei n. 111, 1. ${ }^{\circ}$ out. 1894. Florianópolis, 1894.

376 Assinalamos esse ponto, pois, já no ano de 1880 - portanto, em pleno período imperial -, havia preocupações, por parte da administração pública municipal da cidade do Desterro, quanto à preferência aos hábitos e costumes considerados "civilizados", pois o artigo 11 do "Regulamento para o serviço da $1 .{ }^{a}$ Seção da linha de Carris Urbanos" (bondes), estipula que "Art. 11 - Não poderão ser admitidos nos carros pessoas descalças, maltrapilhas e embriagadas". (Regulamento para o serviço da 1. "Seção da linha de Carris Urbanos. In: THIAGO, Polydoro Olavo de São. (Eng. ${ }^{\text {ro }}$ ). Ofício. Encaminhado ao Presidente da Província João Rodrigues Chaves. Desterro, 03 nov. 1880).

${ }^{377}$ Ver artigo 141. In: Câmara Municipal da Cidade do Desterro. Código de Posturas. Lei n. 1238, de 22 out. $1888 \ldots$... op. cit, p. 28.

${ }^{378}$ Câmara Municipal da Cidade do Desterro. Código de Posturas. Lei n. 1238, de 22 out. 1888... op. cit, p. 28.
} 
voga. Numa dimensão mais ampla, essas preocupações nortearam, sem dúvida, muitas ações municipais e governamentais por todo o País, a partir daquele período.

De outro modo, não é exagero considerarmos que as preocupações quanto ao nivelamento e ao calçamento das ruas da cidade de Florianópolis, determinadas a partir do final do século XIX, objetivavam - afora as razões apontadas anteriormente - oferecer melhores condições ao tráfego de veículos tracionados por força motriz animal. Além disso, vimos que a circulação dos automóveis era incipiente no Estado durante o início da década de 1920, e que só seria regulamentada, com maior propriedade, por ocasião da elaboração do Regulamento para o serviço policial do Estado (1920); tráfego este que apresentava gradual crescimento e que necessitava de reaparelhamento normativo ou preparação das vias trafegáveis para melhor acondicioná-lo.

O texto referente ao Código de Posturas municipais de 1889 nos permite, igualmente, tecer algumas reflexões sobre as determinações do poder público municipal quanto ao saneamento e à higienização do espaço central da capital catarinense. Nesse sentido, destacamos que "Art. 53 É absolutamente proibido: \# $1 .^{\circ}$ - Lançar cisco, palhas, vidros, imundices, materiais fecais, animais mortos, lixo, entulhos, nos quintais, praças, ruas, Cais, praias, ou nos terrenos compreendidos no perímetro da cidade e povoações" ou naqueles locais "designados pela Câmara para edificações", assim como "conservar lamaçais ou águas estagnadas, cloacas abertas, urinar ou fazer dejeções nos mesmos lugares"379. Os parágrafos segundo e quinto desse artigo especificam, igualmente, que não eram permitidas a criação de “\# 2. - Porcos dentro da cidade e seus arrabaldes ou trazê-los a solta nas outras povoações"; além das práticas de se "\# 5. - Estender ou conservar nas praças e ruas quaisquer materiais de cheiro infecto ou objetos que embaracem o trânsito público"380. Além disso, outra determinação estipula que "Art. 54 - A limpeza das águas servidas e materiais fecais só será feita das dez horas da noite às cinco da manhã, lançando-se-as ao mar" ${ }^{\text {381 }}$. Corroborando com esses elementos, o Código de Posturas de 1889 destaca que "Art. 130 - É proibido: \# 1. ${ }^{\circ}$ - Fazer bulhas ou vozeiras, dar altos gritos sem necessidade reconhecida; \# $2 .^{\circ}$ - Fazer sambas ou batuques, quaisquer que sejam as denominações, dentro das ruas da cidade ou das povoações"; e determina, igualmente, nos parágrafos quinto e nono, que é proibido “\# 5. - Proferir palavras obscenas ou licenciosas que ofendam o pudor das famílias ou a moralidade pública" e “\# 9. - Andar pelas ruas indecentemente vestido, com roupas dilaceradas, ou sem que traje, pelo menos, calça e camisa, sendo esta por dentro daquela",382.

\footnotetext{
${ }^{379}$ Câmara Municipal da Cidade do Desterro. Código de Posturas. Lei n. 1238, de 22 out. 1888. Desterro: Tip. da Regeneração, 1889. p. 14.

${ }^{380}$ Idem.

${ }^{381}$ Idem.

${ }^{382}$ Ibidem, p. 25.
} 
Assim, os artigos e respectivos parágrafos assinalados anteriormente permitem-nos tecer considerações importantes. Em primeiro lugar, observamos que o poder público municipal determinava, com maior clareza a partir daquele período, proibições quanto às ações de despejo de materiais e elementos que provocariam odores ou depreciações à plástica urbana; devia-se, portanto, conservar limpos, dentre outros locais, os "quintais, praças, ruas e os terrenos compreendidos no perímetro da cidade e povoações”. De outro modo, conferiu-se especial atenção à livre fluência do trânsito público. Outro aspecto que consideramos importante diz respeito às costas litorâneas e às praias que configuravam, à época, espaços em que se permitia, legalmente, o despejo de materiais não condizentes às tentativas de higienização do perímetro urbano da capital catarinense.

Nos textos registrados anteriormente, é possível percebermos, igualmente, que o conjunto de determinações municipais pretendeu penetrar nas sociabilidades e valores do povo. Assim, foram estipuladas proibições aos hábitos e costumes populares; pois, dentre outros aspectos, "os sambas e batuques" foram impedidos de serem praticados "nas ruas e povoações da cidade". Além disso, foram rechaçadas práticas relativas à pronúncia de palavras ou expressões consideradas chulas e à circulação de pessoas maltrapilhas ou vestidas de maneira vista como inadequada. Desse modo, o que percebemos, já naquela época, é que havia preocupações, por parte do poder público da Capital, em conferir à cidade um aspecto higienizado e aprazível.

Não devemos esquecer que o ano de 1889 marca o início de um novo regime político para o País. A par da consideração de que a proclamação de 1889 apenas assinalou o findar de um regime político que, desde pelo menos a década de 70 do século XIX, já mostrava claros sinais de saturação e esgotamento, podemos assinalar que a organização e a publicação do código de posturas municipal da cidade de Florianópolis (Desterro), datado daquele ano, envolveram, dentre outros elementos, a preocupação em elaborar ou, ao menos, reordenar artigos e dispositivos legais relativos aos principais procedimentos quanto à disciplinarização do espaço urbano e das práticas e vivências populares.

As medidas relativas à higienização do espaço urbano da capital catarinense e à proibição de costumes praticados pela população florianopolitana que, no entendimento das elites locais, não eram condizentes com o asseio e a civilidade, tornaram-se mais incisivas durante as primeiras décadas do século XX e foram propaladas, especialmente, pelos periódicos e órgãos governamentais locais. Nesses instrumentos, percebemos uma profícua discussão sobre as medidas para o equacionamento de doenças infectocontagiosas e sobre a salubridade dos espaços públicos da cidade de Florianópolis. Assim, discutir a questão sanitária em Florianópolis nesse período, como, por exemplo, as doenças, a implementação de serviços de saneamento básico, é 
fundamental para compreendermos os objetivos da ação governamental nas modificações, higienização e embelezamento da parte central da cidade, pois o governador Hercílio Luz, por exemplo, ao iniciar seu segundo mandato (1918-1922) $)^{383}$, declarou que o saneamento, especialmente na região do litoral, era "o problema sobre todos capital, sem cuja solução teremos de assistir impotentes à derrocada de nossos esforços em prol da prosperidade do Estado" ${ }^{\text {384 }}$.

Devemos observar, neste ponto, que o governo de Hercílio Luz representou, para a política local, a consolidação dos ideais republicanos e federativos, simpáticos às iniciativas progressistas e à noção de modernidade; valores estes que se refletiram em mudanças quanto aos enfoques conferidos, por exemplo, à educação. Essa foi pautada pela formação técnica, que era destinada à preparação de profissionais para atuarem, majoritariamente, de maneira prática e direta, nos campos da engenharia e medicina - O Instituto Politécnico de Florianópolis, por exemplo, foi fundado e organizado entre os anos de 1921 e 1923; deu-se, portanto, durante o governo de Hercílio $\mathrm{Luz}^{385}$. A educação objetivava, no período, formar, sobremaneira, técnicos cujas capacidades profissionais fossem direcionadas para equacionar os problemas de saneamento e de higienização do espaço público da Capital. Essas políticas e iniciativas estiveram presentes - e com maior envergadura - na esfera federal, sobretudo nos grandes centros urbanos: Rio de Janeiro, São Paulo, Recife; cujas administrações locais coordenaram esforços direcionados para a efetuação de ações, muitas vezes pontuais, voltadas para o equacionamento dos seus principais problemas sanitários e paisagísticos.

No âmbito da capital catarinense, a Mensagem apresentada pelo superintendente Antônio Pereira da Silva e Oliveira ao Conselho Municipal da cidade de Florianópolis, em 1905, expressa a preocupação com a salubridade do espaço central da cidade; pois, sem a "adoção de medidas que tornem obrigatório o serviço de remoção de matérias fecais e do lixo, proibindo em absoluto o despejo em quintais (principalmente no centro da cidade)", ou em "qualquer parte dentro do perímetro urbano será impossível, ou pelo menos muito difícil, tornar em realidade o saneamento da nossa capital” ${ }^{, 386}$. Assim, o Superintendente municipal em questão assinala, igualmente, que "Parece-me ser este o único meio para de uma vez para sempre, extinguirmos os depósitos de lixo e os poços de materiais fecais que ainda hoje infelizmente existem em acanhados quintais no centro da cidade" ${ }^{\text {387 }}$. Além disso, referencia que a "desagradável impressão que causam as velhas

\footnotetext{
${ }^{383}$ Hercílio Luz governou o Estado em três oportunidades: a) 1894-1898; b) 1918-1922 (Vice-governador eleito com Lauro Muller; exerceu o cargo durante o quatriênio face ao pedido de licença do titular); e c) 1922-1924. Ver, a respeito, MEIRINHO, Jali. República e Oligarquias: subsídios para a história catarinense - 1889-1930. Florianópolis: Insular, 1997. p. 127.

${ }^{384}$ LUZ, Hercílio Pedro da. Vice-Governador, no exercício do cargo de Governador do Estado de Santa Catarina. MENSAGEM apresentada ao Congresso Representativo. Florianópolis, 22 jul. 1919. p. 18.

${ }^{385}$ VEIGA, Eliane Veras da. Florianópolis: memória urbana. Florianópolis: UFSC/Fundação Franklin Cascaes, 1993. p. $261-263$.

${ }^{386}$ OLIVEIRA, Antônio Pereira da Silva. Superintendente Municipal. MENSAGEM dirigida ao Conselho Municipal em $1^{\circ}$ de abril. Florianópolis, Gazeta Oficial, 15 abr. 1905. p. 2.

${ }^{387}$ Idem.
} 
e feias casas da rua Arcipreste Paiva com fundos para a rua Padre Miguelinho, que se tornaram [...] focos de infecção, impõem a necessidade urgente de sua desapropriação, não só para embelezamento, como medida de higiene da cidade" ${ }^{388}$. Quinze anos depois, o artigo do jornal República, de $1 .^{\circ}$ de fevereiro de 1920, salienta a mesma preocupação ao observar que

\begin{abstract}
Florianópolis, a mais formosa Ilha do Atlântico, está, atualmente, sofrendo a influência benéfica da administração progressista, modelar do eminente catarinense sr. Dr. Hercílio Luz, que vai executando no seu governo um vasto programa de melhoramentos indispensáveis. Míster se tornava saneá-la, embelezá-la de acordo com o adiantamento moral, material, intelectual de Santa Catarina, cujo grau de prosperidade era constantemente assinalado e conhecido, através das manifestações da imprensa de todo o País. Com uma feição rotineira, colonial, com suas ruas estreitas, com inúmeros casebres a enfeiar-lhe a estética, Florianópolis impressionava mal ao forasteiro. O beco Irmão Joaquim com os seus cortiços margeando o canal da Fonte da Bulha até a pedreira, era um verdadeiro foco de miasmas e um conhecido antro de vadiagem. Os casebres não tinham instalações de esgotos. As dejeções eram feitas no canal. Quilômetros acima, rumando o leito da Fonte da Bulha, a mesma prática das moradias pobres, sem noção [...] dos bons ensinamentos da higiene. A situação exigia uma vontade disciplinada que executasse um grandioso plano de melhoramento da cidade, extinguindo males inveterados ${ }^{389}$.
\end{abstract}

A par do caráter ufanista e simpatizante às ações do governo estadual expresso pelo artigo do jornal em destaque - o periódico era dirigido por integrantes ou simpatizantes do Partido Republicano local -, as ideias referidas salientam, claramente, durante aproximadamente quinze anos, as preocupações quanto ao embelezamento e à higienização do espaço público relativo ao perímetro urbano da cidade de Florianópolis. Neste ponto, é importante destacarmos que os problemas relativos ao abastecimento de água potável na cidade ou, mesmo, ao equacionamento dos problemas ligados à salubridade da região central da urbe por meio, dentre outras medidas, das discussões para a remoção do antigo outeiro da cidade, estiveram presentes durante os séculos XVIII e XIX. ${ }^{390}$ Entretanto, podemos considerar que, a partir do final do século XIX, até, pelo menos, a década de 1920, as preocupações quanto à salubridade e à higienização do perímetro urbano da cidade de Florianópolis assumiram, junto aos periódicos e órgãos governamentais locais, um teor mais enfático e evidente.

Desse modo, na capital catarinense, durante as primeiras décadas do século XX, médicos, autoridades e políticos descreviam, de maneira dramática, os problemas de saneamento e propunham várias medidas, desde a distribuição gratuita de remédios até o controle dos movimentos populacionais no espaço urbano. Um tom de urgência impregnou, portanto, as manifestações sobre a saúde pública em Santa Catarina, especialmente em Florianópolis, como se os surtos de doenças fossem inusitados para a sociedade daquela época ${ }^{391}$.

\footnotetext{
${ }^{388}$ OLIVEIRA, Antônio Pereira da Silva. Superintendente Municipal. MENSAGEM dirigida ao Conselho Municipal em $\mathbf{1}^{\mathbf{0}}$ de abril. Florianópolis, Gazeta Oficial, 15 abr. 1905. p. 2.

${ }^{389}$ Remodelação de Florianópolis. República. Florianópolis, 1 fev. 1920. p. 1.

${ }^{390}$ Sobre tais discussões ver, por exemplo, a) RIBEIRO, João Alberto Miranda. Ofícios recebidos pela Câmara do Governador João Alberto Miranda Ribeiro. Desterro, 26 jun. 1794; e b) COUTINHO, João José. Relatório apresentado à Assembléia Provincial de Santa Catarina. Desterro, 19 abr. 1854; e c) ROCHA, Francisco José da. Relatório apresentado à Assembléia Legislativa Provincial de Santa Catarina. Rio de Janeiro, 1888.

${ }^{391}$ ARAÚJO, Hermetes Reis de. Fronteiras Internas: Urbanização e Saúde Pública em Florianópolis nos anos 20. In: BRANCHER, Ana (Org.). História de Santa Catarina: estudos contemporâneos. Florianópolis: Letras Contemporâneas, 1999. p. 103.
} 
As doenças mencionadas não eram, pois, novas na região e elas se manifestavam em Nossa Senhora do Desterro desde o século XVIII, conforme relatam antigos cronistas e viajantes ${ }^{392}$. O que teria acontecido para que, nas vésperas dos anos 1920, elas passassem a ser vistas como um problema sanitário de proporções inéditas? Uma aguda deterioração das condições gerais de saúde? Nem tanto, pois a saúde pública, no início do século XX, não estaria sendo comprometida por males muito mais graves do que aqueles que ocorriam nas décadas passadas. Assim, as causas para o surgimento de um problema sanitário ameaçador não se encontram num agravamento das doenças ou numa sensível diminuição dos cuidados com a saúde pública, os quais não haviam mudado de maneira significativa no início do século passado.

A resposta mais imediata indicaria o fato de que surgiu uma nova percepção daquelas doenças em Santa Catarina. Elas teriam adquirido um novo significado em termos de ameaça à saúde e passaram, consequentemente, a demandar formas de prevenção mais eficazes. O aparecimento dessa nova modalidade de enquadramento e combate às epidemias não se deve, contudo, somente à utilização da ciência para resolução dos problemas de saúde pública. Outros fatores também foram decisivos na mudança de relação com a doença; entre eles, dois se destacam. O primeiro foi uma crescente intervenção do Estado na sociedade, por meio de campanhas de profilaxia, inspeções sanitárias e implantação de reformas urbanas - para isso, muito concorreu o ensino politécnico. O segundo corresponde a uma crescente diferenciação social, que identificou uma insuficiência de civilização nos costumes locais e reclassificou os espaços e os indivíduos passíveis de abrigar aquelas doenças como um novo tipo de ameaça, que era eminente para a cidade e seus habitantes ${ }^{393}$.

A importância conferida à saúde pública a partir do final do século XIX, no Brasil, é explicada, em grande parte, pelas transformações socioeconômicas ocorridas no país. Vimos, no capítulo anterior, que os recursos gerados pela economia agroexportadora, especialmente o café, atraíam investimentos estrangeiros aplicados em bancos, ferrovias e obras de infraestrutura. Em vista disso, a atividade comercial foi incrementada, assim como a oferta e a disponibilidade de serviços urbanos. Além disso, o crescimento demográfico experimentado no período especialmente aplicado às cidades do Rio de Janeiro e São Paulo - chocou-se com uma infraestrutura urbana incapaz de acolher tal aumento de contingentes; e, desse modo, essas cidades apresentaram um processo gradual de inchamento populacional, em função do seu crescimento desordenado. Outrossim, verificamos, de maneira paralela, o agravamento das

\footnotetext{
${ }^{392}$ ARAÚJO, Hermetes Reis de. Fronteiras Internas: Urbanização e Saúde Pública em Florianópolis nos anos 20... op. cit., p. 103. Uma discussão mais aprofundada sobre os enquadramentos sociais que se objetivavam traçar à população florianopolitana como forma de disseminar valores considerados morais e civilizatórios pode ser encontrada junto ao seguinte texto: ARAÚJO, Hermetes Reis de. A invenção do litoral: Reformas urbanas e reajustamento social em Florianópolis na Primeira República. Dissertação (Mestrado em História). São Paulo: PUC, 1989.

${ }^{393}$ ARAÚJO, Hermetes Reis de. Fronteiras Internas: Urbanização e Saúde Pública em Florianópolis nos anos 20. In: BRANCHER, Ana (Org.). História de Santa Catarina: estudos contemporâneos. Florianópolis: Letras Contemporâneas, 1999. p. 104.
} 
condições sanitárias, despontando várias áreas insalubres e focos endêmicos de doenças infectocontagiosas: cólera, varíola, tuberculose, febreamarela.

A partir desse momento, notamos que se configura uma crise sanitária nos principais centros urbanos. Ela expôs, abertamente, as precárias condições de saneamento no Brasil e ensejou a mobilização de recursos para a formação de uma estrutura de saúde pública mais eficiente. No Rio de Janeiro, a solução para os problemas sanitários foi estreitamente associada a um amplo programa de reformas urbanas. Foi a época do bota abaixo, quando foram demolidos vários quarteirões populares no centro da cidade e, consequentemente, seus moradores foram expulsos para ceder lugar a praças e avenidas, como a Avenida Central, inaugurada em 1904 e entregue ao tráfego em 1905, que logo se tornou o símbolo máximo de uma nova concepção urbanística no país ${ }^{394}$. (Figura 06, p. 120).

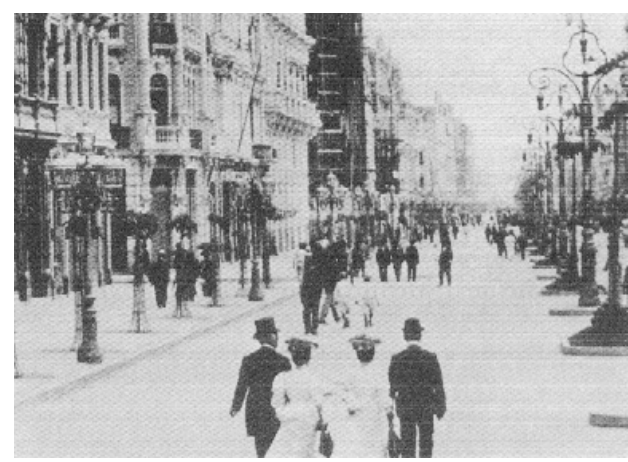

Figura 06 - Avenida Central, c. 1908. Fonte: SEVCENKO, Nicolau. Literatura como Missão: tensões sociais e criação cultural na Primeira República. 2. ed. São Paulo: Companhia das Letras, 2003.

Devemos observar que a construção dessa avenida - assim como das principais obras de infraestrutura efetuadas no espaço central da capital carioca no período - obedeceu aos princípios de circulação e de salubridade urbanos, almejados por muitos setores que compunham a elite carioca. Por outro lado, entre as iniciativas tributárias desse modelo nas capitais brasileiras da época, destacamos a construção e a inauguração das seguintes avenidas: a) Sete de Setembro em Salvador (1912-1916); b) Rio Branco e Marquês de Olinda no Recife (década de 1910); e c) Avenida Borges de Medeiros em Porto Alegre (projetada em 1914 e concluída em 1920) ${ }^{395}$. Essas iniciativas também estavam presentes na maioria das propostas para os melhoramentos urbanos da cidade de São Paulo ${ }^{396}$. Desse modo, a capital paulista também sofreu, nessa época,

\footnotetext{
${ }^{394}$ ARAÚJO, Hermetes Reis de. Fronteiras Internas: Urbanização e Saúde Pública em Florianópolis nos anos 20... op. cit., p. 105. João do Rio expõe, em algumas de suas crônicas sobre o cotidiano carioca, reunidas sob o título A alma encantadora das ruas, alusões e referências à implementação dessa avenida; e Raul Antelo, organizador desta coletânea, observa que tal via é a "[...] atual avenida Rio Branco, construída entre 1903 e 1906, entre o largo da Prainha, hoje praça Mauá, até a praia de Santa Luzia, onde um obelisco relembra sua abertura”. RIO, João do. A Alma encantadora das ruas: crônicas. São Paulo: Companhia das Letras, 2008. p 93. ((Org.). Raúl Antelo).

${ }^{395}$ MORAES, José Geraldo Vinci de. Cidade e cultura urbana na Primeira República. São Paulo: Atual, 1994. p. 44-65.

${ }^{396}$ Para maiores esclarecimentos ver a) BRESCIANI, Maria Stella Martins. Nas Ruas, os Caminhos da Cidade. In: Cadernos de História de São Paulo - A cidade e a rua. São Paulo, n. 2, p. 27-38, jan./dez. 1993; b) ___. História e Historiografia das Cidades: um percurso. In: FREITAS, Marcos Cezar. (Org.). Historiografia brasileira em perspectiva. São Paulo: Contexto, 1998. p. 237-258; c) ___. A Cidade: objeto de estudo e experiência vivenciada. In: Revista Brasileira de Estudos Urbanos e Regionais. São Paulo: ANPUR, v. 6, n. 2, nov. 2004. p. 9-26; d) CAMPOS, Cândido Malta. Os Rumos da Cidade: Urbanismo e Modernização em São Paulo. São Paulo: Senac, 2002; e) MORAES, José Geraldo Vinci de. Cidade e cultura urbana na Primeira República. São Paulo: Atual, 1994; f) SÁVIO, Marco Antônio Cornacioni. A Modernidade sobre Rodas. São Paulo: EDUC, 2002. Para o caso da cidade de Buenos Aires, devemos, entretanto, destacar, sobretudo durante a década de 1930, a formulação da "metáfora biológica" para identificar os pontos doentios da cidade que deveriam ser alvo de intervenção de
} 
alterações significativas em seu espaço urbano, sobretudo no governo municipal de Antônio Prado. Personagem emblemático das primeiras etapas do processo de intensa urbanização da capital paulista, Antônio Prado era vinculado à atividade cafeeira, mas simpatizava com a crescente diversificação de atividades verificadas na cidade de São Paulo.

É válido observarmos que Antônio Prado dedicou seus doze anos de mandato - de 1899 a 1910 - à remodelação física dos espaços e equipamentos urbanos da capital paulista. Neste ponto, podemos relacionar esse processo com aquele sofrido pela cidade do Rio de Janeiro; pois, no mesmo período, grande parte dos investimentos federais aplicados na infraestrutura urbana estava voltada para as obras realizadas na capital fluminense, empreendidas pelo governo federal de Rodrigues Alves (1902-1906), que colocara à frente da prefeitura o engenheiro Francisco Pereira Passos, o qual partilhava com Antônio Prado a ligação com os setores progressistas do governo republicano ${ }^{397}$.

Salientamos, também, que, para o caso da cidade de São Paulo, o secretário de obras Victor Freire observa, em 1914, não haver dúvidas quanto aos benefícios da “[...] influência que a luz e o ar assumem na salubridade das aglomerações humanas ${ }^{\text {"398 }}$. Assim, em sua opinião, assegurar o bom funcionamento do ar e dos raios solares constituía a melhor técnica para combater doenças como a tuberculose e a febre amarela ${ }^{399}$. As autoridades procuravam, também, excluir do centro da cidade as populações cujo estado extremo de miséria as forçavam a aglutinarem-se em casebres às margens da Várzea do Carmo e da Baixada do Piques. Esses eram núcleos paulistanos com forte presença de negros, resultantes de grupos de escravos evadidos das lavouras de café. As iniciativas governamentais objetivavam apenas a evacuação dessas populações, equiparadas em linguagem discricionária agressiva aos estigmas dos insetos, da sujeira, da doença e do crime, sem fazer qualquer menção à sua realocação ou a seu destino ${ }^{400}$.

Dentre outros autores que também se ocuparam do estudo das transformações dos grandes centros urbanos brasileiros, entre o final do século XIX e o início do século XX, destaca-se José

\footnotetext{
médico-higienistas, engenheiros e dos poderes públicos municipais. Os discursos iniciais no campo do planejamento científico para o território da capital argentina, são baseados nos argumentos extraídos da biologia, que se devem aos estudos de Carlos María della Paolera. Engenheiro de profissão, ele havia formulado, a partir do contexto urbano das principais cidades européias, um Plano Regulador para a Aglomeração Buenairense, desenvolvido em sua tese de doutorado, no Instituto de Urbanismo da Universidade de Paris, entre 1922 e 1928. Tal como se debatia no contexto europeu, durante aqueles anos, seus referentes eram algumas grandes cidades que já consideravam, além do núcleo urbano original ou área funcional da cidade, as áreas conurbadas. Assim, no desenvolvimento do Plano, della Paolera visualizou como objeto de estudo o território global da conurbação. Com efeito, as investigações de della Paolera haviam-se traduzido a uma série de planos, na qual a conurbação de Buenos Aires aparecia em sua dimensão histórica e com os limites urbanos sobrepostos com outras cidades européias. Por meio deles, podemos constatar que a cidade superava Paris em extensão, igualava-se a Berlim e se comparava com a dimensão de Londres, naqueles anos, a maior cidade da Europa. Tempos depois, o território da conurbação adquiriu uma dimensão ainda mais precisa dentro de suas propostas. Tratava-se, em síntese, da explicitação do termo Grande Buenos Aires. Ver CARIDE, Horácio E. O polvo, a mancha e a megalópole - o urbanismo como representação, Buenos Aires, 1927-1989. In: BRESCIANI, Maria Stella M. (Org.). Palavras da cidade. Porto Alegre: UFRGS, 2001. p. 41-45.

${ }^{397}$ CAMPOS, Cândido Malta. Os Rumos da Cidade: Urbanismo e Modernização em São Paulo. São Paulo: Senac, 2002. p. 79; SEVCENKO, Nicolau. Orfeu extático na metrópole: São Paulo, sociedade e cultura nos frementes anos 20. São Paulo: Companhia das Letras, 1992. p. $120-122$.

${ }^{398}$ BRESCIANI, Maria Stella Martins. Imagens de São Paulo: Estética e Cidadania. In: Anais do IV Seminário de História da Cidade e do Urbanismo. Rio de Janeiro, v. 1, p. 465-474, nov. 1996.

${ }^{399}$ Idem.

${ }^{400}$ SEVCENKO, Nicolau. Orfeu extático na metrópole: São Paulo, sociedade e cultura nos frementes anos 20... op. cit., p. $140-141$.
} 
Geraldo Vinci de Morais. Formado em História pela Pontifícia Universidade Católica de São Paulo (PUC), publicou, dentre outros textos, Cidade e cultura urbana na Primeira República (São Paulo: Atual, 1994), no qual discute, com especial atenção, os encaminhamentos da cultura popular urbana produzida na capital paulista durante os anos relativos à Primeira República no Brasil. Nesse estudo, o autor analisa, igualmente, a formação do quadro urbano-industrial brasileiro sob os enfoques econômico e urbanístico e destaca o inegável crescimento predial e das atividades urbanas, e os serviços de remodelação dos espaços centrais das principais cidades brasileiras da época.

Desse modo, o autor destaca que "[...] o primeiro sinal das transformações por que passavam as cidades brasileiras entre as últimas décadas do século XIX e as primeiras décadas [do século seguinte] foi a expansão da rede de serviços urbanos"; pois, nos "centros de maior importância [...], as melhorias materiais concretizavam-se rapidamente, revelando, de alguma forma, o desenvolvimento econômico setorial: luz, transporte público, água encanada, calçamento, pontes e parques tomavam os espaços públicos das cidades, dando-lhes características que os aproximavam dos centros urbanos modernos da Europa"401.

Essas ideias são corroboradas quando o autor procede à análise das reformas urbanas colocadas em prática na capital da República, pois destaca que "[...] o Rio de Janeiro precisava, no início do século XX, reaparelhar-se e reestruturar-se. Sendo assim, a elite carioca, tal como a paulistana, queria tornar o Rio de Janeiro uma 'Europa possível'",402. Morais expõe, ainda, que “[...] as obras de remodelação do centro do Rio de Janeiro no início do século (1903-06) foram comandadas pelo prefeito Pereira Passos, nomeado com poderes extraordinários pelo presidente Rodrigues Alves", pois o então chefe do poder público da capital carioca era "engenheiro formado na Escola Militar", que "viveu em Paris durante anos, como funcionário da embaixada brasileira"; e, além "de ter tido formação educacional e técnica baseada em princípios franceses, ele acompanhou de perto as reformas urbanas empreeendidas por Haussmann em Paris, que o influenciaram profundamente" 403 . Desse modo, reunindo "[...] um grupo de engenheiros e especialistas para colocar em prática seu plano, ele encarregou-se do planejamento global da cidade [do Rio de Janeiro]”. Assim, “[...] a abertura de grandes avenidas, a criação dos boulevards e o embelezamento da região central revelaram de maneira clara as influências das reformas parisienses" ${ }^{\prime 404}$.

As análises sobre as tentativas de se equiparar os grandes centros urbanos brasileiros às principais cidades da Europa - especialmente Paris - também estiveram presentes em textos de

\footnotetext{
${ }^{401}$ MORAES, José Geraldo Vinci de. Cidade e cultura urbana na Primeira República. São Paulo: Atual, 1994. p. 44.

402 Ibidem, p. 56-57.

${ }^{403}$ Ibidem, p. 57.

${ }^{404}$ Ibidem, p. 57-58.
} 
outros autores, notadamente aqueles de autoria de Sandra Jatahy Pesavento. A autora direciona seus estudos sob a perspectiva da História Cultural e, nesse âmbito, discute, no texto $O$ Imaginário da Cidade: visões literárias do urbano - Paris, Rio de Janeiro, Porto Alegre (Porto Alegre: UFRGS, 1999), a maneira como o meio urbano das cidades de Paris, Rio de Janeiro e Porto Alegre é representado como moderno pela imprensa, órgãos governamentais e obras literárias locais. Destaca, dentre outros aspectos, que os padrões de metropolização, ditados pelo eixo Paris-Londres, foram adotados e/ou adaptados para as cidades do Rio de Janeiro e Porto Alegre $^{405}$, e que a população dessas cidades as vivenciavam como espaços urbanos efetivamente identificados com a ideia de metrópole.

Veremos, pois, a seguir, que essa perspectiva é passível de questionamentos, uma vez que as mudanças e alterações urbanas verificadas no período, nos principais centros urbanos do país, entraram em choque com visões e tendências políticas diversas que, em inúmeros momentos e ocasiões, salientaram a complexidade e a diversidade das propostas urbanísticas locais. Elas envolveram, portanto, diferentes posturas, divergências teóricas e distintas filiações, e a forma como se procurou adequá-las às limitações impostas pelas condicionantes paisagísticas e político-urbanas de cada localidade.

Nesse sentido, o livro Os Rumos da Cidade: Urbanismo e Modernização em São Paulo (São Paulo: Senac, 2002), do arquiteto Cândido Malta Campos, surge como uma importante contribuição para a compreensão do papel de urbanistas e políticos nas transformações do espaço dessa cidade, no período entre os anos de 1870 e 1945. Produzido como tese de doutorado pelo programa de Pós-Graduação da Faculdade de Arquitetura e Urbanismo da USP, trata-se de um estudo abrangente que recupera e articula aspectos relevantes das transformações pelas quais passou a cidade de São Paulo - especialmente sua área central - ao longo do período em análise.

$\mathrm{O}$ autor investiga a gestação e o conteúdo de projetos urbanísticos e de instrumentos intervencionistas ou reguladores do espaço urbano da capital paulista, como códigos de obras e de zoneamentos, normas de parcelamento, taxas de melhoria, etc. Por outro lado, o autor salienta o papel relevante desempenhado por engenheiros, arquitetos, urbanistas e figuras políticas nacionais e paulistanas perante as transformações urbanas verificadas para a cidade de São

\footnotetext{
${ }^{405}$ Esse ponto de vista é, também, defendido pelo autor Marco Antônio Sávio, no livro A Modernidade sobre Rodas (São Paulo: EDUC, 2002). Embasando seu estudo sob a ótica da História Social, esse autor enfatiza a tecnologia motorizada como inserida em um contexto mais amplo, por ele denominado "artefato técnico", que se refere a uma vasta rede de conhecimentos técnicos e arcabouços legislativos, que, calcados "nos padrões europeus de desenvolvimento", refletiam "a sua dupla natureza: a sua natureza tecnocientífica e a sua natureza social". Além disso, fica clara a simpatia do autor diante da adoção ou adaptação, para a cidade de São Paulo, dos moldes de urbanismo adotados na Europa, pois ele considera, em outro momento do seu texto, que "o automóvel representava - juntamente com uma série de outras inovações, como os bondes e a energia elétrica - o início de uma nova era, marcada pela modernização tecnológica e pela urbanização, tendo como paradigma as grandes cidades da Europa e dos Estados Unidos"; nesse sentido, é que o "artefato técnico é o grande símbolo de um modelo social de desenvolvimento pelo qual procuravam nossas elites no começo do século XX: o mundo europeu”. (SÁVIO, Marco Antônio Cornacioni. A Modernidade sobre Rodas. São Paulo: EDUC, 2002). Ver, respectivamente, desse livro, as páginas 44, 40 e 47. Veremos adiante, que não eram simples as tentativas de se adotarem padrões estrangeiros de urbanismo - sobretudo europeus - em cidades brasileiras, pois que demandavam discussões entre posicionamentos e correntes políticas que, muitas vezes, divergiam sobre um mesmo assunto. Do mesmo modo, tais tentativas enfrentavam, também, dificuldades impostas pelas especificidades topográficas de determinado terreno ou espaço urbano.
} 
Paulo, durante as décadas de 20 e 30 do século passado, e às naturais disputas políticas empreendidas para sua efetivação. Dentre esses personagens, destacamos Victor Freire, Saturnino de Brito, Artur Sabóia, Alexandre de Albuquerque, Anhaia Melo e Prestes Maia. O grande mérito de sua obra é, todavia, precisamente desvendar aspectos desses embates. $\mathrm{O}$ autor sinaliza como essas disputas políticas envolvem demandas simbólicas, estéticas, higienistas, de valorização imobiliária e interesses políticos e comerciais ${ }^{406}$.

Outra questão enfatizada refere-se às diferentes formas de apropriação e à assimilação de experiências e de modelos internacionais. A esse respeito, destacamos que, nas primeiras décadas do século XX, modelos de inspiração "haussmanniana" - então privilegiados nas intervenções urbanísticas nas capitais nacionais - chocaram-se com padrões de inspiração "sittiana", defendidos por urbanistas como Victor Freire e Saturnino de Brito (1864-1929), personagens que simpatizavam com a aplicação de soluções urbanísticas adequadas às situações locais e atentas às particularidades do sítio urbano; avessos, portanto, à aplicação de modelos urbanísticos arbitrários. Cândido Malta Campos demonstra, também, como a ênfase das propostas urbanísticas foi deslocando-se de questões sanitárias para preocupações viárias, num movimento que redefine os padrões estéticos eleitos e sua aplicação nos planos urbanísticos. Desse modo, destacamos que "a São Paulo dos bulevares" e o "estilo neocolonial terão sua época até a chegada dos anos 1920, com as discussões sobre urbanidade e modernismo"407. Assim, ao assinalar o descompasso entre planos e intervenções, o autor sinaliza os limites dos projetos teóricos quando das tentativas de sua aplicação prática no espaço urbano de São Paulo.

O eixo central da obra é, portanto, analisar precisamente o vasto campo de lutas que permeia o pensamento e a prática do urbanismo. Em outras palavras, podemos considerar que os processos de higienização e de disciplinarização urbana eram efetuados de maneira parcial e excludente, pois atendiam a interesses políticos específicos, relacionados à especulação urbana; ou encontravam resistência perante as correntes políticas desfavoráveis ou mesmo às necessidades e aos comportamentos dos habitantes da urbe ${ }^{408}$. Campos evidencia, ainda, que “[...] os projetos modernizadores locais não partilhavam as prioridades que presidiam as reformas urbanísticas do Hemisfério Norte", especialmente quanto ao "reformismo social" e à "racionalização do espaço urbano no interesse do capital produtivo"409. Assim, a coerência e o alcance das propostas urbanísticas elaboradas para as cidades brasileiras eram limitados, e a situação apresentada pela capital paulista aponta, ao que parece, uma primeira diferença

\footnotetext{
${ }^{406}$ CORREIA, Telma de Barros. Os Rumos da Cidade: Urbanismo e Modernização em São Paulo. Resenha. São Paulo: Senac, 2002. In: Revista Brasileira de Estudos Urbanos e Regionais. São Paulo: ANPUR, n. 5, maio 2002. p. 119.

${ }^{407}$ CAMPOS, Cândido Malta. Os Rumos da Cidade: Urbanismo e Modernização em São Paulo. São Paulo: Senac, 2002. p. 11.

408 Para o aprofundamento da discussão sobre normatização e segregação socioterritorial do espaço urbano, ver MARICATO, Ermínia. Metrópole, legislação e desigualdade. Estudos Avançados, v. 17, n. 48, 2003. p. 151-166.

${ }^{409}$ CAMPOS, Cândido Malta. Os Rumos da Cidade: Urbanismo e Modernização em São Paulo... op. cit., p. 20.
} 
fundamental, uma vez que, “[...] ao contrário das cidades de Paris ou Rio de Janeiro, onde os arquitetos se formavam nas Escolas de Belas-Artes, o ensino da arquitetura em São Paulo passou a ser uma especialidade da engenharia" ${ }^{\circ 10}$.

Oferecemos, a seguir, um exemplo dos embates e conflitos envolvidos em torno de projetos de reformulação urbana da cidade de São Paulo. Os inúmeros projetos arquitetônicos e paisagísticos propostos para a capital paulista, entre o final do século XIX e, pelo menos, até a década de 20 do século passado - dentre eles, a construção e inauguração do Viaduto do Chá (1898) e a construção e inauguração da Avenida Paulista (inaugurada por volta de 1896) salientam disputas políticas e posicionamentos divergentes sobre os rumos e direções que tais projetos deveriam assumir. Para termos uma ideia mais aproximada sobre essas disputas, podemos observar o que o então diretor de Obras Municipais de São Paulo, Victor Freire, afirma na Conferência intitulada “Os melhoramentos de São Paulo”, proferida no Grêmio Politécnico, em 15 de fevereiro de 1911. Nessa ocasião, Freire considera que "o paradigma haussmanniano deveria ser superado" ${ }^{411}$, pois

A origem dessa falsa noção vem da transformação de Paris [...] pelo barão Haussmann [...]. O público bateu palmas e o exemplo passou as fronteiras. Porém, 'seria um erro acreditar que os processos empregados em Paris [...] produziriam mais efeitos em outros lugares’. Para resolver aspectos técnicos e estéticos da remodelação de São Paulo, deveriam ser adotados os princípios do urbanismo científico exemplificado nos ensinamentos de $\mathrm{Sitte}^{412}$. O terreno acidentado, a situação do centro urbano sobre uma colina a cavaleiro de dois vales, as linhas de penetração para os bairros, tudo leva à adoção dos traçados não ortogonais, e sugeria o pitoresco como recurso de valorização paisagística: 'não é precisamente a curva que melhor se presta [...] à configuração do novo terreno acidentado, do qual suga a cidade o seu elemento característico de encanto: o pitoresco? ${ }^{413}$

\section{Corroborando com essas explanações, destacamos que Victor Freire}

Considerava exagerado o padrão da rua reta de 16 metros de largura, adotado pelo Código de Posturas paulistano de 1886. Seria uma transposição indevida de normas francesas, compatível apenas com o padrão de ocupação residencial centro-europeu, com seus quarteirões compactos, lotes quadrados e blocos de apartamentos com grandes pátios internos. Freire pretendia, então, que as práticas anglosaxônicas de arruamento (ruas locais mais estreitas), parcelamento (lotes uni familiares) e ocupação (maior proporção de terreno livre) fossem adotadas no caso paulistano, possibilitando economia de área ocupada pelo sistema viário, em benefício de espaços livres no interior das quadras e de pequenos parques nos bairros residenciais ${ }^{414}$.

Analisando as ideias citadas, devemos esclarecer, em primeira mão, que, em sua conferência, Freire apresentou exemplos retirados da obra de Sitte e das realizações do urbanismo sittiano alemão da virada do século. Nesse sentido, buscava argumentos para

\footnotetext{
${ }^{410}$ CAMPOS, Cândido Malta. Os Rumos da Cidade: Urbanismo e Modernização em São Paulo... op. cit., p. 67. A esse propósito, temos que o Instituto e a Escola Politécnica do Estado de São Paulo foram fundados, respectivamente, nos anos de 1892 e 1893. Ibidem, p. 64.

${ }^{411}$ CAMPOS, Cândido Malta. Os Rumos da Cidade: Urbanismo e Modernização em São Paulo... op. cit., p. 128.

${ }^{412}$ Camillo Sitte (1843-1903). Arquiteto e historiador da arte, diretor da Escola Imperial e Real de Artes Industriais de Viena, foi o autor do estudo urbanístico Construção das Cidades Segundo seus Princípios Artísticos ("Der Städtebau nach seinen künstlerischen Grundsätzen"). Nesse estudo, Sitte opera uma análise das cidades na história e propõe a reavalização dos meios urbanos através de seus espaços existentes, principalmente suas praças e parques. Nesse sentido, é possível considerarmos que o seu objetivo foi "polemizar contra as transformações de Viena e o planejamento do Ringstrasse, segundo princípios do Barão Georges-Eugène Haussmann”. Sua obra foi, também, fonte de inspiração para Patrick Geddes e Lewis Mumford.

${ }^{413}$ FREIRE, Victor da Silva. Os melhoramentos de São Paulo. Conferência no Grêmio Politécnico, 15 fev. 1911. p. 101-104 apud CAMPOS, Cândido Malta. Os Rumos da Cidade: Urbanismo e Modernização em São Paulo... op. cit., p. 128.

${ }^{414}$ CAMPOS, Cândido Malta. Os Rumos da Cidade: Urbanismo e Modernização em São Paulo... op. cit., p. 131
} 
desbancar a imagem do bulevar retilíneo e uniforme à parisiense, pois todos os projetos, apresentados até então para a capital paulista, procuravam, sem sucesso, encaixar uma "avenida central" na difícil topografia da cidade ${ }^{415}$. O diretor de Obras atacava, assim, os projetos de Samuel das Neves e Alexandre de Albuquerque ${ }^{416}$, baseados no princípio por ele considerado ultrapassado e antiestético dos alinhamentos em linha reta ${ }^{417}$.

As ideias destacadas, nessas citações, também se referem às críticas às "versões descontextualizadas das realizações de Haussmann"”, qualificando-as de "“horrores [...] impecáveis, aliás, quanto ao alinhamento - como a Avenida Central do Rio" ${ }^{, 418}$. Desse modo, destacamos a preocupação com a irregularidade cuidadosamente controlada, a variedade volumétrio-espacial e a recusa da monotonia ortogonal; elementos estes que ilustravam uma postura crítica em relação aos alinhamentos retilíneos, aos efeitos de perspectiva e às edificações uniformes presentes no modelo parisiense e sonhado pelas elites locais ${ }^{419}$. Salientamos que fica evidente, também, a preocupação em priorizar os espaços livres no interior das quadras e àqueles destinados aos parques, como forma de oferecer melhores condições à circulação do ar e da luz do Sol em meio ao cenário urbano da capital paulista.

Outro aspecto que destacamos é o fato de que os trabalhos relativos à remodelação do espaço central da cidade do Rio de Janeiro, empreendidos, especialmente, durante o início do século XX, serviram de inspiração para a modernização urbana buscada pelos setores dominantes em várias cidades e capitais brasileiras. Assim, esses espaços "almejavam possuir sua pequena 'Étoile"”; "ter a sua 'avenida central'”, e, desse modo, não era apenas a inadequação desse modelo para a situação paulistana que estava em jogo nos argumentos de Victor Freire, mas a necessidade de superar tal paradigma e construir outro, mais autônomo - que estabelecesse para a cidade de São Paulo um caminho próprio, não mais subordinado à capital federal ${ }^{420}$.

É importante considerarmos, também, que, para os efeitos deste estudo, a elaboração e a implementação de projetos de cunho urbanístico para a cidade de São Paulo, especialmente durante o final do século XIX e as três primeiras décadas do século XX, suscitaram discussões e

\footnotetext{
${ }^{415}$ CAMPOS, Cândido Malta. Os Rumos da Cidade: Urbanismo e Modernização em São Paulo. São Paulo: Senac, 2002. p. 128.

${ }^{416}$ Alexandre de Albuquerque, por exemplo, era engenheiro civil e arquiteto formado pela Escola Politécnica em 1905; e a partir de 1909, trouxe da Europa um vasto repertório artístico e arquitetônico, que o tornava qualificado a subscrever um projeto que visava à "haussmannização" de São Paulo. Nesse contexto, em novembro de 1910, um conjunto de notáveis endereçou ao Congresso Legislativo do Estado, petição solicitando apoio oficial para um projeto de urbanização destinado a transformar o quadrante Oeste de São Paulo em novo espaço central, com desenho monumental e caráter europeu. O grupo era formado por alguns dos maiores representantes da elite política e econômica paulistana, incluindo Plínio da Silva Prado, filho de Martinho Prado Júnior e sobrinho do prefeito Antônio Prado; José Paulino Nogueira, fazendeiro e chefe político da região entre Campinas e Limeira; José Martiniano Rodrigues Alves, dentre outros. O projeto de Alexandre de Albuquerque ficou conhecido como o das "grandes avenidas", pois era baseado na superposição de novos eixos viários sobre o tecido urbano existente, a partir do qual três vias largas e retas cortariam os bairros do Morro do Chá e Santa Ifigênia. A principal delas iria da Praça Antônio Prado à chácara do Carvalho; outra ligaria o Teatro Municipal e o Viaduto do Chá às estações da Luz e Sorocabana; e uma terceira partiria do Largo de Santa Ifigênia rumo ao Arouche e Higienópolis. (CAMPOS, Cândido Malta. Os Rumos da Cidade: Urbanismo e Modernização em São Paulo... op. cit., p. 115-117). ${ }^{417}$ CAMPOS, Cândido Malta. Os Rumos da Cidade: Urbanismo e Modernização em São Paulo... op. cit., p. 128.

418 FREIRE, Victor da Silva. Os melhoramentos de São Paulo. Conferência no Grêmio Politécnico, 15 fev. 1911. p. 101-104 apud CAMPOS, Cândido Malta. Os Rumos da Cidade: Urbanismo e Modernização em São Paulo... op. cit., p. 128.

${ }^{419}$ CAMPOS, Cândido Malta. Os Rumos da Cidade: Urbanismo e Modernização em São Paulo... op. cit., p. 128.

${ }^{420}$ Ibidem, p. 139.
} 
embates em torno de um ou mais pontos de vista, o que colocou, lado a lado, posicionamentos ideológicos, muitas vezes, divergentes sobre determinado assunto ou decisão. Sem dúvida, essa situação é aplicável aos demais contextos urbanos brasileiros do período. Não nos cabe, neste espaço, tecer uma discussão aprofundada sobre os meandros das disputas políticas que envolviam a implementação de projetos urbano-paisagísticos para os principais centros urbanos do país. Entendemos, todavia, que as ideias destacadas anteriormente oferecem um parâmetro sobre a complexidade que envolvia a adoção de posturas ou medidas práticas para a higienização ou reformulação urbana dos principais centros urbanos brasileiros.

As estratégias norteadoras das intervenções dos higienistas sociais, na remodelação dos espaços urbanos, envolvem, dentre outros aspectos, a separação dos corpos, aos quais era designado um lugar específico. O esquadrinhamento "científico" rigoroso das populações desfavorecidas facilita o trabalho de desodorização das casas e vias públicas; pois, ao operar a interdição dos contatos muito estreitos, permite exercer um controle científico-político do meio. Assim, o combate aos miasmas, infecções e insalubridades significa, em última análise, anular os odores da corrupção moral, pois o burguês desodorizado vê, nos cortiços e nos casebres, o perigo das emanações pútridas, decorrentes dos vapores acumulados pela reunião de massas confusas e misturadas. Essa política sanitária de descongestionamento dos corpos define a produção do espaço urbano e determina a invasão da moradia dos pobres, impondo-lhes, portanto, novos regimes sensitivos e disciplinas corporais ${ }^{421}$.

Essa discussão pode ser aprofundada ao tomarmos contato com o texto de Margareth Rago, intitulado Do cabaré ao lar: a utopia da cidade disciplinar: Brasil 1890-1930 (Rio de Janeiro: Paz \& Terra, 1. ed. 1985; 3. ed. 1997). O referido texto - que apresenta um viés claramente orientado pelos estudos de Michel Foucault quanto aos aspectos disciplinares e de esquadrinhamento do espaço de instituições como o hospital e a prisão - é bem conhecido dos historiadores, mas propõe, ao mesmo tempo, uma discussão sucinta e bem fundamentada sobre as estratégias que norteavam as ações políticas e médico-higienistas para o controle dos espaços e comportamentos sociais, notadamente nos meios urbanos e fabris; e, de outro modo, lança e discute perspectivas e práticas sociais orientadas pela desobediência ou não adequação às normas disciplinares que se tentavam impor aos espaços e comportamentos anteriormente assinalados.

É importante observarmos que, de acordo com a teoria dos fluídos, que dominava o pensamento médico desde a segunda metade do século XVIII, o ar e a água eram considerados veículos mórbidos, portadores de emanações pútridas, conhecidas como miasmas. A inalação dos miasmas poderia provocar o desequilíbrio biológico do organismo, obstruir as vias de

\footnotetext{
${ }^{421}$ RAGO, M. Do cabaré ao lar: a utopia da cidade disciplinar: Brasil 1890-1930. 3. ed. Rio de Janeiro: Paz \& Terra, 1997. p. 165-166.
} 
circulação do sangue e ocasionar, desse modo, o surgimento da cólera, da febre amarela e da gangrena $^{422}$. Para o caso da cidade de São Paulo, a instalação dos trilhos urbanos para as linhas de ferro-carris, apropriados a cargas e passageiros, a partir de 1872; a reforma e construção de edifícios públicos, a inauguração do Palácio do Governo, em 1864; e da Escola Normal e Instrução Pública, em 1875, indicam que melhoramentos públicos traduzem a finalidade de tornar "a capital engrandecida e circundada de atrativos" $" 23$. Assim, na década de 70 do século XIX, a noção de melhoramentos urbanos assume, amplamente, as diretrizes funcionais e estéticas do sanitarismo: tornar saudável, higiênico e aprazível o ambiente urbano. É, por conseguinte, considerada medida de higiene pública a eliminação dos focos de miasmas que contribuem, significativamente, para viciar a atmosfera e alterar a constituição médica pelo predomínio das febres paludoras ${ }^{424}$.

Assinalamos, entretanto, que, somente a partir do último quarto do século XIX, a teoria dos micróbios, formulada por Louis Pasteur na década de 1870, questiona as crenças anteriores ao mostrar que as doenças contagiosas não se transmitiam pela inalação do ar contaminado, mas por germes infecciosos propagados pelo contado indireto estabelecido entre as pessoas, por meio do uso ou permuta de objetos diversos. Assim, Pasteur assevera que os micróbios não surgiam espontaneamente nas substâncias fermentícias, como então se acreditava, mas eram gerados por outros similares que impregnavam o ar. Tratava-se, então, de descobrir a bactéria específica e a vacina que poderia destruí-la. A teoria dos miasmas e a teoria pasteuriana dos germes fundamentaram, portanto, as campanhas de eliminação, no Brasil, das favelas e cortiços, que os especialistas médico-higienistas passam a defender ${ }^{425}$.

Dentre outros estudos que discutem as questões sanitárias e a higienização de espaços urbanos e comportamentos sociais, destacamos o texto de Sidney Chalhoub: Cidade Febril: cortiços e epidemias na Corte Imperial (São Paulo: Companhia das Letras, 1986). Esse estudo, elaborado junto ao Programa de Pós-Graduação em História da Universidade Estadual de Campinas (UNICAMP), é direcionado sob a perspectiva da História Social e enfoca debates sobre o que o autor chama de "ideologia da higienização", que permeou as ações políticas e médico-higienistas durante o final do século XIX e o início do século passado, direcionadas para a "limpeza" e a "desodorização" dos cortiços cariocas; sobre o combate à febre amarela e, em sua esteira, às populações negras e pobres dos arrabaldes e morros do Rio; e também sobre as campanhas em prol da aplicação da vacina antivariólica, etc.

\footnotetext{
${ }^{422}$ RAGO, Margareth. Do cabaré ao lar: a utopia da cidade disciplinar: Brasil 1890-1930. 3. ed. Rio de Janeiro: Paz \& Terra, 1997. p. 167.

${ }^{423}$ BRESCIANI, Maria Stella Martins. Melhoramentos entre intervenções e projetos estéticos: São Paulo (1850-1950). In: ___. (Org.).

Palavras da cidade. Porto Alegre: UFRGS, 2001. p. 139.

${ }^{424}$ Idem.

${ }^{425}$ RAGO, Margareth. Do cabaré ao lar: a utopia da cidade disciplinar: Brasil 1890-1930_.. op. cit., p. 168-169.
} 
Assim, os “[...] cortiços supostamente geravam e nutriam 'o veneno' causador do vômito preto" ${ }^{426}$. Era preciso, “[...] dizia-se, intervir radicalmente na cidade para eliminar tais habitações coletivas e afastar do centro da Capital as 'classes perigosas' que nele residiam; classes duplamente perigosas, porque propagavam a doença e desafiavam as políticas de controle social no meio urbano" ${ }^{427}$. Percebemos, nesse ponto, claras aproximações com o estudo desenvolvido por Margareth Rago, anteriormente referido.

De outro modo, Chalhoub objetiva, com suas próprias palavras, "reconstruir na longa duração a experiência dos habitantes do Rio diante do serviço de vacinação" e aponta que "[...] felizmente já se foram os tempos em que os historiadores não acreditavam na possibilidade de as idéias também fazerem história» ${ }^{, 28}$. Percebemos que o enfoque trazido pelo autor é pautado pela história social - com forte inspiração nos estudos de Edward Pawmer Thompson, notadamente quanto às concepções sobre a formulação da ideia de "classe" 429 -; enfoque este que, sem dúvida, agrega estimado valor aos estudos e investigações sobre as condições sanitárias e higiênicas da Capital Federal durante o final do século XIX e o início do século XX.

Nesse contexto, Sidney Chalhoub considera que se configura uma oposição entre “civilização" e "tempos coloniais", princípios essenciais para a compreensão de um imaginário em gestação entre os políticos e governantes, nas últimas décadas do século passado. Em primeiro lugar, está presente a ideia de que existe um "caminho da civilização", isto é, um modelo de aperfeiçoamento social e moral. Esse processo configurou os pressupostos da Higiene como um conjunto de princípios que conduziriam o País ao "verdadeiro", à "civilização", e que implicaram na legitimação apriorística das decisões quanto às políticas públicas a serem aplicadas no meio urbano ${ }^{430}$.

Esses enfoques são levados a cabo, sobretudo, no período republicano, especialmente durante a chamada República Velha (1889-1930), pois os grupos políticos e ideológicos que o fundamentaram - ligados à forte orientação positivista e avessos ou não alinhados ao pretenso imobilismo imperial e escravagista - simpatizavam com o progresso material e moral da sociedade brasileira da época. Essa ordem de ideias saturou, portanto, o ambiente intelectual do país nas décadas seguintes, e emprestou suporte ideológico para a ação "saneadora" dos

\footnotetext{
${ }^{426}$ CHALHOUB, Sidney. Cidade Febril: cortiços e epidemias na Corte Imperial. São Paulo: Companhia das Letras, 1996. p. 08.

${ }^{427}$ Idem.

${ }^{428}$ Ibidem, p. 09 e p. 22.

${ }^{429}$ Neste ponto, destacamos que é bem conhecido dos historiadores o conceito de classe expresso por Edward P. Thompson, sobretudo no Prefácio do texto A Formação da Classe Operária Inglesa (1963), que envolve, pois, a ideia do fazer-se (p. 09). De acordo com Thompson, o conceito de classe é um fenômeno histórico que abrange "[...] uma série de acontecimentos díspares e aparentemente desconectados, tanto na matéria-prima da experiência como na consciência" (p. 09). Em outras palavras, podemos destacar que a expressão "classe" envolve as experiências comuns dos trabalhadores e a consciência de classe, que, para o historiador inglês, significa "a forma como as experiências são tratadas em termos culturais" (p. 10). Thompson entende classe não apenas como resultado das relações de produção, mas influenciada por sistemas, ideias e valores culturais; aspectos esses que enriquecem sua construção e consolidação como elemento importante de luta trabalhista, notadamente na Inglaterra. Percebemos, portanto, entre os dois autores aqui abordados - Thompson e Chalhoub -, que a história é pautada pelas experiências sociais, mas também por ideias e valores culturais.

${ }^{430}$ CHALHOUB, Sidney. Cidade Febril: cortiços e epidemias na Corte Imperial... op. cit., p. 35.
} 
engenheiros e médicos, que passaram a encastelar-se e acumular poder na administração pública, especialmente após o golpe militar republicano de $1889^{431}$. Assim, a partir da década de 70 do século XIX, os higienistas passaram a defender, de maneira mais intransigente, a ideia de que era preciso intervir no ambiente urbano com o intuito de controlar doenças e males infecciosos; entretanto, a linguagem por eles utilizada assumiu, todavia, gradativamente, claros significados políticos e discriminatórios raciais. Desse modo, a aliança entre as ações políticas e higienistas foi a principal estratégia adotada pelas elites brasileiras - dirigentes dos principais centros urbanos do país - para coordenar ações no sentido de sanear e prover a higienização de comportamentos sociais e espaços urbanos ${ }^{432}$.

Os motivos para o surgimento de uma crise sanitária nos grandes centros urbanos do país especialmente nas cidades do Rio de Janeiro e São Paulo - não esclarecem as razões pelas quais a saúde pública manifestou-se como uma questão urgente em Florianópolis no mesmo período; pois, no decorrer daqueles anos, a capital catarinense continuou em seu ritmo pacato. Ela não apresentou afluxos populacionais significativos e sua estrutura urbana pouco havia mudado desde o final do século XIX. Além disso, desde 1910, ocorria uma progressiva melhoria dos aspectos sanitário e urbano como decorrência da instalação das redes de água e esgotos e da primeira rede de iluminação elétrica. Em suma, na pequena Florianópolis, poucas características pareciam adequar-se às causas que desencadearam os problemas urbanos e sanitários verificados nas grandes cidades brasileiras, no início do século.

Durante as décadas de 1910 e 1920, a cidade foi, porém, palco de uma série de intervenções na sua área central que, em nome da necessidade de reformas urbanas e sanitárias, prescreveram e introduziram novas regras de convívio urbano. Assim, ruas foram calçadas, ajardinaram-se praças, foi instalada uma rede de energia elétrica, e alguns edifícios públicos foram construídos e reformados. Acompanhando as mudanças que se operavam na paisagem da cidade, passou-se a normatizar e a classificar algumas atitudes cotidianas, como jogar ou lançar materiais fecais, lixo e entulhos nos quintais, praças e ruas do perímetro da cidade e povoações; pendurar roupas e gaiolas nas janelas e fachadas das casas; criar galinhas e outros animais; e manifestar palavras obscenas ou licenciosas que ofendessem a moralidade pública, como práticas não condizentes com a vida de uma Capital $^{433}$.

\footnotetext{
${ }^{431}$ Para uma discussão mais aprofundada, ver CARVALHO, José Murilo de. A formação das almas: o imaginário da República no Brasil. São Paulo: Companhia das Letras, 1990.

${ }^{432}$ Observar, igualmente, a respeito: a) HERSCHMANN, Micael M; PEREIRA, Carlos Alberto M. O imaginário moderno no Brasil. In: (Org.). A invenção do Brasil Moderno: medicina, educação e engenharia nos anos 20 e 30. Rio de Janeiro: Rocco, 1994; b) GONDRA, José G. Medicina, Higiene e Educação Escolar. In: LOPES, Eliane Marta Teixeira; FILHO, Luciano Mendes Faria; VEIGA, Cynthia Greive. (Org). 500 anos de educação no Brasil. 3. ed. Belo Horizonte: Autêntica, 2003. No texto de Sidney Chalhoub, aqui referenciado, ver maiores detalhes sobre essa discussão no capítulo segundo, intitulado "Febre Amarela". In: CHALHOUB, Sidney. Cidade Febril: cortiços e epidemias na Corte Imperial. São Paulo: Companhia das Letras, 1996. p. 60-96.

${ }^{433}$ Câmara Municipal da Cidade do Desterro. Código de Posturas. Lei n. 1238, de 22 out. 1888. Desterro: Tip. da Regeneração, 1889. p. 14 e p. 25; ARAÚJO, Hermetes Reis de. Fronteiras internas: urbanização e saúde pública em Florianópolis nos anos $20 \ldots$... op. cit., p. 107.
} 
Neste ponto, podemos destacar as passagens registradas no código de posturas da cidade do Desterro, datado de 1889, e no Regulamento para o serviço policial do Estado, de 1920. Vimos que seus textos são similares e correlatos, e o teor neles expresso expõe que "todo o cocheiro [ou motorista] de carro [ou automóvel] de praça ou de aluguel é obrigado" a "apresentar-se decentemente vestido"; "a observar polidez para com o passageiro evitando toda e qualquer alteração", e "a guardar silêncio durante o trajeto, abstendo-se de palavras e gestos indecentes"434. Notamos, portanto, que a preocupação em coibir práticas consideradas inapropriadas para o bom decoro dos comportamentos em público abrangia, também, as atitudes daqueles envolvidos com o tráfego diário de carros e automóveis pelas ruas do perímetro urbano da capital catarinense. Em passagens anteriores deste texto, verificamos a preocupação da imprensa e dos órgãos governamentais locais em divulgar a imagem de Florianópolis como uma cidade moderna e civilizada. Práticas e comportamentos considerados incivilizados como os insultos e as batucadas eram, portanto, coibidos e uma grande remodelação urbana foi exigida como forma de conferir à Florianópolis um aspecto moderno - processo este que envolveu, inegavelmente, conflitos, resistências e embates gestados nas esferas política e social da cidade.

Em face às suas dimensões populacional, predial e urbanística, podemos considerar que Florianópolis, apesar de não ser uma cidade moderna como São Paulo ou Rio de Janeiro, era considerada como tal nos discursos da imprensa e do governo. Salientamos, pois, que a capital catarinense não pode ser considerada uma cidade moderna a exemplo dos grandes centros urbanos brasileiros; e, especialmente, se comparada às grandes cidades europeias, sobretudo Paris e Londres, pois as iniciativas governamentais e as transformações urbanas assumiram, aqui, muito menor envergadura. Dado o exposto, como podemos explicar a posição da imprensa e dos órgãos governamentais da época?

Entendemos que a explicação mais apropriada consubstancia-se na ideia de representação que, segundo Le Goff “[...] é a tradução mental de uma realidade exterior percebida e liga-se ao processo de abstração"435. Nesse sentido, o "[...] imaginário faz parte de um campo de representações e, como expressão do pensamento, se manifesta por imagens e discursos que pretendem dar uma definição de realidade"; destacamos, entretanto, que "imagens e discursos sobre o real não são exatamente o real ou, em outras palavras, não são expressões literais da realidade" ${ }^{436}$. Assim, podemos considerar que, “[...] no domínio da representação, as coisas ditas, pensadas e expressas têm um outro sentido além daquele manifesto"; pois, como "representação

\footnotetext{
${ }^{434}$ Observar, respectivamente, artigos 149 e 121 (e parágrafos correspondentes) nos textos: a) Câmara Municipal da Cidade do Desterro. Código de Posturas. Lei n. 1238, de 22 out. 1888. Desterro: Tipografia da Regeneração, 1889; e b) Santa Catarina. Regulamento para o serviço policial do Estado. Florianópolis: Tipografia da Livraria Central, 1920.

${ }^{435}$ LE GOFF, Jacques. L'imaginaire médiéval. Paris: Gallimard, 1985.

${ }^{436}$ PESAVENTO, Sandra Jatahy. Em busca de uma outra história: imaginando o imaginário. Revista Brasileira de História. São Paulo: ANPUH/Contexto, v. 15, n. 29, p. 15, 1995.
} 
do real, o imaginário enuncia, se reporta e evoca outra coisa não explícita e não presente"437. Esse processo envolve, portanto, “[...] a relação que se estabelece entre significantes (imagens, palavras) com os seus significados (representações, significações), processo este que envolve uma dimensão simbólica"; e nessa articulação, "a sociedade constrói a sua ordem simbólica, que, se por um lado não é o que se convenciona chamar de real (mas sim de sua representação), por outro lado é também uma outra forma de existência da realidade histórica"; logo, "o real é, ao mesmo tempo, concretude e representação" ${ }^{\text {438. }}$.

A partir dessas explanações, podemos afirmar que Florianópolis, apesar de não ser uma cidade moderna, como São Paulo ou Rio de Janeiro, era considerada como tal nos discursos da imprensa e do governo. Assim, a representação imaginária da cidade moderna ganhava força de realidade, pois, como vimos, "aqui e ali, ainda se contorcem vilas de aspecto colonial ladeadas de casas quadradas e incompatíveis a uma cidade moderna que se quer salubre e confortável"439. Em vista disso, os discursos proferidos por engenheiros, autoridades governamentais e pela imprensa procuraram perpetuar a ideia de que Florianópolis era uma cidade moderna, pois comportamentos e valores considerados incivilizados e imorais foram coibidos e as reformas urbanas eram salientadas constantemente.

Destacamos que os estudos sobre a modernidade nas cidades do Rio de Janeiro, São Paulo e Florianópolis salientam aspectos similares. Dentre eles, destacam-se o saneamento e a higienização do centro da cidade, pois intervenções governamentais variadas configuraram estratégias sanitárias fundamentadas na eliminação dos focos de doenças e de comportamentos inadequados na área central. Outro elemento que julgamos importante diz respeito às tentativas de se afastar, progressivamente, as populações mais desfavorecidas do centro da cidade. Verificamos que se configura, desse modo, um gradual processo de homogeneização social e paisagística do espaço físico central ${ }^{440}$ - que é operado de maneira lenta e conflituosa, com todas as circunstâncias e especificidades políticas, sociais e sanitárias nele envolvidas.

Neste texto, pretendemos tecer uma análise sobre a atuação dos poderes públicos relativos ao Estado de Santa Catarina e à cidade de Florianópolis quanto à aplicação de leis e de regulamentações viárias e de trânsito, no sentido de oferecer-se certa organização e disciplinarização ao trânsito de veículos motorizados e tracionados por força motriz animal nas

\footnotetext{
${ }^{437}$ PESAVENTO, Sandra Jatahy. Em busca de uma outra história: imaginando o imaginário. Revista Brasileira de História... op. cit., p. 15.

${ }^{438}$ Ibidem, p. 16. Ver, também, da mesma autora, texto recente que trabalha, igualmente, sob essa perspectiva: Cidades visíveis; cidades

sensíveis, cidades imaginárias. In: Revista Brasileira de História. São Paulo, v. 27, n. 53, jan./jun. 2007.

${ }^{439}$ Saneamento de Florianópolis. República. Florianópolis, 08 set. 1919. p. 1.

${ }^{440}$ Ver SENNET, Richard. O declínio do homem público: as tiranias da intimidade. São Paulo: Companhia das Letras, 1998 . p. 361.
} 
estradas estaduais e, principalmente, nas ruas do perímetro urbano da capital catarinense. Assim, objetivamos analisar que, já durante a década de 10 do século passado, verificaram-se preocupações quanto à circulação de veículos, especialmente ao observarmos os conteúdos dispostos nos artigos e parágrafos relativos aos "regulamentos para as estradas estaduais" de Santa Catarina, datados dos anos de 1914 e 1918. Vimos, igualmente, que as medidas relativas à disciplinarização do espaço urbano da cidade de Florianópolis também foram estendidas às ações de calçamento e de nivelamento das ruas da cidade e às determinações quanto ao saneamento e à higienização do espaço central da capital catarinense, sobretudo ao examinarmos o conteúdo do código de posturas datado de 1889 e os textos referentes às mensagens de governo e aos periódicos locais.

Diante desse quadro, a investigação proposta neste capítulo objetivou salientar que as ações governamentais relativas ao Estado e à cidade de Florianópolis, verificadas especialmente durante o final do século XIX e as três primeiras décadas do século seguinte, pretenderam aplicar uma série de medidas para tentar disciplinar o espaço urbano da capital catarinense; e oferecerlhe um aspecto aprazível e organizado para, dentre outros objetivos, equacionar as práticas e os comportamentos populares não condizentes com o status de uma Capital. Assim, as tentativas de disciplinarização também recaíram sobre a circulação e as atividades dos condutores de veículos - motorizados ou operados por tração animal - pelas ruas do perímetro urbano da capital catarinense. Devemos observar que não nos é possível avaliar, com precisão, até que ponto as normas e medidas aplicadas pelos poderes públicos estadual e municipal obtiveram resultados práticos eficientes ou satisfatórios. É importante, todavia, salientarmos que, para os efeitos deste estudo, as regulamentações legais e de trânsito são aplicadas, via de regra, sobre práticas e comportamentos vistos como indevidos ou não apropriados às intenções estipuladas pelos poderes e ações públicas municipais e estaduais.

Essas regulamentações são exigidas, em última análise, ante os comportamentos considerados inapropriados à vivência urbana; e, por outro lado, podemos considerar, acabam por tentar disciplinar a circulação e a convivência simultânea entre pedestres e veículos especialmente àqueles de natureza automotiva. Desse modo, as tentativas de se reordenar o espaço urbano e disciplinar os comportamentos e práticas sociais e a circulação conjunta de pedestres e veículos configuram ou colocam em contato rumos e caminhos variados e imprevisíveis, operados entre as leis e as normas governamentais e as práticas cotidianas da população, o que salienta o descompasso entre normas e regras disciplinares e as vivências, percepções e sensibilidades cotidianas. 
Incrementos a esta discussão podem também ser postos em cena quando observamos que as altas velocidades atingidas pelos automóveis denunciam, pois, que as normas de trânsito colocadas em prática não operavam os efeitos esperados pelos poderes que as instituíram. Neste ínterim, discutiremos, no texto a seguir, o gradativo processo de substituição de antigos hábitos e costumes praticados pelos florianopolitanos nas ruas da cidade, em favor da circulação dos automóveis; que proibidos, com maior ênfase pelo poder público municipal a partir das décadas de 1920 e 1930, sinalizam para o irreversível processo de adensamento do tráfego automobilístico pelas ruas da Capital e estradas de Santa Catarina. Esses aspectos denunciam ou refletem o incremento das legislações estaduais e locais relativas, especialmente, à circulação e ao fluxo automotivo. Tais elementos apontam, pois, para um tempo em que as regras e as legislações de trânsito assumem um tal grau de complexidade que, em parte, influenciam a criação, no ano de 1935, da Secretaria de Segurança Pública ${ }^{441}$, que somente será encarregada da “orientação e físcalização do trânsito nas vias públicas" a partir do ano de $1938^{442}$. Esses apontamentos demonstram o gradativo incremento do tráfego de veículos motorizados pelas ruas da cidade de Florianópolis e, também, de outras cidades do Estado, durante as décadas de 20 e 30 do século passado; assuntos que, dada sua relevância e destaque para o presente estudo, e em face das articulações com o presente texto, serão de nossa alçada no capítulo a seguir.

\footnotetext{
${ }^{441}$ Lei n. 12, de 12 de novembro de 1935. Cria a Secretaria de Segurança Pública. In: Santa Catarina. Coleção de Leis, Decretos, Resoluções e Portarias de 1935. Florianópolis: Livraria Central de Alberto Entres, 1936. p. 13-14.

${ }^{442}$ Decreto-lei n. 24, de 7 jan. 1938. Atribuindo à Secretaria de Segurança a orientação e fiscalização do trânsito nas vias públicas. In: Santa Catarina. Coleção de Decretos-Leis de 1938. Florianópolis: Imprensa Oficial do Estado, 1939. p. 6-10.
} 


\section{Capítulo 3 - Novos Tempos; Outras Legislações: adaptações e reformulação}

\subsection{Os Processos Criminais em Cena 3: legislação e circulação}

\subsubsection{Cuidado! Menores ao volante!!!}

Iniciamos esta discussão observando que as altas velocidades atingidas pelos automóveis atestam que as regulamentações de trânsito que se tentavam aplicar no perímetro urbano da capital catarinense, como forma de disciplinar o exercício e a prática de boleeiros e chauffeurs e a circulação dos transeuntes, não surtiam, muitas vezes, o efeito esperado. Em vista disso, as regras e as leis de trânsito objetivavam oferecer elementos necessários para que a convivência simultânea entre os vários tipos de veículos ${ }^{443}$ e entre estes e os transeuntes se processasse de maneira a oferecer segurança a todos: boleeiros, chauffeurs, passageiros e àqueles que circulavam a pé pelas ruas do espaço urbano da cidade de Florianópolis. Os atropelamentos analisados neste estudo atestam, entretanto, que havia descompassos entre as práticas e as regras disciplinares e a circulação cotidiana de carros, automóveis e transeuntes.

As observações aqui registradas podem ser exemplificadas a partir do processo n. 45, de 13 de abril de 1925, que registra o atropelamento de Orlando Anduzzo, 23 anos, chauffeur, no ponto de autos de Florianópolis. Esse episódio foi ocasionado por Adolfo Nazário Vieira, 38 anos, chauffeur que guiava o automóvel n. 56, de sua propriedade ${ }^{444}$, e que trabalhava no mesmo ponto. Os dois protagonistas desse processo eram colegas de profissão, pois a vítima em questão também trabalhava no local identificado. Assim, o "Auto de perguntas e declarações" prestado pelo acusado, no dia 15 de abril de 1925, registra aspectos curiosos sobre o atropelamento. Ao ser questionado sobre como ocorreu o sinistro, Adolfo Nazário afirma que "no dia 13 do corrente, às oito horas da noite, mais ou menos", o referido "automóvel [era] guiado por seu filho [...] na Avenida Hercílio Luz" ${ }^{445}$. Em outro momento de sua explanação, o acusado declara que,

\footnotetext{
${ }^{443}$ Especialmente automóveis particulares, de praça, de aluguel, ônibus, carros, carroças, tílburys.

${ }^{444}$ Os textos e informações expressos pelo processo em questão não esclarecem a natureza do referido automóvel, ou seja, se ele era de praça ou de aluguel. É, porém, perfeitamente possível argumentar que esse veículo não era de natureza estritamente particular, visto que o acusado, assim como vários colegas seus - os quais são mencionados no processo - trabalhavam no "ponto dos automóveis" como chauffeurs. (Processo n. 45, 13 abr. 1925. Caixa 05). Além disso, devemos observar que junto à denúncia apresentada pelo Promotor Público à pessoa de Adolfo Nazário, no dia 28 de abril de 1925, está registrado que, "No dia 13 do corrente mês deste ano de 1925, pelas oito horas da noite, o acusado guiando o seu automóvel, dirigia-se para o ponto de parada dos carros, à Praça XV de Novembro". Assim, é possível considerarmos que o automóvel referido era de praça ou, mesmo, de aluguel. (Processo n. 45, 13 abr. 1925. Caixa 05). Ver, também, análise ao processo n. 183, de 11 de janeiro de 1932, apresentada no capítulo quinto da tese. Convém observarmos, também, que novamente é atestado o fato de que o chauffeur que conduzia o automóvel, no instante do atropelamento, era o seu proprietário. Esse aspecto corrobora com a análise do processo n. 45 , de 04 de agosto de 1923 , efetuada no primeiro capítulo da tese, na qual Braz de Souza, 19 anos, era chauffeur e proprietário do automóvel n. 88, que ocasionou o atropelamento de Pedro Mansolli. Há, entretanto, entre os dois chauffeurs, considerável diferença de idade, pois Adolfo Nazário tinha 38 anos, o que não reforça a observação de que chauffeurs de pouca idade poderiam ser proprietários de veículos motorizados de aluguel ou de praça. Por outro lado, é válido observarmos que o chauffeur Adolfo Nazário é "casado, com 38 anos de idade, natural deste Estado, chauffeur, residente nesta Capital à Travessa do Triunfo, n. 12, sabendo ler e escrever". (Processo n. 45, 13 abr. 1925. Caixa 05). Do exposto, percebemos que Adolfo Nazário desempenha a profissão de chauffeur, sabe "ler e escrever", e possui residência fixa em Florianópolis. Esses elementos permitem afirmar que o chauffeur em apreço não é pobre, pois, ao que tudo indica, pertence aos estratos sociais médios da sociedade florianopolitana, situação semelhante àquela apresentada pelo chauffeur Braz de Souza, analisada no primeiro capítulo.

${ }^{445}$ Processo n. 45, 13 abr. 1925. Caixa 05.
} 
em certa altura do percurso, seu filho "havia brigado com o chauffeur Antônio Destri"; e, naquele momento, Adolfo Nazário "tomou a direção do auto e dirigiu-se para o ponto, e ali chegando encontrou um grupo de colegas aglomerados no meio da rua interceptando a passagem e, como de costume, fonfonou e fez seguir o auto, tendo pegado o seu colega Orlando Anduzzo"446. Neste ponto, gostaríamos de salientar que o acusado, ao permitir que seu filho, de 16 anos, guiasse o automóvel n. 56, transgrediu normas disciplinares de trânsito, pois o Regulamento para o serviço policial do Estado estipula que somente os indivíduos devidamente habilitados, maiores de dezoito anos, têm permissão para dirigir automóveis ${ }^{447}$.

Outro momento de sua declaração sugere, porém, que Adolfo Nazário obedeceu normas disciplinares de circulação automobilística, pois afirma que, ao encontrar "um grupo de colegas aglomerados no meio da rua interceptando a passagem", fez uso da buzina, anunciando a proximidade de seu automóvel ${ }^{448}$. Salientamos, portanto, que a análise dos processos criminais permite-nos constatar que a circulação automobilística pelas ruas de capital catarinense é um processo complexo, que envolve circunstâncias diversas, uma vez que chauffeurs e transeuntes estavam, a todo o momento, transgredindo ou obedecendo - mesmo que, muitas vezes, de maneira imperceptível - leis ou normas de trânsito.

Em outras palavras, pretendemos observar que o Regulamento para o serviço policial do Estado, legislação de trânsito de maior expressividade em vigor no período, estipula, como vimos, que somente os indivíduos devidamente habilitados, maiores de dezoito anos, têm permissão para dirigir automóveis. Em vista disso, desobediências e transgressões às regras de trânsito eram elementos presentes nas práticas e atitudes cotidianas expressas por chauffeurs e transeuntes, as quais configuram facetas componentes do comportamento dos florianopolitanos diante da gradativa presença e da circulação dos veículos motorizados pelas ruas do perímetro urbano da capital catarinense. Desse modo, podemos considerar que a implementação e/ou aplicação de regras e dispositivos disciplinares de trânsito, na cidade de Florianópolis é operada conforme as diversas práticas e usos da cidade efetuados por seus habitantes; o que atesta, portanto, seu limitado alcance prático. Assim, consideramos que a vivência cotidiana, nos espaços urbanos, não pode ser mensurada pela referência às normas objetivas de regulamentação urbanística, pois a experiência de viver em cidades se constitui como algo que ultrapassa, ou simplesmente não é contida nos saberes analíticos que a tematizam como objeto ${ }^{449}$, como bem

\footnotetext{
${ }^{446}$ Processo n. 45, 13 abr. 1925. Caixa 05. Corroborando com essas explanações, Adolfo Nazário afirma que "quase sempre que chega um automóvel no ponto, os chauffeurs que ali se acham costumam tomar a frente do auto e só saem quando [são] quase alcançados, razão porque foi surpreendido com o incidente de que foi vítima Orlando Anduzzo". (Processo n. 45, 13 abr. 1925. Caixa 05).

${ }^{447}$ Santa Catarina. Regulamento para o serviço policial do Estado. Florianópolis: Tipografia da Livraria Central, 1920.

${ }^{448}$ Conforme estabelece o parágrafo décimo do artigo 121, do Regulamento para o serviço policial do Estado. Ver Santa Catarina. Regulamento para o serviço policial do Estado... op. cit.

${ }_{449}$ BRESCIANI, Maria Stella Martins. Cidade e História. In: OLIVEIRA, Lúcia L. (Org.). Cidade: história e desafios. Rio de Janeiro: FGV, 2002. p. 30.
} 
ficou atestada no presente processo, por ocasião de ser concedida a direção do automóvel n. 56 a um indivíduo menor de idade, filho do chauffeur Adolfo Nazário Vieira. Devemos observar, neste ponto, que as vivências cotidianas operadas nos meios urbanos envolvem táticas e procedimentos práticos direcionados, muitas vezes, para a produção de comportamentos que obedecem a circunstâncias diversas e imprevisíveis, caracterizando usos diferenciados da cidade.

Em outras palavras, podemos considerar que "[...] a tática é 'movimento dentro do campo de visão do inimigo' [...] e no espaço por ele controlado. Ela opera golpe por golpe, lance por lance. O que ela ganha não se conserva. Este não lugar lhe permite, sem dúvida, mobilidade”, pois "tem que utilizar, vigilante, as falhas que as conjunturas particulares vão abrindo na vigilância do poder proprietário"450. Vimos, no capítulo primeiro, que Michel de Certeau trabalha com a noção de homem ordinário ${ }^{451}$, que corresponde ao personagem que opera desvios e comportamentos não adequados às determinações legais em voga. O homem ordinário inventa, portanto, o cotidiano, reapropriando os códigos e determinações legais conforme os usos e práticas por ele operadas no espaço em que vive e transita.

Nesse sentido, podemos perceber que os aparatos legais de trânsito que se tentavam aplicar à cidade de Florianópolis durante as décadas de 1920 e 1930 configuravam ações e estratégias de poder, que objetivavam disciplinar a circulação e os comportamentos de chauffeurs, passageiros e transeuntes. Essas estratégias não impedem, entretanto, que práticas e comportamentos desviantes fossem operados pelos florianopolitanos. Devemos observar, portanto, conforme nos diz Michel Foucault, que "[...] somente pode haver relações de poder na medida em que os sujeitos são livres. Se um dos dois estivesse completamente à disposição do outro e se tornasse uma coisa, um objeto sobre o qual ele pudesse exercer uma violência infinita e ilimitada, não haveria relações de poder" ${ }^{\prime 452}$. Assim, as regulamentações legais e de trânsito que se tentavam aplicar na cidade de Florianópolis eram incapazes de controlar e disciplinar, de maneira integral e absoluta, os comportamentos dos florianopolitanos, pois, dentre outros aspectos, devemos considerar que entre as normas disciplinares de trânsito, seus órgãos e agentes fiscalizadores e a circulação simultânea operada por transeuntes, passageiros e chauffeurs pelas ruas do perímetro urbano da capital catarinense, esboçam-se, diariamente, relações de poder. Michel de Certeau vem, ao certo, enriquecer essas análises, ao assinalar que “[...] as astúcias e surpresas táticas”, operadas no interior das práticas sociais, correspondem aos 'gestos hábeis do 'fraco' na ordem estabelecida pelo forte" ${ }^{, 453}$.

\footnotetext{
${ }_{450}^{450}$ CERTEAU, Michel de. A invenção do cotidiano 1: artes de fazer. 8. ed. Petrópolis: Vozes, 2002. p. $100-101$.

${ }^{451}$ Ibidem, p. 57.

${ }^{452}$ FOUCAULT, Michel. Sexo, Poder e Indivíduo. Florianópolis: Nefelibata, 2003. p. 71; . Ditos e Escritos: ética, sexualidade, política. 1. ed. Rio de Janeiro: Forense Universitária, 2004, v. 5. p. 276-277. Foucault atribui estado de dominação às relações "dissimétricas", em que se opera uma margem limitada de liberdade. Para maiores esclarecimentos, ver FOUCAULT, Michel. Sexo, Poder e Indivíduo... op. cit., p. 72.

${ }^{453}$ CERTEAU, Michel de. A invenção do cotidiano 1: artes de fazer... op. cit., p. 104.
} 
Enriquecemos essas observações ao destacarmos que as ideias defendidas por Michel Foucault e Michel de Certeau, expressas nas passagens anteriores não condizem com a noção de douta ignorância, trabalhada por Pierre Bourdieu, segundo a qual “[...] como os indivíduos não sabem, propriamente falando, o que fazem, o que fazem tem mais sentido do que sabem [...] Douta ignorância, portanto, habilidade que se desconhece" 454 . Refutamos a ideia supracitada no sentido de que, de acordo com as concepções analisadas neste texto, os florianopolitanos adotaram, muitas vezes de maneira consciente, táticas para operar vivências cotidianas e driblar as investidas dos veículos motorizados. Neste ponto, destacamos que Michel de Certeau sinaliza diferenças entre os enfoques propostos por Bourdieu e Foucault, pois observa que

O interesse de Bourdieu está na gênese, no 'modo de geração das práticas'. Não interessa, como Foucault, pelo que produzem, mas por aquilo que as produz. Dos 'estudos etnológicos' que as examinariam para a sociologia que teoriza sobre elas há, portanto, um deslocamento que remove o discurso para o habitus, cujos sinônimos (exis, ethos, modus operandi, 'senso comum', 'natureza segunda', etc.), definições e justificações se multiplicam. [Assim, um] ator passivo e noturno toma o lugar da multiplicidade astuciosa das estratégias ${ }^{455}$.

De outro modo, devemos observar que de acordo com as ideias expressas neste estudo, simpatizamos com a noção de que as relações de poder que se estabelecem entre pedestres ${ }^{456}$, chauffeurs e normas disciplinares de trânsito, discutidas no âmbito da esfera cotidiana da cidade de Florianópolis, podem, portanto, ser captadas em suas extremidades, em suas últimas ramificações; lá onde elas se tornam capilares, onde são encontradas "nas suas formas e instituições mais regionais e locais" ${ }^{457}$.

Voltaremos, em passagens posteriores, à discussão sobre as ideias de Michel Foucault e Michel de Certeau quanto à natureza e à aplicação das estratégias de poder e das táticas resultantes das práticas e vivências cotidianas. Por hora, destacamos que, no processo em discussão, a vítima Orlando Anduzzo afirma, em suas colocações, datadas de 18 de abril de 1925, que "no dia 13 do corrente" estava "no ponto de autos, conversando com os seus colegas" quando "foram surpreendidos com o auto n. 56 guiado pelo chauffeur Adolfo Nazário Vieira que descia com toda a velocidade" em direção "aos mesmos e, ali chegando, atropelou o declarante, que de forma alguma pôde desviar-se, tendo-o atirado ao solo, produzindo-lhes ferimentos no nariz, cabeça e pernas direita e esquerda” ${ }^{, 458}$. (Anexo 08, p. 339). Assim, essas declarações, ao

\footnotetext{
${ }^{454}$ BOURDIEU, Pierre. Esboço de uma teoria da prática. In: ORTIZ, Renato (Org.). Pierre Bourdieu: sociologia. 2. ed. São Paulo: Ática, 1994. p. 73. (Col. Grandes Cientistas Sociais, n. 39).

${ }^{455}$ CERTEAU, Michel de. A invenção do cotidiano 1: artes de fazer. 8. ed. Petrópolis: Vozes, 2002. p. 126.

${ }^{456}$ Em vista ao emprego dos termos "transeunte" e "pedestre", verificados em muitas passagens da tese, esclarecemos que a expressão transeunte se refere, especialmente, àquele que "passa; que é transitório; que vai andando ou passando; caminhante". Significado semelhante assume o termo pedestre, que se refere àquele que "anda ou está a pé; aquele ou aquela que anda a pé". Assim, entendemos que os dois termos podem ser empregados de maneira paralela, pois que se reportam "àquele que anda" ou que "se desloca a pé"; em oposição, portanto, àquele que se desloca em veículos nãomotorizados (boleeiros; cocheiros) ou automotores (chauffeurs; motoristas). Sobre as especificações e definições atribuídas aos termos referidos, ver, Grande Dicionário Enciclopédico Brasileiro Ilustrado. Novo Brasil: São Paulo, 1979. v. VI e V. (“Ortografia de acordo com as Instruções para a Organização do Vocabulário Ortográfico da Língua Nacional, aprovadas pela Academia Brasileira de Letras”).

${ }^{457}$ FOUCAULT, Michel. Microfísica do Poder. 17 ed. Rio de Janeiro: Graal, 2002. p. 182.

${ }^{458}$ Processo n. 45, 13 abr. 1925. Caixa 05.
} 
que parece, sugerem que o chauffeur em apreço dirigia em alta velocidade; informação reforçada pelas observações das testemunhas arroladas no processo.

Nesse sentido, a testemunha João Lopes, por exemplo, afirma no dia 20 de abril de 1925 que, na data do sinistro, estava "com diversos colegas no ponto de automóveis quando chegou o auto n. 56, guiado por Adolfo Nazário com marcha um pouco forçada", obrigando "a ele depoente e a outros colegas que se achavam no meio da rua a desviarem-se com precipitação para não serem apanhados", porém Orlando Anduzzo "não conseguiu desviar-se de todo" sendo "apanhado pelo pára-lama da frente do referido automóvel" e "atirado em baixo de outro carro que se achava parado, recebendo diversos ferimentos" $" 459$.

É válido salientarmos que a testemunha Clemente Rovere, 20 anos, chauffeur que trabalhava no "ponto dos automóveis" da Capital, observa que, "no dia 13 do corrente, às sete horas da noite, achava-se no ponto com outros colegas em palestra no meio da rua, quando chegou o auto n. 56, guiado por Adolfo Nazário, com grande velocidade” e, naquele momento, aqueles que estavam no local "desviaram-se [do auto]"460. Clemente Rovere afirma, entretanto, que Orlando Anduzzo foi atingido pelo automóvel em questão, pois, estando de costas para o veículo, não houve tempo suficiente para que ele pudesse se proteger e, ao ser "apanhado pela ponta do guarda-lama, foi atirado a cinco metros de distância"461.

Essas informações são confirmadas pela mesma testemunha em outra declaração, prestada no dia 27 de maio de 1925; pois, naquela ocasião, ela afirmou que, "em dias de abril cuja data não pode precisar, achando-se ele depoente no ponto dos autos com diversos companheiros, chegou de repente o réu guiando o auto 56 , que vinha com velocidade máxima" ${ }^{\text {"462 }}$. Continuando suas explanações, Clemente Rovere atestou que o automóvel em questão "enveredou para o lugar onde eles se achavam e cada um procurou se livrar ligeiramente, sendo, então, atingido pelo guarda-lama do dito automóvel, um de seus companheiros que se achava de costas e que foi jogado para baixo de um outro auto, o que lhe causou diversos ferimentos" ${ }^{463}$.

As declarações prestadas pelas testemunhas não nos permitem afirmar, com segurança, que o chauffeur Adolfo Nazário guiava o automóvel n. 56 em alta velocidade. Destacamos que esses depoimentos constituem, entretanto, indícios que permitem-nos inferir sobre a considerável velocidade atingida pelo veículo em questão, na ocasião do atropelamento de Orlando Anduzzo.

\footnotetext{
${ }^{459}$ Processo n. 45, 13 abr. 1925. Caixa 05.

${ }^{460}$ Processo n. 45, 13 abr. 1925. Caixa 05. A testemunha Archimino Gonçalves, 21 anos, que trabalhava no ponto, afirma, no dia 22 de abril de 1925, que no momento da aproximação do automóvel guiado por A. Nazário, ela estava "no meio da rua no ponto de automóveis em companhia de mais de dez chauffeurs". (Processo n. 45, 13 abr. 1925. Caixa 05). O atropelamento em questão ocorreu no ano de 1925, portanto um ano antes da inauguração da ponte Hercílio Luz. A existência de regulamentos de trânsito e de "ponto de automóveis" na cidade de Florianópolis onde trabalhavam, ao menos, "mais de dez chauffeurs" - em época anterior à inauguração da primeira ligação terrestre entre Ilha e Continente, sugere que o processo de inserção dos automóveis na capital catarinense já possuía, nesse período, considerável incremento e organização.

${ }^{461}$ Processo n. 45, 13 abr. 1925. Caixa 05.

${ }^{462}$ Idem.

${ }^{463}$ Idem.
} 
Notemos, por exemplo, que as passagens aqui registradas apontam elementos que se tornaram cada vez mais frequentes pelas ruas da cidade de Florianópolis: a) as altas velocidades imprimidas pelos chauffeurs ao guiarem seus automóveis ${ }^{464}$; b) as táticas e estratégias operadas pelos transeuntes para se esquivarem ou se protegerem das investidas dos veículos motorizados, pois as testemunhas e outros colegas que "se achavam no meio da rua", desviaram-se do veículo, e "cada um procurou se livrar ligeiramente" para "não ser apanhado"; e c) a desigual relação de poder que se estabelece, muitas vezes, entre a circulação de automóveis e transeuntes, pois Orlando Anduzzo "não conseguiu desviar-se de todo", por isso foi "apanhado pelo pára-lama da frente do referido automóvel" e "atirado em baixo de outro carro que se achava parado", "o que lhe causou diversos ferimentos". Por outro lado, a análise dessas ideias evidencia que as testemunhas dos sinistros não estão inteiramente sob a influência dos automóveis; pois, como indivíduos conscientes de seus atos, imprimem atitudes e práticas, disponibilizadas por suas capacidades físicas, direcionadas ao ato de esquivar-se ou de fugir à circulação automobilística.

As relações de poder que se estabelecem entre chauffeurs e transeuntes no meio urbano de Florianópolis, durante as décadas de 1920 e 1930, exemplificam, de modo especial, que elas são estabelecidas nas relações institucionais e humanas e que se dissemina pelas diversas esferas microssociais. Assim, podemos observar que não “[...] existe algo unitário e global chamado poder, mas unicamente formas díspares, heterogêneas, em constante transformação" ${ }^{\text {,65 }}$. E essas relações deixam margem às improvisações e às práticas cotidianas expressas, especialmente, pelos transeuntes, uma vez que delas se utilizam para operarem suas próprias vivências no meio urbano de Florianópolis. A cidade é, em síntese, "poetizada" pelo sujeito, pois ele a refabricou para o seu uso próprio, desmontando as correntes do aparelho urbano; e, desse modo, ele impõe à ordem externa da cidade a sua lei de uso e de apropriação do espaço urbano ${ }^{466}$.

O automóvel contribuiu para dinamizar a vida em sociedade. Novos ritmos, condutas e comportamentos foram, por conseguinte, adotados nas ruas dos centros urbanos. O pedestre é, pois, obrigado a conviver com o automóvel e obedecer a seu ritmo de deslocamento. A agitação provocada pela velocidade atingida pelos veículos motorizados condiciona os transeuntes a comportarem-se, de maneira geral, como seres acuados e temerosos. Nesse sentido, os pedestres

\footnotetext{
${ }^{464}$ Neste ponto, é válido salientarmos o que observa a testemunha João Claudino da Rosa, pois, em depoimento prestado no dia 27 de maio de 1925, ela afirma que, no dia do atropelamento, achava-se "na Praça XV de Novembro, no ponto dos automóveis, conversando com outros colegas, quando veio o automóvel dirigido pelo réu presente, que vinha com mais velocidade que a facultada pela Polícia". (Processo n. 45, 13 abr. 1925. Caixa 05). Além disso, no dia 17 de setembro de 1925, o vogal do presente processo, de nome Frederico Silva, indagou o acusado sobre "a velocidade do auto em questão" no instante do atropelamento, e ele respondeu que "a velocidade era de cinqüenta quilômetros" por hora. (Processo n. 45, 13 abr. 1925. Caixa 05). Salientamos que esta velocidade estava bem acima daquela permitida para o tráfego motorizado na área central da cidade de Florianópolis no ano de 1925, pois, naquela época não era permitido aos automóveis imprimirem, no perímetro urbano da capital catarinense, velocidade superior a vinte quilômetros por hora, conforme estabelece o já referido artigo 36 das Instruções Regulamentares para o serviço de trânsito público, de 1928. Ver Santa Catarina. Instruções Regulamentares para o serviço de trânsito público. Florianópolis: Imprensa Oficial, 1928. p. 10. Tal determinação dá-se, portanto, apenas três anos após a ocorrência do sinistro em questão.

${ }_{465}$ MACHADO, Roberto. Introdução: Por uma genealogia do poder. In: FOUCAULT, Michel. Microfísica do Poder. 17 ed. Rio de Janeiro: Graal, 2002. p. X.

${ }^{466}$ CERTEAU, Michel de; GIARD, Luce; MAYOL, Pierre. A invenção do cotidiano 2: morar, cozinhar. 5. ed. Petrópolis: Vozes, 2003. p. 45.
} 
não podem utilizar-se das vias e dos logradouros públicos para parar e conversar; pois, dentre outros elementos, as ruas e as avenidas das cidades foram, no decorrer dos séculos XIX e XX, planejadas e reorganizadas para, como vimos, atender à circulação do crescente número de veículos. Dessa forma, podemos afirmar que as vias públicas tornaram-se, gradativamente, inapropriadas para o trânsito de pedestres, reduzido às calçadas e aos passeios públicos.

Considerando o caso específico da cidade de Florianópolis, temos que as ruas, anteriormente destinadas ao tráfego de pedestres e bondes operados a tração animal, passaram a atender, com maior nitidez a partir das décadas de 1920 e 1930, ao tráfego motorizado de automóveis particulares, de aluguel e de ônibus. A permanência dos pedestres, ao menos nas ruas do espaço central da cidade, tornou-se, senão impossível, muito difícil, especialmente a partir das décadas de 1940 e $1950^{467}$; e atravessá-las exigiu maior atenção e cuidado dos transeuntes, pois, via de regra, não podiam efetuar essa ação despreocupadamente. Essa dinâmica foi, ao certo, verificada - e com maior intensidade - nos espaços centrais dos grandes centros urbanos do país e da Europa Ocidental, onde o comportamento do transeunte tornou-se, progressivamente, uma espécie de segunda natureza, uma vez que estava, muitas vezes, condicionado e inferiorizado nas suas negociações com um trânsito automotivo cada vez mais complicado, intenso e acelerado ${ }^{468}$.

A obediência às regras e sinalizações de trânsito, implantadas na cidade de Florianópolis, envolve circunstâncias múltiplas, inerentes ao próprio uso do espaço urbano efetuado por seus habitantes; circunstâncias estas que operam, muitas vezes, discordâncias frente aos objetivos almejados pelas autoridades municipais e estaduais. Para os efeitos deste estudo, essas autoridades consubstanciam-se nos interventores da urbe, pois são os agentes detentores do saber e do poder de intervir, transformar e edificar a cidade segundo diretrizes e normas legais e jurídicas. Além desses interventores, cabe-nos resgatar os chamados consumidores do urbano personagens que Michel de Certeau identificou pela expressão O homem ordinário - que perfiguram aqueles que vivem, trabalham ou transitam pelo centro da capital catarinense. Homens comuns, cidadãos da urbe, eles não têm, contudo, o saber e o poder de intervir diretamente dentro da ordem legal ${ }^{469}$. Desse modo, a implementação de regras e de dispositivos disciplinares de trânsito opera, portanto, conflitos, fracassos e realizações, decorrentes das múltiplas peculiaridades e circunstâncias que compõem o viver cotidiano no espaço urbano. Nesse sentido, desobediências e transgressões às regras de trânsito eram elementos presentes nas práticas cotidianas expressas, especialmente, por chauffeurs e transeuntes, as quais configuram, ao certo, facetas componentes do comportamento dos florianopolitanos diante da gradativa

\footnotetext{
${ }^{467}$ Ver, deste capítulo, seção Legislação e Circulação: incrementação e complexidade, e, também, análise apresentada no quinto capítulo da tese. ${ }^{468}$ SENNETT, Richard. Carne e Pedra: o corpo e a cidade na civilização ocidental. 2.ed. Rio de Janeiro: Record, 2001. p. 15-24.

${ }^{469}$ PESAVENTO, Sandra Jatahy. História, memória e centralidade urbana. Novos Mundos - Mundos Novos. História Cultural no Brasil, n. 7 , 2007. Faz-se necessário essa referência, cujas ideias, entendemos, são apropriadas para serem acondicionadas nesta parte do texto.
} 
presença e da circulação dos veículos motorizados pelas ruas do perímetro urbano da capital catarinense.

Essa discussão pode ser aprofundada ao observarmos outros contextos urbanos, pois as iniciativas disciplinadoras e normatizadoras, muitas vezes, impuseram-se sobre as condicionantes da vida cotidiana, particularmente nos casos em que as necessidades de reequipamento urbano assumiram importância capital - caso das reformas urbanas viabilizadas no governo de Pereira Passos no Rio de Janeiro (1902-1904), e dos melhoramentos viários e paisagísticos aplicados em São Paulo, durante as primeiras décadas do século XX. Nesses casos, os interesses financeiros e fundiários definiram, de modo especial, os limites das iniciativas de remodelação dos espaços urbanos, pois as qualidades estéticas e funcionais da urbe eram obtidas apenas parcialmente, nos espaços de maior densidade predial ou relevância urbanística ${ }^{470}$.

Tomemos, como exemplo, a cidade do Rio de Janeiro, centro cultural, econômico e político-administrativo do país, na época. A capital federal, antes das reformas urbanas empreendidas pela ação governamental do prefeito Pereira Passos, em articulação com o governo federal, era uma cidade colonial e atrasada, com ruas e vielas estreitas e com sistema de saneamento deficiente. A rigor, os problemas se concentravam na chamada Cidade Velha, com suas ruas escuras, sujas e tortuosas, com lombas e buracos. Em vista disso, a ação governamental concentrou esforços para pavimentar ruas, construir calçadas, demolir antigas construções, como o decrépito mercado municipal, embelezar locais públicos: praças Quinze de Novembro, Onze de Junho, Tiradentes, Glória, o Largo do Machado, o Passeio Público ${ }^{471}$. A alteração do traçado urbano e a renovação arquitetônica tinham, pois, uma função e um sentido. A funcionalidade das reformas era dada pelos princípios da circulação, da higiene e da estética. Simbolicamente, a intenção era tornar o Rio uma metrópole moderna e aprazível à convivência dos estratos sociais mais abastados da capital da República ${ }^{472}$. É importante observarmos, contudo, que, durante as décadas de 10 e 20 do século passado, vivia-se um momento otimista. A crise de superprodução do café da virada do século fora superada; e, após os anos de austeridade do governo Campos Sales (1898-1902), as gestões presidenciais de Rodrigues Alves (1902-1906) e de Afonso Pena (1906-1909) relançaram o programa progressista baseado na economia agroexportadora. A imagem do Brasil agrário combinava-se ao sonho de um país cosmopolita - em suas capitais abertas à recepção das benesses da civilização européia ${ }^{473}$. Assim, a capital federal, ao adquirir

\footnotetext{
${ }^{470}$ CAMPOS, Cândido Malta. Os Rumos da Cidade: Urbanismo e Modernização em São Paulo. São Paulo: Senac, 2002. p. 23.

${ }^{471}$ MORAES, José Geraldo Vinci de. Cidade e cultura urbana na Primeira República. São Paulo: Atual, 1994. p. 55-63.

472 Podemos considerar que, na cidade do Rio de Janeiro, o exemplo máximo que incorpora os processos de higienização e ordenação de seu espaço central é a construção da Avenida Central, inaugurada oficialmente em 1904 e entregue ao tráfego no ano seguinte, que obedeceu aos princípios de circulação e salubridade urbanos, almejados pelos grupos políticos dirigentes da capital da República. Esse paradigma, como vimos, também estava presente na maioria das propostas para os melhoramentos urbanos da cidade de São Paulo.

${ }^{473}$ CAMPOS, Cândido Malta. Os Rumos da Cidade: Urbanismo e Modernização em São Paulo... op. cit., p. 103.
} 
os adereços da modernidade, vendia, ao mesmo tempo, sua imagem em busca dessa aprovação. Nesse intercâmbio, as cidades que dominavam o fluxo comercial tornavam-se portos importadores de costumes, ideias, opiniões e elogios, vitrines de civilização em meio à natureza farta, porém bruta dos trópicos ${ }^{474}$.

Reforçando essas ideias, Nicolau Sevcenko analisa o papel de destaque cultural e políticoeconômico assumido pela cidade do Rio de Janeiro ao considerar que, no Brasil, o papel de motrópole-modelo recai, sem dúvida, sobre a capital fluminense, sede do governo, centro cultural, maior porto, maior cidade e cartão de visitas do país, atraindo tanto estrangeiros quanto nacionais. Além disso, o desenvolvimento de novos meios de comunicação: telegrafia sem fio, telefone, os meios de transporte movidos a derivados de petróleo, a aviação, a imprensa ilustrada intensificarão esse papel da capital da República, e a transformam no eixo de irradiação e caixa de ressonância das grandes transformações em marcha pelo mundo, assim como no palco de sua visibilidade em território brasileiro. O Rio dita não apenas as novas modas e comportamentos, mas também, acima de tudo, os sistemas de valores, o modo de vida, as sensibilidades, o estado de espírito e as disposições funcionais que articulam a modernidade como uma experiência existencial e íntima ${ }^{475}$.

Assim, na virada do século XIX para o século XX, o conjunto das alterações urbanísticas verificadas, sobretudo, na cidade do Rio de Janeiro, não se resumiu ao seu traçado urbano, mas tencionou penetrar fundo nas sociabilidades e valores do povo. Desse modo, a uma deliberada atitude de expulsão dos pobres do centro da cidade, seguiram-se proibições de hábitos e de costumes populares: cães, mendigos, pessoas descalças ou sem paletó são impedidas de circular livremente pela cidade, como até então faziam. Buscou-se, pois, eliminar da vista a pobreza, que, no entendimento das elites, era suja e perigosa. Esse processo ocasionou, naturalmente, resistências diante de grande parte da população carioca, pois objetivou, antes de tudo, atender aos interesses imobiliários e financeiros; e, paralelamente, coibir antigos hábitos e costumes populares. Desse modo, a existência de casas e cortiços insalubres, habitados pelos estratos sociais mais desfavorecidos, e as crianças abandonadas, vagabundeando pelas ruas, descalças e maltrapilhas, revelam, também, a existência da recusa à aceitação da disciplina desodorizante imposta aos comportamentos sociais.

Vimos, no capítulo anterior, que as tentativas de se aplicar, nas cidades brasileiras, os princípios urbanísticos adotados nos grandes centros urbanos europeus - principalmente aqueles de orientação haussmanniana verificados para a cidade de Paris - são enfatizadas, sobretudo, nos

\footnotetext{
${ }^{474}$ CAMPOS, Cândido Malta. Os Rumos da Cidade: Urbanismo e Modernização em São Paulo... op. cit., p. 105.

${ }^{475}$ SEVCENKO, Nicolau. A capital irradiante: técnica, ritmos e ritos do rio. In: _. . (Org.). História da vida privada no Brasil - República: da Belle Èpoque à Era do Rádio. 5. ed. São Paulo: Companhia das Letras, 2002. p. 522.
} 
estudos de autoria de Sandra Jatahy Pesavento. Assim, no texto O Imaginário da Cidade: visões literárias do urbano - Paris, Rio de Janeiro, Porto Alegre (Porto Alegre: UFRGS, 1999), Pesavento discute a maneira como o meio urbano das cidades de Paris, Rio de Janeiro e Porto Alegre é representado como moderno pela imprensa, órgãos governamentais e obras literárias locais e sinaliza que as alterações urbanísticas verificadas na cidade de Paris, durante a gestão do prefeito municipal George Eugène Haussmannn, foram adotados para os grandes centros urbanos brasileiros, especialmente na capital da República. Já discutimos, entretanto, os limites dessas adaptações $^{476}$ e verificamos que a elaboração e a concretização de projetos urbanísticos, para as grandes cidades brasileiras da época, ensejaram disputas teóricas e políticas em torno de pontos de vista divergentes sobre, por exemplo, a manutenção ou não de características topográficas singulares dos cenários urbanos em questão, diante das alterações urbanísticas almejadas por parcelas específicas das elites locais. Assim, nem mesmo entre os próprios órgãos e dirigentes municipais havia consenso sobre o teor e o alcance das obras de remodelação urbanística que se deveriam empreender no respectivo espaço urbano.

De outro modo, vimos, também, que os processos de higienização e de disciplinarização urbana eram efetuados de maneira parcial e excludente, pois eram constantemente violados, desobedecidos ou adaptados às necessidades, aos comportamentos e à circulação dos habitantes das grandes cidades brasileiras. É válido observarmos que, na capital catarinense, ocorria processo semelhante; uma vez que, durante o final do século XIX e início do século seguinte, operou-se um significativo processo de remodelação do aspecto urbano da cidade de Florianópolis. Assim, o poder público municipal concentrou esforços para calçar ruas, ajardinar praças e passeios públicos, instalar redes de água e esgoto. Paralelamente, uma vasta propaganda nos periódicos locais - especialmente aqueles alinhados ou simpatizantes às elites de cunho republicano que, à época, dirigiram a política florianopolitana - assumiu claro sentido normatizador das práticas e dos costumes populares não condizentes com o viver urbano de uma Capital $^{477}$. Desse modo, quase que cotidianamente havia a publicação de artigos chamando a atenção para o depreciado aspecto urbano da cidade de Florianópolis, e para os maus hábitos praticados por seus habitantes. Nesse sentido, em artigo do jornal República, de 1921, encontramos uma explanação que demonstra a preocupação em coibir comportamentos considerados incivilizados:

O Trapiche Municipal onde há um grande número de famílias que tomam as lanchas para o continente, tem se tornado o ponto preferido pelos indivíduos de má educação. Sem a maior consideração, [...] os vagabundos, na sua maioria, rapazes vendedores de balas, amendoim e tutti

\footnotetext{
${ }^{476}$ Ver, especialmente, análise na seguinte publicação: CAMPOS, Cândido Malta. Os Rumos da Cidade: Urbanismo e Modernização em São Paulo. São Paulo: Senac, 2002

${ }^{477}$ ARAÚJO, Hermetes Reis de. Fronteiras Internas: Urbanização e Saúde Pública em Florianópolis nos anos 20. In: BRANCHER, Ana (Org.). História de Santa Catarina: estudos contemporâneos. Florianópolis: Letras Contemporâneas, 1999. p. 107.
} 
quanti [...] proferem as maiores obscenidades. Justamente quanto maior é a aglomeração de famílias, é que se exercitam na detestável prática do insulto e da capoeiragem. À polícia recomendamos os vagabundos que diariamente freqüentam o Trapiche Municipal ${ }^{478}$.

As ideias apontadas atestam, claramente, a preocupação da imprensa em divulgar a imagem da cidade moderna e civilizada. Assim, comportamentos considerados incivilizados, como o insulto e a capoeiragem, são coibidos; e preza-se, portanto, a tentativa de conferir à cidade de Florianópolis um aspecto moderno e aprazível. Por outro lado, podemos considerar que as tentativas de se disciplinar a circulação de pedestres e de veículos motorizados pelas ruas do perímetro urbano da capital catarinense esbarravam em resistências e transgressões operadas por chauffeurs, passageiros e transeuntes. Esse processo é, todavia, extremamente complexo e diversificado; pois, ao circularem cotidianamente pelas ruas da cidade de Florianópolis, condutores, passageiros e pedestres observavam e transgrediam, mutuamente, normas e regulamentações disciplinares de trânsito. Desse modo, configuravam facetas específicas do cotidiano da capital catarinense, conforme verificamos na análise do processo n. 45 , de 13 de abril de 1925, aqui discutido.

Nosso próximo cenário leva-nos à portaria do processo n. 76, que registra que, na madrugada do dia 21 de março de 1926, “o automóvel n. 80, que tem como chauffeur Euclydes Furtado, foi fretado por uns quatro moços para passearem nas ruas desta cidade, sendo a direção do referido veículo entregue a Arthur Poli" ${ }^{479}$. Assim, "na ocasião em que passavam pelo Cais ${ }^{480}$ nos fundos do Mercado Público, o automóvel foi lançado desastrosamente dentro do mar, resultando saírem feridos Arthur Poli, que ia na direção, Euclydes Furtado, chauffeur do referido auto, que ia ao lado [do condutor], e os passageiros Altamiro Luz, Domingos Antônio de Souza e Nilo Mussi, que nada sofreu"481.

Corroborando com essas informações, o "Termo de declarações" prestado por Arthur Poli, datado de 22 de março de 1926, salienta aspectos importantes sobre o ocorrido, pois registra que, "no dia 21 do corrente, pelas quatro e meia horas [da manhã $]^{482}$, achava-se passeando em companhia de seus amigos Altamrio Luz, Nilo Mussi e Domingos Antônio de Souza no automóvel n. 80, que tinha como chauffeur Euclydes Furtado" ${ }^{\text {"43 }}$. Continuando suas explanações,

\footnotetext{
${ }^{478}$ A Vadiagem no Trapiche Municipal. República. Florianópolis, 12 mar. 1921. p. 2.

${ }^{479}$ Processo n. 76, 21 mar. 1926. Caixa 07.

${ }^{480}$ Cais Liberdade, conforme registrado no processo em questão.

${ }^{481}$ Processo n. 76, 21 mar. 1926. Caixa 07. A testemunha Arthur Alves Ouriques registra, no dia 23 de março de 1926 , que o automóvel n. 80 não é de propriedade de Euclydes Furtado, pois afirma que, "no dia 21 do corrente, pelas cinco horas, estando na porta do Mercado Público, viu passar em direção ao Cais o automóvel n. 80, de propriedade do senhor Theodoro Brüggman, e guiado pelo chauffeur Euclydes Furtado". (Processo n. 76, 21 mar. 1926. Caixa 07). O proprietário do referido automóvel ostenta, com certeza, considerável situação financeira, pois é proprietário de veículo de praça ou de aluguel - ver esclarecimentos na nota 488 - e emprega indivíduo que exerce a profissão de chauffeur. Esses elementos permitem-nos confirmar a tendência, apontada neste estudo, de que, nas primeiras décadas do século XX, apenas aqueles indivíduos que apresentavam muito boa condição financeira adquiriam automóveis particulares e dispunham de empregados para servir-lhes.

${ }^{482} \mathrm{O}$ acidente ocorreu de madrugada. $\mathrm{O}$ fato de cinco pessoas estarem passeando, de automóvel, pelas ruas do centro da cidade de Florianópolis, às quatro e meia horas da manhã - conforme é estipulado no presente processo -, explica-se porque, de acordo com as palavras de Nilo Mussi, prestadas no dia 23 de julho de 1926, ele afirma que, "no dia 21 de março do corrente ano, pelas quatro horas, mais ou menos, ao sair do Bilhar do senhor Poli, dirigiu-se à Catedral a qual se achava aberta por ser dia de festa". (Processo n. 76, 21 mar. 1926. Caixa 07).

${ }^{483}$ Processo n. 76, 21 mar. 1926. Caixa 07.
} 
Arthur Poli esclarece que Euclydes Furtado "confiou a direção do seu automóvel ao declarante e quando passavam pela rua Conselheiro Mafra, nas imediações da esquina da rua Jerônimo Coelho, resolveram passar por detrás do Mercado, pelo Cais"; e, ao "fazer a curva, o declarante que se achava na direção do auto, atrapalhou-se, sendo imediatamente auxiliado pelo chauffeur do referido auto que estava sentado ao seu lado" ${ }^{\text {484 }}$. Apesar dos esforços para tentar controlar o veículo, Euclydes Furtado não obteve êxito, “indo o automóvel Cais abaixo, caindo no mar ${ }^{485}$ e resultando saírem feridos o declarante e seu companheiro"486. (Anexo 09, p. 340). Em outra passagem da sua fala, foi-lhe perguntado se sabia "guiar automóvel e se tem carta de habilitação para tal"; e, a esses questionamentos, foi respondido que "sabe guiar automóvel, mas que não tem carta de habilitação" "487. De outro modo, "perguntado se foi o chauffeur do automóvel em questão quem lhe entregou a direção do referido veículo", respondeu "que estava guiando o automóvel", pois "havia pedido ao chauffeur do mesmo"488.

É importante esclarecermos que Arthur Poli é "natural deste Estado, com dezesseis anos de idade, solteiro, empregado no comércio" ${ }^{489}$, ou seja, ele é menor de idade; não tem, portanto, idade suficiente para guiar automóveis. Além disso, é "empregado no comércio", o que permitenos afirmar, com segurança, que ele não exercia a profissão de chauffeur, vedada aos menores de dezoito anos completos. Vale lembrarmos que o Regulamento para o serviço policial do Estado estipula que "os condutores de veículos, quando em serviço, deverão estar munidos da respectiva carta de habilitação", e que ela somente é adquirida mediante o respectivo exame prático ${ }^{490}$.

\footnotetext{
${ }^{484}$ Processo n. 76, 21 mar. 1926. Caixa 07.

485 Essa informação foi confirmada pelas testemunhas Arthur Alves Ouriques e Domingos Antônio de Souza em declarações prestadas, respectivamente, nos dias 23 e 24 de março de 1926. Devemos observar que a primeira testemunha afirma, em outra fala, datada de 17 de abril de 1926, que "no dia 21 de março último, estando na porta do Mercado, viu o auto Ford n. 80, descer em disparada pela rua Conselheiro Mafra, em direção ao Cais, precipitando-se no mar". (Processo n. 76, 21 mar. 1926. Caixa 07). O que queremos destacar dessa passagem é o fato de que o referido automóvel "desceu em disparada pela rua Conselheiro Mafra", ou seja, podemos inferir que o menor Arthur Poli imprimia, no instante do desastre, considerável velocidade ao automóvel n. 80. Vimos que o deslocamento de automóveis, em altas velocidades pelas ruas do espaço central da cidade de Florianópolis, constitui um elemento marcante de seu cotidiano, especialmente durante as primeiras décadas do século XX; aspecto este que não cessou com o passar dos anos, e que podemos verificar, pelo menos, até o início da década de 1940, época que delimita o período final da presente pesquisa.

${ }^{486}$ Processo n. 76, 21 mar. 1926. Caixa 07.

487 Idem.

${ }^{488}$ Processo n. 76, 21 mar. 1926. Caixa 07. É importante esclarecermos que o automóvel n. 80 é, muito provavelmente, um veículo de praça ou de aluguel.(*) Além disso, o chauffeur Euclydes Furtado tem 22 anos de idade. Neste ponto, confirmamos, novamente, a tendência de que, durante as décadas de 1920 e 1930, os chauffeurs dos automóveis particulares, de praça ou de aluguel eram indivíduos muito jovens. De outro modo, o "Termo de declarações" prestadas pelo acusado, datado de 23 de março de 1926, registra que Arthur Poli perguntou ao chauffeur Euclydes Furtado "se queria fazer um frete, nas condições de lhe confiar a direção do referido automóvel; que em vista disso, o declarante perguntou a Arthur Poli se tinha carta de chauffeur, no que foi respondido por Poli que sabia guiar e que possuía a respectiva carta, sendo motivo para o declarante confiar-lhe a direção do seu auto”. (Processo n. 76, 21 mar. 1926. Caixa 07). Pelo exposto, percebemos que há informações desencontradas, manifestadas por Arthur Poli, sobre a posse da carta de habilitação para veículos motorizados; pois o "Termo de declarações" por ele prestado, registra que ele "sabe guiar automóvel, mas que não tem carta de habilitação". (Processo n. 76, 21 mar. 1926. Caixa 07).

(*) Novamente, nesse processo não se define, claramente, se o referido automóvel constituía-se como veículo de praça ou de aluguel; porém, conforme as palavras do passageiro Altamiro da Luz Andrade, tomadas no dia 22 de março de 1925, ele, "em companhia de seus amigos Nilo Mussi, Domingos Antônio de Souza e Arthur Poli, resolveram dar um passeio de automóvel" e, desse modo, "ao chegarem em frente à Catedral, tomaram o auto n. 80, guiado pelo chauffeur Euclydes Furtado". (Processo n. 76, 21 mar. 1926. Caixa 07). Percebemos que o veículo estava estacionado em frente à Igreja Matriz e não exatamente à Praça XV de Novembro, local, à época, comumente destinado ao acondicionamento dos automóveis de praça da cidade - ver nota 464. Vale observarmos que o acondicionamento de veículos de aluguel no "ponto de automóveis da Capital", situado à Praça XV de Novembro, será atestado desde, pelo menos, o início da década de 1930, conforme aponta a análise ao processo n. 183, de 11 de janeiro de 1932, verificada, como visto, no quinto capítulo deste estudo. Além disso, percebemos, na leitura dos processos, que os automóveis de praça eram identificados, comumente, como aqueles que saíam ou demandavam ao "ponto de automóveis" da cidade. Ver, a respeito, neste capítulo, análise aos processos n. 45, 13 de abril de 1925, e n. 173, 20 de agosto de 1931.

${ }^{489}$ Processo n. 76, 21 mar. 1926. Caixa 07.

${ }^{490}$ Santa Catarina. Regulamento para o serviço policial do Estado. Florianópolis: Tipografia da Livraria Central, 1920.
} 
Além disso, o artigo 115 desse regulamento estabelece dentre outros pontos, que "Todo aquele que pretender prestar exame para condutor de veículos, dirigirá uma petição ao delegado auxiliar, delegado de polícia ou delegado regional, instruindo-o" com a "certidão de idade ou declaração firmada por duas pessoas idôneas de que o requerente é maior de dezoito anos"491. Em vista disso, podemos considerar que Euclydes Furtado, ao permitir que seu veículo fosse guiado por um indivíduo com a idade inferior àquela legalmente permitida para a condução de automóveis desrespeitou normas e disposições regulamentares de trânsito vigentes à época.

Entendemos que o exemplo, aqui exposto, serve como gancho para considerarmos que os habitantes da capital catarinense, usuários cotidianos do espaço urbano de Florianópolis, valemse, em situações diversas, de "[...] astúcia e esperteza de modo a utilizar ou driblar os termos dos contratos sociais", ou seja, utilizam-se de "mil maneiras para jogar/desfazer o jogo do outro"; assim, o espaço instituído pela ordem legal vigente é, de fato, palco para práticas que caracterizam a "atividade, sutil, tenaz, resistente, de grupos que, por não ter um próprio, devem

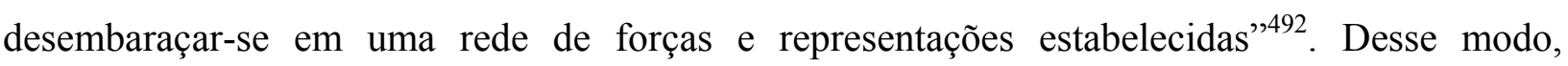
podemos estabelecer correlações com as ideias defendidas por Foucault, quando considera que a “[...] análise dos mecanismos de poder não tende a mostrar que o poder é ao mesmo tempo anônimo e sempre vencedor. Trata-se, ao contrário, de demarcar as posições e os modos de ação de cada um, as possibilidades de resistência e de contra-ataque de uns e outros"493. Dado o exposto, podemos considerar que os mecanismos de poder não são totalmente coercitivos; pois, dentro deles, os indivíduos podem operar certa margem de liberdade. Essas ideias aproximam-se, com efeito, daquelas defendidas por Michel de Certeau, segundo as quais o homem ordinário efetua, dentro do campo social, táticas e procedimentos imprevisíveis que lhe permitem circular e sobreviver com relativo sucesso.

Retomando a análise do processo n. 76, registramos que Euclydes Furtado afirma, em declaração prestada no dia 22 de julho de 1926, que Arthur Poli informou-lhe que "não era a primeira vez que assumia a direção de um auto e que mesmo tinha carta de chauffeur, motivando essas declarações ter o depoente feito entrega da direção de seu auto a Arthur Poli" ${ }^{494}$. Em primeiro lugar, observamos que não há coerência entre as declarações prestadas pelo menor nos dias 22 de março e 22 de julho de 1926; pois, nessas ocasiões, Arthur Poli afirma, respectivamente, que não era possuidor de carta de habilitação e, no segundo momento, atesta que "tinha carta de chauffeur". O que podemos perceber é que Arthur Poli, ao afirmar que era habilitado para conduzir veículos motorizados, utilizou-se de recursos retóricos com o objetivo

\footnotetext{
${ }^{491}$ Santa Catarina. Regulamento para o serviço policial do Estado. Florianópolis: Tipografia da Livraria Central, 1920.

${ }^{492}$ CERTEAU, Michel de. A invenção do cotidiano 1: artes de fazer. 8. ed. Petrópolis: Vozes, 2002. p. 79.

${ }^{493}$ FOUCAULT, Michel. Microfísica do Poder. 17 ed. Rio de Janeiro: Graal, 2002. p. 226.

${ }^{494}$ Processo n. 76, 21 mar. 1926. Caixa 07.
} 
de convencer o chauffeur Euclydes Furtado a emprestar-lhe o automóvel n. 80 para que fosse por ele guiado.

Assim, podemos considerar que circunstâncias diversas compunham o cotidiano dos habitantes da cidade de Florianópolis, notadamente quanto à convivência simultânea de pedestres, chauffeurs e veículos motorizados pelas ruas do perímetro urbano da capital catarinense; pois, para os efeitos deste estudo, vale destacarmos que os indivíduos menores de idade se utilizavam de discursos e artimanhas retóricas para, junto aos respectivos chauffeurs ou proprietários, obterem permissão para guiarem os veículos motorizados. De outro modo, não pudemos verificar, no presente processo, a existência de policiamento nas ruas da cidade de Florianópolis durante altas horas da manhã - o acidente descrito no processo ocorreu, como visto, por volta das quatro e meia horas da madrugada -, pois o menor Arthur Poli guiou o automóvel n. 80 "por diversas ruas desta Capital” e, somente em momento posterior, ocorreu o sinistro, tendo o referido automóvel caído no mar, nas imediações do Cais Liberdade ${ }^{495}$.

Devemos observar que, para os efeitos deste estudo, as práticas e usos da cidade nem sempre respeitavam ou obedeciam às normas disciplinares de trânsito, que objetivavam oferecer certa organização à circulação de pedestres e de veículos pelas ruas do espaço central da cidade de Florianópolis; pois, no processo em questão, foi concedida a direção de um veículo motorizado a uma pessoa menor de idade, não habilitada. $O$ desrespeito às regras de trânsito também é notório no momento em que o menor declara que "não era a primeira vez que assumia a direção de um auto". Apesar do amplo movimento no sentido de ordenar o viver urbano, no que concerne às normas de conduta no trânsito, notamos que continuaram a se manifestar desobediências às tentativas de se imporem padrões de conduta urbana. Assim, é possível compreendermos que os habitantes de Florianópolis apresentavam maneiras diferentes de viver daquelas prescritas pelas normas e regulamentações judiciais e de trânsito que se tentavam aplicar na capital catarinense. Embora as ordenações estivessem marcando as condutas de homens e de mulheres, elas adquiriam, portanto, novas formas diante de suas experiências sociais e vivências cotidianas ${ }^{496}$.

É importante considerarmos, também, que os veículos automotores conquistaram, gradativamente, a primazia quanto à circulação pelas vias dos espaços urbanos, onde boleeiros, ciclistas e pedestres devem obedecer ao padrão de circulação estabelecido pelos automóveis. Há, como vimos, espaços claramente definidos para a circulação de pedestres e veículos motorizados: estes, nas ruas e avenidas; aqueles, nas calçadas e passeios públicos. A violação

\footnotetext{
${ }^{495}$ Processo n. 76, 21 mar. 1926. Caixa 07.

${ }^{496}$ NECKEL, Roselane. A República em Santa Catarina: modernidade e exclusão (1889-1920). Florianópolis: UFSC, 2003. p. 75-76.
} 
inadequada desses espaços acarreta, em diversas situações, consequências desfavoráveis, especialmente para os transeuntes, que sofrem integralmente as investidas dos automóveis, dos quais seus corpos recebem diretamente as colisões e impactos; apresentam, portanto, em muitas dessas ocasiões, ferimentos e mutilações físicas.

De qualquer maneira, verificamos que, nos processos criminais em análise, as testemunhas dos atropelamentos e colisões observavam, em algumas ocasiões, as regras para a circulação dos veículos motorizados ${ }^{497}$, o que contribuía para fiscalizar comportamentos indevidos praticados pelos chauffeurs ao guiarem seus veículos pelas ruas da cidade de Florianópolis. Tendo isso em vista, salientamos que as testemunhas e as vítimas dos atropelamentos e colisões não apenas transgrediam, mas também observavam as regras de conduta no trânsito de maneira positiva; contribuiam, por isso, para a sua fisscalização e obediência. Neste ponto, é importante salientarmos que, nos processos criminais analisados, as testemunhas dos respectivos sinistros tinham, via de regra, entre 18 e 54 anos de idade e apresentavam ocupações profissionais diversas: chauffeurs, "empregados no comércio", funcionários públicos estaduais e federais, praças (soldados, cabos, sargentos) da Força Pública, negociantes e, até mesmo, advogados e jardineiros. Essas testemunhas eram, portanto, indivíduos que desempenhavam as mais variadas atividades profissionais e a grande maioria exercia ocupações que proporcionavam, via de regra, ganhos financeiros razoáveis, correspondente aos estratos médios da sociedade florianopolitana da época. (Ver anexo 20, p. 351).

As normas de trânsito, vigentes na capital catarinense, não eram obedecidas à risca, pois a vivência cotidiana de seus habitantes, que operavam usos e apropriações variadas da cidade, não se enquadrava, integralmente, às intenções e às regulamentações judiciais e de trânsito que se tentavam aplicar na cidade de Florianópolis, propaladas pelos poderes administrativos locais e estaduais. Dessa maneira, operavam-se contrapoderes que eram exercidos no interior das práticas sociais verificadas na vivência cotidiana expressa pelos habitantes da Capital ${ }^{498}$. Desse modo, salientamos que as tentativas de se aplicarem leis e normas de trânsito, que objetivam disciplinar

\footnotetext{
${ }^{497}$ Quanto a esse aspecto, podemos observar que, no dia 25 de março de 1926, a portaria do processo n. 77 registrava o atropelamento do ciclista Johannes Herbig e observa que "hoje, pelas treze horas, ao fazer a curva na rua Padre Miguelinho, o automóvel do Hospital Militar, guiado pelo chauffeur Agostinho da Silva Feijó, foi de encontro a um moço de nome Jonhannes Herbig que por ali passava numa bicicleta, atirando-lhe ao chão, produzindo-lhe ferimentos e quebrando a bicicleta em que ia". (Processo n. 77, 25 mar. 1926. Caixa. 07). Nesse processo, a testemunha Arthur Romeu Lemos, "41 anos, empregado público estadual", observa as normas disciplinares de trânsito em declarações prestadas no dia 16 de abril de 1926, pois registra, naquela ocasião, que "no dia 25 de março último, dirigindo-se para a repartição onde trabalha, ao passar em frente à Matriz, próximo ao passeio do Jardim, viu o automóvel Ford, conduzido pelo acusado Agostinho da Silva Feijó, na entrada da rua Padre Miguelinho, esbarrar em uma bicicleta, onde Johannes Herbig recebeu os ferimentos descritos no "Auto de corpo de delito", e que "a seu ver, o chauffeur acusado agiu com imprudência, contra o regulamento policial, fazendo a volta próxima ao passeio" e que também não ouviu o acusado "fonfonar, ao fazer a curva, o que também é contra o regulamento". (Processo n. 77, 25 mar. 1926. Caixa 07). (Anexo 10, p. 341). Do exposto, é possível considerarmos que a presente testemunha foi devidamente instruída pelo advogado de acusação ou promotor público, pois sua declaração se encaixa de maneira coerente quanto aos preceitos legais relativos à circulação automobilística na capital catarinense, estipulados pelo regulamento policial vigente. Esse regulamento, podemos deduzir, é referente ao serviço policial do Estado, datado de 1920, já mencionado em muitas outras ocasiões no presente texto. De qualquer forma, assinalamos que as testemunhas dos sinistros observavam - por conhecimento ou de maneira instruída - as regras e conduta no trânsito, o que contribuía para observar ou vigiar comportamentos indevidos ao volante. Ver, também, a respeito, análise do processo n. 45, de 04 de agosto de 1923, disposta no capítulo primeiro da tese.

${ }^{498}$ FOUCAULT, Michel. Microfísica do Poder. 17 ed. Rio de Janeiro: Graal, 2002.
} 
a circulação de pedestres e veículos motorizados, esbarram no modo como transeuntes, chauffeurs e passageiros delas se utilizam; assim, verificamos, muitas vezes, descompassos entre as normas disciplinares e os usos e vivências cotidianas operadas no espaço urbano. De outro modo, referenciando Maria Stella Bresciani, podemos considerar que se objetivou estabelecer, na cidade de Florianópolis, especialmente durante as décadas de 1920 e 1930, portas conceituais relacionadas aos saberes normativos e legais que se formaram na intenção "moderna" de defesa e de controle de tudo o que se movimenta ${ }^{499}$. As portas conceituais oferecem, portanto, mecanismos de controle e adestramento, que são de grande eficácia na ordenação racional do espaço - bairros especializados, lugares específicos destinados à circulação de pedestres e automóveis, edifícios organizados e ordenados pelas normas higiênicas e disciplinares -, pois permitem vigiar todos os movimentos dos habitantes da cidade $^{500}$. Esse processo não pode ser, entretanto, operado de maneira integral ou absoluta, pois as circunstâncias estabelecidas pelo fluxo cotidiano de pedestres e de automóveis pelas ruas de Florianópolis não se encaixam, muitas vezes, às intenções disciplinares de ordenação do espaço e das condutas sociais.

A análise dos processos referenciados, nesta parte, serve como instrumento para considerarmos que as vivências cotidianas operadas pelos chauffeurs, passageiros e transeuntes, no meio urbano da cidade de Florianópolis, encerram enquadramentos às normas e às leis de trânsito e, igualmente, às investidas operadas pelos veículos motorizados; mas manifestam, também, transgressões e desobediências, regidas, em última análise, pela liberdade gazeteira das práticas sociais $^{501}$ - conforme ficou exemplificado nos processos em questão, especialmente na ocasião em que Arthur Poli, menor de idade, conduziu um automóvel pelas ruas do espaço central da cidade de Florianópolis, registrada no processo n. 76, de 21 de março de 1926.

De maneira análoga, podemos considerar que os pedestres manifestam, em suas andanças pelas ruas, seus desejos e interesses próprios, os quais, naturalmente, não são determinados pelos ritmos impostos pelo poder advindo das normas e das leis vigentes ou da circulação operada pelos automóveis. Dessa forma, a ordem reinante serve, em última instância, de suporte para inúmeras produções e vivências, pois ela transforma a propriedade do outro em lugar tomado de empréstimo, ao passo que torna os seus proprietários - legisladores e autoridades políticas estaduais e locais - cegos para essa criatividade ${ }^{502}$. Assim, essa ordem encerra um conjunto de imposições e de regulamentações que, em tese, serve para facilitar as improvisações expressas

\footnotetext{
${ }^{499}$ BRESCIANI, Maria S. M. Cidade e História. In: OLIVEIRA, Lúcia L. (Org.). Cidade: história e desafios. Rio de Janeiro: FGV, 2002. p. 32. ${ }^{500}$ BRESCIANI, Maria Stella Martins. Cidade e História. In: OLIVEIRA, Lúcia Lippi (Org.). Cidade: história e desafios... op. cit., p. 32. Para o aprofundamento da discussão dos papéis negativos - repressão, exclusão, censura - e positivos - adestramento, controle e eficácia produtiva - do poder, ver, especialmente: FOUCAULT, Michel. Microfísica do Poder. 17 ed. Rio de Janeiro: Graal, 2002; __. Sexo, Poder e Indivíduo. Florianópolis: Nefelibata, 2003; ___ Ditos e Escritos: estratégia, poder-saber. 1 ed. Rio de Janeiro: Forense Universitária, 2003. v. 4. ${ }^{501}$ CERTEAU, Michel de. A invenção do cotidiano 1: artes de fazer. 8. ed. Petrópolis: Vozes, 2002. p. 16.

${ }^{502}$ Ibidem, p. 49-50.
} 
pelos habitantes da cidade de Florianópolis em inúmeras situações vivenciadas em seu cotidiano $^{503}$.

\subsubsection{Vias e Passeios}

Nesta seção, discutimos de que maneira as ruas e as vias públicas do perímetro urbano da cidade de Florianópolis foram, progressivamente, adaptadas para atender ao tráfego de veículos motorizados. Análises nesse sentido já foram tecidas por nós no presente estudo, especialmente no segundo capítulo da tese, no qual atestamos que, já durante a década de 10 do século passado, verificou-se, entre os principais dispositivos da legislação estadual relativos ao trânsito, nítida preocupação quanto à circulação de veículos automotores e/ou operados por força motriz animal; análise esta que foi enriquecida por meio da investigação dos artigos e dispositivos legais registrados nos códigos de posturas da cidade de Florianópolis (Desterro), datados dos anos de 1889,1896 e 1898.

Julgamos conveniente salientar, uma vez mais, que muitos dos artigos, dispostos nos códigos de posturas supracitados, são similares àqueles registrados pelo Regulamento para o serviço policial do Estado, de 1920. Enfatizamos, todavia, que o principal avanço dessa publicação, em relação ao conteúdo apresentado pelos códigos de posturas municipais de Florianópolis, baixados durante o final do século XIX, está no fato de o texto de 1920 atender, também, ao trânsito de veículos motorizados. Assim, entre o final do oitocentos e as primeiras décadas do século seguinte, houve, ao que parece, uma apropriação dos elementos dispostos nos capítulos e artigos dos códigos de posturas municipais da capital catarinense, a fim de elaborarse o Regulamento para o serviço policial do Estado, com o objetivo de regularizar, dentre outros aspectos, a circulação dos veículos motorizados.

Na presente seção, analisamos, também, a dinâmica envolvida pela substituição de antigos hábitos e costumes praticados pela população florianopolitana nas ruas da cidade, em favor da circulação automobilística; práticas estas que, a partir da década de 1920, são proibidas com maior nitidez pelo aparato legislativo municipal, uma vez que destina as ruas do perímetro urbano da capital catarinense a atender, preferencialmente, ao tráfego de veículos motorizados e, em contrapartida, reduz a circulação dos pedestres às calçadas e passeios públicos. Assim, notamos que o poder público municipal confere preferência à presença e à circulação do automóvel e determina, de modo gradativo, a privatização das ruas como espaço de convívio e sociabilidade cotidianos da população florianopolitana.

\footnotetext{
${ }^{503}$ CERTEAU, Michel de. A invenção do cotidiano 1: artes de fazer. 8. ed. Petrópolis: Vozes, 2002. p. 50.
} 
Nessa investigação, tecemos, paralelamente, uma análise sobre a percepção quanto à circulação automobilística pelas ruas da capital catarinense durante as décadas de 1920 e 1930 . Desse modo, questionamos o seguinte: De que maneira podemos discutir questões atinentes à população florianopolitana da época, especialmente no que tange às suas percepções sensitiva e visual quanto à presença, aproximação e passagem dos automóveis? De que maneira os transeuntes e as testemunhas dos sinistros relatados nos respectivos processos criminais percebiam o ritmo e a velocidade atingidos pelos chauffeurs ao guiarem os veículos motorizados? Suas atenções eram despertadas pela passagem dos automóveis? O deslocamento dos veículos automotores causava espanto e estranheza para aqueles que o presenciavam? Até que ponto os dispositivos legais de trânsito, traçados pelos poderes públicos estadual e municipal, funcionaram como mecanismos para disciplinar as condutas operadas pelos florianopolitanos nas ruas do perímetro urbano da capital catarinense, no período em estudo?

Analisamos, para tanto, ao todo, três processos criminais, datados, respectivamente, dos anos de 1926, 1931 e 1932, por meio dos quais procuramos discutir, no período de duas décadas, situações ilustrativas em que podemos perceber, com maior atenção, as mudanças verificadas quanto à percepção dos habitantes da cidade de Florianópolis sobre o deslocamento dos automóveis. Os textos aqui analisados servem, igualmente, como gancho para discutirmos o processo de internalização das normas legais, como forma de condicionar e disciplinar a circulação dos florianopolitanos frente à presença dos automóveis.

No processo n. 62, de 03 de abril de 1926, verificamos que é abordado o atropelamento do menor Gentil Lemos, de nove anos de idade, na rua Esteves Júnior, ocasionado pelo motorista João Fédrigo, 33 anos, de profissão mecânico. O Delegado de Polícia da cidade de Florianópolis, expõe, na portaria do processo, que, "Chegando ao meu conhecimento, hoje, pelas 10 horas [da noite $]^{504}$, na rua Esteves Júnior, o automóvel n. 46 guiado pelo seu proprietário João Fédrigo, no momento que passava pelo carro de praça, conduzido pelo boleeiro Ladislau Opuska, atropelou um menor, ferindo-o" ${ }^{\lceil 05}$. É importante observarmos que o veículo em questão não configura um automóvel de praça ou de aluguel, pois o acusado não trabalha como chauffeur $^{506}$. Esse é um caso ímpar se consideramos que o referido veículo, de propriedade particular, pertence a um indivíduo que exerce a profissão de mecânico.

Assim, no processo em questão, não há indícios de que João Fédrigo apresente boa condição de vida que lhe permita adquirir um automóvel particular. Esse aspecto contraria a tendência, defendida neste estudo, de que, nas primeiras décadas do século XX, apenas os

\footnotetext{
${ }^{504} \mathrm{O}$ atropelamento em questão ocorreu num sábado, no período noturno, conforme registra o artigo do jornal $O$ Estado, de 05 de abril de 1926.

${ }^{505}$ Processo n. 62, 03 abr. 1926. Caixa 06.

${ }^{506} \mathrm{O}$ acusado é chauffeur amador, sendo o mesmo habilitado para conduzir automóveis, pois "fez exame para chauffeur, e foi aprovado, aos trinta e um dias do mês de março de 1924”. (Processo n. 62, 03 abr. 1926. Caixa 06).
} 
indivíduos que apresentavam muito boa condição financeira poderiam adquirir automóveis de cunho estritamente particulares. Por outro lado, consideramos que João Fédrigo provavelmente não se constituía como o primeiro proprietário do referido automóvel, uma vez que ele era, inclusive, de condição muito modesta. Além disso, é possível inferirmos que o acusado não era paupérrimo, mas gozava de razoável condição financeira, suficiente para que ele pudesse ser proprietário de um veículo motorizado ${ }^{507}$. Apenas dessa forma podemos justificar, na época em estudo, que um indivíduo que exerce a profissão de mecânico apresente condições financeiras apropriadas para adquirir ou manter um veículo motorizado. Esse episódio contribui, no entanto, para atestarmos a complexidade do processo de circulação dos automóveis pelas ruas da capital catarinense, durante as primeiras décadas do século passado.

O “Termo de declarações”, prestado pelo acusado João Fédrigo, expõe outros detalhes do sinistro, pois registra que, "hoje pelas dezoito horas subia a rua Esteves Júnior, guiando o seu automóvel n. 46 e ao chegar à esquina da rua 28 de Setembro ${ }^{508}$, encontrou o senhor Capitão Marcelino Coelho com quem queria falar" ${ }^{, 509}$. Naquele instante, João Fédrigo "deu volta ao seu automóvel e fez embarcar o referido senhor Capitão Coelho, que descia a mesma rua, a fim de levar esse Oficial em sua casa"; e, naquela ocasião, João Fédrigo encontrou, "um pouco acima da casa de residência do doutor Henrique Raupp, o carro de praça conduzido pelo boleeiro Ladislau Opuska" $" 510$. No momento "em que passava o carro pelo automóvel, saiu de trás do referido carro uma criança que correu e atravessou a rua pela frente do auto, quando foi apanhado pelo mesmo, não sendo possível evitar o desastre, embora descesse a rua com marcha muito reduzida"511. Continuando suas declarações, João Fédrigo afirma que "brecou imediatamente o seu automóvel tendo o mesmo parado quase que instantaneamente, mas infelizmente já havia passado sobre a criança" $^{\text {512 }}$. (Anexo 11, p. 342).

O que queremos destacar dessas passagens é que o atropelamento foi provocado, muito provavelmente, porque o menor "saiu de trás do carro" e, ao correr para "atravessar a rua pela

\footnotetext{
${ }^{507}$ Corroborando com essas ideias, destacamos que João Fédrigo era "natural deste Estado, casado, mecânico, residente nesta Capital à rua Largo General Osório, n. 02, sabendo ler e escrever". (Processo n. 62, 03 abr. 1926. Caixa 06). Vale salientarmos que o Largo General Osório corresponde, grosso modo, ao Campo do Manejo, denominação aplicada àquela região ao final do século XIX e início do século XX. Nessa época, o Largo General Osório - juntamente com os bairros adjacentes da Tronqueira e da Toca - era ocupado, majoritariamente, por "[...] lavadeiras, soldados e negros libertos. Nos seus cortiços 'espécies de colméias', havia quartos e outros cubículos habitados promiscuamente por muitas pessoas". (CABRAL, Oswaldo Rodrigues. Nossa Senhora do Desterro: Notícia 1. Florianópolis: Lunardelli, 1990; VEIGA, Eliane Veras da. Florianópolis: memória urbana. Florianópolis: UFSC e Fundação Franklin Cascaes, 1993. p. 106 e p. 110). O Largo General Osório corresponde, atualmente, ao local onde está edificado o Instituto Estadual de Educação (IEE). (Ver mapa 06, p. 155). Pelo exposto, percebemos que, no ano de 1926, data de ocorrência do sinistro em questão, o Largo General Osório não constituía uma região privilegiada da cidade de Florianópolis, pois estava localizado próximo às encostas do Morro da Cruz; não configurava, portanto, parte integrante do seu espaço central. Podemos, por conseguinte, afirmar que João Fédrigo pertencia aos estratos médios ou não exatamente pobres da sociedade florianopolitana da época, pois possuía residência fixa em região não central da capital catarinense. João Fédrigo também sabia ler e escrever, observação que, como visto, é registrada na totalidade dos dezoito processos pesquisados para as décadas de 1920 e 1930, o que atesta, na época, sua relevância como formação pessoal, "vedada" aos estratos mais desfavorecidos da sociedade florianopolitana.

${ }_{508}^{508}$ Atual rua Vidal Ramos. (SILVA, A. Nicolich. Ruas de Florianópolis: resenha histórica. Florianópolis: Fundação Franklin Cascaes. p. 138).

${ }^{509}$ Processo n. 62, 03 abr. 1926. Caixa 06.

${ }^{510} \mathrm{Idem}$.

${ }^{511} \mathrm{Idem}$.

${ }^{512}$ Idem.
} 
frente do mesmo", foi pelo automóvel "apanhado, não sendo possível evitar o desastre". Devemos observar a maneira com que o menor atravessou a rua, pois a fez correndo, passando "pela frente do automóvel", o que evidencia que, diante do conjunto da cidade, atravancado por códigos que o usuário não domina, mas que deve assimilar para poder nele viver e circular, e em face de uma configuração dos lugares impostos pelas normas disciplinares de trânsito, e pelos desníveis sociais internos ao espaço urbano, o usuário - neste caso específico, o transeunte quase sempre consegue criar para si itinerários próprios e particulares, destinados ao melhor aproveitamento da urbe ${ }^{513}$. Esses itinerários são, em síntese, as marcas que os pedestres sabem, por si mesmos, esquadrinhar no espaço urbano da cidade de Florianópolis ${ }^{514}$.

O cenário apresentado pelo processo em discussão nos força, entretanto, a fazer os seguintes questionamentos: $\mathrm{O}$ transeunte, de apenas nove anos de idade, percebeu a aproximação do automóvel? Dada a sua proximidade - ele atravessou a rua correndo no momento "em que passava o carro pelo automóvel" -, não lhe foi possível ouvir a aproximação do veículo dirigido por João Fédrigo? Nessas circunstâncias, até que ponto o transeunte poderia calcular, devidamente, a distância para efetuar a travessia da rua? Ou, coloquemos a questão de uma outra maneira, será que havia, por parte do menor, a preocupação em operar, mentalmente, essas variáveis? Dado o exposto, enfatizamos que esses questionamentos são muito difíceis de serem equacionados. Arriscamos, entretanto, considerar que o ato de "vir sentado no eixo dos carros" ${ }^{\text {515, }}$, como então fez o menor Gentil Lemos ${ }^{516}$, era mesmo uma prática comum dos indivíduos menores de idade e, ao que parece, resistiu por algum tempo após a introdução e a circulação dos veículos motorizados pelas ruas do perímetro urbano da capital catarinense.

Neste ponto, devemos observar que a cidade foge ao controle humano e se configura, gradualmente, como espaço agigantado, o que sugere que a compreensão de cidade não mais encontra correspondência na imagem da cidade que se tem diante dos olhos. Essas ideias são expressas por Maria Stella Martins Bresciani no texto intitulado A Cidade: objeto de estudo e experiência vivenciada ${ }^{517}$. É interessante observarmos que a autora opera estreitas relações entre os campos da História e da Arquitetura e busca aproximações e aproveitamentos entre eles, pois defende que as noções de tempo - trabalhadas, especialmente, nas discussões historiográficas - e

\footnotetext{
${ }^{513}$ CERTEAU, Michel de; GIARD, Luce; MAYOL, P. A invenção do cotidiano 2: morar, cozinhar. 5. ed. Petrópolis: Vozes, 2003 . p. 41-42.

${ }^{514}$ Ibidem, p. 42.

${ }^{515}$ Processo n. 62, 03 abr. 1926. Caixa 06.

${ }^{516}$ Observar, a seguir, referências às passagens assinaladas nas declarações prestadas pelo boleeiro Ladislau Opuska, no dia 03 de abril de 1926. Por hora, entendemos que a prática de "vir sentado no eixo dos carros" corresponde ao ato de, literalmente, estar sentado sobre o eixo dos veículos de tração animal, pois, muito provavelmente, dispunham de plataformas (molas) sobre os eixos - ver, a seguir, artigo do jornal $O$ Estado, de 05 de abril de 1926 -, constituídos de madeira ou ferro, o que possibilitava às pessoas permanecerem sobre eles, quando os veículos se encontravam parados ou em movimento. Apenas dessa maneira podemos compreender como o referido menor se encontrava "sentado no eixo do carro" de praça guiado por Ladislau Opuska, até o momento em que a vítima "saiu de trás do referido carro" e "atravessou a rua pela frente do auto".

${ }^{517}$ BRESCIANI, Maria Stella Martins. A Cidade: objeto de estudo e experiência vivenciada. In: Revista Brasileira de Estudos Urbanos e Regionais. São Paulo: ANPUR, v. 6, n. 2, nov. 2004. p. 9-26.
} 
Mapa 06: Largo General Osório (Instituto Estadual de Educação - IEE) e Bairro Adjacentes - Década de 1920 (*)

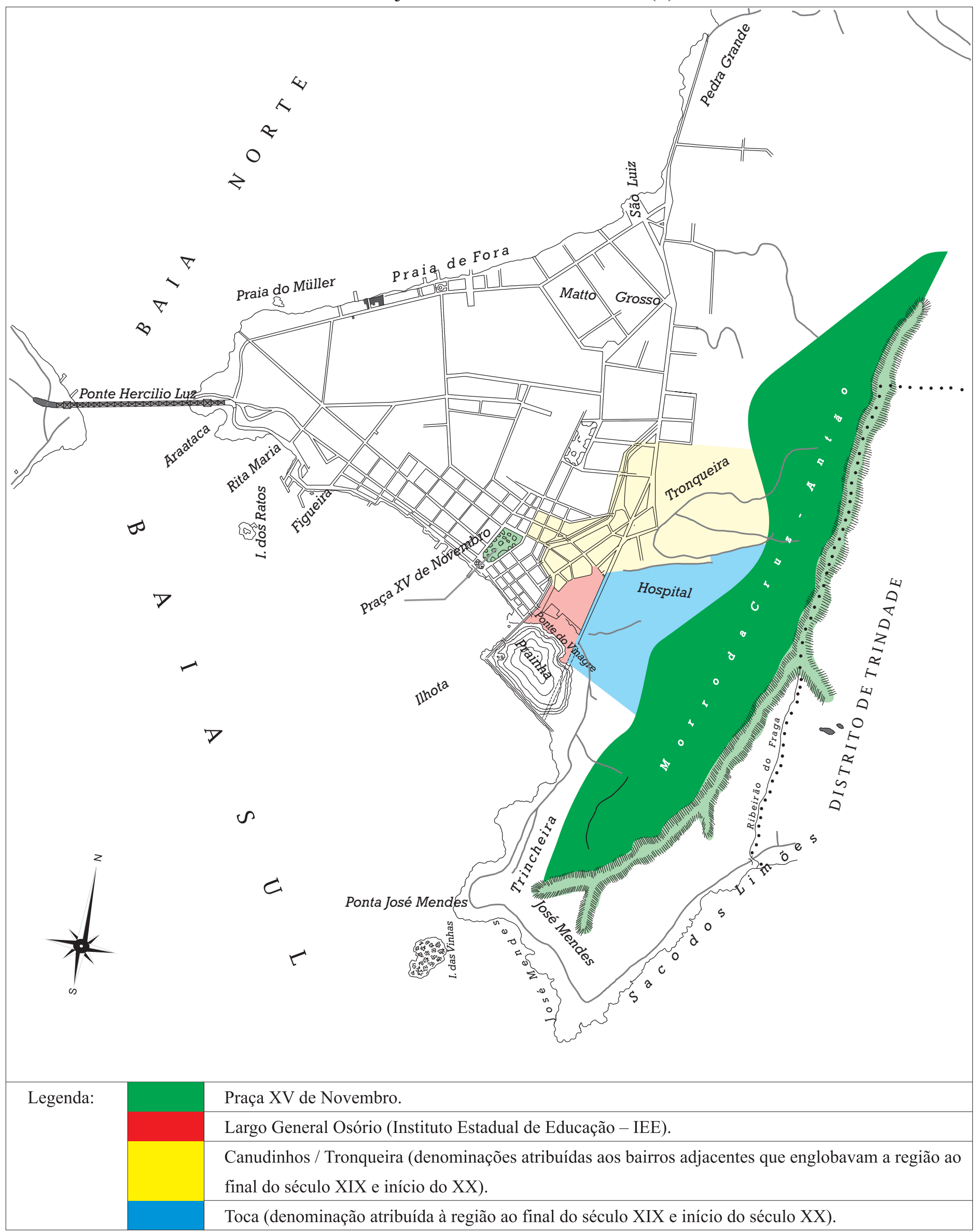

(*) Mapa do perímetro urbano da cidade de Florianópolis - 1940. Fonte: Centro Administrativo do Estado de Santa Catarina - Secretaria de Planejamento/Diretoria de Estatística e Cartografia - Florianópolis - Santa Catarina.

Criação e Diagramação: Duplic Digital Copiadora - Florianópolis - Santa Catarina.

Adaptações feitas pelo autor. 
espaço - discutidas, sobremaneira, entre os arquitetos - devem ser estudadas e entendidas em conjunto, com o objetivo de alcançar-se uma compreensão mais aproximada sobre os contextos e temporalidades urbanas ${ }^{518}$.

No texto aqui referido, a autora analisa, também, as ideias do urbanista e teórico de arte italiano Giulio Carlo Argan (1909-1992) quanto à imagem da cidade moderna como local que encerra ou manifesta insegurança; e isso se deve, em grande parte, à redução do valor do indivíduo "o indivíduo não é mais do que um átomo na massa"519. De acordo com Argan, a aposta humana na potencialidade da técnica certamente subjuga o homem e parece ganhar autonomia, e pode ser assemelhada ao que se tornou a cidade no mundo atual: alguma coisa que não pode mais ser considerada um espaço delimitado, nem um espaço em expansão, mas um sistema de serviços, cuja potencialidade é praticamente ilimitada ${ }^{520}$. Além disso, como urbanista, Argan destaca a questão do "valor estético da cidade", a cidade como espaço visual. Assim, considera que a cidade é, antes de tudo, um impacto visual ou uma experiência estética, que é potencializada pela multiplicação de olhares que os pedestres ou usuários da cidade operam sobre ela; e, desse modo, podemos considerar, parafraseando Stella Bresciani, que "[...] as cidades nunca são inteiramente determinadas pelo alto por forças obscuras que mal podemos identificar, menos ainda controlar, pois nela, se somos pacientes, somos também agentes"

Estendendo um pouco mais essa discussão, destacamos que, no texto Cidade e História ${ }^{522}$ - já referenciado neste estudo -, Maria Stella Bresciani aponta o seguinte questionamento inicial: “O que o saber historiográfico oferece como contribuição para o estudo das cidades, das questões urbanas?" 523 . Para responder a essa questão, a autora destaca que o aspecto que propõe tratar é a interdisciplinaridade constitutiva do urbanismo como campo de saber, e a historicização de sua denominação e reconhecimento na década inicial do século XX. Essas considerações serão apropriadas e enriquecidas no quinto capítulo da tese, especialmente na seção Epílogo. Por hora, destacamos do texto supracitado, a ideia de que o estudo dos espaços urbanos envolve o rompimento com a relação mecânica de causa-efeito, ou com a estreita noção de determinação férrea que, comumente, tem-se sobre a constituição física ou espacial das cidades. Essa operação metodológica objetiva quebrar as resistências e as barreiras teóricas e conceituais havidas entre os campos da História e da Arquitetura; pois, segundo Bresciani, a "[...] contribuição mais

\footnotetext{
${ }^{518}$ Essa operação metodológica também pode ser encontrada na coletânea Palavras da Cidade - já referenciada neste estudo -, pois “[...] reúne trabalhos apresentados no I Seminário Latino-Americano do Programa Internacional "Les Mots de la Ville". Esse encontro foi realizado "nas dependências da Faculdade de Arquitetura e Urbanismo [...] entre os dias 1 e 3 de setembro de 1999" e "congregou pesquisadores da Argentina e Peru, além dos brasileiros". (BRESCIANI, Maria Stella (Org.). Palavras da cidade. Porto Alegre: UFRGS, 2001. p. 9).

${ }^{519}$ BRESCIANI, Maria Stella M. A Cidade: objeto de estudo e experiência vivenciada. In: Revista Brasileira de Estudos Urbanos e Regionais. São Paulo: ANPUR, v. 6, n. 2, nov. 2004. p. 9-26. p. 10.

${ }^{520}$ Ibidem, p. 10-11.

${ }^{521}$ Ibidem, p. 25.

${ }^{522}$ BRESCIANI, Maria Stella Martins. Cidade e História. In: OLIVEIRA, Lúcia Lippi (Org.). Cidade: história e desafios... op. cit., p. 16-35.

${ }^{523}$ Ibidem, p. 17.
} 
importante da disciplina história recai, justamente, na elucidação desse ponto mais obscuro da formação do saber sobre a cidade" ${ }^{, 524}$.

Nesse sentido, o ambiente urbano, como fluxo de contatos, experiências e percepções, não é redutível ao conjunto arquitetônico ou predial edificado, pois opera uma síntese pré-reflexiva, que envolve memórias, desejos e percepções específicas de cada indivíduo ou cidadão, inerentes à sua própria vivência dentro do meio urbano. Desse modo, a circulação e as vivências diárias operadas nas cidades não são, portanto, limitadas pelos seus referencias físicos e prediais, pois suscitam, para seus diversos habitantes, lembranças e apropriações diferenciadas sobre um mesmo espaço urbano ${ }^{525}$. Discussões nesse sentido são, também, expressas pela historiadora Sandra Jatahy Pesavento - centradas sob a ótica da História Cultural. Assim, no texto intitulado Muito além do espaço: por uma história cultural do urbano (Estudos Históricos. Rio de Janeiro, v. 8, n. 16, jul./dez. 1995), a autora registra que o espaço construído, ordenado e transformado suscita sensações, percepções e a elaboração de representações para aqueles que vivenciavam os processos de mudança das cidades. Em vista disso, interessa à autora o aprofundamento de uma história cultural do urbano, na qual "[...] se cruzem os dados objetivos - obras, traços, ou sinais da passeidade que nos chegam, sob a forma de imagens ou discursos, com as possibilidades de leitura que a cidade oferece", pois empreender "este caminho pressupõe pensar para muito além do espaço, enveredando pelas representações simbólicas da urbe, que podem corresponder ou não à realidade sensível, sem que com isso percam sua força imaginária",526.

Percebemos, nas discussões verificadas, aproximações com as ideias discutidas por Michel Foucault e Michel de Certeau, pois veem a atuação dos mecanismos de disciplina como ingrediente que permite aos homens comuns circularem dentro deles e expressarem seus próprios itinerários e saberes sobre os meios urbanos em que vivem e trabalham; procedimentos estes que ultrapassam ou que não são adaptados ao "mundo homogeneizado das normas sociais e das imagens e expectativas", em torno dos ideais modernizadores e civilizatórios propalados pelos poderes públicos estaduais e municipais do período $^{527}$. O viver cotidiano é, portanto, aquilo que nos é dado cada dia; é aquilo que nos prende intimamente, a partir do interior. É uma história a meio-caminho de nós mesmos, guiada pela memória olfativa, dos lugares da infância, do corpo, dos prazeres. Talvez, não seja inútil sublinharmos a importância do domínio dessa história "irracional", pois "o que interessa ao historiador do cotidiano é o invisível",528.

\footnotetext{
${ }_{524}$ BRESCIANI, Maria S. M. Cidade e História. In: OLIVEIRA, Lúcia L. (Org.). Cidade: história e desafios. Rio de Janeiro: FGV, 2002. p. 23.

${ }^{525}$ Ibidem, p. 30.

${ }^{526}$ PESAVENTO, Sandra Jatahy. Muito além do espaço: por uma história cultural do urbano. Estudos Históricos - Cultura e História urbana. Rio de Janeiro, v. 8, n. 16, p. 282, jul./dez. 1995; __. Cidades visíveis; cidades sensíveis, cidades imaginárias. In: Revista Brasileira de História, v. 27, n. 53, São Paulo jan./jun. 2007. A referência a tais artigos se faz apropriada porque neles a autora expressa, com muita clareza, a intenção de se estudar "as representações simbólicas da urbe" que constituem, em sua visão, uma outra possibilidade de existência do urbano.

${ }^{527}$ NECKEL, Roselane. A República em Santa Catarina: modernidade e exclusão (1889-1920). Florianópolis: UFSC, 2003. p. 80.

${ }^{528}$ CERTEAU, Michel de; GIARD, Luce; MAYOL, Pierre. A invenção do cotidiano 2: morar, cozinhar. 5. ed. Petrópolis: Vozes, 2003. p. 31.
} 
No processo em discussão, as declarações do boleeiro Ladislau Opuska registram, igualmente, aspectos importantes para esclarecermos como se deu o atropelamento do menor Gentil Lemos. De acordo com suas colocações, registra-se que, "hoje, pelas dezoito horas, subia com o carro n. 11 à rua Esteves Júnior, conduzindo o passageiro cujo nome ignora [...] e nas imediações da casa de residência do doutor Henrique Raupp cruzou com o automóvel n. 46, guiado pelo seu proprietário, João Fédrigo" ${ }^{, 529}$. Continuando sua fala, o boleeiro esclarece que “[...] logo que passou por este automóvel, o depoente foi chamado pelo senhor Antônio Augusto Schorcht que se achava à janela de sua casa", que lhe mostrou "uma criança que se achava caída no chão, derrubada pelo automóvel 46, que também estava ali parado, e cujo proprietário se achava junto da referida criança" ${ }^{, 530}$. Adiante, ele afirma que o automóvel em questão, ao passar pelo lado do carro que conduzia, não imprimia alta velocidade, "mesmo porque a rua Esteves Júnior é muito estreita e todas as vezes que se cruzam veículos por ali é em marcha muito reduzida" 531 . Questionado sobre o modo como ocorreu o atropelamento, Ladislau Opuska declara que "nada viu, senão depois de ter sido chamado pelo senhor Antônio Augusto Schorcht", que lhe disse "que a referida criança vinha sentada no eixo do carro do depoente e ao passar pelo automóvel n. 46, reduziram as marchas dos veículos"; e, "como a criança desconfiasse qualquer coisa, dada a marcha lenta do carro, precipitou-se do lugar em que estava para o lado em que passava o automóvel em questão"532.

O que objetivamos destacar é que o menor em questão "vinha sentado no eixo do carro" e que essa prática não foi alvo de fiscalização por parte do condutor do mesmo ou de qualquer autoridade policial. Vale lembrarmos que Ladislau Opuska guiava um carro de praça, conduzindo um passageiro. Assim, é muito provável que, nessas circunstâncias, o condutor aqui referido tenha saído com o veículo do "ponto" da Capital situado, à época, na Praça XV de Novembro e, em certa altura do trajeto - ou até mesmo no próprio ponto de parada dos veículos -, o menor tenha subido no eixo traseiro do carro guiado por Ladislau Opuska, o qual só percebeu a presença de Gentil Lemos ao ter sua atenção chamada por um morador da rua Esteves Júnior que, na ocasião do atropelamento, estava à janela de sua residência.

Não nos é possível afirmar que, durante o trajeto efetuado pelo carro n. 11, havia presença policial responsável pela fiscalização do trânsito de veículos. Há, entretanto, indícios que apontam que a prática efetuada pelo menor Gentil Lemos - sentar "sobre" ou "no" eixo do carro - foi, pelo menos a partir do ano de 1928, legalmente proibida, pois o artigo 34 das Instruções Regulamentares para o serviço de trânsito público estabelece que “[...] Os condutores de veículos

\footnotetext{
${ }^{529}$ Processo n. 62, 03 abr. 1926. Caixa 06.

${ }^{530}$ Idem.

${ }^{531}$ Idem.

${ }^{532}$ Idem.
} 
não deverão permitir que os passageiros viajem nos estribos nem subam ou desçam estando o veículo em movimento" ${ }^{, 533}$. Percebemos que esse artigo indica, muito provavelmente, que tal proibição recaía sobre os usuários de veículos de praça ou de aluguel. Evidenciamos que a textualização de normas que regulamentam tal prática sinaliza, entretanto, que ela já era exercida há, pelo menos, algum tempo, pelos habitantes da capital catarinense, e que, a partir daquele momento, precisou ser regulamentada. Devemos observar, ainda, que há indícios que sugerem que mesmo que o boleeiro do carro de praça aqui referido houvesse se deparado, durante o trajeto, com os agentes fiscalizadores de trânsito, eles, provavelmente, não perceberam a presença do menor sobre o eixo traseiro do carro; pois, como vimos, o condutor só foi alertado sobre tal fato na rua Esteves Júnior, por iniciativa do senhor Antônio Augusto Schorcht. Por outro lado, esses elementos nos permitem inferir que a presença da criança "no eixo do carro" pode, mesmo, ser interpretada como uma prática transgressora das leis e das normas de trânsito vigentes na cidade de Florianópolis, naquele período. Assim, a convivência simultânea, nas décadas de 1920 e 1930, de carros e automóveis - percebemos, nesse período, um crescimento do número de veículos motorizados, em detrimento aos demais, conforme podemos ver, especialmente, na seção Legislação e Circulação: incrementação e complexidade - exige a adoção de novas posturas e regulamentos de trânsito, como forma de atender ou tentar equacionar os problemas postos pela circulação desses veículos, e, especialmente, em face ao crescimento do número de veículos automotores. Constatamos, ainda, que essas medidas entram, naturalmente, em choque com práticas exercidas pela população florianopolitana, exemplificadas, pois, pela presença da referida criança "no eixo do carro" de praça conduzido por Ladislau Opuska.

As falas registradas no presente processo apontam que a atitude da criança, precipitando-se "do lugar em que estava para o lado em que passava o automóvel em questão", ocasionou o seu atropelamento. Esse aspecto é reforçado pelas declarações da testemunha Joaquim Marcelino Coelho, 43 anos, passageiro do automóvel guiado por João Fédrigo, pois afirma que, em determinada altura da rua Esteves Júnior, “encontraram um carro de praça guiado pelo boleeiro Ladislau Opuska e ao cruzar carro e automóvel ${ }^{534}$, saltou inesperadamente do eixo daquele um

\footnotetext{
${ }^{533}$ Santa Catarina. Instruções Regulamentares para o serviço de trânsito público. Florianópolis: Imprensa Oficial, 1928. p. 09. Neste ponto, é importante destacarmos que o Regulamento para o serviço policial do Estado, legislação que, à época, regulamentava a circulação dos veículos pelas estradas e ruas intermunicipais e da capital catarinense não menciona, em quaisquer dos seus artigos, proibições quanto à presença de indivíduos nos eixos dos carros que circulavam pelas vias do perímetro urbano da cidade de Florianópolis. Vimos, entretanto, que, já durante o início da década de 1920, era significativa a implantação de dispositivos e órgãos regulamentares de trânsito, sendo, como visto, o próprio Regulamento para o serviço policial do Estado uma adaptação de legislações de trânsito organizadas, na cidade, desde o final do século XIX.

${ }^{534}$ Percebemos, neste instante, que a testemunha identifica, claramente, carro e automóvel: aquele operado com tração animal; e este movido com tração mecânica. Da mesma forma, os termos boleeiro e chauffeur identificam, respectivamente, os condutores de veículos movidos a tração animal e mecânica, conforme critério estabelecido neste estudo. É válido observarmos que associações aos termos "automóvel” e “"chofer" são, também, feitas junto ao contexto urbano carioca do início do século XX; notadamente por João do Rio na crônica intitulada "COMO SE OUVE A MISSA DO "GALO", datada de 26 de dezembro de 1906. Ver, a respeito: RIO, João do. "COMO SE OUVE A MISSA DO GALO" (Crônica). In: A Alma encantadora das ruas: crônicas. São Paulo: Companhia das Letras, 2008. p 132-139. ((Org.). Raúl Antelo).
} 


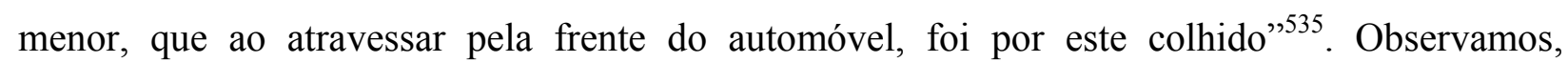
portanto, que o transeunte, alheio ao perigo representado pela circulação do automóvel em questão, salta "inesperadamente do eixo" do carro n. 11; e, "ao atravessar pela frente do automóvel" sofre o atropelamento. Esses elementos nos levam à consideração de que a circulação do automóvel - que é anunciada pelo ronco do motor ou, mesmo, pelo acionamento da buzina - não havia, ainda, ensejado a algumas pessoas - no caso aqui referido, uma criança uma exata "sensibilidade para o perigo" que representava o automóvel. Em vista disso, inferimos que a internalização mental dessa sensibilidade foi, mesmo, elaborada ou construída de maneira progressiva, pois devemos considerar que os florianopolitanos estavam acostumados - pelo menos desde a segunda metade do século XIX - à dinâmica exercida pela circulação dos veículos operados a tração animal, que deslocavam-se de maneira mais lenta e cadenciada.

Práticas como atravessar a rua da maneira exercida pelo menor Gentil Lemos, que não envolvem o procedimento cautelar de olhar para ambos os lados, colocavam em risco a vida dos transeuntes - a vítima faleceu no Hospital de Caridade, no dia seguinte ao atropelamento ${ }^{536}$-, pois são colocados em situação de total desvantagem perante a circulação operada pelos veículos motorizados, ocasião em que se atestam percepções assustadoras em virtude dos choques e atropelamentos por eles causados. Assim, podemos considerar que o ato de sair de casa e circular pelas ruas da cidade é, antes de tudo, um ato cultural, uma vez que inscreve o habitante da urbe em uma rede de sinais sociais que lhe são preexistentes: a circulação dos veículos motorizados, os vizinhos, o esquadrinhamento de ruas e passeios públicos, as lojas e cafés, os lugares que lhe são familiares ou que evocam lembranças passadas, etc ${ }^{537}$.

Desse modo, os indivíduos que vivem, trabalham ou transitam cotidianamente pelas ruas do perímetro urbano da cidade de Florianópolis transformam e vivenciam a urbe. São, portanto, atores e agentes da história, portadores de memórias e desejos próprios ${ }^{538}$. A circulação dos transeuntes - bem como dos passageiros, chauffeurs e boleeiros - pelas ruas da capital

\footnotetext{
${ }^{535}$ Processo n. 62, 03 abr. 1926. Caixa 06. Esses aspectos são, igualmente, referenciados nas declarações prestadas pela testemunha Jesuíno Coelho Pinto, datado de 03 de abril de 1926, pois afirma que João Fédrigo fez a curva da rua 28 de setembro para descer pela rua Esteves Júnior e ao defrontar "o beco dos Franciscanos", encontrou "o carro de praça guiado pelo boleeiro Ladislau Opuska, e ao cruzar o automóvel com o carro surge inesperadamente do eixo deste um menino que ao atravessar a referida rua esbarrou bem em frente do referido automóvel, sendo por este colhido, posto que o chauffeur proprietário do referido automóvel tivesse brecado e feito parar o veículo, não foi possível salvar a criança da imprudência que cometera". (Processo n. 62, 03 abr. 1926. Caixa 06). Da mesma forma, o artigo do jornal $O$ Estado enfatiza a imprudência do menor ao descer inesperadamente do carro em questão, pois observa que "Sábado, à noite, quando o auto n. 46, guiado pelo seu proprietário, João Fédrigo, defrontava com o carro de praça do boleeiro Ladislau Opuska, o menor Gentil Lemos, que ia sentado nas molas do carro, atirou-se ao solo, mas o fez com tanta imprudência que foi alcançado pelo referido auto, sem que ao Sr. Fédrigo fosse dado tempo de evitar o atropelamento. Este fato ocorreu nas imediações da residência do Sr. Dr. Alfredo Araújo, à rua Esteves Júnior, causando espanto o ato inesperado que praticou a pobre vítima, em se atirar do eixo do carro quase às rodas do auto". (O menor Gentil, atropelado por um auto, morre horas depois. O Estado. Florianópolis, 05 abr. 1926). Devemos observar que, em nenhum momento, o artigo menciona reprovação à presença do menor "sentado nas molas do carro", pois o que causou "espanto" foi "o ato inesperado" praticado por Gentil Lemos ao "se atirar do eixo do carro quase às rodas do auto". Esse aspecto é encontrado, também, durante todo o transcorrer do processo. Isso nos sugere, uma vez mais, que a presença de menores no eixo dos carros tracionados por força motriz animal era, mesmo, uma prática comum na época, verificada entre os indivíduos menores de idade. ${ }^{536}$ Processo n. 62, 03 abr. 1926. Caixa 06.

${ }^{537}$ CERTEAU, Michel de; GIARD, Luce; MAYOL, Pierre. A invenção do cotidiano 2: morar, cozinhar. 5. ed. Petrópolis: Vozes, 2003. p. 43.

538 Ver, especialmente, a respeito: BRESCIANI, Maria Stella Martins. A Cidade: objeto de estudo e experiência vivenciada. In: Revista Brasileira de Estudos Urbanos e Regionais. São Paulo: ANPUR, v. 6, n. 2, nov. 2004. p. 9-26.
} 
catarinense constitui, portanto, antes de tudo, uma relação entre os indivíduos e o mundo físico e social que os rodeia ${ }^{539}$. A vivência cotidiana nos meios urbanos suscita, para seus habitantes, lembranças passadas, evocando memórias a respeito de determinado local ou frente a situações experimentadas anteriormente. Os espaços urbanos - vistos para além de sua mera constituição física - alimentam “[...] camadas de memórias fixadas, algumas por monumentos e edifícios espalhados pela cidade"; outras formadas pela maneira pela qual nela se vive, que são transportadas por traços de lembranças históricas, pessoais, "mescladas à escuta e à escrita, aos monumentos e aos costumes" $" 540$. Essas temporalidades diversas constituem cidades ocultas, que são trazidas à tona por meio de percepções e sensações expressas por seus habitantes, diante de determinado cenário ou situação apresentados pelo cotidiano.

Ressaltamos que essas imagens se aproximam à ideia de "vida anterior", expressa por Walter Benjamin que, ao analisar o aspecto urbano de Paris no início do século XX, rememora numa passagem que vale aqui ser retomada - a vida de uma cidade pacata, onde ainda havia "[...] afeição pelas passagens, [e] onde o flâneur escapava ao olhar do veículo, que não tolera a concorrência dos pedestres"; pois naquela época havia "o transeunte que se perde na multidão; mas também havia ainda o flâneur, que precisa de espaço para agir e que não quer privar-se de sua privatização" ${ }^{541}$.

Aprofundando essa discussão, podemos destacar que, conforme salienta Zygmunt Bauman no livro Modernidade Líquida (Rio de Janeiro: Jorge Zahar, 2001), a modernidade chamada, por ele, sólida - referente àquela verificada, especialmente, durante a segunda metade o século XIX e as primeiras décadas do século XX - "[...] era inimiga jurada da contingência, da variedade, da ambigüidade, $[. .$.$] tendo declarado uma guerra santa a todas essas 'anomalias'; e esperava-se que$ a liberdade e a autonomia individuais fossem as primeiras vítimas da cruzada" ${ }^{442}$. Continuando

\footnotetext{
${ }^{539}$ CERTEAU, Michel de; GIARD, Luce; MAYOL, Pierre. A invenção do cotidiano 2: morar, cozinhar... op. cit. p. 43.

${ }^{540}$ BRESCIANI, Maria Stella M. A Cidade: objeto de estudo e experiência vivenciada... op. cit., p. 14.

${ }^{541}$ BENJAMIN, Walter. A Paris do Segundo Império em Baudelaire. In: KOTHE, Flávio R. (Org.). Walter Benjamin: sociologia. 2. ed. São Paulo: Ática, 1991. p. 81. (Col. Grandes Cientistas Sociais, n. 50). Esse esforço de rememoração do passado tem por tarefa, segundo Benjamin, a construção de constelações que ligam o presente ao passado. Essas constelações, esses momentos "arrancados da continuidade histórica vazia, são mônadas, ou seja, são concentrados da totalidade histórica". (LOWY, Michael. Walter Benjamin: aviso de incêndio: uma leitura das teses "Sobre o conceito de história". São Paulo: Boitempo, 2005. p. 131). Outro aspecto importante é a referência à temporalidade vazia, expressa pelo movimento ininterrupto e "vazio" dos relógios (tese XV). Trata-se, pois, do tempo puramente mecânico, automático e quantitativo. Para Benjamin, o tempo histórico não pode ser confundido com o tempo linear e ininterrupto dos relógios. Assim, ele opõe o tempo histórico, permeado pela temporalidade messiânica, ao "infinito temporal vazio" das ideologias do progresso. A concepção de tempo que Benjamin propõe é baseada na tradição messiânica judaica. Para os hebreus, o tempo não é entendido como uma categoria vazia, abstrata e linear, mas inseparável de seu conteúdo. De certa forma, é o conjunto das culturas tradicionais, pré-capitalistas, que guarda em seus calendários e festas, os vestígios da consciência histórica do tempo. Além disso, a revolução é, segundo Benjamin, a tentativa de interromper o tempo vazio e o curso catastrófico do mundo e, nesse sentido, ele esboça sua concepção qualitativa e descontínua do tempo histórico. (LOWY, Michael. Walter Benjamin: aviso de incêndio: uma leitura das teses "Sobre o conceito de história"... op. cit., p. 123-127).

${ }_{542}$ BAUMAN, Zigmunt. Modernidade Líquida. Rio de Janeiro: Jorge Zahar, 2001. p. 33. Neste texto, Bauman discute as principais características do que ele chamou modernidade líquida: ambivalência, quebra das certezas, individualismo extremado, contingências sociais, psicológicas, utilização de recursos - avião, internet, telefone celular -, que, simplesmente, abolem o tempo, onde "a distância em tempo que separa o começo do fim está diminuindo ou mesmo desaparecendo" (p. 137), a anulação do espaço público enquanto elemento para o exercício da política e da cidadania; em contraposição ao que ele também identificou como modernidade sólida; esta característica do século XIX até, pelo menos, a Segunda Guerra Mundial, onde se constata que, de fato, não se cumpriram as promessas aventadas pelas filosofias iluminista (século XVIII) e do progresso (século XIX), que consideraram a razão como elemento capaz de conhecer e dominar a natureza, promover o aperfeiçoamento moral e a emancipação social e política. Vale observar que o livro Modernidade Líquida complementa e conclui a análise realizada pelo autor em Globalização: as conseqüências humanas (Rio de Janeiro: Jorge Zahar, 1999) e Em busca da política (Rio de Janeiro:
} 
seu raciocínio - a partir do qual podemos fazer correlações com as ideias expressas por Walter Benjamim, aqui expostas -, Bauman aponta que, entre “[...] os principais ícones dessa modernidade estavam a fábrica fordista [grifo do autor], que reduzia as atividades humanas a movimentos simples, rotineiros e predeterminados, destinados a serem obedientes e mecanicamente seguidos, sem envolver as faculdades mentais e excluindo toda espontaneidade e iniciativa individual" ${ }^{\circ 43}$.

É precisamente contra essas ideias que Walter Benjamin interpreta, como vimos, a "vida anterior", evocada por Baudelaire, como uma referência a uma era primitiva e edênica, em que “[...] a experiência autêntica ainda existia e as cerimônias do culto e as festividades permitiam a fusão do passado individual com o passado coletivo" ${ }^{\text {"544 }}$. Essa noção de experiência não corresponde ao cenário das grandes cidades, caracteristicamente agitado e catastrófico; pois, dentre outros fatores, "as relações entre os seres humanos nas cidades grandes [...] são caracterizadas por uma preponderância da atividade da visão sobre a da audição" ${ }^{545}$.

Walter Benjamin foi um profundo leitor e conhecedor dos escritos de Baudelaire. Assim, podemos fazer uma correlação com as ideias expressas pelo escritor francês ao observarmos, por exemplo, que o poema $O$ gosto do nada, que integra o livro As flores do mal, registra a seguinte frase: "A adorável Primavera já perdeu seu odor!"546. Acerca dessa passagem, podemos destacar que o desmoronamento da experiência que Baudelaire havia compartilhado é confessado na palavra perdeu. O odor é o refúgio inacessível da mémoire involontaire ${ }^{547}$; não há, portanto, nenhum consolo para quem não pode mais fazer qualquer experiência no mundo moderno, agitado por ritmos e velocidades que estão em descompasso com a cadência natural da vivência humana. Nesse sentido, podemos referenciar as ideias de Walter Benjamin que se contrapõe, nitidamente, ao ritmo acelerado e incessante verificado no cotidiano das grandes cidades europeias no final do século XIX, sobretudo ao referir-se a capital francesa. Assim, Benjamin

Jorge Zahar, 2000). Juntos, esses escritos formam uma profícua análise das condições cambiantes da vida social e política, verificadas na atualidade.

${ }^{543}$ BAUMAN, Zigmunt. Modernidade Líquida. Rio de Janeiro: Jorge Zahar, 2001. p. 33-34. Outras considerações a respeito do que se convencionou chamar "Fordismo" são apontadas por José Luiz Vieira no livro A história do automóvel: a evolução da mobilidade (2008), pois considera que "Em 1. ${ }^{\circ}$ de outubro de 1908, é lançado o Ford Modelo T, o carro que dá rodas ao mundo. Sua produção é iniciada na fábrica de Piquette Avenue, em Detroit. Quase cem anos depois, o Ford T é eleito o 'carro do século XX'. Bem elaborado, de altíssima confiabilidade, fácil de dirigir, de fabricação viável, e com preço acessível, o Ford T conquistou o mundo. Alguns anos depois, foi com a fabricação desse carro que Henry Ford implantou seu sistema de produção em massa, chamado depois de Fordismo, e que possibilitou às pessoas realmente sentirem o que era poder ter e dirigir um automóvel”. (VIEIRA, José Luiz. A história do automóvel: a evolução da mobilidade. São Paulo: Alaúde Editorial, 2008. (v. 1. da Pré-história a 1908). p. 415. Sobre essas considerações tem-se que a consolidação da produção do Ford Modelo T foi conseguida não sem antes haver disputas ideológicas e operacionais com industriais norte-americanos que divergiam da concepção funcional pensada por Ford para os seus automóveis. (VIEIRA, José Luiz. A história do automóvel: a evolução da mobilidade... op. cit., p. 344-345). Além disso, a cidade de Detroit converteu-se, gradualmente, no centro aglutinador da indústria automobilística norte-americana, pois serve de palco para, ao menos, outras duas concorrentes: General Motors e Chrysler.

${ }^{544}$ LOWY, Michael. Walter Benjamin: aviso de incêndio: uma leitura das teses "Sobre o conceito de história"... op. cit., p. 29.

${ }^{545}$ BENJAMIN, Walter. O Flâneur. In: 2000. v. 3. p. 207. (Obras Escolhidas).

${ }^{546}$ BAUDELAIRE, Charles. Poema "LXXXIII - O gosto do nada". In: Charles Baudelaire: um lírico no auge do capitalismo. 2. ${ }^{a}$ reimpressão. São Paulo: Brasiliense, Obra Prima de Cada Autor, n. 52).

${ }^{547}$ Conforme Walter Benjamin: "Se chamarmos de aura às imagens que, sediadas na mémoire involontaire, tendem a se agrupar em torno de um objeto de percepção, então esta aura corresponde à própria experiência que se cristaliza em um objeto de uso sob a forma de exercício. (BENJAMIN, Walter. Sobre alguns temas em Baudelaire. In: Charles Baudelaire: um lírico no auge do capitalismo... op. cit., p. 137). 
trabalha com a ideia de que a "[...] embriaguez anamnéstica em que vagueia o flâneur pela cidade não se nutre apenas daquilo que, sensorialmente, lhe atinge o olhar, pois com freqüência também se apossa do simples saber, ou seja, de dados mortos, como de algo experimentado e vivido" 548 .

De outro modo, podemos ver que o flâneur é o personagem que, por um lado, assume a postura de um homem que se sente olhado por tudo e por todos; e, por outro, é aquele indivíduo que é totalmente insondável, escondido; pois se "[...] a flaneire pode transformar toda a Paris num interior, numa moradia cujos aposentos são os quarteirões, não divididos nitidamente por soleiras como os aposentos de verdade, por outro lado, também a cidade pode abrir-se diante do transeunte como uma paisagem sem soleiras", uma vez que, para o "perfeito flâneur, é um prazer imenso decidir morar na massa, no ondulante... Estar fora de casa; e, no entanto, se sentir em casa em toda a parte [...] são alguns dos menores prazeres desses espíritos independentes, apaixonados, imparciais (!) que a língua só pode definir inabilmente”, onde o "observador é um príncipe que, por toda a parte, usufrui de seu incógnito" "549. É essa, provavelmente, a dinâmica que $O$ homem na multidão - texto de Edgard Allan Poe - igualmente desenvolve ${ }^{550}$.

Destacamos que, para os efeitos deste estudo, a cidade de Florianópolis pode, igualmente, ser tomada como palco de inúmeras sensibilidades e atitudes cotidianas, expressas por seus habitantes, que, no conjunto da urbe, vão trilhando caminhos e itinerários próprios, evocados por percepções sensoriais que identificam e comunicam outros tempos e cidades dentro das ordenações legal e predial vigentes. As ruas são, portanto, a morada do coletivo, que se constitui como "[...] um ser eternamente inquieto e agitado, que, entre os muros dos prédios, vive, experimenta e reconhece tanto quanto os indivíduos ao abrigo de suas quatro paredes" ${ }^{\text {551. }}$.

$\mathrm{Na}$ década de 1930, as ocorrências de atropelamentos e colisões continuaram se processando pelas ruas do perímetro urbano da cidade de Florianópolis. A esse respeito, vimos que a análise dos processos criminais evidencia que a circulação dos transeuntes não está inteiramente submetida à influência dos automóveis; pois, como os indivíduos estão conscientes de seus atos, imprimem atitudes e práticas, disponibilizadas por suas capacidades físicas, direcionadas ao esquivo ou fuga diante da circulação automobilística. Os processos analisados esclarecem, igualmente, que não eram obedecidas as disposições regulamentares de trânsito com alguma frequência; e, além disso, percebemos que as ruas são, progressivamente, transformadas em espaço para a circulação exclusiva de carros e automóveis. Assim, no ano de 1928, o artigo

\footnotetext{
${ }^{548}$ BENJAMIN, Walter. O Flâneur. In: 2000. v. 3. p. 186. (Obras Escolhidas).

${ }^{549}$ Ibidem, p. 192 e p. 221.

${ }^{550}$ Ver POE, Edgard Allan. O homem na multidão. Disponível em: < http://www.alfredo-braga.pro.br/biblioteca/homemnamultidao.html>.

${ }^{551}$ BENJAMIN, Walter. O Flâneur. In:

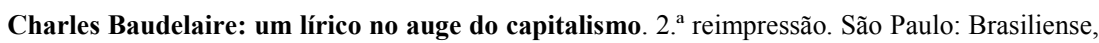
. Charles Baudelaire: um lírico no auge do capitalismo... op. cit., p. 194.
} 
58 das Instruções Regulamentares para o serviço de trânsito público esclarece que “[...] Os pedestres devem evitar caminhar pelo centro das ruas, lugar de preferência destinado a veículos" ${ }^{, 52}$. Neste ponto, é importante esclarecermos que essa determinação não é encontrada em quaisquer das principais leis ou regulamentações policiais e de trânsito, baixadas nos anos anteriores. Isso constitui um indício de que o ato de "caminhar pelo centro das ruas" era, mesmo, uma prática comum dos florianopolitanos.

Devemos considerar, também, que a cidade de Florianópolis ostentava, durante as décadas de 1920 e 1930, cenários urbano e populacional pouco ou razoavelmente adensados; pois, no ano de 1920, a cidade contava, por exemplo, com aproximadamente 41.338 habitantes ${ }^{553}$. Nesses espaços, encontramos, com maior facilidade, práticas e atitudes, como aquelas registradas no artigo supracitado. Além disso, o Decreto n. 2075, de 28 de junho de 1927, que baixa as instruções de trânsito aqui referidas, assinala, como visto, a "necessidade urgente de regulamentar-se o serviço de veículos" ${ }^{554}$. Esse elemento sugere-nos que a circulação de carros e de automóveis, especialmente no perímetro urbano da capital catarinense, exigia, naquele período - tendo em vista seu progressivo adensamento -, uma fiscalização mais incisiva dos poderes públicos municipal e estadual, que implicou maior controle ou mesmo a proibição de práticas contrárias ao livre fluxo de carros e de automóveis pelas ruas da capital catarinense; locais preferencialmente destinados ao deslocamento desses veículos.

No início da década de 1930, o processo n. 173, de 20 de agosto de 1931, registra o atropelamento do transeunte Ernesto Carlos Bayerstoff na rua Silva Jardim, provocado pelo choque com o automóvel n. 219 "do ponto desta Capital, guiado pelo chauffeur de nome João Jesuíno de Souza"555. O "Termo de declarações" prestado pela vítima, datado de 20 de agosto de 1931, esclarece que, “ontem, às dezenove horas, mais ou menos, caminhava pela rua Silva Jardim, em direção à sua residência, quando nas imediações do Hospital Militar, corria em sentido inverso um automóvel de praça cuja luz intensa de seus faróis o deixou perturbado"; e, desse modo, "sem poder defender-se do citado automóvel, pelo motivo exposto e pelo zig-zag que o mesmo fazia, foi alcançado por este que o jogou por terra sem sentidos", e que "quase ao ser alcançado pelo citado automóvel tem lembrança que o mesmo, já de faróis apagados, muito

\footnotetext{
${ }^{552}$ Santa Catarina. Instruções Regulamentares para o serviço de trânsito público. Florianópolis: Imprensa Oficial, 1928. p. 13.

${ }^{553}$ Diretoria Geral de Estatística. Recenseamento do Brasil. Rio de Janeiro, v. IV, 1 set. 1920, 1926. Em 1928, Florianópolis apresentava uma população de, aproximadamente, 60.300 habitantes. (Santa Catarina. Relatório apresentado ao Exm. ${ }^{\circ}$ Sr. Dr. Adolfo Konder, Governador do Estado, pelo Dr. Cid Campos, Secretário do Interior e Justiça, em 24 de maio de 1928. Florianópolis: Tip. São José, 1928).

${ }^{554}$ Decreto 2075. Aprova as Instruções para a Inspetoria de Veículos. Palácio do Governo. Florianópolis, 28 jun. 1927. Essa necessidade foi, também, apontada pelo relatório assinado pelo Secretário do Interior e Justiça, Cid Campos, encaminhado ao Governador do Estado, no ano de 1927. Dentre outros aspectos, diz esse relatório que a Chefatura da Polícia da Capital "sugere, entre outros assuntos de suma necessidade", a "Regulamentação do trânsito público", e esclarece que "o movimento urbano de Florianópolis tem aumentado consideravelmente nestes últimos anos" e novas "instruções melhorarão" os "serviços de polícia urbana, valendo-se do que se fez em São Paulo e do que consegui observar aqui". (Santa Catarina. Relatório apresentado ao Ex. ${ }^{\text {mo }}$ Sr. Dr. Adolfo Konder, Governador do Estado pelo Dr. Cid Campos, Secretário do Interior e Justiça em 24 de Agosto de 1927. Florianópolis: Of. Gráficas da Escola de Aprendizes Artífices, 1927. p. 2 e p. 55 ).

${ }^{555}$ Processo n. 173, 20 ago. 1931. Caixa 17.
} 
concorreu para que ele depoente pudesse fugir do perigo iminente" ${ }^{\text {,556 }}$. (Anexo 12, p. 343). As declarações prestadas pela vítima registram, igualmente, que "ainda à distância do local onde se dera o acidente, pôde verificar que o automóvel que o atropelou vinha desenvolvendo excessiva velocidade, aproveitando com certeza o bom trecho da rua ora conservada"557.

As informações registradas pela vítima expõem aspectos importantes. Percebemos, claramente, que a circulação do automóvel torna-se preferencial e preponderante à circulação dos transeuntes, pois eles são obrigados a obedecer a seu ritmo de deslocamento. Assim, a preferência concedia ao transporte motorizado, no Estado de Santa Catarina e, especialmente, na cidade de Florianópolis, torna-se evidente ao destacarmos que o trecho da rua onde ocorreu o sinistro se encontrava conservado, o que nos sugere que iniciativas municipais e estaduais eram colocadas em prática para oferecer condições adequadas ao tráfego de veículos motorizados, especialmente nas ruas circunscritas ao perímetro urbano da capital catarinense, uma vez que recebiam maior atenção da administração municipal, em detrimento das ruas e estradas que percorriam distritos e áreas limítrofes ao cenário urbano.

Nesse sentido, é importante assinalarmos que o processo em discussão ocorreu no ano de 1931. A desativação completa do serviço de bondes da cidade de Florianópolis ocorreu na década de 1930, pois há apontamentos que indicam que bondes e linhas trafegáveis por esses veículos desapareceram da capital catarinense já em $1936^{558}$. Além disso, de acordo com o artigo do jornal $O$ Estado, de 10 de janeiro de 1925, “Afinal, a nossa capital vai ter o desejado serviço de viação elétrica, há muito reclamado pelo povo" $" 559$. Esclarecemos ao leitor que o processo de eletrificação das linhas de bonde não se concretizou, pois, até sua desativação completa, ocorrida na década de 1930, esse meio de transporte efetuou-se por tração animal. Podemos, desse modo, asseverar que a década de 1930 assinala o período em que se observa a gradativa extinção da circulação de veículos e carros não motorizados - já durante o final da década de 1920, verificamos, na imprensa local, registros de manifestação contrária à manutenção da circulação dos bondes puxados a burros e dos trilhos por eles carroçáveis (maiores detalhes a respeito são encontrados no quinto capítulo da tese) - e, a partir desse momento, as ações governamentais relativas ao tráfego são centradas no atendimento ao fluxo de veículos automotores.

O tráfego de veículos motorizados pelas ruas da cidade de Florianópolis exigia atenção e reflexos rápidos dos transeuntes que, a todo o momento, viam-se diante do ritmo ditado pelos automóveis. A atenção que os transeuntes despendiam para atravessar ruas e observar a

\footnotetext{
${ }^{556}$ Processo n. 173, 20 ago. 1931. Caixa 17. A rua Silva Jardim oferece acesso principal aos hospitais Militar e Caridade. Integra, atualmente, os bairros Prainha e José Mendes. Veremos, a seguir, que o trecho da referida rua onde ocorreu o sinistro em questão, fazia parte, à época, do perímetro urbano da cidade de Florianópolis.

${ }_{557}^{5}$ Processo n. 173, 20 ago. 1931. Caixa 17.

${ }^{558}$ Anuário Estatístico do Brasil, ano III, Rio de Janeiro, 1937. p. 291.

559 Os bondes de Florianópolis. O Estado. Florianópolis, 10 jan. 1925. p. 5.
} 
passagem ou deslocamento dos veículos não era, porém, em algumas situações, suficiente para evitar atropelamentos; pois, no processo em questão, a vítima esclarece que "ainda à distância do local onde se dera o acidente, pôde verificar que o automóvel que o atropelou vinha desenvolvendo excessiva velocidade ${ }^{560}$, aproveitando com certeza o bom trecho da rua ora conservada". Assim, apesar de observar o deslocamento do automóvel n. 219, Ernesto Carlos Bayerstoff foi por ele atropelado - devido, entre outros fatores, à "excessiva velocidade que desenvolvia". Vimos, em passagens anteriores deste texto, que as altas velocidades que os chauffeurs imprimiam aos automóveis foi um aspecto significativamente presente no cotidiano da cidade de Florianópolis. O episódio verificado no presente processo, que aponta, dentre outros fatores, a velocidade de deslocamento do automóvel n. 219 como elemento que contribuiu para o atropelamento da vítima em questão, corrobora com o fato de que as altas velocidades atingidas pelos automóveis e o modo, muitas vezes, impetuoso com que os chauffeurs costumavam guiálos contribuíram, de maneira evidente, para as ocorrências de atropelamentos e colisões verificadas nas vias públicas da capital catarinense e assinalam que as ruas são destinadas, preferencialmente, ao tráfego de veículos automotores.

Outro aspecto que podemos discutir com base nos elementos registrados pelas declarações da vítima é o fato de que, para os efeitos deste estudo, os pedestres e chauffeurs podem ser considerados produtores desconhecidos do espaço urbano. Em vista disso, destacamos que eles operam e inventam trilhas nas selvas da racionalidade funcionalista ${ }^{561}$, ou seja, esses personagens traçam trajetórias indeterminadas, aparentemente desprovidas de sentido porque não são, em muitas ocasiões, coerentes com o espaço construído, escrito e preordenado onde se movimentam ${ }^{562}$. Assim, embora os pedestres e chauffeurs devam obedecer às normas e aos ditames traçados pelas legislações de trânsito locais, eles operam, frequentemente, trilhas heterogêneas que os permitem infiltrar-se dentro das regras e códigos de circulação preestabelecidos pelos poderes. Esboçam, desse modo, astúcias, interesses e comportamentos diversos, não contidos pelos saberes normativos em voga ${ }^{563}$. Vimos, portanto, que transeuntes e

\footnotetext{
${ }^{560}$ De acordo com as palavras prestadas por João Jesuíno de Souza, condutor do veículo n. 219, datadas de 20 de agosto de 1931 , o referido automóvel vinha "sob a sua direção, desenvolvendo a velocidade de trinta quilômetros à hora, mais ou menos". É possível inferirmos que a velocidade atingida pelo veículo em questão, conforme mencionada, era elevada para os padrões da época - embora o próprio acusado, nesse depoimento, tenha afirmado que "o automóvel trazia marcha reduzida". (Processo n. 173, 20 ago. 1931. Caixa 17). Não nos cabe tirar conclusões sobre quão rápido se deslocava o referido automóvel. A testemunha Celso Silveira de Souza, 31 anos, em fala prestada no dia 21 de agosto de 1931, observa, todavia, que "anteontem, às dezenove horas, mais ou menos, quando transitava pela rua Silva Jardim, em demanda à sua residência, viu passar por ele um automóvel marca Ford, desenvolvendo velocidade mais do que a permitida; que por esse motivo a sua atenção voltou-se para o dito veículo; que ao aproximar-se das imediações do Hospital Militar, notou que o mesmo se havia chocado à alguma coisa, e que apagando os faróis, sem diminuir a velocidade, tomou o rumo do Beco Loureiro, perdendo, ele depoente, de vista o citado veículo". (Processo n. 173, 20 ago. 1931. Caixa 17). A par do fato de que as suas declarações foram, provavelmente, instruídas por advogados, vale assinalarmos que a velocidade de "trinta quilômetros à hora", mencionada no depoimento do acusado, é superior, portanto, ao limite de vinte quilômetros horários, estipulado pelo artigo 36 das Instruções Regulamentares para o serviço de trânsito público, para os veículos motorizados. Ver Santa Catarina. Instruções Regulamentares para o serviço de trânsito público. Florianópolis: Imprensa Oficial, 1928. p. 10.

${ }^{561}$ CERTEAU, Michel de. A invenção do cotidiano 1: artes de fazer. 8. ed. Petrópolis: Vozes, 2002. p. 97.

${ }^{562}$ Idem.

${ }^{563} \mathrm{Idem}$
} 
chauffeurs utilizam-se de táticas para evitar sinistros, uma vez que operam simultaneamente, atitudes e trilhas que atestam a adaptabilidade às situações circunstanciais e adversas que ocorriam nos encontros cotidianos efetuados entre pedestres e automóveis pelas ruas do perímetro urbano da cidade de Florianópolis.

De outro modo, podemos pensar que as trilhas heterogêneas esboçadas pelos chauffeurs e pedestres não se tratam, exatamente, de um líquido circulando nos dispositivos do sólido, mas de movimentos diferentes, que utilizam os próprios elementos do terreno disciplinar e edificado. Além disso, notamos que as estatísticas apenas se contentam em classificar e tabular esses elementos e o fazem com categorias e segundo taxinomias conforme às da produção intelectual ou administrativa. Elas só captam, por isso, o material utilizado pelas práticas de consumo e não a formalidade própria dessas práticas, seu movimento astucioso, circunstancial e imprevisível ${ }^{564}$.

A declaração prestada pela testemunha João Antero de Freitas, no dia 20 de agosto de 1931, registra, igualmente, aspectos importantes sobre o ocorrido, pois “ontem às dezoito horas, mais ou menos, partiu desta Capital em seu automóvel de n. 219, em companhia de seus colegas de nomes João Jesuíno, vulgo Joca, e Mário Amorim, conduzindo um aparelho de agrimenssura a fim de entregá-lo ao senhor José Miranda" 565 . O declarante também esclarece que "o referido automóvel era guiado desde a partida desta Capital e do seu regresso ao Saco dos Limões pelo citado chauffeur João Jesuíno"; e que, "na rua Silva Jardim, já de volta à Capital, nas imediações do Hospital Militar, embora o citado automóvel trouxesse marcha reduzida, encontrou um indivíduo que foi alcançado pela parte traseira do veículo em apreço"566. Naquele momento, verificando "achar-se de pé o aludido indivíduo, julgaram os que vinham no automóvel que nada de anormal tivesse acontecido ao mesmo, motivo pelo qual continuaram o caminho"567. Declarou, ainda, que "Em seguida recolheu à respectiva garagem o seu automóvel, tendo ele depoente ficado em sua casa e João Jesuíno e Mário Amorim tomado a direção da Praça XV de Novembro"568. João Antero de Freitas afirma, também, que "mais tarde dirigiu-se ao distrito de João Pessoa e quando da sua volta, veio a saber que o indivíduo que fora encontrado nas imediações do Hospital Militar é quem antes lhe parecera nada ter sofrido com a derrapagem do seu automóvel no citado lugar, mas achava-se ferido e recolhido ao Hospital de Caridade"569.

Essas passagens assinalam aspectos importantes. Em primeiro lugar, é válido registrarmos que o automóvel n. 219, de praça, estava sendo utilizado para atender a interesses particulares, pois conduzia "um aparelho de agrimenssura" para ser entregue "ao senhor José Miranda”. Outro

\footnotetext{
${ }^{564}$ CERTEAU, Michel de. A invenção do cotidiano 1: artes de fazer. 8. ed. Petrópolis: Vozes, 2002. p. 98.

${ }^{565}$ Processo n. 173, 20 ago. 1931. Caixa 17.

${ }^{566}$ Idem.

${ }^{567}$ Idem.

${ }^{568}$ Idem.

${ }^{569}$ Idem.
} 
aspecto importante é o fato de que o trecho da referida rua, onde ocorreu o sinistro em questão, fazia parte, à época, do perímetro urbano da cidade de Florianópolis, conforme aponta a declaração prestada pela testemunha, João Antero de Freitas ${ }^{570}$. Assim, a região da rua Silva Jardim, que se localiza "nas imediações do Hospital Militar"571, integra a capital catarinense. Devemos lembrar, também, que a vítima, Ernesto Carlos Bayerstoff, assinala, em declarações prestadas no dia 20 de agosto de 1931, que "o automóvel que o atropelou vinha desenvolvendo excessiva velocidade, aproveitando com certeza o bom trecho da rua ora conservada"572. Em vista disso, assinalamos, uma vez mais, que as ruas do perímetro urbano da capital catarinense recebiam atenção dos poderes públicos estadual e municipal para que fossem conservadas para oferecer, dentre outros aspectos, boas condições ao tráfego de veículos motorizados ${ }^{573}$.

Discussões sobre a velocidade de deslocamento do automóvel n. 219 já foram tecidas por nós em momentos anteriores deste texto. Salientamos, entretanto, que a fala prestada por João Antero de Freitas, no dia 20 de agosto de 1931, evidencia, também, que o seu automóvel foi recolhido "à respectiva garagem”. Nesse sentido, observamos que as garagens eram elementos que, já há algum tempo, compunham o cenário urbano da capital catarinense. Vimos, no capítulo anterior, que, durante a década de 1920, novos elementos - automóveis e garagens - estavam começando a fazer parte do cenário urbano de Florianópolis, conforme registra o artigo 126 do Regulamento para o serviço policial do Estado. Nele, é mencionado que “[...] Os carros ou automóveis de aluguel em cocheira ou garagem e os particulares, dispensados da numeração externa, terão além de um algarismo interiormente colocado, distintivos especiais de tamanho nunca inferior de cinco centímetros, na parte lateral externa da caixa ou nas portinholas"574. Destacamos esse artigo, pois ele referencia que os veículos de aluguel eram, além de outros locais, acondicionados "em cocheira ou garagem". Assim, parece-nos plausível especular que as garagens atenderam, em primeira mão, aos carros e automóveis de praça ou de aluguel e que somente em momento posterior foram adaptadas nas casas e moradias particulares. Veremos, a seguir, na seção Legislação e Circulação: incrementação e complexidade, ocasiões em que as moradias contemplam garagens para o acondicionamento de veículos particulares.

$\mathrm{Na}$ situação do presente processo, destacamos, contudo, que nos é dada a impressão de que o automóvel n. 219 foi acondicionado em sua respectiva vaga, no estacionamento dos veículos de praça, situado próximo ao ponto desses veículos - localizado à Praça XV de Novembro -,

\footnotetext{
${ }^{570}$ Processo n. 173, 20 ago. 1931. Caixa 17.

${ }^{571}$ Idem.

${ }^{572}$ Idem.

${ }^{573}$ Além disso, Mário Amorim, passageiro do automóvel n. 219, afirma, em declaração prestada no dia 16 de novembro de 1931 , que, "no ponto onde se deu o atropelamento, a rua era muito larga, tendo, talvez, de 10 a 12 metros [de largura]". (Processo n. 173, 20 ago. 1931. Caixa 17). Assim, podemos considerar que a rua Silva Jardim constituía, à época, uma importante via para o escoamento do tráfego de veículos na capital catarinense, o que nos ajuda a compreender porque o trecho dessa rua, onde ocorreu o sinistro, achava-se conservado naquele momento.

${ }^{574}$ Santa Catarina. Regulamento para o serviço policial do Estado. Florianópolis: Tipografia da Livraria Central, 1920.
} 
pois as declarações prestadas pelo acusado João Jesuíno de Souza, no dia 20 de agosto de 1931, observam que "do lugar onde se dera o acidente, seguiu diretamente para a garagem, onde guardou o automóvel, dirigindo-se, então, à Praça XV de Novembro e daí à sua residência",575. Inferimos, portanto, que os veículos de praça ou de aluguel dispunham, ainda na década de 1930, de garagens para o seu melhor acondicionamento. De qualquer forma, é importante considerarmos que os abrigos para antigas charretes ou outras conduções movidas a tração animal foram, gradativamente, substituídas pelas garagens, destinadas, preferencialmente, num primeiro momento, ao acondicionamento dos automóveis de praça, de aluguel ou instaladas, em época posterior, como parte integrante das empresas de transporte coletivo que, a partir das décadas de 1930 e 1940, apresentaram maior diversificação e disponibilizaram maior número de horários para a circulação dos veículos.

A esse respeito, o Guia do Estado de Santa Catarina, datado de 1937, aponta que, naquele ano, existiam diversas empresas e linhas de ônibus que atendiam à população residente na Ilha e em cidades como São José, Palhoça, Santo Amaro, Tijucas, localizadas no Continente, próximas à cidade de Florianópolis ${ }^{576}$. O documento salienta, ainda, que as diversas linhas que atendiam a essas localidades ofereciam vários horários de chegada e de saída de veículos. Como exemplo, destacamos que a empresa “Auto-Viação Florianópolis" dispunha das seguintes linhas e horários para atender às principais ruas do perímetro urbano da capital catarinense:

Empresa Auto-Viação Florianópolis: 1) Linha Circular, percorrendo as seguintes ruas: Praça XV de Novembro, Fernando Machado, Avenida Hercílio Luz, José Veiga [Av. Mauro Ramos], Blumenau [rua Victor Konder], Avenida Trompowsky, Bocaíuva, Esteves Júnior, Álvaro de Carvalho, Felipe Schmidt e Praça XV de Novembro. Horário de 20 em 20 m. Preço: 400 rs; 2) Linha Agronômica: de $1 / 2$ em 1/2 hora. Preço: 300 rs; 3) Linha Saco dos Limões: de 1/2 em 1/2 hora. Preço: 500 rs ${ }^{577}$.

A diversidade de linhas e de horários, apresentada na citação acima, não é encontrada na década de 1920, pois, em maio de 1926, o artigo do jornal O Estado registra as linhas de ônibus e as respectivas taxas de passagem organizadas pela "Empresa Catarinense de auto-ônibus" e aponta que essa empresa oferecia, entre as localidades de Florianópolis e Palhoça, apenas “3 viagens ao dia" ${ }^{578}$. Notamos, portanto, que o serviço de transporte coletivo foi incrementado de maneira gradual, apresentando, já na década de 1930, diversas linhas e horários para atender à população residente na Ilha e no Continente; aspecto este que justifica, perfeitamente, a implementação, naquela época, de garagens para o melhor acondicionamento dos ônibus e de outros veículos destinados ao transporte coletivo.

\footnotetext{
${ }_{575}^{575}$ Processo n. 173, 20 ago. 1931. Caixa 17.

${ }^{576}$ Guia do Estado de Santa Catarina: Suplemento para o ano de 1937. Florianópolis: Livraria Central de Alberto Entres, 1937.

${ }^{577}$ Idem.

${ }^{578}$ Empresa Catarinense de Auto-ônibus. O Estado, 31 maio 1926. p. 5. Como elemento comparativo, destacamos que, no ano de 1937, a empresa "Zacchi \& Filhos" efetuava a linha Palhoça - Florianópolis e dispunha, para tal, dos seguintes horários: "Horário: desce às 6:30 - 8:00 10:10 - 11:30 - 13:30 - 15:30 - 16:30 e 18 horas; volta às 8:30 - 10:10 - 11:45 - 13:00 - 15:00 - 17:00 - 18:00 e 21:30 horas". Guia do Estado de Santa Catarina: Suplemento para o ano de 1937. Florianópolis: Livraria Central de Alberto Entres, 1937. Notamos, portanto, que, entre os anos de 1926 e 1937, houve, para uma mesma localidade, um aumento considerável do número de horários de circulação dos coletivos.
} 
Retomando a análise do processo n. 173, destacamos que outro aspecto que deve ser enfatizado, nas declarações prestadas por João Antero de Freitas, corresponde ao fato de que, em momento posterior ao sinistro, ele "veio a saber que o indivíduo que foi encontrado nas imediações do Hospital Militar" é quem se encontrava no Hospital de Caridade, vítima do atropelamento que sofreu com a investida do seu automóvel. Entendemos que esse aspecto é um importante indício que atesta que, durante as décadas de 1920 e 1930, a cidade de Florianópolis ostentava cenários populacional e predial com pouca, ou razoável densidade, pois se configurava como uma cidade provinciana, onde, um dia após a ocorrência do sinistro em questão, o acusado reconhece a vítima, internada num dos principais hospitais da cidade. Para reforçar esses comentários, a testemunha Mário Amorim, passageiro do automóvel n. 219, em depoimento prestado no dia 20 de agosto de 1931, considera, a respeito da vítima, que "só hoje soube tratarse de um indivíduo seu conhecido de vista e empregado na Casa Comercial do Senhor Carlos Meyer e que se encontrava em tratamento no Hospital de Caridade" ${ }^{\text {"579. }}$.

Essas declarações apontam que, no início da década de 1930, os habitantes da cidade de Florianópolis reconheciam-se uns aos outros, e que, nas ruas da cidade, operavam-se encontros diários entre as mesmas pessoas. Elas conheciam, inclusive, a dinâmica cotidiana da cidade e identificavam estabelecimentos comerciais e seus respectivos proprietários. É claro que o conhecimento dessa dinâmica não se aplicava para a totalidade de sua população, mas o encontro de pessoas conhecidas, nas ruas ou mesmo em locais públicos, parecia, em especial, ser uma prática bastante comum, verificada também em épocas passadas, haja vista as modestas dimensões populacional, urbanística e predial da capital catarinense no período em estudo.

Neste ponto, podemos tomar as ruas do espaço central da capital catarinense como palco onde seus usuários cotidianos sentiam-se, via de regra, reconhecidos. Tendo isso em vista, podemos apreender o núcleo urbano como uma “[...] porção do espaço público em geral”, em que se insinua "um espaço privado particularizado pelo fato do uso quase cotidiano deste espaço"; onde "os processos de reconhecimento - de identificação - se estabelecem graças à proximidade, graças à coexistência concreta em um mesmo território urbano; e todos esses elementos 'práticos' se nos oferecem como imensos campos de exploração em vista de compreender um pouco melhor esta grande desconhecida que é a vida cotidiana" ${ }^{\text {580 }}$. Assim, concebemos que o resgate do passado de uma cidade implica lidar com vários tempos: o da cidade que se vê e aquela oculta e esquecida; o tempo da cidade que se quer, das utopias, das sensações cotidianas e dos projetos arquitetônicos e paisagísticos não realizados, e o da cidade

\footnotetext{
${ }^{579}$ Processo n. 173, 20 ago. 1931. Caixa 17.

${ }^{580}$ CERTEAU, Michel de; GIARD, Luce; MAYOL, Pierre. A invenção do cotidiano 2: morar, cozinhar. 5. ed. Petrópolis: Vozes, 2003. p. 40.
} 
que se tem, resultante de fracassos e vitórias ${ }^{581}$ que colocam em choque visões políticas e conceituais contraditórias sobre um mesmo aspecto. Desses tempos, o centro ou perímetro urbano encerra, de modo especial, um microcosmo do tempo que passou ${ }^{582}$, que apenas pode ser visualizado ao analisarmos textos e documentos específicos sobre determinada área ou região; procedimento que se opera neste estudo, em vista da análise dos processos criminais sobre atropelamentos e colisões verificados no perímetro urbano da capital catarinense, durante as décadas de 1920 e 1930, alvos centrais de investigação neste estudo.

No ano de 1932, o processo n. 194, de 21 de novembro, registra o atropelamento dos menores Manoel Navegantes Rodrigues, doze anos de idade, e Joaquim Donato Coelho, onze anos, "na praça Etelvina Luz, esquina da rua Demétrio Ribeiro" ${ }^{, 583}$. O atropelamento foi causado, segundo apontado no processo, pelo chauffeur Herbert Molenda que, naquela ocasião, guiava a baratinha n. $24 \mathrm{P}^{584}$. O "Termo de declarações" prestado pelo acusado, datado de 23 de novembro, registra que, "no dia 21, às dezessete e meia horas, [ia] na direção da barata n. 24, de sua propriedade, trazendo ao seu lado o chauffeur profissional Alberto Ebert, residente à rua José Veiga" ${ }^{285}$. O declarante afirma, em outro ponto de suas declarações, que "estava praticando para obter a sua carta; que vinha de regresso à sua casa" e que, "quando quis fazer o auto dar volta no canto da rua Blumenau, praça Etelvina Luz, para tomar pela rua José Veiga, a barata apanhou dois rapazes que brincavam perto da casa que foi de Manoel Simões"586. (Anexo 13, p. 344).

Essas colocações apontam aspectos importantes. A barata n. 24 é, por exemplo, de propriedade do seu condutor, Herbert Molenda. Esse personagem ostenta, com certeza, boa condição financeira, pois ele "estava praticando para obter a sua carta" e trazia, a seu lado, o chauffeur profissional Alberto Ebert. Em vista disso, podemos afirmar que o condutor do veículo contava com o auxílio de alguém experiente para ensinar-lhe a dirigir automóvel; e, além disso, é importante destacarmos que Herbert Molenda era "natural da Áustria, com 34 anos de idade, casado, empregado no comércio, residente à rua Esteves Júnior" ${ }^{\circledR 587}$. Dado o exposto, podemos verificar que, no ano de 1932, havia pessoas de relativa idade - faixa etária entre 30 e 40 anos que ainda estavam aprendendo a guiar veículos motorizados e que iriam tirar a sua primeira habilitação. Isso é um claro indício de que, durante as décadas de 1920 e 1930, a circulação dos automóveis pelas ruas do perímetro urbano da cidade de Florianópolis constituía-se num processo que estava sendo gradualmente implementado na cidade. Nesse ponto, é válido

\footnotetext{
${ }^{581}$ PESAVENTO, Sandra Jatahy. História, memória e centralidade urbana. Novos Mundos - Mundos Novos... op. cit.

${ }^{582}$ Idem.

${ }^{583}$ Processo n. 194, 21 nov. 1932. Caixa 20.

${ }^{584}$ A letra $P$ indica que se trata de veículo particular.

${ }^{585}$ Processo n. 194, 21 nov. 1932. Caixa 20.

${ }^{586}$ Processo n. 194, 21 nov. 1932. Caixa 20. A rua Blumenau corresponde, como visto, à atual rua Victor Konder. Fonte: SILVA, Adolfo Nicolich. Ruas de Florianópolis: resenha histórica. Florianópolis: Fundação Franklin Cascaes, 1999. p. 135.

${ }^{587}$ Processo n. 194, 21 nov. 1932. Caixa 20.
} 
observarmos que o processo em questão apresenta, textualmente, o teor do "Edital", datado de 18 de julho de 1927, expedido pelo então tenente coronel Manoel Pereira da Silva e Oliveira, delegado de polícia do município de Florianópolis. Esse edital registra os locais permitidos para a prática e aprendizagem da condução de automóveis. Assim, destacamos o seguinte trecho:

Edital - O tenente coronel Manoel Pereira da Silva e Oliveira, delegado de polícia do município de Florianópolis, encarregado do expediente da delegacia auxiliar, na forma da lei, etc. Faz saber aos que o presente edital virem ou dele conhecimento tiverem que de conformidade com o artigo 129 do regulamento policial de 1920, é expressamente proibido guiar qualquer veículo sem estar para este habilitado com a respectiva carta expedida por esta delegacia auxiliar, bem como ao condutor de veículo que confiar a direção de seu carro à pessoas que não tenham carta, sendo que as que desejarem a aprendizagem, poderão fazê-la com licença prévia desta delegacia, em logradouros públicos, como sejam: Largo 13 de Maio, Largo General Osório e Praça do distrito da Trindade, onde não causarão atropelo aos transeuntes; e isso com o condutor ao lado, ficando o mesmo responsável pela direção ${ }^{588}$.

Pelo exposto, percebemos que Herbert Molenda e o chauffeur Alberto Ebert operaram descumprimentos às normas disciplinares de trânsito registradas na citação acima; pois, dentre outros aspectos, a Praça Etelvina Luz, esquina da rua Demétrio Ribeiro/rua José Veiga, onde ocorreu o atropelamento dos menores, não é contemplada como área destinada à aprendizagem da condução de automóveis. De outro modo, podemos perceber que na data de referência do processo em questão, o Regulamento para o serviço policial do Estado - ao menos alguns dos seus artigos -, ainda vigorava para o Estado de Santa Catarina e para a cidade de Florianópolis.

As declarações prestadas pelo acusado também nos permitem inferir que a denominação "barata" ou Voiturette se refere a um tipo de veículo motorizado de pequeno porte, de cunho esportivo, que apresenta duas portas laterais e que, via de regra, acondicionava, no máximo, duas pessoas: condutor e passageiro. Esse veículo, ao que parece, não dispunha de capotas - estas, se existentes, eram, talvez, retráteis -, o que sinaliza seu apelo esportivo e “despojado". (Figura 07, p. 173). A utilização desse veículo, ao que parece, não tinha o propósito de atender interesses estritamente familiares, ou seja, o indivíduo que o adquiria objetivava empregá-lo em passeios ou para atender a outros interesses de cunho particular; e, para adquiri-lo, era necessário contar, ao menos, com razoável padrão de vida. É importante observarmos que a atividade profissional exercida por Herbert Molenda deveria render-lhe os dividendos necessários para proporcionarlhe uma vida relativamente confortável, haja vista que ele era "residente à rua Esteves Júnior", local, como vimos, ocupado, preferencialmente, por pessoas de destacada posição social ou profissional. Esse aspecto é corroborado pelas declarações prestadas pela testemunha João Justino dos Santos, "natural deste Estado, com 29 anos de idade, casado, Soldado da Força Pública", pois esclarecem que Herbert Molenda era "de estatura alta, de tipo alemão" e que é "empregado na Casa Hoepcke" ${ }^{, 59}$. Assim, o condutor do veículo era empregado num ramo de

\footnotetext{
${ }^{588}$ Processo n. 194, 21 nov. 1932. Caixa 20.

${ }^{589}$ Idem.
} 
atividade bastante expressivo na cidade e que lhe proporcionava, portanto, as condições financeiras necessárias para adquirir e manter um automóvel ${ }^{590}$. É possível, também, inferirmos que a aquisição de seu automóvel foi efetuada por meio de herança familiar, mas esse aspecto é apenas uma hipótese, que, para sua elucidação, necessita de um estudo mais detalhado, que foge aos propósitos da presente investigação.

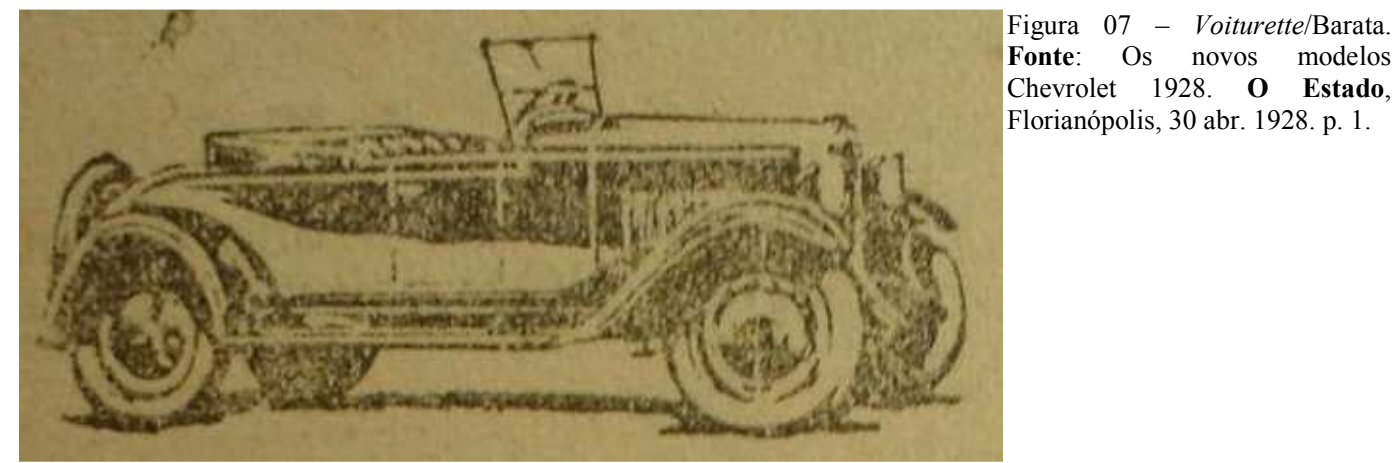

De qualquer forma, é importante destacarmos que os estaleiros e as fábricas estabelecidos na "Rita Maria", durante o final do século XIX e início do século XX, foram empreendimentos iniciados pelo empresário alemão Carl Hoepcke. Em 1918, o complexo industrial e portuário “Hoepcke Irmão \& Cia." era composto pelas fábricas de Pontas Rita Maria (1896); de arame farpado e grampos para cercas; de gelo e de rendas; e bordados Hoepcke (1917). Existiam, também, o estaleiro Arataca (1907) e as empresas de navegação Hoepcke, proprietárias dos vapores Anna e $\mathrm{Max}^{591}$. Além disso, havia, na cidade de Florianópolis, pelo menos durante a primeira metade da década de 1920, a Seção de Máquinas pertencente ao complexo "Hoepcke Irmão \& Cia.”, que agenciava a comercialização dos veículos motorizados das marcas Studebaker ${ }^{592}(1920)^{593}$ e Ford (1923) ${ }^{594}$. Vimos, portanto, que Herbert Molenda era ligado ao setor industrial e, como empregado nesse ramo, teve, ao que nos parece, as condições financeiras que lhe permitiram adquirir seu próprio veículo motorizado.

\footnotetext{
${ }^{590}$ No ano de 1928, o preço para revenda do automóvel Voiturette (barata), incluído os custos do "preço vagão São Paulo", era de 6:700\$ (seis mil e setecentos réis). Fonte: (Os novos modelos Chevrolet 1928. O Estado, Florianópolis, 30 abr. 1928. p. 1). Vimos, no capítulo primeiro, que, no ano de 1920, o preço líquido para compra do veículo Voiturette (barata), incluído os custos de importação da praça de São Paulo, era de 3:400\$000 (três contos, quatrocentos mil réis). Não nos é possível afirmar, com segurança, quais os elementos que determinaram, no espaço temporal de oito anos, uma diferença tão expressiva de preço para a comercialização de um produto, se não idêntico, mas similar. Nas pesquisas realizadas nos artigos jornalísticos locais, encontrados na Biblioteca Pública do Estado de Santa Catarina, observamos, entretanto, que, desde o ano de 1925, atesta-se significativo "barateamento" dos preços de revenda dos veículos motorizados, aplicado nas principais praças agenciadoras do Estado. Essa tendência continua, com maior nitidez, durante todo o ano de 1928. Podemos considerar como elemento indicativo dessa tendência o que é registrado pelo artigo do jornal O Estado, de 13 de agosto de 1925, que observa, naquela data, "Grandes reduções nos preços dos carros Ford" e assinala, igualmente, que "Agora, mais do que nunca, os carros Ford estão ao alcance de todos". (Grandes reduções nos preços dos carros Ford. O Estado, Florianópolis, 13 ago. 1925). Ver, também, Anexo 19, p. 350.

${ }_{591}^{592}$ Ver, a respeito, VEIGA, Eliane Veras da. Florianópolis: memória urbana... op. cit., p. 295-296.

${ }^{592}$ Conforme observa José Luiz Vieira, "A Studebaker Brothers Manufacturing Company é a única fabricante de carroças e carruagens [...] que passa diretamente a produzir automóveis de alta qualidade" e "entre 1902, quando faz seu primeiro carro elétrico, e 1920, quando termina a produção de carruagens, mantem-se produzindo simultaneamente veículos de tração animal e motorizados". (VIEIRA, José Luiz. A história do automóvel: a evolução da mobilidade. São Paulo: Alaúde Editorial, 2008. (v. 1 - da Pré-história a 1908). p. 294-295). Mais um exemplo, portanto, da convivência simultânea verificada, pelo menos no início do século XX, entre carros e automóveis...

${ }_{593}$ Studebaker. Oferece os novos modelos da esplendida série 19. Elegantes, Ultramodernos, Mecanicamente perfeitos. Para ver mais informações: Hoepcke Irmão \& Cia. Seção de Máquinas. O Estado, Florianópolis, 03 jan. 1920. p. 3.

${ }^{594}$ Hoepcke, Irmão \& Cia. Seção de Máquinas - Florianópolis: Ford, auto universal - o novo modelo Double-Phaeton. O Estado. Florianópolis, 08 jan. 1923. p. 4
} 
A análise do presente processo salienta outro elemento importante: o fato de que o condutor do veículo, quando quis fazer "o auto dar volta no canto da rua Blumenau, praça Etelvina Luz, para tomar pela rua José Veiga, a barata apanhou dois rapazes que brincavam perto da casa que foi de Manoel Simões”. Assim, a circulação dos veículos motorizados se impunha frente a antigos hábitos e costumes praticados pela população florianopolitana. $\mathrm{O}$ ato de brincar foi bruscamente interrompido pela investida do automóvel em questão. Diante desse quadro, podemos inferir que, durante as décadas de 1920 e 1930, a atmosfera de modernidade começava a integrar o cotidiano dos habitantes da cidade de Florianópolis. Nesse sentido, destacamos, uma vez mais, o que dispõe o artigo 65 das Instruções Regulamentares para o serviço de trânsito público, de 1928, que registra: “Art. 65 - São rigorosamente proibidos nas vias públicas da Capital, os jogos de fute-bola, diavolô, peteca, amarelinha, bóca, ou quaisquer outros que possam

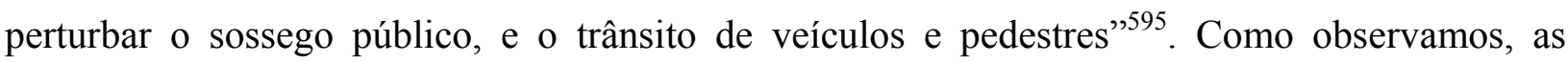
práticas cotidianas arraigadas, de alguma forma, no agir e pensar da população florianopolitana foram, forçosamente, substituídas pelos novos ritmos e tecnologias existentes na cidade de Florianópolis a partir das décadas de 20 e 30 do século passado. Assim, embora as determinações governamentais disciplinassem e cerceassem os comportamentos dos florianopolitanos, estes operavam novos ritmos e enfoques diante de suas práticas e experimentações cotidianas; pois, ao recriarem e reapropriarem a urbe, podiam vislumbrar para além dos movimentos de ordenação e normatização legal e paisagística que incidiram sobre Florianópolis naquele período ${ }^{596}$.

De acordo com as afirmações proferidas por Alberto Ebert, chauffeur profissional, ele "ia ao lado do senhor Herbert Molenda na baratinha de n. 24, particular, com o fim de ensiná-lo a guiar automóvel”, quando "nas imediações da Praça Etelvina Luz, defronte à casa do senhor Riggenbach, achavam-se algumas crianças brincando, o que fez Molenda se atrapalhar na direção da baratinha, resultando não fazer a volta como devia, indo a mesma de encontro ao muro da referida casa, onde apanhou dois rapazes que ali brincavam"597. Corroborando com essas informações, o artigo do jornal $O$ Estado, de 22 de novembro de 1932, que registra o sinistro em questão, esclarece que, perante a situação aqui apresentada, o chauffeur Herbert Molenda "perdeu a calma e, embaraçando-se na direção do veículo, apanhou os dois referidos meninos, que levados contra um muro lateral, sofreram diversos ferimentos"598.

\footnotetext{
${ }^{595}$ Santa Catarina. Regulamento para o serviço policial do Estado. Florianópolis: Tipografia da Livraria Central, 1920. p. 13-14.

${ }^{596}$ CERTEAU, Michel de. A invenção do cotidiano 1: artes de fazer. 8. ed. Petrópolis: Vozes, 2002; NECKEL, Roselane. A República em Santa Catarina: modernidade e exclusão (1889-1920). Florianópolis: UFSC, 2003. p. 76.

${ }^{597}$ Processo n. 194, 21 nov. 1932. Caixa. 20.

${ }^{598}$ A baratinha 24P apanha dois menores. O Estado. Florianópolis, 22 nov. 1932. p. 5. A mesma nota jornalística reafirma, em passagem posterior, o estado de nervosismo apresentado pelo chauffeur Herbert Molenda por ocasião do acidente, ao considerar que "O sr. Molenda, que se apresentou à delegacia de polícia logo após o fato, não pôde, entretanto, fazer declarações, em virtude do estado de nervosismo em que ficara, por motivo do lastimável acidente". (A baratinha 24P apanha dois menores. O Estado... op. cit., p. 5). Desse modo, compreendemos melhor por que o depoimento do acusado foi somente registrado na data de 23 de novembro, ou seja, dois dias após a ocorrência do sinistro.
} 
Vimos, portanto, que a região onde ocorreu o atropelamento não era destinada à aprendizagem da condução de veículos motorizados. De outro modo, podemos perceber que Alberto Ebert observa o modo errôneo com que Herbert Molenda conduzia o veículo, pois ele, ao deparar-se com "algumas crianças brincando", atrapalhou-se "na direção da baratinha, resultando não fazer a volta como devia”. Esse aspecto atesta, claramente, que Herbert Molenda, com 34 anos, estava aprendendo a guiar automóvel ${ }^{599}$, o que reafirma o fato de que a circulação dos automóveis é um processo que estava sendo implementado de maneira gradual na capital catarinense, durante o período em estudo.

As declarações prestadas pela vítima Manoel Navegantes Rodrigues, no dia 21 de novembro de 1932, esclarecem que ele "vinha em companhia de Joaquim Coelho, pela rua Demétrio Ribeiro, caminhando bem junto ao muro que segue à casa do doutor Mileto Tavares [da Cunha Barreto]" 600 e que, "em dado momento, surge uma barata", que "ao dar a volta para entrar na dita rua, a fez com tamanha rapidez que foi de encontro ao declarante e o seu companheiro, resultando a fratura das pernas deste e o ferimento das suas" ${ }^{\text {,601 }}$. Essas declarações são, de fato, confirmadas por Joaquim Donato Coelho que afirma que "achava-se em companhia de um rapaz vendedor de balas, quando foi atropelado por uma baratinha na rua Demétrio Ribeiro" ${ }^{602}$. Esse declarante afirma, ainda, que "a baratinha em apreço [...], ao fazer a curva para entrar na dita [rua], a fez com tanta imperícia, que levou a barata contra o muro, onde caminhava o declarante com o seu companheiro", e que, "nessa ocasião tentou escalar o muro para se salvar do choque, mas não teve tempo, pois a barata já o tinha alcançado, resultando do choque, a fratura das suas duas pernas, em diversos lugares"

Essas declarações apontam, claramente, que, no jogo cotidiano que colocava, de um lado e de outro, veículos e transeuntes, estes estavam em posição de desvantagem, uma vez que os chauffeurs surgiam inesperadamente, em seus veículos, e provocaram atropelamentos e desastres de toda a ordem. Observamos, portanto, que as expectativas dos habitantes da capital catarinense, acostumados que estavam ao ritmo de vida mais lento, pacato e cadenciado, são forçadas a adaptarem-se a tecnologias, velocidades e ritmos diferentes, que, em muitas situações, eram pontuados pelo surgimento "inesperado" de automóveis nas ruas e esquinas do perímetro urbano da cidade de Florianópolis.

\footnotetext{
${ }^{599}$ Em outra passagem da explanação de Alberto Ebert, ele esclarece que "o senhor Molenda já se achava bastante habilitado para guiar, pois pretendia ainda esta semana habilitar-se perante esta delegacia, com a sua carta de chauffeur amador". (Processo n. 194, 21 nov. 1932. Caixa. 20). Vimos, portanto, que Herbert Molenda pretendia, naquela semana, habilitar-se como chauffeur amador, ou seja, o condutor da baratinha n. 24 não é profissional, pois não exerce a atividade de chauffeur, pois, como visto, ele é "empregado na Casa Hoepcke".

${ }^{600}$ Juiz da Segunda Vara da Comarca da Capital, que participou ativamente do andamento e desfecho de grande número dos processos analisados na tese. Maiores detalhes são encontrados no quarto capítulo deste estudo.

${ }^{601}$ Processo n. 194, 21 nov. 1932. Caixa 20.

${ }^{602}$ Idem.

${ }^{603}$ Idem.
} 
A tentativa de esquivar-se do automóvel em questão, esboçada pelo transeunte Joaquim Donato Coelho, evidencia, contudo, que os pedestres não estavam totalmente à mercê dos veículos motorizados, pois se utilizavam de suas próprias forças para deles se esquivarem. De outro modo, o falecimento de Joaquim Donato Coelho, no dia 23 de novembro de 1932, por ocasião dos ferimentos que recebeu em decorrência do sinistro ${ }^{604}$, atesta a violência do choque e a maneira impetuosa com a qual Herbert Molenda guiava seu veículo.

As ideias apontadas esclarecem, contudo, que a imposição dos automóveis não impede o exercício de resistência efetuado pelos transeuntes, pois estes podem operar trilhas móveis e imprevisíveis, a fim de obedecerem a condições circunstanciais inerentes ao cotidiano, momentos em que se desenrolam táticas e estratégias específicas que colocam em evidência suas astúcias e desdobramentos, operados em suas vivências diárias no meio urbano. Transitar e vivenciar a urbe possibilita, portanto, a demarcação dos modos de ação, operados, muitas vezes, de maneira muda e imprevisível ${ }^{605}$. Assim, as condicionantes impostas pelo cotidiano são elementos que permitem ao homem comum alterar os mecanismos de disciplina, como meio para operar suas próprias práticas e percepções cotidianas ${ }^{606}$. Essas práticas constituem, pois, aspectos específicos do cotidiano, envoltos em contextos e jogos de força mais amplos, que, para os efeitos da presente investigação, constituem o viver urbano. Assim, podemos observar, conforme visto, que todo evento histórico encerra uma mistura tal de variáveis, e é fruto do entrecruzamento de muitos eventos e circunstâncias de natureza diferenciada, que o historiador pode, apenas, visualizá-lo de maneira parcial, uma vez que analisa apenas alguns dos elementos que o constituem ${ }^{607}$.

\subsubsection{Legislação e Circulação: incrementação e complexidade}

No texto que ora se inicia analisamos, com especial atenção, o processo de incrementação da legislação de trânsito, verificado no Estado de Santa Catarina, durante o transcorrer da década de 1930. Nesse contexto, discutimos dois processos criminais, que abrangem os anos de $1937 \mathrm{e}$ $1938^{608}$. A análise desses textos serve como pano de fundo para investigarmos o incremento da legislação de trânsito por meio da criação, no ano de 1935, da Secretaria de Segurança Pública, efetuada por meio da Lei Estadual n. 12, de 12 de novembro ${ }^{609}$. Esse órgão será, entretanto, encarregado da "orientação e fiscalização do trânsito nas vias públicas" somente a partir do ano

\footnotetext{
${ }^{604}$ Conforme registrado no "Auto de exame cadavérico", anexo ao presente processo.

${ }^{605}$ FOUCAULT, Michel. Microfísica do Poder. 17 ed. Rio de Janeiro: Graal, 2002. p. 225 e p. 241.

${ }^{606}$ CERTEAU, Michel de. A invenção do cotidiano 1: artes de fazer. 8. ed. Petrópolis: Vozes, 2002.

${ }^{607}$ JÚNIOR, Durval M. de Albuquerque. História: a arte de inventar o passado: ensaios de teoria da História. Bauru: EDUSC, 2007. p. 29.

${ }^{608}$ Esses processos são: a) Processo n. 351, 09 ago. 1937. Caixa 38; e b) Processo n. 373, 27 jan. 1938. Caixa 41.

${ }^{609}$ Lei n. 12, de 12 de novembro de 1935. Cria a Secretaria de Segurança Pública. In: Santa Catarina. Coleção de Leis, Decretos, Resoluções e Portarias de 1935. Florianópolis: Livraria Central de Alberto Entres, 1936. p. 13-14.
} 
de 1938, conforme estipula o Decreto-lei n. 24, de 7 de janeiro de $1938^{610}$. Observamos, pois, que esses elementos atestam, dentre outros aspectos, o gradativo incremento do tráfego de veículos motorizados pelas ruas do perímetro urbano da cidade de Florianópolis e, também, de outras cidades do Estado, durante as décadas de 20 e 30 do século passado. Assim, conforme referenciado, temos que, no ano de 1937, o processo n. 351, de 09 de agosto, registra o atropelamento de Antônio Sabino Fernandes, servente da Secretaria da Segurança Pública, ocasionado pelo chauffeur Átila Silva, ao sair em marcha a ré da rua Victor Meireles com o automóvel n. 197, do ponto da Capital. O episódio ocorreu na Praça XV de Novembro ${ }^{611}$.

O "Termo de declarações" prestado pelo acusado, no dia 11 de agosto de 1937, esclarece outros detalhes sobre o ocorrido; pois, "no dia 08 do corrente, pelas nove e meia horas, mais ou menos, na rua que fica ao lado da Secretaria de Segurança Pública, o declarante, que trabalha como chauffeur, quando dava voltas na manícula do seu carro, este casualmente encontrava-se com a marcha a ré ligada" 612 . Nessas circunstâncias, o "motor funcionou" e o veículo "disparou entrando pelo Jardim Oliveira Belo ${ }^{613}$, passando por cima do senhor Antônio Sabino, tendo este [...] sido conduzido para o Hospital de Caridade"614. (Anexo 14, p. 345). Essas declarações esclarecem, igualmente, que "o declarante trabalha a um ano e pouco como chauffeur", e que ele é "natural deste Estado, com 19 anos, solteiro",615.

Essas afirmações revelam aspectos importantes. Em primeiro lugar, podemos verificar a existência, ainda no ano de 1937, da figura do chauffeur. É importante observarmos que o chauffeur em questão corresponde à atual figura do taxista, pois ele guiava um automóvel de praça $^{616}$. Átila Silva tinha dezenove anos de idade. Esse fato confirma-nos a tendência de que, durante as décadas de 1920 e 1930, os chauffeurs eram indivíduos muito jovens. Além disso, percebemos que o depoimento do acusado registra que "o declarante trabalha a um ano e pouco como chauffeur", ou seja, conforme essas declarações, Átila Silva é habilitado para exercer sua profissão desde, pelo menos, os dezoito anos, idade mínima exigida para aqueles que desejassem obter sua carta de habitação. Segundo as informações constantes nas falas prestadas pelo acusado, vimos que o atropelamento ocorreu porque Átila Silva "dava voltas na manícula do seu

\footnotetext{
${ }^{610}$ Decreto-lei n. 24, de 7 jan. 1938. Atribuindo à Secretaria de Segurança a orientação e fiscalização do trânsito nas vias públicas. In: Santa Catarina. Coleção de Decretos-Leis de 1938. Florianópolis: Imprensa Oficial do Estado, 1939. p. 6-10.

${ }^{611}$ Processo n. 351, 09 ago. 1937. Caixa 38.

${ }^{612}$ Idem.

${ }^{613}$ Conforme referencia Lisabete Coradini, no "[...] final do século XIX, com o advento da República e das transformações urbanas, sociais, políticas e econômicas locais, a Praça [XV], antiga Barão da Laguna, em Desterro, ganhou também uma nova feição. Apropriada pela elite local, tornou-se exclusivamente um espaço de lazer das 'boas famílias'. Em 1892 foi inaugurado, na Praça, o Jardim Oliveira Belo, seguindo os moldes europeus, mais precisamente o traçado geométrico francês. O passeio pela Praia de Fora [altura das ruas Esteves Júnior e Bocaiúva], as corridas a cavalo na 'beira-mar' e o piquenique no morro do Antão [da Cruz] foram substituídos pelo footing no jardim, o Jardim Oliveira Belo, local onde as 'coisas aconteciam'. A dimensão que predominou foi a do olhar e a de ser olhado. Ali se reuniam os advogados, farmacêuticos, poetas, comerciantes, funcionários públicos, escritores, professores e profissionais liberais”. (CORADINI, Lisabete. Praça XV: Espaço e Sociabilidade. Florianópolis: Letras Contemporâneas, 1995. p. 57).

${ }^{614}$ Processo n. 351, 09 ago. 1937. Caixa 38.

${ }^{615}$ Idem.

${ }^{616}$ Ver referências apontadas a seguir, e, também, as ideias expressas pela testemunha Bernardino J. dos Passos, no dia 22 de setembro de 1937.
} 
carro", quando "este, casualmente, encontrava-se com a marcha a ré ligada". Assim, observamos, claramente, que se trata de um veículo motorizado, uma vez que é possível percebermos o mecanismo que o fazia funcionar, pois era operado a manivela, localizada, a rigor, na parte dianteira do veículo.

As declarações prestadas pelo acusado esclarecem-nos, igualmente, que ele circulava com o automóvel n. 197 "na rua que fica ao lado da Secretaria de Segurança Pública”. Nesse ponto, é importante esclarecermos que o Decreto-lei n. 24, de 7 de janeiro de 1938, que atribui "à Secretaria da Segurança Pública a orientação e fiscalização do trânsito nas vias públicas", estabelece, em seu artigo segundo que “[...] Na Capital, será esse serviço executado por intermédio da Inspetoria de Veículos e Trânsito Público, e, no interior, pelas autoridades policiais" ${ }^{\text {} 617}$. Assim, percebemos que, a partir do ano de 1938, o trabalho de físcalização e orientação do trânsito, nas vias públicas estaduais e municipais foi subordinado à Secretaria de Segurança Pública, com sede na Capital do Estado. Para a cidade de Florianópolis, o respectivo trabalho foi aplicado, entretanto, mais diretamente, pela Inspetoria de Veículos, subordinada àquela secretaria. Neste ponto, entendemos ser conveniente registrar, uma vez mais, que, um ano após a inauguração da Ponte Hercílio Luz, o Decreto 2075, de 28 de junho de 1927, assinalava a "necessidade urgente de regulamentar-se o serviço de trânsito" e aprovava as "instruções para a Inspetoria de Veículos"618. Esses apontamentos servem como gancho para observarmos que a elaboração das supracitadas instruções foi assinada pelo secretário do Interior e Justiça do Estado de Santa Catarina, Cid Campos. Salientamos esse fato porque é importante esclarecermos quais órgãos ou instrumentos legais regulamentaram o trânsito nas estradas estaduais e na capital catarinense no período de abrangência da tese.

Quanto à regulamentação do trânsito nas estradas de cunho estadual, temos que, no período entre os anos de 1920 e 1927, o instrumento legal de maior relevância foi aquele representado pelo Regulamento para o serviço policial do Estado, de 1920, que foi aplicado, notadamente, pelas chefaturas de polícia municipais, inclusive quanto à capital catarinense. Destacamos que, a partir do ano de 1927 e, pelo menos, até 1938, vigoraram, majoritariamente, as Instruções Regulamentares para o serviço de trânsito público, instituídas, como visto, em junho de 1927. Esse documento atesta, conforme já referenciado, a "necessidade urgente de regulamentar-se o trânsito de veículos" que, àquela época, já atestava considerável diversidade e adensamento, sobretudo nas ruas do perímetro urbano da capital catarinense, e sua elaboração esteve a cargo da Secretaria do Interior e Justiça ${ }^{619}$. Por outro lado, podemos considerar que, a partir do ano de

\footnotetext{
${ }^{617}$ Decreto-lei n. 24, de 7 jan. 1938. Atribuindo à Secretaria de Segurança a orientação e fiscalização do trânsito nas vias públicas. In: Santa Catarina. Coleção de Decretos-Leis de 1938. Florianópolis: Imprensa Oficial do Estado, 1939.

${ }^{618}$ Decreto 2075. Aprova as instruções para a Inspetoria de Veículos. Palácio do Governo. Florianópolis, 28 jun. 1927.

${ }^{619}$ Santa Catarina. Instruções Regulamentares para o serviço de trânsito público. Florianópolis: Imprensa Oficial, 1928.
} 
1938, "o serviço de orientação e fiscalização do trânsito nas vias públicas" é de responsabilidade da Secretaria de Segurança Pública, criada pela Lei Estadual n. 12, de 12 de novembro de 1935. Essa lei estipula, dentre outros elementos, que "Subordinar-se-ão à Secretaria de Segurança Pública os serviços referentes à polícia civil e militar, ora dependentes da Secretaria dos Negócios do Interior e Justiça" ${ }^{\prime 620}$.

É importante esclarecermos que, para o estrito âmbito da capital catarinense, a organização e a fiscalização do trânsito de carros e automóveis, pelo menos desde o ano de 1922, esteve a cargo da Inspetoria de Veículos, subordinada, à época, à Chefatura de Polícia da cidade de Florianópolis ${ }^{621}$, que, como vimos, foi responsável por aplicar as determinações estipuladas pelo Regulamento para o serviço policial do Estado. Durante todo o período de estudo compreendido pela tese, notamos que o trânsito de veículos nas ruas da capital catarinense foi supervisionado e fiscalizado pela Inspetoria de Veículos, pois o Decreto-lei n. 24, de 7 de janeiro de 1938, estabelece, como vimos, em seu artigo segundo que "Art. 2. ${ }^{\circ}$ - Na Capital, será esse serviço executado por intermédio da Inspetoria de Veículos e Trânsito Público, e, no interior, pelas autoridades policiais" $" 622$.

Vale destacarmos que mesmo após o estabelecimento do primeiro Código Nacional de Trânsito, em 1941, os serviços de orientação e fiscalização do tráfego nas ruas da capital catarinense, especialmente em seu perímetro urbano, foram exercidos pela Inspetoria de Veículos. Assim, a partir do início da década de 1940, foram adotados novos dispositivos penais e de trânsito, vigentes para todo o território nacional. Dentre eles, destacamos: a) o primeiro Código Nacional de Trânsito, instituído, como visto, no ano de 1941; e b) o Novo Código Penal e o primeiro Código de Processo Penal brasileiros ${ }^{623}$. Os dispositivos arrolados objetivavam padronizar a circulação dos veículos motorizados em todo o território nacional e atualizar a aplicação de penas e a organização dos processos criminais elaborados em todo o País.

\footnotetext{
${ }^{620}$ Lei n. 12, de 12 de novembro de 1935. Cria a Secretaria de Segurança Pública. In: Santa Catarina. Coleção de Leis, Decretos, Resoluções e Portarias de 1935... op. cit., p. 13-14. Com relação às atribuições da Secretaria de Segurança Pública, outro texto oficial aponta que "A Secretaria do Interior e Justiça, desmembrada da Secretaria Geral do Estado, pela lei n. 1196, de 26 de setembro de 1918, e dirigida por um Secretário de Estado, superintendencia os serviços referentes à Justiça, polícia militar e civil, instrução pública, higiene e estatística, assistência pública e privada, eleições, Imprensa Oficial, cujos serviços foram desmembrados pelas secretarias do Interior e Justiça e da Instrução Pública, até que, em 1935, criada a Secretaria de Segurança Pública, passou esta secretaria a tomar conta dos serviços referentes à polícia civil e militar”. (Santa Catarina. Secretaria dos Negócios do Interior e Justiça. In: Ofícios Recebidos - Secretaria de Justiça, 1939/1940. p. 139).

${ }^{621}$ Conforme registra o seguinte documento: Santa Catarina. Relatório Apresentado ao Exmo. Sr. Dr. Joë Luiz M. Colaço, Secretário do Interior e Justiça pelo Desembargador Antero de Assis, Chefe de Polícia. Florianópolis, 1922.

${ }^{622}$ Decreto-lei n. 24, de 7 jan. 1938. Atribuindo à Secretaria de Segurança a orientação e fiscalização do trânsito nas vias públicas. In: Santa Catarina. Coleção de Decretos-Leis de 1938... op. cit. Dado o exposto, inferimos que as inspetorias de veículos e trânsito público existentes no País seriam substituídas pelos atuais detrans, somente nos anos de 1966 e 1967, pois "A Delegacia de Trânsito Público, antecessora do atual DETRAN, só surgiria décadas depois, com a criação do Código Nacional do Trânsito, em 1966, então subordinada à Secretaria de Justiça e Segurança Pública"; e "Em 23 de fevereiro de 1967, o Decreto-lei n. 237, assinado pelo então Presidente da República, Marechal Castelo Branco, modificava o Código Nacional [de Trânsito Brasileiro], criando o Sistema Nacional de Trânsito - o SNT, composto pelo Conselho Nacional CONTRAN, pelos Conselhos Estaduais - CETRANS, pelos Departamentos Nacional e Estaduais - [Denatran e Detrans]”. Disponível em: $<$ http://www. Detran.rj.gov.Br/ documento.asp?cód=1484>. Ainda é válido ressaltarmos que, para os efeitos de interesse da presente tese, o detran de Santa Catarina foi, desde o ano de sua criação, subordinado à Secretaria de Segurança Pública do Estado, situação que conserva até os dias atuais.

${ }^{623}$ Esses códigos foram instituídos, respectivamente, nos anos de 1940 e 1941 ; entram, todavia, em vigor no dia $1 .^{\circ}$ de janeiro de 1942.
} 
Percebemos, portanto, nova fase na organização do trânsito e dos dispositivos penais em todo o território nacional.

Devemos, também, chamar a atenção do leitor para o fato de que os códigos penais e de trânsito de cunho nacional, vigentes a partir desse período, estão inseridos em uma política nacionalista e centralizadora que marcou o chamado Estado Novo (1937-1945). Assim, o que ficou evidente, nos discursos e nas práticas difundidas a partir de 1930 e, com maior nitidez a partir do regime estado novista, foram tendências direcionadas para ações e políticas regeneradoras e centralizadoras, pautadas pelas tentativas e esforços para promover o controle, unificação e homogeneização da sociedade brasileira; ações estas gerenciadas pelo Estado. Esses discursos afirmavam sua positividade, ao mesmo tempo em que "dispersão", "isolamento", "falta de controle", "diferenças", "diversidades" e "heterogeneidades" adquiriam conotações negativas, associadas às antigas ações políticas verificadas junto na República Velha ${ }^{624}$. Assim, temos que o governo instaurado em outubro de 1930 afirmou-se pelo fato de ter canalizado "[...] todas as esperanças que as elites organizadas construíram em relação à necessidade de pôr ordem ao chamado 'caos' instalado na Primeira República”; e, desse modo, como os "governos anteriores foram considerados ineficientes para conter uma sociedade que se desintegrava em tensões e conflitos de diferentes naturezas, colocou-se naquele momento [...] a necessidade de renovação do aparelho estatal" ${ }^{\prime 625}$.

Assim, é dentro desse contexto, caracterizado pela crescente centralização das ações na esfera do Estado, que devemos entender, também, a organização dos novos códigos penais e de trânsito que foram instituídos no país, a partir desse período. É pertinente destacarmos que o novo Código Nacional de Trânsito foi aplicado de maneira gradual, obedecendo às exigências estaduais e municipais ${ }^{626}$. Desse modo, entendemos que se processou de maneira progressiva a desativação dos artigos e determinações de trânsito estipulados pelas Instruções Regulamentares para o serviço de trânsito público, vigentes no Estado, para efeitos práticos, desde o ano de 1928.

Retomando a análise do processo n. 351, temos que o atropelamento de que foi vítima Antônio Sabino Fernandes resultou na prisão de Átila Silva. Essa, ao que parece, foi efetuada sem grande demora, pois a testemunha Bernardino José dos Passos, 37 anos, chauffeur, afirma, em declaração tomada no dia 16 de agosto de 1937, que "no dia 08 do corrente o declarante viu quando o comissário de dia, à Secretaria de Segurança Pública, deu ordem de prisão ao chauffeur

\footnotetext{
${ }^{624}$ CAMPOS, Cynthia Machado. Santa Catarina, 1930: da degenerescência à regeneração. Florianópolis: EDUSC, 2008. p. 26.

${ }^{625}$ CAMPOS, Cynthia M. Santa Catarina, 1930: da degenerescência à regeneração... op. cit., 61. Sobre esses aspectos ver, também, de mesma autoria: _. A Política da Língua na Era Vargas: proibição do falar alemão e resistências no Sul do Brasil. Campinas: UNICAMP, 2006. ${ }^{626} \mathrm{O}$ artigo primeiro desse código estipula que “[...] As leis estaduais, relativas ao trânsito e aos condutores dos demais veículos, aos pedestres, aos animais, e à sinalização local, devem adaptar-se às disposições deste código, no que for aplicável”. Decreto-lei 3651: dá nova redação ao Código Nacional de Trânsito. Rio de Janeiro, 25 de setembro de 1941. In: Revista Forense: mensário nacional de doutrina, jurisprudência e legislação. Rio de Janeiro, out. 1941. v. LXXXVIII, ano XXXVIII, fascículo 461, n. 88. p. 578 e p. 581-582. Ressaltamos, pois, que a aplicação deste código operou-se de forma gradual nos estados da federação, obedecendo às suas necessidades e particularidades.
} 
Átila Silva”, em razão de ele, "ao dar a manícula de seu carro, a fim de fazer este funcionar, ter disparado, com a marcha a ré ligada, tendo o referido carro atropelado, na Praça XV, o servente Antônio Sabino Fernandes"627. O que queremos destacar é o aspecto de que a Secretaria de Segurança Pública contava com comissários de polícia para físcalizar o trânsito de veículos pelas ruas da capital catarinense. Esse órgão possuía, muito provavelmente, um ou mais comissários que trabalhavam no período noturno, o que atesta a necessidade de fiscalização durante todos os períodos do dia.

Desse modo, é importante destacarmos que a mesma testemunha, em declaração prestada no dia 22 de setembro de 1937, considera que a circulação dos veículos que trabalhavam no "ponto da Capital" dava-se, também, no período noturno ${ }^{628}$. Isso exigia o trabalho de fiscalização por intermédio das autoridades municipais competentes. Continuando sua declaração, Bernardino José dos Passos afirma que "trabalha na praça de Florianópolis como chauffeur, onde faz ponto na Praça XV de Novembro, das sete horas da manhã às oito horas da noite, e do mesmo modo o denunciado, que é também chauffeur, e que diariamente permanece durante as mesmas horas"629. A presente testemunha assinala, igualmente, aspectos curiosos sobre o cotidiano dos habitantes da cidade de Florianópolis, pois afirma, em outra passagem de sua explanação, que "o depoente e as pessoas por ele conhecidas sabem onde o denunciado reside, no distrito de João Pessoa - atual Estreito ${ }^{630}$-, porque o mesmo sai pela manhã para fazer ponto na Praça XV de Novembro, em Florianópolis, e só à noite regressa para a sua casa"631.

Pelo exposto, percebemos que os chauffeurs circulavam durante todo o dia pelas ruas da capital catarinense e que eles tinham uma jornada de trabalho bastante longa. Além disso, constatamos que indivíduos que moravam no lado continental, como Estreito e regiões circunvizinhas, vinham à Capital para trabalhar. Assim, podemos afirmar que o dia a dia na cidade de Florianópolis parecia, à época (1937), ser muito “intenso", pois seus habitantes exerciam diversas ocupações profissionais e circulavam cotidianamente pelas ruas do espaço central e perímetro urbano da capital catarinense. Esses aspectos salientam, sem dúvida, ações, personagens e tramas que se realizam no cotidiano da cidade de Florianópolis e perfiguram a

\footnotetext{
${ }^{627}$ Processo n. 351, 09 ago. 1937. Caixa 38.

${ }^{628}$ Idem.

${ }^{629}$ Idem.

${ }^{630}$ No ano de 1937 - ano referenciado pelo processo em discussão -, o distrito de João Pessoa (Estreito) não pertencia à Florianópolis. Assim, temos que a ponte Hercílio Luz contribuiu para modificar a paisagem da Capital que incorporou áreas do continente próximo. Esse movimento, porém, efetuou-se progressivamente, pois essas áreas somente foram incorporadas ao município de Florianópolis em 1944. A anexação do distrito de João Pessoa ao município de Florianópolis, em 1944, mais do que pregavam as justificativas governamentais, envolveu grandes interesses políticos e econômicos, representados pelos setores fundiários, imobiliários, madeireiros e exportadores. A anexação do distrito de João Pessoa à cidade de Florianópolis fomentou a localização, naquela região, de um expressivo contingente populacional de menor renda, que se deslocou preferencialmente dos municípios vizinhos à Florianópolis e que almejava permanecer próximo à Capital. Ver, a respeito, a) Decreto-Lei Estadual n. 951. Estabelece os limites do município de Florianópolis com São José; b) FARIAS, Vilson Francisco de. São José: 250 anos: natureza, história e cultura. São José: ed. do autor, 1999; e c) COSTA, Sandro da Silveira. Ponte Hercílio Luz: mutações urbanas em uma cidade insular (1890-1960). Dissertação (Mestrado em História). Florianópolis: UFSC, 2002.

${ }^{631}$ Processo n. 351, 09 ago. 1937. Caixa 38.
} 
dinâmica “"fervilhante da rua', que é, também, a estrutura formigante das atividades ritmadas por espaços e relações"632.

Assim, os episódios de atropelamentos e colisões verificados nas ruas do perímetro urbano de Florianópolis envolvem circunstâncias, falas e percepções que podem ser recuperadas por meio de discursos e de interpretações aplicados a textos específicos, como exemplificam os processos criminais analisados; e esse procedimento metodológico corrobora a ideia de que nenhuma leitura sobre a cidade pode ser tomada como definitiva ou verdadeira ${ }^{633}$. Tendo isso em vista, concordamos com as ideias expressas por Maria Stella Bresciani quando considera que não devemos, propriamente, construir uma história da cidade e, menos ainda, que devamos realçar a "positivação" ou "naturalização" da questão urbana, "acompanhando sua evolução" através do tempo. Stella Bresciani opera outro caminho, pois, ao propor diálogos e aproximações entre os campos da História e da Arquitetura e, também problematizar a constituição do urbanismo como campo de lutas e disputas discursivas, objetiva analisar que os saberes que se constroem sobre o objeto cidade são estruturados no e pelo debate político, indicando o solo tenso e conflituoso de sua formação ${ }^{634}$.

Durante a década de 1930, verificamos a intensificação do tráfego de automóveis pelas vias e estradas intermunicipais de Santa Catarina. Esse processo é sugerido, dentre outros elementos, pela seguinte passagem do Decreto-lei n. 24, de 7 de janeiro de 1938, pois considera, dentre outros aspectos, que "o trânsito pelas vias públicas cada dia mais se intensifica"; e, por esse motivo, é "mister uma legislação adequada, que venha corresponder aos interesses gerais, posto que já não correspondem às necessidades públicas, as leis existentes", e que "é tendência geral e já vencedora a unidade de direção e fiscalização dos serviços de trânsito" ${ }^{635}$.

Nesse sentido, esse mesmo decreto estipula normas específicas para a circulação de veículos automotores. Os artigos terceiro, quarto e sexto desse decreto especificam aspectos importantes, uma vez que "Art. $3 .^{\circ}$ - Nenhum veículo a motor poderá trafegar nas vias públicas, sem estar devidamente registrado na Secretaria de Segurança, ou nas delegacias de polícia dos municípios ${ }^{636}$, sendo para isso necessária a apresentação do certificado de propriedade ou posse, e prova de pagamentos de impostos ou taxas a que tiver sujeito"; “Art. 4. ${ }^{\circ}$ - Ninguém poderá guiar veículos a motor sem estar habilitado, em exame prestado na Inspetoria de Veículos e

\footnotetext{
${ }^{632}$ CERTEAU, Michel de; GIARD, Luce; MAYOL, Pierre. A invenção do cotidiano 2: morar, cozinhar. 5. ed. Petrópolis: Vozes, 2003. p. 32. ${ }^{633}$ BRESCIANI, Maria Stella Martins. Cidade e História. In: OLIVEIRA, Lúcia Lippi (Org.). Cidade: história e desafios... op. cit., p. 18.

${ }^{634}$ Sobre essa discussão, ver, especialmente, BRESCIANI, Maria Stella Martins. Cidade e História. In: OLIVEIRA, Lúcia Lippi (Org.). Cidade: história e desafios... op. cit ; BRESCIANI, Maria Stella Martins. (Org.). Palavras da cidade... op. cit.

${ }^{635}$ Decreto-lei n. 24, de 7 jan. 1938. Atribuindo à Secretaria de Segurança a orientação e fiscalização do trânsito nas vias públicas. In: Santa Catarina. Coleção de Decretos-Leis de 1938. Florianópolis: Imprensa Oficial do Estado, 1939.

${ }^{636}$ Destacamos que, pelo menos desde o ano de 1937, o órgão diretamente responsável pela averiguação das ocorrências de atropelamentos e colisões verificadas nos municípios do Estado, inclusive na Capital, é a Delegacia de Polícia - conforme é registrado pela portaria do processo n. 351, de 09 de agosto de 1937. As delegacias de polícia substituem as chefaturas e delegacias auxiliares e são subordinadas à Secretaria de Segurança Pública que, a partir de 1938, é encarregada, em âmbito estadual, da orientação e fiscalização do trânsito nas vias públicas.
} 
Trânsito, ou nas delegacias de polícia"; e "Art. 6. - Os veículos a motor deverão ser vistoriados anualmente ${ }^{637}$, perante a Inspetoria de Veículos ou delegacias de polícia, e sem ônus para os proprietários, ou possuidores, desde que se achem em bom estado de funcionamento"638.

O que percebemos é que à Secretaria de Segurança Pública coube a fiscalização do tráfego de veículos automotores, pois, como vimos, "é tendência geral e já vencedora a unidade de direção e fiscalização dos serviços de trânsito". A especialização dos serviços de trânsito atesta, por um lado, a complexidade que tomou forma a circulação dos veículos motorizados pelo Estado, com suas diversas normas e agentes fiscalizadores. De outro modo, não devemos esquecer que, como visto, desde o ano de 1937, instituiu-se no país o Estado Novo, regime político de cunho centralizador, dirigido e personificado pela figura de Getúlio Vargas que, desde o ano de 1930, assumiu a presidência da República e que, nos anos seguintes, articulou alianças políticas com o propósito de preparar e reequipar as máquinas estatal e burocrática brasileiras para colocar em prática seus objetivos políticos e econômicos, centrados em amplo dirigismo estatal. Assim, a partir do Estado Novo, o Governo, interessado em intensificar a centralização político-cultural e burocrática, criou o Departamento de Administração e Serviços Públicos (DASP), destinado a racionalizar a máquina administrativa ${ }^{639}$.

Junto às intenções centralizadoras e normativas de hábitos e costumes, os anos 1940 assistiram, em Santa Catarina, durante o governo do interventor federal Nereu Ramos (19371945), “[...] a criação do Serviço de Assistência a Psicopatas, que lançou as bases para a construção do Hospital Psiquiátrico Colônia Sant'Ana, inaugurado em 1941"; do "Serviço de Assistência aos Lázaros, com a instalação do Leprozário Santa Tereza [...] e do Abrigo de Menores em 1940, que ampliou os serviços de assistência à infância já iniciados em 1935, quando foi criado o juizado de menores em Florianópolis" ${ }^{~} 440$. Percebemos, portanto, que o Estado brasileiro atuava, igualmente, nos estados da federação, onde interventores nomeados pelo executivo nacional seguiam as linhas mestras determinadas pelo poder político vargista.

\footnotetext{
${ }^{637}$ Vale salientarmos, neste ponto, que os códigos de posturas aplicados na capital catarinense, pelo menos desde o ano de 1889 , tratam, nos capítulos correspondentes, apenas do trânsito de veículos operados com força motriz animal, e determinaram, com maior nitidez a partir daquele período, a obrigatoriedade de "'todos os carros, carroças e qualquer veículo particular ou de aluguel, empregados em serviços da cidade' de serem matriculados anualmente". (Câmara Municipal da Cidade do Desterro. Código de Posturas. Lei n. 1238 , de 22 out. 1888. Desterro: Tipografia da Regeneração, 1889. p. 28). Por outro lado, notamos que a obrigatoriedade de registro anual, estipulada a partir do ano de 1938, incide, especialmente, sobre os veículos de natureza automotiva.

${ }^{638}$ Decreto-lei n. 24, de 7 jan. 1938. Atribuindo à Secretaria de Segurança a orientação e fiscalização do trânsito nas vias públicas. In: Santa Catarina. Coleção de Decretos-Leis de 1938... op. cit.

${ }^{639}$ Dentro desse quadro, diversos conselhos e departamentos técnicos foram sendo criados pelo governo federal: Conselho Nacional do Petróleo (1938); Comissão do Plano Siderúrgico Nacional (1942); Departamento de Imprensa e Propaganda (DIP), criado em 1939, em substituição ao Departamento de Propaganda e Difusão Cultural (DPDC) que, em 1934, havia substituído ao Departamento Oficial de Propaganda (DOP), existente desde 1931. Esse sucinto quadro mostra que as iniciativas de centralização política estatal se configuravam desde o movimento de 1930. Dentro desse quadro, devemos mencionar a relevância da imprensa para a construção de indicativos em torno de dispositivos que regulamentavam os comportamentos sociais. Assim, a partir da instituição do Estado Novo, foi expressiva a utilização, pelo poder instituído, dos meios de comunicação como veículos de propaganda dos projetos governamentais, e o grande investimento na utilização da propaganda, com objetivos políticos, recaiu sobre o rádio e as manifestações cívicas, mas "[...] nem por isso a máquina do poder deixou de usar todos os recursos e equipamentos de comunicação como dispositivos de formação e controle" da "opinião pública nacional". (CAMPOS, Cynthia Machado. Santa Catarina, 1930: da degenerescência à regeneração. Florianópolis: EDUSC, 2008. p. 42-43).

${ }^{640}$ CAMPOS, Cynthia Machado. Santa Catarina, 1930: da degenerescência à regeneração... op. cit., p. 107.
} 
Devemos observar, igualmente, que, a partir dos anos 1930 e 1940, configura-se com maior nitidez, na esfera nacional, a preocupação em elaborar políticas centralizadoras que eram aplicadas à atividade industrial, às diretrizes que norteavam as políticas públicas e educacionais, ao incremento da infraestrutura urbana, etc.; práticas estas que, sem dúvida, foram estendidas, também, à organização do tráfego motorizado pelas estradas de cunho federal e, também, àquelas geridas pelos estados e municípios. Exemplo, nesse sentido, é evidenciado pela adoção, a partir do ano de 1941, do primeiro Código Nacional de Trânsito.

A conjuntura internacional também contribuiu para a consolidação do Estado Novo, pois, dentre outros fatores, as dificuldades de importação, decorrentes da Segunda Guerra Mundial, favoreceram o aumento da produção industrial interna. Essa, aliás, era vista como prioridade pelas autoridades políticas e militares do Governo. Desse modo, podemos destacar que a política centralizadora do Estado assumiu um caráter industrializante e, em muitos aspectos, nacionalista; e é dentro desse contexto que também devemos entender a incrementação da legislação e dos órgãos fiscalizadores de trânsito, tomados como elementos que perfiguravam as centralizações política e estatal almejadas pelas elites políticas da época. Nesse quadro, evidenciamos a imagem que Getúlio Vargas e os intelectuais que forneceram sustentação ideológica ao Estado Novo se empenharam em propagar, qual seja: a força centralizadora e paternalista do estado era justificada na medida em que se atribuía ao regionalismo ou ao particularismo social, um caráter ameaçador à unidade interna do País ${ }^{641}$.

$\mathrm{Na}$ região Sul do Brasil e, especialmente em Santa Catarina, esse processo assumiu destaque especial; pois, com a instalação do governo Vargas e a intervenção de Nereu Ramos no Estado, efetuou-se uma propaganda mais incisiva sobre o caráter "trabalhador" e "disciplinado" do colono, sobretudo de origem teutônica, como forma de inculcar nas mentes o compromisso com a construção do futuro e do progresso do País. As preocupações sobre as "[...] possibilidades de formação de cistos raciais, grupos lingüísticos, vinculações com o estrangeiro", e o "desrespeito a medidas de caráter nacional e separatismos levaram governos federal e estadual a intervir nas regiões em que se concentravam núcleos de imigrantes estrangeiros e seus descendentes" ${ }^{\prime 642}$. Por trás dessas ações, estava a preocupação central do governo vargista, qual seja: fomentar, por meio de recursos legais, administrativos ou educativos, a ideia ou noção de unidade nacional, tão necessária aos propósitos do governo brasileiro de gerenciar, de maneira centralizadora, os destinos da nação.

\footnotetext{
${ }^{641}$ CAMPOS, Cynthia Machado. Santa Catarina, 1930: da degenerescência à regeneração. Florianópolis: EDUSC, 2008. p. 86.

${ }^{642}$ CAMPOS, Cynthia Machado. A Política da Língua na Era Vargas: proibição de falar alemão e resistências no Sul do Brasil. Campinas: UNICAMP, 2006. p. 103.
} 
Ao nos referirmos à circulação dos veículos motorizados no contexto estadual, destacamos que o Decreto-lei n. 24, de 7 de janeiro de 1938, estipulava, como vimos, que a circulação dos automóveis ficava condicionada à posse do "certificado de propriedade" e à "prova de pagamentos de impostos ou taxas". Vimos, portanto, que o Estado arrecadava recursos por meio da circulação dos automóveis pelas estradas estaduais e municipais ${ }^{643}$. Além disso, na capital catarinense, o motorista ou chauffeur deveria prestar exame para guiar veículos a motor junto à Inspetoria de Veículos e Trânsito Público. Nesse sentido, ressaltamos que a "Tabela anexa, a que se refere o decreto-lei n. 24", estipula "Taxas e emolumentos" da seguinte ordem: "Inscrição para exame de condutor de automóvel - Selos: 10\$000; Matrícula em automóvel - Selos: 2\$000; Licença para aprendizagem de condução de automóveis - Selos: 10\$000; Vistoria em automóvel, ônibus ou caminhão - Selos: 20\$000; Exame médico para inscrição de candidato - Selos: $10 \$ 000 " 644$. Percebemos, portanto, que os serviços relacionados ao funcionamento e à circulação do tráfego de veículos motorizados eram taxados e que os recursos provenientes eram destinados aos cofres do Estado para, dentre outros objetivos, atender à conservação das estradas estaduais.

Outro elemento importante que devemos destacar é que, de acordo com a tabela aqui referida, não havia nenhum registro referente à taxação sobre a circulação dos veículos movidos a tração animal. Em nosso entender, isso não atesta a inexistência desses veículos ao final da década de 1930 - pois, ao certo, continuaram em operação pelas estradas intermunicipais e pelas ruas do perímetro urbano da capital catarinense, mas, proporcionalmente, com menor intensidade que na década anterior -, mas uma especialização das leis e órgãos responsáveis pela fiscalização dos automóveis e daqueles veículos operados a tração animal (ver tabela 04, disposta a seguir).

Salientamos que outro elemento que atesta a necessidade de maior fiscalização do trânsito de veículos automotores é o fato de que eles deveriam ser "vistoriados anualmente". Assim, a vistoria anual para veículos de natureza automotiva, ao que parece, foi, como vimos, instituída pela primeira vez, no Estado de Santa Catarina, no ano de $1938^{645}$. Esses elementos permitemnos atestar o adensamento do tráfego de veículos automotores pelas ruas da cidade de Florianópolis e pelas vias e estradas estaduais, o que exigia a adequação e reaparelhamento dos

\footnotetext{
${ }^{643}$ Aspecto este já verificado nos anos de 1914 e 1918, por ocasião da organização dos "regulamentos para as estradas estaduais" de Santa Catarina, que objetivaram organizar e/ou disciplinar o trânsito de veículos automotores ou operados a tração animal pelas ruas e estradas intermunicipais. É válido observarmos que, nesses regulamentos, são registrados artigos referentes aos impostos cobrados “em postos especiais, localizados nos pontos mais convenientes das estradas construídas pelo Estado, sendo o seu produto escriturado como renda especial [...] para ser exclusivamente aplicado na conservação e reconstrução das ditas estradas". (Regulamento das estradas estaduais e respectivo imposto de trânsito a que se refere o Decreto n. 846, de 29 dez. 1914, de 29 dez. 1914. In: Leis, Decretos, Resoluções e Portarias de 1914. Florianópolis: Gab. Tip. d' O Dia, 1915. p. 187-210). Vimos, portanto, que ao final da década de 1910, os "regulamentos para as estradas estaduais" - anos 1914 e 1918 se ocupavam do trânsito de veículos automotores ou operados a tração animal. O mesmo objetivo foi alçado pelas Instruções Regulamentares para o serviço trânsito público, de 1928, que organizava e orientava a circulação de "carros, automóveis, caminhões, carroças, etc. e às praças que fazem o serviço de trânsito público". Este mesmo regulamento estipulou diversos artigos que se ocupavam da circulação dos "Veículos de tração animal ou mecânica". (Santa Catarina. Instruções Regulamentares para o serviço de trânsito público... op. cit., p. 05).

${ }^{644}$ Decreto-lei n. 24, de 7 jan. 1938. Atribuindo à Secretaria de Segurança a orientação e fiscalização do trânsito nas vias públicas. In: Santa Catarina. Coleção de Decretos-Leis de 1938. Florianópolis: Imprensa Oficial do Estado, 1939.

${ }^{645}$ Ver, a respeito, Decreto-lei n. 24, de 7 jan. 1938. Atribuindo à Secretaria de Segurança a orientação e fiscalização do trânsito nas vias públicas. In: Santa Catarina. Coleção de Decretos-Leis de 1938... op. cit.
} 
recursos utilizados para sua fiscalização e ordenamento ${ }^{646}$. Paralela à adoção das determinações estipuladas pelo Decreto-lei n. 24, de 1938, verificamos que foram estabelecidos, na segunda metade dos anos 1930, outras leis e decretos que estipularam normas para a fiscalização do tráfego automotivo e para o cadastro das estradas de rodagem estaduais. A Lei n. 123, de 10 de novembro de 1936, estabelece o Plano Rodoviário do Estado:

O Doutor Nereu Ramos, Governador do Estado de Santa Catarina. Faço saber a todos os habitantes deste Estado que a Assembléia Legislativa decreta e eu sanciono a seguinte lei:

Art. $1 .^{\circ}$ - É estabelecido o Plano Rodoviário do Estado, obedecendo à seguinte finalidade: a) continuidade e obrigatoriedade do seu cumprimento; b) prolongamento e construção, preferencialmente, de estradas troncos ou estradas reprodutivas; c) coordenação dos sistemas rodoviários das zonas do Estado; d) proibição da construção de estradas que não estejam incluídas no plano rodoviário e que não forem precedidas dos estudos definitivos, na forma dos regulamentos em vigor; e) classificação das rodovias, quer pelas suas dimensões técnicas, ou pela competência do Estado para construí-las, reconstruí-las e conservá-las;

Art. 2. ${ }^{\circ}$ - Fazem parte do plano rodoviário as estradas traçadas e projetadas no mapa organizado no corrente ano, com escala de 1.400 .000 , pela Diretoria de Estradas de Rodagem e aprovado pela Secretaria de Viação e Obras Públicas;

Art. $3 .^{\circ}$ - Compete ao Estado a reconstrução das estradas nele projetadas, os quais, à medida que forem construídas, serão conservadas pelo Estado;

Art. $4^{\circ}$ - Fica o poder executivo autorizado a classificar, por decreto ${ }^{647}$, as estradas previstas dentro do plano rodoviário, pelas suas condições técnicas e definir-lhes o traçado e o percurso, de acordo com o mapa organizado ${ }^{648}$.

Nas pesquisas realizadas para a elaboração do presente estudo, não nos foi possível encontrar qualquer menção à sua efetiva aplicação ou validade. Pelo exposto entendemos, todavia, que a principal preocupação do plano é promover a "coordenação dos sistemas rodoviários das zonas do Estado". Assim, a responsabilidade pela elaboração e execução do plano compete à Diretoria de Estradas de Rodagem e à Secretaria de Viação de Obras Públicas. Notamos que a Secretaria de Segurança Pública não atua neste âmbito, pois ela é encarregada, a

\footnotetext{
${ }^{646}$ No ano de 1940, outros dispositivos legais foram instituídos para melhor prover a fiscalização da circulação de veículos automotores no Estado de Santa Catarina e em sua Capital. Assim, o Decreto-lei n. 489, assinalava que "a experiência tem demonstrado que é míster para a maior eficiência da fiscalização de veículos, que as placas sejam anuais, variando de ano para ano, na cor da pintura"; e, dessa forma, determinava, em seus artigos primeiro e segundo, que "Art. 1. ${ }^{\circ}$ - Fica a Secretaria de Estado dos Negócios da Segurança Pública autorizada a estabelecer os modelos de placas para veículos, inclusive os oficiais, visando a maior facilidade de fiscalização da Inspetoria de Veículos e Trânsito Público, e demais autoridades de trânsito"; e "Art. 2. ${ }^{\circ}$ - As placas serão mudadas anualmente [...]". (Decreto-lei n. 489, de 24 de out. de 1940. Dispõe sobre emplacamento de veículos. In: Santa Catarina. Coleção de Decretos-Leis, Decretos, Resoluções e Portarias, jun. 1940. p. 203-204). Nesse quadro, deve ser observado, também, o que estipula o Decreto-lei n. 261, que "cria a Guarda de Trânsito da Capital do Estado e o cargo de SubInspetor de veículos e trânsito público". Os motivos para tal medida foram justificados devendo-se considerar, dentre outras observações, que "o trânsito público, na Capital do Estado, cada vez se avoluma"; que "o serviço de trânsito exige funcionários especializados, sem o que pouca eficiência terá, como já demonstrou a prática"; que "em quase todas as Capitais dos Estados, senão em todas, já existem guardas de trânsito, o que evidencia a sua absoluta necessidade para a perfeição do serviço". Além disso, o mesmo decreto-lei observa que "há necessidade, na Inspetoria de Vé́culos e Trânsito Público, de mais um funcionário, que auxilie o Inspetor Geral, no orientar e fiscalizar aquele serviço em todo o Estado". O artigo quinto desse decreto determina que “Art. 5. ${ }^{\circ}$ - Este decreto entrará em vigor em 1. ${ }^{\circ}$ de janeiro de 1939". (Decreto-lei n. 261. Cria a Guarda de Trânsito da Capital do Estado e o cargo de subInspetor Geral de Veículos e Trânsito Público. In: Santa Catarina. Coleção de Decretos-Leis de 1938. Florianópolis: Imprensa Oficial do Estado, 1939. p. 435-436). Devemos compreender a adoção dessas medidas como reflexo da intensificação do fluxo de veículos automotores, que necessitava, pois, de maior fiscalização e ordenamento por parte dos poderes públicos municipal e estadual. Além disso, fica, mais uma vez, evidenciada a atuação, à época, do Estado Brasileiro, no sentido de operar-se um dirigismo centralizador às esferas e ações aplicadas em âmbito federal, disseminadas nos estados e municípios. Isso fica evidente ao observarmos que o Decreto-lei n. 261, então referido, foi assinado, conforme registro respectivo, pelo "Doutor Nereu Ramos, Interventor Federal no Estado de Santa Catarina". (Decreto-lei n. 261. Cria a Guarda de Trânsito da Capital do Estado e o cargo de subInspetor Geral de Veículos e Trânsito Público. In: Santa Catarina. Coleção de Decretos-Leis de 1938 ... op. cit).

${ }^{647}$ O Decreto n. 7, de 06 de janeiro de 1937, estipula que são consideradas estradas estaduais "quer para os efeitos da construção, quer para os de reconstrução e conservação, as especificadas por este decreto, de acordo com o mapa organizado pela Diretoria de Estradas de Rodagem e aprovado pela Secretaria da Viação e Obras Públicas". Ver, a respeito, Decreto n. 7. Decretos da Secretaria da Viação e Obras Públicas, 1937. In: Coleção de Decretos, Resoluções e Portarias de 1937. Florianópolis: Imprensa Oficial do Estado, 1939. p. 301-304.

${ }^{648}$ Lei n. 123, 10 nov. 1936. Estabelece o plano rodoviário do Estado. In: Coleção de Leis de 1936. Florianópolis: Imprensa Oficial. p. $92-93$.
} 
partir do ano de 1938, de apenas "orientar e fiscalizar o trânsito nas vias públicas estaduais e municipais". De outro modo, a par dos detalhes apresentados pelo plano rodoviário do Estado, evidenciamos a preocupação com a integração do Estado de Santa Catarina, por intermédio da construção e conservação de estradas de rodagem. O presente plano foi elaborado por órgãos estaduais, o que evidencia uma política de integração estadual gerida pelo Estado. Vale lembrarmos que o dirigismo estatal é uma das principais características imprimidas pelo governo federal de Getúlio Vargas, que, no mesmo ano de 1937, instituiu o Estado Novo e nomeou Nereu Ramos como interventor federal em Santa Catarina. Desse modo, podemos afirmar que o governo de Nereu Ramos objetivou priorizar e ampliar as formas de controle e disciplina social, integrando o território e populações de Santa Catarina aos princípios de homogeneização e afirmação da nacionalidade ${ }^{649}$.

A seguir, a Lei n. 105, de 22 de outubro de 1936, regulamenta as taxas de serviços de conservação e melhoria das estradas de rodagem estaduais e dos serviços de registros e fiscalização de veículos; e estabeleceu, também, em seu artigo primeiro, que “[...] Os serviços de conservação e melhoria das estradas de rodagem estaduais" serão aplicados aos "proprietários individuais, empresas, sociedades ou seus prepostos, de veículos que se utilizarem das estradas de rodagem estaduais como tais consideradas pelo Plano Rodoviário do Estado"650. Esses serviços incidiam, ainda, sobre os "proprietários de terrenos marginais àquelas estradas, até uma profundidade de cinco quilômetros, desde que sejam elas pavimentadas com macadame,

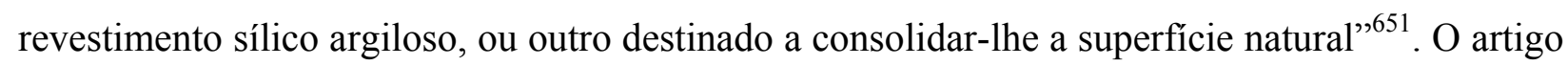
primeiro dessa lei estipulava, igualmente, que os "serviços de registro e físcalização de veículos" devem incidir sobre "todos os proprietários individuais, sociedades ou seus prepostos, de veículos que se utilizarem das estradas fiscalizadas pelo Estado" "652. Além disso, o artigo doze estabelecia que "[...] As taxas previstas nesta lei constituirão uma contribuição especial para ser aplicada exclusivamente nos serviços de conservação e melhoria das estradas de rodagem estaduais e de fiscalização e segurança do tráfego"653.

Analisando o conteúdo aqui apresentado, podemos perceber que "as taxas de serviço de conservação e melhoria de estradas de rodagem estaduais" são cobradas, especialmente, dos proprietários individuais e dos "proprietários de terrenos marginais àquelas estradas, até uma profundidade de cinco quilômetros, desde que sejam elas pavimentadas com macadame, revestimento sílico argiloso, ou outro destinado a consolidar-lhe a superfície natural".

\footnotetext{
${ }^{649}$ CAMPOS, Cynthia Machado. Santa Catarina, 1930: da degenerescência à regeneração. Florianópolis: EDUSC, 2008. p. 115-116.

${ }^{650}$ Lei n. 105, de 22 out. 1936. Cria a taxa de serviço de conservação e melhoria de estradas de rodagem estaduais e de serviços de registro e fisscalização de veículos. In: Coleção de Leis de 1936. Florianópolis: Imprensa Oficial do Estado, 1936. p. 68-73.

${ }^{651}$ Idem.

${ }^{652}$ Idem.

${ }^{653} \mathrm{Idem}$.
} 
Observamos, assim, que a cobrança recaía sobre os proprietários de terrenos marginais às estradas estaduais, desde que elas estivessem devidamente pavimentadas ou calçadas. Notamos, portanto, preocupações similares àquelas verificadas nos "regulamentos para as estradas estaduais" dos anos de 1914 e 1918; pois, nesses textos, verificamos a preocupação expressa pelos poderes públicos estaduais em estipular a limpeza e a desobstrução dos terrenos marginais às estradas para, dentre outros objetivos, prover boas condições ao tráfego de veículos tracionados por força motriz animal, ou mesmo àqueles de natureza automotiva. (Ver capítulo segundo; seção Passagens para Veículos). Percebemos que, durante todo esse período (19141936), verificou-se, nas legislações estaduais, a preocupação em oferecer as condições que se entendiam apropriadas para o livre fluxo de veículos - tracionados por força motriz animal ou motorizados. Assim, a tabela 04, disposta a seguir, anexa à Lei n. 105, de 22 de outubro de 1936, fornece-nos uma ideia mais aproximada dos valores pagos pelos proprietários dos "veículos a motor" e "de tração animal" e, igualmente, permite-nos vislumbrar a variedade de veículos que, à época, circulavam pelas estradas intermunicipais de Santa Catarina.

Tabela 04: Taxas de serviço de conservação de estradas e de registro e fiscalização de veículos - 1936

\begin{tabular}{|c|c|c|}
\hline \multicolumn{3}{|c|}{ Proprietários de veículos a motor (proporcional a cada veículo) } \\
\hline De passageiros particulares & Taxa de serviço de conservação e melhoria & Taxa de registro e fiscalização \\
\hline $\begin{array}{l}\text { Até } 25 \mathrm{HP} \\
\text { De mais de } 25 \mathrm{HP} \text { a } 35 \mathrm{HP} \\
\text { De mais de } 35 \mathrm{HP} \text { a } 60 \mathrm{HP} \\
\text { De mais de } 60 \mathrm{HP} \\
\text { De valor superior a 20:000\$000 (qualquer força) }\end{array}$ & $\begin{array}{r}55 \$ 000 \\
75 \$ 000 \\
95 \$ 000 \\
135 \$ 000 \\
180 \$ 000 \\
\end{array}$ & $\begin{array}{l}25 \$ 000 \\
35 \$ 000 \\
45 \$ 000 \\
65 \$ 000 \\
70 \$ 000 \\
\end{array}$ \\
\hline \multicolumn{3}{|c|}{ Proprietários de veículos movidos a tração animal (proporcional a cada veículo) } \\
\hline De passageiros & Taxa de serviço de conservação e melhoria & Taxa de registro e fiscalização \\
\hline $\begin{array}{l}\text { De } 2 \text { rodas e aros de borracha pneumática } \\
\text { De } 2 \text { rodas e aros de borracha maciça } \\
\text { De } 2 \text { rodas e aros de madeira ou metálicos } \\
\text { De } 4 \text { rodas e aros de borracha pneumática } \\
\text { De } 4 \text { rodas e aros de borracha maciça } \\
\text { De } 4 \text { rodas e aros de madeira ou metálicos }\end{array}$ & $\begin{array}{r}30 \$ 000 \\
50 \$ 000 \\
70 \$ 000 \\
50 \$ 000 \\
70 \$ 000 \\
90 \$ 000\end{array}$ & $\begin{array}{l}10 \$ 000 \\
20 \$ 000 \\
30 \$ 000 \\
20 \$ 000 \\
30 \$ 000 \\
40 \$ 000\end{array}$ \\
\hline De carga & Taxa de serviço de conservação e melhoria & Taxa de registro e fiscalização \\
\hline $\begin{array}{l}\text { De } 2 \text { rodas - com molas } \\
\text { De } 2 \text { rodas - sem molas } \\
\text { De } 4 \text { rodas - com molas } \\
\text { De } 2 \text { rodas }- \text { sem molas }\end{array}$ & $\begin{array}{c}50 \$ 000 \\
70 \$ 000 \\
90 \$ 000 \\
110 \$ 000\end{array}$ & $\begin{array}{l}20 \$ 000 \\
20 \$ 000 \\
30 \$ 000 \\
40 \$ 000\end{array}$ \\
\hline
\end{tabular}

Fonte: Lei n. 105, de 22 de outubro de 1936. Cria a taxa de serviço de conservação e melhoria de estradas de rodagem estaduais e de serviços de registro e fiscalização de veículos. In: Coleção de Leis de 1936. Florianópolis: Imprensa Oficial do Estado, 1936. p. 68-73.

Os dados apontados pela tabela 04 corroboram a análise sobre o conteúdo textual da Lei n. 105, de 22 de outubro de 1936, registrado anteriormente, pois nos permitem uma melhor visualização sobre as taxas cobradas para a conservação das estradas estaduais e para o registro e a fiscalização dos veículos. Essas taxas eram, como visto, aplicadas principalmente na conservação das estradas estaduais e esse propósito estava atrelado à preocupação das autoridades competentes em prover condições favoráveis ao tráfego de veículos; política esta que obedecia, ao certo, àquela junto à esfera federal, pautada pela crescente estatização dos serviços 
relacionados à industrialização, infraestrutura, políticas educacionais, etc., que permearam as ações do governo getulista.

Além disso, a referida tabela permite-nos verificar outros elementos importantes. Em primeiro lugar, percebemos que os veículos motorizados dispunham de propulsores que desenvolviam, ao máximo, 60 HP. Para termos uma ideia, essa potência corresponde, grosso modo, àquela apresentada pelos atuais veículos de mil cilindradas $\left(1.000 \mathrm{~cm}^{3}\right)$. Outro aspecto que julgamos pertinente destacar se refere ao fato de que os valores pagos pelos proprietários dos veículos motorizados, referentes às taxas de serviço de conservação e melhoria e de registro e fiscalização, eram comparativamente maiores do que aqueles pagos pelos proprietários dos veículos tracionados por tração animal. Esse é um indício que, dentre outros elementos, aponta para o aspecto de que os proprietários de automóveis apresentavam, via de regra, maior poder aquisitivo que os proprietários dos demais veículos. Observamos, igualmente, maior diversidade quanto aos veículos de tração animal. Esse elemento permite-nos inferir que os processos de introdução e de circulação dos veículos motorizados nas estradas intermunicipais foram efetuados - a exemplo do que também ocorria na capital do Estado - de maneira gradual.

De outro modo, a mesma tabela permite-nos constatar os diversos tipos de automóveis e veículos tracionados por força motriz animal que, à época, circulavam pelas estradas intermunicipais. É apropriado considerarmos que esses diversos tipos de veículos circulavam, igualmente, pelas ruas da capital catarinense. Além disso, esses elementos nos ajudam, também, a ter uma ideia sobre a crescente complexidade que assumiu a circulação e as atividades relacionadas ao fluxo de veículos durante as décadas de 20 e 30 do século passado; devemos considerar, igualmente, a circulação de ônibus e caminhões que, ao certo, percorriam as estradas e ruas intermunicipais no período ${ }^{654}$.

Nosso próximo episódio nos remete ao ano de 1938, uma vez que o processo n. 373, de 27 de janeiro, registra a colisão entre um ônibus e uma motocicleta, da qual saíram feridos Higino Luiz Gonzaga e Francisco Zenft, ocupantes da moto. Constatamos que o acidente ocorreu na esquina da rua Almirante Alvim com a Praça Getúlio Vargas ${ }^{655}$ e que a abertura do respectivo inquérito se deu no dia 27 do mesmo mês. Assim o "Termo de declarações" prestado por José Afonso Dutra, 38 anos, chauffeur do ônibus envolvido no acidente, esclarece-nos que "no dia 23 do corrente, às três e vinte horas da tarde, saiu da praça conduzindo o seu ônibus ${ }^{656}$, que faz a linha do cemitério" e, “quando passava a Praça Getúlio Vargas, na frente da Igreja da Conceição,

\footnotetext{
${ }^{654}$ Segundo pesquisas realizadas no IBGE, existiam na cidade de Florianópolis, no ano de 1936, o total de vinte e dois auto-ônibus e vinte autocaminhões. (IBGE. Anuário Estatístico do Brasil, ano III, Rio de Janeiro, 1937. p. 294).

${ }^{655}$ Processo n. 373, 27 jan. 1938. Caixa 41.

${ }^{656}$ José Afonso Dutra é o proprietário da empresa de ônibus José Dutra, conforme é possível constatarmos no Guia do Estado de Santa Catarina: Suplemento para o ano de 1937. Florianópolis: Livraria Central de Alberto Entres, 1937.
} 
e que ia dobrar a esquina para a rua Almirante Alvim", encontrou, "subindo a mesma rua, o senhor Higino Luiz Gonzaga em uma motocicleta, trazendo no acento da retaguarda, Francisco Zenft" ${ }^{, 657}$. O depoente, "ao ver a motocicleta que vinha com a velocidade calculada de cinqüenta a sessenta quilômetros, procurou brecar o seu carro, o que conseguiu fazer" ${ }^{\circ 58}$. Apesar disso, “a motocicleta de Higino veio de encontro a seu carro batendo no lado direito do pára-choque, por ter derrapado quando fazia a curva"659. O declarante afirmou, igualmente, que "parou na sua mão" e que "a motocicleta vinha pelo meio da rua"660. (Anexo 15, p. 346).

As afirmações prestadas por José Afonso Dutra esclarecem aspectos importantes. Àquela época (1938), ainda utilizava-se a expressão chauffeur para designar os condutores de veículos motorizados - automóveis e ônibus. Esse aspecto será corroborado no decorrer da análise deste processo. A utilização da expressão "chauffeur" dá-nos a ideia de que a atividade de condução de veículos motorizados ainda era algo que estava "amadurecendo", pois essa atividade tornouse visivelmente comum e corriqueira apenas na década de 1950, uma vez que o Plano Diretor da cidade de Florianópolis (1952/1955) registra que, "nas últimas décadas aparece e cresce o transporte motorizado e a existência da ponte Hercílio Luz faz aumentar bastante o tráfego, na península" ${ }^{\circ 61}$. Esses elementos indicam-nos que a circulação de veículos motorizados, na cidade de Florianópolis, foi intensificada de maneira progressiva, especialmente nas áreas próximas à ponte Hercílio Luz, único acesso terrestre à saída e à entrada de veículos para as partes insular e continental (Estreito) da capital catarinense.

Além disso, devemos observar que a organização do plano diretor atestou, dentre outros aspectos, a necessidade de se oferecer soluções para o equacionamento do fluxo de automóveis na cidade de Florianópolis; elemento este que, de acordo com os autores do plano, exigiria a construção de uma nova ponte para ligar as partes insular e continental da capital catarinense. Esse aspecto será alvo de investigação no quinto capítulo da tese, especialmente na seção Epílogo. É possível inferirmos, ainda, que o ônibus partiu da Praça XV de Novembro, pois esta é situada em local próximo à Praça Getúlio Vargas, onde o veículo trafegou momentos após sua partida. Além disso, podemos inferir que, no final da década de 1930, o ponto inicial e final, de partida e chegada dos veículos de praça e de aluguel, estava situado na Praça XV de Novembro; pois, conforme referencia o Guia do Estado de Santa Catarina, de 1937, o ponto de "parada dos

\footnotetext{
${ }^{657}$ Processo n. 373, 27 jan. 1938. Caixa 41.

${ }^{658}$ Processo n. 373, 27 jan. 1938. Caixa 41. Corroborando com essas informações, a testemunha Genézio José da Silva, 32 anos, funcionário público, e que era passageiro do ônibus envolvido no acidente afirma, em declarações tomadas no dia 28 de janeiro de 1938 , que "o chauffeur do ônibus ao ver a motocicleta brecou o seu carro, de maneira que, quando levou o choque, estava quase parado". Adiante, porém, admite que, "no momento do choque, o ônibus não estava na mão, isto é, fazia a curva muito por dentro" e que "ouviu o fonfonar da motocicleta antes da mesma chegar à esquina", mas "não ouviu nem viu fonfonar o ônibus em que viajava”. (Processo n. 373, 27 jan. 1938. Caixa 41).

${ }^{659}$ Processo n. 373, 27 jan. 1938. Caixa 41.

${ }^{660}$ Idem.

${ }^{661}$ PAIVA, Edvaldo Pereira; RIBEIRO, Demétrio; GRAEFF, Edgar A. FLORIANÓPOLIS: Plano Diretor. Florianópolis: Imprensa Oficial do Estado do Rio Grande do Sul, 1952. p. 42.
} 
autos e carros" correspondia à "Praça XV de Novembro",662. (Figura 08, p. 191). Cabe destacarmos, aqui, que o ônibus fazia a linha do cemitério, que corresponde ao cemitério das Três Pontes, inaugurado no ano de $1925^{663}$, em substituição ao antigo outeiro da cidade, estabelecido no ano de $1840^{664}$. Esse aspecto é importante, pois atesta que, ao final da década de 1930, estava em operação, ao menos, uma linha permanente para atender aos habitantes da região denominada "Três Pontes", que pertencia ao perímetro suburbano de Florianópolis ${ }^{665}$.

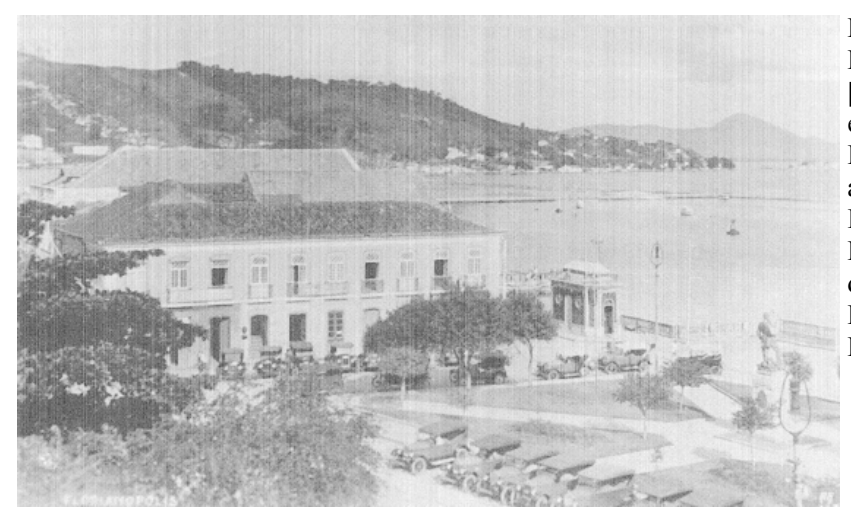

Figura 08 - Praça XV de Novembro / Praça Fernando Machado (Museu do Saneamento). [s/d.] Observamos os automóveis estacionados em toda a extensão da praça Fernando Machado. Em primeiro plano, no canto inferior esquerdo, as copas das árvores da Praça XV de Novembro. Fontes: Banco de Imagens do Instituto Histórico e Geográfico de Santa Catarina (meio digital), $1 \mathrm{CD} / \mathrm{ROM}$ / SILVA, Adolfo Nicolich. Ruas de Florianópolis: resenha histórica. Florianópolis: Fundação Franklin Cascaes,

Os ônibus circulavam, inclusive, aos domingos, pois a testemunha Heroldino Silveira D’Ávila, 34 anos, afirma que, "no dia 23 do corrente, domingo, dirigiu-se à esquina da rua Almirante Alvim com a Praça Getúlio Vargas e lá encontrou Higino Luiz Gonzaga e um outro senhor os quais se achavam ligeiramente feridos" e que "nas proximidades do local se encontravam um ônibus e uma motocicleta danificada"666. De outro modo, é importante observarmos que, pelo menos, desde o final da década de 1920, circulavam pelas ruas da cidade de Florianópolis veículos de duas ou três rodas, denominados "motociclos",667. Percebemos, assim, que a circulação desses veículos, ao final do decênio seguinte, não era algo novo, pois fazia parte, há algum tempo, do cotidiano da cidade.

\footnotetext{
${ }_{662}^{66}$ Guia do Estado de Santa Catarina: Suplemento para o ano de 1937. Florianópolis: Livraria Central de Alberto Entres, 1937.

${ }^{663} \mathrm{Ver}$, a respeito: A Inauguração do Cemitério das Três Pontes. O Estado, Florianópolis, 17 nov. 1925. p. 2.

${ }^{664}$ A implantação desse cemitério foi autorizada pela Lei n. 137 de 22 de Abril de 1840. (Coleção de Leis, 1835-1840. Desterro, 1840). É importante observarmos que o artigo terceiro dessa lei estipula que "Art. $3 .^{\circ}-$ De $1 .^{\circ}$ de janeiro de 1843 em diante, só no cemitério público se sepultarão os cadáveres das pessoas, que falecerem no distrito da Capital, ou que nele queiram sepultar-se". (Lei n. 137 de 22 abr. 1840. Coleção de Leis, 1835-1840... op. cit). Observamos que, a partir dessa data, são proibidos os sepultamentos nos adros das igrejas; prática comum até então, pois, dentre outros aspectos, não contavam, até essa época, com local específico para serem realizados.

${ }^{665}$ Conforme registrado pelo Guia do Estado de Santa Catarina, de 1937, que estipula, como visto, que "o perímetro suburbano de Florianópolis compreende às seguintes regiões: a) Estação Agronômica; b) Penitenciária da Pedra Grande; e c) Três Pontes (atual bairro do Itacorubi)”. (Guia do Estado de Santa Catarina: Suplemento para o ano de 1937. Florianópolis: Livraria Central de Alberto Entres, 1937). É válido observarmos que o referido documento registra que apenas a "Empresa José Dutra" mantinha uma linha regular para o distrito das "Três Pontes", em passagem pelo distrito da "Trindade", e que operava "de hora em hora". (Guia do Estado de Santa Catarina: Suplemento para o ano de 1937... op. cit.). A escassez de linhas regulares para atender ao perímetro suburbano e aos distritos da Capital, conforme aponta a referência em questão, pode ser corroborada pela má situação das estradas que conduziam ao "interior da Ilha", segundo aponta o relatório da Prefeitura Municipal de Florianópolis, datado de 1940, pois registra que "continua sendo difícil a solução do problema das vias de comunicação para o interior da Ilha. Diante da minguada receita da zona rural, vê-se esta administração impossibilitada de reconstruir as estradas que ligam os diversos distritos à esta Capital". (RAMOS, Mauro. Relatório da Prefeitura Municipal de Florianópolis. Apresentado ao Sr. Interventor Federal no Estado. Florianópolis, 1940. p. 47). Sugestiva é a observação de que o interior da Ilha e os "diversos distritos" eram classificados como "zona rural". ${ }^{666}$ Processo n. 373, 27 jan. 1938. Caixa 41.

${ }^{667}$ IBGE: Anuário Estatístico do Brasil, ano II, Rio de Janeiro, 1936; Anuário Estatístico do Brasil, ano V, Rio de Janeiro, 1940. O anuário estatístico correspondente ao ano de 1940, registra que os veículos de passageiros (a motor) que circulavam pela cidade de Florianópolis durante o período compreendido entre os anos de 1937 a 1939, contemplavam o total de "Automóveis comuns, ônibus, ambulâncias e motociclos de 2 ou 3 rodas". (Anuário Estatístico do Brasil, ano V, Rio de Janeiro, 1940).
} 
Esses elementos, aliados àqueles dispostos na tabela 04 (p. 188), fornecem-nos uma ideia de quão diversificados eram os tipos de veículos - motorizados ou tracionados por força motriz animal - que, à época, circulavam pelas estradas intermunicipais e pelas ruas do perímetro urbano da capital catarinense, os quais atestam, dentre outros aspectos, que, já na década de 1930, era marcante a presença dos veículos motorizados que contavam, inclusive, com praças agenciadoras para a sua comercialização, localizadas nas principais cidades do Estado. (Figuras 09 e 10, p. 192). No processo em discussão, enfatizamos que as informações prestadas por José Afonso Dutra apontam que a velocidade da motocicleta, no momento da colisão, era, aproximadamente, "cinqüenta a sessenta quilômetros". Devemos observar que tal velocidade é bem superior àquela permitida para o perímetro urbano de Florianópolis, estipulada pelas Instruções Regulamentares para o serviço de trânsito público, que vigoraram, pelo menos, até o ano de $1934^{668}$.
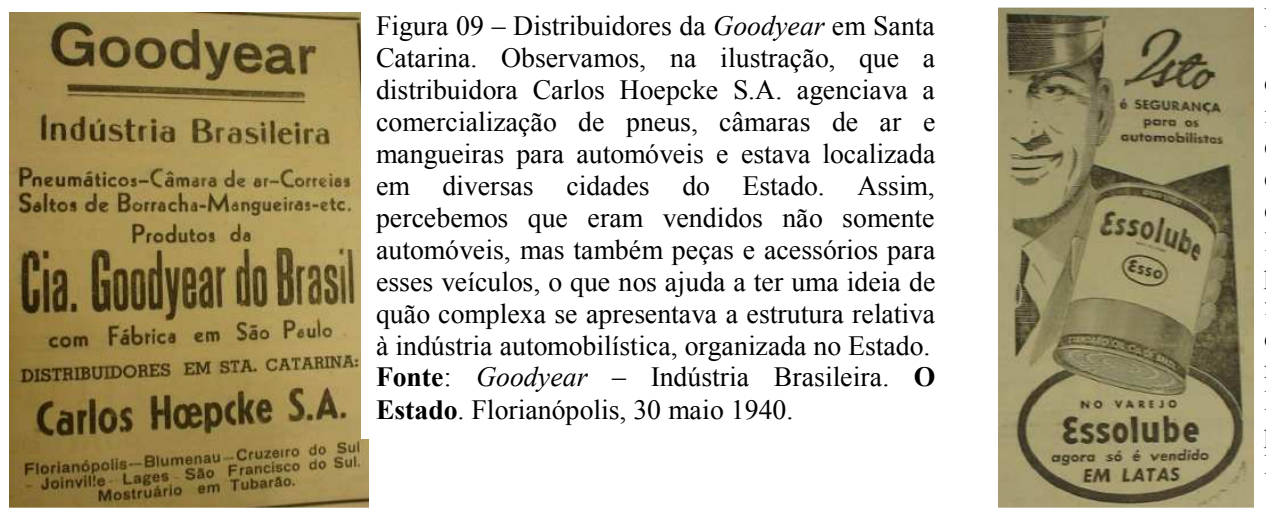
Figura 10 - Óleo Essolube -
1940. Observamos que a partir
do final da década de 1930, a
indústria automobilística está
estabelecida em território
catarinense. A partir dessa
época, os artigos dos periódicos
locais ocupam-se em
propagandear, com maior
frequência, a comercialização
de peças e lubrificantes para
máquinas e motores. Fonte:
Essolube - ISTO é segurança
para os automobilistas. O
Estado, Florianópolis, 13 abr.
1940 p. 3 .

As declarações prestadas por Higino Luiz Gonzaga registram que, "no dia 23 do corrente, às quinze e trinta horas, subia a rua Almirante Alvim em sua motocicleta, trazendo no acento da bagagem Francisco Zeift, quando ao dobrar a esquina, deparou-se com o caminhão guiado pelo chauffeur José Afonso Dutra". ${ }^{669}$ Higino Luiz Gonzaga afirma, igualmente, que "trinta metros, mais ou menos, antes da curva, deu o sinal respectivo, buzinou, não tendo ouvido a resposta; que vinha a sua máquina ligada em marcha de segunda" e que "a velocidade era mais ou menos a normal, ou seja, de vinte e cinco a trinta quilômetros a hora" ${ }^{\natural 70}$.

Dado o exposto, podemos considerar que Higino Luiz Gonzaga era proprietário da motocicleta. Acreditamos, uma vez mais, que a identificação do respectivo condutor ajuda-nos a

\footnotetext{
${ }^{668}$ Ver, no capítulo primeiro da tese, análise relativa ao processo n. 239, de 21 de janeiro de 1934. Caixa 26. Além disso, na vasta documentação pesquisada, não encontramos registros da vigência de novos códigos de trânsito estaduais ou municipais durante a segunda metade da década de 1930. Isso nos leva a crer que as Instruções Regulamentares para o serviço de trânsito público, de 1928, ainda vigoravam no ano de 1938, e estipulavam um limite de velocidade de "vinte quilômetros a hora, de marcha". (Santa Catarina. Instruções Regulamentares para o serviço de trânsito público. Florianópolis: Imprensa Oficial, 1928). Vale lembrarmos que, somente no ano de 1941, é instituído o primeiro código nacional de trânsito, que oferecerá nova organização e padronização aos procedimentos e regras disciplinares de trânsito para todo o território nacional, medidas essas adotadas, pois, de maneira gradual nos estados e municípios. (Decreto-lei 3651: dá nova redação ao Código Nacional de Trânsito... op. cit.). Inferimos, portanto, que esse código não foi aplicado de imediato no Estado de Santa Catarina e em sua Capital; é provável, por isso, que, no início da década de 1940, ainda vigorassem os respectivos códigos e leis estaduais de trânsito.

${ }^{669}$ Processo n. 373, 27 jan. 1938. Caixa. 41.

${ }^{670}$ Idem.
} 
compreender como ele era proprietário de um veículo motorizado. Assim, destacamos que, no registro apontado no processo, consta que Higino Luiz Gonzaga é "natural deste Estado, com 38 anos de idade, casado, escrivão da Primeira Vara Civil, desta Capital, sabendo ler e escrever, residente à rua Visconde de Ouro Preto, número cinqüenta e três" ${ }^{\text {"671 }}$. Em vista disso, notamos que o condutor da motocicleta não era jovem, pois tinha 38 anos de idade. Podemos considerar, também, que ele já trabalhava por bastante tempo, visto que, àquela época, era comum aos chauffeurs profissionais, por exemplo, iniciarem na sua atividade com dezoito ou dezenove anos de idade; portanto, muito jovens. $\mathrm{O}$ fato de o condutor da motocicleta trabalhar, ao que parece, desde considerável tempo, talvez indique-nos o porquê de ele ter adquirido um veículo motorizado. Além disso, ele residia na rua Visconde de Ouro Preto, região próxima ao centro da cidade; era, portanto, privilegiada. Desse modo, entendemos que Higino Luiz Gonzaga era um indivíduo que ostentava, ao menos, razoável condição de vida.

Observamos, também, que ao ônibus guiado por José Afonso Dutra foi dada a denominação “caminhão". As expressões "ônibus" e "caminhão" são, com efeito, utilizadas durante todo o processo para designar o mesmo veículo; e, possivelmente, eram empregadas desse modo entre os habitantes da capital catarinense. Desse depoimento, vimos que o declarante afirma que, "trinta metros antes da curva, buzinou, mas não ouviu a resposta" e que "vinha a sua máquina ligada em marcha de segunda"; enfatiza que "a velocidade era mais ou menos a normal, ou seja, de vinte e cinco a trinta quilômetros a hora". Percebemos, com base nessas informações, que a utilização da buzina é um dispositivo regulamentar de trânsito, exigido "nas esquinas ou nos cruzamentos de ruas" ${ }^{\text {,72. }}$. Além disso, a existência de semáforos supriria a utilização de buzinas no trânsito das ruas do espaço central da cidade de Florianópolis. A inexistência desses recursos, no final da década de 1930, fornece-nos, contudo, para esse período, uma ideia da intensidade do tráfego nas ruas centrais da capital catarinense ${ }^{673}$.

Nesse ponto, entendemos que é válido observarmos as declarações prestadas pelo inspetor de veículos da cidade de Florianópolis, Antônio Palmeiro da Fontoura, 34 anos, que admite, em declarações prestadas no dia 28 de janeiro de 1938, que, "no dia 23 do corrente mês de janeiro, foi chamado para atender um acidente verificado entre a motocicleta de Higino Luiz Gonzaga e o

\footnotetext{
${ }^{671}$ Processo n. 373, 27 jan. 1938. Caixa. 41.

${ }^{672}$ Santa Catarina. Instruções Regulamentares para o serviço de trânsito público. Florianópolis: Imprensa Oficial, 1928. p. 10.

${ }^{673}$ As sinaleiras foram utilizadas nos cruzamentos das ruas centrais da cidade de Florianópolis somente a partir da década de 1950 , pois no ano de 1954, o artigo do jornal $O$ Estado, registrou que "Foram inauguradas as sinaleiras luminosas que criarão permissões verdes e impedimentos vermelhos ao tráfego local". Em outra passagem do mesmo artigo, solicita-se que se "encomende mais sinaleiras", e, "pelo menos uma para a esquina da rua Padre Roma com Felipe Schmidt", as quais "melhorarão, sem dúvida, as condições de trânsito na nossa capital". (Notas \& Comentários - sinaleiras coloridas. O Estado. Florianópolis, 27 jun. 1954. p. 1). A nota não menciona a instalação de sinaleiras no cruzamento da rua Almirante Alvim com a praça Getúlio Vargas, porém registra que a instalação desses recursos no cruzamento das ruas Felipe Schmidt e Padre Roma - ruas centrais da cidade - "é imprescindível", e sugere que outros "quatro entroncamentos de ruas necessitam de idêntica sinalização". Notas \& Comentários - sinaleiras coloridas. O Estado... op. cit., p. 1. A inauguração de sinaleiras no cruzamento das ruas do espaço central de Florianópolis, e a solicitação para a encomenda de novos dispositivos evidenciam, portanto, o crescente trânsito de veículos motorizados pelas ruas da capital catarinense e a respectiva necessidade de dispositivos disciplinadores para melhor organizá-lo.
} 
ônibus de José Afonso Dutra" ${ }^{\text {674 }}$. Continuando suas observações, o inspetor de veículos afirma que "chegando ao local, verificou que o ônibus estava parado na esquina da praça Getúlio Vargas com a rua Almirante Alvim" e que, "na situação em que se achava, o ônibus não estava na mão, como devia"; entretanto, que "a motocicleta vinha em sua mão; isso conclui o depoente em vista do local em que se chocaram, mas que a mesma trazia excesso de velocidade" ${ }^{~} 675$.

A par dos detalhes fornecidos pelo depoimento prestado pelo inspetor de veículos de Florianópolis, é importante considerarmos que as autoridades de trânsito municipais atuavam com certa rapidez para o equacionamento dos acidentes de trânsito; pois, no presente processo, Antônio Palmeiro da Fontoura, ao que parece, compareceu sem demora ao local do ocorrido, uma vez que, segundo suas explanações, ele chegou ao local e pôde verificar que o ônibus ainda estava parado na "esquina da praça Getúlio Vargas com a rua Almirante Alvim", na mesma posição em que se encontrara após a ocorrência da colisão. Além disso, analisamos episódios em que as autoridades policiais do município efetuaram prisões em flagrante daqueles responsáveis por crimes de trânsito. Outro aspecto que podemos observar é que os inspetores de trânsito trabalhavam durante toda a semana, inclusive aos domingos, o que nos permite inferir que a circulação de veículos motorizados pelas ruas da Capital processava-se diariamente, de forma constante, o que exigia a presença e a atuação dos responsáveis pela fiscalização do trânsito local para coibir ou "atender" ocorrências diversas verificadas nas ruas da cidade de Florianópolis ${ }^{676}$.

Os episódios de atropelamentos e colisões, analisados neste texto, atestam, em primeiro lugar, a diversificação da legislação de trânsito aplicada em Santa Catarina, que foi assumindo maior incrementação e complexidade durante a década de 1930; pois, dentre outros elementos, foi atrelada à política nacional vargista, pautada pelo crescente dirigismo estatal, aplicada aos mais diversos setores e atividades administrativos, econômicos e culturais. A criação da Secretaria de Segurança Pública, no ano de 1935, por meio de lei estadual, e a atribuição posterior de seu papel na "orientação e fiscalização do trânsito nas vias públicas", estabelecida através de decreto-lei, ilustram o papel e a atuação do Estado no controle e disciplinarização dos espaços e comportamentos sociais. Assim, a dispersão, as preocupações com o isolacionismo e com a não assimilação dos ideais de brasilidade foram elementos que pautaram as intervenções das autoridades brasileiras, especialmente junto às populações de origem estrangeira sediadas no Sul do Brasil. Desse modo, as cidades catarinenses, em especial do Vale do Itajaí, foram as que mais demandaram ações e atenção dos governantes, pois a iniciativa fez parte de um movimento

\footnotetext{
${ }^{674}$ Processo n. 373, 27 jan. 1938. Caixa 41.

${ }^{675}$ Idem.

${ }^{676}$ A esse respeito, vimos que o Decreto-lei n. 261 cria, a partir de dezembro de 1938, "a Guarda de Trânsito da Capital do Estado e o cargo de Sub-Inspetor Geral de Veículos e trânsito público", a fim de, entre outros objetivos, auxiliar "o Inspetor Geral, no orientar e fiscalizar aquele serviço em todo o Estado". (Decreto-lei n. 261. Cria a Guarda de Trânsito da Capital do Estado e o cargo de subInspetor Geral de Veículos e Trânsito Público. In: Santa Catarina. Coleção de Decretos-Leis de 1938. Florianópolis: Imprensa Oficial do Estado, 1939).
} 
que tentou estender o controle estatal sobre regiões não submetidas aos padrões de homogeneidade que o Estado Novo pretendeu fundamentar ${ }^{677}$.

Neste texto, pudemos, também, vislumbrar um rápido equacionamento sobre os principais instrumentos legais que regulamentaram o trânsito nas estradas estaduais e na capital catarinense durante o período entre os anos de 1920 e 1941; e constatamos que, a partir da década de 1940, adotaram-se novos dispositivos penais e de trânsito, vigentes para todo o território nacional, que foram aplicados de maneira gradual nos estados e municípios. Esses dispositivos objetivaram padronizar a circulação dos veículos motorizados em todo o território nacional e atualizar a aplicação de penas e a organização dos processos criminais elaborados em todo o País, por meio dos quais percebemos nova fase na organização do trânsito e dos dispositivos penais vigentes.

A investigação proposta neste estudo também nos permitiu revelar percepções e sensibilidades expressas pelos florianopolitanos quanto à circulação dos veículos motorizados pelas ruas do espaço central e do perímetro urbano da capital catarinense. Assim, esses aspectos foram revelados, sobretudo, pela análise dos registros escritos apontados nos processos criminais, que envolveram atropelamentos e colisões pelas ruas da cidade de Florianópolis. Entendemos que este "corpus documental" constitui testemunhos históricos expressos pelos florianopolitanos, pois salvaguardam falares ocultos e revelam camadas de significações esquecidas $^{678}$. Dessa forma, podemos afirmar que a análise das linguagens inscritas nos documentos pesquisados é tanto vetor quanto indício das percepções expressas pelos florianopolitanos em relação aos episódios cotidianos dos atropelamentos e colisões aos quais estavam sujeitos. Assim, neste estudo, optamos por pesquisar e analisar textos e percepções anônimos, aparentemente perecíveis que, em síntese, permitem-nos ver a cidade envolta em movimentos e vivências diversas, pontuada por práticas cotidianas; fundadas na relação com o ocasional, que encerram astúcias e combinações de poderes múltiplos e entrelaçados, passíveis de serem recuperados pelo trabalho do historiador ${ }^{679}$.

\footnotetext{
${ }^{677}$ CAMPOS, Cynthia Machado. A Política da Língua na Era Vargas: proibição de falar alemão e resistências no Sul do Brasil. Campinas: UNICAMP, 2006. p. 109.

${ }^{678}$ TOPALOV, Cristian; DEPAULE, Jean-Charles. A Cidade através de suas Palavras. In: BRESCIANI, Maria Stella Martins. (Org.). Palavras da cidade. Porto Alegre: UFRGS, 2001. p. 19.

${ }^{679}$ CERTEAU, Michel de. A invenção do cotidiano 1: artes de fazer. 8. ed. Petrópolis: Vozes, 2002. p. 13 e p. 174. Para outras referências sobre o "colossal agrupamento" e a "espontânea vibração" de "almas" e "vozes" que a urbs representa, ver a seguinte crônica de João do Rio: RIO, João do. A Musa das ruas (Crônica). In: ___ RIO, João do. A Alma encantadora das ruas: crônicas. São Paulo: Companhia das Letras, 2008. p. 234-252. ((Org.). Raúl Antelo). Nesse sentido, para esse autor, a "Musa das ruas" é, também, "policroma", uma vez que "reflete a população confusa e babélica tal qual ela é". Ibidem, p. 240.
} 


\section{Capítulo 4 - Os Processos Criminais em Cena 4: pedagogia e punição}

Neste capítulo, analisamos, de modo especial, a maneira como os processos criminais que envolvem os episódios de atropelamentos e colisões ocorridos no perímetro urbano da cidade de Florianópolis, durante as décadas de 1920 e 1930, foram conduzidos. Assim, tomamos como pano de fundo, as falas e os posicionamentos dos personagens diretamente envolvidos no desenrolar e encerramento dos processos ${ }^{680}$. Objetivamos elaborar uma narrativa que discuta as etapas e os encaminhamentos tomados nos diferentes processos analisados. Para o presente capítulo, selecionamos sete processos, muitos dos quais já analisados nos capítulos anteriores. A utilização desses textos, no presente capítulo, justifica-se pela relevância em relação aos objetivos apresentados, que obedecem a quatro temáticas, destacadas a seguir.

Na seção Inquéritos e Julgamentos: enquadramento e absolvição, analisamos, no processo n. 52, de 05 de novembro de 1925, a maneira como o chauffeur, apontado como diretamente responsável pela ocorrência do choque com o automóvel n. 86, foi julgado e quais intenções, discursos e justificativas - expressos por juízes, advogados de defesa e acusação e, também, pelo próprio chauffeur, testemunhas e vítimas do sinistro - estavam envolvidos nas tentativas de proceder-se à condenação ou à absolvição daquele que foi apontado como responsável pela ocorrência aqui referenciada.

Num segundo momento, na seção Pedagogia e Aprendizado, procedemos à análise dos processos crime ${ }^{681}$ como disputas discursivas nas quais a participação dos chauffeurs, vítimas e testemunhas nos trâmites legais dos processos é vista como uma forma de aprendizado, ou seja, procuramos tecer uma narrativa do aspecto pedagógico que envolve o conhecimento "por ouvir dizer" dos sinistros ocorridos. Assim, é importante assinalarmos que muitas das testemunhas, arroladas nos processos, participaram de determinado sinistro "por ouvir dizer" a seu respeito. O que pretendemos é assinalar que essas testemunhas são ouvidas e "seu papel, deduz-se, [...] é o de participar do processo pedagógico" ${ }^{682}$. Nesse sentido, cada depoente responde perguntas muito bem definidas e sua fala propõe um julgamento antecipado do réu, o que contribui para a construção de discursos, muitas vezes orientados para a condenação ou não dos chauffeurs condutores dos automóveis ${ }^{683}$.

Em cidade e o Automóvel em dois momentos: retórica e jurisprudência, analisamos dois processos criminais $^{684}$ que, entendemos, permitem-nos visualizar, com maior clareza, a

\footnotetext{
${ }^{680}$ Apresentados, em maiores detalhes, nos parágrafos posteriores.

${ }^{681}$ Nesta seção, analisamos os seguintes processos: a) Processo n. 62, 03 abr. 1926. Caixa 06; e b) Processo n. 95 , 05 jul. 1926. Caixa 09.

${ }^{682}$ PEDRO, Joana Maria; NECKEL, Roselane; HAWERROTH, Eliana Izabel; MACHADO, Vanderlei. Aborto e Infanticídio nos Códigos Penais e nos Processos Judiciais: a pedagogia de condutas femininas. In: PEDRO, Joana Maria. (Org). Práticas Proibidas: práticas costumeiras de aborto de infanticídio no século XIX. Florianópolis: Cidade Futura, 2003. p. 93.

${ }^{684}$ a) Processo n. 73, 17 dez. 1926. Caixa 07; e b) Processo n. 171, 27 dez. 1931. Caixa 16.
} 
adequação do aparato legislativo, verificada durante as décadas de 1920 e 1930, especialmente quanto ao tratamento judicial aplicado aos agentes responsáveis pelos atropelamentos e colisões verificados nas ruas do perímetro urbano da capital catarinense, no período supracitado. Os dois textos centram-se, respectivamente, na investigação de atropelamento e colisão. No primeiro processo, verificamos a condenação do réu, ou seja, após enfrentar os trâmites legais que compõem a elaboração e o encerramento do processo, o chauffeur Ervino Raguse, suposto acusado pelo atropelamento verificado no dia 17 de dezembro de 1926, é condenado em decisão final do Tribunal Correcional, datada de 11 de janeiro de 1927. Dentre os textos processuais que estudamos nesta investigação, esse é o primeiro exemplo em que verificamos a condenação do respectivo réu. Assim, analisamos as condicionantes que levaram à sua punição. No processo seguinte, datado de 27 de dezembro de 1931, o chauffeur Oscar John, acusado pela colisão provocada ao automóvel n. 218, guiado por Otaviano dos Santos Botelho, é condenado e, em instância posterior, absolvido da respectiva acusação que lhe cabe. O que pretendemos é, portanto, tomar esses textos como pano de fundo para procedermos a uma investigação sobre os meandros retóricos e discursivos encerrados nos aparatos processuais e legislativos, nas duas décadas estudadas na pesquisa, notadamente quanto ao aspecto de tentar produzir-se a punição dos agentes responsáveis pelos sinistros ocorridos nas ruas do perímetro urbano de Florianópolis.

$\mathrm{Na}$ seção Leis e Finanças, que encerra o presente capítulo, investigamos os processos criminais nos quais é mais claramente perceptível o jogo que envolve a conjugação dos poderes judiciário e financeiro, como fator determinante para o livramento condicional dos chauffeurs presos em função de atropelamentos e colisões, ou, mesmo, para a não condenação desses personagens. Procedemos, também, à análise das questões atinentes à razão por que, em algumas ocasiões, esses poderes estavam comutados para, deliberadamente, inocentar chauffeurs e responsabilizar transeuntes pelos sinistros ocorridos. São dois os processos aqui analisados: a) Processo n. 96, 19 dez. 1928; e b) Processo n. 239, 21 jan. 1934. Percebemos que os dois textos selecionados perpassam as décadas de 1920 e 1930. Assim, objetivamos demonstrar que a conjugação dos poderes judiciário e financeiro, como fator condicionante para a soltura de chauffeurs ou, mesmo, para o indiciamento dos transeuntes, é um elemento que se faz presente durante todo o período analisado e que está imbricado na própria maneira de se elaborar e aplicar leis. Isso coloca, lado a lado, chauffeurs e transeuntes; personagens estes que constituem os protagonistas dos embates que verificamos, diariamente, nas ruas do perímetro urbano de Florianópolis, durante todo o período em estudo, por ocasião dos episódios de atropelamentos e colisões aqui analisados. 


\subsection{Inquéritos e Julgamentos: enquadramento e absolvição}

Nesta seção, retomamos as condicionantes do processo n. 52 - já analisadas no capítulo primeiro (ver seção Deslocamento e Velocidade) -, que registram o desastre sofrido com o automóvel n. 86, guiado pelo chauffeur amador Max Muller, ocorrido na Avenida Hercílio Luz. O sinistro em questão ocorreu no dia 05 de novembro de 1925. Para melhor situar o leitor, destacamos que o acusado aponta que, naquele dia "foi ao ponto dos automóveis e tomou o auto n. 86 para ir ao Tiro Alemão" e, naquela ocasião, "encontra no ponto de automóveis da Capital, seu amigo Hans Lepell e o convida para acompanhá-lo"685. Após "ter saído do Tiro Alemão", Max Muller “encontra na rua Blumenau o seu amigo Emílio Brosig, que [...] guiava o auto n. 102; e, ao "passarem pela Avenida Hercílio Luz, o [acusado] notou um forte estampido, tendo nesta ocasião [manobrado] a direção do referido auto 86 , virando em seguida" ${ }^{\text {, }} 86$. Continuando seu depoimento, o acusado afirma que "só soube saírem feridos Hans Lepell e Jorge Sandmann ${ }^{687}$ após ir ao Hospital de Caridade, pois não viu [o que aconteceu após o incidente] porque estava sem sentidos devido ao abalo produzido pelo desastre" ${ }^{688}$. Esse é, portanto, o cenário a partir do qual se desenrola o processo em discussão...

Assim, é importante observarmos que, no presente texto processual, o acusado Max Muller foi submetido a um julgamento, composto por etapas bem definidas ${ }^{689}$. No dia 09 de novembro de 1925 - já se passavam, portanto, quatro dias após a ocorrência do sinistro - foi-lhe dirigido o “Auto de perguntas e declarações", formulado pelo Delegado de Polícia João Baptista Paiva ${ }^{690}$. Ao ser questionado sobre se os envolvidos no acidente "conduziam os automóveis com excesso de velocidade", o acusado respondeu que "vinha em marcha regular"691. Vimos, no capítulo primeiro, que as declarações prestadas pelo chauffeur Emílio Brosig, no dia do sinistro, consideram que "atrás [de si] vinha em vertiginosa velocidade pela mesma avenida, o auto n. 86, [...] guiado pelo senhor Max Muller" ${ }^{\prime 692}$. É importante observarmos, também, que Emílio Brosig considerou o chauffeur Max Muller culpado pela ocorrência do desastre; e, nesses termos, é plausível considerarmos que ele tenha afirmado que Max Muller imprimia alta velocidade ao seu automóvel.

Corroborando com essas ideias, a testemunha Elzínio Maurício Wanderley, Primeiro Sargento do Segundo Batalhão de Infantaria da Força Pública, salienta, como visto no capítulo

\footnotetext{
${ }^{685}$ Processo n. 52, 05 nov. 1925. Caixa 05.

${ }^{686}$ Processo n. 52, 05 nov. 1925. Caixa 05. Para maiores detalhes sobre o cenário deste acidente, ver Anexo 02, p. 333.

${ }^{687}$ Jorge Sandmann é, como visto, chauffeur profissional e proprietário do automóvel n. 86. Ele faleceu no Hospital de Caridade no mesmo dia do sinistro, em função dos ferimentos que sofreu por ocasião do desastre.

${ }^{688}$ Processo n. 52, 05 nov. 1925. Caixa 05.

${ }^{689}$ Os vistos finais do processo, que apontam para a absolvição do réu, são datados de 19 de fevereiro de 1926.

${ }^{690}$ Processo n. 52, 05 nov. 1925. Caixa 05.

${ }^{691}$ Idem.

${ }^{692}$ Idem.
} 
primeiro, que, no dia do ocorrido, "estava em sua casa [quando] ouviu um estampido, e chegando à janela para verificar do que se tratava, viu o automóvel n. 86 que se achava virado"693. Observando mais atentamente o que tinha ocorrido, "soube que os referidos automóveis vinham com excesso de velocidade, supondo [...] que este desastre fosse devido à velocidade que os mesmos traziam" ${ }^{\text {694 }}$. É importante destacarmos que essa testemunha afirma que os automóveis envolvidos no acidente imprimiam alta velocidade, notadamente após ser informada, verbalmente, por outras pessoas que ali já estavam. É válido, ainda, observarmos que o processo em discussão apresenta, em sua fase de inquérito, ao menos cinco testemunhas ${ }^{695}$. Com isso, queremos dizer que a ideia de "excessiva velocidade" já havia sido previamente formulada por outras pessoas que estavam à volta do cenário descrito no processo em questão como veremos, com maiores detalhes, adiante. Não podemos, todavia, esquecer que o desastre que envolveu diretamente o automóvel 86 resultou no falecimento, momentos após o acidente, de Jorge Sandamann, proprietário do mesmo veículo, que vinha ao lado do chauffeur Max Muller. Em vista disso, esse aspecto nos permite inferir a ideia de que os referidos veículos imprimiam, na ocasião do acidente, alta velocidade.

Uma passagem importante do processo, que corrobora com as ideias expostas acima, destaca as palavras da testemunha Aristides de Aguiar Júnior, Cabo do Segundo Batalhão da Força Pública do Estado, que, em declaração prestada no dia 26 de dezembro de $1925^{696}$, afirma que dirigindo-se ao local do desastre, "viu o automóvel n. 86 quebrado e duas pessoas feridas e ensangüentadas, e viu outra que lhe parecia também ferida, estando todas rodeadas de muitos populares" ${ }^{\prime 697}$. De outro modo, a testemunha afirma, na mesma ocasião, que "ouviu dizer que o automóvel vinha em grande disparada e que tinha havido um esbarro" ${ }^{998}$. Notamos, com efeito, que essa é outra testemunha que, em face ao que lhe foi informado por outras pessoas, soube que

\footnotetext{
${ }^{693}$ Processo n. 52, 05 nov. 1925. Caixa 05.

${ }^{694}$ Idem.

${ }^{695}$ Para esse processo, consideramos vigente o Código Judiciário do Estado de Santa Catarina, de 1925, baixado pela Lei Estadual n. 1526 , de 14 de novembro de 1925. Com relação ao número de testemunhas que devem participar do respectivo processo, destacamos como referência o artigo 2169 do Código Judiciário supracitado, que estabelece: “Art. 2169 - No sumário de culpa de crimes, afiançáveis, em que não caiba ação do Ministério Público, serão ouvidas de duas a cinco testemunhas, e nos demais de cinco a oito, quer na acusação, quer na defesa”. (Código Judiciário do Estado de Santa Catarina. Lei n. 1526, de 14 de novembro de 1925. Florianópolis: Oficinas à Eletricidade da Imprensa Oficial, 1925, 352 p.). Destacamos esse trecho porque, de fato, os processos criminais ou cíveis eram regidos por códigos e leis préestabelecidos, e suas etapas obedeciam determinações legais claramente estipuladas. Além disso, o presente processo não envolveu, segundo critério acima estipulado, a atuação do Ministério Público, pois nele foi inquirido apenas um total de cinco testemunhas em ambas as ocasiões em que foram ouvidas, quais sejam: entre os dias 05 e 10 de novembro de 1925, e entre os dias 26 de dezembro de 1925 e 04 de fevereiro de 1926.

${ }^{696}$ É importante destacarmos que os processos obedecem a etapas específicas, estipuladas, como visto, por códigos ou leis preestabelecidas. Nos inquéritos policiais anexos aos processos criminais relativos à década de 1920, os responsáveis pelos crimes de atropelamento e colisão, e, bem assim, as vítimas e testemunhas, são indagadas pela figura do delegado de polícia, sendo a elas dirigidas os "autos" ou "termos" de "perguntas e declarações". Na fase posterior, que corresponde à instauração do processo propriamente dito, as testemunhas - incluída(s), aí, a(s) figura(s) da(s) vítima(s) - são intimadas a depor por intermédio da figura do Oficial de Justiça que, a mando do Juiz de Direito respectivo, "na forma da lei", informa-lhes a data, hora e local para que se procedam aos respectivos depoimentos junto "ao processo crime em que é A. a Justiça". O não comparecimento de quaisquer das testemunhas ou partes à audiência então marcada, implica em nova intimação, oficiada, igualmente, por mandado judicial. A rigor, as testemunhas intimadas se fazem presentes às audiências; e, vez por outra, são intimadas, também, testemunhas que não foram ouvidas na fase inicial de inquérito. Processo n. 52, 05 nov. 1925. Caixa 05. Os processos relativos à década de 1930 obedecem, a rigor, os mesmos procedimentos e etapas. Assim, para maiores detalhes a respeito, ver passagens posteriores deste texto.

${ }^{697}$ Processo n. 52, 05 nov. 1925. Caixa 05.

${ }^{698}$ Idem.
} 
o veículo n. 86 imprimia, na ocasião do acidente, alta velocidade. Com isso, queremos frisar que outras pessoas também compartilharam da opinião de que os referidos veículos imprimiam velocidade considerável. Não é, portanto, nenhum absurdo supormos que a declaração do chauffeur Max Muller, aqui apontada, segundo a qual ele, no momento do desastre, "vinha em marcha regular", foi formulada com o objetivo intencional de inocentá-lo da possível culpa frente ao ocorrido. De outro modo, devemos considerar a hipótese de que os relatos e falas, presentes nos processos judiciais, que envolvem discursos de delegados de polícia, juízes, advogados e promotores, traçam um jogo de possíveis justificativas para a afirmação ou negação do ato criminoso ${ }^{699}$. Além disso, esses discursos contribuem para a formação de uma ideia estigmatizada sobre as condutas, comportamentos e, mesmo, sobre o caráter dos chauffeurs e vítimas, o que implica o esquadrinhamento de posturas entendidas como "normais" ou “desviantes" perante a ordem legal estabelecida ${ }^{700}$. Nesses caminhos, percebemos que se constroem as ideias e justificativas para a identificação, condenação ou para a libertação da figura do réu. Veremos isso, com maiores detalhes, a seguir.

Assim, no dia 26 de dezembro de 1925, foi formulado o "Auto de Qualificação", dirigido ao chauffeur Max Muller, que salienta questionamentos a seu respeito: nome, idade, profissão, naturalidade, estado civil, saber ler e escrever ${ }^{701}$. Naquela data e também nos dias subsequentes, foram ouvidas, uma vez mais, as testemunhas arroladas no processo. As testemunhas ouvidas pelo menos algumas delas - evidenciam que o chauffeur Max Muller imprimia, no momento do desastre, alta velocidade.

\footnotetext{
${ }^{699}$ PEDRO, Joana Maria; NECKEL, Roselane; HAWERROTH, Eliana Izabel; MACHADO, Vanderlei. Aborto e Infanticídio nos Códigos Penais e nos Processos Judiciais: a pedagogia de condutas femininas. In: PEDRO, Joana Maria. (Org). Práticas Proibidas: práticas costumeiras de aborto de infanticídio no século XIX. Florianópolis: Cidade Futura, 2003. p. 86.

${ }^{701}$ Uma ideia aproximada a esse respeito nos é dada pelo artigo 2177, do Código Judiciário do Estado de Santa Catarina, de 1925, pois ele estabelece que "Art. 2177 - No interrogatório, quer no sumário, quer no plenário, só poderá ser perguntado ao réu: I - Qual o seu nome, naturalidade, idade, estado, filiação, residência e tempo dela no lugar indicado?; II - Quais seus meios de vida e profissão?; III - Se sabe ler e escrever?; IV - Onde estava ao tempo em que diz ter tido cometido o crime?; V - Se conhece as testemunhas arroladas, desde que tempo, e se tem alguma coisa que lhe opor?; VI - Se é verdade o que se alega na denúncia, ou queixa?; VII - Se quer fazer alguma declaração, ou apresentar defesa oral ou escrita?". (Ver Código Judiciário do Estado de Santa Catarina. Lei n. 1526, de 14 de novembro de 1925. Florianópolis: Oficinas à Eletricidade da Imprensa Oficial, 1925, 352 p). Muitos desses quesitos já estavam presentes no processo n. 30 , de 05 de março de 1923. Caixa 03, analisado no capítulo primeiro da tese. A esse propósito, a Lei n. 919, de 22 de setembro de 1911, estabelece, anteriormente ao texto de 1925, a organização judiciária do Estado de Santa Catarina. Assim, pelo menos desde o início da década de 1910, o Estado de Santa Catarina já contava com um conjunto de leis que determinava a sua organização judiciária, contemplando artigos e determinações que, dentre outros objetivos, norteavam os procedimentos e atitudes dos advogados, juízes e promotores, por ocasião do julgamento dos réus. Com isso, queremos dizer que os autos de qualificação ou interrogatórios - como acima exemplificado - dirigidos aos réus, eram previamente elaborados e codificados, o que sugere, como visto, um julgamento antecipado do réu, que contribui para sua condenação ou absolvição. Como exemplo, destacamos que a Lei n. 919, de 22 de setembro de 1911, registra em seu artigo 198 que "[...] O presidente do Tribunal Correcional apresentará sempre [no ato do julgamento] os quesitos seguintes: I - A infração penal está provada?; II - É responsável o réu pela infração penal?; III - Há circunstâncias agravantes? Quais são?; IV - Há circunstâncias atenuantes? Quais são?”. (Lei n. 919, de 22 set. 1911. Organização Judiciária [do Estado de Santa Catarina]. In: Santa Catarina. Coleção de Leis do Estado de Santa Catarina Relativo ao Ano de 1911. Florianópolis: Oficinas à Eletricidade da Imprensa Oficial, 1925. p. 85-199). Esses itens são, igualmente, descritos no artigo 2298 do Código Judiciário do Estado de Santa Catarina, de 1925. Além disso, destacamos que o Código Judiciário do Estado de Santa Catarina, de 1928 - baixado pela lei estadual n. 1640, de 03 de novembro de 1928 - estabelece, respectivamente nos artigos 2188 e 2305, que "Art. 2188 - No interrogatório, quer no sumário, quer no plenário, só poderá ser perguntado ao réu: I - Qual seu nome, naturalidade, idade, estado, filiação, residência e tempo dela no lugar indicado", e "Art. 2305 - O Presidente do Tribunal Correcional apresentará os quesitos seguintes: I - A infração penal está provada?; II - É responsável o réu pela infração penal?; III - Há circunstâncias agravantes? Quais são?; IV - Há circunstâncias atenuantes? Quais são?”. (Código Judiciário do Estado de Santa Catarina. Lei n. 1640 de 03 de novembro de 1928. Florianópolis: Imprensa Oficial, 1928). Como percebemos, os processos criminais eram previamente dirigidos, pois leis específicas norteavam seu andamento e, também, os procedimentos das autoridades judiciais competentes, o que, de certa forma, implicava num julgamento a priori da figura do réu.
} 
Devemos, entretanto, considerar que a testemunha Aristides de Aguiar Júnior, "Cabo da Força Pública"702, em depoimento prestado no dia 26 de dezembro de 1925, afirma, como vimos, que "ouviu dizer que o automóvel vinha em grande disparada"703, mas que "ignora que o chauffeur Max Müller e os passageiros do automóvel” estivessem “embriagados" "704. Nesse ponto, devemos levar em conta que a testemunha Elzínio Maurício Wanderley, "Sargento da Força Pública",705, ao ser inquirida pelo Promotor Público, em data de 26 de dezembro de 1925, disse que "soube que o auto [86] vinha em velocidade, com os passageiros e o chauffeur um pouco embriagados, de volta do Tiro ao Alvo [Tiro Alemão]" ${ }^{\text {706 }}$. Ao ser interpelada pelo advogado do réu no mesmo depoimento, a presente testemunha alegou, porém, que "foi de um civil que não conhece que ouviu trazer o auto velocidade, e o chauffeur e os passageiros embriagados; que também não se lembra quem estava presente quando o referido civil lhe disse isso"707, e que "conhece o réu há muito tempo, dele fazendo o melhor juízo"708.

Entendemos que essas passagens sugerem que a participação de promotores e de advogados de defesa influenciam as falas das testemunhas, pois as direcionam no sentido de, nesse caso, amenizar a possível responsabilidade do chauffeur Max Muller diante da respectiva ocorrência do sinistro. Outro forte indício nessa direção nos é apresentado pelas declarações da testemunha Aristides de Aguiar Júnior que, no mesmo dia 26 de dezembro de 1925, considera, como vimos, que "ouviu dizer que o automóvel vinha em grande disparada e que tinha havido um esbarro"709; entretanto, em outro ponto de sua fala, o advogado de defesa do réu o indaga sobre "qual pessoa ou pessoas de que ouviu dizer que o auto vinha em grande velocidade?"710. A esse questionamento, Aristides de Aguiar Júnior disse que "ouviu pessoas estarem dizendo isto, mas não prestou atenção, e por isso não lhe pode precisar o nome", e que "não sabe como se deu o desastre, pois quando chegou ao local, já encontrou os passageiros e o chauffeur no estado a que já referiu, não podendo por isso [observar] se houve ou não culpa ou imprudência do

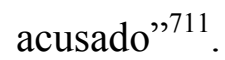

Salientamos, em passagens anteriores deste texto, que o desastre que envolveu o automóvel n. 86 produziu ferimentos em, ao menos, duas pessoas ${ }^{712}$ e ocasionou o falecimento de Jorge

\footnotetext{
${ }^{702}$ Processo n. 52, 05 nov. 1925. Caixa 05.

${ }^{703}$ Idem.

${ }^{704}$ Idem.

${ }^{705}$ Idem.

${ }^{706}$ Idem.

${ }^{707}$ Idem.

${ }^{708}$ Idem.

${ }^{709}$ Idem.

${ }^{710}$ Idem.

${ }^{711}$ Processo n. 52, 05 nov. 1925. Caixa 05. Mais esclarecedor ainda é o depoimento da testemunha Emílio Brosig, chauffeur do auto n. 102, que, no dia do ocorrido, afirmou que, atrás de si, vinha o auto n. 86 em "vertiginosa velocidade", pela avenida Hercílio Luz; entretanto, em depoimento prestado no dia 21 de janeiro de 1926, o referido chauffeur, respondendo às indagações do Promotor Público, considerou que "não pode afirmar se o automóvel sinistrado vinha a grande velocidade”. (Processo n. 52, 05 nov. 1925. Caixa 05).

${ }^{712}$ Conforme registram os respectivos autos de exame de corpo de delito, aos quais foram submetidos o chauffeur Max Muller e o passageiro do auto 86, Hans Lepell, no dia 05 de novembro de 1925, anexos ao presente processo.
} 
Sandmann, proprietário do mesmo veículo ${ }^{713}$. A gravidade do acidente foi, conforme salientam as impressões e falas daqueles que o presenciaram ou que "ouviram dizer" a seu respeito, corroborada pela velocidade com que os veículos se deslocavam na ocasião do ocorrido. Assim, os posicionamentos das testemunhas são aqui tomados, podemos dizer, como elementos que informam aos aparatos policial e jurídico sobre as circunstâncias dos sinistros. Não estamos preocupados em identificar culpados ou concluir sobre a participação da velocidade de deslocamento dos automóveis no acidente referido. Acreditamos, entretanto, que apontamentos importantes nos remetem à ideia de que a ocorrência do desastre, verificado nesse processo, foi ocasionada - pelo menos em parte - pela postura dos chauffeurs ao conduzirem seus automóveis. A esse respeito, devemos salientar as palavras de um personagem que, entendemos, apontam para o possível estado de embriaguez dos envolvidos no acidente. Desse modo, assinalamos que a testemunha Alvina Zimmer, zeladora da Sociedade Tiro Alemão de Florianópolis, afirma, no dia 04 de fevereiro de 1926, que "não presenciou o desastre, comparecendo ao local do mesmo quando este já havia se dado"; registra, porém, que "os três passageiros do auto sinistrado, momentos antes do desastre, tinham estado na Sociedade ou Tiro de Florianópolis", onde a "depoente serviu-lhes três garrafas de cerveja"714. Essas informações reforçam a ideia de que o chauffeur Max Muller estava, ao menos, levemente embriagado; o que, entendemos, constitui-se como um indício para a ocorrência do acidente ${ }^{715}$.

A ideia sobre o estado de embriaguez do chauffeur Max Muller ou sobre a velocidade de deslocamento do automóvel n. 86 na ocasião do ocorrido, não pode ser incrementada por meio da formulação do interrogatório, datada de 04 de fevereiro de 1926, à qual o réu é submetido ${ }^{716}$. Isso é notório porque, como vimos, os instrumentos legais que norteavam o andamento dos processos eram previamente elaborados, codificados em leis ou códigos penais e judiciários. Como exemplo, lançamos o interrogatório aqui referido, que especifica apenas algumas informações sobre o chauffeur Max Muller.

\footnotetext{
${ }^{713}$ Essa informação é confirmada pelo "Auto de Exame Cadavérico”, de 05 de novembro de 1925. (Processo n. 52, 05 nov. 1925. Caixa 05).

${ }^{714}$ Processo n. 52, 05 nov. 1925. Caixa 05. É importante observarmos que, nesse processo, não há qualquer registro referente ao respectivo "exame de embriaguez", ao contrário do que presenciamos na análise do processo n. 171, de 27 de dezembro de 1931 , disposta no capítulo primeiro da tese e que será retomada a seguir. Assim, o "Auto de exame de embriaguez" é dirigido ao chauffeur Oscar John, então responsabilizado pela ocorrência da colisão entre os automóveis ns 218 e 99, no cruzamento das ruas Artista Bittencourt e Visconde de Ouro Preto - ver, especialmente, naquele capítulo, nota 284. A não existência - ou presença - do auto de embriaguez respectivo não nos autoriza a pensar - especialmente pelas arguições aqui registradas - que o chauffeur Max Muller não estivesse sobre efeito de álcool, no instante em que ocorreu o desastre mencionado no respectivo processo. Além disso, os dois processos mencionados nesta nota, datados, respectivamente, de novembro de 1925 e dezembro de 1931, compreendem um espaço temporal que contempla a vigência do Código Penal brasileiro de 1890 substituído pela Consolidação das Leis Penais, de 1932 - e dos códigos judiciários do Estado de Santa Catarina, de 1925 e 1928 . Assim, entendemos que a exigência de autos de exame de embriaguez seria, a princípio, válida para ambos os processos. Por outro lado, o Regulamento para o serviço policial do Estado, de 1920, e as Instruções Regulamentares para o serviço de trânsito público, de 1928, não registram artigos ou parágrafos a esse respeito.

${ }_{715}$ Processo n. 52, 05 nov. 1925. Caixa 05.

${ }^{716}$ Processo n. 52, 05 nov. 1925. Caixa 05. Ver, também, a respeito, artigo 2177, no Código Judiciário do Estado de Santa Catarina, do ano de 1925. (Código Judiciário do Estado de Santa Catarina. Lei n. 1526, de 14 de novembro de 1925. Florianópolis: Oficinas à Eletricidade da Imprensa Oficial, 1925, 352 p.).
} 
Dessa forma, logo após ser ouvida a testemunha Alvina Zimer, o Juiz da Segunda Vara da Comarca da Capital, Mileto Tavares da Cunha Barreto, interroga o réu Max Muller, dirigindolhe os seguintes questionamentos: "Qual o seu nome, naturalidade, idade, estado [civil], filiação, residência e tempo dela no lugar indicado?"717. Notamos, assim, que o Juiz apenas reproduz o que é estabelecido no Código Judiciário do Estado de Santa Catarina, datado de $1925^{718}$. A esses questionamentos, o réu respondeu "chamar-se Max Müller, brasileiro, com vinte e cinco anos de idade, solteiro, filho de João Müller, residente nesta cidade desde o nascimento" ${ }^{, 719}$. Seguindo com o interrogatório, o respectivo Juiz ainda o indagou sobre "Quais seus meios de vida e profissão?"; "Se sabe ler e escrever?"; e "Onde estava ao tempo em que se diz ter cometido o crime?"720. A essas perguntas, o réu respondeu que era "empregado no comércio", sabe ler e escrever e que, na ocasião do desastre, estava "na avenida Hercílio Luz, no próprio local do desastre"721. As respostas dadas pelo réu também pouco ou nada esclarecem sobre as circunstâncias que cercaram o acidente. Devemos atentar, contudo, para o aspecto de que esse interrogatório foi formulado no dia 04 de fevereiro de 1926; deu-se, portanto, três meses após a ocorrência do sinistro. Em vista disso, podemos afirmar que, nesse tempo, o réu Max Muller foi, muito provavelmente, instruído por seu advogado para responder apenas àquilo que lhe fosse inquirido, e que suas respostas não deveriam ser comprometedoras, a fim de não levá-lo a cair em contradições ou armadilhas. Em outro sentido, podemos pensar que, de fato, verificam-se disputas discursivas nos processos nos quais os chauffeurs estão, via de regra, colocando-se como os cumpridores das leis, e as vítimas e testemunhas dizem, em inúmeras vezes, o contrário. Ao levarmos isso em conta, podemos considerar que os motoristas afirmam, em seus depoimentos, aquilo que se espera deles.

Além disso, evidenciamos que os jogos, discursos e falas apresentadas nos processos, mencionados por juízes, promotores, advogados e também por réus e testemunhas, seguiam, via de regra, orientações pré-formuladas, uma vez que cada parte objetivava a absolvição ou, mesmo, a condenação dos réus. Essa dinâmica, arriscamos considerar, ocorria com frequência nos processos criminais - presente, inclusive, na totalidade dos dezoito processos analisados na tese -, e se torna, mesmo, uma prática comum nas encenações e julgamentos judiciais.

Podemos considerar, ainda, que a tendência à absolvição do réu Max Muller é bem explícita - com não poderia deixar de ser - pelo registro feito pelo Dr. Nereu Ramos, advogado de defesa do réu, datado de 08 de fevereiro de 1926. Salientamos, abaixo, um trecho de sua

\footnotetext{
${ }^{717}$ Processo n. 52, 05 nov. 1925. Caixa 05.

${ }^{718}$ Ver artigo 2177. In: Código Judiciário do Estado de Santa Catarina. Lei n. 1526, de 14 de novembro de 1925... op. cit.

${ }^{719}$ Processo n. 52, 05 nov. 1925. Caixa 05.

${ }^{720}$ Processo n. 52, 05 nov. 1925. Caixa 05. Ver a respeito destes itens, artigo 2177. In: Código Judiciário do Estado de Santa Catarina. Lei n. 1526 , de 14 de novembro de $1925 \ldots$ op. cit.

${ }^{721}$ Processo n. 52, 05 nov. 1925. Caixa 05.
} 
manifestação escrita e, em seguida, procedemos à sua análise. Assim, conforme suas alegações, temos que

\begin{abstract}
A 1. ${ }^{a}$ testemunha, [Elzínio Maurício Wanderley,] diz [...] que soube que o 'auto vinha em velocidade com os passageiros e o chauffeur um pouco embriagados, de volta do Tiro Alemão'. Inquirida, disse que 'foi de um civil que não conhece que ouviu trazer o auto velocidade e o chauffeur e passageiros embriagados e que não se lembra quem estava presente quando o referido civil lhe disse isto'. A 2. ${ }^{\text {a }}$ testemunha [Aristides de Aguiar Júnior] declara que 'ouviu dizer por pessoas que ali estavam que o automóvel vinha em grande disparada e que tinha havido um esbarro'. Reinquirida, respondeu 'que ouviu pessoas estarem dizendo isto, mas não prestou atenção e por isto não lhe pôde precisar o nome'. Ora, é pacífico que 'se a testemunha depõe por ter ouvido, só tem mérito a sua narração quando confirmada pelo depoimento daquele a quem ouviu (Whitacker Jury, p. 154)'. Ambas essas testemunhas depõem por ouvir dizer. Não sabem, contudo, de quem ouviram. Merecerão acaso fé esses depoimentos? Estarão elas dizendo a verdade? Ouviram efetivamente o que narraram? ${ }^{722}$
\end{abstract}

Essas explanações são suficientes para procedermos à sua respectiva análise. Vimos, em passagens anteriores deste texto, que as duas testemunhas citadas consideraram, inicialmente, a "alta velocidade" de deslocamento do automóvel 86, e que essas informações foram obtidas "por ouvir dizer" de outras pessoas que estavam no entorno do acidente, comentando, ao que tudo indica, as circunstâncias do acidente. Percebemos, ao que parece, que o advogado de defesa do chauffeur Max Muller não concedeu crédito às informações fornecidas oralmente pelas testemunhas aqui arroladas, ou seja, pelas pessoas que já estavam às voltas com as circunstâncias do ocorrido ${ }^{723}$. Além disso, é curioso observarmos que, conforme apontado no presente processo, as testemunhas ouvidas - pelo menos algumas delas - informaram as circunstâncias do sinistro “por ouvir dizer" de outras pessoas que já estavam próximas ou no cenário do acidente. Desse modo, devemos indagar o porquê de essas pessoas não serem ouvidas no presente processo. Julgamos que o trecho a seguir seja, talvez, esclarecedor a esse respeito, pois, ao parafrasearmos Joana Maria Pedro e outros, observamos que os réus mais pobres tinham, via de regra, maior número de testemunhas que não participaram dos acontecimentos, e que souberam do caso apenas porque "ouviram dizer" 724 . Assim, notamos que os processos judiciais constituíam-se em pedagogia para as camadas populares ${ }^{725}$, o que, sugerimos, também ocorria - pelo menos com alguma frequência - nos julgamentos de chauffeurs $^{726}$.

\footnotetext{
${ }^{722}$ Processo n. 52, 05 nov. 1925. Caixa 05.

${ }^{723}$ Neste ponto, destacamos o que registra o artigo 2171, do Código Judiciário do Estado de Santa Catarina, de 1925, pois o mesmo salienta que “Art. 2171 - Além das testemunhas numeradas na acusação, devem ser inquiridas, sempre que possível, as referidas”. (Código Judiciário do Estado de Santa Catarina. Lei n. 1526, de 14 de novembro de 1925. Florianópolis: Oficinas à Eletricidade da Imprensa Oficial, 1925 , 352 p.).

${ }^{724}$ PEDRO, Joana Maria; NECKEL, Roselane; HAWERROTH, Eliana Izabel; MACHADO, Vanderlei. Aborto e Infanticídio nos Códigos Penais e nos Processos Judiciais: a pedagogia de condutas femininas. In: PEDRO, Joana Maria. (Org). Práticas Proibidas: práticas costumeiras de aborto de infanticídio no século XIX. Florianópolis: Cidade Futura, 2003. p. 92.

${ }^{725}$ Notadamente em relação ao julgamento de crimes de aborto e infanticídio que, entendia-se, eram praticados por mulheres dos estratos sociais inferiores da sociedade florianopolitana. Ver PEDRO, Joana Maria; NECKEL, Roselane; HAWERROTH, Eliana Izabel; MACHADO, Vanderlei. Aborto e Infanticídio nos Códigos Penais e nos Processos Judiciais: a pedagogia de condutas femininas. In: PEDRO, Joana Maria. (Org). Práticas Proibidas: práticas costumeiras de aborto de infanticídio no século XIX... op. cit., p. 93.

726 Vimos, especialmente no capítulo primeiro, que os chauffeurs não pertenciam, exatamente, aos estratos mais pobres da capital catarinense, pois muitos tinham residência fixa na cidade; possuíam, vez por outra, seu próprio automóvel e, inclusive, sabiam ler e escrever; aspecto presente nos 18 dezoito processos verificados nas décadas de 1920 e 1930 e que atestam, portanto, a relevância dessas habilidades para aqueles que, naquela época, habitavam a Capital ou mesmo outras cidades do Estado. Esses aspectos são discutidos, com maior propriedade, na seção a seguir.
} 
Esclarecemos que “[...] estamos falando de um momento em que a sociedade brasileira passava por profundas modificações: primeira metade do século XX"727. Esse era um tempo em que "as cidades foram atingidas por novas concepções urbanísticas, na qual a população pobre, compreendida tanto de trabalhadores quanto de mendigos e prostitutas, era vista como uma ameaça à saúde pública, precisando ser disciplinada e educada"728 - aspecto, aliás, a que já nos referimos no transcorrer da tese, notadamente no capítulo segundo. Esses, entendemos, são possíveis caminhos para o esclarecimento da questão proposta...

Devemos, entretanto, considerar, também, que o ato de "ouvir dizer" sobre a "excessiva velocidade" dos automóveis ou sobre o possível estado de embriaguez do chauffeur Max Muller nos leva a considerar que ideias a este respeito já haviam sido elaboradas pelas pessoas que estavam próximas ao local do sinistro. Faz-se, necessário, portanto, questionarmos, uma vez mais, o porquê de essas pessoas não serem ouvidas no presente processo, pois nenhum de seus depoimentos ou opiniões foram ali registrados ${ }^{729}$. Ou coloquemos esse questionamento de outro modo: o processo em discussão não apresenta nenhum registro escrito das pessoas que, segundo consta, informaram oralmente as circunstâncias do ocorrido às testemunhas aqui arroladas. Dessa forma, será que houve interesse em tomar esses depoimentos? Esse procedimento obedecia aos trâmites legais para a formulação de processos e inquirições judiciais? ${ }^{730}$ Essas são indagações que, mesmo frente aos esclarecimentos prestados, servem, pois, para pensarmos a respeito... Nesse sentido, arriscamos considerar que o processo em discussão foi conduzido no sentido de produzir-se, de antemão, a absolvição do réu. Isso é, no entanto, uma outra história...

Observamos, uma vez mais, que o desastre ocorrido com o automóvel n. 86 produziu o falecimento do passageiro J. Sandmann ${ }^{731}$; elemento que não é considerado pelas declarações do advogado de defesa do réu, Nereu Ramos. O falecimento de uma pessoa, decorrente de acidentes de trânsito, envolve alguns ingredientes favoráveis para tal, como, por exemplo, excesso de velocidade ou estado de embriaguez do(s) condutor(es); aspectos estes que, como visto, foram considerados nas falas das testemunhas registradas junto no processo.

As ideias formuladas pelo advogado de defesa do réu, expostas anteriormente, evidenciam, também, que a testemunha Elzínio Maurício Wanderley diz, por exemplo, no dia 26 de fevereiro de 1926, que soube que o "auto vinha em velocidade com os passageiros e o chauffeur um pouco

\footnotetext{
${ }^{727}$ PEDRO, Joana Maria; NECKEL, Roselane; HAWERROTH, Eliana Izabel; MACHADO, Vanderlei. Aborto e Infanticídio nos Códigos Penais e nos Processos Judiciais: a pedagogia de condutas femininas. In: PEDRO, Joana Maria. (Org). Práticas Proibidas: práticas costumeiras de aborto de infanticídio no século XIX. Florianópolis: Cidade Futura, 2003. p. 92.

${ }^{728}$ Ibidem, p. 92-93.

${ }^{729}$ Processo n. 52, 05 nov. 1925. Caixa 05.

${ }^{730}$ O parágrafo único do artigo 2171 do Código Judiciário do Estado de Santa Catarina, de 1925, expõe que: “Art. 2171. \# Único - As [testemunhas] informantes também não serão computadas no número geral”. (Código Judiciário do Estado de Santa Catarina. Lei n. 1526, de 14 de novembro de 1925. Florianópolis: Oficinas à Eletricidade da Imprensa Oficial, 1925, 352 p.).

${ }^{731}$ Confirmado, como visto, pelo "Auto de Exame Cadavérico", datado de 05 de novembro de 1925.
} 
embriagados, de volta do Tiro Alemão"732. Vimos, entretanto, que, ao ser questionada, pelo próprio advogado de defesa do réu, no mesmo depoimento ${ }^{733}$, a referida testemunha considera apenas que "foi de um civil que não conhece que ouviu trazer o auto velocidade e o chauffeur e passageiros embriagados e que não se lembra quem estava presente quando o referido civil lhe disse isto",734. Assim, verificamos que passagens como essa sugerem que as falas e arguições de promotores e advogados de defesa influenciam as declarações das testemunhas, pois as orientam sobre a melhor maneira de se manifestarem, em prol de seus interesses.

De outro modo, observamos, a seguir, que, em outro momento do mesmo registro, o advogado Nereu Ramos salienta que a "polícia devia ter examinado o auto. Só assim se teriam elementos para encaminhar este processo. Sem esse exame, e sem a prova do excesso de velocidade, única imprudência atribuída ao acusado, não há como responsabilizá-lo pela morte e ferimentos de seus companheiros" ${ }^{\$ 735}$. Diante dessas considerações, podemos tecer o seguinte questionamento: Por que esses procedimentos não foram tomados? Com isso, não objetivamos tomar partido em relação à condenação ou não do réu Max Muller, mas apenas frisar que, em face às declarações das testemunhas, mencionando, dentre outros aspectos, o deslocamento em alta velocidade dos veículos números 86 e 102 e o relativo estado de embriaguez do chauffeur Max Muller, essas, se consideradas mais a fundo, produziriam, talvez, outros possíveis resultados?

Os vistos finais do processo, assinados no dia 19 de fevereiro de 1926, concordam, ao que parece, com as declarações do advogado do réu Max Muller, pois o Juiz alega, na ocasião, que

\begin{abstract}
O crime culposo, isto é, aquele que sendo praticado sem intenção de fazer o mal resulta, entretanto, de uma falta qualquer. No caso da culpa sem previdência o autor não calcula o perigo da sua ação, mas deveria ter previsto os resultados prejudiciais. A culpa com previdência, o que é mais grave do que a primeira, existe quando o agente previu, como possível [...] o resultado funesto da sua ação e, contudo, por falta de cuidado, temeridade, etc., pratica-a sem desejar o mal que produz. Em qualquer destas hipóteses, a responsabilidade do agente pelos crimes previstos nos artigos 297 e 306 do código penal consiste na imprudência, negligência ou imperícia na sua arte ou profissão, ou por inobservância de alguma disposição regulamentar ${ }^{736}$.
\end{abstract}

Diante desse quadro, o Juiz não considera que o chauffeur Max Muller tenha praticado imprudência, negligência ou imperícia. Enfatizamos que mais importante é, porém, atentarmos para as justificativas apresentadas para tal, pois se considera, quanto à avaliação de imprudência,

\footnotetext{
${ }^{732}$ Processo n. 52, 05 nov. 1925. Caixa 05.

${ }^{733}$ Idem.

${ }^{734}$ Idem.

${ }^{735}$ Processo n. 52, 05 nov. 1925. Caixa 05. Essas informações são confirmadas pelo Promotor Público da Comarca, em texto dirigido ao Juiz da Segunda Vara de Florianópolis, Mileto Tavares da Cunha Barreto, no dia 12 de janeiro de 1926. (Processo n. 52, 05 nov. 1925. Caixa 05).

${ }_{736}$ Processo n. 52, 05 nov. 1925. Caixa 05. Os artigos 297 e 306 do Código Penal brasileiro de 1890 - vigente à época - expõem, em verdade, outros detalhes, como os que seguem “Art. 297 - Aquele que, por imprudência, negligência ou imperícia, na sua arte ou profissão, ou por inobservância de alguma disposição regulamentar, cometer ou for causa involuntária, direta ou indiretamente, de um homicídio, será punido com prisão celular por dois meses a dois anos"; "Art. 306 - Aquele que, por imprudência, negligência ou imperícia, na sua arte ou profissão, ou por inobservância de alguma disposição regulamentar, cometer ou for causa involuntária, direta ou indiretamente, de alguma lesão corporal, será punido com a pena de prisão celular por quinze dias a seis meses". (PIERANGELI, José Henrique. Códigos Penais do Brasil: evolução histórica. 2. ed. São Paulo: Revista dos Tribunais, 2004. p. 307-308). Veremos, adiante, como podemos melhor avaliar esses artigos.
} 
que essa "consiste em não ter o agente previsto a conseqüência que resultou de sua ação"737, e, nesses termos, o Juiz afirma que "não existe prova, pelo menos não foi feita no sumário, de que o acusado conduzia o auto com excesso de velocidade, na ocasião do desastre e de que estivesse embriagado",738. Reiteramos que não estamos preocupados em apontar culpados ou inocentes essa não é nossa tarefa -; é importante, entretanto, destacarmos que, se testemunhas apontaram o possível estado de embriaguez do acusado, e também o deslocamento do automóvel n. 86, operado com "excesso de velocidade", caberia, entendemos, às autoridades competentes averiguarem com maior propriedade tais circunstâncias, não limitadas à investigação presente no sumário, de acordo com o que apontamos no presente estudo.

Um aspecto instigante é o fato de que o Juiz considera que "não houve imperícia por parte do chauffeur quando guiava o auto", pois ele era habilitado "há mais de dois anos"739; e, nessa direção, o Juiz considera, "a seu favor", a "presumível prática de tal serviço". ${ }^{740}$ Evidenciamos, assim, que o Juiz apenas presumiu a destreza do acusado. Além disso, temos que considerar, também, que os vistos finais do processo concluem, portanto, que "o desastre foi obra puramente do acaso" "741; e, nesses termos, o Juiz o isenta da "idéia de dolo e de culpa, e como tal não sujeita o acusado a nenhuma responsabilidade criminal" ${ }^{, 742}$.

Corroborando com esses apontamentos, destacamos, por exemplo, que o artigo 297, do Código Penal de 1890, estipula como agente criminoso aquele que "cometer ou for causa involuntária, direta ou indiretamente, de um homicídio"743. Tendo isso em vista, ressaltamos que o ato criminoso é aqui considerado mesmo em face a atitudes involuntárias - aspecto, aliás, não mencionado pelo Juiz por ocasião da formulação dos vistos finais do processo ${ }^{744}$. Lembremos, também, ao leitor, que o acidente que envolveu o auto n. 86 ocasionou o falecimento de Jorge Sandmann, ocorrido no mesmo dia do sinistro. Destacamos ainda que os códigos penais - como então o que aqui apresentamos - devem ser historicamente localizados.

Desse modo, parafraseando Michel Foucault, temos que o protesto contra os suplícios e os castigos físicos é encontrado em toda a parte, a partir da segunda metade do século XVIII. Assim, os reformadores do setecentos denunciaram o que excede o exercício legítimo do poder,

\footnotetext{
${ }^{737}$ Processo n. 52, 05 nov. 1925. Caixa 05.

${ }^{738}$ Idem.

${ }^{739}$ Processo n. 52, 05 nov. 1925. Caixa 05. Vimos, no capítulo primeiro, que, no dia 13 de fevereiro de 1926, o Delegado de Polícia de Florianópolis assina o ofício n. 36, em resposta ao documento anterior, de autoria do Juiz Mileto Tavares da Cunha Barreto. Esse ofício registra que "Em resposta ao seu ofício de ontem datado, sob n. 15, tenho a informar-lhe que Max Müller é chauffeur desde 25 de outubro de 1923 , data essa que fez exame". (Processo n. 52, 05 nov. 1925. Caixa 05). Isso confirma, claramente, que Max Muller tinha carta de chauffeur há, pelo menos, dois anos.

${ }_{740}$ Processo n. 52, 05 nov. 1925. Caixa 05.

${ }^{741}$ Processo n. 52, 05 nov. 1925. Caixa 05. Nesse processo, não é mencionado, em nenhuma de suas passagens, o parágrafo sexto do artigo 27 do Código Penal de 1890, que estipula que "Art. 27 - Não são criminosos: \# 6. ${ }^{\circ}$ - Os que cometerem crime casualmente, no exercício ou prática de qualquer ato lícito, feito com atenção ordinária”. (PIERANGELI, J. Henrique. Códigos Penais do Brasil: evolução histórica... op. cit., p. 275).

${ }_{742}$ Processo n. 52, 05 nov. 1925. Caixa 05.

${ }^{743}$ PIERANGELI, José Henrique. Códigos Penais do Brasil: evolução histórica. 2. ed. São Paulo: Revista dos Tribunais, 2004. p. 307.

${ }^{744}$ Processo n. 52, 05 nov. 1925. Caixa 05.
} 
pois "[...] no pior dos assassinos, uma coisa pelo menos deve ser respeitada quando punimos: sua humanidade" "745. Portanto, “[...] chegará o dia, no século XIX, em que esse 'homem', descoberto no criminoso, se tornará o alvo da intervenção penal, o objeto que ela pretende corrigir e transformar" 746 .

Aprofundando essa análise, temos que a instituição do regime republicano, operada na última década do século XIX, foi acompanhada por importantes mudanças na organização administrativa e jurídica brasileira; pois, dentre outros elementos, observamos uma maior inserção dos juristas na conjuntura de reestruturação do Estado e na participação dos bacharéis na vida pública e na formação ideológica brasileira ${ }^{747}$. Assim, foram esses personagens, possuidores de um discurso autorizado, alinhados com outros setores da sociedade - sobretudo médico-higienista e agentes ligados à engenharia - que formularam leis e códigos que criminalizaram práticas cotidianas e, igualmente, definiram atitudes e condutas que possuiriam estatuto criminal ou, apenas, contraventor.

Os elementos discutidos, no processo aqui referido, sugerem, a princípio, que houve, ao que parece, uma investigação direcionada sobre as circunstâncias que envolveram o desastre nele apontado; ou, em outros termos, devemos considerar, também, que os automóveis são, como visto, elementos que estão sendo gradualmente implementados na cidade. Assim, as ocorrências de atropelamentos e colisões provocadas por automóveis não dispunham, à época, de uma legislação específica para averiguarem-se crimes e acidentes de trânsito - lembremos, portanto, que o Código Penal brasileiro, então vigente, é datado de $1890^{748}$. Por outro lado, não objetivamos, como visto, tomar partido em relação à condenação ou não do réu Max Muller. Devemos, entretanto, observar que diante das arguições das testemunhas, assim como ao que estabelecem os artigos 297 e 306 do Código Penal brasileiro de 1890, teríamos, provavelmente, resultados ou encaminhamentos diversos daqueles, então, apresentados?

\footnotetext{
${ }_{745}^{746}$ FOUCAULT, Michel. Vigiar e Punir: nascimento da prisão. 16 ed. Petrópolis: Vozes, 1997. p. 63.

${ }^{746}$ Ibidem, p. 63-64.

${ }^{747}$ CARVALHO, José Murilo de. A formação das almas: o imaginário da República no Brasil. São Paulo: Companhia das Letras, 1990. p. 132-139; CUNHA, Luís Antônio. Ensino Superior e Universidade no Brasil. In: LOPES, Eliane Marta Teixeira; FILHO, Luciano Mendes Faria; VEIGA, Cynthia Greive. (Org.). 500 Anos de Educação do Brasil. 3. ed. Belo Horizonte: Autêntica, 2003. p. 151-204.

${ }^{748}$ Sobre o início da história do automóvel no mundo, parece-nos digno de nota o que observa o texto As 100 maiores personalidades da História, pois no capítulo reservado a Henry Ford, registra que "O famoso industrial americano foi - sozinho e mais do que qualquer outro - o responsável pela introdução das técnicas de produção em massa na indústria moderna. Ford, que nasceu perto de Dearborn, no Estado de Michigan, nunca cursou o ginásio. Depois de terminar o primário, trabalhou como aprendiz de mecânico em Detroit e a seguir como mecânico de consertos e maquinista. Ainda era jovem quando, em 1885, Karl Benz e Gottlieb Daimler (independentemente) inventaram e começaram a vender o automóvel - [data considerada, aqui, para efeitos estatísticos]. Ford logo ficou interessado nessas 'carruagens sem cavalos' e, em 1896, já havia construído um automóvel com base em projeto próprio. Entretanto, apesar de seus talentos, suas duas primeiras especulações não tiveram sucesso. Mas Ford, em 1903, tentou novamente; e foi com essa terceira empresa, a Ford Motor Company, que obteve riqueza, fama e importância duradoura. O famoso Modelo T, lançado em 1908, [...] foi, sem dúvida, o carro mais célebre jamais produzido, e [...] mais de 15 milhões foram vendidos". (HART, Michael H. As 100 maiores personalidades da história. 8. ed. Rio de Janeiro: DIFEL, 2003. p. 506-507). Sobre essas informações, ver, também, VIEIRA, José Luiz. A história do automóvel: a evolução da mobilidade. São Paulo: Alaúde Editorial, 2008. (v. 1. da Pré-história a 1908). p. 124-125; p. 139-144; p. 153-159; p. 180-183; p. 209; p. 218-220 segs. e p. 415. Devemos observar, também, as informações constantes na seção Elementos Incipientes, integrante do capítulo primeiro da tese. Além disso, destacamos que o Estado de Santa Catarina terá, apenas em 1927, um conjunto de artigos e determinações legais que tratarão, especialmente, do tráfego de veículos automotores e, também, daqueles tracionados por força motriz animal, reunidos sob o título Instruções Regulamentares para o serviço de trânsito público, assinado pelo então Secretário do Interior e Justiça, Cid Campos, em 28 de junho de 1927.
} 


\subsection{Pedagogia e Aprendizado}

Nessa seção, investigamos, de modo especial, a participação de testemunhas que "ouviram dizer" a respeito das ocorrências de atropelamentos e colisões registradas nos processos criminais aqui analisados. Isso nos remete para o fato de que o ato de "ouvir" sobre essas ocorrências desempenhava um papel importante como forma de se obterem informações sobre os sinistros; servindo, inclusive, de instrumento de contribuição para a abertura de inquéritos policiais. Mais do que isso, o que pretendemos, de fato, é analisar o teor dos discursos proferidos pelas testemunhas que souberam dos sinistros "por ouvir dizer" a seu respeito e, desse modo, construir uma narrativa do aspecto pedagógico que envolve a presenciação ou conhecimento "indireto" desses acontecimentos; aspecto este que corrobora para a edificação de um comportamento reprovador ou vigilante para com a própria conduta dos chauffeurs ou motoristas ao volante. Assim, objetivamos analisar, também, os termos e palavras que as testemunhas usavam para se referirem aos chauffeurs, e procuramos tecer uma discussão sobre possíveis confrontos de opiniões e percepções diferenciadas sobre uma mesma situação. Como exemplo, destacamos que o que chama a atenção dessas testemunhas é, dentre outros elementos, a "excessiva" velocidade atingida pelos automóveis no instante em que atropelam pedestres ou colidem com outros veículos - aspecto, inclusive, a que já nos referimos na seção anterior. Esse ponto constitui um gancho para tecermos, paralelamente, uma discussão acerca da noção de alta velocidade para a época em estudo.

Nesse sentido, objetivamos elaborar uma análise das falas desses personagens como elementos que encerram, muitas vezes, caráter punitivo e/ou condenatório em relação aos episódios de atropelamentos e colisões registrados nos processos criminais em análise, pois emitem, em várias situações, ideias ou opiniões que desenham julgamentos antecipados das circunstâncias que envolveram determinado sinistro; e, também, sobre o próprio caráter do chauffeur ou motorista que, segundo apontado nos processos, ocasionou o incidente. Esse aspecto envolve, naturalmente, um prejulgamento do agente causador do atropelamento ou colisão, o que influencia os depoimentos dessas testemunhas, prestados nos inquéritos policiais e processos judiciais.

Nosso primeiro cenário de análise nos remete ao que é descrito no processo n. 62 , de 03 de abril de 1926 - por nós já abordado no terceiro capítulo (seção Vias e Passeios) -, pois referencia o atropelamento do menor Gentil Lemos, de nove anos de idade, na rua Esteves Júnior, ocasionado pelo chauffeur amador João Fédrigo, de profissão mecânico ${ }^{749}$. O Delegado de Polícia da Capital, Cantídio Quintino Régis, expõe, na portaria do processo, que "hoje, pelas

\footnotetext{
${ }^{749}$ Processo n. 62, 03 abr. 1926. Caixa 06.
} 
dez horas [da noite], na rua Esteves Júnior, o automóvel n. 46 guiado pelo seu proprietário João Fédrigo, no momento que passava pelo carro de praça, conduzido pelo boleeiro Ladislau Opuska, atropelou um menor, ferindo-o" 750 .

O "Termo de declarações" prestado pelo acusado expõe outros detalhes do ocorrido, pois registra, dentre outros elementos, que "hoje pelas dezoito horas subia a rua Esteves Júnior, guiando o seu automóvel n. 46" e, "um pouco acima da casa de residência do doutor Henrique Raupp", encontrou "o carro de praça [n. 11] conduzido pelo boleeiro Ladislau Opuska"751. Continuando suas declarações, o acusado afirma que, no momento "em que passava o carro pelo automóvel, saiu de trás do referido carro uma criança que correu e atravessou a rua pela frente do auto, quando foi apanhado pelo mesmo, não sendo possível evitar o desastre, embora descesse a rua com marcha muito reduzida"752. A partir dessas informações, analisaremos as falas das testemunhas que prestaram os respectivos depoimentos por "ouvir dizer" a respeito das circunstâncias que envolveram o sinistro em questão. Assim, intentamos para possíveis construções discursivas que apontam para a busca de informações sobre o comportamento e postura praticados pelo chauffeur amador João Fédrigo e, também, sobre as circunstâncias que cercaram o referido sinistro.

Desse modo, consideramos, em primeira mão, que os episódios de atropelamentos e colisões eram, com certa frequência, alvos de observação e comentários das pessoas que circulavam pelas ruas e avenidas da cidade, no momento em que esses incidentes ocorriam. A testemunha Odílio Pinto da Luz ${ }^{753}$, por exemplo, no dia 03 de abril de 1926, registra o ocorrido da seguinte maneira: "hoje pelas dezoito horas, quando subia a rua Esteves Júnior, viu o automóvel n. 46 de propriedade do senhor João Fédrigo parado um pouco acima da casa de residência do doutor Henrique Raupp e bem assim o carro de praça que [era guiado pelo] senhor Ladislau Opuska"754. Naquela ocasião, a testemunha observou "uma certa quantidade de pessoas; e perguntando a uma [delas] o que havia acontecido, soube que o automóvel acima referido, na ocasião que descia a citada rua, [acabou por] passar pelo carro já mencionado, [apanhando] uma criança que vinha na mola do referido [veículo]"755. A mesma testemunha afirma que ouviu, de todas as pessoas presentes, "mover-se o carro em marcha reduzida e da mesma forma o automóvel"756; porém, "perguntando onde se achava a criança", disseram-lhe "que tinha sido transportada para a residência do doutor Alfredo de Araújo pelos senhores Marcelino Coelho e o

\footnotetext{
${ }^{750}$ Processo n. 62, 03 abr. 1926. Caixa 06.

${ }^{751}$ Idem.

${ }^{752}$ Processo n. 62, 03 abr. 1926. Caixa 06. Ver, também, Anexo 11, p. 342.

${ }^{753}$ Este tem 22 anos e é "Praça do 14. ' Batalhão". Processo n. 62, 03 abr. 1926. Caixa 06.

${ }^{754}$ Processo n. 62, 03 abr. 1926. Caixa 06.

${ }^{755}$ Idem.

${ }^{756}$ Idem.
} 
chauffeur e proprietário do automóvel n. 46 João Fédrigo"; e, "dirigindo-se para a residência do doutor Araújo encontrou a referida criança bastante ferida, que, na falta de recursos, o senhor Capitão Marcelino Coelho transportou a criança para esta delegacia de polícia em companhia dele depoente, de João Fédrigo e de seu irmão Oscar Pinto da Luz"757.

O que percebemos é que os episódios de atropelamentos e colisões atraíam curiosos que objetivavam interar-se do que havia acontecido; ou seja, esses acontecimentos não passavam despercebidos para aqueles que circulavam pela cidade ${ }^{758}$. Embora a cena do respectivo atropelamento tenha sido - conforme mencionado no processo - observado por "uma certa quantidade de pessoas", nenhuma delas teve, entretanto, o seu testemunho tomado no referido processo. Esclarecimentos nesse sentido já foram, com efeito, apontados por nós na seção anterior. De qualquer forma, deixamos, aqui, essa observação, chamando a atenção, uma vez mais, para o aspecto de que os processos que envolviam o julgamento de chauffeurs, naquela época, não contemplavam, ao que parece, a participação textual desses personagens.

Acerca desse aspecto, é válido salientarmos o que observa a testemunha Odílio Pinto da Luz, ao ser novamente ouvida, no dia 28 de abril de $1926^{759}$, pois, nessa oportunidade, ela argumenta que, "quando subia a rua Esteves Júnior, viu o automóvel n. 46 [...] parado um pouco acima da casa do Sr. Henrique Raupp, onde também se achava um carro de praça, ambos cercados por grande número de pessoas", e que "indagando do que havia ocorrido, lhe foi informado que o automóvel 46, ao descer aquela rua e ao passar pelo carro mencionado [...] apanhou uma criança que vinha na mola de trás do carro" ${ }^{\text {760 }}$. Notamos também, que, adiante, em suas declarações, Odílio Pinto da Luz, ao ser inquirido pelo "Promotor Público", disse que, entre “as pessoas presentes ao local do desastre[,] era máxima em atribuir a culpa do [lastimável acontecimento?] à imprudência do menor vitimado; que de todas ouviu mover-se o carro em marcha reduzida, e da mesma forma o automóvel" ${ }^{\text {,761. }}$.

\footnotetext{
${ }^{757}$ Processo n. 62, 03 abr. 1926. Caixa 06.

${ }^{758}$ Corroborando com essas observações, a testemunha José Meira, que "vinha no carro de praça n. 11 ", afirma, ao ser indagada no dia 03 de abril de 1926, que, "ao passar pela rua Esteves Júnior, um pouco acima da casa de residência do senhor Henrique Raupp, passou pelo automóvel n. 46" e "logo que esses dois veículos passaram um pelo outro o declarante ouviu gritos de pessoas que se achavam nas janelas de suas casas e olhando para trás viu um menino caído ao solo, tendo o depoente feito parar o carro em que vinha", e "saltando do auto para saber o que havia acontecido, soube que o referido menino vinha na mola traseira do carro [...] e que ao passar pelo citado veículo, o menino saiu de trás do carro, indo esbarrar-se no automóvel". (Processo n. 62, 03 abr. 1926. Caixa 06).

${ }^{759}$ Nesse processo, as testemunhas foram ouvidas em duas oportunidades: a primeira, entre os dias 03 e 06 de abril de 1926 ; e a segunda, entre os dias 22 e 28 de abril de 1926. (Processo n. 62, 03 abr. 1926. Caixa 06).

${ }^{760}$ Processo n. 62, 03 abr. 1926. Caixa 06.

${ }^{761}$ Devemos assinalar que, nesse processo - e, assim como, no anterior - não verificamos a participação ou atuação do Júri Popular, mas tão somente de advogado de defesa, bem como da figura do promotor público, que expressa a sua "vontade" em punir o chauffeur João Fédrigo na forma do Código Penal. Assim, o respectivo Promotor Público, "representante do Ministério Público com exercício neste Juízo [e] usando das atribuições que lhe são conferidas pela lei", declara, ao solicitar a instauração do processo, que "vem perante V. Exa. denunciar João Fédrigo [...] pelo fato delituoso seguinte: Pelas dezoito horas do dia três do corrente, quando descia com o automóvel n. 46, de sua propriedade, a rua Esteves Júnior, apanhou o menor Gentil Lemos, que atravessava despreocupadamente aquela via pública, produzindo-lhe os ferimentos descritos no auto de exame de corpo de delito [...], todas eles por tal forma graves, que constituíram causa oficial da morte do referido menor. Estando assim incurso o denunciado na sanção do artigo 297 do Código Penal, requer o abaixo assinado que, autuada a presente, instaure o competente processo-crime, procedendo-se aos termos da formação da culpa”. (Processo n. 62, 03 abr. 1926. Caixa 06). Vemos, claramente, que o Promotor Público esforçava-se por aplicar as leis contidas no Código Penal e, comumente, exigia a punição do réu; e, apesar de não mencionar a velocidade do automóvel n. 46 à ocasião do referido atropelamento, o promotor afirma que a vítima "atravessava despreocupadamente" a rua Esteves Júnior e salienta, também, que os ferimentos nela produzidos ocasionaram sua morte. É, entretanto, curioso observarmos que, no dia 30 de abril de 1926
} 
Assim, vimos que as pessoas que presenciavam atropelamentos ou colisões, que envolviam veículos ou automóveis, ocupavam-se em proferir opiniões sobre as circunstâncias que cercavam tais eventos. A par dessas observações, temos, entretanto, que ressaltar que, no caso aqui referido, as testemunhas que já estavam ao local do acidente afirmaram - segundo as colocações registradas pelo testemunho de Odílio Pinto da Luz - que a culpa devia-se à "imprudência do menor" e que os veículos se deslocavam em "marcha reduzida". Em vista dessas informações, é possível fazermos a seguinte indagação: Por que as pessoas que já estavam às voltas com o cenário do desastre - ou, ao menos, algumas delas - não foram inquiridas no presente processo? Já tecemos considerações a esse respeito. Vimos, portanto, que não temos respostas imediatas. Tal indagação serve, no entanto, para refletirmos a respeito. ${ }^{762}$

Em relação às colocações expostas anteriormente, devemos considerar - parafraseando Roger Chartier - que o trabalho do historiador se reporta, em última análise, ao ato de construir o objeto de conhecimento de sua disciplina, e o constrói a partir das questões colocadas por seu próprio tempo e indagações. Isso não significa, todavia, que ele aleatoriamente "inventa" a História, pois o que ocorre é que procura estabelecer uma possibilidade de diálogo entre as evidências - vestígios representantes -, e os discursos e posicionamentos que os textos deixam transparecer em suas entrelinhas, considerados como práticas representadas; discursos estes que, em síntese, assumem estatuto de verdade histórica, ainda que provisória, na medida em que for plausível, coerente e explicativo ${ }^{763}$. Aprofundando essa discussão, retomamos as ideias do mesmo autor ao observarmos que a questão com que se defronta a História, nos dias de hoje, é a passagem para um tipo de validação do discurso histórico que nos permite "[...] encarar como possíveis, prováveis, verossímeis, as relações postuladas pelo historiador entre os vestígios documentais e os fenômenos indiciados por eles" ou, noutros termos, "as representações manipuláveis hoje em dia e as práticas passadas que elas designam»764. Assim, é possível considerarmos que os homens "inventam" a História por meio de suas ações e representações.

\footnotetext{
- portanto, no mesmo dia da assinatura dos vistos finais do processo -, o Promotor Público, em consonância à derradeira decisão judicial, que inocenta o réu João Fédrigo, assinala que "nenhuma culpa deve ser atribuía ao condutor do veículo, senão exclusivamente à imprudência e a má sorte do referido menor". Ressalta, portanto, que "não houve, bem se percebe, da parte do Sr. João Fédrigo - em obediência à 'mão' em marcha reduzida, tanto assim que conseguiu pará-lo imediatamente -, 'imprudência, negligência ou imperícia, na sua arte', nem tampouco 'inobservância de qualquer dispositivo regulamentar', requisitos indispensáveis à caracterização do delito, previsto no artigo 297 do Código Penal”. (Processo n. 62, 03 abr. 1926. Caixa 06). Como vemos, ficou muito claro, nos exemplos acima citados, que o Promotor Público, além de efetuar seu ofício acusar o réu -, é-lhe também conveniente acompanhar a decisão judicial que, nesse caso, inocenta o referido acusado. Para isso, o Promotor Público - e, assim, também o Juiz - faz, entretanto, sempre uso do aparato legal, o que os coloca, sob quaisquer circunstâncias, como agentes cumpridores das leis, portanto em consonância com os interesses do Estado. Sobre a participação do Júri Popular nos processos analisados, veremos maiores detalhes nas passagens e seções subsequentes deste capítulo. Ver, também, PEDRO, Joana M.; NECKEL, R.; HAWERROTH, Eliana Izabel; MACHADO, Vanderlei. Aborto e Infanticídio nos Códigos Penais e nos Processos Judiciais: a pedagogia de condutas femininas. In: PEDRO, Joana Maria. (Org). Práticas Proibidas: práticas costumeiras de aborto de infanticídio no século XIX... op. cit., p. 105.

762 Apontamentos nessa direção são também sugeridos ao considerarmos o interrogatório dirigido ao réu, datado de 28 de abril de 1926 ; pois, nessa ocasião, é perguntado se ele “conhece as testemunhas que depuseram neste processo?”; e a esse questionamento foi por ele respondido que "as conhece todas há muito tempo, e nada tem que lhes opor". (Processo n. 62, 03 abr. 1926. Caixa 06). Afirmações instigantes, não? Essas passagens dão-nos a impressão de que apenas as testemunhas conhecidas do réu foram selecionadas para depor junto ao processo, e que o questionamento acima referido foi feito considerando-se, mesmo, uma resposta que, presumidamente, já se sabida.

${ }^{763}$ CHARTIER, Roger. À Beira da Falésia: a história entre incertezas e inquietudes. Porto Alegre: UFRGS, 2002. p. 88.

${ }^{764}$ Ibidem, p. 86.
} 
Essa expressão remete-nos a uma temporalização dos eventos, dos objetos e dos sujeitos, podendo se referir a um momento de emergência, fabricação ou instituição de algo que surge como novo.

O uso do termo invenção, por nós aqui apropriado, remete-nos para uma abordagem do evento histórico que enfatiza a descontinuidade, a ruptura, a diferença, a singularidade, além de que afirma o caráter subjetivo da produção histórica. Assim, damos, ao certo, “[...] primazia à análise das atividades descritas como culturais ou mais ligadas ao campo das práticas simbólicas [...] ou discursivas", pois contribui para que a dimensão inventiva humana e a própria prática histórica sejam ressaltadas ${ }^{765}$. Objetos e sujeitos são, portanto, pensados como "[...] fabricação histórica, como fruto de práticas discursivas [...], que os instituem, recortam-nos, nomeiam-nos, classificam-nos, dão-nos a ver e a dizer" ${ }^{\text {766 }}$.

Nesse sentido, ao nos apropriarmos das ideias expostas por Michel Foucault, no livro Vigiar e Punir, podemos argumentar que os efeitos de dominação, postos pelos cenários montados nos processos criminais, são, em síntese, calculados, organizados e tecnicamente pensados. A atuação do aparato jurídico opera uma estratégia, na qual seus efeitos de dominação não são atribuídos a uma apropriação, mas a disposições e técnicas, que configuram uma rede de relações. Temos, em suma, que "[...] admitir que esse poder se exerce mais que se possui, que não é o 'privilégio' adquirido ou conservado da classe dominante, mas o efeito de conjunto de suas posições estratégicas"

Esse poder, por outro lado, “[...] não se aplica pura e simplesmente como uma obrigação ou uma proibição, aos que 'não têm'; ele os investe, passa por eles e através deles, do mesmo modo que eles, em sua luta contra esse poder, apóiam-se por sua vez nos pontos em que ele os alcança" ${ }^{, 768}$. Observamos, em tais passagens, que os textos Vigiar e Punir (1975) e Microfísica do Poder (1979) operam um estudo genealógico do poder, uma vez que o autor introduz, nas análises históricas, a questão do poder como que estabelecida nas relações humanas; um instrumento capaz de explicar a produção dos saberes. Assim, devemos abolir a ideia do sujeito único, coerente e universalmente constituído, e tentarmos chegar a uma análise que possa dar conta da constituição do sujeito na trama histórica.

Vimos, em passagens anteriores deste texto, que a testemunha Odílio Pinto da Luz, em seu depoimento prestado no dia do ocorrido, afirma que se preocupou em verificar o estado físico da vítima, pois "dirigindo-se para a residência do doutor Araújo encontrou a referida criança bastante ferida", acompanhando-a, inclusive, à Delegacia de Policia. Desse modo, destacamos

\footnotetext{
${ }^{765}$ JR., Durval Muniz de Albuquerque. História: a arte de inventar o passado: ensaios de teoria da História. Bauru: EDUSC, 2007. p. $20-21$.

${ }^{766}$ Ibidem, p. 21.

${ }^{767}$ FOUCAULT, Michel. Vigiar e Punir: nascimento da prisão. 16 ed. Petrópolis: Vozes, 1987. p. 26.

${ }^{768}$ Idem.
} 
que os pedestres, ao presenciarem ou tomarem ciência das ocorrências de atropelamento ou colisão, procuravam observar o que havia acontecido, a fim de comentar e exprimir opiniões sobre as circunstâncias que cercavam a ocorrência desses sinistros, a maneira com que os chauffeurs guiavam os automóveis, o estado físico das vítimas, etc. O olhar das testemunhas inquiridas aparece, portanto, como "um olhar que a polícia investiga e que, depois, informa: são os olhos que vigiam" ${ }^{, 769}$. Por outro lado, embora não verificamos, nas falas dessa testemunha, nenhum posicionamento que condene a maneira como o chauffeur amador João Fédrigo conduzia seu automóvel no instante do atropelamento, é válido observarmos que a testemunha Oscar Pinto da Luz aponta, no dia 05 de abril de 1926, que "no dia três do corrente pelas dezoito horas, mais ou menos, subindo a rua Esteves Júnior, viu um pouco acima da casa de residência do senhor doutor Henrique Raupp Júnior, um carro e um automóvel parado e diversas pessoas que comentavam o fato de ter um automóvel atropelado um menino",770. Informando-se "onde se achava a vítima e como se havia dado o desastre, soube pelo chauffeur e proprietário do automóvel 46, senhor João Fédrigo, que na ocasião que esse senhor descia a rua Esteves Júnior”, ao "passar pelo carro de praça conduzido pelo boleeiro Ladislau Opuska, surgiu inesperadamente um menino que vinha sentado na mola traseira do carro e atravessou-se na frente do automóvel, sendo, então, por este colhido"771. Evidenciamos, portanto, que a presente testemunha obteve essas informações do próprio chauffeur João Fédrigo. Salientamos esses aspectos, pois o acusado argumenta, por ocasião de seu depoimento tomado no dia da ocorrência do sinistro, que descia "a rua com marcha muito reduzida"772.

Corroborando com essas ideias, o boleeiro Ladislau Opuska argumenta, em suas declarações prestadas no dia do atropelamento, que os veículos se deslocavam em marcha lenta, pois "a rua Esteves Júnior é muito estreita e todas as vezes que se cruzam veículos por ali é em marcha muito reduzida, visto terem que tomar a mão muito em cima dos respectivos passeios" ${ }^{\text {,773 }}$. Pelo exposto, é possível considerarmos que os referidos veículos não se deslocavam a grande velocidade. Mas nossa preocupação não é exatamente essa. Desse modo, observemos que, ao ser inquirido pelo delegado de polícia da Capital, no dia 05 de abril de 1926, a testemunha Antônio Augusto Schorcht ${ }^{774}$ destaca que "soube por ouvir dizer que o menino, vítima do desastre, faleceu ontem no Hospital de Caridade, onde se achava em tratamento em

\footnotetext{
${ }^{769}$ PEDRO, Joana Maria; NECKEL, Roselane; HAWERROTH, Eliana Izabel; MACHADO, Vanderlei. Aborto e Infanticídio nos Códigos Penais e nos Processos Judiciais: a pedagogia de condutas femininas. In: PEDRO, Joana Maria. (Org). Práticas Proibidas: práticas costumeiras de aborto de infanticídio no século XIX. Florianópolis: Cidade Futura, 2003. p. 90.

${ }^{770}$ Processo n. 62, 03 abr. 1926. Caixa 06.

${ }^{771}$ Idem.

${ }^{772}$ Idem.

${ }^{773}$ Idem.

${ }^{774}$ Essa personagem "se achava à janela de sua casa", quando viu proceder-se ao atropelamento do menor Gentil Lemos. Processo n. 62, 03 abr. 1926. Caixa 06.
} 
conseqüência dos ferimentos que recebeu"775; e "perguntado se os veículos [...] iam com excesso de velocidade, e se havia probabilidade de evitar esse desastre", respondeu que "qualquer dos veículos iam em marcha muito moderada, tanto assim que o automóvel pôde parar quatro ou cinco metros distante do menino" ${ }^{\text {776 }}$. Tendo isso em vista, percebemos que, apesar das indicações que apontam que os veículos se deslocavam em velocidades moderadas, o delegado de polícia - a par de possíveis orientações processuais ou legais - pede esclarecimentos não, exatamente, sobre como os veículos se deslocavam na ocasião do sinistro, mas, sim, se eles o faziam "com excesso de velocidade"777.

Desse modo, assinalamos que, ao trazermos à tona os motivos e justificativas construídas nas malhas do judiciário, devemos perceber, em síntese, a maneira como se investiu sobre os diferentes sujeitos envolvidos nos processos - no caso aqui referido, uma testemunha do ocorrido - e, paralelamente, a forma como foram tomadas suas respectivas falas e depoimentos $^{778}$. Nesse caso, verificamos que a testemunha estava atenta e vigilante ao que se procedia na rua e podemos mesmo considerar que o aparato policial e jurídico local inquiria e investigava falas dessa natureza, pois era procedimento para se obterem informações importantes sobre os ocorridos. Esse conjunto de procedimentos e de práticas era comumente exercido na elaboração e desenrolar dos processos criminais aqui analisados. A majoração produtiva da observação visual e disciplinar é, assim, exercida e assegurada ao considerarmos que a vigilância é operada de maneira frequente, até o "mais fino grão" da sociedade, e que funciona, também e, talvez, principalmente, fora daquelas formas súbitas, violentas e descontínuas que estão ligadas ao exercício da soberania ${ }^{779}$. Por outro lado, vimos, em inúmeras passagens nos capítulos anteriores deste estudo, que as altas velocidades atingidas pelos automóveis, especialmente no espaço central da cidade de Florianópolis, foram elementos que, durante as décadas de 1920 e 1930, eram verificados com certa frequência no cotidiano da cidade, especialmente apontados pelos registros jornalísticos locais.

\footnotetext{
${ }^{775}$ Conforme atesta o "Auto de Exame Cadavérico", datado de 04 de abril de 1926. É importante observarmos que, para os processos instaurados sob a influência do Código Penal de 1890 - que abarcam, ao certo, todos aqueles verificados na década de 1920 -, os exames cadavéricos e, bem assim, os de "Corpo de Delito" eram realizados por médicos peritos convocados pelo delegado de polícia. Ver PEDRO, Joana Maria; NECKEL, Roselane; HAWERROTH, Eliana Izabel; MACHADO, Vanderlei. Aborto e Infanticídio nos Códigos Penais e nos Processos Judiciais: a pedagogia de condutas femininas. In: PEDRO, Joana M. (Org). Práticas Proibidas: práticas costumeiras de aborto de infanticídio no século XIX. Florianópolis: Cidade Futura, 2003. p. 97. Nos processos aqui analisados dentro do período supracitado, o órgão diretamente responsável pela realização desses exames, na capital do Estado, foi o "Gabinete de Identificação e Médico Legal", em funcionamento, pelo menos, desde o ano de 1919. Ver a) Processo n. 62, 03 abr. 1926. Caixa 06; b) Santa Catarina. Relatório apresentado ao Exmo. Sr. Dr. Governador do Estado, pelo Juiz de Direito Dr. Gil Costa, Chefe de Polícia do Estado. Florianópolis, 1919; c) Santa Catarina. Relatório apresentado ao Exmo. Sr. General Ptolomeu de Assis Brasil, Interventor Federal, pelo Dr. Manoel Pedro Silveira, Secretário de Estado dos Negócios do Interior e Justiça. Florianópolis, nov. 1931. p. 11-12. Devemos observar, também, que os processos criminais analisados sugerem que ao menos a partir de 1937, paralelo à criação da Secretaria de Segurança Pública (SSP), efetuada em 1935, é organizado o "Serviço Médico Legal", encarregado de proceder, também, aos "auto exames" de "Corpo de Delito" e "Cadavérico". Ver Processo 351, 09 ago. 1937. Caixa 38.

${ }^{776}$ Processo n. 62, 03 abr. 1926. Caixa 06.

${ }^{777}$ Idem.

${ }^{778}$ PEDRO, Joana Maria; NECKEL, Roselane; HAWERROTH, Eliana Izabel; MACHADO, Vanderlei. Aborto e Infanticídio nos Códigos Penais e nos Processos Judiciais: a pedagogia de condutas femininas. In: PEDRO, Joana Maria. (Org). Práticas Proibidas: práticas costumeiras de aborto de infanticídio no século XIX. Florianópolis: Cidade Futura, 2003. p. 87.

${ }^{779}$ FOUCAULT, Michel. Vigiar e Punir: nascimento da prisão. 16 ed. Petrópolis: Vozes, 1987. p. 172.
} 
Dessa maneira, é possível considerarmos que as altas velocidades de deslocamento dos veículos motorizados era, mesmo, um elemento com o qual o aparato de polícia local lidava cotidianamente, pois é, também, reiterado em ocasiões em que percebemos que os registros testemunhais, então colhidos, apontavam outras informações, como os exemplificados pelo processo em discussão ${ }^{780}$. Isso nos sugere um certo condicionamento do aparato policial em inquirir sobre as altas velocidades dos automóveis, pois podemos pensar que esse procedimento constituía-se, mesmo, como elemento que fazia parte do ofício cotidiano de policiais, delegados e inspetores de trânsito ${ }^{781}$, os quais lidavam com as altas velocidades dos veículos motorizados em várias situações postas pelo cotidiano da cidade, assinaladas em inúmeras passagens nos processos analisados neste estudo.

$\mathrm{Na}$ presente seção, não objetivamos, propriamente, analisar o andamento e desenrolar dos processos criminais em pauta; ou seja, neste espaço, nosso intento não é discutir os meandros que levaram à condenação ou à absolvição daqueles identificados como responsáveis pelos crimes de atropelamento ou colisão. Assim, o que queremos é investigar as falas das testemunhas que "ouviram dizer" a respeito de determinado sinistro e construir uma narrativa das suas percepções quanto às circunstâncias que envolveram o mesmo e também quanto ao personagem que, entendemos, o ocasionou. Tendo isso em vista, destacamos que o processo seguinte nos fornece elementos ilustrativos a esse respeito, especialmente porque as testemunhas falam e opinam, dentre outros elementos, sobre a velocidade de deslocamento dos dois automóveis de praça $^{782}$ envolvidos em mútua colisão, havida no perímetro urbano da Capital, na esquina da Avenida Rio Branco com a rua Esteves Júnior. O processo ao qual nos referimos é o de n. 95, datado de 05 de julho de 1926 - analisado, sob outra perspectiva, no capítulo primeiro; seção Deslocamento e Velocidade -, que registra, naquela data, a colisão ocorrida entre o automóvel n. 132, guiado pelo chauffeur Aniceto Machado de Souza, e o carro de praça conduzido pelo boleeiro Onofre de Aquino, na esquina das vias acima referidas ${ }^{783}$.

Vimos, no capítulo primeiro, que Aniceto Machado de Souza declara que, no dia 05 de julho de 1926, "estava fazendo um frete com os seus colegas chauffeurs, Clemente Rovere, José Soares, Euclydes de Souza e Izidoro de Souza", e que o veículo que dirigia na ocasião se deslocava à "velocidade de trinta quilômetros a hora",784. Veremos adiante, como as testemunhas,

\footnotetext{
${ }^{780}$ Outros apontamentos nessa direção são registrados pelo artigo do jornal $O$ Estado, que registra, na imprensa local, o sinistro em questão, embora também não aponte para a ocorrência de excesso de velocidade por ocasião do deslocamento dos referidos veículos. Ver O menor Gentil Lemos, atropelado por um auto, morre horas depois. O Estado. Florianópolis, 05 abr. 1926. Além disso, à testemunha José Meira também lhe foi perguntada: "os veículos [...] iam com excesso de velocidade?" ao que foi respondido que "ambos os veículos eram conduzidos em marcha mui moderada, mesmo porque a rua é estreita". (Processo n. 62, 03 abr. 1926. Caixa 06).

${ }^{781}$ Vimos, no capítulo terceiro da tese, que o órgão que fiscalizará diretamente o tráfego de veículos e automóveis na cidade de Florianópolis, durante as décadas de 1920 e 1930 e, mesmo, nos decênios de 1940 e 1950, é a Inspetoria de Veículos.

${ }^{782}$ Ver Processo n. 95, 05 jul. 1926. Caixa 09.

${ }^{783}$ Processo n. 95, 05 jul. 1926. Caixa 09.

${ }^{784}$ Idem.
} 
que "ouviram dizer" sobre o sinistro, reportam-se sobre o deslocamento daquele veículo. Por hora, destacamos que outros elementos sobre o ocorrido podem ser assinalados ao observarmos, do mesmo depoimento, que, "ao chegar à esquina da Avenida Rio Branco", Aniceto Machado "encontrou o carro de praça conduzido pelo boleeiro Onofre de Aquino; que desse encontro resultou ter o seu automóvel quebrado a lança do referido carro e a cabeça de um dos cavalos" ${ }^{, 785}$. Observamos que o acidente resultou no agravante de que o automóvel n. 132 "virou, ficando completamente quebrado, [e] os passageiros Euclydes de Souza e Izidoro de Souza, receberam graves ferimentos na cabeça" ${ }^{, 786}$. Nesse ponto, destacamos que, na fase de inquérito policial, são tomadas as declarações de, ao menos, oito pessoas; dentre elas, o acusado, Aniceto Machado; os passageiros do automóvel n. 132, chauffeurs Clemente Rovere e José Soares; o boleeiro Onofre de Aquino, envolvido na colisão, que conduzia o carro de praça n. $30^{787}$. Além dessas pessoas, foram ouvidas aquelas identificadas, no processo, como testemunhas, quais sejam: Marcolino José Espíndola, jardineiro; Jorge Josmiach, Músico de Primeira Classe da Força Pública do Estado, e Joaquim Marcelino Coelho, Capitão Farmacêutico do Exército ${ }^{788}$.

O acusado, Aniceto Machado, e os chauffeurs, Clemente Rovere e José Soares, ao se referirem à velocidade de deslocamento do automóvel n. 132, não expressam, textualmente, que o veículo se deslocava em grande velocidade, mas apenas registram que o automóvel estava, aproximadamente, a "trinta" consideram que o boleeiro Onofre de Aquino, ao efetuar a curva "para entrar na rua Esteves Júnior", não fez uso da buzina ou instrumento equivalente; embora o próprio boleeiro, em depoimento prestado no dia 05 de julho, tenha afirmado que naquele dia "descia a Avenida Rio Branco em marcha lenta e fonfonando, porque ia fazer a curva" para entrar na referida rua ${ }^{791}$. Ressaltamos que as declarações de Onofre de Aquino se mostram, novamente, dissonantes em relação às demais, especialmente ao considerar, em outra passagem de sua declaração, que, "no momento em que ia fazer a referida curva, subia em grande velocidade e sem fonfonar o automóvel de praça n. 132, guiado pelo chauffeur Aniceto Machado de Souza”, e que esse veículo "esbarrou com tanta violência no seu carro que quebrou a lança do mesmo e a cabeça de um dos cavalos"792. Onofre de Aquino afirma, ainda, que o automóvel, "logo que se chocou com

\footnotetext{
${ }^{785}$ Processo n. 95, 05 jul. 1926. Caixa 09.

${ }^{786}$ Segundo registra o depoimento prestado por Aniceto Machado, por ocasião do "termo de perguntas e declarações" a ele dirigido, datado de 05 de julho de 1926. (Processo n. 95, 05 jul. 1926. Caixa 09). Para maiores detalhes sobre o cenário do acidente, ver, também, Anexo 03 , p. 334.

${ }^{787}$ Processo n. 95, 05 jul. 1926. Caixa 09.

${ }^{788}$ Idem.

${ }^{789}$ Ver ideias expostas por Aniceto Machado de Souza, em data de 05 de julho de 1926, dia do ocorrido. (Processo n. 95, 05 jul. 1926. Caixa 09).

${ }^{790}$ Nesse caso, os chauffeurs Clemente Rovere e José Soares expressam essa mesma informação. (Processo n. 95, 05 jul. 1926. Caixa 09).

${ }^{791}$ Processo n. 95, 05 jul. 1926.

792 Processo n. 95, 05 jul. 1926. Caixa 09. Quanto a essas declarações, vimos que o acusado, Aniceto Machado, também afirmou em seu depoimento, que, do encontro dos dois veículos, resultou "ter o seu automóvel quebrado a lança do carro e a cabeça de um dos cavalos", e que o primeiro veículo "virou, ficando completamente quebrado, [e que] os passageiros Euclydes de Souza e Izidoro de Souza, receberam graves ferimentos na cabeça”. (Processo n. 95, 05 jul. 1926. Caixa 09).
} 
o seu carro, [...] capotou, [...] cuspindo todos os que nele iam ao chão, tal a velocidade em que ia",793.

Assim, percebemos que, nas falas aqui tomadas, há uma disputa discursiva sobre o que é considerado alta velocidade. Não objetivamos tomar partido de um ou outro personagem; mas, diante dos danos materiais causados, especialmente ao carro de praça n. 30 - conforme destacado no processo - e, igualmente, com base nas declarações de pessoas que afirmaram que o automóvel n. 132 se deslocava em "grande velocidade" ou mesmo em "velocidade assustadora"794, devemos considerar que o posicionamento de Aniceto Machado, assim como dos chauffeurs Clemente Rovere e José Soares, em apenas informar a velocidade de deslocamento do auto n. 132, soa, ao que parece, como recurso discursivo com o propósito de, entre outros elementos, afastar a ideia de que o mesmo veículo se deslocava em "grande velocidade". Mais do que isso, essas passagens nos dão conta de que os chauffeurs referidos produziram discursos convergentes, no sentido de operar-se, se assim podemos chamar, uma certa "proteção de classe", que objetiva minimizar a participação do chauffeur Aniceto Machado no desastre em questão. Vale lembrarmos, neste ponto, que o chauffeur Aniceto aponta, em suas considerações, que, na ocasião do sinistro, estava "fazendo um frete com os seus colegas chauffeurs Clemente Rovere, José Soares, Euclydes de Souza e Izidoro de Souza"795 . Em vista disso, podemos, mesmo, especular que os chauffeurs referidos se conheciam ${ }^{796}$ e que, hipótese plausível, trabalhavam, inclusive, no mesmo local ou em locais e pontos próximos.

É importante assinalarmos que o passageiro Clemente Rovere afirma, em outro momento de sua fala, que a colisão provocou a quebra da lança do carro e a cabeça de um dos cavalos e que "o automóvel capotou, atirando todos ao solo; [...] tendo [...] seus colegas, Euclydes de Souza e Izidoro de Souza, recebido graves ferimentos [...]",797. Esse personagem também considera que o carro de praça n. 30 "surge inesperadamente" na esquina da Avenida Rio Branco com a rua Esteves Júnior, e que "nestas condições foi inevitável o encontro dos dois veículos"798. Com base nessa informação, podemos considerar que a colisão não poderia ser evitada, talvez numa tentativa de minimizar a participação de um de seus colegas - no caso, Aniceto Machado no sinistro em questão. Além disso, quanto ao ato de fazer uso da buzina, Clemente Rovere

\footnotetext{
${ }^{793}$ Processo n. 95, 05 jul. 1926. Caixa 09.

${ }^{794}$ Informação dada por Marcolino José Espíndola, “jardineiro”, no dia 05 de julho de 1926. (Processo n. 95, 05 jul. 1926. Caixa 09).

${ }^{795}$ Essa informação é, igualmente, corroborada pelos chauffeurs Clemente Rovere e José Soares. (Processo n. 95, 05 jul. 1926. Caixa 09). O chauffeur Euclydes de Souza faleceu no Hospital de Caridade, no dia 06 de julho de 1926, em decorrência dos ferimentos provocados pelo acidente com o automóvel n. 132, conforme informações constantes no "Auto de Exame Cadavérico", anexo ao presente processo.

${ }^{796}$ Sobre esses aspectos, vejamos o que diz o chauffeur José Soares, pois ele afirma, no dia 05 de julho, que "o automóvel que ocupavam era [...] guiado por um colega do declarante, e chamava-se Aniceto Machado de Souza, chauffeur do mesmo automóvel de n. 132". Além disso, temos que considerar que os chauffeurs José Soares e Clemente Rovere eram "residentes nesta Capital à rua Camboriú", respectivamente aos "números um e dois". (Processo n. 95, 05 jul. 1926. Caixa 09). A rua Camboriú corresponde à atual rua Ferreira Lima; centro de Florianópolis. Ver SILVA, Adolfo Nicolich. Ruas de Florianópolis: resenha histórica. Florianópolis: Fundação Franklin Cascaes, 1999. p. 134.

${ }_{797}$ Processo n. 95, 05 jul. 1926. Caixa 09.

${ }^{798}$ Idem.
} 
observa que "o chauffeur Aniceto Machado [...] não fonfonou ${ }^{799}$; mas também não viu se o boleeiro fez o mesmo" ${ }^{\sharp 00}$. Assim, não é nenhum absurdo considerar que, em vários momentos de suas considerações, os chauffeurs, Clemente Rovere e José Soares, utilizam argumentos para, de certa forma, atenuar a participação de Aniceto Machado no sinistro em questão, pois lembremos que os chauffeurs aqui mencionados, ao que tudo indica, conheciam-se e, nesses termos, é possível que eles tenham prestado declarações não comprometedoras. Pensemos, pois, a respeito...

A seguir, destacamos trechos das declarações das pessoas identificadas como testemunhas no processo e, a partir dessas colocações, observemos como elas se manifestaram em relação ao episódio de colisão aqui discutido. Marcolino José Espíndola, “jardineiro”, considera que, no dia do ocorrido, “achava-se na rua Esteves Júnior, em frente ao Palacete do Bispado e, portanto, bem próximo à esquina da Avenida Rio Branco ${ }^{801}$; que viu quando passou o automóvel n. 132"802. Em seguida, "ouviu um grande ruído e correu para ver do que se tratava, e viu muita gente correndo para a esquina da Avenida Rio Branco e para lá se dirigiu” ${ }^{\prime 03}$. Esses elementos apontam que muitas pessoas se dirigiram para o local do acidente a fim de se interarem sobre o que havia ocorrido.

A cena de colisão, verificada no presente processo, ilustra que episódios dessa natureza chamavam a atenção dos transeuntes que observavam visualmente o deslocamento de automóveis; ou mesmo para aqueles que "ouviam ruídos" os quais foram identificados como procedentes de possível atropelamento ou colisão. Com isso, queremos frisar, uma vez mais, que esses episódios faziam parte do cotidiano da cidade de Florianópolis, uma vez que, dentre outros aspectos, estavam atrelados - se assim podemos chamar - à ardilagem e/ou identificação mental operada pelos florianopolitanos, conforme ilustram as passagens anteriores, pois elas apontam para o fato de que a visualização de automóveis em movimento ou a audição de sons identificados com esbarros ou colisões automobilísticas condicionam comportamentos e práticas a partir das quais se opera o respectivo deslocamento em direção ao cenário do ocorrido, conforme identificado no presente processo. Corroborando com essas considerações, a testemunha Jorge Josmiach, 27 anos, "Músico de Primeira Classe da Força Pública", observa em declaração tomada no dia 05 de julho, que

Ontem, pelas dezenove horas, mais ou menos, ia pela rua Presidente Coutinho e ao sair na rua Esteves Júnior encontrou uma senhora que não conhece e que lhe informou que tinha havido um esbarro na [própria] rua Esteves Júnior, [...] e para lá se dirigiu; que quando lá chegou viu o automóvel n. 132 [...] completamente quebrado e dois chauffeurs [...] caídos no chão, gravemente feridos; que foi

\footnotetext{
${ }^{799}$ Essa observação é, também, assinalada pelo outro passageiro do auto n. 132, o chauffeur José Soares. (Processo n. 95, 05 jul. 1926. Caixa 09).

${ }^{800}$ Processo n. 95, 05 jul. 1926. Caixa 09.

${ }^{801}$ Observar Anexo 03, p. 334.

${ }^{802}$ Processo n. 95, 05 jul. 1926 . Caixa 09.

${ }^{803}$ Idem.
} 
informado por várias pessoas que o desastre se deu porque o referido automóvel [...] subia a rua Esteves Júnior em grande velocidade [...]; que finalmente [...] ouviu dizer por várias pessoas que o desastre se deu porque o chauffeur Aniceto conduzia seu carro com excesso de velocidade, não tendo fonfonado ao atravessar em frente à Avenida Rio Branco e que também não o fez o boleeiro Onofre de Aquino $^{804}$.

Essas passagens permitem-nos apontar aspectos importantes. Em primeiro lugar, Jorge Josmiach foi informado sobre a ocorrência de uma colisão ao encontrar uma senhora na esquina das ruas Presidente Coutinho e Esteves Júnior. Notamos, assim, que essa mesma senhora, não conhecida da testemunha, já havia presenciado ou ouvido dizer a respeito da referida colisão, por isso lhe informou sobre. Jorge Josmiach, tomando ciência do ocorrido, dirigiu-se para o local do desastre e, naquela ocasião, soube, ao ser "informado por várias pessoas", que o incidente se dera porque o automóvel era guiado em alta velocidade. Percebemos, portanto, que não faltaram comentários sobre a velocidade de deslocamento do automóvel, o que sinaliza para o fato de que esse aspecto também não passava despercebido para aqueles que presenciavam ou "ouviam dizer" a respeito de determinada ocorrência. Enfatizamos que, mais do que isso, a observação sobre a velocidade de deslocamento do automóvel n. 132 foi feita por pessoas que, antes da chegada da testemunha Jorge Josmiach, já estavam às voltas com o cenário do sinistro, emitindo suas opiniões a respeito ${ }^{805}$.

Vimos que várias dessas pessoas transmitiram à testemunha aqui referida que "o desastre se deu porque o chauffeur Aniceto conduzia seu carro com excesso de velocidade, não tendo fonfonado ao atravessar em frente à Avenida Rio Branco e que também não o fez o boleeiro Onofre de Aquino" ${ }^{\sharp 06}$. Cabe salientarmos, portanto, que observações quanto à falta de utilização da buzina também foram feitas, o que sinaliza para o aspecto de que o emprego desse recurso era, mesmo, um elemento comum na prática da direção automotiva, regulamentada, inclusive, na legislação de trânsito local, como então aponta o parágrafo décimo do artigo 121 do Regulamento para o serviço policial do Estado ${ }^{807}$. Dessas passagens, consideramos, portanto, que “[...] da mesma forma que a notícia percorre as casas e as ruas, sendo divulgada de boca em boca, as normas que devem reger os comportamento e a divulgação das práticas seguem, pois, o

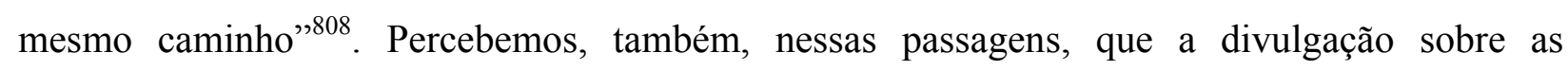
circunstâncias que envolveram a referida colisão constitui-se numa pedagogia, uma vez que a

\footnotetext{
${ }^{804}$ Processo n. 95, 05 jul. 1926. Caixa 09.

${ }^{805}$ Nesse ponto, questionamos o porquê de essas pessoas não serem ouvidas no presente processo; o que endossa, portanto, inquirições anteriores feitas neste texto.

${ }^{806}$ Processo n. 95, 05 jul. 1926. Caixa 09.

${ }^{807}$ Este parágrafo estabelece, como visto, que, dentre as "obrigações especiais de cocheiros e motoristas, de carros e automóveis de praça", deve “\# $10{ }^{\circ}$ - Fazer o motorista do automóvel uso da buzina todas as vezes que tiver de dobrar alguma esquina ou tiver na sua frente, algum outro veículo, transeunte ou outro qualquer móvel, semovente, que lhe impeça ou dificulte o trânsito". (Santa Catarina. Regulamento para o serviço policial do Estado. Florianópolis: Tipografia da Livraria Central, 1920). Observamos que essa determinação incidia apenas sobre os "motoristas dos automóveis de praça" e não, propriamente, sobre os cocheiros e/ou boleeiros, condutores dos carros movidos a força motriz animal.

${ }^{808}$ PEDRO, Joana Maria; NECKEL, Roselane; HAWERROTH, Eliana Izabel; MACHADO, Vanderlei. Aborto e Infanticídio nos Códigos Penais e nos Processos Judiciais: a pedagogia de condutas femininas. In: PEDRO, Joana Maria. (Org). Práticas Proibidas: práticas costumeiras de aborto de infanticídio no século XIX. Florianópolis: Cidade Futura, 2003. p. 93.
} 
população presente à cena do ocorrido, ao assimilar, de alguma forma, as normas e regras de trânsito e/ou de convívio social, transmitiram-nas ou as expressaram em falas e discursos que assumiram, muitas vezes, caráter reprovador às práticas exercidas pelos chauffeurs ao conduzirem seus automóveis ${ }^{809}$.

Desse modo, parafraseando Maria Stella Bresciani - cujas ideias sobre a interlocução entre os campos da História e da Arquitetura foram aproveitadas em muitas passagens deste estudo -, podemos considerar que o léxico popular expressa, em memórias e depoimentos, o espanto e/ou o entusiasmo pelas paisagens e particularidades do cotidiano citadino. Espanto e sedução se dão, também, perante o progresso, crescimento e alterações na materialidade da cidade. Desse modo, notamos que personagens diferentes, "uns simples trabalhadores, outros com instrução superior" - como exemplificam as testemunhas ouvidas nas passagens assinaladas nesta seção (ver, também, Anexo 20, p. 351), expressam suas opiniões, as quais nem sempre coincidem sobre as ocorrências de atropelamentos e colisões verificadas no perímetro urbano da cidade de Florianópolis; suas palavras mantêm, contudo, referências comuns sobre a cidade, seu crescimento e sua transformação ${ }^{810}$.

O excesso de velocidade, que, como visto nos capítulos anteriores, era praticado costumeiramente pelos chauffeurs que trabalhavam em Florianópolis, foi alvo de observação reprovadora por parte da testemunha Henrique Raupp Júnior, 45 anos, advogado. Essa testemunha, em data de 07 de julho de 1926, afirma que "no dia cinco do corrente, às sete horas da noite, estava ele no jardim de sua casa, que fica na esquina da rua Esteves Júnior com a Avenida Rio Branco, quando ouviu o ruído forte de um automóvel que vinha em vertiginosa correria do lado de baixo da rua Esteves Júnior em direção ao centro da cidade" ${ }^{\text {} 811}$. Depois de transcorridos "alguns segundos", a testemunha observou, ainda, "o aparecimento do automóvel na esquina da Avenida Rio Branco, ouvindo imediatamente um forte ruído e em seguida o tombamento do mesmo automóvel na esquina oposta ao seu jardim" ${ }^{\text {}}$. Segundo Henrique Raupp, “o tombamento tivera por causa o encontro com o carro do boleeiro Onofre, que na mesma ocasião vinha de cima da Avenida Rio Branco, dobrando a esquina, como quem queria se dirigir para a Praia de Fora"; e, adiante, afirma que "a culpa do desastre" deve "ser exclusivamente atribuída ao chauffeur do automóvel que vinha em correria vertiginosa rua

\footnotetext{
${ }^{809}$ Apontamentos nesse sentido são expressos pela testemunha Joaquim Marcelino Coelho, 43 anos, "Capital Farmacêutico do Exército"; pois, no dia 07 de julho de 1926, ao ser inquirido pelo Delegado de Polícia, disse que "no dia 05 do corrente, pelas dezenove horas, vinha subindo a rua Esteves Júnior com a sua família, quando por ele passou o automóvel de n. 132; que o mesmo automóvel chocou-se com um carro na esquina da Avenida Rio Branco; que quando chegou ao local, viu que o referido automóvel estava tombado e que tiravam debaixo dele um chauffeur ferido [...]; que procurando o chauffeur que guiava o auto, disse-lhe que ele precisava ser preso". (Processo n. 95, 05 jul. 1926. Caixa 09).

${ }_{810}$ BRESCIANI, Maria Stella Martins. Melhoramentos entre intervenções e projetos estéticos: São Paulo (1850-1950). In: Palavras da cidade. Porto Alegre: UFRGS, 2001. p. 346.

${ }^{811}$ Processo n. 95, 05 jul. 1926. Caixa 09.

${ }^{812}$ Idem. (Org.).
} 
acima" ${ }^{\$ 13}$. Em outra passagem de sua declaração, disse que "não se admirava do desastre porque constantemente verifica que os chauffeurs fazem da rua Esteves Júnior uma pista de corridas, sendo particularmente de notar-se a fúria com que constantemente por ali passa o automóvel da Empresa Força e Luz, para o qual em nome dos habitantes da referida rua, pede a intervenção da Polícia" ${ }^{\natural 14}$. Novamente aqui, percebemos um posicionamento reprovador ao modo como era guiado o automóvel n. 132; pois, segundo essa testemunha, o carro "vinha em vertiginosa correria" pela rua Esteves Júnior.

As altas velocidades, quando observadas pelas testemunhas, fazem-se presentes em suas falas e depoimentos, ao que parece, num tom frequentemente reprovador e vigilante. Nesse caso, a testemunha pede, inclusive, a intervenção da polícia para coibir tais abusos, em nome da segurança e tranquilidade públicas. Nesse sentido, percebemos que as falas tomadas dos inquéritos e dos processos judiciais, assim como das notas da imprensa local - que, como visto, apontavam para o aspecto de que a imprudência era, mesmo, algo corriqueiro nas ruas do perímetro urbano da $\mathrm{Capital}^{815}$-, constituíam-se numa pedagogia, segundo a qual a população assimilaria, gradualmente, as regras que deveriam gerir o bom andamento da sociedade ${ }^{816}$. Enfatizamos, pois, que muitas das falas e depoimentos, tomados dos processos criminais analisados neste estudo, apontam, inclusive, nessa direção.

Após a conclusão do inquérito, ocorrida no dia 07 de julho de 1926, as testemunhas arroladas no processo foram ouvidas em duas outras oportunidades; a primeira, entre os dias 30 de julho e 06 de agosto; e a segunda, entre os dias 28 de outubro e 23 de novembro de $1926^{817}$. Nessas passagens, o tom geral que percebemos é a reafirmação de posicionamentos registrados nos depoimentos tomados do inquérito policial ${ }^{818}$. Destacamos, entretanto, o registro de três

\footnotetext{
${ }^{813}$ Processo n. 95, 05 jul. 1926. Caixa 09. Indícios que corroboram com a ideia de que o chauffeur Aniceto Machado imprimia, no momento do acidente, "alta velocidade" podem ser destacados ao considerarmos os "Antecedentes" relativos ao mesmo chauffeur, registrados no texto conclusivo do respectivo inquérito policial, assinado no dia 07 de julho de 1926; e que, aliás, afirma que ficou "evidentemente provado que Aniceto Machado [...] subia em marcha vertiginosa a rua Esteves Júnior, sem fonfonar, infringindo, assim, as disposições do Regulamento Policial [do Estado]". Esses "Antecedentes" observam que "Aniceto Machado de Souza é 'chauffeur' e fez exame nesta Delegacia de Polícia em 24 de dezembro de 1925, [e] até a presente data já foi chamado, por várias vezes, à esta Delegacia e observado por excesso de velocidade". (Processo n. 95, 05 jul. 1926. Caixa 09). Essas considerações, além de reforçar a ideia de que Aniceto Machado imprimia, na ocasião do sinistro, alta velocidade ao automóvel n. 132, sugerem que o aparato policial local era atuante e se fazia presente de maneira frequente - Aniceto Machado, segundo apontado, era habilitado há menos de sete meses, quando chamado para depor no inquérito policial contra ele movido -, no sentido de coibir abusos ou condutas consideradas inapropriadas ao volante, praticados por chauffeurs habilitados, alguns já conhecidos da polícia e que estavam, portanto, previamente identificados. Veremos, adiante, que essas considerações não concordam com o que registra o artigo do jornal $O$ Estado, datado de 06 de julho de 1926; que, fazendo referência ao sinistro em questão, aponta para a falta de policiamento nas ruas do perímetro urbano da capital catarinense.

${ }_{814}$ Processo n. 95, 05 jul. 1926. Caixa 09.

${ }^{815}$ Ver, a respeito, artigo de jornal $O$ Estado, disposto no capítulo primeiro da tese, que referencia o sinistro em questão. Assim, esse artigo registra que "mais uma vez a imprudência redundou em prejuízos lamentáveis e conseqüências fatais", produzindo "um violentíssimo encontro entre o auto n. 132 e o carro de praça n. 30". Além disso, retomando ideias postas naquele capítulo, temos que o mesmo artigo sugere que não havia policiamento ostensivo, nas ruas de Florianópolis, como forma de coibir ou fiscalizar o desrespeito às normas de trânsito, pois os chauffeurs abusavam "da liberdade mais que ampla que lhes têm sido dada pela polícia", efetuando, com os seus veículos, "correrias loucas" pelas ruas da capital catarinense, e, "ao mesmo tempo, "contra-a-mão". (Os autos, sempre os autos! O Estado. Florianópolis, 06 jul. 1926. p. 1).

${ }^{816}$ PEDRO, Joana Maria; NECKEL, Roselane; HAWERROTH, Eliana Izabel; MACHADO, Vanderlei. Aborto e Infanticídio nos Códigos Penais e nos Processos Judiciais: a pedagogia de condutas femininas. In: PEDRO, Joana Maria. (Org). Práticas Proibidas: práticas costumeiras de aborto de infanticídio no século XIX. Florianópolis: Cidade Futura, 2003. p. 109.

${ }_{817}$ O processo crime já está instaurado, pelo menos, desde o dia 27 de julho de 1926, data em que foi assinada a Procuração ao chauffeur Aniceto Machado de Souza, e que nomeia Álvaro Tavares da Cunha Mello como seu advogado de defesa. (Processo n. 95, 05 jul. 1926. Caixa 09).

${ }^{818}$ Processo n. 95, 05 jul. 1926. Caixa 09.
} 
personagens que salientam, ainda, observações sobre a conduta do chauffeur Aniceto Machado, por ocasião do sinistro. Entre eles, Nicolau Carlos Mães, 54 anos, negociante, que "ouviu dizer” a respeito das circunstâncias que envolveram o sinistro em questão, fornece-nos, igualmente, elementos ilustrativos sobre as maneiras como essas testemunhas participavam das ocorrências de atropelamento e de colisão verificadas no perímetro urbano de Florianópolis - personagem, aliás, não ouvido na abertura do processo.

Antes, porém, observemos que, nos vistos finais junto do primeiro julgamento ao qual o réu é submetido, assinados no dia 23 de agosto de 1926, o Juiz da Segunda Vara da Comarca de Florianópolis, Mileto Tavares da Cunha Barreto, assinala para a absolvição do réu e, nesse sentido, argumenta que "culpa em direito penal é a voluntária omissão da diligência no calcular as conseqüências do próprio fato, passíveis de acontecer e de serem previstas (Marcondes Romeiro)"; ou "como ensina Von Lisvt (?), é a acusação ou o não impedimento, por ato voluntário, de um resultado que não foi previsto, mas que podia selo"; e continua ao afirmar que, "no caso destes autos, apurada a prova testemunhal, não ocorreram nenhuma das condições necessárias para que se possa considerar de caráter culposo o mal que aconteceu ao denunciado" 819 . O Juiz em apreço considera, finalmente, que "a idéia de culpa, no caso sub judice está inteiramente afastada", pois observa que "o acusado, no exercício de sua profissão de chauffeur, agindo com atenção ordinária e fiel observância às disposições do regulamento policial, foi inopinadamente ferido pela fatalidade" ${ }^{n 20}$.

Nesse ponto, notamos, claramente, que o Juiz não considera culpado o chauffeur; pois, segundo suas constatações, Aniceto Machado, por estar no exercício de sua profissão, obedeceu de maneira fiel às disposições regulamentares de trânsito então vigentes. Além disso, queremos chamar a atenção para o teor com que foram registradas as considerações formuladas pela figura do magistrado, postas no parágrafo acima, uma vez que apontam, também, para o caráter pedagógico - as leis e as formulações dos juristas ensinam! - que, em certo sentido, deveria assumir o discurso jurídico junto à sociedade.

Diante desse quadro, a Promotoria Pública entrou com recurso junto ao Superior Tribunal de Justiça do Estado, no dia 31 de agosto de 1926, para que o réu fosse submetido a novo julgamento; apresentou, pois, as razões para tal no dia 02 de setembro de 1926, obedecendo ao que estabelece o artigo 2500 do Código Judiciário do Estado ${ }^{821}$. Dentre as alegações para

\footnotetext{
${ }^{819}$ Processo n. 95, 05 jul. 1926. Caixa 09.

${ }^{820}$ Idem.

${ }^{821}$ Esse artigo estabelece que “Art. 2500 - Os recursos serão interpostos dentro de cinco dias, contados da intimação às partes, ou seus advogados, ou curadores, por meio de simples petição, ou por termo nos autos, especificando-se todos os traslados que se pretenderem, quando o recurso houver de subir em apartado". (Código Judiciário do Estado de Santa Catarina. Lei n. 1526 , de 14 de novembro de 1925. Florianópolis: Oficinas à Eletricidade da Imprensa Oficial, 1925. p. 349). Percebemos, portanto, que os processos criminais obedeciam, como visto, trâmites legais fundamentados em códigos e textos judiciais. Assim, podemos considerar que os processos eram conduzidos obedecendo a uma certa lógica, que era afinada, em última instância, aos interesses do Estado e dos legistas que elaboraram aqueles códigos. Como
} 
imputar ao réu novo julgamento, a Promotoria aponta que Aniceto Machado conduzia “o automóvel n. 132 na rua Esteves Júnior em marcha aceleradíssima” e, desse modo, "fê-lo chocarse com o carro guiado por Onofre de Aquino, que, lentamente, descia a Avenida Rio Branco" ${ }^{\text {}}$.

Outro elemento que fundamentou o recurso ao novo julgamento foi o fato de a Promotoria Pública considerar a declaração da testemunha Marcolino José Espíndola que, no dia 05 de julho de 1926, afirmou que "o chauffeur que conduzia o automóvel não fonfonou, atribuindo a culpa do desastre ao excesso de velocidade com que ia o referido chauffeur ${ }^{\prime 823}$. Da mesma forma, a Promotoria salienta que "o Dr. Henrique Raupp, morador à rua Esteves Júnior, declara que Onofre de Aquino vinha em passo lento com seu carro, devendo a culpa do desastre ser exclusivamente atribuída ao chauffeur do automóvel que vinha em correria vertiginosa rua acima"; e além disso, expôs que "não se admirava do desastre, porque constantemente verifica que os 'chauffeurs' de Florianópolis fazem da rua Esteves Júnior uma pista de corridas" ${ }^{\text {„24. }}$.

Aqui, é válido observarmos o questionamento efetuado pela mesma Promotoria ao considerar que o réu, ao praticar "manifesta desobediência ao regulamento policial [e] desdém pela vida de transeuntes inexpertos, dentro do perímetro urbano, [...] desenvolvendo quarenta quilômetros a hora em seu automóvel, não definem, esclarecem e robustecem crime culposo?" ${ }^{825}$. Vemos, claramente, que o Promotor Público utiliza trechos das declarações das testemunhas a fim de solicitar a punição do réu; e, para isso, coloca-se contra o posicionamento inicial do Juiz, pois salienta que Aniceto Machado desobedeceu ao regulamento policial. Percebemos, todavia, que esse personagem, para fundamentar sua posição, utiliza falas e trechos de depoimentos que, em síntese, corroboraram com a sua intenção. Esse procedimento, claro, não é uma exclusividade reservada aos promotores públicos.

Em vista disso, podemos arguir que o ato de punir ou inocentar os réus envolve, mesmo, discursos que são construídos de maneira tendenciosa, os quais objetivam a condenação ou a absolvição desses personagens. Assim, na tentativa de trazermos à tona os meandros envoltos nas malhas do judiciário, buscamos, através do exemplo registrado, perceber as maneiras com que se investiu sobre os diferentes sujeitos envolvidos nos processos criminais analisados ${ }^{826}$.

percebemos, os processos criminais eram, portanto, previamente dirigidos, pois que regras e leis específicas estabeleciam o seu desenrolar; e, igualmente, os procedimentos das autoridades judiciais; e esses elementos implicavam, de certa forma, num julgamento a priori da figura do réu.

${ }^{822}$ Processo n. 95, 05 jul. 1926. Caixa 09

${ }^{823}$ Idem.

${ }^{824}$ Idem.

${ }^{825}$ Processo n. 95, 05 jul. 1926. Caixa 09. A informação sobre a velocidade de "quarenta quilômetros a hora" foi dada, como visto, pelo chauffeur Clemente Rovere, passageiro do automóvel n. 132, por ocasião de sua declaração junto ao inquérito policial. Notamos, neste ponto, que o Promotor Público, diante dos vários trechos dos depoimentos dos chauffeurs e testemunhas envolvidos no acidente; que são registrados no recurso por ele imputado ao Superior Tribunal de Justiça, opta por destacar o trecho do depoimento de Clemente Rovere que observa, portanto, que o veículo n. 132 se deslocava à velocidade de "quarenta quilômetros a hora", quando o próprio chauffeur Aniceto, em sua fala no inquérito policial, afirma que se deslocava à velocidade de trinta quilômetros a hora, informação não considerada pelo Promotor Público, ao fazer a respectiva denúncia. (Processo n. 95, 05 jul. 1926. Caixa 09).

${ }^{826}$ PEDRO, Joana Maria; NECKEL, Roselane; HAWERROTH, Eliana Izabel; MACHADO, Vanderlei. Aborto e Infanticídio nos Códigos Penais e nos Processos Judiciais: a pedagogia de condutas femininas. In: PEDRO, Joana Maria. (Org). Práticas Proibidas: práticas costumeiras de aborto de infanticídio no século XIX. Florianópolis: Cidade Futura, 2003. p. 87. 
No dia 11 de outubro de 1926, o Superior Tribunal de Justiça dá "provimento ao recurso interposto" para "anular o processo" a fim de que "o Promotor ofereça nova denúncia contra o réu", por ele ter "cometido os crimes previstos nos artigos 297 e 306 do Código Penal" 827. Assim, as testemunhas são, novamente, inquiridas a partir do dia 28 de outubro de 1926. Nessa oportunidade, destacamos, pois, as declarações de três testemunhas que salientam, sobremaneira, o modo como o chauffeur Aniceto Machado guiava o automóvel n. 132 no instante do desastre.

Nicolau Carlos Maes, ouvindo dizer a respeito do ocorrido, oferece-nos outros elementos sobre o episódio. Assim, em data de 12 de novembro de 1926, essa testemunha afirma que, no dia da colisão entre o automóvel n. 132 e o carro de praça n. 30, “estava no Café Royal, quando soube do desastre sucedido na rua Esteves Júnior, onde é morador" e "se dirigindo ao local do desastre, verificou um automóvel estragado, e que soube fora dirigido por Aniceto Machado, vendo ainda um carro de praça com a lança partida"; e que "soube pelas pessoas que estavam no local, que o automóvel se chocara com o carro porque vinha à toda, desenvolvendo grande velocidade pela rua Esteves Júnior” ${ }^{, 828}$. Em outro momento de sua declaração, Nicolau Carlos Maes, em resposta à inquirição feita por Francisco de Oliveira e Silva, Promotor Público, disse que "ouviu de diversas pessoas comentários terríveis contra Aniceto Machado [...], reprovando o excesso de velocidade do automóvel" ${ }^{\prime 829}$.

Corroborando com essas ideias, a testemunha Marcolino J. Espíndola expressa, no mesmo dia 12 de novembro, que "estava na Casa de Negócio do Snr. Carlos Maes, em frente ao Palácio do Snr. Bispo", quando "passou o automóvel de Aniceto Machado a toda a velocidade, o que fez exclamar à copeira do negócio: 'Que horror!'. Logo depois ouviu o barulho de um grande choque e, em seguida, pessoas passavam narrando o desastre" ${ }^{\Perp 30}$. A testemunha acrescentou que "foi ao local" e, naquela ocasião, verificou que "[tinha?] gente que reprovava o procedimento de Aniceto Machado, comentando a grande velocidade em que vinha o seu automóvel" ${ }^{\prime 831}$.

\footnotetext{
${ }^{827}$ A respectiva denúncia foi assinada no dia 20 de outubro de 1926. (Processo n. 95, 05 jul. 1926. Caixa 09). É importante esclarecermos que, nos episódios aqui analisados, o Promotor Público, quase sempre, exigia a punição dos responsáveis pelos crimes de trânsito. No processo ora analisado, o Promotor Público, apresentando, portanto, nova denúncia em 20 de outubro de 1926, observa que "Com o choque dos veículos, os chauffeurs Euclydes de Souza e Izidoro de Souza receberam ferimentos graves, falecendo o primeiro, na madrugada de 06 de julho findo no Hospital de Caridade. E, como o indiciado, assim procedendo, incorra na sanção dos artigos 297 e 306 do Código Penal; esta Promotoria oferece a presente denúncia, que recebida e provada, seja o Indiciado punido nas penas do grau médio dos referidos artigos, na ausência de circunstâncias agravantes e atenuantes". (Processo n. 95, 05 jul. 1926. Caixa 09).

${ }^{828}$ Processo n. 95, 05 jul. 1926. Caixa 09.

${ }^{829}$ Idem.

${ }^{830}$ Idem.

${ }^{831}$ Processo n. 95, 05 jul. 1926. Caixa 09. A par de outras etapas que compuseram o longo processo ao qual o réu Aniceto Machado foi submetido - o "Termo de Decisão Final do Conselho de Sentença" foi assinado no dia 28 de março de 1928 -, verificamos, em apenas uma oportunidade, a prisão do réu, posto em liberdade condicional frente ao pagamento da fiança estipulada em lei. Nesse quadro, a condenação do réu foi assinada no dia 15 de março de 1927; e, no dia 19 do mesmo mês, foi designada a cadeia pública de São José para o cumprimento da respectiva pena. O valor da fiança foi arbitrada "na quantia de seiscentos mil réis (600\$000)". Assim, a lavração do Termo de Fiança, datada de 21 de abril de 1927, garante ao réu Aniceto Machado de Souza "o livramento condicional da pena que lhe foi imposta por ocasião do desastre de automóvel, ocorrido no dia 05 de julho de 1926" - o Alvará de Soltura foi assinado no dia 22 de abril de 1927. (Maiores detalhes a respeito ver, deste capítulo, seção Leis e Finanças). De outro modo, a utilização das provas testemunhais objetivando a condenação do réu feita, especialmente, pela figura do Promotor Público, e os termos de apelação subsequentes, justificando a conduta imprudente do motorista, pois "desobedece[u], pela velocidade excessiva, o dispositivo notório do regulamento policial [do Estado]" - observamos, pois, que o Promotor Público se utiliza do argumento da prática da "velocidade excessiva" e do desrespeito ao regulamento policial, como forma de provocar a condenação de Aniceto Machado -, não impediram que ao final do recurso impetrado junto ao "Egrégio Superior Tribunal de Justiça", efetuado,
} 
Do exposto, registramos, uma vez mais, que os florianopolitanos tinham sua atenção desviada para observar e comentar acidentes de trânsito, pois, pelo que pudemos perceber, estavam atentos às ocorrências de atropelamentos e de colisões verificadas nas ruas da cidade ${ }^{832}$, observando, muitas vezes de maneira crítica, comportamentos considerados indevidos ao volante. Assim, as passagens registradas nos parágrafos anteriores sugerem-nos que essas observações incidiam, especialmente, sobre os comportamentos que envolviam excesso de velocidade. Desse modo, destacamos que os pedestres, ao presenciarem ou tomarem conhecimento "por ouvir dizer" das ocorrências de atropelamento ou de colisão, procuravam observá-las criticamente, a fim de comentar e expedir opiniões sobre a maneira como os chauffeurs dirigiam os veículos e, também, sobre a observância, ou não, das normas de trânsito vigentes. Tendo isso em vista, podemos considerar que a participação das testemunhas nos processos criminais aqui analisados - mesmo daquelas que apenas informavam as circunstâncias dos ocorridos àqueles personagens que falavam nos processos - opera um estado consciente e, mesmo, permanente de visibilidade. A vigilância é, com efeito, uma armadilha, pois assegura o funcionamento automático do poder de vigília que, em síntese, faz com que a observação e a vigilância sejam permanentes em seus efeitos, mesmo que descontínuas em suas ações ${ }^{833}$.

Nesse ponto, podemos observar que as representações e as práticas discursivas que se efetivam no contexto urbano ligam-se à lógica das intervenções e ao lugar ocupado por distintos atores sociais. É, portanto, na instituição do imaginário que a cidade dá a ver um diálogo com o seu passado, que aparece como texto a ser evocado, sem que haja uma ordem hierárquica de prioridade ${ }^{834}$. As falas de "advogados", “jardineiros”, “soldados” e "capitães” da Força Pública, expressas e resignificadas nas passagens aqui citadas, revelam-nos leituras e interpretações sobre

por fim, no dia 27 de junho de 1927, fosse concedido, "por unanimidade de votos", respostas negativas aos quesitos para o julgamento do réu Aniceto Machado de Souza, onde o Juiz Mileto Tavares da Cunha Barreto julga-o "isento de culpa e o absolve da acusação que lhe foi intentada". Assim, em outros termos, o Juiz considerou que Aniceto Machado não cometeu "negligência", nem "imperícia", pois que correspondem aos segundo e terceiro "quesitos para o julgamento" do acusado. (Processo n. 95, 05 jul. 1926. Caixa 09).

${ }^{832}$ Sobre esse aspecto, é interessante destacarmos, também, o teor do que foi observado pela testemunha Nicolau Carlos Maes, em declaração prestada no dia 06 de agosto de 1926, pois, naquela ocasião, afirmou que, "na noite do dia do desastre, às 07 horas, achava-se o depoente no Café Royal, na Praça XV de Novembro" e "em dado momento ouviu certo alarido da parte de fora do estabelecimento". Verificando do que se tratava, "viu desembarcarem de um automóvel para entrar na Farmácia Popular dois passageiros feridos, que soube então por populares serem vítimas de um desastre de automóvel ocorrido naquele momento na rua em que o depoente residia" e, "em vista disso, ele depoente seguiu naquela direção e ao passar pela esquina da rua Esteves Júnior com a Avenida Rio Branco viu tombado um automóvel danificado e um carro de praça com a lança partida". (Processo n. 95, 05 jul. 1926. Caixa 09). Fica claro, portanto, que a testemunha em questão, ao saber, "por populares", que havia ocorrido um desastre de automóvel na rua onde ela residia, seguiu "naquela direção" para verificar o que havia acontecido.

${ }^{833}$ FOUCAULT, Michel. Vigiar e Punir: nascimento da prisão. 16 ed. Petrópolis: Vozes, 1987. p. 166. Devemos observar, também, que, a partir do final do século XVIII, torna-se cada vez mais comum a prática de que o "[...] Juiz não julga mais sozinho. Ao longo do processo penal, e da execução da pena, prolifera toda uma série de instâncias anexas" - conforme exemplificada no processo aqui em discussão. Assim, "[...] pequenas justiças e juízes paralelos se multiplicam em torno do julgamento principal: peritos psiquiátricos ou psicólogos, magistrados da aplicação das penas, educadores, funcionários da administração penitenciária fracionam o poder legal de punir. [...]. Resumindo: desde que funciona o novo sistema penal - o definido pelos grandes códigos dos séculos XVIII e XIX -, [...] a operação penal inteira carregou-se de personagens extra jurídicos"; e podemos dizer que "não há nisso nada de extraordinário; que é do destino do direito absorver pouco a pouco elementos que lhe são estranhos. Mas uma coisa é singular na justiça criminal moderna: se ele se carrega de tantos elementos extra jurídicos, não é para poder qualificá-los juridicamente e integrá-los pouco a pouco no estrito poder de punir; é, ao contrário, para poder fazê-los funcionar no interior da operação penal como elementos não jurídicos; é para evitar que essa operação seja pura e simplesmente uma operação legal; é para excusar o Juiz de ser pura e simplesmente aquele que castiga”. FOUCAULT, Michel. Vigiar e Punir: nascimento da prisão... op. cit., p. $22-23$

${ }^{834}$ BARREIRA, Irlys Alencar F. A cidade no fluxo do tempo: invenção do passado e patrimônio. Sociologias, Porto Alegre, n. 9 , jan./jun. 2003. Versão Impressa. 
aspectos do cotidiano da cidade de Florianópolis que assumem, ao mesmo tempo, formas variadas e aproximadas de interlocução, que incluem ajustes e conflitos discursivos que vão adquirindo nuances diferenciadas, conforme os tempos e atores envolvidos nos destinos e rumos cotidianos da cidade ${ }^{835}$. Os discursos e saberes elaborados sobre os meios urbanos são, em síntese, tributários de vários outros saberes que, situados em campos e olhares diversos, enfeixam um saber multifacetado sobre a cidade ${ }^{836}$. Desse modo, as visões e as interpretações de personagens anônimos, que expõem olhares diferenciados e, ao mesmo tempo, convergentes sobre cenários, referenciais e circunstâncias específicas, presentes no emaranhado da vida urbana, podem, por fim, dar a ver e a ler um pouco do passado urbano aqui estudado.

\subsection{A Cidade e o Automóvel em dois momentos: retórica e jurisprudência}

Nessa seção pretendemos analisar dois processos criminais que, entendemos, exemplificam as etapas e os trâmites legais que culminaram com a prisão daqueles identificados como responsáveis pelos crimes de atropelamentos e de colisões ocorridos na cidade de Florianópolis durante as décadas de 1920 e 1930. No primeiro caso, temos um processo em que o chauffeur, Ervino Raguse, é condenado, em decisão final do Tribunal Correcional - datada de 11 de janeiro de 1927 -, a cumprir "03 meses, 23 dias e 18 horas de prisão simples” na "Cadeia pública de São José’ ${ }^{, 837}$. Antes de analisarmos as circunstâncias que culminaram na sua prisão, devemos observar, contudo, que o processo n. 73 - inédito, neste estudo - registra, em dezembro de 1926, o atropelamento do carroceiro Francelino Manoel da Costa, funcionário da prefeitura municipal de Florianópolis; ocasionado, portanto, pelo chauffeur Ervino Raguse que, na ocasião do sinistro, guiava o automóvel de praça n. $166^{838}$. Esse episódio ocorreu na rua Conselheiro Mafra, no dia 17 do mês de dezembro.

A vítima em questão tem 44 anos e reside no distrito da Trindade ${ }^{839}$. Conforme suas declarações, prestadas no dia do ocorrido, afirma que "hoje pelas duas horas da tarde, no princípio da rua Conselheiro Mafra, estava no seu trabalho apanhando lixo na mesma rua, quando foi jogado ao chão pelo automóvel n. 166, que lhe feriu o pé esquerdo e parte do corpo" ${ }^{840}$. (Anexo 16, p. 347). Continuando suas alegações, a vítima afirma, igualmente, que "não ouviu o fonfonar do carro; [e] que atribui ter sido apanhado devido à grande corrida do

\footnotetext{
${ }^{835}$ BARREIRA, Irlys Alencar F. A cidade no fluxo do tempo: invenção do passado e patrimônio. Sociologias... op. cit.

${ }^{836}$ BRESCIANI, Maria Stella Martins. Cidade e História. In: OLIVEIRA, Lúcia Lippi (Org.). Cidade: história e desafios. Rio de Janeiro: FGV, 2002. p. 23.

${ }^{837}$ Processo n. 73, 17 dez. 1926. Caixa 07.

${ }^{838}$ Processo n. 73, 17 dez. 1926. Caixa 07. Ver, também, O auto 166 atropelou, ontem, um lixeiro. O Estado. Florianópolis, 18 dez. 1926. p. 2.

${ }^{839}$ É importante observarmos que o atual bairro da Trindade foi classificado, na época, como distrito. Assim, podemos afirmar com segurança que, durante a década de 1920, a região conhecida como Trindade não integrava a cidade de Florianópolis e, tampouco, pertencia ao seu perímetro urbano, pois se localizava em uma região afastada da urbe, "atrás" do Morro da Cruz; longe, portanto, do alcance territorial do núcleo urbano da capital catarinense. Ver, no capítulo primeiro, Mapa 02, p. 53.

${ }^{840}$ Processo n. 73, 17 dez. 1926. Caixa 07.
} 
referido [veículo]" ${ }^{\prime 41}$. Ideias nesse sentido são apontadas pelo artigo do jornal O Estado, de 18 de dezembro de 1926, intitulado $O$ auto 166 atropelou, ontem, um lixeiro, que faz referência ao sinistro em questão. $\mathrm{O}$ artigo registra, dentre outros aspectos, que "várias pessoas, que assistiram ao acidente, afirmaram que o auto corria em velocidade proibida pelo regulamento de veículos" ${ }^{842}$. É curioso observarmos que as vítimas de atropelamento fazem referência, de modo especial, à velocidade de deslocamento dos veículos motorizados e sinalizavam, quase sempre, que os chauffeurs os guiavam com "excesso de velocidade". Além disso, é possível argumentarmos que as notas jornalísticas da época se empenhavam em divulgar campanhas com o propósito de disciplinar as condutas dos chauffeurs ao volante. Lembremos, ainda, que, em inúmeras passagens deste estudo, especialmente no capítulo primeiro, chamamos a atenção para esses procedimentos, pois, como visto, os chauffeurs eram, em sua maioria, indivíduos muito jovens. O chauffeur Ervino Raguse, por exemplo, tinha 22 anos de idade ${ }^{843}$ e, nessas condições, jovens como ele eram mais facilmente seduzidos pelos apelos de velocidade e juventude, propagados, em parte, pelas notas jornalísticas locais ao noticiarem a venda dos automóveis nas praças agenciadoras do Estado.

Vejamos, a seguir, como se posicionou o chauffeur Ervino Raguse, em seu "Termo de declarações" prestado no dia 17 de dezembro de 1926, na abertura do inquérito policial. Naquela ocasião, o referido chauffeur aponta que "hoje pelas duas horas da tarde" estava "na direção do carro n. 166" quando "entrou na rua Conselheiro Mafra, conduzindo passageiros para a Rita Maria $^{844}$, em velocidade de quinze quilômetros por hora ${ }^{845}$; [e] que na dita rua achava-se uma carroça de lixo" ${ }^{846}$. Raguse afirma, também, que "antes desta aproximar-se, fonfonou, não sabendo como apanhou o trabalhador da mesma, que supõe ter sido ligeiramente ferido, [e] que não o conduziu à Farmácia pela urgência dos passageiros de seu carro ${ }^{847}$, e que de volta [da Rita Maria], soube ter sido o ferido conduzido para a Farmácia" ${ }^{\$ 48}$.

\footnotetext{
${ }^{841}$ Processo n. 73, 17 dez. 1926. Caixa 07.

${ }^{842} \mathrm{O}$ auto 166 atropelou, ontem, um lixeiro. O Estado. Florianópolis, 18 dez. 1926. p. 2.

${ }^{843}$ Processo n. 73, 17 dez. 1926. Caixa 07.

${ }^{844}$ Esse aspecto nos permite inferir que o carro conduzido por Ervino Raguse era de praça e não, propriamente, de natureza particular.

${ }^{845}$ A velocidade mencionada pelo acusado não extrapola àquela determinada pelos órgãos fiscalizadores de trânsito no Estado e na capital catarinense; pois, um ano após o sinistro em questão, o Decreto 2075, de 28 de junho de 1927, registrava a "necessidade urgente de regulamentarse o serviço de trânsito" e aprovava as "instruções para a Inspetoria de Veículos". Essas instruções, como visto, estabeleciam, dentre outros dispositivos, que "Art. 36 - Nas ruas e praças da Capital, os automóveis e auto-caminhões" não poderiam exceder à velocidade de "vinte quilômetros a hora, de marcha", e os "carros [teriam] a velocidade de um animal a trote". (Santa Catarina. Instruções Regulamentares para o serviço de trânsito público. Florianópolis: Imprensa Oficial, 1928. p. 10). É importante registrarmos que, no mês de dezembro de 1926, data de ocorrência do atropelamento registrado no processo n. 73, a ponte Hercílio Luz já havia sido inaugurada, fato ocorrido no dia 13 de maio de 1926. Há, portanto, desencontros entre as declarações prestadas pelo acusado, pela vítima e, também, pelo artigo do jornal $O$ Estado, de 18 de dezembro de 1926, sobre a velocidade atingida pelo automóvel n. 166 no momento do atropelamento de Francelino Manoel da Costa.

${ }^{846}$ Processo n. 73, 17 dez. 1926. Caixa 07.

${ }^{847}$ Essas informações são corroboradas pelo registro do jornal $O$ Estado, datado de 18 de dezembro de 1926, que expõe: a "vítima, que saiu com um ferimento, de pouca importância, no pé direito, recebeu curativos na Farmácia da Fé, de onde foi conduzido para a Trindade", e que o "chauffeur Ervino, posteriormente preso pela polícia, declarou que, no momento do desastre, não parou o carro, porque os passageiros estavam apressados". (O auto 166 atropelou, ontem, um lixeiro. O Estado... op. cit., p. 2).

${ }^{848}$ Processo n. 73, 17 dez. 1926. Caixa 07.
} 
Percebemos, dentre outros aspectos, que o chauffeur Ervino Raguse preocupa-se em frisar que conduzia o automóvel em velocidade abaixo daquela permitida para o tráfego de veículos no perímetro urbano da capital catarinense. Essas arguições, podemos especular, foram formuladas para produzir-se os efeitos esperados pelo chauffeur, ou seja, fazer ver aos olhos do delegado que ele, sob todos os aspectos, adotou posturas e comportamentos exemplares, pois estava no exercício de sua profissão; conduzia o automóvel em velocidade aceitável para o tráfego de veículos nas ruas do espaço central de Florianópolis; fez uso da buzina ao aproximar-se da carroça de lixo, e que "não sabe como atingiu o trabalhador da mesma". Outro elemento que julgamos importante assinala para o aspecto de que o chauffeur estava, segundo suas declarações, ciente de que, perante a situação de atropelamento, era de sua responsabilidade conduzir a vítima para "à Farmácia”, e que não procedeu dessa forma, tendo em vista seu compromisso profissional de atender aos interesses dos passageiros que conduzia; e essas palavras, de certa forma, objetivavam produzir a intenção de dirimi-lo da responsabilidade em relação ao atropelado. Assim, percebemos que suas declarações oferecem, a todo o momento, justificativas plausíveis para os procedimentos e atitudes que tomou diante das circunstâncias que envolveram o acidente.

No presente processo, as testemunhas arroladas foram ouvidas em duas oportunidades. A primeira, no dia 18 de dezembro de 1926, ocasião em que foram inquiridas três testemunhas; e a segunda, no dia 11 de janeiro de 1927, quando foi ouvida, pelo menos, uma das testemunhas aqui referidas $^{849}$. Vejamos, então, como elas se referem às circunstâncias que envolveram o atropelamento em questão. Pantaleão Aphanasio, "natural da Grécia, com 34 anos de idade, negociante, residente nesta Capital à rua Conselheiro Mafra" ${ }^{\circledR 550}$, observa, no dia 18 de dezembro, que, "ontem, pelas duas horas da tarde, na rua Conselheiro Mafra, viu passar o auto n. 166, com regular velocidade", e que também "viu na mesma rua um carroceiro da Municipalidade com um pé ferido, dizendo ter sido obra do auto referido" 851 . É curioso observarmos que as considerações da testemunha João Elyseu di Bernardi, “com 36 anos de idade, negociante, residente no distrito do Estreito, Município de São José" ${ }^{852}$, são similares àquelas expressas por Pantaleão Aphanasio, notadamente ao também considerar que, "ontem viu na rua Conselheiro Mafra, o auto n. 166 em velocidade regular" ${ }^{853}$. A seguir, destacamos as palavras de João Farias dos Passos, testemunha

\footnotetext{
${ }^{849}$ Processo n. 73, 17 dez. 1926. Caixa 07. A testemunha João Farias dos Passos, apesar de intimada, não compareceu à sessão do Tribunal Correcional, agendada para aquele dia. Naquela ocasião, foi ouvida a testemunha João di Bernardi, 34 anos, "farmacêutico", irmão de João Elyseu di Bernardi. Veremos, a seguir, as considerações dessa testemunha. (Processo n. 73, 17 dez. 1926. Caixa 07).

${ }^{850}$ Processo n. 73, 17 dez. 1926. Caixa 07.

${ }^{851}$ Idem.

${ }^{852}$ Processo n. 73, 17 dez. 1926. Caixa 07. O distrito do Estreito passa a pertencer definitivamente a Florianópolis a partir do ano de 1944. Daquela data em diante, a referida região integra a parte continental da cidade de Florianópolis, composta, também, atualmente, pelos bairros Coqueiros, Jardim Atlântico, dentre outros. Ver especialmente: a) Decreto-Lei Estadual n. 951. Estabelece os limites do município de Florianópolis com São José; e b) FARIAS, Vilson Francisco de. São José: 250 anos: natureza, história e cultura. São José: ed. do autor, 1999.

${ }^{853}$ Processo n. 73, 17 dez. 1926. Caixa 07.
} 
que a exemplo de Francelino Manoel da Costa, também “trabalhava na Municipalidade" e que se autoidentifica como sendo "companheiro" de trabalho da vítima ${ }^{854}$. Essa testemunha afirma que “o auto n. 166 passava à rua Conselheiro Mafra em regular velocidade e por isso apanhou seu companheiro Francelino Manoel da Costa, ferindo um dos pés" ${ }^{\prime 85}$.

Percebemos, pelo exposto, que as três testemunhas expressam ideias convergentes sobre a velocidade de deslocamento do automóvel n. 166. Diante dessas informações, é importante frisarmos, uma vez mais, o posicionamento do artigo do jornal $O$ Estado, datado de 18 de dezembro de 1926, que observa que "várias pessoas, que assistiram o acidente, afirmaram que o

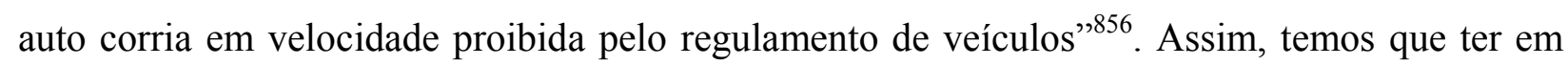
mente que, como visto, os artigos jornalísticos locais lançavam posicionamentos chamando a atenção para as altas velocidades que "certos condutores" imprimiam aos automóveis e, também, à imprudência dos mesmos chauffeurs; aspectos estes que, segundo as notas dos periódicos, eram verificados com frequência nas ruas do perímetro urbano da capital catarinense, os quais exigiam, segundo as mesmas notas, maior presença do efetivo policial local ${ }^{857}$.

Vimos que esse processo culminou com a prisão celular do chauffeur Ervino Raguse, determinada no dia 11 de janeiro de 1927. Bom, a julgarmos pelas passagens expressas pelas testemunhas aqui destacadas, não poderíamos prever que o respectivo chauffeur fosse preso e condenado ao cumprimento da respectiva pena. É importante observarmos, ainda, que o atropelamento discutido no presente processo não acarretou a morte da vítima. Além disso, outros episódios de atropelamentos e colisões, analisados neste capítulo, produziram o falecimento das respectivas vítimas; culminaram, todavia, com a absolvição dos réus ${ }^{858}$. Desse modo, instigantes são as condicionantes que levaram à prisão do réu Ervino Raguse.

Após o encerramento do inquérito policial, datado de 18 de dezembro de 1926, o Promotor Público da Comarca, "no uso de suas atribuições", oferece denúncia ao réu Ervino Raguse e argumenta para tal que "o automóvel n. 166, dirigido pelo indiciado [...] apanha no começo da rua Conselheiro Mafra” o carroceiro Francelino Manoel da Costa, "produzindo-lhe os ferimentos

\footnotetext{
${ }^{854}$ Processo n. 73, 17 dez. 1926. Caixa 07.

${ }^{855}$ Idem.

${ }^{856} \mathrm{O}$ auto 166 atropelou, ontem, um lixeiro. O Estado. Florianópolis, 18 dez. 1926. p. 2.

${ }^{857}$ Ver análise relativa ao artigo do jornal $O$ Estado, de 06 de julho de 1926, disposto no capítulo primeiro da tese. O ano, aliás, é o mesmo em que se verificou o atropelamento descrito no processo em questão. A referência ao artigo é a seguinte: Os autos, sempre os autos! O Estado. Florianópolis, 06 jul. 1926. p. 1.

${ }^{858}$ Caso do episódio verificado no processo n. 52, de 05 de novembro de 1925, no qual foi identificado que o chauffeur Max Muller, no momento em que conduzia o automóvel n. 86 pela Avenida Hercílio Luz, "notou um forte estampido", e que o veículo, naquela ocasião, virou. O sinistro ocasionou o falecimento de Jorge Sandmann que, como visto, era chauffeur profissional e proprietário do automóvel n. 86. Ele falece no Hospital de Caridade no mesmo dia ao ocorrido, como consequência dos ferimentos que sofreu por ocasião do desastre. (Processo n. 52 , 05 nov. 1925. Caixa 05). Outro exemplo é encontrado no processo n. 95, de 05 de julho de 1926, no qual o chauffeur Aniceto Machado de Souza foi, como visto, acusado pela colisão entre o automóvel de praça n. 132, por ele guiado, e o carro n. 30, conduzido pelo boleeiro Onofre D'Aquino. Como consequência do sinistro, os passageiros Euclydes de Souza e Izidoro de Souza receberam ferimentos graves, falecendo o primeiro, na madrugada de 06 de julho, no Hospital de Caridade. Mesmo diante do falecimento de um dos passageiros do auto guiado por Aniceto Machado, este, após ser preso, é posto em liberdade condicional mediante o pagamento de fiança, quando o Juiz Mileto Tavares da Cunha Barreto, em decisão final datada de 27 de junho de 1927, inocenta o réu das acusações que lhe são intentadas no processo. (Processo n. 95, 05 jul. 1926. Caixa 09).
} 
de natureza leve, constantes no auto de exame de corpo de delito" ${ }^{859}$; e "como assim procedendo, incorra o indiciado na sanção do artigo 306 do Código Penal" ${ }^{160}$. A expectativa da promotoria, uma vez oferecida a denúncia, gira sempre em torno da ideia de que seja "esta recebida e, afinal, julgada provada" 861 . Ervino Raguse deveria, então, ser punido "no grau médio do referido artigo, na ausência de circunstâncias agravantes e atenuantes" ${ }^{\text {"862 }}$. O Promotor Público requer, igualmente, que "sejam inquiridas as testemunhas [...] no dia do julgamento, ciente o denunciado, tudo na forma da lei”,863.

O Juiz da Segunda Vara da Comarca da Capital, Mileto Tavares da Cunha Barreto, julga procedente a denúncia oferecida pelo Promotor Público, pois designa “o dia 03 de janeiro próximo futuro, às 12 horas, na sala das audiências deste juízo, para o sorteio das vogais que deverão servir no julgamento deste processo, convocado o Dr. Promotor Público" 864 e, "para a sessão do Tribunal Correcional", designa "o dia 11 do referido mês, às 13 horas, no lugar de costume, fazendo-se as citações e intimações legais" "865.

Assim, segundo os trâmites legais, o processo apresenta o "Termo de sorteio do Tribunal Correcional", no qual consta que "Aos três dias do mês de janeiro de 1927, às 13 horas, na sala das audiências do Juiz de Direito da Segunda Vara da Comarca da Capital, no edifício da Superintendência Municipal”, é procedido “o sorteio de 02 (duas) vogais” para comparecerem "no dia 11 do corrente mês, às 13 horas" a fim de proceder-se ao "julgamento do acusado Ervino Raguse, em processo correcional pelo crime em que é acusado" ${ }^{\text {866 }}$. Percebemos, ainda, que o sorteio das vogais era sempre efetuado por um indivíduo menor de idade. A esse respeito, é importante destacarmos que o parágrafo segundo do artigo 2287, do Código Judiciário do Estado, de 1925, estabelece que “[...] Os nomes das vogais serão tirados da urna por um menor de entre sete e dez anos" ${ }^{\$ 67}$. Além disso, os parágrafos primeiro e segundo do artigo 27 , do Código Penal de 1890, determinam que, dentre os que “Art. 27 - Não são criminosos”, estão “\# 1. - Os menores de 09 anos completos" e “\# 2. ${ }^{\circ}$ - Os maiores de 9 e menores de 14, que obrarem sem discernimento" ${ }^{868}$.

\footnotetext{
${ }^{859}$ Processo n. 73, 17 dez. 1926. Caixa 07. O referido exame foi feito no mesmo dia do ocorrido, 17 de dezembro de 1926.

${ }^{860}$ Processo n. 73, 17 dez. 1926. Caixa 07.

${ }^{861}$ Idem.

${ }^{862}$ Idem

${ }^{863}$ Idem

${ }^{864}$ Esses procedimentos obedeciam ao que era estipulado nos códigos judiciários estaduais, pois, neste caso, o artigo 2287 do Código Judiciário do Estado de Santa Catarina, de 1925, determina que "Art. 2287 - Apresentada a denúncia, ou queixa, o presidente do Tribunal Correcional, dentro de vinte e quatro horas, mandará autuá-la [...], determinando dia, hora e lugar para o sorteio das vogais e para esse ato convocará o Promotor Público". (Código Judiciário do Estado de Santa Catarina. Lei n. 1526, de 14 de novembro de 1925 . Florianópolis: Oficinas à Eletricidade da Imprensa Oficial, 1925. p. 319).

${ }^{865}$ Seguindo o que determina o Código Judiciário do Estado, o artigo 2288 estabelece que "Art. 2288 - No mesmo despacho em que designar dia para o sorteio, mandará o réu para se ver processar e julgar em dia que marcará, bem como as testemunhas, para deporem sobre o fato e suas circunstâncias". (Código Judiciário do Estado de Santa Catarina. Lei n. 1526, de 14 de novembro de 1925... op. cit, p. 319).

${ }^{866}$ Processo n. 73, 17 dez. 1926. Caixa 07.

${ }^{867}$ Código Judiciário do Estado de Santa Catarina. Lei n. 1526, de 14 de novembro de 1925... op. cit, p. 319.

${ }^{868}$ Ver artigo 27 e parágrafos subsequentes. In: PIERANGELI, José Henrique. Códigos Penais do Brasil: evolução histórica. 2. ed. São Paulo: Revista dos Tribunais, 2004. p. 275. Ideias nesse sentido são também expressas pelo artigo 68 do Decreto n. 17943A, de 12 de outubro de 1927,
} 
Notamos, em vista do exposto, que o objetivo principal em delegar a um indivíduo menor de idade "o sorteio das vogais" centrava-se em evidenciar, ou, ao menos, tentar, teoricamente, transmitir a intenção de que não se estava fazendo uso de má-fé na escolha das pessoas que iriam julgar, nos casos aqui referidos, os réus imputados por crimes de trânsito. Em outras palavras, podemos afirmar que se estava zelando, ao menos aos olhos de quem presenciava o sorteio, pela prática de se "dizer a verdade" no transcorrer dos processos criminais ${ }^{869}$.

Assim, no caso do processo em questão, esse procedimento foi feito por um indivíduo de "nove anos de idade, residente nesta Capital à rua Itajaí, filho do senhor Durval Coelho Pinto" o menor parece ser conhecido do Juiz ou de outros personagens que integravam a cena de julgamento do réu Ervino Raguse! - que "extraiu da respectiva urna, 02 cédulas, e que observadas pelo dito menor, foram sorteadas [as vogais] Idelfonso Juvenal e Feris Boaibad"870. Em seguida, foi ordenado ao escrivão que "passasse mandado de intimação a fimm de intimá-las a comparecer no dia 11, às 13 horas, na sala das Sessões do Tribunal Correcional [...]; bem assim a Ervino Raguse, para se ver processar pelo crime de que é acusado e as testemunhas para [con?]firmarem os seus depoimentos" ${ }^{, 871}$. Todos esses personagens deveriam, portanto, comparecer "no local, dia e hora acima designados, sob as penas da lei" ${ }^{872}$. Percebemos, nessas

que estipula, dentro do "Capítulo VII - Dos Menores Delinqüentes", que "Art. 68 - O menor de 14 anos, indigitado autor ou cúmplice de fato qualificado crime ou contravenção, não será submetido a processo penal de espécie alguma; a autoridade competente tomará somente as informações precisas, registrando-as, sobre o fato punível e seus agentes, o estado físico, mental e moral do menor, e a situação social, moral e econômica dos pais ou tutor ou pessoa em cuja guarda viva”. (Decreto n. 17943A: consolida as leis de Assistência e Proteção aos Menores. Rio de Janeiro, 12 out. 1927). Essas observações, até onde se pode perceber, constituem aprimoramentos em relação ao artigo do código penal de 1890, aqui citado, pois os menores de 14 anos são, agora, identificados como autores de crimes ou contravenções; e, embora não respondam criminalmente pelos atos cometidos, devem ser levantados dados sobre os estados físico, mental e moral do menor, bem como a situação social, moral e econômica de seus tutores ou pais. Observamos que se dá ênfase à questão moral, podendo-se entender que "bons e convenientes comportamentos" dificilmente produziriam indivíduos delinquentes ou contraventores. Assim, percebemos, aqui, que as leis e códigos penais eram elaborados para, dentre outros objetivos, fomentar uma prática pedagógica em prol dos costumes e condutas consideradas civilizadas, que desviariam os indivíduos do caminho do crime e da contravenção. Para não nos alongarmos nas exposições desde decreto, basta mencionar que o seu artigo 79 disserta sobre "o menor de idade inferior a 14 anos", que "indigitado autor ou cúmplice de fato qualificado crime ou contravenção", e verificando-se que "as condições pessoais do agente ou de seus pais, tutor ou guarda, torna-se perigoso deixá-lo a cargo destes, o Juiz ou tribunal ordenará sua colocação em asilo, casa de educação, escola de preservação, ou o confira a pessoa idônea, até que complete 18 anos de idade". (Decreto n. 17943A: consolida as leis de Assistência e Proteção aos Menores... op. cit). Nesse caso, o menor de idade inferior a 14 anos é também considerado potencialmente um agente criminoso ou contraventor, mas, para o seu conveniente encaminhamento social - diante do perigo de deixá-lo com pais ou tutores que não apresentem "boas condições" ou "posturas" -, é ordenada a sua alocação em asilos, casas de educação ou escolas de preservação, ou, mesmo, a pessoas reconhecidamente idôneas. De qualquer forma, em todas essas alternativas, está presente a intenção de encaminhar este menor aos órgãos ou agentes que, pretensamente, zelarão pela sua educação sociomoral, com o fim de produzir-se indivíduos com comportamento aceitável, ou seja, passíveis de conviverem em sociedade, afastados de qualquer contato com o mundo do crime. Reforçamos, aqui, novamente, o papel pedagógico dos agentes judiciários que, em síntese, estavam a serviço do Estado. Os encaminhamentos dados ao menor, nos casos acima referidos, corroboram essa mútua relação que deveria haver entre o Estado e o poder judiciário. Frente ao exposto, devemos apontar que, no caso dos indivíduos considerados delinquentes, sua diferença em relação aos infratores refere-se ao fato de que, para a figura do delinquente, não seria tanto o seu ato que o caracterizaria, mas a sua vida. Nessa direção, a operação penitenciária, ou mesmo, no caso dos menores de idade, o seu encaminhamento a "asilos, casas de educação ou escolas de preservação", encerra uma prática reeducativa e esta deveria totalizar a existência do delinquente. Assim, a prisão ou as demais instituições aqui citadas eram os locais onde ela seria refeita totalmente. Ver, a respeito, FOUCAULT, Michel. Vigiar e Punir: nascimento da prisão. 16 ed. Petrópolis: Vozes, 1987. p. 215-226. Ainda, o Decreto n. 17943A também versa sobre menores "de mais de 14 anos e menos de 18 "; sobre aqueles que têm "mais de 16 e menos de 18 anos", e observa, igualmente, que "A idade de 18 a 21 anos constitui circunstância atenuante (Cód. Penal, art. 42, \# 11)". Ver, nesse decreto, artigos e parágrafos subsequentes. Sobre os artigos e observações feitos nesta nota ver, também, a) Decreto n. 17943A: consolida as leis de Assistência e Proteção aos Menores. Rio de Janeiro, 12 out. 1927. Disponível também em <http://www.senado.gov.br>; e b) MINEIRO, Beatriz Sofia. Código dos Menores dos Estados Unidos do Brasil Comentado. São Paulo: Companhia Editora Nacional, 1929.

${ }^{869}$ A esse respeito, todos os processos que analisamos dão conta de que as testemunhas ouvidas, sobretudo na fase de processo judicial, prestavam o juramento de "dizer a verdade do que soubessem e perguntado lhes fossem sobre os fatos constantes da denúncia". Assim, a organização e o andamento dos processos objetivavam, ao fim, buscar "a verdade" sobre o ocorrido, pelo menos em disputas discursivas colocadas textualmente.

${ }^{870}$ Processo n. 73, 17 dez. 1926. Caixa 07.

${ }^{871}$ Idem.

${ }^{872}$ Idem. 
passagens, que o Juiz, em especial, agia sempre dentro dos trâmites legais e que, portanto, suas atitudes e decisões estariam, pois, sempre acima de quaisquer suspeitas ${ }^{873}$.

Constatamos, também, que o "Mandado de Intimação", datado de 04 de janeiro de 1927, condiciona as testemunhas arroladas no processo para "deporem no processo crime correcional em que é acusado Ervino Raguse, que também será intimado para se ver processar pelo crime de que é acusado, e, bem assim, intime as vogais Idelfonso Juvenal e Feris Boaibad, para julgarem o referido processo, no dia 11 do mês corrente" ${ }^{\text {874 }}$. Inquirida novamente, a testemunha Pantaleão Aphanasio expõe ideas ilustrativas sobre os jogos discursivos que envolviam o desenrolar dos processos criminais aqui analisados; pois, após "jurar dizer a verdade do que soubesse", disse que, "no dia 17 do mês de dezembro último, passando o depoente pela rua Conselheiro Mafra, viu quando o automóvel n. 166, em corrida vertiginosa, dirigido pelo acusado Ervino Raguse, apanhou a carroça da Limpeza Pública [...], produzindo ferimentos no respectivo carroceiro Francelino Manoel da Costa" ${ } 875$. Percebemos, nesse ponto, que o teor do discurso da testemunha difere daquele expresso por ela no dia 18 de dezembro de 1926, quando afirmou que, "ontem [...] viu passar o auto n. 166, com regular velocidade". Pantaleão Aphanasio considera, ainda, que "no seu modo de ver, o acusado, com o procedimento que teve, infringiu disposições regulamentares" ${ }^{\prime 876}$. Outras observações importantes feitas por essa testemunha referenciam, ao ser inquirida pelo Promotor Público, que "em uma rua transitada e estreita como a que se deu o desastre, considera imperícia do chauffeur o fato do mesmo imprimir ao seu automóvel velocidade anormal" ${ }^{, 877}$.

Observamos, nesse ponto, que Pantaleão Aphanasio considerou que o chauffeur Ervino Raguse foi imprudente, pois, dentre outros aspectos, destaca que o automóvel por ele dirigido não poderia deslocar-se em "velocidade anormal", visto que a rua Conselheiro Mafra era "estreita" e movimentada. Assim, as ideias expostas permitem-nos considerar que as afirmações dadas pela testemunha, em seu segundo depoimento, foram condicionadas ou instruídas por figuras que integravam a esfera judiciária. Acreditamos que uma delas é o próprio Promotor Público, que, segundo podemos supor, elaborou arguições com o claro sentido de produzir argumentos testemunhais que viessem corroborar para a condenação do réu. Essas colocações ganham força ao também considerarmos que, na ocasião do primeiro depoimento dado por Pantaleão Aphanasio, tomado junto ao inquérito policial, não se fez qualquer menção à prática

\footnotetext{
${ }^{873}$ O parágrafo terceiro do artigo 2287 do Código Judiciário do Estado de Santa Catarina, de 1925, estabelece, por exemplo, que “Art. 2287 - \# $3 .^{\circ}$ - Feito o sorteio, serão os vogais notificados, por mandato, a comparecerem no dia, hora e lugar designados, sob pena de multa a que se refere o artigo 90”. (Código Judiciário do Estado de Santa Catarina. Lei n. 1526, de 14 de novembro de 1925. Florianópolis: Oficinas à Eletricidade da Imprensa Oficial, 1925. p. 319).

${ }^{874}$ Processo n. 73, 17 dez. 1926. Caixa 07.

${ }^{875}$ Idem.

${ }^{876}$ Idem.

${ }^{877}$ Idem.
} 
de "imprudência" do chauffeur Ervino Raguse e, também, ao perfil e/ou condição da rua em que ocorreu o referido atropelamento.

Desse modo, podemos perceber alterações nas falas das testemunhas, tomadas em um e outro momento do processo em questão ${ }^{878}$. Os discursos processuais elaborados são, assim, palco de elaborações e resignificações diversas, consoante com os interesses de cada parte neles envolvida. Nesse sentido, devemos atentar para o caráter político e relacional que encerram. Assim, devemos relativizar, inclusive, procedimentos correntes nos processos, que apontam, como visto anteriormente, para a prática de jurar e prometer "dizer a verdade do que soubesse e lhe perguntado fosse ${ }^{„ 879}$. Julgamos pertinente esclarecer, entretanto, que tal procedimento deveria, mesmo, fazer parte do papel que as autoridades judiciárias desempenhavam, pois eram portadoras de uma pretensa alçada científica, no sentido de produzir-se conhecimento e poder sobre os personagens que estavam inseridos, de uma maneira ou outra, nos processos criminais analisados $^{880}$.

Outras circunstâncias, que nos ajudam a compreender por que o chauffeur Ervino Raguse foi levado à prisão, estão colocadas nas respostas dadas aos "Quesitos para o Julgamento" do acusado $^{881}$. Esses quesitos, formulados no dia 11 de janeiro de 1927 , sinalizam o seguinte: " $1 .{ }^{\circ}$ A infração penal está provada?; $2^{\circ}$ - É responsável o réu pela infração penal?; $3 .^{\circ}$ - Há circunstâncias agravantes? Quais são?; 4. ${ }^{\circ}$ - Há circunstâncias atenuantes? Quais são?"882 Nessa ocasião, o Juiz de direito da Segunda Vara da Comarca da Capital, Mileto Tavares da Cunha Barreto, observa que, "quanto ao primeiro quesito, o Tribunal Correcional respondeu sim, por unanimidade de votos" $" 883$. Quanto ao segundo quesito, o tribunal também apresentou resposta positiva, "por unanimidade de votos" $" 884$. Não se apontou, no entanto, que houve circunstâncias agravantes ou atenuantes, ou seja, o que queremos destacar é que se provou, ou se quis provar, ter havido infração penal; e que, nesse caso, o respectivo réu foi considerado, "por unanimidade de votos", o agente responsável por tal infração.

\footnotetext{
${ }^{878}$ Ideias nesse sentido são, também, apontadas pela testemunha João Di Bernardi, "com 34 anos de idade, Farmacêutico" que considera, no dia 11 de janeiro de 1927, que "no dia e hora referidos na denúncia, estando ele em sua farmácia à rua Trajano, lhe apareceu o senhor Francelino Manoel da Costa, encarregado da Limpeza Pública, que lhe disse ter sido apanhado pelo auto n. 166 [...]; que efetivamente o ofendido, que foi acompanhado até a farmácia pelo irmão do depoente, Elyseu di Bernardi, apresentava ferimentos nas mãos e nos pés, tendo recebido curativos; que segundo ouviu de Elyseu, o acusado na ocasião do acidente passava em corrida vertiginosa pela rua Conselheiro Mafra, não tendo evitado o [esbarro?] por imperícia ou propósito”. (Processo n. 73, 17 dez. 1926. Caixa 07). Percebemos, aqui, que Elyseu di Bernardi considerou que o chauffeur Ervino Raguse incorreu em imperícia, não tendo descartado a hipótese de que o acidente foi provocado intencionalmente. É importante considerarmos que nenhuma dessas observações foram anotadas no seu primeiro depoimento, tomado no dia 18 de dezembro de 1926 , junto à abertura do inquérito policial; pois, naquela ocasião, Elyseu di Bernardi apenas considerou que "viu na rua Conselheiro Mafra, o automóvel n. 166, em velocidade regular". (Processo n. 73, 17 dez. 1926. Caixa 07). Reforçamos, portanto, as observações expostas no corpo textual acima.

${ }^{879}$ Processo n. 73, 17 dez. 1926. Caixa 07.

${ }^{880}$ PEDRO, Joana Maria; NECKEL, Roselane; HAWERROTH, Eliana Izabel; MACHADO, Vanderlei. Aborto e Infanticídio nos Códigos Penais e nos Processos Judiciais: a pedagogia de condutas femininas. In: PEDRO, Joana Maria. (Org). Práticas Proibidas: práticas costumeiras de aborto de infanticídio no século XIX. Florianópolis: Cidade Futura, 2003. p. 90.

${ }^{881}$ Processo n. 73, 17 dez. 1926. Caixa 07.

${ }^{882}$ Processo n. 73, 17 dez. 1926. Caixa 07. Ver artigo 2298. In: (Código Judiciário do Estado de Santa Catarina. Lei n. 1526 , de 14 de novembro de 1925. Florianópolis: Oficinas à Eletricidade da Imprensa Oficial, 1925, 352 p.).

${ }^{883}$ Processo n. 73, 17 dez. 1926. Caixa 07.

${ }^{884}$ Idem.
} 
Nesse sentido, enfatizamos que o Juiz, em resposta aos "Quesitos para o julgamento do réu" e "em conformidade às decisões do Tribunal Correcional, julgando o réu Ervino Raguse incurso no grau médio da penas do artigo 306 do Código Penal", condena-o a "03 meses, 23 dias e 18 horas de prisão simples e nas custas do processo" 885 . Por fim, designa "a Cadeia Pública de São José, neste Estado, para o cumprimento da pena" ${ }^{\text {886 }}$. Corroborando com essas considerações, a "Ata da Sessão do Tribunal Correcional", datada de 11 de janeiro de 1927, ratifica o que foi exposto, pois registra que "pelo senhor Presidente foi lavrada a sentença seguinte" a qual expõe que, "Em conformidade das decisões do Tribunal Correcional", julga-se "o réu Ervino Raguse incurso no médio das penas do artigo 306 do Código Penal” ${ }^{\wedge 87}$. Em vista disso, temos que os conhecimentos da infração; do responsável pela mesma, e, também, da lei, constituem importantes condições que permitem, aos olhos do aparato judiciário, estabelecer um julgamento como verdade bem fundada ${ }^{888}$. É válido observarmos, ainda, que o processo em questão termina sem que haja menção a qualquer ação de soltura do réu Ervino Raguse. Desse modo, afirmamos que, frente à totalidade dos documentos analisados até este momento, o presente processo foi o único que estipulou - até onde pudemos ver - a condenação integral do réu.

Assim, o mais importante é salientarmos que "tornada pública a sessão [do Tribunal Correcional], foi pelo Sr. Dr. Presidente, lida de pé e em voz alta as suas respostas aos quesitos e à sentença acima [...] do que para constar lavra-se a presente ata que vai assinada na forma da lei" ${ }^{889}$. Com base nisso, queremos realçar a postura adotada pelo Juiz ao comunicar a sentença final; pois, colocando-se de pé e a proferindo em voz alta, constrói, em síntese, um papel emblemático sobre a atuação do poder judiciário no julgamento das penas relativas aos crimes de trânsito, estudados nesta investigação. Em outras palavras, podemos argumentar que o caráter simbólico dessa cena transmite uma clara ideia sobre quais as instâncias e personagens que se colocavam como porta-vozes legitimadores da "verdade", uma vez que, "após deliberarem sobre o crime e suas circunstâncias", proferem a decisão final, que é formalizada em ata própria, a qual foi "assinada na forma da lei" ${ }^{890}$. É preciso, portanto, atentarmos para o aspecto de que

\footnotetext{
${ }^{885}$ A esse respeito, o parágrafo primeiro do artigo 62 do Código Penal de 1890, estabelece que, “[...] Nos casos em que este código não impõe pena determinada e somente fixa o máximo e o mínimo, considerar-se-ão três graus na pena, sendo o grau médio compreendido entre os extremos, com atenção às circunstâncias agravantes e atenuantes, às quais serão aplicadas na conformidade do disposto no art. 38, observadas as regras seguintes: \# $1 .^{\circ}$ - No concurso de circunstâncias agravantes e atenuantes que se compensem, ou na ausência de umas e outras, a pena será aplicada no grau médio". (PIERANGELI, José Henrique. Códigos Penais do Brasil: evolução histórica. 2. ed. São Paulo: Revista dos Tribunais, 2004. p. 279). Considerando-se o teor do artigo 306 do Código Penal de 1890, este estabelece como pena a "prisão celular por quinze dias a seis meses". (PIERANGELI, José Henrique. Códigos Penais do Brasil: evolução histórica... op. cit., p. 306). Assim, Ervino Raguse, como visto, foi enquadrado no grau médio, conforme pena exposta pelo artigo 306 do referido código.

${ }^{886}$ Processo n. 73, 17 dez. 1926. Caixa 07.

${ }^{887}$ Idem.

${ }^{888}$ FOUCAULT, Michel. Vigiar e Punir: nascimento da prisão. 16 ed. Petrópolis: Vozes, 1987. p. 20.

${ }^{889}$ Processo n. 73, 17 dez. 1926. Caixa 07.

${ }^{890}$ Processo n. 73, 17 dez. 1926. Caixa 07. Assim, podemos argumentar que "as Leis previstas no Código Penal, que eram formuladas por grandes juristas brasileiros", "terminavam por legislar, também, em sintonia com os grandes interesses da elite nacional”. PEDRO, Joana Maria; NECKEL, Roselane; HAWERROTH, Eliana Izabel; MACHADO, Vanderlei. Aborto e Infanticídio nos Códigos Penais e nos Processos Judiciais: a pedagogia de condutas femininas. In: PEDRO, Joana Maria. (Org). Práticas Proibidas: práticas costumeiras de aborto de infanticídio no século XIX. Florianópolis: Cidade Futura, 2003. p. 105.
} 
posicionamentos e decisões judiciais são, em síntese, práticas construídas que encerram o papel de legitimar uma pretensa verdade, mas que, em última instância, estão imbricadas em discursos e posicionamentos expressos nos processos; discursos estes que, ao disputarem espaço frente ao papel de se fazerem cumpridores das normas e leis, inscrevem, nos corpos, as prerrogativas do poder.

Assim, em conformidade com as análises tecidas neste estudo, destacamos que a mecânica do poder se expande por toda a sociedade e assume as formas mais regionais e concretas ao investir em instituições e tomar corpo em técnicas de dominação específicas ${ }^{891}$. De fato, “[...] o poder produz [...] domínios de objetos e rituais de verdade" ${ }^{\$ 92}$. O poder possuí, em síntese, “[...] uma eficácia produtiva, uma riqueza estratégica, uma positividade"; e é "justamente este aspecto que explica o fato de que tem como alvo o corpo humano, não para suplicá-lo, mas para adestrá1o"893. Nesse ponto, percebemos o caráter pedagógico da prisão; pois, ao referenciarmos um recente estudo sobre os meandros e a metodologia adotada no texto Vigiar e Punir, de Michel Foucault ${ }^{894}$, temos que, pelo menos até a segunda metade do século XVIII, eram correntes os rituais públicos de suplício e, nesses casos, a presença do soberano pretendia restaurar a sua soberania lesada. Além disso, nos códigos penais formulados, especialmente a partir do século XIX, percebemos uma importante mudança de direção: as penas instituídas e a leitura das leis objetivavam expressar o pacto dos cidadãos com a sociedade, e deixavam claro que o crime representava a quebra desse pacto; e o infrator, desse modo, ofendia a sociedade inteira ao cometer uma infração. Assim, os crimes cometidos são provas de que o criminoso violou a lei; ele deveria, portanto, ser isolado da sociedade ${ }^{895}$.

Devemos considerar, ainda, que a prisão moderna excede à simples privação da liberdade e tende a tornar-se um instrumento de modulação da pena. Assinalamos que o aparelho da prisão seria, portanto, encarregado de executar a sentença dada pela justiça ${ }^{896}$ - como, então, verificamos no julgamento do réu Ervino Raguse, que culminou com sua prisão na cadeia pública de São José, município que, hoje, integra a chamada "Grande Florianópolis". Queremos, com isso, dizer que as estratégias e posturas verificadas nas malhas do judiciário produzem poder-saber. Desse modo, lutas e processos discursivos, que as atravessam e as constituem, configuram formas e campos possíveis de conhecimento, que são investidos sobre os corpos dos condenados - no caso aqui referido, sobre o chauffeur Ervino Raguse - assim como sobre os

\footnotetext{
${ }^{891}$ MACHADO, Roberto. Introdução: Por uma genealogia do poder. In: FOUCAULT, Michel. Microfísica do Poder. 17 ed. Rio de Janeiro: Graal, 2002. p. XII.

${ }^{892}$ Ibidem, p. XVI.

${ }^{893}$ Idem.

${ }^{894}$ Ver, a propósito: VIEIRA, Priscila Piazentini. Michel Foucault e a História Genealógica em Vigiar e Punir. (Monografia). Campinas: IFCH/UNICAMP, 2006.

${ }^{895}$ Ibidem, p. 44-45.

${ }^{896}$ Ibidem, p. 52.
} 
demais personagens que participaram, de uma maneira ou outra, nas etapas do processo aqui analisado $^{897}$.

No início da década de 1930, temos, no ano de 1931, o texto processual n. 171, datado de 27 de dezembro. Obedecendo à abordagem que destinamos à presente seção, interessa-nos ver, nesse processo, os meandros discursivos e retóricos que permearam os posicionamentos das testemunhas e das personagens que compunham o quadro jurídico na ocasião dos dois julgamentos aos quais o chauffeur Oscar John foi submetido, uma vez que foi acusado de ser o responsável por provocar a colisão do automóvel particular n. 99, por ele guiado, com outro veículo, de aluguel, de n. 218, guiado pelo chauffeur profissional Octaviano dos Santos Botelho $^{898}$. Lembramos ao leitor que esse processo já foi abordado por nós, por ocasião da elaboração do capítulo primeiro da tese. Bom, mas por que outra análise do processo n. 171, nesta passagem de nossa investigação? A razão que se coloca é que, nesse caso, o chauffeur Oscar John foi, num primeiro momento, condenado, pois a ele foi imputada a "sanção do artigo 306 do Código Penal" ${ }^{899}$. O parecer do Juiz frente ao julgamento do réu, em segunda instância, datado de 08 de agosto de 1932, corroborou o que foi decidido anteriormente, pois Oscar John foi, naquela ocasião, condenado "a 03 meses, 07 dias e 12 horas de prisão celular [...], grau médio das penas do artigo 306 do Código Penal e do artigo segundo da Lei n. 4294, de 06 de julho de $1921^{900}$, na ausência de circunstâncias atenuantes a agravantes" ${ }^{901}$. Verificamos, porém, que os vistos finais do processo, assinados em 19 de agosto de 1932, estabelecem a suspensão condicional da pena anteriormente exposta. Assim, vamos aos trâmites e meandros legais que culminaram com o estabelecimento dessa decisão final.

Em primeira mão, vejamos como o acusado, chauffeur Oscar John, se coloca-se perante as arguições que lhe são feitas pelo delegado de polícia, por ocasião da abertura do inquérito policial, datada de 27 de dezembro de 1931. Nessa ocasião, Oscar John, ouvido no dia 28 de dezembro, argumenta, como visto no capítulo primeiro, que, "ontem, às vinte e três e meia horas, conduzia o seu auto, em companhia de dois amigos, pela rua Artista Bittencourt; que ao se aproximar da esquina dessa rua com a Visconde de Ouro Preto, fonfonou, dando assim sinal; que seu auto tinha os faróis acesos"902. Continuando a responder às suas arguições, o acusado considera que "assim que ia fazer a curva para entrar na rua Visconde de Ouro Preto, pelo centro

\footnotetext{
${ }^{897}$ FOUCAULT, Michel. Vigiar e Punir: nascimento da prisão. 16 ed. Petrópolis: Vozes, 1987. p. 27.

${ }^{898}$ Processo n. 171, 27 dez. 1931. Caixa 16.

${ }^{899}$ Idem.

${ }^{900}$ Esse artigo estipula que "Art. $2 .^{\circ}$ - Apresentar-se publicamente em estado de embriaguez que cause escândalo, desordem ou ponha em risco a segurança própria ou alheia: Pena - de multa de $20 \$ 000$ a 200\$000. O dobro em cada reincidência”. NETO, Alvarenga. Código Penal Brasileiro e [leis penais subsequentes]. Rio de Janeiro: Leite Ribeiro, 1929. p. 207. (Col. Biblioteca Jurídica, v. 4). Veremos, a seguir, que Oscar John foi submetido ao “Auto de Exame de Embriaguez", formulado no dia 27 de dezembro de 1931.

${ }^{901}$ Processo n. 171, 27 dez. 1931. Caixa 16.

${ }^{902}$ Idem.
} 
da rua, encontrou-se com um outro auto que vinha em sentido contrário; que o referido auto também ia tomar a rua Artista Bittencourt, e que transitando pela 'mão' do depoente, fez com que ambos se chocassem" ${ }^{903}$. (Ver Anexo 06, p. 337). Observamos que, em nenhum momento, o respectivo chauffeur fez qualquer menção que o comprometesse. Ele afirma que, ao se aproximar da esquina das ruas Artista Bittencourt e Visconde de Ouro Preto, fez uso da buzina, e que seu carro "tinha os faróis acesos"; práticas que, aliás, são determinadas pelo regulamento de trânsito vigente à época ${ }^{904}$. Vale observarmos que Oscar John era chauffeur amador, pois conforme sua descrição, ele "era empregado no comércio" "905. O automóvel que conduzia não era, portanto, de praça ou de aluguel, mas de natureza estritamente particular ${ }^{906}$.

Neste estudo, não é nossa preocupação buscar culpados ou inocentes - observação, aliás, já feita em outras passagens da tese -, mas é possível considerarmos outras ideias, produzidas pelo chauffeur Oscar John, que objetivavam corroborar para a sua não responsabilidade diante do ocorrido, pois ele afirma, em outra passagem do seu depoimento, que "procurou evitar o encontro, brecando o seu carro; porém, como a distância entre um carro e outro era pouca, não foi possível evitar o choque" ${ }^{907}$. Assim, percebemos, a todo o momento, que o chauffeur Oscar John procura elucidar que o acidente ocorreu sem que ele tivesse qualquer participação efetiva no desastre. Bom, talvez fosse esse o seu papel. Podemos argumentar, ainda, que as declarações prestadas pelo acusado parecem encaixar-se, perfeitamente, às determinações legais então vigentes; e, nesse sentido, podem ter sido devidamente instruídas por advogados ou, também é possível, formuladas pelo próprio acusado, para que fossem produzidos os efeitos desejados.

Assinalamos, ainda, que o chauffeur Otaviano dos Santos Botelho, envolvido no acidente e ouvido no dia 28 de dezembro de 1931, aponta, como vimos, que "às onze e meia horas da noite, de ontem, conduzia o seu veículo pela rua Visconde de Ouro Preto, trazendo um passageiro que sabe [...] chamar-se Carlos Lopes Reis" e "que ao se aproximar da esquina dessa rua com a Artista Bittencourt, intensificou a luz dos faróis do seu carro, para dar sinal, fonfonando em seguida" $" 908$. Naquele momento, “ouviu o fonfonar de um veículo; que procurou colocar o seu auto bem na 'mão'; que assim que chegou na curva, procurou desviar-se do outro veículo que vinha transitando na mão do depoente", mas foi "então impossível ter evitado que o seu

\footnotetext{
${ }^{903}$ Processo n. 171, 27 dez. 1931. Caixa 16.

${ }^{904}$ Os artigos 43 e 46 das Instruções Regulamentares para o serviço de trânsito público estabelecem, respectivamente, como visto, que “Art. 43 Nenhum veículo poderá usar buzinas, tympanos, gláxons, etc., depois da meia noite, salvo quando dobrar uma esquina ou nos cruzamentos de ruas"; e "Art. 46 - À noite os veículos não poderão transitar sem as lanternas acesas e colocadas lateralmente". (Santa Catharina. Instruções Regulamentares para o serviço de trânsito público. Florianópolis: Imprensa Oficial, 1928. p. 10-11).

905 Processo n. 171, 27 dez. 1931. Caixa 16.

${ }^{906}$ Informação corroborada pela testemunha Carolino Serzedello Machado, que no dia 28 de dezembro de 1931 afirma que "ontem, às vinte e três horas e meia [...] estava em companhia de um cidadão que lhe fôra apresentado no carro particular e guiado pelo cidadão Oscar John". (Processo n. 171, 27 dez. 1931. Caixa 16).

${ }_{907}$ Processo n. 171, 27 dez. 1931. Caixa 16.

${ }^{908}$ Idem.
} 
automóvel fosse apanhado pelo outro" e que "o auto que batera no seu era guiado pelo chauffeur amador Oscar John"909 . Dado o exposto, constatamos que, tal como as declarações prestadas por Oscar John, essas também dão conta de que pouca ou nenhuma responsabilidade deveria recair sobre a pessoa de Otaviano dos Santos Botelho, pois suas declarações foram elaboradas para evidenciar seu correto comportamento no trânsito, afinado com as determinações legais de trânsito em voga.

A testemunha Carolino Serzedello Machado, passageira do automóvel n. 99, guiado por Oscar John, lança, porém, apontamentos que sugerem que o referido chauffeur seria considerado o responsável pela colisão dos dois veículos, pois afirma que “Oscar John conduzia o seu carro pela 'mão' esquerda, motivo porque chocou-se com o carro que se aproximava" ${ }^{910}$. Além disso, outro passageiro do mesmo automóvel, a testemunha Horst Wehling, considera que o chauffeur Oscar John "vinha transitando com o seu carro "contra-mão", procurando "um metro antes da esquina tomar o lado direito"911. A esse respeito, vimos, no texto do capítulo primeiro da tese, que o chauffeur, que transita pela rua Artista Bittencourt e pretende alcançar a rua Visconde de Ouro Preto, deve efetuar o cruzamento à direita (observar, no capítulo primeiro, mapa 05, p. 87). Essas passagens dão-nos conta de que as argumentações das vítimas, testemunhas e dos supostos responsáveis pelos ocorridos compõem um mosaico discursivo no qual se destacam posicionamentos que objetivam amenizar a responsabilidade dos chauffeurs e/ou boleeiros apontados como autores dos crimes de atropelamento e colisão ou, mesmo, declarações que corroboram para reforçar sua parcela de participação na efetivação dos acidentes de trânsito aqui referidos. Assim, o que queremos destacar é que os depoimentos tomados, na fase de inquérito policial, servem, também - assim como aqueles tomados nos processos judiciais propriamente ditos -, como palco de disputas discursivas, que objetivavam incriminar, ou não, as partes vistas como diretamente envolvidas nos episódios de atropelamentos e colisões verificados no espaço urbano de Florianópolis, no período estudado.

As disputas discursivas acima referidas eram tomadas, também, no momento de ocorrência dos sinistros; pois, no caso do processo aqui analisado, a testemunha Teotônio Felisbino da Rosa argumenta, por exemplo, que, "passando com o seu automóvel pela rua Artista Bittencourt, viu parado na esquina dessa rua com a Visconde de Ouro Preto, dois autos" e que "ouviu o chauffeur do carro n. 218, Otaviano dos Santos Botelho, dizer ao senhor Oscar John, chauffeur do carro n. 99, que ele era o culpado, porque não tinha brecado o auto em tempo" ${ }^{912}$. Ideias nesse sentido são, também, expressas pela testemunha Mário Gottardi, “natural deste Estado, com 20 anos de

\footnotetext{
${ }^{909}$ Processo n. 171, 27 dez. 1931. Caixa 16.

${ }^{910}$ Idem.

${ }^{911}$ Idem.

${ }^{912}$ Idem.
} 
idade, solteiro, de cor branca, estudante" ${ }^{\text {"913 }}$, que, aos 28 dias do mês de dezembro de 1931, observa que se dirigia "para a sua residência em um automóvel de aluguel, em companhia de alguns amigos, quando passando pela rua Artista Bittencourt para tomarem a Visconde de Ouro Preto"914, "notaram algo de anormal"915; e, desse modo, "depararam com dois autos parados em uma curva das ruas acima [...]"; que "o depoente viu ali Oscar John e Otaviano Botelho em discussão sobre a responsabilidade do ocorrido" ${ }^{916}$. Com isso, queremos reforçar a ideia de que os posicionamentos tomados, em cada processo criminal analisado, não compõem discursos coesos ou afinados diante da pretensa apuração sobre a responsabilidade dos sinistros, o que reflete, antes de tudo, campos conflituosos de disputas e posicionamentos discursivos. Devemos, portanto, atentar para o caráter político e relacional que os textos processuais encerram. Esses textos constituem, por conseguinte, um universo riquíssimo para percebermos, especialmente, o quê e quem era alvo da vigilância e da punição.

O inquérito policial é concluído em 02 de janeiro de 1932 e aponta que "Oscar John conduzia seu carro contra-mão, e por achar-se alcoolizado, conforme auto de exame de embriaguez de fls. $7^{917}$, não evitou que seu carro fosse de encontro ao de Otaviano dos Santos Botelho, que fazia a curva na referida esquina" ${ }^{918}$. Adiante, o delegado de polícia considera o seguinte: "parece-me, pelas provas testemunhais acima expostas, que Oscar John incidiu na sanção do artigo 306 do Código Penal"; e, nesses termos, determina que os autos fossem enviados "ao M.M. Sr. Dr. Juiz de Direito da Segunda Vara desta Comarca"919. Observamos que o parecer do delegado de polícia da Capital deu ensejo à ideia de que o acidente em questão foi causado, especialmente, porque o chauffeur Oscar John dirigia o automóvel n. 99 na contramão, e que ele estava alcoolizado, conforme aponta o "auto de exame de embriaguez", referido na conclusão do inquérito policial. Inferimos, portanto, que já na fase de inquérito policial, é enfatizada a ideia de que Oscar John é o principal agente causador do sinistro em questão.

Nesse ponto, é válido observarmos que não nos interessa, propriamente, tecer comentários sobre todas as etapas que envolveram o processo em discussão, pois entendemos que é importante atentarmos para o teor de algumas falas e posicionamentos que, a nosso ver, realçam com maior nitidez o caráter relacional e discursivo que encerram.

\footnotetext{
${ }^{913}$ Processo n. 171, 27 dez. 1931. Caixa 16.

${ }^{914} \mathrm{Idem}$.

${ }^{915}$ Observação feita pela testemunha Francisco Gottardi, "natural deste Estado, com 21 anos de idade, solteiro, de cor branca, estudante", irmão da testemunha Mário Gottardi. (Processo n. 171, 27 dez. 1931. Caixa 16).

${ }_{916}^{916}$ Processo n. 171, 27 dez. 1931. Caixa 16.

${ }^{917}$ O "Auto de Exame de Embriaguez" é assinado no dia 27 de dezembro de 1931 e aponta, como vimos no capítulo primeiro da tese, que Oscar John se encontrava no "segundo período de embriaguez alcoólica". (Processo n. 171, 27 dez. 1931. Caixa 16). Nessa situação, o indivíduo apresenta "leve euforia, menos inibições e aparente confiança. As reações se retardam em até $40 \%$ " e são observadas, também, "alterações psíquicas, neurológicas, sensoriais, pequenas confusões, atenção perturbada". (FILHO, Dilermando Brito. Toxicologia Humana e Geral. 2. ed. Rio de Janeiro/São Paulo: Atheneu, 1988. p. 92-93).

${ }_{918}$ Processo n. 171, 27 dez. 1931. Caixa 16.

${ }^{919}$ Idem.
} 
Dado o exposto, evidenciamos que na primeira vez em que foi ouvida, a testemunha Mário Gottardi nada acrescentou que corroborasse para a ideia de que Oscar John fosse apontado como principal responsável pelo ocorrido, como, ao contrário, foi salientado pelos vistos finais do inquérito policial, aqui referido. Notamos, porém, que no dia 16 de fevereiro de 1932, ao ser inquirida pelo Promotor Público, essa testemunha observou que, por "ouvir dizer, soube que Oscar John conduzia o seu carro contramão, ao descer a rua Artista Bittencourt, quando se verificou o acidente; que também não sabe se o auto fonfonava, se desenvolvia velocidade [máxima?] ou se estava com os faróis acesos" ${ }^{920}$. Podemos, assim, considerar que outras pessoas a informaram de que o chauffeur Oscar John conduzia o automóvel n. 99 na contramão, o que nos faz refletir sobre o aspecto de que, para os efeitos deste estudo, as circunstâncias que envolviam os episódios de atropelamento ou colisão eram transmitidas oralmente de uma para outra pessoa, e essas informações eram utilizadas pelas testemunhas em suas falas, não exatamente para construir-se uma ideia errônea sobre a conduta dos chauffeurs ao volante, mas para expor ou comunicar aquilo que souberam, por terceiros. Mário Gottardi salienta, todavia, que não era do seu conhecimento se o chauffeur Oscar John fazia uso da buzina, qual a velocidade de deslocamento do auto n. 99 e se o respectivo chauffeur mantinha acesos os faróis do seu automóvel.

Assim, curioso é observamos o que disse a testemunha Carolino Serzedello Machado, no dia 16 de fevereiro de 1932. Nessa data, a testemunha argumentou, dentre outros aspectos, que "o automóvel em que ia, marchava pelo meio da rua, desenvolvendo pequena velocidade, nada

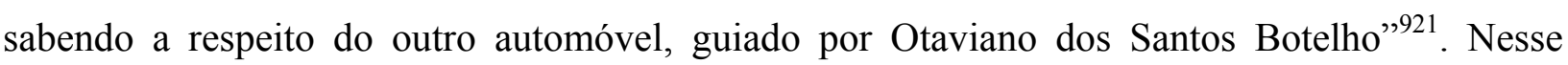
ponto, percebemos o caráter relacional dos posicionamentos das testemunhas, pois a afirmação de que nada sabia em relação ao automóvel n. 218 vem de encontro ao que a mesma testemunha afirmou em seu primeiro depoimento, datado de 28 de dezembro de 1931, uma vez que, naquela ocasião ela argumentou que, "próximo à esquina da rua Artista Bittencourt com a Visconde de Ouro Preto, o companheiro de viagem do depoente, Horst Whelling, preveniu a John que se aproximava um veículo, pois projetava-se a luz dos seus faróis" ${ }^{\text {922 }}$. Constatamos, a respeito do veículo n. 218, que era de conhecimento de Carolino Serzedello Machado, por intermédio da fala de Horst Welling, que o automóvel transitava com os faróis acesos. Podemos, portanto, especular que as falas das testemunhas eram influenciadas conforme as ocasiões e circunstâncias em que eram tomadas, e isso revela o seu caráter relacional que, em última instância, exprimiam.

\footnotetext{
${ }^{920}$ Processo n. 171, 27 dez. 1931. Caixa 16.

${ }^{921}$ Idem.

${ }^{922}$ Idem.
} 
Após a expedição de dois mandados de intimação, datados, respectivamente, dos dias $14 \mathrm{e}$ 28 de março de $1932^{923}$, são ouvidas mais duas testemunhas. Dessas, o "chauffeur do Palácio do Governo" "924, Eduardo Rocha, ouvido no dia 02 de abril de 1932, expõe que "a barata que o acusado guiava no momento do acidente ainda estava no mesmo ponto e contra-mão, quando ele depoente ali chegou"; que "ignora que o acusado estivesse embriagado no momento do acidente, assim como não sabe se o mesmo acusado é dado ao fracasso da embriaguez" "925. Essas colocações foram reafirmadas, inclusive, nas inquirições feitas pelo Promotor Público; pois, naquela ocasião, Eduardo Rocha responde que, "apesar de ter visto o acusado no local do acidente, nada pode adiantar sobre se estava ou não embriagado", e que "as pessoas que assistiram ao acidente, declararam a ele que o automóvel causador do desastre corria regularmente" ${ }^{, 926}$. Percebemos, nesse ponto, a relatividade dos posicionamentos das testemunhas uma vez que, em dadas ocasiões, não corroboraram ou estavam impossibilitadas de ratificar aquilo que o respectivo Promotor Público considerou, por ocasião da formulação da denúncia apresentada contra o réu Oscar John.

Evidenciamos, ainda, que a construção de versões sobre as circunstâncias que envolveram o sinistro verificado no processo n. 171 pode ser também exemplificada pelas palavras iniciais expostas pelo advogado de defesa do réu, que, ao dirigir-se ao "M.M Julgador", em data de 22 de maio de 1932, afirmou que, "confiando na serenidade com que esse juízo costuma decidir as questões que lhe são sujeitas, vem Oscar John, por seu advogado, em rápidas palavras, expor o

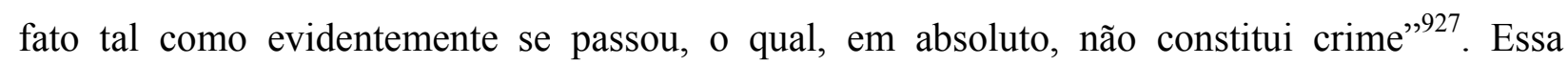
passagem evidencia, com efeito, que o advogado do réu tece estimas de consideração em relação à figura do Juiz; assim, "trata de evidenciar o que, de fato, aconteceu" e destaca que tal posição, sob qualquer ponto de vista, não constitui crime. Para corroborar com suas colocações iniciais, o respectivo advogado de defesa ainda observa que Oscar John é "hábil chauffeur, acostumado a percorrer no seu carro, todas as vias e praças desta Capital" e que, um pouco antes de verificar-se o acidente, "nas proximidades da esquina [da rua Artista Bittencourt] com a Visconde de Ouro

\footnotetext{
${ }^{923}$ Antes dessa ocasião, porém, é assinada a "Precatória de Diligência Criminal", na qual o Promotor Público da Comarca, "baseado nos autos do inquérito policial", oferece denúncia contra Oscar John, argumentando que "infere-se do exame [de embriaguez] e dos depoimentos e declarações referidas, que o denunciado estava no segundo período de embriaguez alcoólica, quando guiava o automóvel, pondo assim em risco a segurança própria e alheia". (Processo n. 171, 27 dez. 1931. Caixa 16). Diante desse quadro, o Promotor Público diz que o referido chauffeur cometeu o crime "previsto no art. 306 do Código Penal e a contravenção do decreto n. 4294, de 06 de julho de 1921 ", por isso pede para que Oscar John seja "condenado no grau mínimo das penas do artigo 306 [...], por ocorrer a circunstância atenuante do \# 10 . do art. 42 do supracitado Código". (Processo n. 171, 27 dez. 1931. Caixa 16). O teor do parágrafo segundo do decreto 4294, por exemplo, já foi exposto nas notas e passagens acima. Salientamos, porém, a seguir, o alcance do parágrafo décimo do artigo 42 do Código Penal de 1890. Assim, temos que “Art. 42 - São circunstâncias atenuantes: - \#10. ${ }^{\circ}$ - Ter o delinqüente cometido o crime em estado de embriaguez incompleta, e não procurada como meio de o animar à perpetração do crime, não sendo acostumado a cometer crimes nesse estado". (PIERANGELI, José Henrique. Códigos Penais do Brasil: evolução histórica. 2. ed. São Paulo: Revista dos Tribunais, 2004. p. 277-278). Percebemos, aqui, que se considerou que o chauffeur Oscar John não tinha como hábito estar alcoolizado quando da prática da direção.

${ }^{924}$ Processo n. 171, 27 dez. 1931. Caixa 16.

${ }^{925}$ Idem.

${ }^{926}$ Idem.

${ }^{927}$ Idem.
} 
Preto, fonfonando sempre" e "conservando os faróis do automóvel iluminados”, trafegava com o automóvel em "pequena velocidade" 928.

O advogado considera, por fim, que "não houve, por conseguinte, no caso, falta de atenção ordinária, sendo produto de mera casualidade" $" 929$. Ao nosso ver, mais ilustrativo ainda se torna a sua declaração de que "o que serviu de base ao presente não pode ser tomada em consideração, por não exprimir a verdade, sendo imprecisas as declarações das testemunhas no tocante [...] à embriaguez de John, e provada como estão, ainda, a casualidade do acidente"; o ato, portanto, “era lícito, e assim não se pode considerar criminoso o acusado (art. 27; \# 6. o dód. Penal)"930. Dado o exposto, percebemos que o papel do advogado de defesa é, pois, colocar-se a favor da inocência do suposto responsável pelo crime de trânsito, verificado no presente processo; e, para isso, constrói argumentos e justificativas que objetivam edificar a conduta do chauffeur em apreço na prática da direção. Assim, destaca que o réu obedeceu determinações regulamentares de trânsito, e que não se pode afirmar o estado de embriaguez de Oscar John e, bem assim, atribuir a ocorrência do sinistro à simples casualidade. Enfatizamos, ainda, que o referido chauffeur procedeu dentro das leis e das normas legais vigentes.

A par da intencionalidade expressa pelas declarações prestadas pelo advogado de defesa do réu Oscar John, devemos observar que o aparelho policial-judiciário parece constituir-se como um mecanismo de poder que ultrapassa a função repressiva. Assim, durante o final do século XIX e as primeiras décadas do século seguinte, observamos várias mudanças no aparato policialjudiciário ${ }^{931}$, no sentido de “[...] aprimorar formas de vigilância e intervenção, sobre a cidade e seus habitantes, para não só abolir condutas indesejáveis, como produzir indivíduos adaptados aos padrões de conduta urbana então em circulação"; e, para tanto, "suas ações não deveriam mais simplesmente punir o delito, mas evitá-lo, assumindo um caráter exemplar diante da coletividade" ${ }^{, 932}$. Assim, podemos realçar o caráter pedagógico do aparato policial-judiciário.

Os esforços argumentativos expressos pelo advogado de defesa não surtiram, pelo menos num primeiro momento, o efeito esperado, pois o Juiz da Segunda Vara da Comarca de Florianópolis considera, dentre outros aspectos, no dia 27 de maio de 1932, que "mesmo que desenvolvesse pequena velocidade e que tivesse buzinado, o acusado, guiando o veículo contramão, o que ficou patente nos autos, não está de forma alguma isento de culpa" ${ }^{933}$. Continuando

\footnotetext{
${ }^{928}$ Processo n. 171, 27 dez. 1931. Caixa 16.

${ }^{929}$ Idem.

${ }^{930}$ Idem

931 Ver, por exemplo, a instituição do Código Penal brasileiro, de 1890, dos códigos judiciários estaduais de 1925 e 1928 ; e quanto à regulamentação e fiscalização do trânsito local, ver, especialmente, o Regulamento para o Serviço Policial do Estado, de 1920, e as Instruções Regulamentares para o serviço de trânsito público, de 1928.

${ }^{932}$ KUPKA, Roselane Neckel. Tensões e Imagens do Viver Urbano em Florianópolis (1910-1930). Dissertação (Mestrado em História). São Paulo: PUC, 1993. p. 88.

${ }^{933}$ Processo n. 171, 27 dez. 1931. Caixa 16.
} 
sua exposição, o Juiz observa que “a observação da 'mão' é imposta por expressa disposição regulamentar ${ }^{934}$. A culpa ficou assim perfeitamente caracterizada"; e, nesse sentido, "nada mais é preciso para que incorra na sanção do artigo 306 do Código Penal"935, ainda mais que "a embriaguez", conforme suas constatações, “está demonstrada não só pelo auto de fls. 10 e 11 , como pelos depoimentos das testemunhas" ${ }^{936}$. Desse modo, observamos que o Juiz refutou as principais argumentações apresentadas pelo advogado de defesa do réu. Instauram-se, assim, nos processos, disputas discursivas que, objetivando produzir os efeitos esperados, lutam por cumprir as determinações legais e, para isso, colocam-se sempre ao lado daquilo que entendiam como verdade. As argumentações e justificativas apresentadas, neste caso, por ambos os lados, evidenciam tais pretensões.

Os vistos finais assinados pelo Juiz legalizam o mandado de prisão, a partir do qual a mesma autoridade manda, em data de 08 de junho de 1932, que "o Oficial de Justiça deste Juízo [...] prenda e recolha à Cadeia Pública de São José, o réu Oscar John", por "se achar pronunciado por este Juízo como incurso nas penas do art. 306 do Código Penal e do art. 2. ${ }^{\circ}$ da Lei n. 4294, de 06 de julho de 1921; com a fiança arbitrada em 600\$000 [seiscentos mil réis] e custas", para que "cumpra sob as penas da lei" 937 . Nesse ponto, uma indagação pode ser colocada: De que modo eram determinados os valores das fianças? Um indicativo a esse respeito nos é dado pelos artigos sétimo e oitavo do Decreto 1285, de 27 de setembro de 1919, que estabelecem, respectivamente, que "Art. 7..$^{\circ}$ - Para determinar o valor da fiança, a autoridade atenderá ao máximo do tempo da prisão a que possa ser condenado o réu pelo fato criminoso" ${ }^{, 938}$, tendo em consideração "não só a gravidade do dano causado pelo delito, como também as condições pessoais e de fortuna do réu, incluindo a importância do selo, e fixará este valor dentro dos dois extremos da tabela, constante no artigo seguinte" ${ }^{\text {"939 }}$. Assim, o artigo oitavo estipula que "Art. 8. ${ }^{\text {o }}$ - A tabela a que se refere o artigo anterior será a seguinte:"940

\footnotetext{
${ }^{934}$ Notamos que o Juiz não especifica, exatamente, qual a disposição regulamentar que foi, no caso, desrespeitada. A seguir, apontamos, entretanto, alguns artigos da legislação estadual vigente à época que, talvez, ajudem-nos a visualizar a que aspecto o Juiz estava se referindo, naquele momento. Assim, os artigos terceiro, oitavo e nono das Instruções Regulamentares para o serviço de trânsito público, de 1928, estabelecem, por exemplo, de maneira respectiva, que "Art. $3 .^{\circ}$ - Todo o veículo deve caminhar, quando possível junto à guia do passeio direito, só podendo deixar este lado quando tiver que passar por outro veículo"; "Art. 8. - Quando dobrar uma esquina à direita deverá conservar-se junto ao passeio da mão direita", e "Art. 9. - Quando dobrar uma esquina à esquerda, só tomará a direita depois do ponto central das ruas". (Santa Catarina. Instruções Regulamentares para o serviço de trânsito público. Florianópolis: Imprensa Oficial, 1928. p. 05-06).

${ }_{935}$ Processo n. 171, 27 dez. 1931. Caixa 16. Em dezembro de 1932, é instituída, em âmbito nacional, a Consolidação das Leis Penais. Para a presente ocasião, ainda era válido, em sua integralidade, o Código Penal brasileiro de 1890. Junto à Consolidação das Leis Penais, porém, observamos semelhanças ao artigo 306 do Código Penal brasileiro de 1890, pois esse código sofreu inúmeras alterações e atualizações no período compreendido entre os anos de 1890 e 1932. Em 1932, portanto, o Decreto 22213, de 14 de dezembro, aprova e adota a Consolidação das Leis Penais. Esse documento organiza e oferece nova redação às inúmeras alterações sofridas pelo Código Penal de 1890, durante o período supracitado. Ver, a respeito, PIERANGELI, José Henrique. Códigos Penais do Brasil: evolução histórica. 2. ed. São Paulo: Revista dos Tribunais, 2004. p. 323-403.

${ }_{936}^{9}$ Processo n. 171, 27 dez. 1931. Caixa 16.

${ }^{937}$ Idem.

${ }^{938}$ O artigo 306 do Código Penal brasileiro de 1890, ao qual o réu Oscar John foi enquadrado, estipula, como prazo máximo de prisão celular, seis meses. (PIERANGELI, José Henrique. Códigos Penais do Brasil: evolução histórica... op. cit., p. 308). Daí o valor da fiança a ele atribuído. Ver, a respeito, tabela 05.

${ }^{939}$ Decreto n. 1285, de 27 de setembro de 1919. In: Santa Catarina. Coleção de Leis, Decretos e Resoluções - Ano de 1919. Florianópolis: Oficinas à Eletricidade da Imprensa Oficial, 1922. p. 72-73.

${ }^{940}$ Ibidem, p. 73.
} 
Tabela 05: Tempo de Prisão e Respectivos Valores Afiançáveis

\begin{tabular}{c|c|c}
\hline \multicolumn{2}{c|}{ Termos } & Penas \\
\hline Mínimo & Máximo & Tempo de Prisão \\
\hline $200 \$ 000$ & $1: 200 \$ 000$ & Até um ano \\
$400 \$ 000$ & $2: 600 \$ 000$ & Até dois anos \\
$600 \$ 000$ & $4: 600 \$ 000$ & Até três anos \\
$800 \$ 000$ & $10: 000 \$ 000$ & Até quatro anos \\
\hline
\end{tabular}

Fonte: Decreto n. 1285, de 27 set. 1919. In: Santa Catarina. Coleção de Leis, Decretos e Resoluções - Ano de 1919. Florianópolis: Oficinas à Eletricidade da Imprensa Oficial, 1922. p. $73^{941}$.

A fim de termos uma ideia do valor de fiança cobrado à pessoa de Oscar John, observamos que, na Tabela 03: Preços dos principais gêneros alimentícios no comércio varejista do município de Florianópolis - 1925, exposta no capítulo primeiro da tese, o maior valor é atribuído à aquisição do quilo do café, cerca de $2 \$ 500$ (dois mil e quinhentos réis) ${ }^{942}$. Assim, o valor de $600 \$ 000$ (seiscentos mil réis), relativo à fiança atribuída a Oscar John, é suficiente para a aquisição de 240 quilos do produto. Os elementos discutidos, com base na tabela 05, esclarecem, também, dentre outros elementos, que o Juiz se esforçava por aplicar a lei, seja na ocasião de proceder-se à condenação, seja, quando determinava a soltura ou livramento condicional dos réus. O pagamento do valor da fiança atribuída ao chauffeur Oscar John foi efetuado no dia 15 de julho de 1932, “a fim [de ele] livrar-se solto [...] até ser definitivamente julgado, apresentando-se a todos os atos dos processos, sob pena de ser definitivamente quebrada a dita fiança" $"$ "943 . Assinalamos, ainda, que, com base nas argumentações colocadas pelo Promotor Público, o réu Oscar John é submetido a novo julgamento, datado de 08 de agosto de 1932.

Antes, porém, vejamos mais de perto quais as argumentações formuladas pela promotoria pública para imputar ao réu novo julgamento. O Promotor Público Hercílio João da Silva Medeiros argumenta, dentre outros fatores, que Oscar John "foi, por inobservância de alguma disposição regulamentar, causa involuntária da lesão corporal em Carlos Lopes Reis, descrita no auto de exame de corpo de delito" 944 . Outra justificativa é expressa quando considera que "o réu aludido [...] apresentou-se publicamente em estado de embriaguez, pondo em risco a segurança própria e alheia" 945 . Nesses termos, "pede-se a condenação do réu no grau médio das penas do artigo 306 do Código Penal e do artigo 2. ${ }^{\circ}$ do Decreto n. 4294, de 06 de julho de 1921" "946. Dado o exposto, percebemos, aqui, que o promotor público estava atento ao seu papel, que era oferecer denúncia contra os réus, a fim de imputar-lhes as punições expressas na lei. Outra observação que julgamos importante é quanto ao aspecto relativo à formulação da denúncia que levava em

\footnotetext{
${ }^{941}$ Ver, também, artigo 1994 do Código Judiciário do Estado de Santa Catarina, de 1928. (Código Judiciário do Estado de Santa Catarina. Lei n. 1640 de 03 de novembro de 1928 ... op . cit). Para esse caso, os valores das fianças e os respectivos tempos de prisão celular são equivalentes ou aproximados àqueles verificados no decreto datado de 1919, acima exposto; apresenta, apenas, algumas poucas alterações.

${ }_{942}$ Ver, a respeito, VIANNA, Antonio Vicente Bulcão. Presidente do mesmo Congresso, no exercício do cargo de Governador do Estado de Santa Catarina. MENSAGEM apresentada ao Congresso Representativo do Estado. Florianópolis, 22 jul. 1926.

${ }_{943}$ Processo n. 171, 27 dez. 1931. Caixa 16

${ }^{944}$ Idem.

${ }^{945}$ Idem.

${ }^{946}$ Idem.
} 
conta, quando pertinente, a questão de que os réus não cumpriam as disposições regulamentares de trânsito, pois os promotores, via de regra, estavam atentos para realçar essas supostas faltas.

Vimos, em passagens anteriores deste texto, que o Interrogatório ao qual o réu foi submetido, formulado pelo Juiz de Direito, após acatada a denúncia da promotoria pública, não esclarece pontos importantes para proceder-se à condenação ou não do réu; pois, no transcorrer dele, é perguntado "qual o seu nome, naturalidade, estado, filiação, residência e tempo dela no lugar indicado?"947. O interrogatório, "ato exclusivamente pessoal" $" 948$, ainda versa sobre "quais os seus meios de vida e profissão?"; "sabe ler e escrever?”; “onde estava ao tempo em que se diz ter cometido o crime?"; "conhece as testemunhas assentadas desde que tempo?", e "tem alguma coisa a lhes opor?"949. Entendemos, pois, que esses ingredientes estão presentes uma vez que são etapas que atendem às formalidades legais dos processos, determinadas em lei ${ }^{950}$; é, por conseguinte, o Juiz a autoridade máxima encarregada de as fazer cumprir.

A denúncia apresentada pela figura do promotor público parece ter surtido os efeitos esperados, pois Oscar John é submetido a novo julgamento, datado de 08 de agosto de 1932. Nessa ocasião, o Juiz apresenta como justificativas para a condenação do réu, a ideia de que "o acusado, no momento em que se deu o acidente [...], guiava o seu automóvel contra a mão"951. Além disso, observa que "o acusado tendo sido causa involuntária da lesão sofrida pelo passageiro [Carlos Lopez Reis], por haver conduzido o seu automóvel contra a disposição regulamentar, incidiu na sanção do artigo 306 do Código Penal"952. O Juiz alegou, também, que, "considerando-se que em face da prova testemunhal colhida, e do exame de fls. 10, o acusado achava-se em estado de embriaguez, na ocasião em que se deu o encontro dos automóveis, pondo em risco a segurança própria e alheia" ${ }^{953}$. Julgamos, pois, que dois aspectos devem ser, aqui, enaltecidos. Em primeiro lugar, o Juiz considera que as declarações prestadas pelas testemunhas servem de prova para produzir-se a condenação do réu Oscar John. O estado de embriaguez do réu está, assim, na visão do Juiz, comprovado de maneira irrefutável. No segundo momento, percebemos que o Juiz elabora justificativas que, em linhas gerais, convergem para as argumentações anteriormente expressas pelo Promotor Público, por ocasião da formulação da denúncia à pessoa de Oscar John, pois observa, dentre outros aspectos, que o réu procedeu "contra a disposição regulamentar".

\footnotetext{
${ }^{947}$ Processo n. 171, 27 dez. 1931. Caixa 16

${ }^{948}$ Conforme estabelecido no artigo 2187, do Código Judiciário, de 1928. Código Judiciário do Estado de Santa Catarina. Lei n. 1640 de 03 de novembro de 1928. p. 371.

${ }_{949}$ Processo n. 171, 27 dez. 1931. Caixa 16.

${ }^{950}$ Ver, a respeito, Código Judiciário do Estado de Santa Catarina, de 1928. Código Judiciário do Estado de Santa Catarina. Lei n. 1640 de 03 de novembro de 1928 ... op. cit., p. 371 e segs.

${ }^{951}$ Processo n. 171, 27 dez. 1931. Caixa 16.

${ }^{952}$ Idem.

${ }^{953}$ Idem.
} 
Essas passagens dão-nos conta de que, a exemplo do que já verificamos em observações anteriores, operava-se, no interior dos processos, discursos e posicionamentos devidamente alinhados, expressos, de maneira especial, pelas figuras que compunham o seu quadro jurídico. Enfatizamos, pois, que a organização e a formulação dos processos refletem, de uma ou outra maneira, seu aspecto político, colocado pelas visões e argumentações de juízes, promotores e advogados que, a par de uma pretensa abordagem neutra de cientificidade, expõem, no fundo, os meandros do poder jurídico, no qual os réus estavam - mesmo que, às vezes, de maneira inconsciente - inteiramente imersos.

Assim, ao analisarmos os códigos penais ou judiciários, não estamos buscando neles a origem de um poder que age de forma hegemônica sobre os agentes ou personagens neles envolvidos, pois compartilhamos a concepção de que o poder não está localizado em uma dada pessoa ou instituição. Assim, referenciamos que o poder não deve ser concebido como uma propriedade, mas como uma estratégia, na qual seus efeitos devem ser compreendidos em manobras, táticas e funcionamentos que refletem, antes de tudo, uma rede de relações, sempre tensas, sempre em atividade ${ }^{954}$. Nesse sentido, para entendermos os saberes que contribuíam na formulação de discursos que buscavam normatizar condutas e comportamentos no trânsito, é, pois, necessário analisarmos - como aqui tentamos fazer - os meandros discursivos envoltos nos saberes jurídicos que, expressos de alguma forma nos processos criminais em análise, permitemnos visualizar os trâmites legais que davam ensejo às tentativas de proceder-se à prisão, soltura ou, mesmo, à não condenação daqueles entendidos como diretamente responsáveis pelos crimes de atropelamento e colisão verificados nas ruas do perímetro urbano da capital catarinense, no período em estudo.

Em outra passagem dos vistos assinados no dia 08 de agosto de 1932, o Juiz condena “Oscar John a 03 meses, 07 dias e 12 horas de prisão celular, e mais a multa de cento e dez mil réis $[110 \$ 000,00]$ - grau médio das penas do artigo 306 do Código Penal e do art. 2. ${ }^{\circ}$ da Lei n. 4294, de julho de 1921"955. Percebemos, aqui, também, afinidades com o posicionamento colocado pelo Promotor Público, por ocasião da formulação da denúncia; pois, nesse ponto, ele igualmente alenta para que o réu Oscar John fosse enquadrado no "grau médio" das penas expostas anteriormente.

A formulação e a organização dos processos criminais, analisados nesta tese, compõem um verdadeiro palco, onde cada personagem desempenha o seu papel, dentro das atribuições profissionais que lhe cabem. Assim, após a comunicação da sentença condenando o réu Oscar

\footnotetext{
${ }^{954}$ FOUCAULT, Michel. Vigiar e Punir: nascimento da prisão. 16 ed. Petrópolis: Vozes, 1987. p. 26.

${ }^{955}$ Processo n. 171, 27 dez. 1931. Caixa 16.
} 
John, como já exposto, o advogado de defesa daquele chauffeur alega, no dia 12 de agosto, que "é a primeira condenação que sofre o acusado [...] não tendo jamais revelado caráter perverso ou corrompido"; e, nesses termos, "vem, respeitosamente, requerer a V. Ex. a que se digne de suspender a execução da dita pena" ${ }^{956}$. Novamente, aqui, evidenciamos que as solicitações de promotores ou advogados de defesa eram, ao que parece, atendidas, via de regra, pela figura do Juiz. Assim, o magistrado da Segunda Vara da Comarca de Florianópolis, Mileto Tavares da Cunha Barreto, formula no dia 19 de agosto de 1932 - dez dias após a expedição da sentença anterior - os vistos finais do processo, nos quais expõe as justificativas para operar-se a suspensão condicional da pena. Dentre elas, o Juiz argumenta que Oscar John é "acusado de primeira condenação" e "não tem revelado caráter perverso ou corrompido, conforme se evidencia dos autos" $" 957$. Nesse sentido e "tendo em vista as condições pessoais do réu e circunstâncias que cercaram a infração cometida", o Juiz considera que "hei por bem suspender por dois anos a execução da pena a que o mesmo réu foi condenado, e fixar-lhe o prazo de trinta dias para pagar as custas do processo"; designou, por fim, "o dia 24 do corrente, às 14 horas, na sala das audiências deste juízo, para ser lida a presente sentença ao réu"958.

Esses elementos são, com efeito, suficientes para considerarmos que o posicionamento e as justificativas apresentadas pelo Juiz, para o livramento condicional da pena do réu Oscar John, vão ao encontro das ideias expostas pelo advogado de defesa. Os integrantes do quadro judiciário compunham, ao que parece, um verdadeiro grupo ou "classe", a partir do qual transparecem afinidades de posicionamento, tanto na ocasião de condenar-se os réus quanto na oportunidade de operar-se a suspensão de suas penas. É importante destacarmos que essas práticas eram feitas estritamente dentro da lei. No caso aqui referido, o Juiz, ao apresentar as justificativas para o livramento condicional do acusado, observa que "sua pretensão encontra apoio" no que determina "o artigo 2470 do Código Judiciário do Estado" "959. Além disso, o teor das justificativas apresentadas pelo magistrado é afinada àquilo que determina o artigo supracitado. Dessa forma, verificamos que advogados, juízes e promotores, ao se colocarem sempre do lado da lei, entendiam, ou faziam entender, que seus procedimentos não faltavam com a verdade.

\footnotetext{
${ }^{956}$ Processo n. 171, 27 dez. 1931. Caixa 16.

${ }^{957}$ Idem.

${ }^{958}$ Idem.

${ }^{959}$ Esse artigo observa que "Art. 2470 - Em caso de primeira condenação às penas de multa conversível em prisão, ou de prisão de qualquer natureza, até um ano, tratando-se de acusado que não tenha revelado caráter perverso ou corrompido, o Superior Tribunal de Justiça, ou o Juiz de Direito, ou o distrital, tomando em consideração as condições individuais do réu, os motivos que determinaram a infração da lei penal e circunstâncias que a cercaram, poderá suspender a execução da pena, por prazo expressamente fixado, de dois a quatro anos, se se tratar de crime, e de um a dois anos, se de contravenção". (Código Judiciário do Estado de Santa Catarina. Lei n. 1640 de 03 de novembro de 1928. p. 418 ). Em pesquisas feitas no setor de Obras Raras da Biblioteca do Tribunal de Justiça de Santa Catarina, encontramos o Código Judiciário do Estado, datado de 1931, baixado pelo Decreto n. 157, de 19 de setembro daquele ano. Esse código apresenta o Livro I - Organização Judiciária, e os respectivos títulos. Não dispõe dos livros subsequentes. Assim, não são contemplados, dentre outros, os Livros XII - Ação Penal; e XIII Execução da Sentença, como então são registrados junto aos códigos judiciários do Estado, de 1925 e 1928 . Além disso, o teor do artigo 2470, apresentado junto a este último código, apresenta clara convergência em relação às justificativas apresentadas pelo Juiz para o livramento condicional da pena imposta a Oscar John. Assim, optamos por trabalhar, neste estudo, com os códigos judiciários de 1925 e 1928 , aplicados conforme as datas dos processos.
} 
Salientamos, portanto, aqui, o seu pretenso caráter científico, isento de qualquer juízo de valor. Isso é o que, à primeira vista, percebemos transparecer nas falas desses personagens. Uma análise mais acurada nos permite considerar, entretanto, nos seus discursos, afinidades de interesses e proposições que, a par do seu pretenso caráter neutral, revelam, antes de tudo, o aspecto relacional e político de seus posicionamentos.

Sobre esse aspecto, vimos que, a partir do final do século XIX, foram verificadas importantes mudanças na organização administrativa e jurídica brasileira; pois, dentre outros elementos, observamos uma maior inserção dos juristas na conjuntura de reestruturação do Estado e na atuação e engajamento direto dos bacharéis na vida pública e na formação ideológica do País ${ }^{960}$. Esses personagens, ao elaborarem seus discursos nos jornais e ao formularem as leis que compunham o Código Penal de 1890, não produziam, todavia, discursos neutros; pois, possuidores de um discurso autorizado e em consonância com outros setores da sociedade, formularam leis que acabaram por criminalizar práticas corriqueiras ${ }^{961}$. Assim, devemos considerar que, antes mesmo do aparecimento do automóvel nas cidades, os seus habitantes já haviam tomado contato diário com tílburys, carroças ou carros tracionados por força motriz animal. Os choques e encontros de veículos e pedestres já se processavam, portanto, em período muito anterior ao aparecimento do automóvel, como, aliás, ficou exemplificado nas análises feitas no segundo capítulo da tese, por ocasião do estudo das determinações regulamentares dispostas nos códigos de posturas municipais de Desterro/Florianópolis dos anos de 1889, 1896 e 1898 e, igualmente, nos "regulamentos para as estradas estaduais" de Santa Catarina, datados de 1914 e 1918, que objetivaram organizar e/ou disciplinar, de maneira incipiente, o trânsito de veículos automotores e operados a tração animal pelas ruas e estradas intermunicipais.

\subsection{Leis e Finanças}

Nesta parte, investigamos os processos criminais nos quais, entendemos, podemos perceber, com maior clareza, o jogo que envolve a conjugação dos poderes judiciário e financeiro, como fator determinante para o livramento condicional dos chauffeurs presos em função dos episódios de atropelamentos e de colisões ou, mesmo, para a não condenação desses personagens. Damos ênfase, também, ao aspecto de que, em algumas ocasiões, esses poderes estavam comutados para, deliberadamente, inocentar chauffeurs e responsabilizar transeuntes pelos sinistros ocorridos. Analisamos, para tanto, os processos números 96 e 239. O primeiro é

\footnotetext{
${ }^{960}$ CARVAlHO, José Murilo de. A formação das almas: o imaginário da República no Brasil. São Paulo: Companhia das Letras, 1990. p. 132-139; CUNHA, Luís Antônio. Ensino Superior e Universidade no Brasil. In: LOPES, Eliane Marta Teixeira; FILHO, Luciano Mendes Faria; VEIGA, Cynthia Greive. (Org.). 500 Anos de Educação do Brasil. 3. ed. Belo Horizonte: Autêntica, 2003.

${ }^{961}$ PEDRO, Joana Maria; NECKEL, Roselane; HAWERROTH, Eliana Izabel; MACHADO, Vanderlei. Aborto e Infanticídio nos Códigos Penais e nos Processos Judiciais: a pedagogia de condutas femininas. In: PEDRO, Joana Maria. (Org). Práticas Proibidas: práticas costumeiras de aborto de infanticídio no século XIX. Florianópolis: Cidade Futura, 2003. p. 100.
} 
datado de 19 de dezembro de 1928 e o segundo, de 21 de janeiro de 1934. Optamos, portanto, por analisar textos processuais que perpassam as décadas de 1920 e 1930. Desse modo, objetivamos demonstrar que a conjugação dos poderes judiciário e financeiro, como fator condicionante para a soltura de chauffeurs, ou, mesmo, para o indiciamento dos transeuntes, é um elemento que se faz presente durante todo o período analisado na tese e que está imbricado na própria maneira de se elaborar e aplicar leis. Percebemos, aqui, o caráter político que, em última instância, estava envolto na elaboração dos textos processuais e no teor das sentenças que eram expedidas a favor ou contra a condenação dos chauffeurs responsabilizados pelos atropelamentos e colisões nas ruas da capital catarinense. Nos embates discursivos verificados junto nos textos processuais analisados nesta seção, procuramos observar que os chauffeurs e os transeuntes eram colocados lado a lado, em torno das circunstâncias que envolviam os episódios de atropelamentos e colisões; personagens estes que constituem os protagonistas dos embates entre máquinas e homens, que se verificam, diariamente, nas ruas do perímetro urbano da Capital, durante todo o período em estudo.

No ano de 1928, o processo n. 96, de 19 de dezembro, referencia o atropelamento de "Romão Antônio Gonçalves, 67 anos, operário"962, na esquina das ruas Trajano e Felipe Schmidt, vias centrais da cidade, ocasionado, segundo consta na portaria do processo, pelo chauffeur José Correia Dias, que, naquela ocasião, guiava o automóvel n. 151, da cidade de Lages. Assim, o "Termo de declarações" prestado pela vítima registra que "hoje às dezesseis horas mais ou menos, o depoente atravessava a rua Trajano, esquina da rua Felipe Schmidt, quando foi alcançado pelo automóvel n. 151, guiado pelo chauffeur José Dias" "963. A vítima esclarece, igualmente, que "não acredita que o chauffeur do referido automóvel tivesse feito propositalmente, porém os chauffeurs desta Capital não guiam com prudência os seus automóveis", pois “em conseqüência do atropelamento de que foi vitima, ficou com um ferimento na perna esquerda e que o automóvel vinha em velocidade fora do normal o que motivou o atropelamento" 964 .

Apontamos, ainda, que contrariando a afirmação acima, o chauffeur José Correia Dias expõe, em declaração prestada no dia 19 de dezembro de 1928, que "o automóvel vinha em uma velocidade o máximo de dez quilômetros ${ }^{965}$ e também vinha fonfonando; que na esquina onde se

\footnotetext{
${ }_{962}^{96}$ Processo n. 96, 19 dez. 1928. Caixa 02.

${ }^{963}$ Idem.

${ }^{964}$ Idem

${ }_{965}$ A velocidade "máxima de dez quilômetros a hora", atingida pelo automóvel à hora do atropelamento, segundo registra o depoimento do acusado, está em conformidade com o que estipulam os artigos 36 e 37 das Instruções Regulamentares para o serviço de trânsito público, de 1928, pois especificam, como visto, que "Art. 36 - Nas ruas e praças da Capital, os automóveis e auto-caminhões não poderão passar de vinte quilômetros a hora, de marcha, e os carros terão a velocidade máxima de um animal a trote"; e "Art. 37 - Na parte central da cidade e nos cruzamentos de ruas, os veículos deverão reduzir aquela velocidade”. (Santa Catarina. Instruções Regulamentares para o serviço de trânsito público. Florianópolis: Imprensa Oficial, 1928. p. 10). O chauffeur José Correia Dias também afirma que "vinha fonfonando". Esse elemento obedece, igualmente, ao que estipula o artigo 43 do mesmo regulamento, pois registra, conforme já referenciado em passagens anteriores deste
} 
deu o fato não se achavam praças de polícia nem, tão pouco, autoridade policial" ${ }^{\text {966 }}$. Essa declaração é confirmada pela testemunha Cyrillo Manoel da Cunha; pois, em depoimento prestado no dia 22 de dezembro de 1928, esclarece que, "no momento não existia naquele local, autoridade alguma policial" $" 967$.

Nesse ponto, devemos esclarecer que não estamos preocupados em tomar partido frente às declarações prestadas pelo transeunte ou, também, pelo chauffeur. É possível inferirmos, entretanto, que o chauffeur, apontado como responsável pelo atropelamento à pessoa de Romão Antônio Gonçalves, procura elaborar declarações que, sob todos os aspectos, corroboram para a correta condução do veículo, ou seja, em plena concordância ao que estipula as Instruções Regulamentares para o serviço de trânsito público, de $1928^{968}$.

É importante destacarmos que o chauffeur José Correia Dias é "natural do Estado de São Paulo, com 22 anos de idade, solteiro, residente na cidade de Lages"969. Assim, em primeiro lugar, devemos observar que esse personagem apresenta pouca idade e não é natural do Estado de Santa Catarina. Os dados apresentados sugerem-nos que ele deveria ter algum aporte financeiro; próprio, familiar ou de terceiros, pois que deveria conseguir manter o automóvel em outra praça, visto que o veículo que dirigia era "da cidade de Lages"970. O referido automóvel poderia, mesmo, ser de natureza particular, pertencente a terceiros, dada a pouca idade do chauffeur - isso é, contudo, apenas uma hipótese -, e o mesmo ser emplacado em outra cidade do Estado, apesar de estar circulando pelas ruas da Capital. Além disso, não devemos desconsiderar o fato de que, naquela época, os chauffeurs atendiam, em muitas ocasiões, aos próprios proprietários dos veículos que dirigiam; personagens estes que apresentavam, via de regra, confortável situação financeira, que lhes permitia manter os veículos motorizados e os respectivos empregados para servir-lhes - ver, por exemplo, análise exposta no capítulo primeiro da tese. Enfatizamos, pois, que entra, aqui, a questão financeira como elemento que, ao que parece, condicionará a não responsabilidade do referido chauffeur frente ao ocorrido, como se verá, com maiores detalhes, a seguir.

\footnotetext{
texto, que "Art. 43 - Nenhum veículo poderá usar buzinas, tympanos, gláxons, etc.; depois da meia-noite, salvo quando dobrar uma esquina ou nos cruzamentos de ruas". (Santa Catarina. Instruções Regulamentares para o serviço de trânsito público... op. cit. p. 10). O que percebemos é que os chauffeurs eram obrigados a utilizar a buzina todas as vezes que dobrassem as esquinas ou cruzassem duas ou mais vias transversais. Vale observarmos que a obrigatoriedade do emprego da buzina, nessas situações, fazia sentido, se considerarmos que à época não havia semáforos sinalizando os momentos de fluxo e parada dos veículos, elementos que existirão nos cruzamentos das ruas do espaço central da cidade de Florianópolis apenas a partir da década de 1950. Não discordamos desses aspectos. Devemos, entretanto, chamar a atenção para a intencionalidade que, expressa nas entre linhas do discurso do chauffeur em apreço, procurou realçar o seu bom comportamento no trânsito.

${ }^{966}$ Processo n. 96, 19 dez. 1928. Caixa 02.

${ }^{967}$ Idem.

${ }^{968}$ Esse regulamento de trânsito é assinado pelo Secretário do Interior e Justiça do Estado de Santa Catarina, Cid Campos, no dia 28 de junho de 1927. O artigo segundo do Decreto n. 2075, que baixa o referido regulamento, observa que "Art. 2. ${ }^{\circ}$ - Estas instruções entrarão em vigor desde a dada de sua publicação". A folha de apresentação dessa legislação aponta, porém, que ela foi publicada pela "Imprensa Oficial" no ano de 1928. Desse modo, considerar-se-á, sob todos os aspectos, o ano de 1928 como aquele referente à publicação original desta legislação estadual de trânsito - como, aliás, é registrado nas passagens da tese em que ela é referida. Ver Decreto n. 2075. Aprova as instruções para a Inspetoria de Veículos... op. cit.; Santa Catarina. Instruções Regulamentares para o serviço de trânsito público. Florianópolis: Imprensa Oficial, 1928.

${ }^{969}$ Processo n. 96, 19 dez. 1928. Caixa 02.

${ }^{970}$ Conforme informação apontada na portaria do Processo. Ver Processo n. 96, 19 dez. 1928. Caixa 02.
} 
Vejamos, agora, como as testemunhas do ocorrido se referiram às circunstâncias que envolveram esse caso. Entendemos, todavia, que são ilustrativas as observações feitas por Cyrillo Manoel da Cunha sobre o sinistro, pois ele observa que, "no dia 19 do corrente, às quinze horas, mais ou menos", achava-se na "porta do Café 'Rio Branco', onde é empregado"; que "nessa ocasião viu um automóvel que vinha subindo a rua Trajano e ao chegar à esquina da rua Felipe Schmidt, um homem que atravessava a rua naquele momento foi de encontro ao referido automóvel, ferindo a perna esquerda"971. (Anexo 17, p. 348). Essa testemunha observa, ainda, que “o automóvel não é desta Capital, pois não conhece o respectivo 'chauffeur', que o automóvel subia a rua em marcha bastante lenta"972.

As declarações registradas acima apontam que a testemunha observou visualmente a passagem do automóvel n. 151; e, logo após, a ocorrência do atropelamento ao transeunte Romão Antônio Gonçalves. É curioso salientarmos que Cyrillo Manoel da Cunha diz - ou, ao menos, sugere - que o respectivo transeunte foi o agente que provocou seu próprio atropelamento, pois "foi de encontro ao referido automóvel”. Essas observações são, ao que parece, corroboradas em passagens posteriores do depoimento dessa mesma testemunha, quando ela considera que, com relação ao homem "que se pisou no automóvel, o depoente soube ser o mesmo surdo e pouco enxergar" ${ }^{\prime 973}$.

As colocações expostas nos dois parágrafos anteriores são, inclusive, corroboradas pela fala do delegado de polícia da Capital, no dia 22 de dezembro de 1928, como veremos adiante. Além disso, as observações de Cyrillo Manoel da Cunha também dão margem à especulação de que o automóvel n. 151, guiado pelo chauffeur José Correia Dias, era de natureza particular, pois o veículo "não é desta cidade", e o respectivo chauffeur não era conhecido da testemunha ${ }^{974}$. Durante todo o processo não observamos, inclusive, qualquer menção ao tipo de veículo utilizado por José Correia Dias, ou seja, era de natureza particular, de praça ou de aluguel. Devemos, todavia, observar que, se o referido veículo fosse utilizado para o propósito de atender cotidianamente aos passageiros - como, então, são empregados os táxis ou veículos de aluguel -, seria natural que permanecesse circulando na cidade de Lages, local em que, segundo consta, foi originalmente registrado, e não em outra localidade do Estado.

A seguir, a testemunha Manoel Antônio Ferreira, "54 anos, empregado público federal" "975 diz que, "no dia 19 do corrente", estava "no balcão do Café Rio Branco, quando viu um automóvel aproximar-se com marcha muito lenta" e, naquele momento, “ouviu um grito o qual

\footnotetext{
${ }^{971}$ Processo n. 96, 19 dez. 1928. Caixa 02.

${ }^{972}$ Idem.

${ }^{973}$ Idem.

${ }^{974}$ Idem.

${ }^{975}$ Idem.
} 
lhe chamou a atenção, que olhando para a rua viu o referido automóvel parado e um homem em pé na frente ao mesmo, um pouco curvado para trás"976. Essa testemunha afirma que "não sabe se o automóvel atingiu ou não o referido homem", mas que "o chauffeur foi de uma calma extraordinária, pois não houve imprudência alguma da parte do chauffeur na direção do automóvel"977. Essas observações dão ensejo à não responsabilidade do chauffeur José Correia Dias perante o ocorrido, pois ele guiava o automóvel n. 151 "com marcha muito lenta" e, assim, "não houve imprudência por parte daquele chauffeur".

Entretanto, curioso é atentarmos para o que observou o tenente delegado de polícia da Capital, Aprígio José da Silva, no dia 22 de dezembro de 1928, que, nessa ocasião, declarou que

Tendo chegado ao conhecimento desta Delegacia ter o automóvel n. 151, da cidade de Lages, guiado pelo chauffeur José Correia Dias, no dia 19 do corrente, atingido o transeunte Romão Antônio Gonçalves, na rua Trajano, às 16 horas, produzindo-lhe no mesmo o ferimento constante do auto de corpo de delito [...] foi aberto o presente inquérito. Segundo as provas testemunhais parece-me não ter havido culpabilidade alguma da parte do referido chauffeur, dado a marcha vagarosa em que corria o automóvel, segundo afirmam as testemunhas; não havendo negligência nem imperícia por parte do chauffeur que guiava o automóvel; parecendo-me, entretanto, caber a culpa do acidente ao transeunte referido visto ter o mesmo procurado atravessar a rua naquele momento, imprudentemente ${ }^{978}$.

Ao analisarmos as ideias apontadas, percebemos claramente a tentativa de inocentar o chauffeur de qualquer responsabilidade no acidente. Contatamos, também, que é deliberada a intenção de culpar o transeunte pelo ocorrido, pois o delegado de polícia afirma categoricamente "ter o mesmo procurado atravessar a rua naquele momento, imprudentemente" "979. Além disso, o delegado, ao que parece, faz questão de frisar que as falas das testemunhas servem de prova ao aspecto de que, segundo sua visão, não houve qualquer parcela de culpa do chauffeur perante o sinistro, pois afirma, inclusive, não haver "negligência nem imperícia por parte do chauffeur que guiava o automóvel".

O acidente ocorreu na esquina das ruas Trajano e Felipe Schmidt. No final da década de 1920, essas vias constituíam importantes meios de escoamento do tráfego na parte central da cidade (Figura 11, p. 254), contudo “o automóvel vinha em uma velocidade o máximo de dez quilômetros". Devemos considerar que a pequena velocidade atingida pelo veículo, como então verificamos na fala do acusado, possibilitaria ao chauffeur evitar o acidente. Além disso,

\footnotetext{
${ }^{976}$ Processo n. 96, 19 dez. 1928. Caixa 02.

${ }^{977}$ Idem.

${ }^{978}$ Processo n. 96, 19 dez. 1928. Caixa 02. O tenente delegado de polícia da Capital expõe, em outra passagem destas declarações, que determina "ao Sr. Escrivão que preenchidas as formalidades legais, faça remessa destes autos ao Sr. Promotor Público, oficiando-se ao M.M. Juiz de Direito da Comarca”. (Processo n. 96, 19 dez. 1928. Caixa 02).

${ }_{979}$ Nesse ponto, destacamos, uma vez mais, o conteúdo integral dos artigos 303 e 306 do Código Penal brasileiro, de 1890 , pois estipulam que: a) “Art. 303 - Ofender fisicamente alguém, produzindo-lhe dor ou alguma lesão no corpo, embora sem derramamento de sangue. Pena - de prisão celular por três meses a uma ano"; e b) “Art. 306 - Aquele que, por imprudência, negligência ou imperícia, na sua arte ou profissão, ou por inobservância de alguma disposição regulamentar, cometer ou for causa involuntária, direta ou indiretamente, de alguma lesão corporal, será punido com a pena de prisão celular por quinze dias a seis meses". (PIERANGELI, José Henrique. Códigos Penais do Brasil: evolução histórica. 2. ed. São Paulo: Revista dos Tribunais, 2004. p. 307-308). É relevante observarmos que o inquérito policial não registra ou referencia qualquer dos artigos apontados acima. Percebemos, novamente, a intenção deliberada de inocentar o chauffeur.
} 
atestamos a conjugação dos poderes judiciário e financeiro ${ }^{980}$, como forma de culpar o transeunte, que se torna, de alguma forma, inferiorizado ante a presença do automóvel, pois esse se impõe à menor velocidade atingida pelo pedestre ao atravessar a rua. Observemos, também, que, ao menos, uma das testemunhas considera que "soube ser [o referido transeunte] surdo e pouco enxergar". Assim, conforme essas colocações, Romão Antônio Gonçalves não dispunha de condições físicas apropriadas que lhe permitissem circular, a pé, com certa desenvoltura, especialmente pelas ruas centrais da cidade, uma vez que, nesses espaços, verificamos maior presença e circulação dos automóveis, em relação às demais vias e logradouros da Capital.

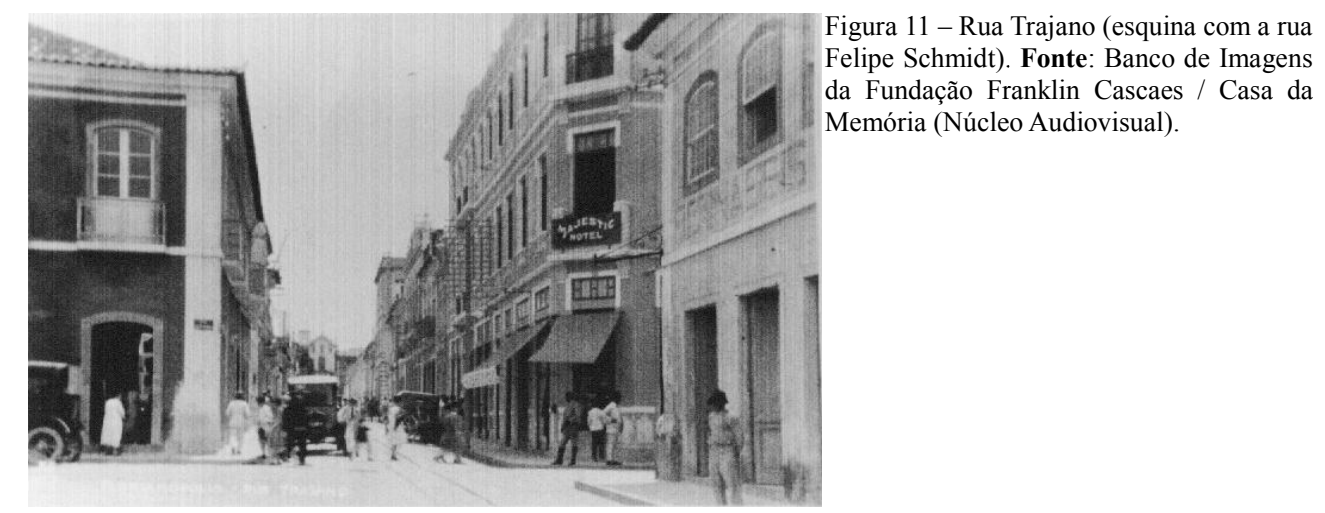

No presente processo, é endereçado ao Juiz de Direito da Segunda Vara de Florianópolis, no dia 18 de janeiro de 1929, o registro assinado por Germano de Oliveira, adjunto do promotor público, que solicita a imputabilidade de crime ao acusado José Correia Dias. O referido documento registra a "não responsabilidade" do chauffeur pelo sinistro ocorrido da seguinte maneira: "O inquérito policial referente ao fato que constitui objeto do presente processo, conclui pela não responsabilidade do acusado José Dias, que segundo o depoimento das testemunhas, agiu com calma e prudência, não se verificando, pois, os elementos constitutivos do delito"981. Germano de Oliveira assinala, também, que "em vista disso, opina pelo arquivamento do presente inquérito, decidindo entretanto, afinal, o M. M. Juiz, como for de justiça"982.

Ao analisarmos essas ideias, percebemos, claramente, a nítida intenção de inocentar o chauffeur José Correia Dias pelo atropelamento de que foi vítima o transeunte Romão Antônio Gonçalves. As passagens aqui expressas corroboram, inclusive, as palavras manifestadas pelo tenente delegado de polícia da Capital, Aprígio José da Silva, no dia 22 de dezembro de

\footnotetext{
${ }^{980}$ Vimos que o acusado pelo atropelamento, José Correia Dias, é "natural do Estado de São Paulo, com 22 anos de idade, solteiro, chauffeur". Na ocasião do acidente, ele "guiava o automóvel n. 151, do Município de Lages". (Processo n. 96, 19 dez. 1928. Caixa 02). Como vimos, nas décadas iniciais do século XX, apenas os indivíduos que tinham considerável condição financeira adquiriam automóveis e mantinham empregados para servir-lhes; assim, atestamos, claramente, a íntima relação entre o automóvel e o poder financeiro. O processo criminal descreve o transeunte da seguinte maneira: "Romão Antônio Gonçalves, natural deste Estado com sessenta e sete anos de idade, casado, operário, residente nesta cidade". (Processo n. 96, 19 dez. 1928. Caixa 02). Vimos, também, que se considerou a vítima culpada pelo acidente. Desse modo, podemos afirmar que sua condição financeira não lhe permitia adquirir bons advogados para elaborar sua defesa. Além disso, a avançada idade dificultou-lhe a natural tentativa de se esquivar da aproximação do automóvel. O transeunte torna-se, portanto, impotente para lutar contra a conjugação do poder financeiro e os veículos motorizados.

${ }_{981}$ Processo n. 96, 19 dez. 1928. Caixa 02.

${ }^{982}$ Idem.
} 
1928. No presente processo, o chauffeur não foi responsabilizado pelo ocorrido. Devemos, entretanto, atentar para a relativa rapidez com que o caso foi julgado; pois, segundo consta, foi concluído no dia 22 de janeiro de 1929; deu-se, portanto, pouco mais de um mês após a ocorrência do sinistro, ocasião em que o Juiz da Segunda Vara da Comarca da Capital ordena que se arquive o processo ${ }^{983}$. Outro elemento que julgamos importante é que não se verificou a abertura do processo judicial propriamente dito, ou seja, o chauffeur José Correia Dias não foi alvo de julgamento processual, pois o encerramento do caso se deu ao concluir-se o respectivo inquérito. Consideramos ilustrativas, ainda, as palavras do próprio tenente delegado da Capital, expressas no dia 22 de dezembro; pois, naquela ocasião, ele afirma, com muita clareza, que a culpa pelo ocorrido cabe, exclusivamente, ao transeunte Romão Antônio Gonçalves. Ratificamos, novamente, aqui, a deliberada intenção de produzir-se a inocência do chauffeur e responsabilizar o transeunte pela ocorrência do sinistro.

Esse fato permite-nos considerar que nos embates diários havidos entre chauffeurs e transeuntes, estes últimos eram desfavorecidos frente aos condutores e proprietários de veículos motorizados; pois, via de regra, os transeuntes ostentavam modesta condição social - a vítima em questão era operário -; dessa forma, eram, em certas ocasiões, preteridos ou não devidamente atendidos nas audiências dos julgamentos constantes nos processos criminais em análise. A análise dessas ideias permite-nos afirmar que o desfavorecimento dos transeuntes é operado, portanto, num duplo viés: a) nas audiências e julgamentos havidos nos tribunais; e b) nas ocorrências diárias de atropelamentos e colisões; pois, por meio delas se verificam, dentre outros aspectos, desiguais relações de poder operadas na circulação de veículos e transeuntes.

Nosso próximo episódio nos remete ao ano de 1934, e ao processo n. 239, de 21 de janeiro, que registra o atropelamento da menor Alice Grumiché. Esse processo já foi, com efeito, por nós analisado no primeiro capítulo da tese. É válido, entretanto, neste ponto, retomarmos as circunstâncias que o envolveram, pois pretendemos tecer uma análise sobre a associação entre os poderes judiciário e financeiro como importante fator do livramento condicional do chauffeur Hélio Souza Silva, apontado, num primeiro momento, como responsável pelo atropelamento da menor acima referida. Os meandros jurídicos envoltos nesse processo dão, igualmente, margem à ideia de que se operou uma clara associação ou interferência da classe jurídica, a partir da qual é possível visualizarmos que o Juiz ocupou-se, em última análise, em produzir a defesa do respectivo chauffeur, pois este, provavelmente, figurava como um empregado de um indivíduo seu conhecido.

\footnotetext{
${ }^{983}$ Processo n. 96, 19 dez. 1928. Caixa 02.
} 
De outro modo, é válido observarmos, também, que a figura paterna da vítima, de nome Eurico Grumiché, parece ser um personagem de destacada situação social e financeira na sociedade florianopolitana da época, pois a testemunha Alexandre Gevaerd, 33 anos, maquinista, observa que "não sabe o nome da vítima, mas sabe ser filha de Eurico Grumiché" 984. Corroborando com essas informações, a própria nota da imprensa local, que noticia o atropelamento, referencia, ao que parece, que esse personagem era conhecido nos círculos sociais da cidade e informa, inclusive, seu local de moradia, pois salienta que "ontem, cerca das vinte e quinze horas, o automóvel 246P, de propriedade do Sr. Arlindo Pinto da Luz e guiado pelo motorista Hélio Souza, subia com grande velocidade da Praça XV para a rua Arcipreste Paiva, quando ao chegar em frente ao Cine Palace, atropelou e derrubou por terra a menor Alice, filha do Sr. Eurico Grumiché, residente à rua Itajaí, s/n" ${ }^{\text {"985 }}$. Essas passagens dão conta, também, que o veículo era guiado em alta velocidade. A vítima falece em decorrência dos ferimentos recebidos. Nesse sentido, é razoável pensarmos que os familiares da menina estivessem interessados que se efetivasse a condenação do chauffeur Hélio Souza Silva. Notamos que se estabelecem, portanto, nesse processo, disputas discursivas a favor ou não simpatizantes à condenação do respectivo réu ${ }^{986}$. Vamos, então, às circunstâncias que culminaram com o livramento condicional de Hélio Souza Silva.

É importante assinalarmos que, no presente processo, o referido chauffeur foi preso em flagrante. Assim, destacamos que o Cabo da Força Pública, Leopoldo João dos Santos, afirma, como visto, que "hoje, às vinte e trinta horas, achava-se em frente ao Cine Palace à rua Arcipreste Paiva, quando viu um automóvel particular, de propriedade do senhor Arlindo Pinto da Luz, e guiado pelo chauffeur Hélio Souza Silva, o qual trazia velocidade excessiva" "987. A testemunha também observa que, "ao defrontar o dito cinema, atropelou uma menor que por ali passava, atirando-a ao solo", e "que tratando-se de um desastre efetuou a prisão do chauffeur em apreço nos seguintes termos: 'o senhor está preso, acompanhe-me à Chefatura de Polícia'”,988.

As ideias expostas permitem-nos constatar que o veículo é de natureza particular - como, aliás, já observamos -, pois era guiado por um chauffeur que estava a serviço de uma terceira pessoa, esta proprietária do automóvel. Isso confirma a tendência de que, nas primeiras décadas do século XX, apenas os indivíduos que apresentavam muito boa condição financeira adquiriam automóveis e dispunham de empregados para servir-lhes. Assim, as declarações do cabo da

\footnotetext{
${ }^{984}$ Processo n. 239, 21 jan. 1934. Caixa 26.

${ }^{985}$ Um automóvel: atropela e fere uma menina. O Estado. Florianópolis, 22 jan. 1934. p. 8

${ }^{986}$ A nota da imprensa local, por exemplo, coloca-se plenamente a favor da condenação do chauffeur Hélio Souza, pois observa, também, que “A cena foi rápida e brutal, pois não se concebe que, num ponto como aquele, onde o movimento de pedestres era intenso, um chauffeur ousasse fazer passar seu carro com tal velocidade. Brecando pouco além o veículo, o motorista foi preso em flagrante pelo cabo Leopoldo dos Santos, sendo conduzido à Chefatura de Polícia”. (Um automóvel: atropela e fere uma menina. O Estado... op. cit., p. 8).

${ }_{987}$ Processo n. 239, 21 jan. 1934. Caixa 26.

${ }^{988}$ Idem.
} 
Força Pública apontam-nos que o referido automóvel era guiado em alta velocidade pelas ruas centrais da cidade.

Esse aspecto é corroborado pelas testemunhas que presenciaram o atropelamento da menor Alice Grumiché e, também, pela nota da imprensa jornalística local, já referida. Assim, o testemunho prestado pelo Primeiro Sargento Músico da Força Pública, Paulo José dos Santos, 34 anos, no dia 16 de fevereiro de 1934, destaca que, "no dia e hora referidos na denúncia, estando ele depoente em frente à Catedral, viu passar da Praça XV de Novembro em linha reta para a rua Arcipreste Paiva o auto 246, guiado pelo acusado Hélio Souza Silva, em alta velocidade”, tendo, "ao defrontar o Cine Palace, atropelado uma menor, que foi atirada ao solo" 989 . Em outro momento de seu posicionamento, essa testemunha ainda observou que "o acusado não pode evitar o atropelamento devido exatamente a velocidade em que ia na ocasião"990.

A testemunha José Bento Franzoni, "26 anos, carpinteiro", também observa a alta velocidade de deslocamento do automóvel guiado por Hélio Souza Silva, no momento do atropelamento da menor Alice Grumiché, pois argumenta que "hoje, às vinte e trinta horas, mais ou menos, achava-se em frente ao 'Cine Palace' à rua Arcipreste Paiva, quando viu um automóvel, cujo número ignora, que subia a Praça XV de Novembro, lado do Palácio Presidencial, com excessiva velocidade" 991 . Essa testemunha declara, ainda, que "a seu lado estavam diversas crianças e que quando o referido auto passou em frente ao dito cinema, colheu uma das referidas crianças, jogando-a ao chão"992. (Anexo 04, p. 335).

É importante realçarmos que as testemunhas, aqui destacadas, tiveram a sua atenção despertada pela passagem do veículo n. 246 e esse episódio, segundo as mesmas, deveu-se, principalmente, à alta velocidade de deslocamento do automóvel que, segundo referenciam, não era apropriada ao trânsito de veículos nas ruas centrais da cidade. Devemos, ainda, esclarecer que a ideia ou noção de velocidade corresponde, em última análise, a uma construção linguística; é, portanto, discursiva, pois depende da ótica de quem a ela se reporta ${ }^{993}$. Devemos, pois, olhar as falas aqui expostas como elementos referenciais que nos permitem, ao máximo, ter uma ideia sobre o deslocamento do veículo em questão, mas nunca como aspectos que venham comprovar, inegavelmente, o modo como o chauffeur Hélio Souza Silva conduzia o referido veículo.

O "Auto Exame de Corpo de Delito", ao qual a menor Alice Grumiché foi submetida, é datado de 21 de janeiro de 1934; corresponde, portanto, ao mesmo dia em que ocorreu o

\footnotetext{
${ }^{989}$ Processo n. 239, 21 jan. 1934. Caixa 26.

${ }^{990}$ Idem.

${ }^{991}$ Aspecto também realçado pela testemunha Tomaz Gonçalves, "36 anos, chauffeur”. (Processo n. 239, 21 jan. 1934. Caixa 26).

992 Processo n. 239, 21 jan. 1934. Caixa 26.

${ }_{993}$ O chauffeur Hélio Souza Silva, por exemplo, observa em suas declarações, prestadas no dia 21 de janeiro de 1934 , que guiava o automóvel n. 246 “com a velocidade de quarenta quilômetros a hora”. (Processo n. 239, 21 jan. 1934. Caixa 26). Essa velocidade está, inclusive, acima daquela legalmente permitida. Ver, a respeito, artigo 36 das Instruções Regulamentares para o serviço de trânsito público, de 1928, já antes mencionado.
} 
respectivo sinistro. É curioso observarmos que o 1. ${ }^{\circ}$ Suplente do Delegado de Polícia da Capital, Rodolfo Geraldo da Rosa, julga "procedente o presente exame" e confere, portanto, "nota de culpa ao acusado Hélio Souza Silva como incurso na sanção do artigo 306 do Código Penal”; determinou, assim, que o referido acusado fosse "recolhido [...] à Cadeia Pública de São José", a fím de que ficasse à disposição daquela autoridade policial ${ }^{994}$. Notamos que, já a partir do dia 21 de janeiro de 1934, data de ocorrência do atropelamento, o chauffeur Hélio Souza Silva foi, portanto, enquadrado com base no "art. 306 do Código Penal" brasileiro ${ }^{995}$.

No dia seguinte, o chauffeur Hélio Souza Silva "vem mui respeitosamente apresentar fiador idôneo a fim de se defender solto, o fazendo desde já nas pessoas dos srs. Arlindo Pinto da Luz e Eurico Couto, requerendo que a fiança seja tomada por termo"996. É importante destacarmos o que contempla "o livro de fiança da Delegacia de Polícia da Capital”, no qual é registrado o Termo de Fiança datado de 22 de janeiro de 1934, prestado à pessoa de Hélio Souza Silva, pois esse termo estipula que, naquela data, estavam presentes à delegacia de Florianópolis

Os senhores Tenente Arlindo Pinto da Luz, secretário da Capitania dos Portos do Estado, residente nesta Capital à rua Blumenau, e Eurico Couto, chefe da Estação Meteorológica, residente à Avenida Hercílio Luz [...] ambos casados e bastante conhecidos e reconhecidamente abonados, os quais declararam que na qualidade de fiadores obrigavam-se, sob a garantia de oitocentos mil réis (800\$000), a que Hélio Souza Silva, preso em flagrante pelo crime previsto no artigo trezentos e seis do código penal, compareça a todos os termos do processo em julgado, sob pena de ser definitivamente quebrada a dita fiança ${ }^{997}$.

Essa citação evidencia que o chauffeur Hélio Souza Silva foi preso em flagrante. Esse agravante não impediu que, sob a influência de fiadores "bastante conhecidos e abonados" - um dos quais, proprietário do veículo - fosse concedida ao chauffeur a "suspensão condicional da pena", registrada, como se verá, nos termos finais do processo ${ }^{998}$. Esses aspectos evidenciam, uma vez mais, a conjugação dos poderes judiciário e financeiro como forma de operar-se a suspensão condicional das penas impostas aos apontados como diretamente responsáveis pelos crimes de atropelamento ou colisão, verificados nas ruas do perímetro urbano da cidade de Florianópolis, no período em estudo. Além disso, a participação de indivíduos “casados, bastante conhecidos e reconhecidamente abonados" e, acima de tudo, idôneos, no pagamento dos valores

\footnotetext{
${ }^{994}$ Processo n. 239, 21 jan. 1934. Caixa 26.

${ }^{995}$ Processo n. 239, 21 jan. 1934. Caixa 26. Nesse ponto, é importante esclarecermos que a Consolidação das Leis Penais, então em vigor; pois, aprovada e adotada pelo Decreto 22213, de 14 de dezembro de 1932, apresenta idêntico teor ao que é estabelecido pelo artigo 306 do Código Penal Brasileiro, de 1890. Esse artigo é, inclusive, descrito, em ambos os documentos, no "Título X - Dos Crimes contra a Segurança da Pessoa e Vida", e especificado no capítulo quinto deste título: "Capítulo V - Das lesões corporais". A referência que fizemos, portanto, com relação ao respectivo artigo do código penal brasileiro, pode, muito bem, referir-se, de fato, ao artigo exposto na Consolidação das Leis Penais, de 1932. Ver PIERANGELI, José Henrique. Códigos Penais do Brasil: evolução histórica. 2. ed. São Paulo: Revista dos Tribunais, 2004. p. 306 (Código Penal de 1890) e p. 380 (Consolidação das Leis Penais, de 1932). Ainda é válido observarmos que o artigo primeiro do Decreto 22213, estabelece que "Art. $1^{\circ}$ - Fica aprovado e adotado, como 'Consolidação das Leis Penais', o trabalho do Sr. Desembargador Vicente Piragibe, publicado sob o título Código Penal Brasileiro, completado com as leis modificadas em vigor, que a este acompanha, subscrito pelo Ministro da Justiça". (Decreto 22213 - aprova e adota a Consolidação das Leis Penais de autoria do Sr. Desembargador Vicente Piragibe. Rio de Janeiro, 14 dez. 1932. In: PIERANGELI, José Henrique. Códigos Penais do Brasil: evolução histórica... op. cit., p. 325-326). Afirmamos, assim, que a Consolidação das Leis Penais, ela própria, era identificada sob o título "Código Penal Brasileiro".

${ }^{996}$ Processo n. 239, 21 jan. 1934. Caixa 26.

${ }^{997}$ Idem.

${ }^{998}$ Idem.
} 
afiançáveis atribuídos ao livramento condicional de chauffeurs - como é exemplificado no presente processo -, leva-nos a considerar que havia, mesmo, uma certa comutação de interesses financeiros e particulares que culminavam com a absolvição dos réus ${ }^{999}$. As figuras envolvidas no termo de fiança aqui analisado compunham estratos sociais privilegiados da sociedade florianopolitana da época. Assim, no caso do exemplo dado acima, consideramos, pelo menos, sugestiva a ideia de que se produziu - se assim podemos chamar - uma interferência de classe, na qual a figura do Juiz defende, em última análise, um chauffeur que, possivelmente, era empregado de um colega ou amigo do magistrado ${ }^{1000}$.

Verificamos, ainda, que mediante o pagamento da respectiva fiança, é concedido ao chauffeur Hélio Souza Silva o direito de ele responder o processo em liberdade ${ }^{1001}$. É importante observarmos, aqui, que o Juiz da Segunda Vara da Comarca da Capital, Mileto Tavares da Cunha Barreto, observa, no dia 16 de fevereiro de 1934, que, "sendo menor de 21 anos o réu Hélio Souza Silva", nomeia "curador ao mesmo" a pessoa do "Dr. Eugênio Figueiredo Condessa" 1002 . Devemos registrar, também, que em nenhum outro processo analisado neste estudo, foi encontrada qualquer menção à nomeação de curadores aos menores de 21 anos, imputados por crimes de trânsito. Evidenciamos, por outro lado, que o parágrafo 11 do artigo 42 da Consolidação das Leis Penais estabelece que "[...] São circunstâncias atenuantes: \# 11 - Ser o delinqüente maior de 18 e menor de 21 anos"1003. Esse mesmo parágrafo nos remete às “Disposições do artigo 76 do Código de Menores". Tal artigo, por sua vez, estipula que "Art. 76 - A idade de 18 a 21 anos constitui circunstância atenuante" ${ }^{\text {"1004 }}$. Além disso, o artigo 77 do mesmo código esclarece que "Art. 77 - Si, ao perpetrar o crime ou contravenção, o menor tinha mais de 18 e menos de 21, o cumprimento da pena será, durante a menoridade do condenado, completamente separado dos presos maiores" ${ }^{\prime 1005}$. Esses elementos permitem-nos, pois, especular que a maioridade criminal era atingida, de fato, após o indivíduo ter completado os 21 anos de idade, uma vez que esse quesito é considerado, inclusive, circunstância atenuante. Percebemos,

\footnotetext{
${ }^{999}$ No presente processo, o 1. Suplente em exercício do delegado de polícia da Capital, Rodolfo Geraldo da Rosa, observa, no dia 22 de janeiro de 1934, que julga "idônea a fiança prestada no termo constante da certidão de fls. destes autos a fim de que produza os devidos e legais efeitos". Desse modo, determina ao "sr. Escrivão" que "expeça alvará de soltura a favor do acusado Hélio Souza Silva e o intime a pagar as custas". Adiante, expõe, porém, que se "dê vista do presente processo ao sr. Dr. Promotor Público, afim de reclamar o que convier aos interesses da justiça”. (Processo n. 239, 21 jan. 1934. Caixa 26).

${ }_{1000}$ Não devemos esquecer que os chauffeurs ocupavam uma posição de bastante visibilidade na sociedade florianopolitana, pois conduziam veículos motorizados pela cidade, o que por si só já lhes garantia prestígio e certa diferenciação social ante o restante dos trabalhadores e personagens das camadas médias urbanas da população da capital catarinense. Conforme já referimos, ver, respectivamente, para o caso das cidades de São Paulo e Rio de Janeiro, a) SÁVIO, Marco Antônio Cornacioni. A Modernidade sobre Rodas. São Paulo: EDUC, 2002. p. 66-67; e b) RIO, João do. A Alma encantadora das ruas: crônicas. São Paulo: Companhia das Letras, 2008. p. 64-65. ((Org.). Raúl Antelo).

${ }^{1001} \mathrm{O}$ artigo 401 do Código Penal brasileiro de 1890 estabelece que "Art. 401 - A pena imposta aos infratores a que se referem os artigos precedentes, ficará extinta se o condenado provar superveniente aquisição de renda bastante para a sua subsistência; e suspensa, se apresentar fiador idôneo que por ele se obrigue". (PIERANGELI, José Henrique. Códigos Penais do Brasil: evolução histórica. 2. ed. São Paulo: Revista dos Tribunais, 2004. p. 320). O pagamento da fiança, nas circunstâncias aqui analisadas, apenas suspendeu a pena imposta ao réu Hélio Silva, e não, propriamente, a extinguiu.

${ }^{1002}$ Processo n. 239, 21 jan. 1934. Caixa 26.

${ }^{1003}$ PIERANGELI, José Henrique. Códigos Penais do Brasil: evolução histórica... op. cit., p. 334.

${ }_{1004}$ Decreto n. 17943A: consolida as leis de Assistência e Proteção aos Menores. Rio de Janeiro, 12 out. 1927.

${ }^{1005}$ Idem.
} 
outrossim, a preocupação em preservar a pessoa do menor delinquente ou contraventor, pois se lutava para evitar que esse personagem se corrompesse social e moralmente - ver nota 868 -, se lhe fosse permitido o contato com indivíduos maiores de idade que, supõe-se, já tinham um maior contato com o crime. Isso poderia conduzi-los a progressivos desvios de conduta ou comportamento, ou apenas os fariam exacerbar atitudes socialmente condenáveis, as quais já eram por eles praticadas antes mesmo de ingressarem no mundo do crime.

Façamos, aqui, um parênteses para observarmos que, ao estipular diferenças entre as figuras do delinquente e do infrator, Michel Foucault esclarece que "[...] o delinquente se distingue do infrator pelo fato de não ser tanto seu ato quanto sua vida o que mais o caracteriza" "1006 . Além disso, o delinquente é aquele que “[...] não somente [é] o autor de seu ato (autor responsável em função de certos critérios da vontade livre e consciente), mas também de estar amarrado a seu delito por um feixe de fios complexos (instintivos, pulsões, tendências, temperamentos) ${ }^{\prime 1007}$. Concebemos, assim, que se deveria, pois, incidir sobre o delinquente para recuperá-lo e para torna-lo apto a conviver em sociedade.

Desse modo, devemos considerar, segundo aponta o mesmo autor, que "[...] a operação penitenciária, para ser uma verdadeira reeducação, deve totalizar a existência do delinqüente, tornar a prisão uma espécie de teatro artificial e coercitivo, onde é preciso refazê-la socialmente" ${ }^{, 1008}$. Registramos, novamente, aqui, o caráter educativo e pedagógico que os aparatos legal e institucional deveriam assumir. Assim, sobre as figuras do infrator e do delinquente eram aplicadas as ciências médica e jurídica, que produziriam um conhecimento que era propagado como verdadeiro e que favorecia, portanto, a educação de costumes ${ }^{1009}$. Nesse ponto, observamos que as testemunhas arroladas no processo foram ouvidas, novamente, entre os dias 16 e 21 de fevereiro de 1934; e, nessas ocasiões, temos que não há unanimidade quanto à velocidade de deslocamento do automóvel n. 246, no instante do atropelamento da menor Alice Grumiché, e nem mesmo sobre o número estimado de pessoas que, àquela hora, encontrava-se nas calçadas e na própria rua Arcipreste Paiva. A grande maioria considera, entretanto, que o chauffeur Hélio Souza Silva conduzia o veículo em grande velocidade e que o movimento de pedestres era intenso.

A testemunha Tomás Gonçalves expõe, por exemplo, que, estando "sentado em um dos bancos da Praça XV de Novembro, em frente ao Palácio do Governo, viu quando o acusado guiando o carro 246 atropelou em frente ao cinema Palace uma menor [...]; que o carro em

\footnotetext{
${ }^{1006}$ FOUCUALT, Michel. Vigiar e Punir: nascimento da prisão. 16 ed. Petrópolis: Vozes, 1987. p. 211.

${ }^{1007}$ Idem.

${ }^{1008}$ Idem.

${ }^{1009}$ FOUCUALT, Michel. Microfísica do Poder. 17 ed. Rio de Janeiro: Graal, 2002. p. 80; PEDRO, Joana M.; NECKEL, R.; HAWERROTH, Eliana Izabel; MACHADO, Vanderlei. Aborto e Infanticídio nos Códigos Penais e nos Processos Judiciais: a pedagogia de condutas femininas. In: PEDRO, Joana Maria (Org). Práticas Proibidas: práticas costumeiras de aborto de infanticídio no século XIX... op. cit., p. 106.
} 
questão [...] desenvolvia uma velocidade mais ou menos de trinta quilômetros a hora" e que "o acusado, quinze metros antes do local do acidente, buzinou anunciando sua aproximação"1010. Ela afirmou, também, que, na qualidade de chauffeur, considerava ser impossível ao acusado evitar o acidente; pois, se tentasse evitar a ofendida, teria fatalmente que atropelar diversas outras pessoas que se encontravam do lado esquerdo" ${ }^{\text {1011. }}$.

Notamos que, pelo menos, quatro testemunhas sinalizam para a circunstância de que o chauffeur Hélio Souza Silva imprimia alta velocidade ao automóvel. Assim, Alexandre Gevaerd, que estava "na esquina da praça XV com a rua Tenente Silveira", teve, segundo observa, "sua atenção voltada para um automóvel que passava em alta velocidade, cerca de quarenta a cinqüenta quilômetros"1012. À frente, considera que "sabe ter sido [uma] criança [...] atropelada pelo automóvel n. 246, guiado pelo acusado Hélio Souza Silva, o mesmo que havia passado algum tempo antes em vertiginosa corrida" ${ }^{\prime 1013}$.

Percebemos, pelo exposto, que a atenção dessa testemunha à passagem do automóvel n. 246 foi despertada em função de o veículo estar sendo guiado em "alta velocidade". Essa testemunha, como vimos no capítulo primeiro, considera também que "não pôde ver o desastre por achar-se virado de costas para o local em que o auto apanhou a vítima" $" 1014$; entretanto, mesmo nessas circunstâncias, teve a sua atenção desperta pela passagem do veículo n. 246. Destacamos que Paulo José dos Santos considerou, também, que o automóvel n. 246 passou por ele em "alta velocidade", e que o acusado não pôde evitar o atropelamento devido, exatamente, à velocidade excessiva em que ia na ocasião" ${ }^{1015}$.

Observamos, nesse ponto, que a testemunha considera "excessiva" a velocidade de deslocamento do veículo n. 246. Ainda a testemunha Leopoldo João dos Santos, que efetuou a prisão em flagrante do chauffeur Hélio Souza Silva, argumentou que o automóvel n. 246 subia a rua Arcipreste Paiva "em alta velocidade", sendo calculada pela referida testemunha "em quarenta ou cinqüenta quilômetros por hora"1016. Acrescentou, ainda, em resposta ao "Dr. Promotor Público", que "o automóvel de que se trata não buzinou ao aproximar-se do local do desastre" e que, "no trecho da rua Arcipreste Paiva onde se verificou o atropelamento, o movimento de pedestres era grande"; expôs, todavia, que "conhece o acusado e que nada pode dizer em desabono à conduta do mesmo" 1017 .

\footnotetext{
${ }^{1010}$ Processo n. 239, 21 jan. 1934. Caixa 26.

${ }^{1011}$ Idem.

${ }^{1012}$ Idem.

${ }^{1013}$ Idem.

${ }^{1014}$ Idem.

${ }^{1015}$ Idem.

${ }^{1016}$ Idem.

${ }^{1017}$ Idem.
} 
Ainda devemos observar que a testemunha Altino Flores, "42 anos de idade, professor e jornalista"1018, declarou, no dia 21 de fevereiro de 1934, que, "no dia e hora referidos na denúncia, na ocasião em que ele depoente subia a Praça XV em direção ao Cinema 'Royal', ouviu o ruído de um automóvel que subia da praça para a rua Arcipreste Paiva, em alta velocidade"1019. A seguir, destacou que "lhe havia chamado a atenção passar o carro no local referido, em dia de grande movimento" ${ }^{\# 1020}$. Essa testemunha considerou, pois, que o automóvel n. 246 era guiado em alta velocidade e que sua atenção foi, portanto, despertada pela passagem do referido auto, em face de haver, àquele momento, grande movimento de pedestres.

Percebemos, pelo exposto, que não há consenso sobre as circunstâncias que envolveram o sinistro em questão. Há referências ao acionamento da buzina, no momento da aproximação do automóvel n. 246, às pessoas presentes à rua Arcipreste Paiva. Verificamos, entretanto, que há, também, declarações que negam que o chauffeur Hélio Souza Silva tenha feito uso de tal recurso. Quanto ao movimento de pedestres na rua Arcipreste Paiva, Tomás Gonçalves, por exemplo, apontou, em resposta ao "Dr. Promotor", que, "no trecho [...] em que se verificou o atropelamento em questão, o movimento de pedestres na ocasião do acidente, era diminuto"1021. Vimos, porém, que, pelo menos, duas das demais testemunhas apontaram que, "no trecho da rua Arcipreste Paiva onde se verificou o atropelamento, o movimento de pedestres era grande". As circunstâncias que envolviam os episódios de atropelamentos e colisões nas ruas do perímetro urbano da capital catarinense eram, portanto, percebidas e resignificadas de diversas maneiras pelos florianopolitanos.

Assim, os argumentos expostos pelas testemunhas revelam-nos posicionamentos nem sempre convergentes sobre um mesmo aspecto. É importante salientarmos, todavia, que a testemunha Tomás Gonçalves não expõs, em nenhum momento de sua fala, qualquer aspecto que viesse comprometer a pessoa de Hélio Souza Silva, pois argumentou que esse chauffeur fez uso buzina, anunciando a sua aproximação. A testemunha também não faz referências explícitas à alta velocidade do automóvel n. 246, pois apenas considerou que esse veículo se deslocava a "uma velocidade mais ou menos de trinta quilômetros a hora". Além disso, ocupou-se em dizer que "o movimento de pedestres, na ocasião do acidente, era diminuto". Em outras passagens de sua declaração, essa testemunha observou, também, que "o automóvel dirigido pelo denunciado vinha na mão" e que, em resposta "ao curador do réu, Dr. Eugênio Figueiredo Condessa", disse que "o acusado não tem mau procedimento" e que ele "costuma conduzir o seu carro no interior da cidade na marcha normal, sem transgredir as disposições inerentes ao tráfico de veículos das

\footnotetext{
${ }^{1018}$ Processo n. 239, 21 jan. 1934. Caixa 26.

${ }^{1019}$ Idem.

${ }^{1020}$ Idem.

${ }^{1021}$ Idem.
} 
ruas da Capital"1022. Ressaltamos que todas as suas colocações corroboram para produzir-se a ideia de que o chauffeur Hélio Souza Silva conduzia o automóvel n. 246 sem transgredir quaisquer normas ou condutas no trânsito. Devemos observar, ainda, que a referida testemunha era, também, um chauffeur e, nesses termos, seria, ao menos, natural que tomasse o devido cuidado em não desabonar a conduta de um indivíduo que desempenhava idêntica função profissional.

Após a formulação do interrogatório dirigido a pessoa de Hélio Souza Silva, datado de 21 de fevereiro de 1934, o curador do respectivo chauffeur expôs os motivos que, segundo ele, deveriam ser observados para que não se consumasse a condenação e posterior prisão de seu cliente. Ele argumentou no dia 24 de fevereiro de 1934, por exemplo, que "não houve, através das declarações das testemunhas, qualquer um que afirmasse ter o réu sido imprudente", e acrescentou que "se houve imprudência, esta culpa cabe à pessoa que tendo uma pessoa à sua mão, deu-lhe a liberdade de por motivo próprio, cruzar uma via movimentada, como estava a rua Arcipreste Paiva, em dias de folia" 1023 . Argumentou, pois, que "não houve nem negligência, nem imperícia por parte do acusado", e também disse que "ele fonfonou"; "brecou o carro" e "procurou desviar da rota [...], tomando todo o cuidado no sentido de evitar um desastre"1024.

As disputas discursivas, em favor ou contra a condenação do acusado Hélio Souza Silva, estão presentes em todas as etapas e falas constantes do presente processo. Desse modo, entendemos que, nesse ponto, podemos partir para a análise das ideias expostas pelo Juiz da Segunda Vara da Comarca da Capital, ao formular os vistos processuais, datados de 09 de março de 1934. Naquela ocasião, o magistrado lançou, inicialmente, indicativos de que o chauffeur Hélio Souza Silva seria condenado, pois formulou posicionamentos alinhados ao que considerava a promotoria pública, uma vez que observou que ela, "com fundamento no inquérito policial [...], apresentou denúncia contra o chauffeur [respectivo] pelo fato de haver este, no dia 21 de janeiro último, [...] atropelado por imprudência, quando guiava o automóvel n. 246, a menor Alice Grumiché ${ }^{1025}$. Destacamos, ainda, que o Juiz considerou que Hélio Souza Silva foi, naquela ocasião, imprudente, ao guiar o referido automóvel.

O Juiz considerou, também, que o curador do réu "alegou em suas razões de defesa [...] ter sido casual o delito atribuído ao acusado"; observou, porém, que "a materialidade do delito está provada", pois o acusado conduzia "um automóvel em grande velocidade, em lugar bastante movimentado", e que "não previu a conseqüência que resultou de sua ação"1026. Diante dessas

\footnotetext{
${ }^{1022}$ Processo n. 239, 21 jan. 1934. Caixa 26.

${ }^{1023}$ Processo n. 239, 21 jan. 1934. Caixa 26. A testemunha Leopoldo João dos Santos observou, no dia 16 de fevereiro de 1934 , que "a menor ofendida, embora estivesse em companhia de pessoa adulta, ao tentar atravessar a rua, a fez sozinha". (Processo n. 239, 21 jan. 1934. Caixa 26).

${ }^{1024}$ Processo n. 239, 21 jan. 1934. Caixa 26.

${ }^{1025}$ Idem.

${ }^{1026}$ Idem.
} 
informações, o magistrado destacou, também, que “o Decreto n. 2075, de 28 de junho de 1927 , que aprovou as instruções para a Inspetoria de Veículos do Estado, e o edital de 18 de julho do mesmo ano ${ }^{1027}$, proíbem terminantemente que os motoristas conduzam automóveis com alta velocidade, no centro da cidade, impondo multa aos transgressores ${ }^{\text {"1028 }}$. Verificamos, portanto, que o Juiz considerou que o acusado estava em alta velocidade com o veículo n. 246, no momento em que atropelou a menor Alice Grumiché, e que o local onde ocorreu o atropelamento era "bastante movimentado"; observou, ainda, a proibição estipulada pelas legislações de trânsito locais de se conduzir veículos em alta velocidade pelas ruas centrais de Florianópolis. Além disso, percebemos, claramente, que, no ano de 1934, ainda vigoravam - como, aliás, já mencionamos em passagens anteriores deste estudo - as Instruções Regulamentares para o serviço de trânsito público.

O Juiz, por fim, observou que "o acusado tendo omitido voluntariamente a diligência em calcular as conseqüências possíveis e previsíveis do próprio ato, cometeu delito culposo; tendo agido com manifesta imprudência e inobservância das disposições regulamentares" ${ }^{1029}$. Considerou, portanto, uma vez mais, ter sido imprudente, o acusado. Conforme o magistrado, Hélio Souza Silva incorreu, por conseguinte, "em responsabilidade penal”; e, desse modo, pronunciou o referido acusado "como incurso na sanção do artigo 306 da Consolidação das Leis Penais, aprovada e adotada pelo Decreto n. 22213, de 14 de dezembro de 1932”; e observou, por fim, que o acusado ficava "sujeito a prisão e livramento" ${ }^{1030}$.

Abreviando as discussões sobre as etapas componentes desse processo, temos que, no dia 10 de abril de 1934, portanto, um dia após a formulação dos vistos anteriores, analisados nos parágrafos precedentes, o Juiz de direito da Segunda Vara da Comarca da Capital, Mileto Tavares da Cunha Barreto, formulou, novamente, os vistos para o julgamento do réu Hélio Souza Silva. Nessa oportunidade, percebemos, grosso modo, idêntico teor aos vistos assinados no dia anterior, pois o Juiz observou, dentre outros aspectos, que "o fato delituoso está plenamente provado nos autos" ${ }^{\text {1031 }}$. O magistrado considerou, ainda, que o automóvel n. 246 era guiado em alta velocidade "em local movimentado da cidade" e, desse modo, Hélio Souza Silva incorreu na “inobservância de disposição regulamentar de trânsito" e demonstrou "descaso pelas disposições

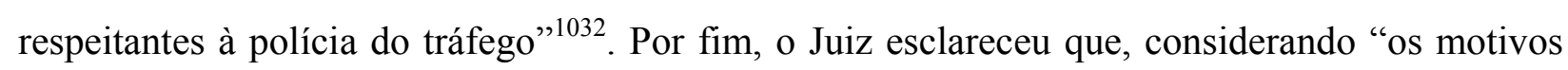
expostos", julgava "procedente a acusação para condenar, como condeno, o referido Hélio Silva,

\footnotetext{
${ }^{1027}$ Vimos, no capítulo terceiro, por ocasião da análise do processo n. 194, de 21 de novembro de 1932, que esse escrito apresenta, textualmente, o teor do "Edital" acima referido; expedido pelo então tenente coronel Manoel Pereira da Silva e Oliveira, delegado de polícia da Capital. Esse edital registra os locais permitidos para a prática da condução de automóveis. Ver descrição integral desse edital na página 172.

${ }^{1028}$ Processo n. 239, 21 jan. 1934. Caixa 26.

${ }^{1029}$ Idem.

${ }^{1030}$ Idem.

${ }^{1031}$ Idem.

${ }^{1032}$ Idem.
} 
a 15 dias de prisão celular, grau mínimo do artigo 306 da Consolidação das Leis Penais”, visto ter "militado em favor do réu a circunstância atenuante do artigo 42, \# 11 da supracitada Consolidação"1033; desse modo, o magistrado designou "a Penitenciária da 'Pedra Grande"1034 para o cumprimento da pena"1035. Assim, no dia 25 de abril de 1934, foi expedido o mandado de prisão ao chauffeur Hélio Souza Silva.

Devemos sublinhar que, conforme consta no presente processo, o respectivo chauffeur foi denunciado no dia 07 de fevereiro de 1934, e julgado no dia 10 de abril do mesmo ano. Foi, posteriormente, condenado “a quinze dias de prisão celular, grau mínimo do artigo 306 da aludida Consolidação" ${ }^{1036}$. Vimos, anteriormente, os motivos que levaram o Juiz da Segunda Vara da Comarca da Capital a determinar tal decisão. É importante, porém, constatarmos que os termos finais desse processo, datados de 30 de abril de 1934, registram que "foi concedida ao réu [Hélio Souza Silva] suspensão condicional da pena que lhe foi imposta de 10 de abril do corrente

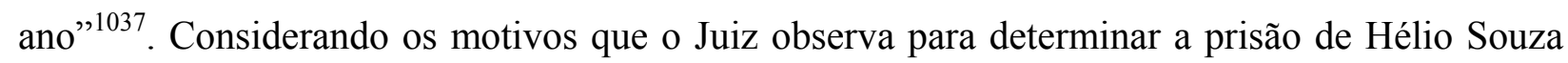
Silva - guiar o automóvel em alta velocidade; não obedecer ao que determina as instruções de trânsito locais, dentre outros -, como se explica tal decisão final?

\footnotetext{
${ }^{1033}$ Essa circunstância refere-se, como vimos, ao fato de o respectivo chauffeur ser "maior de 18 e menor de 21 anos".

${ }^{1034}$ Sobre a penitenciária da Pedra Grande, temos que ela foi inaugurada no dia 21 de setembro de 1930. Vale salientarmos, entretanto, que, durante as primeiras décadas do século XX, diversas instituições foram criadas em Florianópolis com a função clara de ordenar uma sociedade que ainda trazia resquícios da época imperial. Assim, junto com o Asilo de Órfãos São Vicente de Paula (1910) e o Asilo de Mendicidade Irmão Joaquim (1910), surgiram a Penitenciária Pedra Grande (construção iniciada em 1926), a Colônia Santana (1941), o Leprosário Santa Tereza (1938) e o Abrigo de Menores da Congregação dos Maristas (1940), instituições que funcionariam como agentes de poder; espaços onde seriam exercidos saberes experimentais e observacionais, ou seja, tecnologias de poder que objetivavam "resolver os problemas de vigilância". (FOUCAULT, Michel. Microfísica do Poder. 17 ed. Rio de Janeiro: Graal, 2002. p. 211). Cada indivíduo agora tinha o seu devido lugar, principalmente os conhecidos como pertencentes aos estratos sociais pobres e/ou perigosos. $\mathrm{O}$ debate em torno da necessidade de implantação do regime penitenciário, no Estado, teve início nos anos 1920, junto com as remodelações social e urbana. A ideia de implantação do modelo penitenciário casa com o pensamento das autoridades em relação ao controle social dos pobres e aos preceitos higienistas. Foi no governo de Adolfo Konder, iniciado em 1926, que começou a construção do prédio que abrigaria a Penitenciária Pedra Grande. Advogado formado, Konder era um porta-voz da elite que acompanhava, com avidez, as novidades das teorias científicas européias e o que acontecia nos outros centros urbanos do país, e a penitenciária fazia parte da plataforma de seu governo. A superação do atraso era, inclusive, um aspecto que muito permeava o seu discurso político, para agrado das elites e dos grupos dirigentes locais. A construção de uma penitenciária aparece, portanto, como símbolo de modernidade e de 'boa cultura'. Foi nesse contexto de saberes e de relações de poder que se realizou a reforma da penitenciária estadual; pois, segundo uma nota da imprensa local, nas cadeias já existentes no Estado, "a construção áspera e hostil, a estreiteza dos compartimentos, a falta de luz e de ar, as paredes enxovalhadas, a umidade do[s] pavimento[s], a atmosfera nauseabunda [...], formam um conjunto repulsivo, em que a ignomínia do ambiente vai a par das impurezas morais que ali se formam". (Uma Penitenciária. República. Florianópolis, 07 out. 1926). Além disso, as transformações urbanas e a instauração de instituições de controle e disciplina fazem parte não só de aspirações locais, mas também de algo mais abrangente, que envolve a ideia de projeto nacional, de civilização e de progresso, baseada em teorias científicas que nortearam o pensamento das elites nacionais a partir do fortalecimento das instituições de ensino. A construção de uma penitenciária estava na ordem do dia na cidade, no discurso de todos os dirigentes e na imprensa. Na verdade, a questão tornara-se parte importante na construção de um projeto nacional, e era extremamente relevante para o Estado de Santa Catarina cumprir com o dever de se modernizar. Ver a) Uma Penitenciária. República. Florianópolis, 07 out. 1926; b) CAMPOS, Cynthia Machado. A Política da Língua na Era Vargas: proibição de falar alemão e resistências no Sul do Brasil. Campinas: UNICAMP, 2006; c) _.. Santa Catarina, 1930: da degenerescência à regeneração. Florianópolis: EDUSC, 2008, e d) REBELO, Fernanda; CAPONI, Sandra. O gabinete do doutor Edelvito Campelo D'Araújo: a Penitenciária Pedra Grande como espaço de construção de um saber (1933-1945). In: História; Ciências; Saúde-Manguinhos. Rio de Janeiro, v. 14, n. 4, out./dez. 2007. Disponível em: <http://www.scielo.br/scielo.php?script=sci_arttext\&pid=S0104-59702007000400007>. Percebemos pelos processos analisados que, pelo menos, durante a primeira metade da década de 1930, outra instituição penal, a "Cadeia Pública de São José", era também utilizada para acolher os condenados por crimes de trânsito verificados nas ruas da Capital. O seu aproveitamento nessa época, podemos especular, era, mesmo, efetuado de maneira frequente; pois, de acordo com a nota jornalística já referida, essa instituição era considerada "a mais segura do Estado"; porém "é um caixão hediondo, com paredes de alvenaria descomunais, onde se sepultam os réprobos perigosos", para que "no isolamento e na treva, agucem a temibilidade". (Uma Penitenciária. República... op. cit). A partir da segunda metade daquele decênio, a Penitenciária da "Pedra Grande" foi utilizada, entretanto, de forma cada vez mais constante, como, então, sinaliza o processo ora em discussão. ${ }^{1035}$ Processo n. 239, 21 jan. 1934. Caixa 26.

${ }^{1036}$ Processo n. 239, 21 jan. 1934. Caixa 26. Esse artigo estipula que "Aquele que, por imprudência, negligência ou imperícia, na sua arte ou profissão, ou por inobservância de alguma disposição regulamentar, cometer ou for causa involuntária, direta ou indiretamente, de alguma lesão corporal, será punido com a pena de prisão celular por quinze dias a seis meses". (PIERANGELI, José Henrique. Códigos Penais do Brasil: evolução histórica. 2. ed. São Paulo: Revista dos Tribunais, 2004. p. 380). Observamos semelhanças em relação ao artigo 306 do Código Penal brasileiro de 1890, pois, como visto, esse código sofreu inúmeras alterações e atualizações no período entre os anos de 1890 e 1932.

${ }^{1037}$ Processo n. 239, 21 jan. 1934. Caixa 26.
} 
Nesse ponto, é válido observarmos que não encontramos, na sentença que determinou a suspensão condicional da pena imposta a Hélio Souza Silva e no respectivo alvará de soltura, quaisquer justificativas para tal procedimento. Vimos, entretanto, que qualquer decisão tomada, no caso, pelo juiz de direito é, a princípio, embasada em trâmites e determinações legais. No caso de efetivar-se a suspensão da pena ao acusado Hélio Souza Silva, o Juiz, ao que tudo indica, observou, muito provavelmente, artigos do Código Judiciário do Estado. Lembremos, por exemplo, que o artigo 2470 do Código Judiciário do Estado, de 1928, estipula, dentre outros aspectos, que o Juiz "poderá suspender a execução da pena" ao tomar "em consideração as condições individuais do réu, os motivos que determinaram a infração da lei penal e circunstâncias que a cercaram"1038. É importante notarmos que, nesse caso, o magistrado não é obrigado a fazê-la, pois se trata de uma decisão opcional. Assim, para que seja creditada, devem se por ele avaliadas, segundo referido, diversas variáveis constantes no sinistro. O artigo 2470 estipula, também, que a suspensão da pena pode ser aplicada ao avaliar-se que o acusado "não tenha revelado caráter perverso ou corrompido"1039. Indicativos nesse sentido podem ser observados ao destacarmos o que considera o escrivão do Juízo Federal, na Seção do Estado de Santa Catarina, no dia 28 de abril de 1934, pois, nessa ocasião, ele afirmou, "a pedido verbal por parte de pessoa interessada, que revendo em meu cartório o arquivo dos processos crime, nele nada encontrei com referência ao menor Hélio Silva, residente nesta cidade, que o desabone em sua conduta" $" 1040$.

Além disso, ante as considerações anteriores, apontadas pelo próprio juiz de direito, de que o automóvel era guiado "em alta velocidade" no instante do atropelamento e que houve, por parte do chauffeur, "a inobservância de disposição regulamentar de trânsito de veículos",1041, acreditamos que a suspensão da pena decorreu, também, de dois outros aspectos, quais sejam: a) o automóvel, guiado pelo chauffeur Hélio Souza Silva, era particular, ou seja, de "propriedade do Sr. Arlindo Pinto da Luz"1042. Esse fato confirma, novamente, a tendência de que, nas primeiras décadas do século XX, apenas os indivíduos que apresentavam muito boa condição financeira adquiriam automóveis e dispunham de empregados para servir-lhes; e b) vimos que o chauffeur Hélio Souza Silva foi preso em flagrante e que esse aspecto não impediu que, sob a participação de fiadores "bastante conhecidos e abonados", fosse concedida ao chauffeur a “suspensão condicional da pena", assinada junto aos termos finais do processo ${ }^{1043}$. Esses

\footnotetext{
${ }_{1038}^{1039}$ Código Judiciário do Estado de Santa Catarina. Lei n. 1640 de 03 de novembro de 1928. p. 418.

${ }^{1039}$ Idem.

${ }^{1040}$ Processo n. 239, 21 jan. 1934. Caixa 26.

${ }^{1041}$ Idem.

1042 Idem.

1043 Junto ao processo n. 95, de 05 de julho de 1926, analisado no capítulo primeiro da tese, vimos que o chauffeur Aniceto Machado de Souza foi apontado como culpado pelo acidente que envolveu o automóvel n. 132, guiado pelo referido chauffeur, e o carro de praça n. 30 , guiado pelo boleeiro Onofre D’Aquino. Esse acidente ocorreu na esquina da rua Esteves Júnior com a Avenida Rio Branco. Nesse episódio, o chauffeur
} 
aspectos sugerem-nos, uma vez mais, a conjugação dos poderes judiciário e financeiro, como

forma de inocentar chauffeurs pelos sinistros ocorridos, o que implicou na respectiva suspensão condicional de suas penas.

Aniceto Machado foi enquadrado nas penas dos artigos 297 e 306 do Código Penal brasileiro, de 1890. Desse modo, o réu é sujeito "à prisão e livramento condicional", e seu nome é lançado "no ról dos culpados, estabelecendo as ordens necessárias para sua prisão". (Processo n. 95, 05 jul. 1926. Caixa 09). O valor da fiança foi estipulado em "seiscentos mil réis $(600 \$ 000)$ ". A condenação do réu foi assinada no dia 15 de março de 1927 e, no dia 19 daquele mês, foi designada a cadeia pública de São José para o cumprimento da respectiva pena. (Processo n. 95, 05 jul. 1926 Caixa 09). Diante desse quadro, é importante observamos que o "Termo de Fiança", datado de 21 de abril de 1927, é endereçado pelo respectivo fiador ao "Exmo. Sr. Dr. Juiz de Direito da Comarca da Capital" e registra que "Aniceto Machado de Souza, preso e recolhido à cadeia pública, querendo prestar fiança [...] requer à V. ${ }^{a}$ Ex. ${ }^{a}$ que se mande tomar por termo a sua fiança que arbitrada a mesma oferece como seu fiador o Sr. Júlio Moura, negociante e proprietário nesta Capital”. (Processo n. 95, 05 jul. 1926. Caixa 09). Devemos observar que o fiador em questão foi o personagem diretamente responsável pela organização da Sociedade que adquiriu os direitos para a exploração da primeira linha de autoônibus na cidade de Florianópolis, estabelecida em 1920. A figura do fiador possuí, invariavelmente, muito boa situação financeira, suficiente para atender ao valor da fiança. Esse aspecto envolve, portanto, o poder financeiro como agente diretamente responsável pelo livramento condicional dos responsáveis por crimes de trânsito na capital catarinense. Nesse ponto, devemos observar, portanto, que, ao final do recurso impetrado junto ao Superior Tribunal de Justiça do Estado, acabou-se por conceder, "por unanimidade de votos", respostas negativas aos quesitos para o julgamento do réu Aniceto Machado de Souza, uma vez que o Juiz Mileto Tavares da Cunha Barreto julga-o "isento de culpa e o absolve da acusação que lhe foi intentada". (Processo n. 95, 05 jul. 1926. Caixa 09). O poder financeiro, posto ao lado dos chauffeurs no pagamento dos valores afiançáveis que lhes eram atribuídos, deve, talvez, ter contribuído para a soltura do respectivo réu, como verificamos no final do processo. 


\section{Capitulo 5 - Os Transportes Coletivos: convivência e preterimento}

No texto que se inicia, procedemos à análise da circulação e/ou convivência simultânea dos bondes e ônibus que circulavam pelas ruas da capital catarinense, durante as décadas de 20 e 30 do século passado. Fugimos um pouco, portanto, das análises feitas até o presente momento, nas quais nos debruçamos sobre os episódios de atropelamentos e colisões ocasionados por veículos ou automóveis particulares, de praça ou de aluguel. A intenção, com este capítulo final, e, também, em última análise, com o conjunto da tese, é oferecermos ao leitor um panorama rico e diversificado sobre as circunstâncias e episódios que envolveram a circulação automobilística seja em veículos motorizados de passeio, seja em coletivos - verificada na cidade de Florianópolis no período estipulado. Além disso, atentamos para as percepções e sensibilidades dos florianopolitanos a respeito.

A investigação proposta para os dois primeiros subtítulos deste capítulo baseia-se na análise dos artigos de periódicos locais da época, dando-se ênfase àqueles registrados nos jornais $O$ Estado, República e A Semana. Assim, consideramos válido o esclarecimento de que o presente capítulo será dividido em três seções. Na primeira, intitulada Os Coletivos na Ótica da Imprensa Local, pretendemos verificar os posicionamentos da imprensa florianopolitana em relação à manutenção e ao funcionamento dos serviços de bondes e ônibus. É importante ressaltarmos que, durante a década de 20 do século passado e com maior nitidez a partir da década seguinte, introduziu-se, na capital catarinense, o ônibus como transporte público alternativo - ver introdução. Assim, a partir desse período e durante, aproximadamente, quinze $\operatorname{anos}^{1044}$, os bondes e ônibus circularam e/ou conviveram simultaneamente nas ruas do perímetro urbano da cidade de Florianópolis. Nesse período, percebemos posições diferenciadas da imprensa florianopolitana ${ }^{1045}$ quanto à presença e manutenção dos serviços de bondes e ônibus.

As notas jornalísticas locais, analisadas neste texto, ocupavam-se em tecer ideias favoráveis à implementação do serviço de auto-ônibus, pois destacavam suas qualidades, e, paralelamente, expressavam nítida hostilidade quanto à circulação dos bondes puxados a burros, qualificando-os, dentre outros adjetivos, como um "antiquado sistema de viação urbana"1046. Podemos considerar, desse modo, que o descontentamento com a manutenção do serviço de bondes e a satisfação pela implantação e circulação dos coletivos motorizados pelas ruas de Florianópolis, como expostos anteriormente, eram, na época, as posições correntes nos

\footnotetext{
${ }^{1044}$ As pesquisas realizadas apontam que os bondes e linhas trafegáveis por esses veículos eram inexistentes na cidade de Florianópolis em 1936. (Anuário Estatístico do Brasil, ano III, Rio de Janeiro, 1937. p. 291)

${ }^{1045}$ Representada, aqui, pela análise aos artigos dos periódicos já citados.

${ }^{1046}$ Os trilhos 'mortos'. O Estado, Florianópolis, 14 mar. 1927. p. 2.
} 
periódicos locais? Os registros jornalísticos apontam nessa direção, mas as pesquisas e análises podem confirmar ou não essas suposições.

Na segunda seção desse capítulo, intitulada Conflitos e Disputas: os coletivos motorizados pedem passagem, analisamos, nos artigos de jornal e nos órgãos governamentais locais, como os bondes foram sendo, gradualmente, substituídos pelos ônibus. Destacamos, também, choques e disputas discursivas favoráveis ou contrárias a seu fomento ou manutenção. Objetivamos, dessa forma, verificar que a preferência pelo serviço de transporte coletivo motorizado não foi aceito sem conflitos ou disputas de interesses financeiros e/ou discursivos. Salientamos, pois, o caráter político que, ao certo, também permeou as discussões em torno da gradual implementação do transporte motorizado de passageiros na capital catarinense.

Nesse sentido, a fim de estabelecermos uma melhor conexão deste capítulo com os demais dispostos na tese, investigamos, paralelamente, o episódio de atropelamento apresentado pelo processo n. 183, ocorrido no dia 11 de janeiro de 1932. Esse processo ocupa-se da investigação do atropelamento da menor Rosa Tomázia Vidri, de sete anos de idade, ocasionado, segundo consta, pelo chauffeur José Arcênio Freitas, vinte anos, que, na ocasião do acidente, guiava o automóvel n. $244 \mathrm{~A}^{1047}$. A escolha desse processo, nesta altura da tese, é justificada uma vez que envolve o atropelamento de pessoa menor de idade e, nesses termos, deixa mais evidente a presença e a imposição dos veículos motorizados pelas ruas da capital catarinense no período estudado. Isso corrobora, portanto, com a intenção expressa pelos órgãos governamentais e pelas notas jornalísticas estudadas, em oferecer apoio à implementação dos serviços de instalação e manutenção das linhas operadas por coletivos motorizados na cidade.

A terceira seção constitui um Epílogo no qual elaboramos uma discussão sobre o processo inicial de implementação dos semáforos nos principais cruzamentos de ruas da cidade de Florianópolis, a partir da década de 1950. Essa discussão será efetuada por meio da análise de artigos jornalísticos e do Primeiro Plano Diretor da Capital, datado de 1952/1955. Objetivamos, assim, constatar que, nesse período, havia considerável adensamento do fluxo de veículos motorizados pelas ruas do espaço central da capital catarinense; processo este que atesta a preferência concedida ao transporte rodoviário, em detrimento do marítimo e ferroviário. Esse aspecto obedece, em síntese, àquele traçado pela esfera federal, no qual verificamos especial atenção e fomento ao transporte rodoviário e à incrementação da indústria automobilística nacional, especialmente durante o governo de Juscelino Kubitschek (1956-1961). Pretendemos, desse modo, relacionar os contextos nacional, estadual e local ante a preferência concedida ao rodoviarismo, a fim de inserir o contexto florianopolitano num cenário mais amplo.

\footnotetext{
${ }^{1047}$ Processo n. 183, 11 jan. 1932. Caixa 19.
} 
Neste ponto, é válido observarmos que, no presente capítulo, não pretendemos realçar as linhas e os itinerários percorridos pelos coletivos, cujas discriminação e análise, aliás, já foram efetuadas por estudos anteriores, especialmente aqueles de autoria da professora Eliane Veiga. Assim, no texto Transporte Coletivo em Florianópolis: origens e destinos de uma cidade à beira-mar (Florianópolis: Insular, 2004), a autora analisa, por exemplo, a incrementação do transporte coletivo na cidade de Florianópolis, desde o século XVII até os dias atuais. Na primeira parte, intitulada Vencendo as barreiras e o isolamento, descreve e analisa os meios de transporte da cidade de Desterro dos séculos XVII a XIX; o surgimento, em 1920, do primeiro sistema de ônibus em Florianópolis e as linhas e itinerários dos coletivos durante as décadas de 1940, 1950 e 1960. Na segunda parte, intitulada Novas demandas numa cidade que cresce, Eliane Veiga analisa a incrementação do transporte coletivo a partir da década de 1970, até os dias atuais, e confere especial destaque ao atual Sistema Integrado de Transporte Coletivo de Florianópolis ${ }^{1048}$. Essa parte centra-se, igualmente, na descrição e na análise dos itinerários, terminais e empresas de ônibus que serviam à cidade neste período. O livro é rico em informação e documentação jornalística e iconográfica, porém entendemos que seu período de abrangência é muito extenso, o que foge, em muitos momentos, à periodização estabelecida para este estudo.

Assim, devemos ter em mente que o palco principal, apresentado no transcorrer desta investigação, constitui-se no perímetro urbano da capital catarinense e nas vivências e percepções cotidianas operadas por seus habitantes. O estudo proposto nesta tese analisa fontes inéditas, notadamente quanto aos processos criminais e códigos de trânsito locais ${ }^{1049}$. Além disso, a problemática central proposta, que objetiva analisar as percepções cotidianas expressas pelos habitantes da cidade de Florianópolis, quanto à implementação e à circulação dos veículos motorizados, no período de 1920 a 1941, considera o jogo de poder implícito nas relações estabelecidas entre veículos, chauffeurs e pedestres, sobre o qual alicerçamos a elaboração desta pesquisa. Entendemos, dessa forma, que ambos os trabalhos não são, de maneira alguma, semelhantes, mas complementares. Observamos, também, que, a partir da ótica de artigos jornalísticos e de textos dos órgãos governamentais locais, analisamos, neste capítulo, a dinâmica operada pela convivência simultânea dos bondes e ônibus pelas ruas da capital catarinense, durante as décadas de 20 e 30 do século passado; análise esta que encerra a presente tese.

\subsection{Os Coletivos na Ótica da Imprensa Local}

Iniciamos, nesta seção, uma discussão sobre as apreciações dos artigos jornalísticos locais quanto à manutenção dos serviços de bondes e ônibus na cidade de Florianópolis. Assim, nos

\footnotetext{
${ }^{1048}$ VEIGA, Eliane. Transporte Coletivo em Florianópolis: origens e destino de uma cidade à beira-mar. Florianópolis: Insular, 2004.

${ }^{1049}$ Ver, especialmente, Santa Catarina. Instruções Regulamentares para o serviço de trânsito público. Florianópolis: Imprensa Oficial, 1928.
} 
períodos $O$ Estado e A Semana, encontramos o maior número de artigos que envolvem essa temática e, por esse motivo, nossa investigação será concentrada nesses textos. Julgamos, porém, apropriado observar, novamente, que os bondes e ônibus conviveram pelas ruas da cidade de Florianópolis por, aproximadamente, quinze anos, entre 1920 até, pelo menos $1934^{1050}$. Nesse período, notamos, por certo, que houve, especialmente nos periódicos locais, posicionamentos contrários ou a favor da manutenção de um e outro serviço de transporte público. Salientamos, entretanto, que, de fato, prevaleceram, nesses periódicos, posicionamentos favoráveis à manutenção e ao fomento do serviço de auto-ônibus, conforme constatamos a partir das avaliações que deles fizemos.

Antes de adentrarmos na discussão proposta, devemos observar que os bondes puxados por burros funcionavam na cidade de Desterro desde o ano de 1880, pois, naquela data, o Ofício encaminhado pelo engenheiro Polydoro Olavo de São Thiago ao Presidente da Província, João Rodrigues Chaves, dava conta de que se tencionava "inaugurar no dia 06 de novembro, às cinco horas da tarde, o tráfego da 1 a $^{\text {S Seção da linha de Carris Urbanos" }}{ }^{1051}$. Na mesma ocasião, o referido engenheiro, na qualidade de "concessionário" da respectiva linha, convidava "V. Ex. ${ }^{a}$ [Presidente da Província]" para que se digne de assistir ao ato de inauguração"1052. Pompa e circunstância cercaram, portanto, o evento.

O "Regulamento para o serviço da 1. "Seção da linha de Carris Urbanos", anexo ao Ofício supracitado, estabelecia, em seu artigo primeiro, que “[...] Começará o tráfego diário das cinco horas da manhã e terminará ordinariamente às dez e meia horas da noite"1053. Constatamos, entretanto, que "Art. 12 - Nas noites em que o tráfego prolongar-se além das dez e meia horas, o preço das passagens será duplo"1054. Como observamos, esse serviço de bondes, iniciado ainda no período imperial, permitia aos usuários circularem pela cidade durante grande parte do dia, não excluindo tal possibilidade para além das vinte e duas horas. A inauguração desse serviço proibiu aos seus usuários estarem "descalços, maltrapilhos ou embriagados"1055. Assim, percebemos que novas posturas e comportamentos foram exigidos daqueles que pretendiam fazer uso desse novo sistema de locomoção urbana. As autoridades competentes, ao que parece, ofereceram todas as atenções e cuidados possíveis à manutenção desse serviço...

Nove anos após a inauguração da primeira linha de bondes na cidade de Desterro, o Código de Posturas Municipal de 1889 chamava atenção para aspectos semelhantes, pois salienta que a administração local determinava que "os cocheiros" dos bondes tivessem "toda urbanidade

\footnotetext{
${ }^{1050}$ Ver Um bonde destruído por populares. O Estado. Florianópolis, 26 set. 1934. p. 6. A seguir, procederemos à análise deste artigo.

${ }^{1051}$ THIAGO, Polydoro Olavo de São. (Eng. ${ }^{\text {ro }}$ ). Ofício. Encaminhado ao Presidente da Província João Rodrigues Chaves. Desterro, 03 nov. 1880.

${ }^{1052}$ Idem.

${ }^{1053}$ Idem.

${ }^{1054}$ Idem.

${ }^{1055}$ Idem.
} 
e polidez para com os [...] passageiros" ${ }^{\text {"1056 }}$. Esses elementos permitem-nos inferir que, pelo menos até essa data, os bondes circularam com certa regularidade pelas ruas da cidade de Desterro. Outro aspecto que vem corroborar com essas observações diz respeito à determinação de que "Em todas as ruas e largos onde houver trilhos de bondes, é proibido a parada ou estação de carros, carroças ou outros quaisquer veículos, de modo que não embarace a circulação daqueles"; era, também, vedado "depositar qualquer objeto sobre os trilhos, afim de não embaraçar o livre trânsito da linha" ${ }^{\text {1057 }}$. Como vemos, a administração pública municipal lutava para prover boas condições ao tráfego de bondes, e para não impedi-lo.

O fomento aos serviços de bondes urbanos pode ser estendido para os anos seguintes ao considerarmos que a Mensagem lida na Sessão de Abertura do Congresso Representativo do Estado, em 1907, observa que, em "21 de março deste ano, organizou-se nesta Capital uma Sociedade Anônima ${ }^{1058}$ com o fim de explorar o contrato assinado com a Superintendência Municipal da Capital para a construção nos perímetros urbano e suburbano de diversas linhas de bondes de tração animal para passageiros e cargas" ${ }^{1059}$. Constatamos que observa, também, esse texto oficial que são "em número de três as linhas que a Sociedade pretende estabelecer, tendo o percurso de 5.450 metros, explorando desde já a da Rita Maria ao Largo 13 de Maio"1060 e "com uma extensão de 02 quilômetros mais ou menos"1061. Percebemos que, naquela época, os serviços de bondes estavam em expansão na capital do Estado. Assim, verificamos que a mesma mensagem salienta que as iniciativas aqui expostas são exemplos dignos a serem seguidos e que devem "servir de estímulo para o emprego do capital individual em obras produtivas no Estado" e destaca, por fim, que sociedades "desta ordem e outras similares que dizem respeito à viação

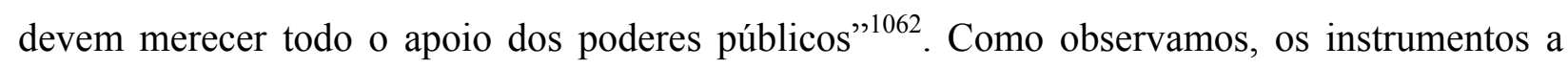
serviço dos órgãos governamentais locais expressavam, naquela época, claro entusiasmo pela

\footnotetext{
${ }^{1056}$ Câmara Municipal da Cidade do Desterro. Código de Posturas. Lei n. 1238, de 22 out. 1888. Desterro: Tipografia da Regeneração, 1889. ${ }^{1057}$ Essas determinações foram estipuladas pelos códigos de posturas municipais de 1889 e 1896 . Ver a) Câmara Municipal da Cidade do Desterro. Código de Posturas. Lei n. 1238, de 22 out. 1888... op. cit.; e b) Santa Catarina. Código de Posturas Municipais de Florianópolis. Florianópolis: Tipografia da República, 1896.

${ }^{1058}$ Essa "Sociedade Anônima" ficou depois conhecida como "Companhia de Carris Urbanos e Suburbanos". Ver RAMOS, Vidal José de Oliveira. MENSAGEM apresentada ao Congresso Representativo do Estado. Florianópolis, 23 jul. 1911. p. 56.

${ }^{1059}$ RICHARD, Gustavo. MENSAGEM lida na Sessão de Abertura do Congresso Representativo. Florianópolis, 05 ago. 1907. p. 38 . Nesse ponto, devemos observar que o Projeto n. 4, de 20 de fevereiro de 1907, esclarece que "Art. $1 .^{\circ}$ - Fica concedida à empresa que organizarem os cidadãos Eduardo Horn, José Bueno Vilella, Emílio Blum e outros, a permissão de uso e gozo, por espaço de sessenta anos de uma linha de bondes a tração animal, a vapor ou elétrica, para condução de passageiros e cargas, no município da Capital, podendo para tal fim assentar trilhos nas estradas e caminhos". (Câmara Municipal de Florianópolis. Projeto n. 4 (Redação final). Concede à empresa que organizarem os cidadãos Eduardo Horn, José Bueno Vilella, Emílio Blum e outros a permissão de uso, por espaço de sessenta anos, de uma linha de bondes a tração animal, a vapor ou elétrica, para condução de passageiros e cargas na Capital. Florianópolis, 20 fev. 1907. Caixa 03). Notamos que a concessão dos serviços foi de sessenta anos, ou seja, naquela época não se aventava a possibilidade da implementação, na cidade, do serviço de auto-ônibus. ${ }^{1060}$ Região localizada entre a rua Bulcão Viana e as futuras avenidas Hercílio Luz (1922) e Mauro Ramos (décadas de 1930/1940). (SILVA, Adolfo Nicolich. Ruas de Florianópolis: resenha histórica. Florianópolis: Fundação Franklin Cascaes, 1999. p. 113). Ver, também, Mapa 06: Largo General Osório (Instituto Estadual de Educação - IEE) e Bairros Adjacentes - Década de 1920, disposto no capítulo terceiro (p. 155).

${ }^{1061}$ RICHARD, Gustavo. MENSAGEM lida na Sessão de Abertura do Congresso Representativo, 1907... op. cit., p. 38. Essa mesma linha foi inaugurada no dia 12 de abril de 1908 e "o movimento de passageiros de abril a maio foi de 49.081", sendo que o material dela existente é "de 2 quilômetros de linhas de trilhos, 4 carros para passageiros, 9 de cargas e 20 muares”. (RICHARD, Gustavo. MENSAGEM lida na 2. 'Sessão da 7. ${ }^{a}$ Legislatura do Congresso Representativo. Florianópolis, 02 ago. 1908. p. 30).

${ }^{1062}$ RICHARD, Gustavo. MENSAGEM lida na Sessão de Abertura do Congresso Representativo, 1907... op. cit., p. $38-39$.
} 
incrementação do serviço de bondes urbanos, que deveria receber "todo o apoio dos poderes públicos ${ } 1063$.

A expansão do serviço de bondes urbanos, na capital catarinense, torna-se notória ao observarmos que a Mensagem, apresentada ao Congresso Representativo do Estado, em 1911, pelo então governador José Vidal de Oliveira Ramos, considera que "A Companhia Carris Urbanos e Suburbanos instalada em 1907 [...] está em condições muito animadoras”, pois a "extensão da linha construída é de 10 quilômetros, aproximadamente, sem incluir os desvios na soma total de 580 metros" e com "a próxima conclusão de uma nova linha, serão estabelecidas viagens circulares e que atenderão às principais exigências da viação urbana" ${ }^{\text {1064 }}$. Observamos, portanto, que houve, até o ano de 1911, um incremento de, aproximadamente, 50\% na extensão da linha trafegável por bondes, em relação ao percurso inicial estipulado em 1907, que era de 5.450 metros; e aventava-se, naquele momento, para a concreta possibilidade do aumento do número das linhas trafegáveis, o que atenderia "às principais exigências da viação urbana". Além disso, é importante observarmos que, pelo menos até o ano de 1913, os "serviços da Companhia Carris Urbanos e Suburbanos de Florianópolis" eram feitos "com a possível regularidade, esforçando-se a empresa para bem servir a população"1065.

Ainda no ano de 1920, data de inauguração da primeira linha de auto-ônibus na cidade de Florianópolis, ${ }^{1066}$ a imprensa local noticiava, por meio do artigo do jornal $O$ Estado, que "o governo [...] aceitou a proposta apresentada pela companhia General Eletric para o estabelecimento de linhas de bondes elétricos no Continente" e acrescentava que "o contrato para esse grande melhoramento, si já não foi assinado, deverá sê-lo por estes poucos dias, dando-se início imediatamente ao trabalho de construção da referida linha"1067.

Diante do exposto, interessa-nos destacar que, ainda no início da década de 1920, aventava-se a possibilidade para a eletrificação de linhas de bondes que, no caso aqui observado,

\footnotetext{
${ }^{1063}$ Isso fica evidente ao observarmos, na mensagem datada de 1908, que a Companhia Carris Urbanos, "por deliberação da última assembléia de acionistas, foi autorizada a emitir mais 100:000\$000 [cem contos de réis] para o aumento do capital, mas resolveu servir-se somente da autorização para 60:000\$000 [sessenta contos de réis], os quais já estão subscritos”. (RICHARD, Gustavo. MENSAGEM lida na 2." Sessão da 7. ${ }^{a}$ Legislatura do Congresso Representativo, 1908... op. cit., p. 30).

${ }^{1064}$ RAMOS, Vidal José de Oliveira. MENSAGEM apresentada ao Congresso Representativo do Estado, 1911... op. cit., p. 56.

${ }^{1065}$ RAMOS, Vidal José de Oliveira. MENSAGEM apresentada ao Congresso Representativo do Estado. Florianópolis, 24 jul. 1913. p. 93.

${ }^{1066}$ Já nos referimos a esse aspecto nos capítulos anteriores. Destacamos, porém, a respeito, o seguinte texto pesquisado no ao Arquivo Histórico da Prefeitura Municipal de Florianópolis: Câmara Municipal de Florianópolis. Série: Documentos, Ofícios, Projetos, Pareceres. Projeto n. 13. Concede à Sociedade organizada pelos Srs. Antonio Babitonga Linhares e Julio Nicolau de Moura o direito de uso e gozo, pelo espaço de cinco anos, do serviço de transporte por meio de 'auto-ônibus', dentro do perímetro urbano da Capital. Florianópolis, jul. 1920. Caixa 03. Sobre a inauguração desse novo serviço, a imprensa local a noticia considerando, por meio do artigo do jornal $O$ Estado, de 08 de julho de 1920 , que "será inaugurado por estes dias, o serviço regular de 'auto-ônibus' que vai ser estabelecido nesta Capital pela Empresa Moura \& Cia”. Esse mesmo artigo dá conta de que "o primeiro dos carros encomendados pela referida empresa já está a caminho de Florianópolis e os três restantes chegarão aqui dentro de poucos dias". (Florianópolis vai ter 'auto-ônibus'. O Estado. Florianópolis, 08 jul. 1920. p. 6). Observamos, pois, que esse novo serviço contaria, inicialmente, com quatro veículos. Ratificando essas informações, o mesmo periódico noticiava, cinco dias após, que "a "Empresa Moura \& Cia. inaugurou ontem um serviço regular de 'auto-ônibus' nesta Capital" e que na "linha da Praça XV à Estação Agronômica, única, por enquanto, funcionando com regularidade, trabalham dois carros". (Serviço de 'auto-ônibus'. O Estado. Florianópolis, 13 set. 1920. p. 6). Ver, também, a respeito, VEIGA, Eliane. Transporte Coletivo em Florianópolis: origens e destino de uma cidade à beiramar. Florianópolis: Insular, 2004. p. 64-66.

${ }^{1067}$ Bondes para o Continente. O Estado. Florianópolis, 12 abr. 1920. p. 8.
} 
seria implementada naquelas estabelecidas no Continente. Desse modo, o serviço de transporte público operado por bondes, se não podemos afirmar que estava em franca expansão - dada, dentre outros motivos, a inauguração do novo serviço de 'auto-ônibus' -, sofria, contudo, claras tentativas para o seu aprimoramento. Cabe ratificarmos, também, que o referido periódico considerou que a eletrificação das citadas linhas prestaria melhoramentos aos serviços já existentes. Vemos, portanto, que havia, naquela época, a manifestação de entusiasmo da imprensa local pela manutenção e/ou reformulação das linhas trafegáveis por bondes.

Um mês após este registro, o mesmo periódico, em data de 20 de maio, volta a noticiar os serviços de eletrificação das linhas de bondes que seriam implementadas no Continente, e destaca, com entusiasmo, que "a notícia de ter sido assinado ontem, no Tesouro do Estado, com a General Eletric, o contrato para a viação elétrica no Continente despertou em toda a cidade as mais vivas demonstrações de júbilo e de alegria”, pois “às dezenove horas reuniu-se grande massa popular defronte ao Café Natal, improvisando-se, desde logo, uma brilhante manifestação de apreço ao Dr. Hercílio Luz, eminente governador do Estado" ${ }^{\text {1068 }}$. Percebemos, novamente, o tom de apoio que o periódico em questão manifestou pelos serviços aventados, uma vez que destacou, para esse fim, as ações tomadas pelo poder público estadual.

Devemos, entretanto, observar que havia, naquela época, manifestações do poder público municipal que também expressavam entusiasmo pela implementação do novo serviço de ônibus na cidade, pois o Projeto n. 13, referido anteriormente, destaca, em 1920, que, de acordo com os responsáveis pela implantação do serviço de auto-ônibus, "É verdade que já temos a Companhia de C. U. e S.; mas esta mantém apenas uma linha da Praça XV de Novembro à Estação Agronômica, o que incontestavelmente não satisfaz as exigências da locomoção para aqueles que, devido aos seus pequenos recursos pecuniários, não podem se dar ao luxo dos automóveis"1069. Essas informações sinalizam - a par do caráter claramente simpatizante ao estabelecimento do novo serviço de ônibus - para a futura concorrência entre a circulação dos bondes e dos coletivos motorizados na cidade de Florianópolis, o que, dentre outros fatores, implicaria, já na década de 1930, na completa desativação dos veículos operados por tração animal. Outro aspecto que podemos perceber é a referência ao alto custo de aquisição dos automóveis na época, ponto que já discutimos no capítulo primeiro da tese (Ver, também, Anexo 19, p. 350). Além disso, o teor do Projeto n. 13 também salienta que a Companhia Carris Urbanos mantinha, ainda em 1920, apenas uma linha de bondes em operação na cidade; aspecto este que retomaremos nas passagens seguintes.

\footnotetext{
${ }^{1068} \mathrm{O}$ contrato para a viação elétrica no Continente: as manifestações do júbilo popular. O Estado. Florianópolis, 20 maio 1920. p. 1.

${ }^{1069}$ Câmara Municipal de Florianópolis. Série: Documentos, Ofícios, Projetos, Pareceres. Projeto n. 13. Concede à Sociedade organizada pelos Srs. Antonio Babitonga Linhares e Julio Nicolau de Moura o direito de uso e gozo, pelo espaço de cinco anos, do serviço de transporte por meio de 'auto-ônibus', dentro do perímetro urbano da Capital. Florianópolis, jul. 1920. Caixa 03.
} 
A convivência simultânea dos bondes e de ônibus pelas ruas do perímetro urbano da cidade de Florianópolis teve reflexos na imprensa e nos órgãos governamentais locais; pois, no ano de 1924, o poder público estadual ainda aventava a possibilidade de contratar "a construção de uma linha de tramways elétricos de Florianópolis a São José, passando pela ponte Independência [Hercílio Luz], e de outras linhas na Capital, dentre elas uma até o lugar Três Pontes, no distrito

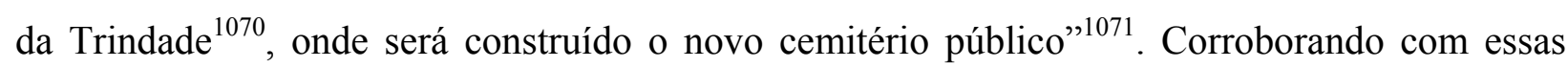
informações, o artigo do jornal $O$ Estado, de janeiro de 1925, considerava que "Afinal, a nossa capital vai ter o desejado serviço de viação elétrica, há muito reclamado pelo povo"; pois, "como houve um certo número de dificuldades a remover no contrato celebrado entre o Estado e o $\mathrm{Sr}$. Byngton, o Sr. Cel. Governador tratou de afastar essas dificuldades no interesse do Estado"1072. Desse modo, "a primeira linha de bondes a construir-se partirá do Estreito à Três Pontes" e "ficará pronta dentro de um ano""1073.

Percebemos, claramente, que a nota jornalística expressa euforia e motivação pela instalação do "serviço de viação elétrica" que, segundo ela, era, inclusive, esperada há muito tempo pelos florianopolitanos. Devemos observar, ainda, que as discussões sobre a eletrificação das linhas trafegáveis por bondes estavam presentes nos veículos de comunicação local impressa, pelo menos, desde o ano de $1919^{1074}$. Destacamos, porém, como já vimos no capítulo terceiro, que o processo de eletrificação das linhas de bonde não se concretizou, pois até a sua completa desativação, ocorrida na década de 1930, esse meio de transporte efetuou-se por tração animal $^{1075}$.

\footnotetext{
${ }^{1070}$ Ver Mapa 02: Perímetro Suburbano e Distritos de Florianópolis - Décadas de 1920 e 1930, disposto no capítulo primeiro da tese. (p. 53). ${ }^{1071}$ OLIVEIRA, Antonio Pereira da Silva. Vice-Governador no exercício do cargo de Governador do Estado de Santa Catarina. MENSAGEM apresentada ao e Congresso Representativo do Estado. Florianópolis, 22 jul. 1924. p. 31.

${ }^{1074}$ Nesse ano, o Relatório da Secretaria da Fazenda, Viação, Obras Públicas e Agricultura dá conta, por exemplo, de que se haveria de instalar, na Ilha, um "sistema de Tramways elétricos" que consiste de duas linhas, "uma linha circular próxima ao Cais, da Rita Maria à Avenida Hercílio Luz" e que atravessaria a cidade "pelas ruas José Veiga, Quintino Bocaíuva, Esteves Júnior, Tenente Silveira, Praça XV de Novembro e terminando no Hospital"; e "uma linha suburbana, partindo da Praça XV de Novembro à Trindade, em uma extensão de 15 quilômetros", sendo de "um metro a bitola do sistema". (Secretaria da Fazenda, Viação, Obras Públicas e Agricultura. Relatório Exercício 1919. Florianópolis, 1. maio 1920. p. 268). De acordo com Eliane Veiga, em “[...] abril de 1919, ressurgiu a discussão sobre a possibilidade de eletrificação das linhas de bondes", aspecto que, segundo aponta a mesma autora, "era debatido desde 1912". (VEIGA, Eliane. Transporte Coletivo em Florianópolis: origens e destino de uma cidade à beira-mar. Florianópolis: Insular, 2004. p. 36). Devemos, porém, salientar que o trecho destacado por essa citação não apresenta, no respectivo livro, qualquer referência à fonte de onde, presumidamente, foi mencionado.

${ }^{1075}$ De acordo com J. D. Needell, citado por Nicolau Sevcenko, "Uma primeira tentativa de instalar um serviço de bonde puxado a burros no Rio de Janeiro foi malsucedida, durando apenas de 1859 a 1864 . Somente em 1868 o novo sistema se firmaria, através da linha que ligava a Cidade Velha ao Flamengo, Botafogo e Jardim Botânico, acompanhando e definindo o eixo da especulação imobiliária e a instalação das residências mais luxuosas. Os bondes elétricos só seriam instalados em 1892”. (NEEDELL, J.D. Belle Époque tropical, p. 46 e p. 182 apud SEVCENKO, Nicolau. A capital irradiante: técnica, ritmos e ritos do rio. In:___. (Org.). História da vida privada no Brasil - República: da Belle Èpoque à Era do Rádio. 5. ed. São Paulo: Companhia das Letras, 2002. p. 650). Sobre esses aspectos, ver, igualmente, FAORO, Raimundo. Machado de Assis: a pirâmide e o trapézio. 4. ed. São Paulo: Globo, 2001. p. 53-66. Para a cidade de São Paulo, pode-se considerar que as primeiras linhas de bondes elétricos foram estabelecidas a partir do ano de 1900. Ver a) VIEIRA, José Luiz. A história do automóvel: a evolução da mobilidade. São Paulo: Alaúde Editorial, 2008. (v. 1. da Pré-história a 1908). p. 255; b) SÁVIO, Marco Antônio Cornacioni. A Modernidade sobre Rodas. São Paulo: EDUC, 2002. p. 18. Os anos de 1892 e 1900 e o intervalo entre 1919 e 1925 correspondem, respectivamente: a) à instalação do serviço de bondes elétricos nas cidades do Rio de Janeiro e São Paulo; b) às tentativas de instalação desse serviço na cidade de Florianópolis. A distância temporal compreendida entre os eventos então tidos nessas cidades, corresponde, aproximadamente, ao espaço que varia entre o máximo de trinta e três e o mínimo de dezenove anos. Considerando-se as devidas proporções urbanísticas entre as cidades de São Paulo, Rio de Janeiro e Florianópolis, atestadas na época, verificamos que os espaços temporais, respectivamente então registrados, não são significativos. Nesse sentido, podemos afirmar que as mudanças e as alterações urbanísticas, apontadas acima, desenrolaram-se dentro de um lapso temporal próximo, o que registra certa sintonia entre elas.
} 
A não concretização do processo de eletrificação das linhas de bondes foi endossada pelas dificuldades enfrentadas para o aumento do capital da Cia. Carris Urbanos e também pelo impacto ocasionado pela Primeira Guerra Mundial (1914-1918), o que implicou no adiamento dos planos que, por fim, nunca se concretizaram. Além disso, automóveis movidos a gasolina já circulavam pela cidade, e o sistema de bondes vinha sofrendo a concorrência, cada vez maior, dos auto-ônibus e as críticas dos usuários, devido à má qualidade dos serviços ${ }^{1076}$, como veremos à seguir.

É importante observarmos que, durante a primeira metade da década de 1920, pontuaram, na imprensa local, notas jornalísticas que chamavam a atenção para as precárias condições dos serviços de bondes puxados a burros, oferecidos na cidade de Florianópolis. Assim, em 18 de abril de 1922, o artigo do jornal $O$ Estado destacava que "Desde ontem pela manhã, foi suspenso mais uma vez, o tráfego do único bonde da Companhia Carris Urbanos, que fazia a linha, também única, da Praça XV de Novembro à Estação Agronômica, por se terem quebrado suas rodas" ${ }^{1077}$. Essa nota apresenta aspectos importantes. Em primeiro lugar, percebemos que os serviços de bondes existentes na cidade de Florianópolis sofriam, à época, paralisações frequentes. No caso aqui relatado, tal paralisação ocorreu "por se terem quebrado" as rodas do veículo, o que nos pode indicar que as ruas e trilhos trafegáveis não se encontravam em bom estado de conservação ou que o próprio serviço de bondes carecia de manutenções; estas, portanto, se existentes, não eram, ao que tudo indica, efetuadas com regularidade. Além disso, o mesmo periódico, que se ocupou em tecer comentários elogiosos às tentativas de proceder-se à eletrificação das linhas de bondes para o Continente, não expressou surpresa em relação à suspensão do tráfego do "único bonde da Companhia Carris Urbanos" que, segundo consta, fazia a única linha em operação na época.

Pelo que percebemos, a Companhia Carris Urbanos mantinha, desde sua inauguração, em 1907, em intervalos anuais específicos, apenas uma linha de bondes em operação - aspecto já sugerido em 1920 pelo Projeto n. 13, anteriormente analisado -, apesar das promessas iniciais para a "construção nos perímetros urbano e suburbano de diversas linhas de bondes de tração animal para passageiros e cargas". ${ }^{1078}$ Esse aspecto reforça o posicionamento de que os serviços de bondes prestados na capital do Estado não deslancharam; notamos que entraram, a partir do ano de 1920, em concorrência com os ônibus.

A par das considerações aqui expressas, devemos mencionar que a Companhia Carris Urbanos se esforçava por implementar novas linhas trafegáveis por bondes, pois a nota do jornal

\footnotetext{
${ }^{1076}$ VEIGA, Eliane. Transporte Coletivo em Florianópolis: origens e destino de uma cidade à beira-mar. Florianópolis: Insular, 2004 . p. 36. 1077 Os bondes. O Estado. Florianópolis, 18 abr. 1922. p. 2.

${ }^{1078}$ RICHARD, Gustavo. MENSAGEM lida na Sessão de Abertura do Congresso Representativo. Florianópolis, 5 ago. 1907. p. 38. Ver, também, VEIGA, Eliane. Transporte Coletivo em Florianópolis... op. cit., p. 37.
} 
O Estado, de 05 de março de 1923, aponta que "foram iniciados hoje, pela Companhia Carris Urbanos, os serviços de instalação de uma nova linha de bondes, ligando a Praça XV de Novembro às imediações do Depósito Hoepcke, na Rita Maria” e acrescenta que, "nessa nova linha, que muito auxiliará o nosso comércio, correrão diariamente, um bonde de cargas e um de passageiros" $" 1079$. Esses aspectos permitem-nos inferir que os serviços de bondes implementados na cidade e a linha trafegável que, segundo indicada pela nota jornalística, seria instalada num futuro próximo, ainda assinalavam, à época, préstimos ao comércio e à população local, pois os bondes estiveram em operação, pelo menos, até o ano de $1934^{1080}$. Apesar disso, a tendência que observamos a partir da década de 1920, é a decadência desse meio de transporte, em substituição à circulação dos coletivos motorizados: os ônibus.

Indicativos a esse respeito podem ser assinalados ao observarmos o que é explanado pelo artigo do jornal $O$ Estado, de 09 de setembro de 1925. Nessa ocasião, o referido periódico registra que "Queixam-se, e com justa razão, certos passageiros que costumam transitar nos bondinhos da companhia Carris [Urbanos], contra o mau estado de um dos carros", que "à força de dar tamanhos trancos e pulos sobre a linha, tem obrigado a diversas pessoas descerem no meio da viagem, pois não podem conter o mal estar que as afligem"1081. O artigo endossa o tom de sua abordagem ao considerar que "Pessoas há, que sentem a impressão de terem feito uma travessia penosa, em mar grosso, quando não se queixam de males piores", e conclui afirmando que "o tal bonde suplício, cujas rodas já não assentam mais nos trilhos, bem poderia ser retirado da linha onde trafega"1082.

Esses aspectos são indicativos de que os serviços de bondes prestados pela companhia Carris Urbanos operavam com dificuldades e aventava-se, inclusive, para a ideia da retirada de circulação do referido veículo. Assim, a nota jornalística em questão permite-nos inferir que os trilhos trafegáveis pelos bondes não se encontravam, à época, em bom estado de conservação, o que nos sugere que a referida companhia apresentava dificuldades financeiras para, então, prover a respectiva manutenção desses trilhos. Percebemos, pois, que, especialmente a partir da segunda metade da década de 1920, começaram a aparecer, na imprensa local, notas jornalísticas que davam conta do estado de conservação das linhas e trilhos trafegáveis pelos bondes, as quais indicavam, inclusive, a possibilidade de retirada dos veículos de circulação. Vimos, ainda, que ,

\footnotetext{
${ }^{1079}$ Nova linha de Bondes. O Estado. Florianópolis, 05 mar. 1923. p. 2.

1080 Ainda em 1924, o artigo do jornal O Estado noticiava que "Avisa-nos a Secretaria da Companhia de Carris Urbanos e Suburbanos, que os carros trafegarão do dia primeiro de abril em diante na linha da Avenida Hercílio Luz à Rita Maria”. (Os Bondes. O Estado. Florianópolis, 26 mar. 1924. p. 3). Isso não quer dizer, exatamente, que a referida companhia inaugurou uma nova linha de bondes, mas, antes, que houve, ao que nos parece, uma alteração no ponto inicial de partida dos bondes, alocados anteriormente na Praça XV de Novembro. Esses dois logradouros da cidade são, inclusive, situados próximos um ao outro, o que nos permite, mesmo, considerar que houve uma alteração na parada inicial dos bondes, determinada pela secretaria da companhia de bondes da Capital.

${ }^{1081}$ Um bonde suplício. O Estado. Florianópolis, 09 set. 1925. s/p.

${ }^{1082}$ Idem.
} 
em 1920, havia apenas uma linha de bondes em funcionamento, da Praça XV de Novembro à Estação Agronômica, mas sofria reclamações quanto à morosidade de deslocamento no trajeto e ao mau estado de conservação dos trilhos, pois, "incontestavelmente", não satisfazia as exigências da locomoção urbana ${ }^{1083}$.

No ano de 1927, verificamos outras manifestações contrárias à circulação dos bondes e à manutenção dos trilhos por onde eles se deslocavam. O artigo do jornal $O$ Estado, de 09 de março, chama a atenção para o fato de que "apresenta lamentável aspecto a linda rua Esteves Júnior cujo calçamento foi em parte removido, a fim de serem arrancados os trilhos da extinta linha de bondes, sem que, até hoje, se ultimasse o devido recalçamento"; mas destaca que "a continuarem as coisas nesse pé, melhor fora que se conservassem os trilhos mortos daquela rua" ${ }^{2084}$. Cinco dias após, em data de 14 de março, o mesmo periódico qualifica os bondes como "antiquado sistema de viação urbana" e evidencia com entusiasmo a desativação de algumas linhas, pois “Das capitais do Brasil, é Florianópolis a única que ainda está no tempo dos 'bondes a burros'; além disso, nem mesmo entre nós, puderam conservar-se alguns dos ramais desse

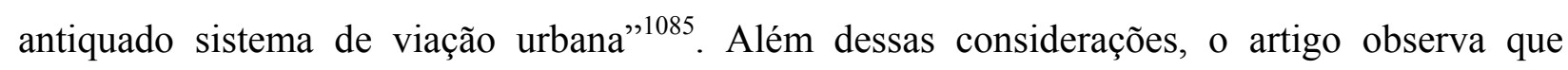
"Extinguiram-se esses ramais, porém os trilhos respectivos continuam encravados em várias ruas, sem préstimo algum, apenas atestando que por ali, outrora, passavam os míseros bondinhos

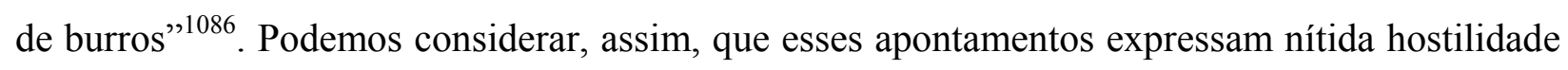
quanto à circulação dos bondes puxados a burros, a ponto de serem qualificados como um "antiquado sistema de viação urbana". Assim, podemos considerar que o descontentamento com a manutenção do serviço de bondes demonstrado pela imprensa local foi, com o passar do tempo, mostrando-se cada vez mais, evidente e enfático.

Os artigos jornalísticos da época também enfatizavam o prejuízo causado pelos bondes à convivência urbana. Isso é o que podemos aventar do teor expresso pela nota publicada pelo jornal $O$ Estado, no dia 11 de abril de 1928, que, na ocasião, referencia o seguinte: a "companhia Carris Urbanos e Suburbanos está ensaiando a adaptação de motor de um caminhão Ford [...] aos antigos bondes, com o fim de dispensar os burros tradicionais"1087. Acrescenta, porém, que "não sabemos como se conseguirá esta adaptação, visto que os bondes que circulam nesta Capital são feitos por tração animal"; contudo, "se não se vai transformar o antigo sistema de burros por outro mais risível, qual o de um inestético carroção, arrastando-se, com ensurdecedor barulho,

\footnotetext{
${ }^{1083}$ Câmara Municipal de Florianópolis. Série: Documentos, Ofícios, Projetos, Pareceres. Projeto n. 13. Concede à Sociedade organizada pelos Srs. Antonio Babitonga Linhares e Julio Nicolau de Moura o direito de uso e gozo, pelo espaço de cinco anos, do serviço de transporte por meio de 'auto-ônibus', dentro do perímetro urbano da Capital. Florianópolis, jul. 1920. Caixa 03.

${ }^{1084}$ Ruas em mau estado. O Estado. Florianópolis, 09 mar. 1927. p. 1.

${ }^{1085}$ Os trilhos ‘mortos'. O Estado. Florianópolis, 14 mar. 1927. p. 2.

${ }^{1086}$ Idem.

${ }^{1087}$ Um novo meio de tração para os bondes. O Estado. Florianópolis, 11 abril 1928. p. 1.
} 
sobre trilhos e puxados por um caminhão, tudo ficará mais ou menos bem"1088. O que "não se poderá deixar sem protesto será a substituição, por um trambolho trovejante de outro a que já nos havíamos habituado, nesta vida de solidão e silêncio provinciano" ${ }^{\text {"1089 }}$.

Em outra passagem desse artigo, são tecidos comentários não simpatizantes à circulação inaugural desse sistema, pois destaca que "algumas pessoas, dentre as que constituíam a pequena e seleta assistência ao concerto do violonista Sr. Wenceslau Schwansee, no Teatro Álvaro de Carvalho, queixaram-se de que o barulho infernal do motor do caminhão não lhes deixou apreciar a segunda parte do concerto"; e, desse modo, ao concluir-se o artigo, é observado que "se a companhia Carris Urbanos e Suburbanos quer fazer a adaptação desse novo sistema nos seus carros, tem, pois, dois problemas a enfrentar: um, a estética dos carros, assim puxados por tratores 'Ford'; outro, o silêncio com que se devem respeitar os nervos do próximo... esteja ele são ou doente, à beira de uma rua por onde passar o pavoroso treme-terra" ${ }^{" 1090}$.

Como podemos observar, o artigo tece comentários contundentes contra o atentado ao silêncio que se deveria manter nas ruas e nos espaços públicos da capital catarinense. De outro modo, podemos verificar que mesmo as tentativas operadas pela Companhia Carris Urbanos para a melhoria e adaptação dos bondes, tentando, no caso aqui referido, substituir os "burros tradicionais" pela alocação, nos veículos, de um motor mecânico, sofriam críticas da imprensa local, pois o artigo em questão considerou que o respectivo "carroção" não deveria arrastar-se "com ensurdecedor barulho" pelos trilhos e linhas. Enfatizamos, ainda, que se deveria cuidar para preservar "o silêncio com que se devem respeitar os nervos do próximo"; e, nesse sentido, a respectiva nota não se mostra simpática à ideia de substituição de um sistema "a que já nos havíamos habituado". Em face às análises expostas até o presente momento, podemos afirmar que, a partir da segunda metade da década de 1920, torna-se cada vez mais comum, na imprensa local, a publicação de notas e apreciações desfavoráveis à manutenção dos serviços de bondes que operavam na cidade de Florianópolis ${ }^{1091}$. Em contraposição, podemos, também, observar que, a partir desse mesmo período, há uma tendência, nos artigos de jornais, em emitir opiniões favoráveis ao fomento e à manutenção do serviço de auto-ônibus.

A esse respeito, devemos observar que, durante os anos 20 do século passado e com maior nitidez a partir do decênio seguinte, introduziu-se, na capital do Estado, o ônibus como

\footnotetext{
${ }^{1088}$ Um novo meio de tração para os bondes. O Estado. Florianópolis, 11 abril 1928. p. 1.

1089 Idem.

${ }^{1090}$ Idem.

1091 Já em 1915, observamos, na imprensa local, notas que se ocupam em comentar o mau estado de conservação dos bondes. Assim, o artigo do jornal $A$ Semana aponta que é "lamentável o estado em que se acham alguns carros dos que, vencidos pelos automóveis, estacionam à Praça XV. Até boleeiros há, que para não destoar da feiúra do veículo, nem usam colarinhos, e mesmo com passageiros dentro, não dispensam o horrível cigarro de palha!”. (Os Automóveis. A Semana. Florianópolis, 24 jan. 1915. p. 2). Sugestiva é a apreciação de que os bondes já estavam, à época, "vencidos pelos automóveis". Além disso, fica clara a campanha em prol das condutas consideradas civilizadas que, via de regra, deveriam ser observadas nos meios urbanos e ao transportar-se passageiros em veículos de praça ou de aluguel.
} 
transporte público alternativo. A primeira linha de ônibus existente em Florianópolis foi, como vimos, implantada no ano de 1920. De acordo com o Projeto n. 13:

Art. $1 .^{\circ}$ - Fica concedida à sociedade organizada pelos Srs. Antonio Babitonga Linhares e Julio Nicolau de Moura o direito de uso e gozo, pelo espaço de cinco anos, do serviço de transporte por meio de auto-ônibus movidos a gasolina ou eletricidade, dentro do perímetro urbano da Capital.

Art. 2. $^{\circ}$ - A sociedade obrigar-se-á: \# I - A iniciar o tráfego dentro de sessenta dias; \# II - A manter o serviço com carros confortáveis, e com pontualidade, segurança e asseio, desde as seis às vinte e duas horas, horário que será prorrogado nos dias de festa; \# IV - A parar o curso em qualquer parte da seção para embarque quando houver lugar desocupado, e para desembarque sempre que for exigido.

Art. $3 .^{\circ}-$ A sociedade gozará, durante cinco anos, ${ }^{1092}$ de isenção de qualquer imposto municipal, tanto para sua individualidade social, como para seus carros, garagens e depósito ${ }^{1093}$.

Art. $4^{\text {o }}$ - Revogam-se as disposições em contrário ${ }^{1094}$.

Durante as décadas de 1920 e 1930, época em que se verifica a convivência simultânea dos bondes e ônibus pelas ruas da Capital, percebemos posições diferenciadas da imprensa florianopolitana quanto à presença e à manutenção dos respectivos serviços. (Figuras 12 e 13, p. 281). Vimos, ainda, que, a partir da segunda metade da década de 1920, é cada vez mais comum o aparecimento de artigos de jornal que se ocupam em tecer comentários depreciativos contra o serviço de bondes oferecido na cidade. $\mathrm{Na}$ mão inversa, verificamos, na imprensa local, uma tendência a expressar, na mesma época, entusiasmo e contentamento quanto ao serviço de autoônibus. Destacamos, porém, que, já em 1920, o artigo do jornal $O$ Estado, de 11 de junho, registra o estabelecimento, "dentro em curto prazo", de um "serviço regular de 'auto-ônibus". Dentre outros aspectos, o artigo destaca as vantagens do novo sistema ao considerar que

Fomos informados de que os srs. Antonino Babitonga e Julio Nicolau de Moura constituíram uma sociedade para exploração, em Florianópolis, de um serviço regular de 'auto-ônibus', idêntico ao existente no Rio e em quase todas as principais cidades da Europa. Os que tiveram a feliz iniciativa do estabelecimento desse serviço pensam em inaugurá-lo dentro de curto prazo e esperam que ele seja recebido com simpatia pela população desta Florianópolis, a qual, é fora de dúvida, os 'ônibus' vem

\footnotetext{
1092 A Emenda ao Projeto n. 13, datada de 05 de julho de 1920, autoriza o estabelecimento da primeira linha de auto-ônibus "nesta capital e seus subúrbios" e concede, para esse fim, a isenção de impostos durante três anos. Ver Comissão de Leis e Posturas. Emenda ao Projeto n. 13. Autoriza o estabelecimento da primeira linha de ônibus da cidade de Florianópolis e concede isenção de impostos à sociedade organizada para este fim pelo prazo de 03 anos. Florianópolis, 05 jul. 1920. O Projeto n. 13 foi datado de 02 de julho de 1920 , portanto, três dias antes da promulgação de sua respectiva emenda. Percebemos, aqui, que a Emenda ao Projeto n. 13 autoriza a exploração do "transporte por meio de autoônibus" não apenas no perímetro urbano da Capital - como então estabelecia o Projeto -, mas, também, em "seus subúrbios".

${ }^{1093}$ De acordo com a Lei 1340, de 20 de agosto de 1920, "Art. 1. - - Fica o Poder Executivo autorizado a conceder isenção de impostos estaduais, durante três anos, a contar da data desta lei, à empresa de auto-ônibus organizada por Julio Nicolau de Moura e Antonio B. Linhares [...]". (Lei 1340, de 20 de Agosto de 1920: concedendo isenção de imposto a prazo à empresa de auto-ônibus organizada por Julio Nicolau de Moura e Antonio B. Linhares. In: Coleção de Leis, Decretos, Resoluções e Portarias de 1920. Florianópolis: Imprensa Oficial, 1920. p. 34-35). A diferença fundamental entre o Projeto n. 13 e a Lei consiste em que esta última reduziu para três anos - conforme já havia sinalizado a Emenda ao Projeto respectivo - o prazo das isenções requeridas. Apesar da isenção de impostos autorizada pelo poder público municipal, o sistema de auto-ônibus era precário e apresentava paralisações decorrentes de problemas financeiros e operacionais. Nesse sentido, é interessante observarmos, um ano após a inauguração do serviço de auto-ônibus, o que registra o artigo do jornal O Estado, datado de 13 de maio; pois, nessa ocasião, afirma que se avisa "ao público que os auto-ônibus só trafegarão aos domingos, dias de festa e feriados, cobrando-se 400 réis por passagem em qualquer percurso, dentro das linhas José Mendes, Avenida Trompowsky, Esteves Júnior e São Luiz”. O tráfego nessas linhas, segundo informado, "não obedece horário" e para "pic-nics, passeios, etc., a Empresa tem sempre à disposição dos interessados dois auto-ônibus que trabalharão [...] a qualquer hora do dia". Por fim, o artigo orientava aos interessados "tratar com Júlio Moura no Café Natal ou com Theodolino Pereira, na garagem da mesma empresa". (Empresa de auto-ônibus. O Estado. Florianópolis, 13 maio 1921. p. 11). O que podemos perceber, a princípio, é que os veículos que faziam as linhas mencionadas apenas trafegariam em datas específicas, portanto, não diariamente. O tráfego desses veículos, segundo consta, também não obedeceria horários, aspecto que entra em desacordo com o que foi estipulado inicialmente para o serviço inaugural de auto-ônibus, no qual os coletivos deveriam circular "com pontualidade". Tais aspectos sugerem que o primeiro sistema de auto-ônibus implementado na Capital operava, desde o seu início, com relativa dificuldade, inclusive quanto ao aventado cumprimento de horários. Dessa forma, foi somente após a inauguração da ponte Hercílio Luz, em 1926, que surgiram empresas e linhas de ônibus que prestavam o serviço com maior regularidade.

${ }^{1094}$ Câmara Municipal de Florianópolis. Série: Documentos, Ofícios, Projetos, Pareceres. Projeto n. 13. Concede à Sociedade organizada pelos Srs. Antonio Babitonga Linhares e Julio Nicolau de Moura o direito de uso e gozo, pelo espaço de cinco anos, do serviço de transporte por meio de 'auto-ônibus', dentro do perímetro urbano da Capital. Florianópolis, jul. 1920. Caixa 03.
} 
prestar um relevantíssimo serviço. Meio de transporte seguro, rápido, barato e cômodo, o 'autoônibus' é, nas grandes cidades, a providência dos que não se podem dar ao luxo dos automóveis. Em Florianópolis, o estabelecimento de um serviço regular de 'auto-ônibus' prestará preciosos serviços a sua população, hoje quase inteiramente privada de meios de transporte baratos e cômodos ${ }^{1095}$.

A citação permite-nos inferir que, antes da inauguração da ponte Hercílio Luz, era premente a necessidade de melhoramentos no sistema de transporte coletivo da Capital, efetuado, majoritariamente, por bondes operados a tração animal. Atestamos, portanto, ideias favoráveis à implementação do serviço de ônibus, expressas pela imprensa da época. A nota jornalística, que aqui destacamos, ocupa-se em realçar que os ônibus, diferentemente dos bondes, configuravam um meio de transporte "seguro, rápido, barato e cômodo", ou seja, podemos pensar que, em sua visão, os novos veículos apresentavam todos os ingredientes para que fossem estabelecidos definitivamente na cidade.

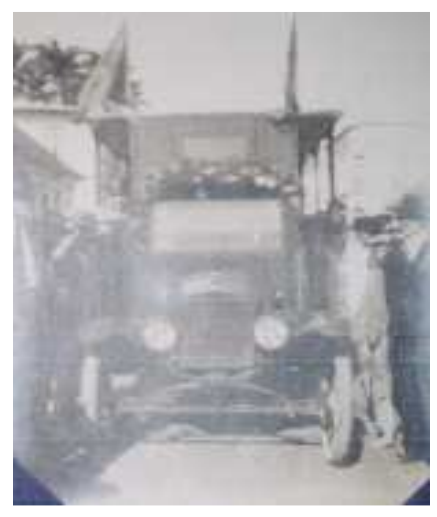

Figura 12 - Foto ilustrando o primeiro ônibus de Florianópolis no momento de sua inauguração - 1920 (parte frontal).

Fonte: Arquivo Histórico da Prefeitura Municipal de Florianópolis.

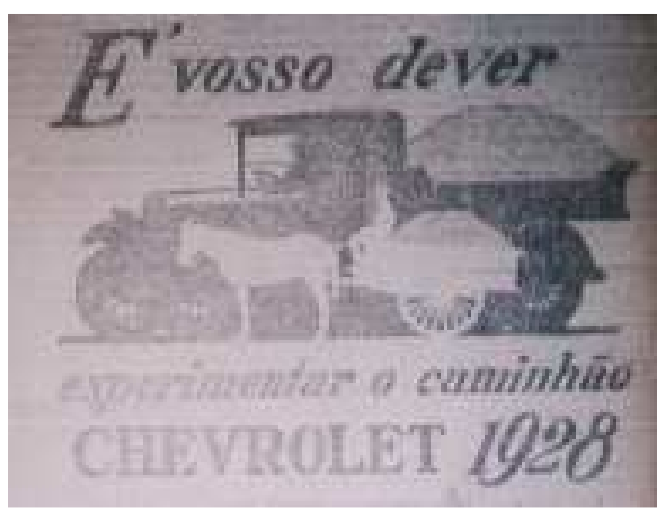

Figura 13 - Caminhão X Carroça - 1928. Observam-se maior segurança e capacidade de carga oferecidas pelo veículo motorizado, frente ao veículo operado com tração animal. Fonte: E' vosso dever experimentar o caminhão Chevrolet 1928. O Estado. Florianópolis, 21 maio 1928. p. 1.

O exemplo dado pela nota jornalística destacada anteriormente, que realça as vantagens do sistema de ônibus, é endossado pelo mesmo periódico nos anos seguintes. Assim, no ano de inauguração da ponte Hercílio Luz, 1926, verificamos que novas empresas já tinham adquirido concessão para operarem no transporte de passageiros pelas ruas da Capital e de cidades próximas. Nesse sentido, o artigo do jornal O Estado, de 21 de maio de 1926, observa que

A Empresa Auto-Viação Corsini contratante dos serviços de transporte de passageiros desta capital para o Continente pela ponte Hercílio Luz, recebeu quatro carros de luxo, envidraçados, apresentando todo o conforto necessário. Os carros têm a lotação para 20 passageiros, resguardando-os do vento e da chuva. Há um mês que [os carros] estavam nas docas de Santos aguardando praça nos navios que se destinavam a este porto. Hoje, os carros fizeram experiência com excelente resultado ${ }^{1096}$.

Um dia após esse registro, o mesmo jornal, corroborando as ideias expressas acima, salienta as vantagens dos novos coletivos, pois destaca que "Convidados, ontem, gentilmente, pela Empresa Auto-Viação Corsini, para assistirmos as experiências dos novos e confortáveis carros que a referida empresa recebeu, comparecemos com muito prazer"1097. Sobre a avaliação

\footnotetext{
${ }^{1095}$ Florianópolis vai ter 'auto-ônibus'. O Estado. Florianópolis, 11 jun. 1920. p. 1.

${ }^{1096}$ Quatro carros de luxo para o serviço da Empresa Corsini. O Estado. Florianópolis, 21 maio 1926. p. 1.

${ }^{1097}$ Os novos carros da Empresa Auto-Viação Corsini. O Estado. Florianópolis, 22 maio 1926. p. 2.
} 
dos veículos, destaca que, “dos quatro carros recebidos, dois porém ontem foram postos à prova. Confortáveis e elegantes, luxuosos mesmo, os novos autos são iguais aos que circulavam na Avenida Paulista"; e "oferecem, além de tudo, absoluta comodidade aos passageiros, resguardando-os da chuva e vento, quando tinham de fazer a travessia desta Capital para o Continente, pela ponte Hercílio Luz, em dias de mau tempo"1098. A nota acrescenta, ainda, que "os auto-ônibus fizeram uma grande excursão, passando pelas ruas principais da nossa cidade, dirigindo-se ao Continente [e] regressando a esta Capital”, ${ }^{1099}$.

As citações aqui referidas indicam-nos que, em época um pouco anterior à inauguração da ponte Hercílio Luz, são organizadas novas empresas para efetuar o transporte de ônibus nas ruas da cidade de Florianópolis e entre a Capital e o Continente próximo. É importante destacarmos que os veículos se encontravam, há “[...] um mês nas docas de Santos aguardando praça nos navios que se destinavam ao porto de Florianópolis". Além disso, salientam as vantagens dos coletivos, considerando-os "confortáveis", "elegantes" e "luxuosos" e que oferecem "absoluta comodidade aos passageiros, resguardando-os da chuva e vento". Acrescem-se a essas vantagens a rapidez e a segurança que ofereciam. Outro aspecto importante diz respeito aos novos veículos, os quais ofertavam maior conforto e segurança, especialmente quando se era obrigado à travessia, pela ponte Hercílio Luz, entre a Ilha e o Continente. Devemos lembrar que, em época anterior à inauguração da ponte, eram comuns os protestos da população sobre as dificuldades na travessia do canal - efetuada por canoas e barcos a remo e também por lanchas motorizadas (Figura 14, p. 283) -; reclamações realçadas, também, na imprensa local ${ }^{1100}$. Tais aspectos nos ajudam a compreender, pois, a completa substituição dos bondes, ocorrida na década de 1930.

No dia 31 de maio de 1926, o mesmo periódico registra as linhas de ônibus e as respectivas taxas de passagem organizadas pela Empresa Catarinense de Auto-ônibus. Essas linhas atendiam aos bairros e cidades continentais próximas à Florianópolis. Assim, temos que essa empresa

\footnotetext{
${ }^{1098}$ Os novos carros da Empresa Auto-Viação Corsini. O Estado. Florianópolis, 22 maio 1926. p. 2.

${ }^{1099}$ Idem.

${ }^{1100}$ Oferecemos, aqui, um exemplo de como a imprensa abordava essa questão, pois, em abril de 1924, a nota do jornal $O$ Estado expressava que “Em nossa edição de segunda-feira, dia 14 do corrente, atendendo diversos pedidos, publicava 'O Estado' a seguinte local: 'Queixas e Reclamações' - Pedem-nos solicitarmos das Empresas de Passagem do Estreito, maior regularidade no serviço de balsas que, segundo fomos informados, está sendo feito de um modo bastante prejudicial aos interessados'. Agora, dois fatos vêm de sedar, sendo que o primeiro ontem à noite e o segundo às onze e trinta de hoje. Ontem, a balsa da empresa de Passagem Soncini tomou, no Estreito, a seu bordo, o automóvel n. 63 e um cavalo do Sr. Braziliano Silveira, para fazer a travessia do canal. Na altura dos Estaleiros Arataca, à Rita Maria, a balsa foi ao fundo por um descuido qualquer, sofrendo bastante com o acidente não só o auto 63, que ficou avariado, como o Sr. Braziliano Silveira, que acompanhado do cavalo, vinha na balsa. Embora isso tivesse acontecido, [...] hoje a referida embarcação continuou a ser utilizada. E um outro desastre ocorreu, mais lamentável que o primeiro. Na Rita Maria, às onze horas, José Tavares, apresentava-se para embarcar umas vacas na balsa da Empresa Soncini. Os referidos animais [...] destinavam-se ao Continente. Nesta ocasião apareceu na Rita Maria o estivador Manoel Jerônimo que, entrando em combinação com José Tavares, tratou logo de auxiliar o serviço de embarque. No entretanto, mal recebera o reboque da lancha de passagem, deu-se um desastre. Uma das vacas, encostando-se ao cercado que rodeava a balsa, fez demasiado peso, derrubando a grade que protegia a embarcação. Como conseqüência disso a vaca caiu no mar, seguindo-se uma natural oscilação da balsa. Espantados com isso, os outros animais, estabeleceu-se para logo grande balburdia, que aumentou o 'jogo' da embarcação. O balseiro e José Tavares seguraram-se como puderam. Manoel Jerônimo, no entretanto, pensando que a balsa fosse ao fundo, atirou-se ao mar, para, depois de alguns minutos permanecer à flor d'água, desaparecer e para sempre. Até a hora de encerrarmos o nosso expediente, ainda não havia sido encontrado o cadáver de Manoel Jerônimo". (Dois Desastres: a morte de um estivador. O Estado. Florianópolis, 16 abr. 1924. p. 3). Como podemos perceber, havia, na imprensa local, reclamações quanto às irregularidades e aos atrasos praticados pelas empresas responsáveis em efetuar o transporte marítimo de cargas e passageiros entre Ilha e Continente, inclusive quanto à falta de segurança que tal transporte proporcionava aos usuários.
} 
efetuava a "Linha de Palhoça" e oferecia, para tanto, "3 viagens ao dia" "1101. Os referidos veículos faziam, ainda, os trajetos da Praça XV à Capoeiras; e daquela a São José ${ }^{1102}$. Adiante, o artigo registra que "esta Empresa, tendo feito encomenda de mais dois carros, tipo chevrolet, pretende manter uma nova linha, da Praça XV à vila de Biguaçú" ${ }^{1103}$. Por fím, a mesma nota salienta a ideia de que os ônibus eram veículos confortáveis e o serviço prestado era, na medida do possível, efetuado com regularidade, pois os "carros da Empresa Catarinense de Auto-ônibus primam pela presteza com que atendem o serviço e pela comodidade que oferecem aos senhores passageiros. Mais barato e mais cômodo" ${ }^{1104}$.

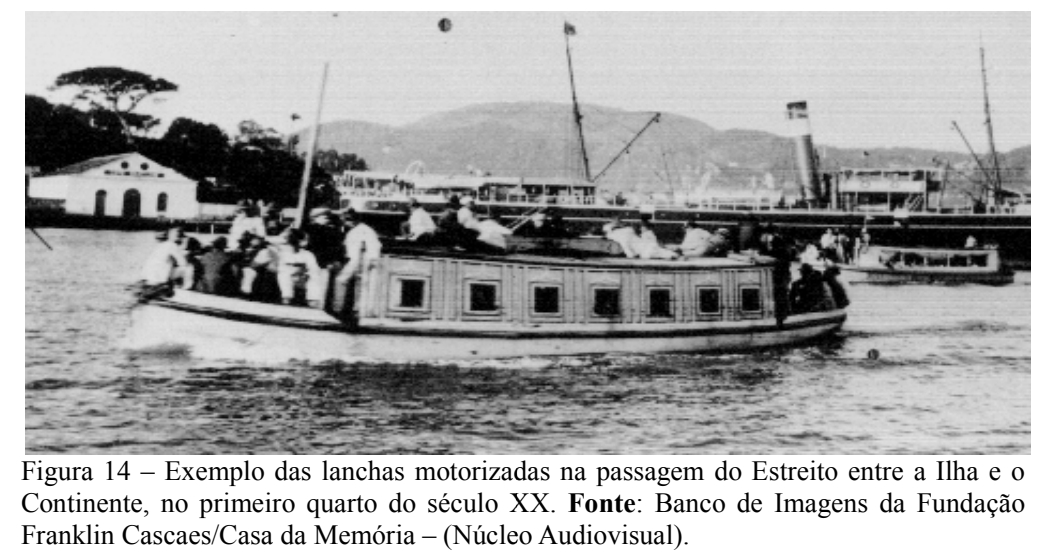

Analisando esses aspectos, é importante destacarmos que existiam taxas de passagem e horários estabelecidos pelas empresas que organizavam o serviço de ônibus. Dessa forma, a "Linha de Palhoça", por exemplo, oferecia três viagens diárias aos passageiros. Outro aspecto que consideramos importante é a possibilidade de abertura de uma nova linha, "da Praça XV à vila de Biguaçú". Como podemos perceber é o serviço de auto-ônibus que, nessa época, está em expansão na cidade de Florianópolis. Além disso, podemos inferir que a população, que residia nas regiões e cidades continentais próximas, deslocava-se frequentemente para a Capital do Estado a fim de, entre outras razões, trabalhar e fazer compras nas lojas comerciais e no Mercado Público. Os ônibus, segundo constatamos, demonstravam ser mais rápidos e seguros que os bondes e os barcos e lanchas que efetuavam a travessia do canal. Nesse sentido, a população optou, gradativamente, pelo novo sistema de transporte.

Esse aspecto é, igualmente, salientado pela seguinte nota jornalística da época, datada de julho de 1928: “A Empresa Auto-Viação Florianópolis está construindo um auto-ônibus para o serviço circular da cidade com lotação para 23 passageiros" "1105. O novo veículo “terá 30 centímetros mais de largura do que o que se acha presentemente em trânsito. Será provido de

\footnotetext{
${ }_{1102}^{1101}$ Empresa Catarinense de Auto-ônibus. O Estado. Florianópolis, 31 maio 1926. p. 5.

1102 Idem.

${ }^{1103}$ Idem.

${ }^{1104}$ Idem.

${ }^{1105}$ Novo ônibus 'Circular'. O Estado. Florianópolis, 28 jul. 1928. p. 2.
} 
motor e chassi 'Novo Ford'. É um melhoramento assinalável"1106. Dado o exposto, vemos que, a partir da segunda metade da década de 1920, torna-se cada vez mais comum surgirem registros jornalísticos que se ocupavam em tecer avaliações e comentários favoráveis à manutenção e ao incremento do serviço e das empresas de auto-ônibus estabelecidas na capital catarinense e em cidades próximas ${ }^{1107}$. Além disso, podemos considerar que, somente após a inauguração da ponte, Florianópolis passou a ter empresas e linhas de ônibus regulares, que atendiam à população na Ilha e no Continente ${ }^{1108}$.

De acordo com a Guia do Estado de Santa Catarina, datado de 05 de setembro de 1927, o transporte de passageiros é feito por automóveis, carros, autocaminhões e bondes de tração animal; e destaca que, à época, já funcionavam algumas empresas de ônibus, pois, dentre outros aspectos, observa que "uma empresa de auto-ônibus mantêm uma linha Circular, com ponto inicial e terminal à Praça XV de Novembro" e "varias outras empresas possuem linhas de autoônibus entre a Praça XV de Novembro e o Estreito, São José, Palhoça e Biguaçú, pela Ponte Hercílio Luz"1109. Dez anos após esse registro, o mesmo texto considera, em 1937, que existiam, naquela época, diversas empresas e linhas de ônibus que atendiam à população residente na Capital e em cidades próximas, quais sejam:

Empresa Auto-Viação Florianópolis: 1) Linha Circular, percorrendo as seguintes ruas: Praça XV de Novembro, Fernando Machado, Avenida Hercílio Luz, José Veiga [Avenida Mauro Ramos], Blumenau, Avenida Trompowsky, Bocaíuva, Esteves Júnior, Álvaro de Carvalho, Felipe Schmidt e Praça XV de Novembro. Horário de 20 em 20 minutos. Preço: 400 réis; 2) Linha Agronômica: de 1/2 em 1/2 hora. Preço: 300 réis; 3) Linha Saco dos Limões: de 1/2 em 1/2 hora. Preço: 500 réis ${ }^{1110}$.

Para os distritos, outras empresas apresentavam, conforme referido, as seguintes linhas:

\footnotetext{
${ }^{1106}$ Novo ônibus 'Circular'. O Estado. Florianópolis, 28 jul. 1928. p. 2.

1107 Apesar disso, surgiam também nesta época registros que se ocupavam em noticiar atropelamentos e colisões ocasionados por ônibus, salientando, inclusive, a falta de segurança dos automóveis e coletivos. O artigo do jornal $O$ Estado, de 30 de abril de 1928, observa que "Hoje pela manhã, como de costume, Francisco Cardoso, empregado na casa do Sr. Felisberto Bonasis, saiu para fazer compras no Mercado Público. Quando regressava, mais ou menos às oito e meia horas [da manhã], ao subir a rua Conselheiro Mafra, pouco além da esquina da rua Padre Roma, foi o infeliz Francisco vítima dum auto-ônibus da Empresa Auto-viação Josefense, o qual era guiado pelo 'chauffeur' Bolislau Estainski e subia a mesma rua. Francisco, que caminhava pelo passeio da rua, ia distraído e não prescindiu o perigo, quando o auto-ônibus, tendo perdido a direção, foi apanhá-lo em cheio, atirando-o ao solo, onde o pobre homem caiu já agonizando, para falecer minutos depois. A polícia compareceu ao local, com o médico-legista Dr. Fernando Wendhausen e o fotógrafo Eugênio Souza, sendo, depois, o cadáver transportado ferido para o necrotério da Polícia Central. O chauffeur Bolislau Estainski, que se apresentou na Polícia Central, onde ficou detido, alega não ser culpado do desastre, visto haver-se deslocado a roda de direção, que se soltou do eixo. De fato, ao que se diz, notava-se já antes do desastre a ausência da porca que firma a roda da direção do ônibus - o que, aliás, depõe contra o zelo profissional do chauffeur, que devia ter imediatamente reparado esta falta. Esse acidente mostra a necessidade que temos de maior vigilância por parte da Inspetoria de Veículos, à cerca do bom funcionamento dos automóveis, a alguns dos quais podem faltar as condições de segurança do próprio trânsito. Seria até conveniente que se responsabilizassem os condutores sob cuja guarda fossem encontrados carros com irregularidades para que, assim, houvesse mais consciência da responsabilidade profissional. Também conviria que os exames de veículos não fossem feitos tão espaçadamente". (Vítima de um ônibus. O Estado. Florianópolis, 30 abr. 1928. p. 2). Vamos às considerações. Em primeiro lugar, não encontramos, nas pesquisas efetuadas no Arquivo Central do Tribunal de Justiça do Estado de Santa Catarina, qualquer menção, se existente, ao processo criminal respectivo. De outro modo, essa nota da imprensa local ocupa-se em tecer considerações quanto à necessidade "do bom funcionamento dos automóveis" e, também, da responsabilidade que deve recair sobre os chauffeurs na conveniente manutenção de seus veículos. Além disso, o artigo chama a atenção para a "necessidade que temos de maior vigilância por parte da Inspetoria de Veículos" que, dentre outros aspectos, deveria promover, com maior regularidade, os "exames de veículos". Outro ponto: se em 1915 a nota do jornal $A$ Semana ocupava-se em tecer críticas ao mau estado de conservação dos bondes; agora, a imprensa local, por meio do artigo do jornal $O$ Estado, tece observações quanto à falta de segurança dos automóveis, "a alguns dos quais podem faltar as condições de segurança do próprio trânsito". Apreciações quanto às "medidas emergenciais da fiscalização do trânsito", especialmente junto ao tráfego efetuado diariamente "sobre a ponte Hercílio Luz" podem ser encontradas no mesmo periódico, em data de 04 de junho de 1928. Sobre isso ver O ônibus da 'Estação Agronômica' perdeu a direção. O Estado. Florianópolis, 04 jun. 1928. p. 1.

${ }_{1108} \mathrm{O}$ artigo do jornal $O$ Estado, por exemplo, noticia, em 1928, que "Os srs. Buattin \& Santos inauguraram, anteontem, uma linha de auto-ônibus para o Pantanal, passando pelo Saco dos Limões”. (Nova Empresa de auto-ônibus. O Estado. Florianópolis, 04 maio 1928. s/p).

${ }_{1109}$ Guia do Estado de Santa Catarina. Rio de Janeiro, 05 set. 1927. p. 218-219.

${ }^{1110}$ Guia do Estado de Santa Catarina: Suplemento para o ano de 1937. Florianópolis: Livraria Central de Alberto Entres, 1937.
} 
Empresa José Dutra: Linha Trindade, de hora em hora. Preço: até Penitenciária 500 réis; até Trindade 600 réis; Empresa José Evaristo: Linha Canasvieiras, desce de manhã e sobe à tarde. Preço: $2 \$ 500$ réis; Empresa Norberto Silva: Linha Ribeirão, 3 vezes por semana; desce de manhã e sobe à tarde. Preço: $2 \$ 500$ réis $^{1111}$.

Por fim, as empresas e linhas que atendiam às localidades no Continente eram as seguintes:

Empresa Taranto \& Cia: Linha Coqueiros - Florianópolis, de hora em hora. Preço 600 réis; Empresa Filomeno \& Cia: Linha São José - Florianópolis, de hora em hora. Horário: desce às $6-7-8-9-10$ $-12,30-14-15-16,30$ e 18 horas; volta às $7-8-9-11-12,20-14,20-16-16,30-17,30$ e 19 horas. Preço: até Estreito 500 réis, até Capoeiras 600 réis; até São José $1 \$ 000$ réis; Empresa Zacchi \& Filhos: Linha Palhoça e Florianópolis. Horário: desce às 6,30-8 - 10,10-11,30-13,30-15,3016,30 e 18 horas; volta às 8,30 - 10,10 - 11,45-13-15-17-18 e 21,30 horas. Preço: até Estreito 500 réis. Capoeiras 600 réis. São José $1 \$ 000$. Palhoça 1\$500; Empresa Ulysses F. Souza: Linha Santo Amaro - Florianópolis. Horário: desce às 7,30, volta às 15 horas. Preço: $6 \$ 000$ réis; Empresa Peixoto: Linha Tijucas - Florianópolis. Horário: chega de manhã e volta às 16 horas. Preço: 6\$000; Empresa Auto-Viação Tijucas, de Pedro Flores: Linha Tijucas - Florianópolis. Horário: chega de manhã e volta às 16 horas. Preço: 7\$000; Empresa Viação Glória: ${ }^{112}$ Preço: até Enseada de Brito 5\$000; até Paulo Lopes: $11 \$ 500^{1113}$.

Nossa intenção, ao apontarmos as considerações tecidas anteriormente, é esclarecer que, na década de 1930, existiam diversas empresas e linhas de ônibus na Ilha e no Continente, em número significativamente maior que as existentes na década anterior. Inferimos esse fato especialmente porque, durante a primeira metade da década de 1920 e, mesmo poucos anos após a inauguração da ponte Hercílio Luz, os ônibus constituíam novidade. Ressaltamos, ainda, que os registros da imprensa da época consideravam que - a par de críticas que, também, já pontuavam nos periódicos -, diferentemente dos bondes, os ônibus "eram elegantes, luxuosos e ofereciam absoluta comodidade aos passageiros, resguardando-os da chuva e vento". Além disso, constatamos que, em 1937, as diversas linhas que atendiam às localidades de Coqueiros, São José e Palhoça ofereciam vários horários de chegada e saída dos veículos. Não constatamos, todavia, esse fato na década de 1920; pois, em 1926, a Empresa Catarinense de Auto-ônibus oferecia, como vimos, da cidade de Florianópolis à de Palhoça, apenas "3 viagens ao dia""1114. Assim, podemos afirmar que foi progressiva a preferência da população de Florianópolis pela utilização do ônibus; aspecto que foi fomentado pela extinção dos bondes na década de 1930 .

É importante observarmos que a preferência da população de Florianópolis pelos serviços de ônibus está relacionada, também, ao custo das passagens. Esse aspecto é especialmente válido

\footnotetext{
${ }^{1111}$ Guia do Estado de Santa Catarina: Suplemento para o ano de 1937. Florianópolis: Livraria Central de Alberto Entres, 1937.

${ }^{1112}$ Essa empresa possuía também as linhas: a) Florianópolis - Laguna; b) Florianópolis - Araçatuba; c) Florianópolis - Mirim; d) Florianópolis Vila Nova; e) Florianópolis - Imbituba. (Guia do Estado de Santa Catarina: Suplemento para o ano de $1937 . . .0 p$. cit).

${ }^{1113}$ Guia do Estado de Santa Catarina: Suplemento para o ano de 1937... op. cit.

${ }^{1114}$ Empresa Catarinense de Auto-ônibus. O Estado... op. cit., p. 5. A esse respeito, o artigo do jornal O Estado, de agosto de 1923 , noticiava, no dia 21 daquele mês, que a Empresa Afonso H. Delembert \& Cia "avisa aos seus [...] fregueses que resolveu reiniciar a linha de ônibus entre Palhoça e Estreito no dia 20 do corrente, obedecendo ao seguinte horário e tabela de preços: Partidas da Palhoça: às 7, 9, 11, 13, 15 e 16 1/2 horas; Partidas do Estreito: às 8, 9, 11, 13, 15 e 16 1/2 horas". (Auto-ônibus. O Estado. Florianópolis, 21 ago. 1923. p. 3). Percebemos que essa empresa oferecia viagens a Palhoça em intervalos aproximados de duas horas. Apesar de disponibilizar, para essa localidade, maior número de viagens e horários do que aquele estipulado, em 1926, pela "Empresa Catarinense de Auto-ônibus", que oferecia apenas " 3 viagens ao dia"; ainda assim está muito aquém da diversidade de horários diários de saída e chegada oferecida à mesma região pela Empresa Zacchi \& Filhos, em 1937; pois, nessa oportunidade, a referida empresa disponibilizava, como visto, viagens em intervalos médios de uma hora e meia, estendendo os horários diários de atendimento, inclusive para as dezoito ou vinte e uma e meia horas. Ver Guia do Estado de Santa Catarina: Suplemento para o ano de 1937. Florianópolis: Livraria Central de Alberto Entres, 1937.
} 
para as pessoas que utilizavam diariamente as linhas Circular e Agronômica, que atendiam preferencialmente às ruas e bairros do perímetro urbano de Florianópolis. Dessa forma, o custo médio das passagens de ônibus era de 400 réis; entretanto, "quando entram os navios no porto, no trapiche da Cia., na Rita Maria, e caso não atraquem, [o transporte é] feito por meio de botes e lanchas a gasolina", e os "preços convencionais" eram assim estipulados: "lanchas a gasolina $2 \$ 000$ por pessoa", isto "quando ficam os navios ancorados perto das Ilhas dos Ratones"; pois, "saindo e atracando no Trapiche Municipal” (Figura 15, p. 286), os preços eram estipulados em “2\$500 por pessoa; ida e volta $5 \$ 000 " 1115$. Notamos que os preços pagos para o transporte em lanchas à gasolina custavam, portanto, em média, cinco vezes mais do que aqueles pagos pelos usuários dos coletivos que circulavam pelas ruas do perímetro urbano da Capital.

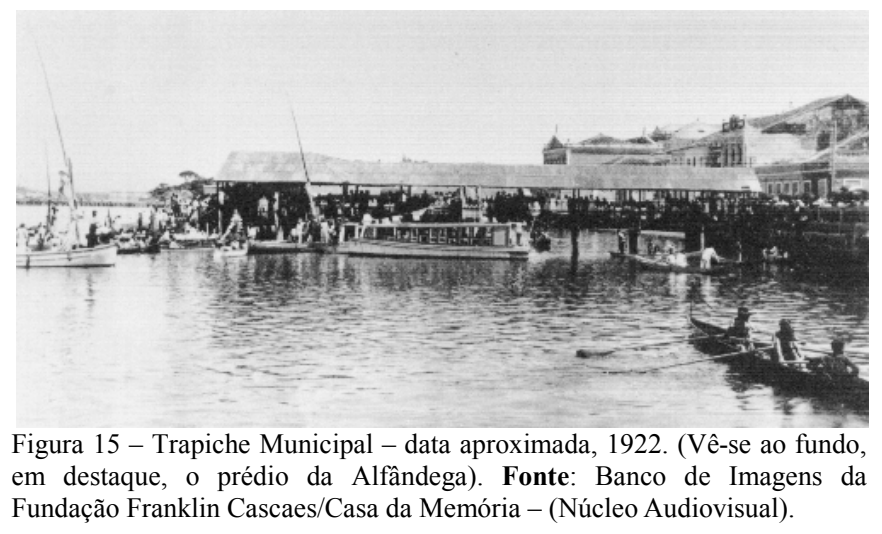

Vimos, em passagens anteriores deste texto, que os bondes puxados por burros eram inexistentes nas ruas da Capital já em $1936^{1116}$. A concorrência com os ônibus, somado às dificuldades enfrentadas pela Companhia Carris Urbanos para manter em operação linhas e veículos, determinaram, em meados da década de 1930, a desativação daqueles serviços. A isso se acrescem as campanhas existentes na imprensa local que, em linhas gerais, ocupavam-se em tecer comentários depreciativos contra o mau estado de conservação dos veículos e linhas; e registravam, também, a suspensão de serviços e, inclusive, queixas e reclamações feitas pelos próprios usuários, como podemos perceber em artigo do jornal $O$ Estado, de setembro de $1925^{1117}$. Nesses termos, arriscamos considerar que uma das últimas manifestações efetuadas pela imprensa local quanto ao serviço de bondes urbanos e aos respectivos protestos populares foi datada de 26 de setembro de 1934.

Nessa oportunidade, a nota do jornal $O$ Estado dava conta de que "ontem, às vinte e trinta horas, um grupo de populares, atraindo avultada assistência de curiosos, avançou contra os bondes da Cia. Carris Urbanos e Suburbanos, que acabava de parar na Praça XV de Novembro"

\footnotetext{
${ }^{1115}$ Guia do Estado de Santa Catarina: Suplemento para o ano de 1937. Florianópolis: Livraria Central de Alberto Entres, 1937.

${ }^{1116}$ Anuário Estatístico do Brasil, ano III, Rio de Janeiro, 1937. p. 291.

${ }^{1117}$ Um bonde suplício. O Estado. Florianópolis, 09 set. $1925 . \mathrm{s} / \mathrm{p}$.
} 
e "desatrelando os muares, o levou ao cais próximo, lançando-o daí abaixo e atando-o fogo""1118. É interessante observarmos que, adiante, a mesma nota considerou que "é inútil fazer comentários", pois o "fato ocorreu a poucas dezenas de metros da Chefatura de Polícia, que, em seu livro de ocorrências policiais, o registrou displicentemente e nestes termos: 'ontem entre às vinte e vinte e trinta horas, um grupo de pessoas, sem distinção de classe, formando um número superior a mil [...], porém com a descida àquela hora, do único bonde da Companhia Carris Urbanos e Suburbanos, ora trafegando, o povo se lançou contra o mesmo desatrelando os respectivos animais, e levando o veículo para o Cais Liberdade, jogando-o ao mar e ateando-o fogo",1119. O artigo considera, ainda, que "não obstante aos esforços empregados pela autoridade, não foi possível evitar a consumação do ato de destruição verificado"; e que, "às vinte e uma horas, o Sr. Braz Florenzano informou pelo telefone à Chefatura de Polícia, que talvez o povo que destruiu o bonde fosse à Estação para incendiá-la" ${ }^{\text {1120 }}$.

Em primeira mão, é importante esclarecermos que as apreciações feitas pela nota jornalística em questão apresentam convergência com as considerações efetuadas pela Chefatura de Polícia. Além disso, notamos que se evidencia, portanto, o total descontentamento do citado grupo de populares quanto à manutenção dos bondes em circulação. Nas pesquisas efetuadas no Arquivo Central do Tribunal de Justiça do Estado de Santa Catarina, onde foram selecionados os processos criminais que referenciam os episódios de atropelamentos e colisões analisados na tese, não encontramos qualquer menção a processos respectivos que referenciem os episódios mencionados no artigo de jornal em apreço ${ }^{1121}$. Por outro lado, essa nota da imprensa local permite-nos especular que, ao menos, boa parcela da população da cidade de Florianópolis já não mais simpatizava com os serviços de bondes oferecidos, pois devemos observar que os

\footnotetext{
${ }^{1118}$ Um bonde destruído por populares. O Estado. Florianópolis, 26 set. 1934. p. 6.

${ }^{1119}$ Idem.

${ }^{1120}$ Idem.

${ }^{1121}$ O primeiro capítulo do título terceiro da Consolidação das Leis Penais, de 1932, trata do "incêndio e outros crimes de perigo comum". O artigo 136 desse capítulo estipula, por exemplo, que "Art. 136 - Incendiar edifício, ou construção de qualquer natureza, própria ou alheia, habitada ou destinada à habitação, ou reuniões públicas, ou particulares, ainda que o incêndio possa ser extinto logo depois de sua manifestação e sejam insignificantes os estragos produzidos: Penas - de prisão celular por dois a seis anos, e multa de 5 a $20 \%$ do dano causado". Esse artigo referencia, ainda, que "Incluem-se na significação dos termos - construção habitada ou destinada à habitação: $1 .^{\circ}-$ Os armazéns; $2 .^{\circ}$ - As oficinas; $3 .^{\circ}$ - As casas de banho e natação; $4 .^{\circ}$ - As embarcações ou navios; $5 .^{\circ}$ - Os veículos de estradas de ferro pertencentes a comboios de passageiros, ou na ocasião de entrar em movimento; $6^{\circ}$ - As casas de máquinas, armazéns e edifícios dos estabelecidos agrícolas". Por outro lado, o artigo 138 especifica que "Art. 138 - Se os edifícios, ou construções, não forem habitados ou destinados para habitação, e não pertencerem ao autor do crime: Penas - de prisão celular por um a três anos e multa de 5 a $20 \%$ do dano causado". É válido observarmos, porém, o que determina o artigo 147, pois referencia que "Art. 147 - O incêndio de coisas não compreendidas neste Capítulo será regulado pelas disposições que se aplicam ao dano”. (PIERANGELI, José Henrique. Códigos Penais do Brasil: evolução histórica. 2. ed. São Paulo: Revista dos Tribunais, 2004. p. 349). Nesses termos, devemos observar que o artigo 55 das Instruções Regulamentares para o serviço de trânsito público, de 1928, estipula, quanto aos "Acidentes e Infrações", que "Art. 55 - O soldado que estiver de ronda ou de serviço no local em que se verificar uma infração destas instruções ou do Regulamento em vigor, ou qualquer acidente, deverá imediatamente intervir e comunicar o fato à Inspetoria de Veículos". (Santa Catarina. Instruções Regulamentares para o serviço de trânsito público. Florianópolis: Imprensa Oficial, 1928. p. 12). Entendemos que os artigos e determinações aqui estipulados são apenas elementos referenciais que nos ajudam a compreender quais penalidades poderiam ter sido aplicadas aos citados responsáveis pelo incêndio causado ao bonde e à aventada possibilidade de incineração da Estação de bondes da Companhia Carris Urbanos e Suburbanos, mencionados na nota jornalística em questão (*). Não podemos, todavia, certificarmos que tais penalidades foram aplicadas ou mesmo se a legislação de trânsito estadual ou o Código Penal de 1932 estipulavam penas específicas para essas atitudes. Assim, os elementos legais aqui mencionados podem, no máximo, fornecer-nos uma ideia de como as legislações penal e de trânsito vigentes tratariam tais práticas, se as mesmas tivessem, efetivamente, sido alvo de processo criminal.
}

(*) Não encontramos, nos dias subsequentes, qualquer menção nos jornais $O$ Estado, República e $A$ Gazeta, a respeito desses episódios. 
envolvidos no ocorrido formavam "um grupo de pessoas, sem distinção de classe" e que eles não apenas desatrelaram os animais, como lançaram ao mar o veículo, "ateando-o fogo".

As considerações feitas até aqui nos permitem tirar algumas conclusões quanto à posição corrente da imprensa local frente à manutenção dos serviços de bondes e ônibus? Bem, cremos que tal objetivo é por demais pretensioso. É possível, porém, vislumbrarmos alguns indicativos a este respeito. Em primeira mão, cabe-nos observar que as análises feitas às mensagens de governo datadas do início da década de 10 do século passado dão conta de que os órgãos governamentais locais expressavam claro entusiasmo quanto à manutenção do serviço de bondes, pois apontavam, inclusive, para a ampliação das linhas trafegáveis, as quais, segundo consta, atendiam "às principais exigências da viação urbana"1122. É importante observarmos, também, que, pelo menos desde o ano de 1919, verificam-se, nos veículos de comunicação local impressa, noticiários e campanhas favoráveis à eletrificação das linhas de bondes, especialmente aquelas que seriam instaladas na Ilha ou mesmo que demandavam às localidades no Continente.

Quanto ao serviço de auto-ônibus, notamos que aparecem, na imprensa local, a partir do ano de 1920 e, especialmente, a partir da segunda metade desse decênio, apreciações favoráveis à implementação de serviços e linhas relacionadas aos coletivos motorizados. Isso é especialmente válido quanto à apreciação referente à inauguração de linhas e companhias que explorariam, portanto, aqueles serviços. Paralelamente, porém, não faltam, nessa época, nos periódicos locais, avaliações quanto aos problemas enfrentados pelas primeiras sociedades organizadas para a exploração dos serviços de auto-ônibus.

O que, talvez, possamos argumentar com maior propriedade é que, a partir da segunda metade da década de 1920, aparecem, com maior frequência, notas e comentários depreciativos quanto à manutenção dos serviços de bondes prestados, na cidade, pela Companhia Carris Urbanos. Os artigos jornalísticos analisados a partir dessa época traçam, sem dúvida, avaliações claramente negativas quanto às tentativas de manter-se em atividade um serviço que "nem mesmo entre nós puderam conservar-se alguns dos ramais desse antiquado sistema de viação urbana”, pois “das capitais [...] do Brasil, é Florianópolis a única que ainda está no tempo dos 'bondes a burros" ${ }^{\prime 1123}$. Desse modo, o maior conforto e comodidade, oferecidos pelos ônibus, acrescida à gradual oferta de maiores linhas e horários e, igualmente, às dificuldades para a travessia do canal efetuada por barcos e lanchas à gasolina, fizeram desses serviços os preferidos pela população florianopolitana; preferência esta que, a partir da segunda metade da década de 1920, também se fez sentir, com muita propriedade, na imprensa local.

\footnotetext{
${ }^{1122}$ RAMOS, Vidal de Oliveira. MENSAGEM apresentada ao Congresso Representativo do Estado. Florianópolis, 23 jul. 1911. p. 56.

${ }^{1123}$ Os trilhos mortos. O Estado. Florianópolis, 14 mar. 1927. p. 2.
} 


\subsection{Conflitos e Disputas: os coletivos motorizados pedem passagem}

Qualquer invenção ou novidade técnica demanda, em seus primeiros tempos, resistências ou posicionamentos nem sempre simpáticos, sejam eles expressos, verbalmente, por ideias, sejam por comentários entre amigos e vizinhos ou, mesmo, nas ruas e espaços públicos, entre pessoas desconhecidas e, também, entre colegas de trabalho. Esse debate pode se dar, também, e com maior fervor, entre os veículos de comunicação local de uma dada cidade ou região.

Tendo isso em vista, verificamos que, no decorrer das três primeiras décadas do século XX, os periódicos e órgãos governamentais do Estado e da cidade de Florianópolis apresentaram posicionamentos ora contrários, ora a favor da manutenção dos serviços de bondes e ônibus na Capital. Vimos na seção anterior, discussões e abordagens quanto ao posicionamento da imprensa local referente ao fomento e à manutenção desses serviços. Na presente seção, ampliamos essa análise ao investigarmos, especialmente, as discussões expressas entre os principais veículos de comunicação mantidos pelos órgãos governamentais locais, conferindo especial atenção ao teor e ao conteúdo expressos em relatórios e mensagens de governo. Pretendemos, pois, verificar que, além da imprensa florianopolitana, também a esfera governamental do Estado e de sua Capital estava atenta ao incremento automobilístico havido na cidade; e que, por intermédio da introdução gradativa dos coletivos motorizados em Florianópolis, expressou, de maneira também gradativa, apoio e favorecimento à incrementação dos serviços de ônibus, em detrimento daqueles oferecidos pelos bondes.

O favorecimento aos serviços de ônibus oferecidos na cidade de Florianópolis, expresso com maior nitidez pelos órgãos governamentais locais a partir segunda metade da década de 1920, não ocorreu sem antes verificarem-se, nesses meios, choques e disputas discursivas favoráveis ou contrárias ao fomento e à manutenção daqueles serviços. Assim, objetivamos destacar que a preferência pelo serviço de transporte coletivo motorizado não foi aceito sem conflitos ou disputas de interesses financeiros e/ou discursivos. Atentamos, portanto, para o seu caráter político e conflituoso. Assim, tais discussões são temperadas com as análises paralelas efetuadas nos artigos e notas jornalísticas locais.

Nesta parte do texto, analisamos, também, o processo n. 183, de 11 de janeiro de 1932, que referencia o atropelamento da menor Rosa Tomázia Vidri, de sete anos de idade, ocasionado pelo chauffeur José Arcênio Freitas, condutor do automóvel n. 244A. A análise desse processo criminal objetiva estabelecer uma melhor conexão do presente texto com os outros capítulos da tese, pois, sem esquecer as amarras e ligações com os objetivos traçados para essa seção, pretendemos reforçar a ideia da crescente presença do automóvel pelas ruas da capital catarinense - já que se trata de um episódio de atropelamento causado a um indivíduo menor de 
idade e, nesses termos, deixa mais clara e evidente a imposição da tecnologia motorizada -, o que corrobora com o posicionamento corrente, verificado nos órgãos governamentais locais, em oferecer-se apoio ao incremento do transporte motorizado - particular ou coletivo - na cidade de Florianópolis.

O fomento ao transporte público efetuado por veículos motorizados na Capital torna-se mais evidente entre os órgãos governamentais locais a partir da segunda metade da década de 20 do século passado. Vale, entretanto, observarmos que, pelo menos desde os anos de 1914/1915, o governo do Estado assinala que "um dos maiores obstáculos ao nosso rápido desenvolvimento é, sem dúvida alguma, a falta de estradas de ferro", pois as "linhas atualmente em tráfego não correspondem às necessidades do comércio ou por sua pequena extensão ou por suas condições técnicas"; e, desse modo, observa o mesmo texto que a "extensão da nossa pequena rede ferroviária em tráfego, dentro do nosso Estado, é de 877,371 quilômetros" "1124. Assim, as dificuldades aqui alentadas são corroboradas pela observação de que a "receita bruta" das quatro empresas que operavam no Estado foi, em 1914, “de 3.759:751\$933 [três mil setecentos e cinquenta e nove contos setecentos e cinquenta e um mil e novecentos e trinta e três réis] e a despesa de 4.199:945\$390, havendo, pois, um déficit de 440:191\$457"1125. Por outro lado, “à pobreza da nossa viação férrea, possuímos uma grande rede de estradas de rodagem e de cargueiros, em cuja construção, reconstrução e conservação, o Estado tem aplicado milhares de contos de réis" $" 1126$.

Essas considerações são importantes. Vimos, na seção anterior, que, até pelo menos a primeira metade da década de 1920, transpareceram nas notas jornalísticas locais, observações de apoio à eletrificação das linhas de bondes em Florianópolis; e, somente a partir da segunda metade daquele decênio, observamos, com maior nitidez, comentários e avaliações positivas quanto à implementação dos ônibus na cidade. Assim, na mesma época em que se observam, dentre os órgãos governamentais locais, notas que realçam as dificuldades da organização ferroviária no Estado, e dos investimentos feitos na rede de estradas de rodagem, transparecem, nos artigos jornalísticos da Capital, mensagens de apoio à eletrificação dos bondes que, caso concretizada, possibilitariam aos veículos circularem sobre trilhos de ferro. Além disso, vimos que, a partir da segunda metade da década de 1920, houve, na imprensa local, paralelamente ao fomento do serviço de auto-ônibus, notas e apreciações que se ocupavam em noticiar atropelamentos e colisões ocasionados por coletivos motorizados, as quais salientavam,

\footnotetext{
${ }^{1124}$ PINHO, João Guimarães. [Presidente do Congresso Representativo, no exercício do cargo de Governador]. MENSAGEM apresentada ao Congresso Representativo do Estado. Florianópolis: Gab. Tip. D’ O Dia, 29 jul. 1915. p. 18.

${ }_{1125}$ Ibidem, p. 19.

${ }^{1126}$ Idem.
} 
inclusive, a falta de segurança deles ${ }^{127}$. Queremos, pois, atentar para o aspecto dinâmico e conflituoso que assumiram as posturas teóricas e discursivas, perpassadas na imprensa e órgãos governamentais locais, quanto à manutenção e ao fomento aos serviços de bondes e ônibus em Florianópolis e à incrementação das redes ferroviária e rodoviária no Estado.

O incremento ao transporte rodoviário, em Santa Catarina e em sua Capital, fica evidente ao observarmos a Mensagem apresentada ao Congresso Representativo do Estado, em 22 de julho de 1920, pois destaca que "até a presente data, o número de quilômetros de estradas de rodagem em construção eleva-se a 1.350, cujo custo foi orçado em 7:340:000\$000 (sete mil trezentos e quarenta contos)" $" 1128$. O texto da mensagem observa, ainda, que "evidentemente, o Estado com o simples recurso de suas rendas ordinárias não poderia dispor de soma tão elevada; graças, porém, ao aproveitamento de valores que, em absoluto não convinha deixar inativos, conseguimos contratar a construção de tão considerável número de novas vias de comunicação" "1129. Complementando essas observações, destaca o mesmo texto que "assim é que quase $50 \%$ do valor total das novas estradas deverá ser pago em terras devolutas", pois "cumpre ainda notar que tal extensão se refere apenas às que estão sendo construídas conforme o novo regulamento ${ }^{1130}$, que exige condições técnicas compatíveis com um intenso tráfego de automóveis" $" 1131$.

Dessas passagens, é importante observarmos que, até o ano de 1915, "numa estatística organizada pelo Dr. Secretário Geral”, foram “constatados 8.873,155 quilômetros de estradas, sendo 4.777,455 de rodagem, e 4.095,700 de cargueiro"1132. Desse modo, o Estado apresentava, no início da década de 1920, uma extensão aproximada de dez mil quilômetros de estradas de rodagem ${ }^{1133}$. Em contrapartida, nessa mesma época, o governo do Estado assinalava, em 1920, a possibilidade da construção de "uma estrada de ferro com bitola de $1^{\mathrm{m}}$, 44, que partindo do porto da Ilha de Santa Catarina, vá, pela ponte projetada ${ }^{1134}$, até o Estreito, daí até São Pedro de

\footnotetext{
${ }^{1127}$ Ver, por exemplo, o seguinte artigo: Vítima de um ônibus. O Estado. Florianópolis, 30 abr. 1928. p. 2, já apresentado neste texto, na nota 1107 , p. 284.

${ }^{1128}$ LUZ, Hercílio Pedro da. Vice-Governador, no exercício do cargo de Governador do Estado de Santa Catarina. MENSAGEM apresentada ao Congresso Representativo do Estado. Florianópolis, 22 jul. 1920. p. 37.

${ }^{1129}$ Idem.

${ }_{1130}$ A esse respeito, a mesma mensagem observa que "a fim de uniformizar os serviços de construção das novas estradas de rodagem, foi elaborado um regulamento onde se encontram as instruções necessárias para os estudos, projetos e respectivas construções. Este regulamento foi aprovado pelo decreto n. 31, de 19 de agosto de 1919. Ver LUZ, Hercílio Pedro da. Vice-Governador, no exercício do cargo de Governador do Estado de Santa Catarina. LUZ, Hercílio Pedro da. Vice-Governador, no exercício do cargo de Governador do Estado de Santa Catarina. MENSAGEM apresentada ao Congresso Representativo do Estado. Florianópolis, 22 jul. 1920. p. 35.

${ }^{1131}$ LUZ, Hercílio Pedro da. Vice-Governador, no exercício do cargo de Governador do Estado de Santa Catarina. MENSAGEM apresentada ao Congresso Representativo do Estado, 1920... op. cit., p. 38.

${ }^{1132}$ PINHO, João Guimarães. [Presidente do Congresso Representativo, no exercício do cargo de Governador]. MENSAGEM apresentada ao Congresso Representativo do Estado. Florianópolis: Gab. Tip. D’ O Dia, 29 jul. 1915. p. 19.

${ }^{1133}$ LUZ, Hercílio Pedro da. Vice-Governador, no exercício do cargo de Governador do Estado de Santa Catarina. MENSAGEM apresentada ao Congresso Representativo do Estado, 1920... op. cit., p. 37.

${ }_{1134}$ Ponte Hercílio Luz. Aqui é importante observarmos que os engenheiros Oscar Machado da Costa e Mário de Faria Bello apresentaram, em abril de 1926, ao término dos trabalhos de inspeção da ponte, um minucioso relatório ao governo do estado de Santa Catarina. Nesse relatório, fez-se um estudo de todas as peças e fundações e concluiu-se, dentre outros aspectos, que "1 - O projeto apresentado foi elaborado de inteiro acordo com a melhor técnica moderna e calculada com grande precisão; 2 - Este projeto, aprovado pelo Governo do Estado, foi fielmente executado pelos contratantes, quer na parte metálica, quer nas alvenarias; 5 - Tomando por base a qualidade do material especificado no projeto, poderão trafegar sobre a ponte, com perfeita segurança, as sobrecargas mencionadas [...] abaixo: a) um trem de bitola de 1 metro, composto de
} 
Alcântara, em direção ao vale do rio das Perdidas, descendo este rio e passando por Angelina, até alcançar o vale do rio Garcia" ${ }^{1135}$. Essa estrada de ferro percorreria, segundo o contrato assinado, outras localidades do Estado.

Não podemos afirmar, neste espaço, se essa via foi, efetivamente, concluída, apesar de o governo estadual ter estipulado no referido contrato, assinado a 28 de maio de 1920, "o prazo de três meses para a apresentação dos estudos de reconhecimento dos primeiros 200 quilômetros"; estudos estes que "permitirão fixar os principais pontos de passagem da estrada e marcar as seções para a apresentação dos estudos definitivos"1136. Apesar das considerações sobre a ponte Hercílio Luz, não foi verificado, pelo que sabemos, qualquer registro da passagem de trens ou locomotivas ${ }^{1137}$. Assim, podemos considerar que o governo do Estado conferia, de fato, preferência ao transporte rodoviário, pois, dentre outros aspectos, assinalava, como vimos, que as terras devolutas constituiriam, já em 1920, parte importante do pagamento "do valor total das novas estradas", que, construídas "de acordo com o novo regulamento", deveriam atender o “intenso tráfego de automóveis"1138. Além disso, devemos observar que, por volta de 1915, a já referida pequena extensão da rede ferroviária em tráfego somava, até aquele ano, apenas 877,371 quilômetros. Acrescentamos, a esse aspecto, a respectiva dívida acumulada pelas quatro empresas que, então, exploravam a viação férrea no Estado ${ }^{1139}$.

Os incentivos ao transporte rodoviário no Estado se fizeram sentir, a partir da segunda metade da década de 10 do século passado, de maneira contínua e crescente. Assim é que, ainda na esfera estadual, podemos observar o que destaca a Mensagem apresentada à Assembleia Legislativa de Santa Catarina, em 16 de julho de 1937. Naquela oportunidade, o então governador do Estado, Nereu Ramos, observou que "teve o governo de iniciar, no ano passado, a reconstrução de várias estradas, devido ao seu mau estado de conservação"; acrescenta, porém, que "este trabalho continua metodicamente", pois "as obras de arte, projetadas dentro do maior

uma locomotiva elétrica de 50 toneladas, seguida por vagões de 30 toneladas; b) uma fila de auto-caminhões de 6 toneladas; c) pedestres à razão de $300 \mathrm{~kg} / \mathrm{m}^{2}$, ou seja, cerca de 4 pessoas em cada metro; d) um encanamento de água, com um peso máximo de $650 \mathrm{~kg}$ por metro corrente". O relatório considera ainda que, "6 - Estas sobrecargas não poderão ser excedidas, em hipótese alguma, visto os coeficientes de trabalho já terem atingido os limites permissíveis". (Ponte Hercílio Luz. Relatório. Apresentado ao Governo do Estado de Santa Catarina pelos Engenheiros Oscar Machado da Costa e Mário de Faria Bello. Rio de Janeiro, 23 abr. 1926). Como podemos observar, foi estipulada a possibilidade do tráfego de trens sobre a ponte.

${ }^{1135}$ LUZ, Hercílio Pedro da. Vice-Governador, no exercício do cargo de Governador do Estado de Santa Catarina. MENSAGEM apresentada ao Congresso Representativo do Estado . Florianópolis, 22 jul. 1920. p. 43-44.

${ }^{1136}$ Idem.

1137 Em entrevista concedida a mim, em 14 de maio de 2002, o engenheiro da CASAN, Paulo Ricardo Caminha, considerou, naquela oportunidade, que "[...] existia um projeto para escoamento da produção utilizando um trem que iria até Santo Antônio de Lisboa. Ali tem um posto fiscal, na ponta do Sambaqui. E a informação que eu tenho é que essa linha de trem iria até lá, e passaria pela ponte para escoar a produção. Só que isso nunca foi concretizado. Nunca chegou a passar trem pela ponte". CAMINHA, Paulo Ricardo. Entrevista concedida a Sandro da Silveira Costa. (Impressa). Florianópolis, Santa Catarina, 14 maio 2002. Transcrita por Sandro da Silveira Costa. Biblioteca particular do autor. Essa entrevista encontra-se, também, anexa ao seguinte texto: COSTA, Sandro da Silveira. Ponte Hercílio Luz: mutações urbanas em uma cidade insular (1890-1960). Dissertação (Mestrado em História). Florianópolis: UFSC, 2002.

${ }_{1138}$ LUZ, Hercílio Pedro da. Vice-Governador, no exercício do cargo de Governador do Estado de Santa Catarina. MENSAGEM apresentada ao Congresso Representativo do Estado. Florianópolis, 22 jul. 1920. p. 38.

${ }^{1139}$ Essas quatro empresas são as seguintes: a) Tereza Cristina; b) Santa Catarina; c) São Paulo-Rio Grande, e d) São Francisco. Ver PINHO, João Guimarães. MENSAGEM apresentada ao Congresso Representativo do Estado. Florianópolis: Gab. Tip. D’ O Dia, 29 jul. 1915. p. 19. 
rigor técnico, orientam-se no sentido da padronização dos tipos, visando economia de tempo e despesas" "1140. É importante observarmos, também, que essas vias "são calculadas para suportar carga móvel até dez toneladas e carga uniformemente distribuída até 400 quilos por metro quadrado", pois "a intensificação do movimento nas nossas principais estradas tem forçado a reconstrução imediata de inúmeras obras de arte, visto que as primitivas haviam sido calculadas para o tráfego de carretas, e não para caminhões com toneladas de peso"1141.

Dessas considerações, o que podemos observar é que, durante a década de 1930, configurase uma preocupação central com a integração do Estado e do País ${ }^{1142}$, fruto da política centralizadora do governo Vargas - conforme já discutimos no capítulo terceiro da tese - que nomeou Nereu Ramos como interventor do Estado, em 1937, com a instituição, a partir de 10 de novembro daquele ano, do regime estado-novista. Essa tendência à centralização estatal esteve, porém, presente no governo Vargas desde o golpe de 1930, pois “[...] o programa que orientou” esse movimento "denunciou o caráter liberal do regime anterior e referenciou-se nos princípios do fortalecimento do Estado, construção da nacionalidade e aperfeiçoamento dos dispositivos de intervenção na sociedade"1143. Assim, para ampliar o controle sobre "[...] atividades sociais e sobre a população, foi reforçada uma tendência estatizadora, que marcou a história política e social brasileira nos anos posteriores", e que atingiu seu ápice por conta da adoção, a partir de 1937, do Estado Novo ${ }^{1144}$. Além disso, fica evidente, a partir do mesmo decênio, o apoio dado ao rodoviarismo, pois a intensificação do tráfego de automóveis e caminhões, segundo apontado no trecho da Mensagem referida, forçou o governo estadual a reconstruir, de maneira imediata, inúmeras estradas que, em princípio, não haviam sido calculadas para o tráfego de "caminhões com toneladas de peso".

O fomento ao transporte rodoviário foi também verificado - como, aliás, já observamos -, na esfera da capital do Estado. Os automóveis começam a circular já a partir da década de 10 do século passado. Já os coletivos motorizados são introduzidos, na cidade, também de maneira gradual, mas aparecem com maior força a partir da segunda metade da década de 1920. Dado o exposto, não é nenhum absurdo considerarmos que os veículos motorizados tenham tomado conta, nas décadas seguintes, das ruas e avenidas da cidade, restringindo o espaço destinado à circulação de pedestres e bondes tracionados por força motriz animal. A esse respeito, o

\footnotetext{
${ }^{1140}$ RAMOS, Nereu. MENSAGEM apresentada á Assembléia Legislativa de Santa Catarina. Florianópolis, 16 jul. 1937. p. 81.

${ }^{1141}$ Idem.

${ }^{1142}$ Nesse sentido, devemos observar que a mesma mensagem, aqui discutida, observa, em outra parte, que "o sexto Congresso Nacional de Estradas de Rodagem, reunido na Capital Federal em novembro do ano passado, consagrou o esforço catarinense no sentido do desenvolvimento do plano rodoviário estadual". (RAMOS, Nereu. MENSAGEM apresentada á Assembléia Legislativa de Santa Catarina, 1937... op. cit., p. 74-75). A esse respeito, vimos no capítulo terceiro da tese que a preocupação central do "plano rodoviário" era, de fato, promover a integração do Estado por meio da construção de novas estradas e rodovias e da melhoria daquelas já existentes.

${ }^{1143}$ CAMPOS, Cynthia Machado. A Política da Língua na Era Vargas: proibição de falar alemão e resistências no Sul do Brasil. Campinas: UNICAMP, 2006. p. 39.

${ }^{1144}$ Idem.
} 
Relatório do prefeito Mauro Ramos, apresentado ao Interventor Federal no Estado, no ano de 1937, observa, com muita propriedade, que a capital do Estado é uma "cidade antiga e, portanto, com ruas mal alinhadas"1145. Desse modo, "requer um vasto plano de urbanismo”, porém, “a exigüidade dos recursos não nos permite, desde logo, resolver o problema" ${ }^{\not 146}$. Nesse sentido, o relatório aponta que "as artérias centrais merecem cuidado especial", pois "ali as condições já não satisfazem as exigências do trânsito, com o grande desenvolvimento que tem tomado os meios de transporte motorizados"1147 e, com "o movimento sempre crescente do nosso comércio, localizado em sua maior parte, nas ruas Conselheiro Mafra e Felipe Schmidt, e em cujos trechos, devido à pouca largura das ruas, é quase impossível o trânsito em certas horas do dia"1148.

As soluções apresentadas envolviam a compra, pela Prefeitura, de prédios existentes na parte central da cidade, especialmente "entre as ruas Deodoro e Jerônimo Coelho que estavam, aliás, fora do alinhamento"1149. Em vista disso, um processo de desapropriação dessas edificações foi lançado para tentar resolver o problema da mobilidade urbana que, àquela época, já era apontado pelo poder público municipal ${ }^{1150}$. Para auxiliar nesse objetivo, foram também estabelecidos acordos "entre a Prefeitura e os proprietários dos prédios situados na rua Conselheiro Mafra cujas as partes frontais encontravam-se fora do alinhamento". Nesse sentido, tencionava-se que elas fossem modificadas, a fim de fazer-se "platibanda em todos" os edifícios, "recuando-os para o alinhamento"1151. Por fim, o relatório ocupa-se em considerar que "tais obras [...] muito melhorarão as condições das ruas mencionadas" $" 1152$.

Diante desse quadro, o que nos interessa observar é que a própria administração municipal assinalava para o problema do alinhamento e calçamento das ruas que, ante o desenvolvimento dos meios de transporte motorizados, já não ofereciam livre fluência ao tráfego, especialmente

\footnotetext{
${ }_{1146}^{1145}$ RAMOS, Mauro. Relatório. Apresentado ao Sr. Interventor Federal no Estado. Florianópolis, 1937. p. 19-21.

${ }^{1146}$ Idem.

${ }^{1147}$ Dez anos antes dessa observação, o Relatório do exercício de 1929, elaborado pela administração municipal do prefeito Heitor Blum, salientava, referindo-se ao relatório de 1927, que "o calçamento da cidade" é um "problema de alta importância pelo grande desenvolvimento que estão tendo as linhas de auto-ônibus"; e, nesse sentido, o então prefeito renovava "o pedido feito na mensagem [dirigida] a esse ilustrado Conselho por ocasião de ser votado o orçamento para o exercício vigente", pois, segundo apontado, era "necessário elevar-se para um terço a contribuição dos proprietários de prédios em ruas e para a metade a dos prédios em praças e Cais". (BLUM, Heitor. Relatório do exercício de 1929. Apresentado ao Sr. Prefeito Municipal, Dr. José da Costa Moellmann. Florianópolis, 1935. Cópia entregue em 09 de Agosto de 1935 ao Prefeito Municipal Sr. Olivio J. de Amorim, por se haver extraviado o original entregue ao então Prefeito em 31 de Janeiro de 1931. Florianópolis: Imprensa Oficial do Estado, 1935. p. 18). Vimos, portanto, que a expansão e o "grande desenvolvimento que estão tendo as linhas de auto-ônibus", atestados, pois, já em 1927, contribuíram para que fossem tomadas medidas no sentido de se verem aprovados recursos orçamentários destinados, dentre outros objetivos, à melhoria do calçamento da cidade.

${ }_{1148}$ RAMOS, Mauro. Relatório, 1937... op. cit., p. 19-21.

1149 Idem.

${ }^{1150}$ Tal aspecto, entretanto, não era novidade, pois o mesmo relatório apontado anteriormente, datado de 1927/1929, considerava, à época, que “a nossa capital" é uma "cidade antiga [...], de ruas estreitas, sem redes de águas pluviais, tendo um grande número de casas velhas, sem possuir um cadastro pelo qual se possa traçar definitivamente, o alargamento, nivelamento e alinhamento de suas vias públicas". (BLUM, Heitor. Relatório do exercício de 1929. Apresentado ao Sr. Prefeito Municipal, Dr. José da Costa Moellmann. Florianópolis, 1935. Cópia entregue em 09 de Agosto de 1935 ao Prefeito Municipal Sr. Olivio J. de Amorim, por se haver extraviado o original entregue ao então Prefeito em 31 de Janeiro de 1931. Florianópolis: Imprensa Oficial do Estado, 1935). Pelo que percebemos, esses problemas não foram totalmente solucionados nos dez anos seguintes, conforme foi registrado no relatório do prefeito Mauro Ramos, de 1937. No transcorrer desse tempo, o adensamento progressivo do tráfego de veículos motorizados pelas ruas centrais da cidade só fez agravar-se o problema, contribuindo para manifestações não muito simpáticas à circulação dos automóveis e ônibus naquelas vias.

${ }_{1151}$ RAMOS, Mauro. Relatório, 1937, op. cit, p. 19-21.

${ }^{1152}$ Idem.
} 
em “em certas horas do dia". Assim, observamos, pelo menos desde o final da década de 1920 e com maior nitidez no decênio seguinte, os problemas trazidos, em parte, pela presença e pela circulação dos veículos motorizados, os quais precisavam ser equacionados; uma vez que, conforme o relatório de 1937, “de todos os serviços municipais", as “obras públicas” eram as que requeriam "maiores cuidados"1153. Com isso, queremos observar que a circulação dos veículos motorizados - sejam eles automóveis particulares, sejam de praça, de aluguel ou ônibus ${ }^{1154}$ pelas ruas da cidade de Florianópolis não ocorreu sem existirem, junto à administração municipal, menções aos problemas por ela trazidos, que exigiram, pois, medidas a curto prazo, as quais seriam pagas, "no exercício de 1938, com os recursos orçamentáveis""1155.

Três anos depois, em 1940, outro relatório da mesma administração municipal assinalava que, no decorrer daquele ano, "foram calçados [...] 13.359,85 metros quadrados de ruas, contra 12.501 metros quadrados do ano de 1938", e "recalçados trechos das ruas Deodoro, Álvaro de Carvalho e Praça XV de Novembro" "1156. Esses elementos são importantes para destacarmos que se completou - conforme expresso pelo mesmo relatório - "a pavimentação das ruas de maior tráfego, evitando as grandes despesas de conservação que oneravam os cofres municipais" "1157. Assim, algumas outras ruas do espaço central da cidade, como a "Alameda João Pessoa, o Largo Benjamin Constant, e as ruas Felipe Schmidt, Jerônimo Coelho, Conselheiro Mafra, Alves de Brito, acham-se completamente calçadas" $" 1158$.

Constatamos, portanto, que a administração municipal estava atenta aos problemas trazidos pelo crescente tráfego de veículos motorizados, verificado, especialmente, nas vias do espaço central da Capital. Podemos, talvez, dizer, que o calçamento dessas vias foi a solução encontrada pela prefeitura municipal para tentar equacionar o fluxo de automóveis, inclusive aquele que demandava ao Continente ou ao Centro, pela Ponte Hercílio Luz; visto, por exemplo, que as ruas Felipe Schmidt e Conselheiro Mafra, paralelas entre si, constituíam, à época, vias principias de escoamento viário para aqueles que, por meio da referida ponte, dirigiam-se à Ilha ou ao Continente próximo ${ }^{1159}$.

\footnotetext{
${ }^{1153}$ RAMOS, Mauro. Relatório. Apresentado ao Sr. Interventor Federal no Estado. Florianópolis, 1937. p. 19-21.

${ }^{1154}$ O relatório de 1937, por exemplo, registra apenas a expressão "meios de transporte", sem, contudo, fazer quaisquer especificações. Vimos que os bondes puxados por burros eram inexistentes na capital do Estado, já em 1936. Assim, podemos argumentar, com certa propriedade, que aquela expressão se refere, especialmente, aos meios de transporte motorizados.

${ }^{1155}$ RAMOS, Mauro. Relatório, 1937, op.cit., p. 19-21.

${ }^{1156}$ RAMOS, Mauro. RAMOS, Mauro. Relatório da Prefeitura Municipal de Florianópolis. Apresentado ao Sr. Interventor Federal no Estado. Florianópolis, 1940. p. 68-70.

${ }^{1157}$ Idem.

${ }^{1158}$ Idem.

1159 A rua Felipe Schmidt, por seu turno, sofreu, a partir da segunda metade da década de 1920, um processo de renovação arquitetônica, ao tornar-se um importante eixo de ligação com a ponte Hercílio Luz. De acordo com o Relatório da prefeitura municipal de Florianópolis de 1940, "Em Outubro do ano findo, foram iniciados os serviços de prolongamento da rua Felipe Schmidt até o mar. Essa área teve por finalidade aproximar uma das zonas mais promissoras da cidade ao centro urbano e, ao mesmo tempo, eliminar o mau aspecto do final da principal artéria florianopolitana que terminava em um barranco. Esse prolongamento mede 420 metros, o que vem deixar a rua com o comprimento de 1.400 metros. O cruzamento dessa rua com o futuro prolongamento da Avenida Rio Branco até a entrada majestosa da Ponte Hercílio Luz nos levou a remover um grande volume de terra. O total do desmonte para a abertura da rua era de 13.764 metros cúbicos, sendo que no ano findo foram retirados 9.704 metros cúbicos. O rampamento dos cortes exigirão um desmonte de mais de 3 mil metros cúbicos. Com o trabalho de escavação
} 
Como podemos observar, os automóveis não apenas trouxeram benefícios - como quiseram mostrar alguns artigos jornalísticos da época, analisados neste texto -, mas também problemas, dentre os quais aqueles relacionados à mobilidade urbana. Tendo isso em vista, enfatizamos que a preferência pelo uso cotidiano de automóveis e ônibus não foi, portanto, operada sem que existissem conflitos ou disputas de interesses financeiros e/ou discursivos, expressos, especialmente, em relatórios municipais e mensagens de governo.

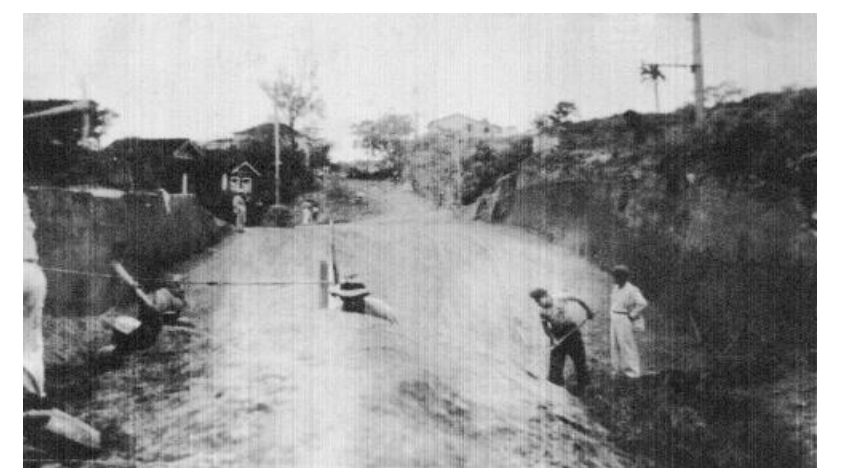

Figura 16 - Abertura do trecho terminal da rua Felipe Schmidt, próximo à ponte Hercílio Luz - 1940. Fonte: Banco de Imagens da Fundação Franklin Cascaes/Casa da Memória - (Núcleo Audiovisual).

O progressivo adensamento do tráfego de veículos automotores pelas ruas do espaço central da cidade de Florianópolis, durante as décadas de 1920 e 1930, acarretou, naturalmente a par, como vimos, dos esforços feitos pela administração municipal para o calçamento das principais vias e artérias -, problemas de mobilidade para chauffeurs e pedestres, o que ocasionou, inclusive, colisões e atropelamentos diários. A esse respeito, temos que o artigo do jornal República, de 27 de dezembro de 1931, registra que, naquele dia, “o caminhão da Empresa de Luz e Força, guiado pelo chauffeur Coriolano Mattos, atropelou ontem pela manhã, à rua Conselheiro Mafra, a menina Maria Sílvia, de 04 anos, filha do Sr. J. Brasil, funcionário da Empresa Telefônica", e considera, adiante, que "a menor ficou ferida na cabeça e nos membros inferiores, tendo sido medicada na Farmácia Popular"1160. Com base nessas considerações, podemos arguir que, nos artigos da imprensa local, assim como entre os órgãos governamentais locais, circulavam, paralelamente às manifestações de apoio, notas e comentários sobre os problemas trazidos pelos automóveis, ônibus e caminhões, como, aliás, já observamos em passagens anteriores deste capítulo. Desse modo, os pedestres - a par de suas táticas e

\footnotetext{
da rua Felipe Schmidt foi projetado o prolongamento da Alameda João Pessoa até a rua Almirante Lamego, atravessando a referida rua e o prolongamento da Avenida Rio Branco". (Figura 16, p. 296). (RAMOS, Mauro. Relatório da Prefeitura Municipal de Florianópolis. Apresentado ao Sr. Interventor Federal no Estado. Florianópolis, 1940. p. 71-72). Como podemos perceber, as ruas listadas anteriormente fazem, mesmo, parte do espaço central da cidade de Florianópolis, localizadas, inclusive, próximas às vias Felipe Schmidt e Conselheiro Mafra. Outro aspecto a considerarmos é que a região insular próxima à cabeceira da ponte Hercílio Luz foi considerada pela administração municipal "uma das zonas mais promissoras da cidade", aventando, inclusive, a possibilidade de prolongamento de outras vias, como a Avenida Rio Branco; hoje importante via de escoamento do tráfego de automóveis no centro da cidade de Florianópolis, bem como a conexão entre essas e a "entrada da Ponte Hercílio Luz". Tais aspectos permitem-nos considerar que os esforços efetuados pela prefeitura municipal para o prolongamento e ampliação das referidas vias tinham, sim, um claro propósito: oferecer melhores condições à circulação dos automóveis, que tendeu, naturalmente, após a inauguração da ponte Hercílio Luz, ao seu progressivo adensamento, especialmente no espaço central de Florianópolis.

${ }^{1160}$ O Auto atropelou a criança. República. Florianópolis, 27 dez. 1931. p. 4.
} 
mobilidade - eram alvos diários dos automóveis e, vez por outra, sofriam ferimentos ou, mesmo, eram levados à morte por ocasião das investidas dos veículos motorizados.

As ocorrências diárias de atropelamentos são atestadas ao observarmos que, aproximadamente quinze dias depois desse episódio, a portaria do processo criminal n. 183, de 11 de janeiro de 1932, registrava que teve "ciência esta Delegacia Auxiliar, que hoje às treze e trinta horas, na rua Silva Jardim, o auto n. 244A, do ponto desta Capital, guiado pelo chauffeur José Arcênio Freitas ${ }^{1161}$, atropelou a menor Rosa Tomázia Vidri, resultando ficar a mesma, seriamente contundida"1162. Muito já discutimos, neste estudo, sobre as circunstâncias que cercaram os episódios de atropelamentos e de colisões verificados nas ruas do perímetro urbano de Florianópolis, registrados junto os processos criminais. Assinalamos, porém, que a menção ao processo aqui destacado objetiva chamar a atenção para o aspecto de que, no início da década de 1930, a par de manifestações favoráveis ao fomento do serviço de auto-ônibus, registradas, sobretudo, na imprensa local, transpassavam, também nesse veículo de comunicação, assim como nas avaliações feitas em relatórios, mensagens de governo e na esfera policial local, notas e apreciações as quais atestavam os problemas trazidos pelo crescente fluxo de automóveis, notadamente relacionados aos atropelamentos, colisões, à mobilidade urbana e às altas velocidades dos veículos.

A esse respeito, a testemunha Manoel Alexandre da Silveira, "60 anos, marítimo”, observa, por exemplo, que "achava-se à rua Silva Jardim quando por ali viu passar o automóvel n. 244A guiado pelo chauffeur José Arcênio Freitas”, e que "o referido automóvel desenvolvia velocidade maior do que a regulamentar" ${ }^{, 163}$. Em outra passagem de sua fala, a mesma testemunha observa que "o condutor do referido veículo, ao fazer uma pequena curva, atropelou uma menor de nome Rosa Tomázia Vidri, residente na citada rua, que [...] pode bem observar quando uma das rodas traseiras do automóvel passou por cima da referida menor"1164. (Anexo 18, p. 349). Dado o acidente, "diversas pessoas correram ao local, inclusive a autoridade policial, providenciando esta a remoção da menor acidentada para o hospital de Caridade" ${ }^{\Perp 165}$.

Corroborando com essas declarações, é importante observarmos o que disse a testemunha Alice Firmina Martins, 27 anos, no dia 14 de janeiro de 1932; pois, nessa oportunidade, considera que, "no dia onze do corrente, era passageira do automóvel n. 244A, guiado pelo chauffeur José Arcênio Freitas, e ao passar pela rua Silva Jardim, nas imediações da vila 'Aldo Luz', viu atravessar a rua uma menor que pretendeu passar pela frente do dito automóvel”; que

\footnotetext{
${ }^{1161} \mathrm{O}$ "Termo de declarações" prestado pelo referido chauffeur, no dia 11 de janeiro, registra que o mesmo tinha "vinte anos de idade". (Processo n. 183, 11 jan. 1932. Caixa 19). Observamos, uma vez mais, que durante as décadas de 1920 e 1930, os chauffeurs têm, comumente, pouca idade. ${ }_{1162}$ Processo n. 183, 11 jan. 1932. Caixa 19.

${ }^{1163}$ Idem.

${ }^{1164}$ Idem.

${ }^{1165}$ Idem.
} 
“corrido como vinha o citado veículo, não foi possível ao chauffeur [...] evitar o acidente [...], tendo sido a menor apanhada pelo automóvel em apreço, ficando seriamente contundida" "1166. Vale observarmos, aqui, a "alta velocidade" com que se deslocava o automóvel, sugerida pela testemunha em questão. Assim, as altas velocidades imprimidas pelos automóveis são, como vimos, elementos que faziam parte do cotidiano da cidade, registradas, inclusive, nas notas jornalísticas locais.

As observações processuais destacadas até aqui são suficientes para argumentarmos que a circulação dos automóveis ocasionava transtornos aos pedestres - como, aliás, já observamos em inúmeras passagens deste estudo -, a par das notas jornalísticas que se ocupavam em tecer comentários elogiosos com relação à introdução e ao incremento da frota de coletivos motorizados que circulavam pela cidade e localidades próximas.

A resistência à presença e à circulação dos automóveis e de ônibus pode, também, ser assinalada no artigo do jornal Folha Nova, de 18 de novembro de 1926. Assim, na mesma época em que começaram a pontuar, na imprensa e nos órgãos governamentais locais, notas e apreciações favoráveis à implementação dos veículos motorizados, esse artigo assinala que "a nevrose da velocidade e da elegância faz o automóvel rechaçar de todas as cidades, quase completamente, a presença dos carros de tração animal. Raro é a capital, e até mesmo o povoado do interior, em que o carro tenha conseguido defrontar o arrogante concorrente" ${ }^{\not 167}$. Essa mesma nota observa, adiante, que a preferência ao automóvel está "por toda a parte, menos nesta cidade, onde o carro, com suas rodas de borracha e seus modestos e pacientes dromedários, defendem, com ardor, seu antigo posto de honra", pois "à chuva", ao "sol" e "ao vento", estão "firmes e inabaláveis, bem ao lado dos Rugobys, Chevrolets, dos Fords, dos Studebackers, de toda esta vasta família de nomes bárbaros e arrevesados, ei-los a resistirem a todos os embates e a todas as ironias"1168. A par das considerações simpáticas à presença e circulação dos automóveis, essa nota jornalística, ao sublinhar o posicionamento do cocheiro Pepino, observa o seguinte: “- Mas [os carros] ainda são procurados pelo público, pois não é verdade? - Naturalmente, respondeu meio a sorrir, o antigo e estimado cocheiro, Sr. Pepino"; e continuando a responder ao repórter, disse que “- Os autos nos fazem muito mal, mas estamos nos agüentando", pois "há muita gente que [ nos dá ?] preferência" ${ }^{1169}$. Além desses aspectos, o mesmo cocheiro, fazendo observações

\footnotetext{
${ }^{1166}$ Processo n. 183, 11 jan. 1932. Caixa 19. O "Auto de Exame de Corpo de Delito", assinado no mesmo dia do sinistro, observa, por exemplo, que "examinando uma menina de sete anos de idade, apresentada a exame de corpo de delito pelo boletim número quatro da Delegacia Auxiliar, constataram o seguinte: 'escoriação na região frontal do lado direito; escoriações e contusões no terço superior e médio da coxa esquerda em sua face interna; escoriação na região lombar e infra-escapular esquerda”. (Processo n. 183, 11 jan. 1932. Caixa 19).

${ }^{1167}$ Os Cocheiros de Florianópolis defendem seu antigo posto de honra - Palestra com o cocheiro Pepino. Folha Nova. Florianópolis, 18 nov. 1926. p. 1. Percebemos que se estabelece, aqui, uma diferenciação entre dois tipos de veículos: a) os carros, operados por tração animal; e b) os automóveis: operados com tração mecânica. Essa é, inclusive, a classificação que adotamos neste estudo.

${ }_{1168}$ Os Cocheiros de Florianópolis defendem seu antigo posto de honra - Palestra com o cocheiro Pepino. Folha Nova... op. cit., p. 1.

${ }^{1169}$ Idem.
} 
sobre a viabilidade econômica dos veículos motorizados e aqueles operados a tração animal, considera que "- $\mathrm{O}$ auto come o dono por uma perna, às vezes engole. $\mathrm{O}$ carro não. $\mathrm{O}$ carro é econômico" $" 1170$.

Com essas considerações, queremos destacar, novamente, que a preferência pelos automóveis ou, mesmo, pelos serviços de transporte coletivo motorizado não foi aceita sem embates, conflitos ou disputas discursivas verificados, especialmente, nas notas jornalísticas, processos criminais e órgãos governamentais locais, mas também entre os próprios personagens do cotidiano da cidade de Florianópolis. Assim, apesar das manifestações sobre atropelamentos, acidentes ou, mesmo, sobre as dificuldades para a implementação e manutenção dos serviços de ônibus que, como vimos, estavam presentes, também, nas notas jornalísticas, relatórios e mensagens de governo, o que observamos nesses veículos, como regra geral, foram incentivos e fomento à incrementação do rodoviarismo, bem como aos serviços de auto-ônibus. Assinalamos, ainda, que o Anuário Catarinense datado de 1949, registra a variedade de empresas e horários de ônibus que, naquela época, serviam à Capital e às regiões circunvizinhas. Sobre o "transporte urbano e suburbano", o referido anuário apresenta as seguintes linhas e horários dos coletivos:

Agronômica - Ponto - Rua Arcipreste Paiva, edifício do Ipase. Itinerário: Praça Pereira Oliveira; rua Visconde de Ouro Preto, Praça Getúlio Vargas, rua Almirante Alvim, Praça Benjamin Constant, Avenida Trompowsky, rua Bocaíuva, Frei Caneca e Rui Barbosa. Horários: Partidas da Praça XV: $6 ; 30,6: 45,7: 00,7: 15,7: 30,7: 45,8: 00,8: 20,8: 40,9: 20,10: 00,10: 40,11: 20,11: 40,11: 55,12: 05$, $12: 20,12: 40,13: 00,13: 15,13: 30,14: 00,14: 30,15: 30,16: 10,16: 30,16: 50,17: 05,17: 25,17: 45$, 18:05, 18:20, 18:50, 19:15, 20:30, 21:15, 22:00, 22:30. Partidas da Estação Agronômica: 6:15, 6:30, $6: 40,7: 00,7: 15,7: 30,7: 40,8: 00,8: 20,8: 40,9: 00,9: 40,10: 15,11: 00,11: 40,11: 55,12: 05,12: 20$, $12: 40,13: 00,13: 15,13: 30,13: 40,14: 15,14: 40,15: 15,15: 45,16: 30,17: 05,17: 25,17: 45,18: 05$, 18:30, 19:00, 19:30, 20:10, 20:40, 21:30. Passagem: Cr\$ 0,60 ${ }^{1171}$. Passagens escolares: abatimento de $25 \%{ }^{1172}$.

A circulação nos perímetros "urbano e suburbano" também era efetuada, dentre outras, pela linha circular, que oferecia os seguintes trajetos e horários:

Circular - Ponto - Praça XV, Jardim Fernando Machado. Linha A: Itinerário: Praça XV, Rua Visconde de Ouro Preto e Anita Garibaldi, Avenidas Hercílio Luz e Mauro Ramos, Praça Etelvina Luz, rua Blumenau, Praça Benjamin Constant, Avenida Trompowsky, ruas Bocaíuva e Esteves Júnior, Avenida Rio Branco, rua Padre Roma, Felipe Schmidt, Deodoro, Conselheiro Mafra, Praça XV. Horário Linha A: desde 6:30, de meia em meia hora, até 11:30;11:50, 12:10, 12:30, e daí em diante de meia em meia hora, até 22:30 horas. Passagem: Cr\$ 0,50. Passes escolares: abatimento de 25\%. Linha B: Itinerário: Praça XV, rua Frederico Rola, Largo da Alfândega, ruas Trajano, Felipe Schmidt, Padre Roma, Avenida Rio Branco, ruas Esteves Júnior, Bocaiúva, Avenida Trompowsky, Praça Benjamin Constant, rua Blumenau, Praça Etelvina Luz, Avenidas Mauro Ramos e Hercílio Luz, rua Tiradentes, Praça XV. Horário Linha B: desce 6:45, de meia em meia hora até 11:45, 12:05, 12:20, 12:45, e daí por diante de meia em meia hora, aos 15 e 45 minutos, até 22:45 horas. Passagem: Cr\$ 0,50. Passagens Escolares: abatimento de $25 \%{ }^{1173}$.

\footnotetext{
${ }^{1170}$ Os Cocheiros de Florianópolis defendem seu antigo posto de honra - Palestra com o cocheiro Pepino. Folha Nova... op. cit., p. 1.

${ }^{1171} \mathrm{O}$ cruzeiro, como unidade monetária nacional, foi instituída pelo Decreto-lei n. 4791 , de 05 de outubro de 1942 . Esse decreto entrou em vigor no dia $1^{\circ}$ de novembro de 1942. Ver Decreto-lei n. 4791: institui o cruzeiro como unidade monetária brasileira e dá outras providências. Rio de Janeiro, 05 de outubro de 1942. (Diário Oficial de 06 out. 1942). In: Revista Forense: mensário nacional de doutrina, jurisprudência e legislação. Rio de Janeiro, dez. 1942. v. XCI, ano XXXIX, fascículo 474, n. 92. p. 831.

${ }_{1172}$ Anuário Catarinense. Ano II, n. 2. Florianópolis, jan. 1949. p. 38-44.

${ }^{1173}$ Idem.
} 
Os aspectos descritos anteriormente nos fornecem elementos importantes para demonstrarmos ao leitor que, ao final da década de 1940, os coletivos motorizados já tinham integrado o cotidiano da cidade de Florianópolis, pois eram oferecidas, ao menos em "quatro" linhas que atendiam às ruas e aos logradouros dos perímetros urbano e suburbano, passagens escolares com preços menores do que aqueles comumente praticados aos demais usuários ${ }^{1174}$. Isso permite-nos argumentar que o uso dos coletivos era diário; efetuado, talvez, por grande parcela da população, inclusive, como ficou demonstrado, por crianças em idade escolar ${ }^{1175}$. Vimos, na seção anterior, ao analisarmos o Guia do Estado de Santa Catarina, de 1937, que, na década de 1930, existiam diversas empresas e linhas de ônibus na Ilha e no Continente, em número significativamente maior que as existentes na década anterior. Destacamos, porém, que para esse ano, a empresa “Auto-Viação Florianópolis", mantinha apenas uma linha Circular, que percorria praças e ruas do espaço central e do perímetro urbano da cidade de Florianópolis, oferecendo horários de vinte em vinte minutos ${ }^{1176}$.

Por outro lado, no ano de 1949, os ônibus que efetuavam o "transporte urbano e suburbano" e que, na primeira linha apresentada nas citações anteriores, partiam da Praça XV de Novembro ou da Estação Agronômica, circulavam em intervalos de tempo diferenciados, sendo de quinze minutos o tempo médio no início dos períodos matutino e vespertino; depois, no transcorrer desses períodos, em intervalos médios de vinte a quarenta minutos, e retomavam, no final desses mesmos períodos, ao intervalo médio de quinze minutos. Para o período noturno podemos considerar, para a linha Agronômica, que os ônibus circulavam em intervalos de tempo de trinta a quarenta e cinco minutos. Percebemos, pois, maior variedade de horários para aqueles

\footnotetext{
${ }^{1174}$ Além das linhas acima discriminadas, existiam, conforme o mesmo anuário, outras oito linhas que atendiam as ruas e os logradouros dos perímetros urbano e suburbano da Capital. Dessas, as linhas "Florianópolis-Barreiros" e "Florianópolis-Trindade" também discriminavam - a exemplo das outras duas linhas já destacadas - que os "passes escolares" teriam "abatimento de 25\%". (Anuário Catarinense, 1949... op. cit., p. 38-44). Isso permite-nos considerar que, ao menos, crianças em idade escolar se deslocavam dessas regióes, localizadas, conforme sugerido pelo texto em análise, no "perímetro suburbano" da cidade, para estudarem em escolas localizadas no centro ou no perímetro urbano da Capital. Notamos que a região denominada "Trindade" pertence, agora, ao "perímetro suburbano", deixando de ser considerada distrito, como então se apresentava por volta de 1937. Ver, no capítulo primeiro da tese, Mapa 02: Perímetro Suburbano e Distritos de Florianópolis - Décadas de 1920 e 1930. (p. 53).

${ }_{1175}$ Podemos considerar que durante a década de 1940, a utilização dos coletivos operou-se de maneira constante pelos florianopolitanos. Essa observação pode ser corroborada pelo que determina o Decreto n. 26, de 1. ${ }^{\circ}$ de fevereiro de 1941, pois, dentre outros elementos, destaca que "O Doutor Nereu Ramos, Interventor Federal no Estado de Santa Catarina, no uso de suas atribuições", "considerando que o praxe de receberem os auto-ônibus os passageiros em suas residências, vem em detrimento dos proprietários de automóveis de praça, que pagam imposto e licença para transporte de passageiros nas cidades onde exercem sua profissão, Decreta: Art. 1. ${ }^{\circ}-$ Os auto-ônibus que transitarem em linhas intermunicipais terão fixados, na Capital, na Inspetoria de Veículos e Trânsito Público e, no interior, pelas Delegacias de Polícia, seus locais de saída e chegada, onde embarcarão e desembarcarão os passageiros, tanto nas cidades que forem pontos iniciais e terminais, quanto nas que forem pontos intermediários, ficando vedados, sob pena de multa de $200 \$ 000$ [duzentos mil réis], e o dobro nas reincidências, paga pela Empresa ou proprietário, ou possuidor de veículo e cassação da carteira de motorista que o dirigir, embarcar e desembarcar passageiros naquelas cidades, ou em qualquer outro local. Parágrafo Único - Os auto-ônibus que trafegarem nas linhas urbanas terão, também, pontos de saída, parada e chegada, onde embarcarão e desembarcarão seus passageiros, sob as penas acima estabelecidas". (Secretaria da Segurança Pública. Decreto n. 26. In: Santa Catarina. Coleção de Decretos-Leis, Decretos, Resoluções e Portarias, jan-jun. 1941. p. 98-99). Frente ao exposto, destacamos que estavam em curso medidas que visavam coibir antigas práticas, verificadas na Capital, mas também em outras cidades do Estado, onde os motoristas de ônibus recebiam e deixavam os passageiros em suas habitações. Além disso, as regulamentações quanto aos pontos de parada dos coletivos, atestadas a partir desse momento, objetivam, também, disciplinar o fluxo diário de passageiros, cada vez mais intenso e densificado. Neste ponto, notemos que para a cidade de Blumenau, as autoras Méri Frotscher e Lea Maria Vedana, no livro Viagens pela cidade: o transporte coletivo de Blumenau, assinalam que "ao longo da rua XV de Novembro, contudo, desde da década de 30" já se tinham "fixado pontos de parada para embarque de passageiros". (FROTSCHER, Méri; VEDANA, Lea Maria Ferreira. Viagens pela Cidade: o transporte coletivo de Blumenau. Florianópolis: Insular, 1999. p. 53-54).

${ }^{1176}$ Guia do Estado de Santa Catarina: Suplemento para o ano de 1937. Florianópolis: Livraria Central de Alberto Entres, 1937.
} 
que precisavam utilizar o transporte coletivo nas ruas e logradouros do espaço urbano da Capital. $\mathrm{Na}$ outra linha (Circular) que atendia aos perímetros urbano e suburbano, eram oferecidos dois trajetos diferentes, correspondentes às "linhas A e B", cujos coletivos saíam da Praça XV de Novembro em intervalos médios de meia hora, salvo nos horários próximos ao meio-dia, quando os ônibus circulavam, aproximadamente, em intervalos médios de vinte minutos.

Quanto ao atendimento às regiões localizados no Continente próximo, existiam, ao menos, duas empresas que ofertavam linhas ${ }^{1177}$ e itinerários diários, cujos coletivos partiam do Largo da Alfândega. Assim, as empresas "Auto-Viação Santa Catarina” e "Auto-Viação Santa Cruz" ofereciam, respectivamente, as linhas: a) "Florianópolis-Estreito"; "Florianópolis-Barreiros"1178; e b) "Florianópolis-Coqueiros"; e os horários eram variados ${ }^{1179}$. A Empresa "Auto-Viação Santa Catarina", no trajeto "Florianópolis-Estreito", ofertava, por exemplo, saídas da Alfândega ao intervalo médio de duas horas; porém, a partir das dezesseis horas, fazia viagens em intervalos médios "de dez em dez minutos ou, antes, se a lotação estiver completa"1180. Já os coletivos da Empresa "Auto-Viação Santa Cruz", ao efetuarem a linha "Florianópolis-Coqueiros", circulavam em intervalos médios de meia hora nos inícios da manhã e da tarde e, no restante do dia, em intervalos médios de uma hora ${ }^{1181}$.

Vale mencionarmos que as regiões insulares do "Cemitério do Itacorubi", "Saco dos Limões" e "Pirajubaé", localizadas, conforme consta, no perímetro suburbano da cidade, eram servidas, ao menos, por duas empresas de ônibus, as quais efetuavam viagens diárias, cujos horários, variados, pontuavam durante os períodos matutino e vespertino, sendo mais escassos à noite $^{1182}$. É importante observarmos, também, que, ao final da década de 1940, as empresas “Auto-Viação Biguaçu”, “Auto-Viação Santo-Amaro", "Shell \& Cia”, “Auto-Viação Josefense” e "Auto-Viação São Pedro" efetuavam viagens intermunicipais de ida e de volta que, partindo de Florianópolis, atendiam aos municípios próximos à Capital, quais sejam: Biguaçu, Santo Amaro, Palhoça, São José e São Pedro de Alcântara ${ }^{1183}$.

Do exposto, podemos considerar que os coletivos cobriam, à época, diversas linhas e itinerários, e as respectivas empresas ofertavam uma gama variada de horários diários, o que atesta, sem dúvida, a consolidação dos coletivos motorizados como veículos preferenciais no deslocamento e transporte de passageiros entre os perímetros urbano e suburbano e, igualmente,

\footnotetext{
${ }^{1177}$ Essas estão inseridas no total de oito linhas que, à época, eram ofertadas para os perímetros urbano e suburbano da Capital; linhas estas já anteriormente apresentadas.

1178 A Empresa "Auto-Viação Santa Catarina" também disponibilizava viagens e itinerários que, partindo de Florianópolis, dirigiam-se para Caiacanga (Ribeirão); Canasvieiras e Cachoeira do Bom Jesus. Anuário Catarinense. Ano II, n. 2. Florianópolis, jan. 1949. p. 38-44.

${ }_{1179}$ Anuário Catarinense. Ano II, n. 2. Florianópolis, jan. 1949. p. 38-44.

${ }^{1180}$ Idem.

${ }^{1181}$ Idem.

${ }^{1182}$ As considerações sobre os horários também são válidas para os coletivos que demandavam para as localidades da "Trindade" e "Volta ao Morro". (Anuário Catarinense, 1949... op. cit., p. 38-44).

${ }^{1183}$ Anuário Catarinense, 1949 ... op . cit., p. 38-44.
} 
aos distritos da Capital e regiões e cidades continentais próximas ${ }^{1184}$. Além disso, podemos perceber que a cidade de Florianópolis constituía-se, nesse período, como polo de aglutinação populacional; pois, conforme apontado pelo texto em discussão, todas as viagens intermunicipais partiam ou chegavam à Capital.

O fomento concedido ao transporte rodoviário, envolvendo, dentre outros aspectos, maior número de linhas e horários de circulação dos coletivos e, igualmente, maiores somas financeiras destinadas à conservação, melhoria e ampliação da malha viária, como já observamos neste texto, atesta, sem dúvida, os interesses financeiros que estiveram envolvidos no incremento ao transporte rodoviário operado por automóveis, ônibus e caminhões. Desse modo, as dificuldades enfrentadas, nos planos estadual e municipal, para tentar equacionar os problemas relativos ao fluxo e adensamento dos automóveis, foram refletidas em artigos de jornal, relatórios e mensagens de governo, pois esses textos, em especial, não deixaram de registrar os problemas aqui citados, decorrentes, em parte, do maior incentivo dado ao rodoviarismo e à circulação automobilística. Retórica e finanças estiveram, assim, envoltas nas críticas e apoio conferidos pela imprensa e órgãos governamentais ao transporte rodoviário e à circulação dos veículos automotores, especialmente nas ruas do perímetro urbano da capital catarinense. Constatamos, entretanto, que, a par de todos os reclames assinalados por conta dos problemas de circulação e mobilidade urbano-viárias, prevaleceram, ao certo, nas esferas municipal e estadual, fomento e incentivo à motorização veicular, apoio este que, sem dúvida, deu o tom de seus discursos e

\footnotetext{
${ }^{1184}$ O processo de consolidação do transporte coletivo motorizado na Capital e no Estado de Santa Catarina esteve, pois, atrelado às iniciativas e aos incentivos governamentais, refletindo as ações tomadas em conjunto, muitas vezes, entre os poderes estaduais e municipais. Assim é que outro indicativo a esse respeito pode ser observado ao assinalarmos que, já no final da década de 1930 , o Decreto n. 14, de 03 de novembro de 1939, destaca, dentre outros aspectos, que

"O Doutor Nereu Ramos, Interventor Federal no Estado de Santa Catarina, no uso das suas atribuições,

Considerando que é mister incentivar o tráfego de auto-ônibus na Capital do Estado, Decreta:

Art. 1. ${ }^{\circ}$ - O tráfego de auto-ônibus fica subordinado à Secretaria de Estado dos Negócios da Segurança Pública e a cargo da Inspetoria de Veículos e Trânsito Público e seus auxiliares, em coordenação com [...] as Prefeituras Municipais. \#1. ${ }^{\circ}$ - Nenhum auto-ônibus poderá ser licenciado para transitar nas vias públicas do Estado, em linhas intermunicipais, sem, antes obter o certificado de conveniência e utilidade, concedido pela Diretoria de Estradas de Rodagem; \#2..$^{\circ}$ Só poderão ser licenciados para transitar, em linhas urbanas, os auto-ônibus que obtiverem, previamente, do poder municipal competente, o certificado de conveniência e utilidade". Para poderem circular os coletivos deveriam, a partir deste momento, apresentar dimensões, especificidades técnicas e condições específicas de segurança e asseio, conforme estipuladas pelo artigo segundo deste decreto que discrimina que "Art. $2 .^{\circ}$ - Os auto-ônibus deverão preencher as seguintes condições: a) chassis especialmente construídos para ônibus, ou a eles convenientemente adaptados, com centro de gravidade baixo, capacidade mínima de 2.500 quilogramas, motor de explosão ou de bateria elétrica; b) carroceria ampla, inteiramente envidraçada na parte superior, com capacidade, no mínimo, para 20 passageiros e, no máximo, de 40, e altura mínima, internamente, de 1,75 cm nas linhas urbanas, e de 1,50 nas linhas intermunicipais, e máxima de $80 \mathrm{~cm}$ entre o piso e o solo [...]; e) bancos de almofadas alcochoadas, com molas e encosto, assentos de $85 \mathrm{~cm}$ de comprimento e setenta de espaço entre um e outro, permitindo a sua disposição à passagem central de $43 \mathrm{~cm}[. .$.$] ; j) janelas com vidraças e cortinas de proteção contra os$ elementos naturais, tendo, ainda, três varões de metal com vão de cinco a seis centímetros [...]; 1) iluminação interna; m) extintor manual de incêndio; n) seta indicativa de direção". (Santa Catarina. Legislação Estadual. Decreto n. 14, 03 nov. 1939. In: Decretos-Leis, Decretos, Resoluções e Portarias. Janeiro a junho de 1940. Imprensa Oficial do Estado, jan. 1940. p. 74-79).

Esses elementos são suficientes para argumentarmos que, de fato, os coletivos motorizados apresentavam maior segurança do que aquela oferecida pelos bondes. Percebemos, igualmente, que o poder público estadual conferiu atenção especial ao preparo e reequipamento dos ônibus para circularem nas vias intermunicipais e, bem assim, nas ruas dos municípios. Os elementos destacados refletem, também, as iniciativas políticas centralizadoras expressas pelos poderes públicos estadual e municipal; iniciativas estas que, de fato, caracterizaram suas ações, no período - Nereu Ramos, interventor federal do regime estado-novista, em Santa Catarina, assina, pois, o presente decreto. Outra observação importante é que o primeiro código nacional de trânsito (1941) irá estabelecer, também, regras e condições específicas para a circulação dos coletivos motorizados, como veremos, com maiores detalhes, na seção seguinte. Esse código estipula, entretanto, apenas, regras gerais de circulação aos veículos automotores; assim, regras específicas e detalhadas ficam a cargo das determinações estaduais e municipais, que são, em última análise, autorizadas pelos encaminhamentos gerais dados pelo código nacional de trânsito.
} 
avaliações a partir da segunda metade da década de 1920, e que contribuiu para a maior intensificação do tráfego motorizado nos decênios subsequentes.

\subsection{Epílogo}

Neste estudo investigamos, por meio da análise dos processos criminais, os episódios de atropelamentos e colisões verificados no perímetro urbano da cidade de Florianópolis, durante as décadas de 1920 e 1930; e, a partir da ótica do homem comum, procuramos discutir suas visões e sensibilidades em relação à introdução e à circulação dos veículos motorizados. Objetivamos discutir, também, o processo inicial de inserção dos automóveis no Estado e na capital catarinense, e constatamos que, de fato, esse meio de transporte apresentou um alto custo de aquisição, sobretudo até a primeira metade da década de 1920. (Anexo 19, p. 350). Observamos, igualmente, uma tendência que aponta para o aspecto de que os indivíduos que podiam adquirir automóveis tinham uma situação econômica muito confortável e dispunham, muitas vezes, de empregados para servir-lhes. Vimos, ainda, que, até mesmo, os chauffeurs constituíam-se como proprietários dos veículos que utilizavam em sua profissão; e, nesse sentido, podemos considerar que tais personagens faziam parte dos estratos médios da sociedade florianopolitana da época, pois alguns deles tinham, inclusive, residência fixa na cidade, conforme pudemos verificar nos processos criminais analisados.

Os cenários aqui apresentados foram muito comuns nas décadas de 1920 e 1930. Nesse período pudemos verificar, também, episódios de colisões ocorridos entre automóveis e veículos tracionados por força animal. A figura do boleeiro se fez, com efeito, presente, à época, sendo obrigada a dividir o espaço das ruas e avenidas com chauffeurs e automóveis. Durante o período estudado, pudemos, igualmente, verificar a convivência simultânea, pelas ruas da cidade, dos bondes e ônibus; convivência esta que nos foi apresentada pelos artigos jornalísticos locais e pelos instrumentos governamentais no âmbito do Estado e de sua Capital, notadamente quanto aos relatórios e mensagens de governo.

Em face aos aspectos estudados até aqui, não é nenhum absurdo considerarmos que as décadas de 1920 e 1930 constituíram-se como um período transitório, no qual ainda podíamos verificar, com certa frequência, a presença simultânea, pelas ruas da cidade, de personagens como os carroceiros, boleeiros e chauffeurs e, também, dos carros, automóveis, bondes e ônibus. Com o passar dos anos, observamos uma tendência ao adensamento do fluxo de automóveis, tanto nas ruas do perímetro urbano da Capital como nas vias e estradas do Estado.

A esse respeito, vimos, neste capítulo, que o governo de Santa Catarina esforçou-se por operar melhorias nas estradas estaduais; processo que foi observado com maior nitidez a partir 
da década de 1930; pois, em 1937, por exemplo, o então governador do Estado, Nereu Ramos, observou, em julho daquele ano, que "teve o governo de iniciar, no ano passado, a reconstrução de várias estradas, devido ao seu mau estado de conservação" ${ }^{1185}$. Assim, essas vias foram reequipadas e preparadas para "suportar carga móvel até dez toneladas e carga uniformemente distribuída até 400 quilos por metro quadrado", pois “a intensificação do movimento nas nossas principais estradas tem forçado a reconstrução imediata de inúmeras obras de arte, visto que as primitivas haviam sido calculadas para o tráfego de carretas, e não para caminhões com toneladas de peso" $" 1186$.

O poder público municipal também empreendeu, a partir da década de 1930, um claro programa para a melhoria das ruas do perímetro urbano de Florianópolis. Recordemos, pois, o que assinalou o Relatório do prefeito Mauro Ramos (1937), uma vez que, nessa oportunidade, o chefe político do município expressava ao governador de Santa Catarina que a Capital é uma "cidade antiga", "com ruas mal alinhadas"; e, assim, apontava que "as artérias centrais merecem cuidado especial", pois "ali as condições já não satisfazem as exigências do trânsito, com o grande desenvolvimento que tem tomado os meios de transporte motorizados" e, "devido à pouca largura das ruas, é quase impossível o trânsito em certas horas do dia"1187.

A par das medidas tomadas pelo poder público municipal para tentar solucionar os entraves viários à circulação e mobilidade urbanas - vistas, com maiores detalhes, na seção anterior - o que observamos, com o passar dos anos, é o agravamento dessa situação. Nesta parte da tese analisamos, portanto, o considerável adensamento do fluxo de veículos motorizados pelas ruas do espaço central da capital catarinense; processo este que atesta a implementação inicial, a partir da década de 1950, dos semáforos nos cruzamentos das principais vias centrais da cidade e, igualmente, a preferência concedida ao transporte rodoviário, em detrimento do marítimo e ferroviário. O maior apoio ao rodoviarismo encontrou respaldo junto à esfera federal, pois ali observamos forte atenção e investimentos ao transporte rodoviário e à incrementação da indústria automobilística, notadamente durante o governo de Juscelino Kubitschek. Com esse Epílogo, pretendemos, dentre outros aspectos, relacionar os contextos nacional, estadual e local frente à preferência concedida ao rodoviarismo, a fim de inserir o contexto florianopolitano num cenário mais amplo e obedecer, em linhas gerais, aos objetivos traçados por ocasião da elaboração da presente tese.

Já vimos que a maior atenção ao rodoviarismo esteve muito presente na esfera estadual a partir da década de 1930, quando o governo de Nereu Ramos - nomeado interventor federal em

\footnotetext{
${ }^{1185}$ RAMOS, Nereu. MENSAGEM apresentada á Assembléia Legislativa de Santa Catarina. Florianópolis, 16 jul. 1937. p. 81.

${ }^{1186}$ Idem.

${ }^{1187}$ Ibidem, p. 19-21.
} 
Santa Catarina, no ano de 1937 - seguiu, em linhas gerais, as orientações dadas pela política centralizadora do governo Vargas, que direcionou grandes investimentos para os campos viário e industrial brasileiros, processo este que foi acelerado a partir da instituição do Estado Novo. Um forte indicativo a essa política nos é apresentado, em 1941, por meio da instituição, nesse ano, do primeiro Código Nacional de Trânsito. Esse conjunto de normas estipulou regulamentações para uma variada gama de práticas e posturas ${ }^{188}$ que, a partir daquele momento, deveriam ser observadas e adotadas, especialmente pelos condutores e motoristas de veículos motorizados, sejam automóveis particulares, sejam ônibus, caminhões, dentre outros ${ }^{1189}$. Essa iniciativa deixa, pois, bem claro o desejo de o governo federal intensificar o seu controle na esfera da circulação viária $^{1190}$. O referido código estabelece, dentre outros aspectos, que "Art. 5. ${ }^{\circ}-E$ É dever de todo o condutor de veículos: \# 10 - Trazer consigo os documentos de habilitação e de identificação" ${ }^{1191}$.

Sobre as determinações quanto à permissão para o exercício da direção, o referido código determina, dentre outros aspectos, que “Art. 103 - O candidato a exame de habilitação deverá instruir o requerimento respectivo com os seguintes documentos ou comprovações: a) carteira de identidade; b) atestado de bons antecedentes; c) ser maior de dezoito anos; d) haver pago os emolumentos relativos ao exame; e) saber ler e escrever" ${ }^{, 192}$. Em seu artigo 105, é especificado, ainda, que "[...] O candidato a exame para condutor de veículos deverá ser submetido, antes do

\footnotetext{
${ }^{1188}$ Dentre essas, destacam-se, em alguns de seus capítulos, determinações quanto às "Capítulo II - Regras gerais para circulação"; à "Capítulo V - Sinalização"; às "Capítulos VI - Espécies, categorias, dimensões, pesos e equipamentos" dos veículos; à "Capítulo IX - Habilitação de condutores", etc. (Decreto-lei 3651: dá nova redação ao Código Nacional de Trânsito. Rio de Janeiro, 25 de setembro de 1941. In: Revista Forense: mensário nacional de doutrina, jurisprudência e legislação. Rio de Janeiro, out. 1941. v. LXXXVIII, ano XXXVIII, fascículo 461, n. 88). Sobre esses aspectos veremos, à frente, maiores detalhes.

${ }^{1189} \mathrm{O}$ artigo terceiro do código nacional de trânsito de 1941 determinava que a circulação dos bondes não seria regulamentada por aquele código. Decreto-lei 3651: dá nova redação ao Código Nacional de Trânsito. Rio de Janeiro, 25 de setembro de 1941. In: Revista Forense: mensário nacional de doutrina, jurisprudência e legislação. Rio de Janeiro, out. 1941. v. LXXXVIII, ano XXXVIII, fascículo 461, n. 88. p. 578).

${ }^{1190} \mathrm{O}$ artigo primeiro desse código estabelece, por exemplo, que "Art. $1 .^{\circ}-\mathrm{O}$ trânsito de veículos automotores de qualquer natureza nas vias terrestres abertas à circulação pública, em todo o território nacional, regular-se-á por este Código". (Decreto-lei n. 3651: dá nova redação ao Código Nacional de Trânsito. Rio de Janeiro, 25 de setembro de 1941... op. cit., p. 578). É importante destacarmos que apenas no ano de 1966 regulamentou-se um novo código nacional de trânsito. Ver Lei 5108: institui o Código Nacional de Trânsito. Brasília, 21 set. 1966 (Diário Oficial de 22 set. 1966). Além disso, observemos, aqui, que o primeiro código de processo penal brasileiro foi também instituído no ano de 1941. Ver Decreto-lei 3689, de 03 de outubro de 1941. Código de Processo Penal - 1941. Rio de Janeiro, 1941. O artigo 810 deste código estabelece que "Art. 810 - Este Código entrará em vigor no dia 1ำ de janeiro de 1942". Outrossim, o artigo 1..$^{\circ}$ expõe que "Art. $1 .^{\circ}-$ O processo penal regerse-á, em todo o território brasileiro, por este Código". (Decreto-lei 3689, de 3 de outubro de 1941. Código de Processo Penal - 1941... op. cit). Dessa forma, padronizaram-se a organização e a apresentação dos processos e inquéritos policiais abertos no País. Instituíram-se, então, na década de 1940, novas regras que objetivavam disciplinar a atividade policial na investigação de delitos e crimes. Além disso, percebemos a atuação do Estado brasileiro na disciplinarização e organização das esferas viária e policial brasileiras. A unidade nacional dada a esses serviços fica bem evidente ao observarmos o teor do artigo do jornal Diário da Tarde, de 07 de janeiro de 1942. Segundo esse artigo, "A Inspetoria do Tráfego do Distrito Federal já iniciou a substituição das placas de sinalização das vias públicas estabelecidas no Código Nacional de Trânsito. A nova sinalização está enquadrada no que ficou aprovado em uma convenção Internacional. Conquanto o Brasil houvesse promulgado e ratificado essa convenção, por decreto federal, vinha se observando certa balbúrdia em matéria de sinalização de trânsito, com a adoção progressiva de sinais que não obedeciam às normas e acordos internacionais. A Inspetoria Geral da Polícia, corrigindo esses senões, fez incluir no novo código a remodelação e uniformização de todos os sinais, cujas placas começam a surgir nas ruas da capital do Rio, para a orientação dos condutores nacionais e estrangeiros". (A nova sinalização do Tráfego. Diário da Tarde. Florianópolis, 07 jan. 1942. p. 4). Essas colocações permitem-nos especular que o Código Nacional de Trânsito, de 1941, operou - senão de imediato, mas, ao certo, progressivamente - em todo o território nacional, uma efetiva padronização quanto à sinalização do tráfego de veículos. Além disso, podemos inferir que antes da adoção desse código que foi, conforme sugerido pela nota, orientado por "uma Convenção Internacional" -, a sinalização para o tráfego de veículos - automotores ou não - era elaborada e adotada pelos poderes públicos locais - estaduais ou municipais. (Exemplo disso são as próprias Instruções Regulamentares para o serviço de trânsito público de Santa Catarina (1928), assinadas pelo secretário de Estado do Interior e Justiça). Outra observação é o fato de que o código nacional de trânsito, aqui discutido, entrou em vigor, como visto, no dia $1 .^{\circ}$ de janeiro de 1942 . Assim, apenas seis dias depois, as placas de sinalização já começavam a surgir "nas ruas da capital do Rio", o que indica que as determinações estipuladas no código foram, ao certo, aplicadas, em primeira-mão, na capital federal, e, posteriormente, nos outros estados e cidades da federação.

${ }_{1191}$ Decreto-lei n. 3651: dá nova redação ao Código Nacional de Trânsito. Rio de Janeiro, 25 de setembro de 1941... op. cit., p. 579.

${ }^{1192}$ Ibidem, p. 586.
} 
exame técnico, a uma junta ou serviço médico oficial, a fim de verificar se o mesmo satisfaz as condições de sanidade física e mental admissíveis para o exercício da atividade" ${ }^{\Perp 193}$.

Além disso, determina, em seu artigo nono, que “[...] A velocidade para os veículos será estabelecida em cada localidade pela repartição competente"1194, mas quanto aos "veículos automóveis serão observados os seguintes limites": a) para "os veículos de carga, até quarenta quilômetros, nas zonas urbanas e suburbanas", e "até sessenta quilômetros na zona rural"; b) para "os veículos de transporte coletivo, até quarenta ou sessenta quilômetros, nas zonas urbana e suburbana, conforme o maior ou menor movimento na via pública, e sessenta quilômetros na zona rural"; c) para "os veículos de passeio, até cinqüenta quilômetros nos centros urbanos; até sessenta quilômetros nas grandes avenidas", e "até oitenta quilômetros na zona rural" 1195 .

É relevante observarmos que o primeiro código nacional de trânsito traz novas exigências aos candidatos a motorista - se comparadas àquelas expressas nos artigos 113 e 115 do Regulamento para o serviço policial do Estado, de $1920^{1196}$-, como a comprovação das práticas de leitura e escrita e a necessidade da submissão a uma junta médica para a avaliação dos seus estados físico e mental. Devemos observar, também, as velocidades permitidas "nos centros urbanos", as quais são superiores às estipuladas pelas Instruções Regulamentares para o serviço de trânsito público ${ }^{1197}$. Segundo o artigo 36 desse regulamento - já citado em outros momentos -, “[...] Nas ruas e praças da Capital, os automóveis e auto-caminhões não poderão passar de vinte quilômetros a hora, de marcha e os carros terão a velocidade de um animal a trote" ${ }^{\text {1198 }}$. Percebemos, portanto, que, para a década de 1940, foram permitidos maiores limites de velocidade aos veículos motorizados, notadamente quanto aos "veículos de carga" e "de passeio", que poderiam circular, "nas zonas urbanas" com velocidades máximas de, respectivamente, "quarenta" ou "cinqüenta" quilômetros horários. Para os veículos motorizados

\footnotetext{
${ }^{1193}$ Idem. Ver, também, a respeito: Santa Catarina. Secretaria da Segurança Pública. Ofício n. 1083, expedido pela Inspetoria de Veículos e Trânsito Público ao Capitão Antônio de Lara Ribas, Responsável pelo Expediente da SSP. Florianópolis, 11 dez. 1941 . p. 11

${ }^{1194}$ Já vimos, no capítulo terceiro, na seção Legislação e Circulação: incrementação e complexidade, que o artigo primeiro desse código estipula, também, que "Art. 1..$^{\circ}$ - As leis estaduais, relativas ao trânsito e aos condutores dos demais veículos, aos pedestres, aos animais, e à sinalização local, devem adaptar-se às disposições deste código, no que for aplicável”. Além disso, o artigo segundo estabelece que "Art. 2. ${ }^{\circ}$ - Cada Estado organizará, de acordo com as suas necessidades, os serviços administrativos destinados ao cumprimento dos dispositivos deste Código, obedecendo às normas gerais da legislação federal”. (Decreto-lei 3651: dá nova redação ao Código Nacional de Trânsito. Rio de Janeiro, 25 de setembro de 1941... op. cit., p. 578). Assim, frisemos, uma vez mais, que a aplicação desse código operou-se de forma gradual nos estados da federação, obedecendo às suas necessidades e particularidades.

${ }^{1195}$ Decreto-lei 3651: dá nova redação ao Código Nacional de Trânsito. Rio de Janeiro, 25 de setembro de 1941... op. cit., p. 580). Com relação às velocidades estipuladas para os coletivos motorizados, já no início da década de 1940 o Decreto estadual n. 14, de 03 de novembro de 1939 , estipulava que "o máximo de velocidade permitida" é de "sessenta quilômetros, nos lugares de pouco movimento, fora das cidades e vilas". (Santa Catarina. Legislação Estadual. Decreto n. 14, 03 nov. 1939. In: Decretos-Leis, Decretos, Resoluções e Portarias. Janeiro a junho de 1940. Imprensa Oficial do Estado, jan. 1940. p. 74-79). Percebemos, pois, certa sintonia aos limites de velocidade estipulados pelo primeiro código nacional de trânsito, para os veículos automotores.

${ }^{1196}$ As Instruções Regulamentares para o serviço de trânsito público, de 1928, determinam, apenas, que "Art. 1. ${ }^{\circ}$ - Os condutores de veículos de qualquer natureza deverão estar munidos, quando em serviço, da respectiva caderneta de direção". (Santa Catarina. Instruções Regulamentares para o serviço de trânsito público. Florianópolis: Imprensa Oficial do Estado, 1928. p. 5). Observamos que essa determinação é válida para os condutores de automóveis ou carros operados por tração animal, ao passo que as exigências estipuladas no primeiro código nacional de trânsito, de 1941, são relacionadas apenas aos condutores dos veículos motorizados.

${ }^{1197}$ Mencionemos, novamente, que, nas pesquisas realizadas, não encontramos, para a década de 1930, outros códigos de trânsito estaduais ou municipais que pudessem então estar em vigência. Tal aspecto nos leva a considerar que as Instruções Regulamentares para o serviço de trânsito público, de 1928, ainda vigoravam em 1941.

${ }^{1198}$ Santa Catarina. Instruções Regulamentares para o serviço de trânsito público... op. cit., p. 10.
} 
de passeios, foram permitidos, inclusive, limites de até "oitenta quilômetros na zona rural" 1199 . Para os coletivos, estipulou-se, como vimos, o limite de sessenta quilômetros "nas zonas urbana e suburbana". As velocidades agora permitidas suplantaram, em pelo menos o dobro, àquelas estipuladas pelo regulamento estadual de trânsito, datado de 1928. Esses elementos sinalizam, sem dúvida, para o gradativo aperfeiçoamento de máquinas e automóveis ${ }^{1200}$.

As diretrizes políticas centralizadoras, verificadas, especialmente, a partir das décadas de 1930 e 1940, foram mantidas nos anos seguintes; pois, durante o decênio subsequente, a esfera federal investiu prioritariamente nas indústrias automobilística e de bens de consumo duráveis. Esse aspecto tornou-se claro durante o governo de Juscelino Kubitschek. Em um texto já bastante conhecido dos historiadores, o brasilianista Thomas Skidmore diz, a esse respeito, que

\begin{abstract}
O período Kubitschek tornou-se conhecido por suas realizações econômicas, e é daí que devemos começar analisando a presidência. O dinâmico presidente prometeu 'cinqüenta anos de progresso em cinco de governo' e não há dúvida de que de 1956 a 1961 o Brasil apresentou um crescimento econômico real e marcante. A base para o progresso foi uma extraordinária expansão da produção industrial. Às firmas estrangeiras foi dado um incentivo especial para investir na indústria brasileira. A fim de encorajá-las para trazer equipamentos industriais para o Brasil, o que era extremamente necessário, o governo fez uso liberal da Instrução 113 da SUMOC, baixada durante o Governo Café Filho [1954-1955]. Essa regulamentação isentava as firmas estrangeiras da necessidade de providenciar cobertura cambial externa para importar maquinaria, desde que estivessem associadas a empresas brasileiras. $\mathrm{O}$ apelo aos investimentos privados, estrangeiros e nacionais, foi bastante bem sucedido, especialmente em indústrias chaves tais como produção de veículos, onde uma virtual autosuficiência foi conseguida em apenas cinco anos, com a produção alcançando 100.000 veículos por ano, no fim do governo. A estratégia de Kubitschek, contudo, não repousava exclusivamente no setor privado. O governo empreendeu um programa escalonado de investimentos públicos, dirigido para a superação dos estrangulamentos estruturais nas áreas dos transportes e [...] energia. Ordenando a estratégia completa de desenvolvimento econômico de Kubitschek, tínhamos uma série de metas de produção, que abrangiam tudo, alinhadas formalmente em $1958^{1201}$. Executando o seu programa, o governo era pragmático, enfatizando o crescimento das indústrias de base e virtualmente ignorando áreas como a agricultura e a educação, apenas nominalmente incluídas no Programa de Metas ${ }^{1202}$.
\end{abstract}

\footnotetext{
${ }^{1199}$ Acreditamos que os maiores limites de velocidade permitidos para o tráfego na "zona rural" dos tipos de veículos então mencionados, não se devem às condições das respectivas estradas, pois se encontravam, comumente, em pior estado de conservação do que aquelas existentes nos perímetros urbano e suburbano. Assim, observamos que esses limites foram legalmente permitidos em função da menor concentração e/ou densidade populacional apresentada naquela área.

${ }^{1200}$ Sobre o gradativo aperfeiçoamento dos automóveis no período, ver, também, Tabela 04: Taxas de serviço de conservação de estradas e de registro e fiscalização de veículos - 1936, disposta no capítulo terceiro deste estudo (p. 188). O aperfeiçoamento dos veículos motorizados também é estendido aos coletivos. A esse respeito, o artigo 66 do primeiro código nacional de trânsito estipula, dentre outros dispositivos, que "Art. 66 - Nenhum veículo a motor de explosão, de transporte coletivo a frete, com exceção dos usados somente para excursões de turismo poderá trafegar sem observância das seguintes condições: a) ser a respectiva carroceria fechada, provida de janelas, portas de subida e descida, dispositivos para ventilação e bancos para os passageiros; b) serem as janelas protegidas do exterior, até a altura de 0,15 ou 0,20 do peitoril, com barras metálicas com diâmetro inferior a 0,01 m”. (Decreto-lei n. 3651: dá nova redação ao Código Nacional de Trânsito. Rio de Janeiro, 25 de setembro de 1941... op. cit., p. 584-585). Essas determinações eram, ao que tudo indica, seguidas pelas leis estaduais e municipais; pelo menos , isso é o que podemos especular quanto à instituição, na cidade de Florianópolis, dos pontos de parada dos coletivos. Já vimos considerações a esse respeito, mas destacamos, aqui, que o próprio código nacional de trânsito estipulou regras para tal, pois em seu artigo 68 é especificado que "Art. 68 - Os pontos ou paradas para embarque e desembarque dos veículos de transporte coletivo serão determinados pelas autoridades de trânsito, devendo ter sinalização visível". (Ibidem, p. 585). Ver, também, a) Santa Catarina. Secretaria da Segurança Pública. Ofício expedido pelo Inspetor Geral de Trânsito em Florianópolis, Raimundo Vieira, à Secretaria de Segurança Pública. Florianópolis, 27 maio 1942. p. 118-119; b) Santa Catarina. Legislação Estadual. Decreto n. 14, 03 nov. 1939. In: Decretos-Leis, Decretos, Resoluções e Portarias. Janeiro a junho de 1940. Imprensa Oficial do Estado, jan. 1940. p. 74-79. As políticas e determinações viárias e de trânsito, instituídas nos estados e municípios, seguiam em linhas gerais, as diretrizes alçadas na esfera federal. Controle e dirigismo estatal centralizados eram, pois, as linhas mestras de atuação do governo brasileiro, no período.

${ }_{1201}$ Conforme Boris Fausto, "Apresentado já na campanha eleitoral de Juscelino como triunfo importante, o Plano, ou mais propriamente, o Programa de Metas, consistia num reforço do planejamento estatal contido em 31 metas, distribuídas em seis grandes grupos: energia, transportes, alimentação, indústrias de base, educação, e a 'meta-síntese', a construção de Brasília. O êxito do Programa é inegável, tanto na implantação do setor de bens de consumo durável, com ênfase especial para a indústria automobilística, quanto no amplo desenvolvimento da siderurgia e outros ramos do setor de bens de produção. O crescimento do setor de transportes foi bastante intenso, e o da produção energética atingiu um tal porte que exigiu a reforma administrativa que criou o Ministério das Minas e Energia". (FAUSTO, Boris. História Geral da Civilização Brasileira. 9. ed. Rio de Janeiro: B. Brasil, 2000. Tomo III: O Brasil Republicano. v. 4: Economia e Cultura (1930-1964). p. 266).

${ }^{1202}$ SKIDMORE, Thomas. Brasil: de Getúlio a Castelo (1930-1964). 12. ed. Rio de Janeiro: Paz e Terra, 2000. p. 204-207.
} 
Corroborando com esses elementos, Margarida Cintra Gordinho, no livro Transportes no Brasil: a opção rodoviária (São Paulo: Marca D’água, 2003), considera que “[...] o período de 1954-1956 foi marcado pela redução das atividades econômicas e do ritmo de crescimento, não podendo ser superados os pontos de estrangulamento do setor de transportes" ${ }^{" 1203}$. Entretanto, “[...] a partir de 1957, o governo JK fez investimentos diretos no setor de transportes, energia e refino de petróleo" ${ }^{\text {1204 }}$. Expandia-se, assim, a industrialização e a necessidade de transportes.

A autora considera, ainda, que "o ponto de partida para a produção automobilística foi [...] o incentivo à fabricação dos caminhões e tratores. A intensificação do programa do caminhão pesado e do trator, dos investimentos à indústria nacional produtora de autopeças e de uma política de fomento à indústria do automóvel visava, também, à rápida instalação da indústria automobilística"1205. Assim, "em 1957, todas as facilidades foram criadas para a indústria automobilística no Brasil. A General-Motors, a Ford, a Mercedes-Benz, a Scania-Vabis, a Vemag, a Simca, a Toyota, a Volkswagen e a Willys Overland se instalaram para atender o crescente mercado brasileiro" 1206 . Segundo a mesma autora, tais fábricas "começaram a produzir veículos modernos, com maior capacidade de volume de carga e mais compatíveis com o uso demandado pelo amplo território brasileiro. A integração regional se sedimentava ${ }^{1207}$; crescia o mercado e, em conseqüência, aumentava o tráfego de carga" ${ }^{" 1208}$. Nesse quadro, Margarida Cintra Gordinho aponta, inclusive, dados numéricos que indicam que "no início dos anos 50, o país tinha 262.529 automóveis e 210.244 caminhões e ônibus, num total de 472.772 veículos" ${ }^{209}$.

Esses dados só adquirem, porém, maior sentido ao apontarmos, no mesmo período, os investimentos feitos pelo governo estadual nas redes ferroviária e rodoviária de Santa Catarina, conforme registrados na "Mensagem à Assembléia Legislativa", apresentada pelo então governador do Estado, Irineu Bornhausen, no ano de 1954. Esse texto apresenta que, "no exercício de 1953 , o $\mathrm{DER}^{1210}$ programou uma receita de $\mathrm{Cr} \$ 76.553 .077,50$, e despesa de igual

\footnotetext{
${ }^{1203}$ GORDINHO, Margarida Cintra. Transportes no Brasil: a opção rodoviária. São Paulo: Marca D’Água, 2003. p. 123.

${ }^{1204}$ Idem.

1205 Idem.

1206 Idem.

${ }^{1207}$ É importante observarmos que, nessa época, “A construção da nova capital e o translado do poder decisório do Rio de Janeiro para Brasília deram impulso ao setor rodoviário", pois se tornou "prioridade máxima a integração de Brasília com todas as regiões do país, e as rodovias cumpriram esse papel. Do plano rodoviário daquele período, cabe ressaltar as construções das rodovias pioneiras: Belém-Acre, São PauloBrasília e Cuiabá-Porto-Velho". (GORDINHO, Margarida Cintra. Transportes no Brasil: a opção rodoviária... op. cit., p. 127).

${ }^{1208}$ GORDINHO, Margarida Cintra. Transportes no Brasil: a opção rodoviária... op. cit., p. 123. Sobre o sistema ferroviário nacional, a mesma autora considera que "[...] até a década de 1960 foi executado $80 \%$ da reparação de vias permanentes e incorporaram-se à rede [ferroviária nacional] 7.052 vagões, um crescimento de 3,2\%. A dieselização e a melhoria das condições de tráfego possibilitaram a ampliação de $21,7 \%$ do volume de carga transportada; entre 1955 e 1960, o número de passageiros cresceu 19\%. Foi um desempenho significativo, mas certamente muito inferior ao desenvolvimento do sistema rodoviário". (Ibidem, p. 79).

1209 GORDINHO, Margarida Cintra. Transportes no Brasil: a opção rodoviária... op. cit., p. 123. Outros informes apontam, de modo aproximado, que, no ano de 1950, o País possuía 200.141 automóveis comuns e 145.552 caminhões. Totalizava, dessa forma, 345.693 veículos desse tipo. (Anuário Estatístico do Brasil, ano XII, Rio de Janeiro, 1952. p. 174).

${ }^{1210}$ Departamento de Estradas de Rodagem. Esse órgão foi criado, como pessoa jurídica, pelo Decreto-lei n. 217 , de 12 de setembro de 1946. Conforme o decreto-lei aqui assinalado, esse departamento foi organizado, considerando-se, dentre outros aspectos, que "a estrada de rodagem contribui, hoje, graças à perfeição atingida pelo automóvel, para o desenvolvimento econômico do Estado", pois a mesma "representa elemento de importância básica no sistema de viação interna de qualquer Estado". (Decreto-Lei n. 217, de 12 de set. de 1946. Reorganiza a Diretoria de Estradas de Rodagem do Estado, nos moldes do decreto-lei federal n. 8.463, de 27 de dezembro de 1945. In: Santa Catarina. Legislação 1946. Florianópolis: Imprensa Oficial do Estado, 1946. p. 70-76). Além disso, esse mesmo decreto-lei deixa claro que as políticas nacional e estadual
} 
valor, contando com as seguintes: Estadual: Cr\$ 47.303.077,50; Federal: (FRN): Cr\$ 29.250.000,00"; mas salienta que "as circunstâncias determinaram, entretanto, modificações, havendo necessidade de reajustar-se o Programa, de forma a estimar em Cr\$ 98.153.733,50 a Receita e Despesa"1211. No “encerramento do exercício, porém, verificou-se que o movimento havia sido o seguinte: Receita: Cr\$ 100.402.780,30; Despesa: 95.610.463,80”, para um saldo de "4.082.102,30"; em contrapartida, as receitas orçada e realizada junto à "Estrada de Ferro Santa Catarina", foram, respectivamente, da ordem de Cr\$ 5.949.000,00 e Cr\$ 4.471.848,60, apresentado uma "diferença para menos de Cr\$1.477.151,40"; e, na mesma linha, "as despesas orçadas e realizadas foram assim discriminadas, Cr\$ 13.272.500,00 e Cr\$ 12.323.372,30, apresentando uma 'diferença para menos' de Cr\$949.127,70”1212.

As expressões numéricas apresentadas são importantes apenas na medida em que nos fornecem um panorama dos investimentos e despesas feitos pelo governo estadual nos planos rodoviário e ferroviário; por meio delas, podemos, ainda, observar o maior montante investido em estradas e rodovias. Além disso, cabe salientarmos que, no quadro relativo à "Estrada de Ferro Santa Catarina", nem mesmo o total orçamentário de apenas Cr\$ 5.949.000,00 - se comparado ao valor total orçado para investimentos em estradas de rodagem, da ordem de Cr\$ 100.402.780,30 - foi completamente utilizado, pois houve uma "diferença para menos" de Cr\$ 1.471.848,60. Ademais, as despesas realizadas, no ano de 1953, para com aquela estrada de ferro, ultrapassaram consideravelmente as respectivas receitas orçada e realizada, o que nos indica, muito provavelmente, problemas e dificuldades encontradas para a conveniente manutenção da malha ferroviária referida ou, também, o tratamento não prioritário concedido pelo governo a essas atividades ${ }^{1213}$. No quadro dos investimentos aplicados nas estradas de

para o fomento à viação rodoviária e ao transporte automotivo estavam entrelaças, pois destaca que "compete ao Estado providenciar a conservação e melhoramento progressivo das rodovias de interesse geral dentro do seu território, o que depende, em grande parte, da colaboração racional com a União". (Idem). Nesse sentido é que, a partir deste momento, compete ao Departamento de Estradas de Rodagem, dentre outras atribuições, "Art. 2. ${ }^{\circ}$; a) - executar e fiscalizar todos os serviços técnicos e administrativos concernentes a estudos, projetos, especificações, orçamentos, locação, construção, reconstrução e melhoramento das estradas no Plano Rodoviário Estadual [sobre este plano, ver capítulo terceiro], inclusive pontes de demais obras complementares"; “[...] j) - prestar assistência técnica aos municípios no planejamento e execução de estradas e caminhos municipais". (Idem). Como podemos perceber, as políticas estaduais e municipais voltadas ao incremento ao rodoviarismo estavam integradas em um plano mais abrangente, que envolvia as diretrizes gerais estabelecidas pela esfera federal.

${ }^{1211}$ BORNHAUSEN, Irineu. MENSAGEM à Assembléia Legislativa: apresentada pelo Governador do Estado por ocasião da abertura da Sessão Legislativa de 1954. Florianópolis, 15 abr. 1954. p. 72.

1212 Idem.

${ }^{1213}$ A esse respeito, já em 1948 a Mensagem apresentada à Assembleia Legislativa, em 15 de abril daquele ano, dava conta de que “a direção da Estrada [de Ferro Santa Catarina], nas três seções de transporte - Férrea; Rodoviária e Fluvial - continua lutando com dificuldades, determinadas, principalmente, pela deficiência de material rodante e de tração, cuja capacidade permite atender somente cerca de um terço da produção da zona servida pelo Estado". A mesma Mensagem registra, também, que, "em 1946, dada a deficiência dos serviços de tráfego, a arrecadação verificada (Cr\$ 5.128.344,70) foi insuficiente para cobrir a despesa (Cr\$ 5.600.722,20), havendo déficit de Cr\$ 532.377,60.” Apesar das dificuldades assinaladas, o "Governo Federal" dotou, "para o exercício de 1947”, a "verba de nove milhões de cruzeiros para prosseguimento dos serviços de construção do trecho "Itajaí-Blumenau", inclusive as despesas com a construção da grande ponte em concreto armado, sobre o rio Itajaí-Açu, no perímetro urbano da cidade de Blumenau”. (SILVA, Aderbal Ramos da. MENSAGEM apresentada à Assembléia Legislativa. Florianópolis: Imprensa Oficial do Estado, 15 abr. 1948. p. 132-133). Destacamos esses trechos para argumentar que, apesar das dificuldades apresentadas para manter-se em atividade a "Estrada de Ferro Santa Catarina", o governo estadual, em parceria com a União, também alçou investimentos para operar o prolongamento e as melhorias no serviço ferroviário no Estado. Esses elementos permitem assinalar similitudes às ideias expressas por Margarida Cintra Gordinho, pois, como visto, essa autora observou que, "[...] até a década de 1960 foi executado $80 \%$ da reparação das vias [férreas] permanentes" e foram incorporados perto sete mil vagões àqueles já existentes; assim, argumenta, houve entre 1955 e 1960 , "um desempenho significativo" dessas atividades, mas "certamente muito inferior ao desenvolvimento do sistema rodoviário". Assim, o que observamos, como tendência geral, verificada durante as décadas de 1940, 1950 e 1960, é o maior investimento feito no campo rodoviário, em 
rodagem, vemos bem o contrário, uma vez que houve um "saldo para 1954" da ordem de "Cr\$ 4.082.102,30"; isso em relação às despesas e aos investimentos aplicados, no valor de Cr\$ $95.610 .463,80^{1214}$.

Desse modo, os aspectos analisados permitem-nos constatar que, durante a década de 1950, o incentivo ao transporte rodoviário e o incremento da frota e do fluxo de automóveis tornaram-se significativos nos cenários nacional, estadual e municipal. Atestamos, igualmente, como já referido, o gradativo barateamento do custo dos automóveis, o que viabilizou sua aquisição por um maior contingente populacional. (Anexo 19, p. 350).

Incrementando essa discussão, temos que, no plano municipal, as percepções expressas pelos florianopolitanos sobre a circulação do trânsito pelas ruas da capital catarinense constituem, como visto, objeto central de investigação para o presente estudo. Essas percepções relacionam-se, intimamente, ao incremento da velocidade atingida pelos automóveis; pois, no período em estudo, atestamos o gradual aperfeiçoamento de veículos, regras e condutas de trânsito que salientam o encurtamento das distâncias e a gradativa e conflituosa adaptação dos pedestres e transeuntes ante a circulação dos meios de transporte motorizados. Assim é que, no plano municipal, o adensamento do fluxo de automóveis já fica bem evidente no transcorrer da década de 1950. Pelo menos isso é o que podemos constatar a partir das considerações feitas pelo primeiro Plano Diretor ${ }^{1215}$ da cidade, datado de $1952 / 1955^{1216}$.

detrimento do marítimo e ferroviário. Esses investimentos refletiram ou foram exigidos pela intensificação do fluxo automotivo nas estradas intermunicipais de Santa Catarina e, especialmente, em sua Capital. Assim, retomamos algo já visto no capítulo terceiro da tese - ver seção Legislação e Circulação... (p. 184 segs.) -, que remete à adoção, pelo Decreto-lei n. 489, de 24 de outubro de 1940, da obrigatoriedade do emplacamento anual de veículos automotores, decreto que entrou em vigor em 1 . $^{\circ}$ de janeiro de 1941 . (Decreto-lei n. 489 , de 24 de out. de 1940. Dispõe sobre emplacamento de veículos. In: Santa Catarina. Coleção de Decretos-Leis, Decretos, Resoluções e Portarias, jun. 1940. p. 203204). Observamos, assim, a necessidade de regulamentar-se, com maior ênfase, um fluxo automotivo cada vez mais intenso e diversificado.

${ }^{1214}$ Corroborando com esses elementos, o discurso proferido por Irineu Bornhausen, no dia 31 de janeiro de 1955 , no Anuário Catarinense daquele ano, aponta que, durante os quatro anos do seu governo (1951-1954), o DER. operou "além dos trabalhos de conservação, melhoramento e reconstrução de centenas de quilômetros", a construção, "durante esses quatro anos, [de] mais de 300 quilômetros de estradas novas. Entre as principais rodovias em construção, cumpre mencionarmos a que liga Joinville à São Francisco do Sul, a reconstrução da Antiga Estrada Dona Francisca e a abertura da Serra do Rio de Rastro, entre Lauro Müller e Bom Jardim da Serra, ligando-se duas regiões geoeconômicas isoladas pelos paredões da Serra Geral". Além disso, o mesmo discurso aponta que "quem transita, hoje, pelas estradas estaduais, já deve ter observado que o trabalho de recuperação vai marchando em ritmo animador, observando-se sensível melhora no estado geral das estradas". Ver No $4 .^{\circ}$ Aniversário do Governo Estadual: Damos, a seguir, a íntegra do importante discurso proferido pelo Exmo. Sr. Governador Irineu Bornhausen, no dia 31 de janeiro de 1955, no ensejo do transcurso do $4 .^{\circ}$ aniversário de sua profícua administração. In: Anuário Catarinense. Ano VIII, n. 8. Florianópolis, 1955. p. 169-180. Do exposto, podemos observar dois aspectos principais: a) a preocupação em operar-se a integração do Estado por meio da construção e melhoria das estradas de rodagem; e b) os claros investimentos destinados pelos governos estadual e federal neste setor. Salientamos, portanto, para aquele período, nítida afinidade entre as políticas estadual e federal, que primavam pelos investimentos que se deveriam destinar à melhoria e re-equipamento das malhas rodoviárias existentes no Estado e no País.

${ }^{1215}$ Maria Stella Bresciani, ao referenciar a Encyclopédie d'Hygiène et de médicine publique (1891), observa que, a partir da década de 70 do século XIX, “[...] a noção de melhoramentos [grifo da autora] assume amplamente as diretrizes funcionais e estéticas do sanitarismo: tornar saudável ou higienizar e aprazível ou embelezar". (ROCHARD, Jules. (Org.). Encyclopédie d'Hygiène et de médicine publique. Paris: Lecrosnier et Babe, Libraires-Éditeurs, 1891 apud BRESCIANI, Maria Stella Martins. Melhoramentos entre intervenções e projetos estéticos: São Paulo (1850-1950). In: . (Org.). Palavras da cidade. Porto Alegre: UFRGS, 2001. p. 349). Referindo-se aos dois momentos seguintes observados nos estudos sobre os meios urbanos, Maria Cristina da Silva Leme expõe que "A partir de 1920, a palavra urbanismo se torna de uso corrente. Não designa apenas uma prática como melhoramento, mas pretende conceituar uma área de conhecimento", e é "utilizada referindo-se inicialmente às questões da administração e, em seguida, ao planejamento da cidade". (LEME, Maria Cristina da Silva. Urbanismo: a formação de um conhecimento e de uma atuação profissional. In: BRESCIANI, Maria Stella M. (Org.). Palavras da cidade... op. cit., p. 85). Na década de 1950, a palavra urbanismo é, porém, substituída pelo termo Planejamento. Observando, novamente, as palavras de Maria Cristina da Silva Leme: "Planejamento urbano que a substitui, a partir dos anos 50, é novamente a defesa de um campo profissional concentrando [...]; o plano urbano. Com o tempo a ideia do plano sobrepõe-se e esvazia a de planejamento urbano". (Ibidem, p. 88). Temos, portanto, a grosso modo, três momentos distintos quanto às concepções e estudos sobre os ambientes urbanos. Podemos referir, portanto, que o primeiro plano diretor da cidade de Florianópolis enquadra-se, pelo menos de maneira conceitual, no terceiro momento aqui apresentado.

${ }^{1216}$ A versão final do documento foi aprovada pela Câmara Municipal em 1955, mediante a Lei 246/55. Ver Lei 246, 15 nov. 1955. Diário Oficial. Estado de Santa Catarina. Ano III, n. 5.495, Florianópolis, 21 nov. 1955. 
Nesse texto, os responsáveis por sua elaboração consideraram que a ocupação dos terrenos baldios e das áreas desocupadas e situadas ao norte do perímetro central da cidade - resquícios das antigas chácaras - seria efetuada com a ampliação do sistema viário. Assim, de acordo com o Plano Diretor, previa-se, na Ilha, "um sistema de vias que partem da Avenida Tronco, ligando as praias Sul e Norte em diversos pontos"1217. Desse sistema fazem parte, dentre outras, a Avenida Rio Branco, que "incluirá a rua Padre Roma, alargada para 18 metros, desde o centro cívico até a rua Tenente Silveira (prolongamento). Seu prolongamento até a praia Norte será feito através de terrenos baldios, com uma largura de 25 metros"1218. Está incluído, naquele sistema, “o prolongamento da Rua Padre Roma (Norte): vias com 18 metros de largura, provenientes de alargamento, através de recuo de alinhamento das ruas: Esteves Júnior, Trompowsky, Vidal Ramos"; além disso, "o alargamento das ruas Esteves Júnior, Vidal Ramos e Nereu Ramos tem como finalidade ligar melhor o atual centro comercial à zona da praia Norte" ${ }^{, 1219}$.

Salientamos, dado o exposto, que a abertura de novas ruas garantiria a ocupação e a acessibilidade à área norte, mediante ligação com a ponte Hercílio Luz e com o centro administrativo-comercial da cidade, localizado na parte sul da península ${ }^{1220}$. Vale observarmos que na parte insular, o plano diretor deteve-se apenas à área central, para a qual propunha a implantação da já referida Avenida-Tronco, que se originava no Continente, efetuava a conexão com a ponte Hercílio Luz e, na Ilha, contornava a orla sul da península. Ao longo dessa avenida, seriam instalados um centro cívico e comercial e a Cidade Universitária ${ }^{1221}$. Neste contexto, é importante destacarmos, também, que a abertura de novas ruas e o prolongamento e alargamento das antigas vias, como então propostos, estão intimamente relacionados a outra observação feita pelos autores do plano, que aponta que nas "últimas décadas, aparece e cresce o transporte motorizado e a existência da ponte Hercílio Luz faz aumentar bastante o tráfego, na península"1222. Continuando, registram que "esse novo núcleo funcional teve que ocorrer no mesmo espaço viário primitivo, e entrará, cada vez mais, em conflito com a forma urbana original, com o traçado herdado do passado"1223. Assim é que "o tráfego é obrigado a fluir

\footnotetext{
${ }^{1217}$ PAIVA, Edvaldo Pereira; RIBEIRO, Demétrio; GRAEFF, Edgar A. FLORIANÓPOLIS: Plano Diretor. Florianópolis: Imprensa Oficial do Estado do Rio Grande do Sul, 1952. p. 42. (Administração do Prefeito Dr. Paulo de Tarso da Luz Fontes).

${ }^{1218}$ Idem.

${ }^{1219}$ Idem

${ }^{1220}$ A esse respeito, o plano considerou que "a existência de grandes chácaras dentro do perímetro urbano e nas proximidades do centro atual, de propriedade de famílias tradicionais, foi um dos fatores determinantes da existência, até o presente momento, de extensas áreas vazias nas zonas mais próprias para habitações. Caracterizou-se, assim, um desequilíbrio de crescimento entre os dois lados da península. O lado Sul, primitivamente ocupado, cresceu e se densificou mais rapidamente que o lado Norte. O lado Norte, em sua maior parte, mantém-se, até hoje, dividido em grandes glebas, servindo de anteparo ao natural crescimento dos núcleos residenciais". (PAIVA, Edvaldo Pereira; RIBEIRO, Demétrio; GRAEFF, Edgar A. FLORIANÓPOLIS: Plano Diretor... op. cit., p. 12). Sobre uma maior discussão a respeito da existência e ocupação de chácaras na parte norte da península, ver capítulo primeiro da tese e Mapa 03: Localização das Chácaras dentro do Perímetro Urbano de Florianópolis - final do século XIX e início do XX, incluso naquele capítulo (p. 54).

${ }^{1221}$ PAIVA, Edvaldo Pereira; RIBEIRO, Demétrio; GRAEFF, Edgar A. FLORIANÓPOLIS: Plano Diretor... op. cit., p. 21 e segs.

1222 Ibidem, p. 16.

${ }^{1223}$ PAIVA, Edvaldo Pereira; RIBEIRO, Demétrio; GRAEFF, Edgar A. FLORIANÓPOLIS: Plano Diretor... op. cit., p. 16. Segundo os autores do plano, durante o século passado "a cidade de Florianópolis continuou crescendo lentamente e se densificando, junto à primitiva praça principal [hoje, Praça XV de Novembro]”. (Ibidem, p. 12). Neste ponto, parafraseando Murilo Marx, devemos observar que, no Brasil colonial, "[...]
} 
através de ruas inapropriadas"; e, desse modo, o plano estipulou, em última análise, regulamentos para a abertura, pavimentação e alargamento das ruas ${ }^{1224}$.

Os aspectos observados anteriormente são, igualmente, registrados pelas notas jornalísticas da época. Assim, no ano de 1953, o artigo do jornal $A$ Gazeta, salientou que "o problema da locomoção em Florianópolis está exigindo providências urgentes, pois dentre poucos anos, a situação se tornará muito grave" ${ }^{, 1225}$. A mesma nota observa, em outro momento, que "as nossas ruas centrais são estreitas, e não tardará a necessidade da proibição total de tráfego de veículos no centro comercial", visto que "os veículos estão sendo construídos cada vez mais compridos e já não se concebe dos modernos ônibus ainda continuarem utilizando ruas estreitíssimas como são a Conselheiro Mafra, a Tiradentes e a João Pinto"1226. Os elementos aqui destacados permitem-nos considerar que os problemas relativos ao deslocamento e mobilidade urbanos, na parte central da capital do Estado, apontados pelo menos desde a década de 1930, faziam-se ainda presentes duas décadas depois.

O Projeto de Lei de Urbanismo e Zoneamento, incluso no Plano Diretor, atendeu grande parte das solicitações expressas anteriormente e determinou, portanto, “Art. 36 - Para aos novos arruamentos", as "seguintes condições: a) Percentagem mínima de verde público (praças, etc.) $10 \%$; b) Para os quarteirões de uso residencial: Forma retangular, com medida menor de cinqüenta a setenta metros [...] e maior de trezentos e sessenta metros" ${ }^{\text {1227 }}$. Nesse item, também foram especificados "Lotes com frentes mínimas de doze metros e área mínima de trezentos metros quadrados"1228. O projeto de lei especificava, igualmente, que “c) Para os quarteirões de

muitos núcleos populacionais testemunharam um esforço lento e diversificado de ações oficiais conscientes para alargar as fronteiras, ou garantilas, como no caso de Nossa Senhora do Desterro. Essa localidade é um exemplo de fundação lusitana na América portuguesa, onde as ruas começaram a se destacar entre os inúmeros vazios, partindo do núcleo gerador que representava o poder político-administrativo e religioso: a Praça ou Largo da Matriz, a Casa do Governo, a Câmara, de forma a manter alguma regularidade, dentro do que concebiam as Provisões Régias. Mas o notório crescimento das vilas e cidades no Brasil colonial extrapolou os traçados iniciais, perfilando-se os casarios na direção dos pontos de interesse e de concentração, descendo encostas ou alinhando-se à praia. Este aspecto caracterizou as fundações lusitanas no território brasileiro, conferindo-lhe fisionomia própria". (MARX, Murilo. Cidade Brasileira. São Paulo: Melhoramentos/Universidade de São Paulo, 1980. p. 36). Ver, também, a respeito: REIS, Nestor Goulart. Imagens de Vilas e Cidades do Brasil Colonial. São Paulo: EDUSP/Imprensa Oficial do Estado/Fapesp, 2000. (Estande USP - Brasil 500 Anos).

${ }^{1224}$ PAIVA, Edvaldo Pereira; RIBEIRO, Demétrio; GRAEFF, Edgar A. FLORIANÓPOLIS: Plano Diretor... op. cit., p. 16

${ }^{1225}$ Problemas de Trânsito em Florianópolis. A Gazeta. Florianópolis, 26 mar. 1953. s/p.

${ }^{1226}$ Problemas de Trânsito em Florianópolis. A Gazeta... op. cit. A esse respeito, outra nota do periódico O Estado, de 25 de novembro de 1949 , registra, nessa data, a opinião de um "leitor assíduo" daquele jornal, que, endereçando seus reclames ao diretor do mesmo, observa que "A rua Conselheiro Mafra" é "por demais estreita". Assinala, também, que, "Na rua João Pinto, Sr, diretor, depois do Cine Imperial, a calçada desaparece, porque o meio-fio está colocado bem rente às soleiras das portas". Frente a estas colocações, o referido personagem sugere àquele Diretor que proíba "o trânsito de veículos por aquela rua, por demais estreita", ainda mais que "do lado direito estacionam automóveis e caminhões, que congestionam metade da rua". Observa, ainda, que "os pesados ônibus que demandam à Praça da Bandeira e os caminhões que transportam terra para o aterro que se faz naquele local, passam com suas 'caixas' por cima dos passeios, e por pouco não ocasionam violento choque aos que caminham no mesmo sentido sobre a calçada, arriscados que estão de serem projetados ao solo, de nariz no chão". Assim, o mesmo leitor sugere que "A Inspetoria de Veículos, ou proíbe o estacionamento de veículos do lado direito, ou impede o trânsito dos ônibus e caminhões, por aquela rua, obrigando-os a transitarem pela rua do Cais [Liberdade], como faz o ônibus da linha Mauro Ramos", pois "esta seria uma providência acertada"; afirma, por fim, estar "certo de que as autoridades competentes estudarão devidamente o assunto". (Com a Inspetoria de Veículos. O Estado. Florianópolis, 25 nov. 1949. p. 8). Essa nota possibilita termos uma ideia de quão problemático era o fluxo de automóveis nas ruas mencionadas, e sinaliza, também, para o perigo dos atropelamentos, algo que, neste estudo, discutimos à exaustão, especialmente para os decênios de 1920 e 1930; e, pelo que percebemos, continuaram ocorrendo nas décadas seguintes. Atropelamentos e dificuldades na locomoção urbana exigiam, conforme apontado, a atuação do poder público para que se tentasse equacioná-los.

${ }^{1227}$ PAIVA, Edvaldo Pereira; RIBEIRO, Demétrio; GRAEFF, Edgar A. FLORIANÓPOLIS: Plano Diretor. Florianópolis: Imprensa Oficial do Estado do Rio Grande do Sul, 1952. p. 76-78. (Administração do Prefeito Dr. Paulo de Tarso da Luz Fontes).

${ }^{1228}$ Idem. 
uso industrial" deveria haver uma "área mínima de quinze mil metros quadrados; lotes mínimos de mil metros quadrados” e que "d) As ruas serão de 4 tipos: 1) Avenidas locais - residenciais comerciais. Largura - vinte e dois metros, sendo doze de caixa, e dois passeios arborizados; 2) Ruas locais ajardinadas. Largura - dezessete metros sendo sete de caixa e dez de passeio; 3 ) Ruas de habitação. Largura - doze metros, sendo 6,00 seis de caixa; 4) Passagens para pedestre. Não permite o tráfego de veículos. Largura mínima - 4,00 quatro metros"1229 .

A análise desses elementos permite-nos constatar a preferência concedida à circulação automobilística no perímetro urbano de Florianópolis. Além disso, nas "últimas décadas aparece e cresce o transporte motorizado e a existência da ponte Hercílio Luz faz aumentar bastante o tráfego, na península". Na década de 1950, era, portanto, notória e significativa a presença dos veículos motorizados no perímetro central da capital catarinense. A elaboração e a aplicação do plano diretor testemunham, com efeito, a necessidade de ordenação do espaço urbano de Florianópolis para atender, dentre outros aspectos, ao crescente fluxo de automóveis.

É importante considerarmos que o Plano Diretor propunha, igualmente, a construção da avenida Beira-Mar. Essa via contornaria a orla norte e, tendo 30 metros de largura, seria implementada sobre o fundo das propriedades existentes - resquícios das antigas chácaras. Além disso, seria conectada à avenida Tronco Sul, alcançando o centro administrativo-comercial da cidade pela orla marítima. Essa nova avenida, conhecida posteriormente como Avenida BeiraMar Norte, foi implantada na década de 1960 e se constituiu na intervenção viária precursora da atual Via de Contorno Norte-Ilha ${ }^{1230}$. Das proposições do Plano Diretor, foram implementadas principalmente aquelas de caráter rodoviário, que garantiram acessibilidade às áreas ao norte da península. Assim, das proposições viárias mais importantes definidas para a parte insular da cidade, apenas a Avenida Beira-Mar Norte foi executada de acordo com o Plano ${ }^{1231}$. Percebemos, portanto, no decorrer da década de 1950, a marcante presença dos veículos motorizados e a prioridade concedida pelo poder público municipal aos investimentos no transporte rodoviário. É por isso que, nos decênios de 1940, 1950 e 1960, o transporte rodoviário

\footnotetext{
${ }^{1229}$ PAIVA, Edvaldo Pereira; RIBEIRO, Demétrio; GRAEFF, Edgar A. FLORIANÓPOLIS: Plano Diretor... op. cit., p. 76-78.

${ }^{1230}$ SUGAI, Maria Inês. As Intervenções Viárias e as Transformações do Espaço Urbano: A Via de Contorno Norte-Ilha. Dissertação (Mestrado em Arquitetura e Urbanismo). São Paulo: USP, 1994. p. 66. De acordo com a autora, "A abertura da Avenida Beira-Mar Norte garantiu a acessibilidade e a conseqüente valorização da área norte da península. A construção desta avenida foi iniciada na década de 60 , na gestão do governador Celso Ramos, e concluída e pavimentada no início da década de 70, no governo de Ivo Silveira. A Avenida Beira-Mar Norte iniciava na Praça Celso Ramos, no bairro Agronômica, margeava a orla em aterro sobre a Praia de Fora e a Praia do Müller, até alcançar a cabeceira da ponte Hercílio Luz. No início da década de 70, iniciaram-se a construção dos primeiros edifícios residenciais ao longo da orla da avenida, posteriormente denominada Avenida Rubens de Arruda Ramos". (Idem).

${ }^{1231}$ O Plano Diretor expôs que o atraso apresentado pela cidade de Florianópolis em relação a outras cidades do Estado advinha de seu fraco desenvolvimento econômico, do baixo poder aquisitivo de sua população e dos reduzidos recursos da administração municipal. Partia-se, assim, da ideia de que era necessário criar um fator positivo que incrementasse o desenvolvimento econômico da cidade. O plano estabeleceu que esse fator positivo era a construção de um moderno porto em Florianópolis, pois "esse é o fato mais importante a considerar para uma justa interpretação do futuro desenvolvimento da cidade. O porto será um fator importante para o seu progresso econômico. Esse progresso, significando desenvolvimento industrial e comercial, virá condicionar fundamentalmente a concepção do Plano". (PAIVA, Edvaldo Pereira; RIBEIRO, Demétrio; GRAEFF, Edgar A. FLORIANÓPOLIS: Plano Diretor... op. cit., p. 16). A ideia da construção de um "novo porto" na cidade, aventada pelos autores do plano, não saiu, entretanto, do papel. Outras considerações a esse respeito serão expostas a seguir.
} 
de mercadorias, efetuado entre a capital catarinense e as cidades continentais próximas e demais cidades do Estado e do País, demonstrou ser mais vantajoso que o transporte marítimo.

Esse aspecto reflete não apenas a melhoria progressiva das estradas e dos veículos automotores, como também os incentivos financeiros dos governos estadual e federal ao transporte rodoviário. Além disso, a construção da ponte Hercílio Luz e as dificuldades técnicas do porto de Desterro estimularam, progressivamente, o transporte rodoviário. De acordo com o Guia do Estado de Santa Catarina, de 05 de setembro de 1927,

\begin{abstract}
Os portos de fato utilizados para a comunicação entre a navegação e a viação terrestre, existem deles no nosso estado, 5, a saber: São Francisco, Itajaí, Florianópolis, Imbituba e Laguna. Nenhum, porém, de todos estes portos está provido de um cais e fácil acesso, que permitisse a atracação de navios de longo curso, nem de meios adequados para um carregamento e descarregamento expedito, nem de armazéns suficientes, nem finalmente de uma rápida comunicação com a região a servir; por outro lado não possuímos nenhum porto moderno. Não fosse o nosso estado um dos politicamente mais fracos e de situação financeira meio delicada, não se compreenderia porque o governo federal até agora tem mostrado tão pouco interesse em dotar esta parcela de nossa pátria de um meio de comunicação que de um lado é absolutamente indispensável para o progresso industrial e comercial duma região, e para o qual, de outro lado, existem aqui as melhores condições naturais prérequisitadas [para tal $]^{1232}$.
\end{abstract}

O registro ressalta as dificuldades técnicas dos portos catarinenses. Essas dificuldades contribuíram, como vimos, para a desativação do porto da capital catarinense na década de $1970^{1233}$. Além disso, apesar de salientar a importância da atividade portuária, uma vez que a considera "absolutamente indispensável para o progresso industrial e comercial de uma região", fica evidente a falta de interesse do governo federal no investimento ao transporte marítimo, pois “até agora este governo tem mostrado pouco interesse" em dotar o Estado de portos modernos e bem equipados. Inferimos, portanto, que a construção da ponte Hercílio Luz e a deficiência de investimentos governamentais no transporte náutico - aspecto este já sentido a partir das décadas de 1920 e 1930, como, aliás, referimo-nos em passagens anteriores deste texto -, sinalizaram para o direcionamento de investimentos no transporte rodoviário.

Esse aspecto é, como vimos, claramente visível a partir da década de 1950, haja vista os consideráveis recursos aplicados na incrementação do parque urbano-industrial e da atividade automobilística, no país. Concomitantemente, no cenário da capital do Estado, é, pois, a partir dessa época que percebemos, claramente, o quão é irreversível a opção pelo transporte rodoviário, no que muito contribuiu a primeira ligação terrestre entre Ilha e Continente que,

\footnotetext{
${ }^{1232}$ Guia do Estado de Santa Catarina. Florianópolis, 05 set. 1927. p. 39-40.

${ }^{1233}$ Um apontamento nesse sentido também nos é apresentado pelo Anuário Estatístico do Brasil, do ano de 1971, pesquisado no IBGE. Segundo esse texto, entraram, no porto de Florianópolis, no ano de 1970, apenas quinze navios, entre estrangeiros e nacionais. Similar texto apresentado pelo Instituto Nacional de Estatística, datado de 1936, aponta que entraram, no porto da Capital, no ano de 1933 , 946 navios; número que inclui, igualmente, embarcações estrangeiras e nacionais. Segundo os dados levantados junto a ambas as instituições, houve, todavia, para o período de 1933 a 1970, um claro declínio do movimento de navios no porto da cidade. Ver a) Instituto Nacional de Estatística. Anuário Estatístico do Brasil, ano II, Rio de Janeiro, 1936; b) Instituto Nacional de Estatística. Anuário Estatístico do Brasil, ano III, Rio de Janeiro, 1937; c) IBGE. Anuário Estatístico do Brasil, ano IV, Rio de Janeiro, 1938; d) IBGE. Anuário Estatístico do Brasil., ano V, Rio de Janeiro, 1940; e) IBGE. Anuário Estatístico do Brasil, ano VI, Rio de Janeiro, 1946; f) IBGE. Anuário Estatístico do Brasil, ano XIII, Rio de Janeiro, 1953; g) IBGE. Anuário Estatístico do Brasil, ano XXII, Rio de Janeiro, 1961; h) IBGE. Anuário Estatístico do Brasil, v. 32. Rio de Janeiro, 1971.
} 
desde a segunda metade da década de 1920, vem progressivamente substituindo o porto como principal eixo de comunicação da cidade com o restante do Estado e do País.

A intensificação do tráfego de veículos motorizados, no espaço central da cidade de Florianópolis, verificada especialmente a partir da década de 1950, é corroborada pelo aspecto de que, nessa época, presencia-se a instalação dos primeiros semáforos, instalados preferencialmente nos cruzamentos das ruas e vias centrais da cidade que apresentavam maior movimento de veículos. Acerca disso, no ano de 1954, o artigo do jornal $O$ Estado registrou que "Foram inauguradas as sinaleiras luminosas que criarão permissões verdes e impedimentos vermelhos ao tráfego local. Estão de parabéns o Prefeito Paulo Fontes, que patrocinou a melhoria e Julinho Gonçalves que foi o feliz fornecedor das sinaleiras" ${ }^{\text {"234 }}$. Em outra passagem do mesmo artigo, é solicitado que se "encomende mais sinaleiras" e, "pelo menos uma para a esquina da rua Padre Roma com Felipe Schmidt”, as quais “melhorarão, sem dúvida, as condições de trânsito na nossa capital"1235. A nota registra, ainda, que a instalação desses recursos, no cruzamento das ruas Felipe Schmidt e Padre Roma, "é imprescindível"; e, igualmente, sugere que outros "quatro entroncamentos de ruas necessitam de idêntica sinalização" ${ }^{236}$.

Entendemos, pois, que a inauguração de sinaleiras no cruzamento das ruas do espaço central de Florianópolis está relacionada a dois aspectos. Em primeiro lugar, não devemos esquecer as determinações do Código Nacional de Trânsito, de 1941, que, ainda em vigência, estipulava, a esse respeito, o seguinte: “Art. 22 - “Ao longo das vias públicas haverá, sempre que necessário, sinais indicadores da direção do tráfego, de advertência e de informação" "1237. $\mathrm{O}$ artigo 29 especificava, por sua vez, que "Art. 29 - Os sinais luminosos terão as seguintes cores e significados: 1. Verde - trânsito livre; 2. Amarelo Alaranjado - advertência; 3. Vermelho perigo; ordem de parar"1238. Vimos que o código nacional de trânsito estipulava que "as leis estaduais", relativas, dentre outros assuntos, ao tráfego de veículos motorizados, deveriam adaptar-se às suas disposições, naquilo que fosse aplicável. Assim, é possível argumentarmos que a instalação das sinaleiras luminosas, no cruzamento das ruas do espaço central da cidade de Florianópolis, estava em conformidade com o que foi determinado pela esfera federal, no que diz respeito, especialmente, ao tráfego de automóveis - particulares, de aluguel; caminhões e ônibus - nos meios urbanos. Não podemos, entretanto, descartar a ideia de que a instalação desses recursos, na capital do Estado, demonstra, para essa localidade, a intensificação do tráfego de veículos motorizados, especialmente aquele operado nas ruas do seu espaço central.

\footnotetext{
${ }^{1234}$ Notas \& Comentários - sinaleiras coloridas. O Estado. Florianópolis, 27 jun. 1954. p. 1.

${ }^{1235}$ Idem.

${ }^{1236}$ Idem.

${ }^{1237}$ Decreto-lei n. 3651: dá nova redação ao Código Nacional de Trânsito. Rio de Janeiro, 25 de setembro de $1941 \ldots$ op. cit., p. 581.

${ }^{1238}$ Ibidem, p. 582.
} 
Neste ponto, é importante observarmos que, nos cruzamentos das ruas que não apresentavam semáforos, o fluxo de automóveis era, muito provavelmente, auxiliado por meio do acionamento de buzinas ${ }^{1239}$; aspecto que fornece uma ideia da intensidade do tráfego nesses locais. Por outro lado, a instalação de semáforos nos cruzamentos das ruas de maior movimento de veículos automotores, verificada a partir do ano de 1954, evidencia o gradativo adensamento do respectivo fluxo; aspecto este que também foi apresentado, à época, pelo Plano Diretor e pelas notas jornalísticas locais. Devemos, pois, salientar que a inauguração de sinaleiras, no cruzamento das ruas do espaço central de Florianópolis, e a solicitação para a encomenda de novos dispositivos evidenciam o crescente trânsito de veículos motorizados pelas ruas da Capital e a respectiva necessidade de dispositivos disciplinadores para melhor organizá-lo.

A intensificação do fluxo de automóveis pelas ruas do espaço central da capital catarinense, assim como de outros núcleos urbanos referenciais do Estado, perceptível com maior nitidez a partir da década de 1950, pode também ser avaliada a partir dos elementos dispostos nas tabelas 06 e 07 , apresentadas a seguir.

Tabela 06: Número de Registro de Veículos Motorizados - 1951

\begin{tabular}{l|c}
\hline & $\mathbf{1 9 5 1}$ \\
\hline Florianópolis & 968 \\
São José & 85 \\
Palhoça & 148 \\
Baguaçu & 29 \\
Lages & 662 \\
Blumenau & 1.557 \\
Itajaí & 378 \\
Joinvile & 866 \\
Rio do Sul & 702 \\
Tubarão & 283 \\
\hline Total de Veículos Registrados & $11.314\left({ }^{*}\right)$ \\
\hline
\end{tabular}

(*) O número total de veículos registrados no Estado compreende o somatório dos valores referentes a vinte e três municípios. As localidades listadas acima englobam, a grosso modo, aquelas já referidas na tabela 02, disposta no capítulo primeiro da tese. Com esse procedimento, pretendemos efetuar uma análise comparativa entre esses municípios; análise esta disposta nos parágrafos a seguir.

Fonte: Santa Catarina. Secretaria da Segurança Pública. Relatório das Atividades desta Secretaria no ano de 1951. Apresentado ao Exmo. Sr. Governador Irineu Bornhausen, pelo Secretário da Segurança Pública, Dr. Luiz de Souza. Florianópolis, 29 fev. 1952.

Os documentos da Secretaria de Segurança Pública, consultados para a elaboração das referidas tabelas, registram informações quanto à situação do trânsito pelas ruas das principais cidades catarinenses e, especialmente, da capital do Estado. Os textos discutem, também, informações quanto aos problemas de expedição e transferências irregulares de carteiras de motoristas verificadas em todo o território estadual durante os anos de 1951, 1954 e 1960 . Além disso, sinalizam para a situação de precariedade em que se encontrava a Inspetoria de Veículos,

\footnotetext{
${ }^{1239}$ As análises dos processos criminais, efetuadas nos capítulos anteriores, permitiu-nos verificar, dentre outros aspectos, que o emprego de buzinas ou recursos similares era, durante as décadas de 1920 e 1930, um costume muito comum, praticado notadamente por chauffeurs e boleeiros, quando em tráfego com os seus veículos pelas ruas do perímetro urbano da cidade de Florianópolis. Existiam, inclusive, à época, artigos e determinações legais que regulamentavam o seu emprego diário. Ver, especialmente, Santa Catarina. Instruções Regulamentares para o serviço de trânsito público. Florianópolis: Imprensa Oficial do Estado, 1928.
} 
sediada em Florianópolis, e as delegacias auxiliares de polícia, sediadas nos principais municípios do interior do estado, como Blumenau, Joinvile, Rio do Sul, Tubarão, Itajaí.

Tabela 07: Exames para Condutores de Veículos no Estado de Santa Catarina - 1954 - 1960 Relatórios da Secretaria de Segurança Pública

\begin{tabular}{l|c|c}
\hline & $\mathbf{1 9 5 4}$ & $\mathbf{1 9 6 0}$ \\
\hline Carteiras de Amador: & 1.373 & (*) Para a cidade de Florianópolis foi expedido, ano de \\
Carteiras de Profissional: & 3.200 & 1960, o total de 5.091 carteiras. \\
Carteiras de Tratorista: & 02 & \\
Carteiras de Motociclistas: & 13 & \\
\hline Total: & 4.083 & \\
\hline
\end{tabular}

Fontes: 1954: Santa Catarina. Secretaria da Segurança Pública. Relatório do Exercício de 1954. Apresentado ao Excelentíssimo Senhor Irineu Bornhausen, DD. Governador do Estado, pelo Snr. Desembargador Dr. Nelson Nunes de Souza Guimarães, Secretário de Estado dos Negócios da Segurança Pública. Florianópolis, 24 mar. 1955.

1960: Santa Catarina. Secretaria da Segurança Pública. Relatório das Atividades da Secretaria da Segurança Pública, durante o exercício de 1960. Florianópolis, mar. 1961.

As tabelas 06 e 07 apontam outros aspectos importantes sobre a circulação dos veículos motorizados no Estado e em sua Capital. A tabela 06 dispõe que, no ano de 1951, houve 968 registros para veículos motorizados na cidade de Florianópolis. Entendemos, pois, que esse total corresponde àqueles automóveis que foram licenciados ou emplacados naquele ano ${ }^{1240}$. Vale lembrarmos que, a partir do ano de 1940, o emplacamento dos veículos automotores é realizado anualmente, conforme estabelece o Decreto-lei n. 489 , de 24 de outubro do mesmo ano ${ }^{1241}$. Isso atesta, claramente, a intensificação do tráfego de automóveis pelas estradas estaduais e, especialmente, pelas ruas do perímetro urbano da capital catarinense.

A tabela 06 aponta, igualmente, que as cidades de Blumenau, Florianópolis e Joinvile, apresentaram o maior número de registros de veículos motorizados, com, respectivamente, 1.157, 968 e 866 automóveis licenciados. Esse é um dado importante, pois verificamos que essas mesmas cidades apresentaram, para o ano de 1922, o maior número de cartas expedidas para boleeiros/cocheiros e chauffeurs, perfazendo, à época, o total de 64 (Florianópolis), 54 (Blumenau) e 44 (Joinvile) cartas expedidas, conforme dados apresentados pela tabela 02: Número de cartas expedidas por município no Estado de Santa Catarina (1911-1922), disposta no capítulo primeiro da tese (seção Elementos Incipientes). São aspectos que nos permitem vislumbrar, na apreciação aqui feita, que essas cidades mantiveram o status de principais polos econômico e populacional do Estado - mantendo tal posição, talvez, durante todo o período mencionado, entre os anos de 1922 e 1951.

Os dados registrados pela tabela 06 apontam, também, outras cidades que apresentaram um número considerável de registro de veículos automotores, quais sejam: Rio do Sul e Lages, com,

\footnotetext{
1240 Os dados coletados não discriminam automóveis particulares, de aluguel, caminhões ou ônibus.

${ }^{1241}$ Decreto-lei n. 489, de 24 de outubro de 1940. Dispõe sobre o emplacamento de veículos. In: Santa Catarina. Coleção de Decretos-Leis, Decretos, Resoluções e Portarias, jun. 1940. p. 203-204.
} 
respectivamente, 702 e 662 veículos registrados. A cidade de Lages é, ainda hoje, o principal núcleo populacional do planalto catarinense e, à época, arregimentava as áreas e populações de, pelo menos, mais três localidades, quais sejam: Anita Garibaldi, Campo Belo do Sul e São José do Cerrito ${ }^{1242}$. Já a cidade de Rio do Sul está localizada na atual região do Vale do Itajaí, cujo núcleo de maior destaque e referência é Blumenau. Nesse sentido, não é nenhum absurdo considerarmos que cidades e núcleos populacionais dessa região, com forte atividade industrial, sobretudo têxtil, apresentaram altos índices de expedição de carteiras de motoristas (1911-1922) e de registros de veículos motorizados $(1951)^{1243}$. Talvez, os dividendos proporcionados pelas atividades econômicas da região possibilitaram a um número razoável ou, mesmo, significativo de pessoas adquirirem ou manterem veículos automotores.

Lembremos, por exemplo, que, no capítulo terceiro, ao analisarmos o processo n. 194, de 21 de novembro de 1932, vimos que o condutor da baratinha n. 24P, Herbert Molenda, era o proprietário daquele veículo e que ele era "residente à rua Esteves Júnior"; local, como visto, ocupado preferencialmente por pessoas de destacada posição social ou profissional na sociedade florianopolitana ${ }^{1244}$. Além disso, notamos que Herbert Molenda era "de estatura alta, de tipo alemão" e que era "empregado na Casa Hoepcke", ou seja, o condutor da baratinha era empregado num ramo de atividade industrial bastante expressivo na cidade, que lhe deveria, pois, render os dividendos necessários para proporcionar-lhe uma vida relativamente confortável, inclusive, com a possibilidade para adquirir e manter um veículo motorizado. Assim, os ramos industriais de destaque no Estado deviam, portanto, proporcionar aos agentes a eles ligados sejam patrões, sejam empregados - condições financeiras e socioeconômicas suficientes para que pudessem adquirir e manter os automóveis os quais, mesmo com sua progressiva popularização exigiam, ainda na década de 1950, que os respectivos proprietários apresentassem, ao menos, razoável condição de vida para adiquiri-los e mantê-los.

Evidenciamos que esse, ao que tudo indica, foi o caminho trilhado por considerável número de habitantes da região que tinha Blumenau e Rio do Sul como polos econômicos referenciais. Isto nos ajuda a compreender o maior montante de veículos automotores registrados naquelas praças, excluída a Capital e a cidade de Joinvile; esta, aliás, com eixo econômico centrado nas atividades industriais de siderurgia e metal-mecânica, seguiu, muito provavelmente,

\footnotetext{
${ }^{1242}$ CABRAL, Oswaldo Rodrigues. História de Santa Catarina. 4. ed. Florianópolis: Lunardelli, 1994. p. 368. No ano de 1928, por exemplo, dos vinte e nove municípios que compunham o Estado de Santa Catarina, a cidade de Lages, com 41.600 habitantes, ocupava a quarta posição entre os núcleos mais populosos, ficando atrás, apenas, das cidades de Blumenau, que contabilizou, para aquele ano, 99.104 habitantes; Florianópolis, com 70.000; e Joinvile com 52.000 habitantes. (Santa Catarina. Secretaria do Interior e Justiça. Relatório apresentado ao Presidente do Estado de Santa Catarina, Exmo. Sr. Dr. Adolfo Konder, pelo Secretário do Interior e Justiça Dr. Cid Campos, ano de 1928. Florianópolis: Gab. Tip. Brasil, 1930). Esses dados apontam que as cidades listadas eram as mais importantes do Estado, ao menos em termos econômicos e populacionais e considerando suas posições de claro destaque frentes às suas respectivas regiões.

${ }^{1243}$ A cidade de Rio do Sul destaca-se na área industrial, com foco nos setores metal-mecânico, eletrônico e vestuário (principalmente na confecção de jeans). No setor agropecuário, destaca-se a produção de leite, suinocultura e avicultura.

${ }^{1244}$ Processo n. 194, 21 nov. 1932. Caixa 20.
} 
no contexto aqui discutido, o mesmo caminho aventado para as cidades de Blumenau e Rio de Sul.

A tabela seguinte (07) apresenta o número de exames para condutores de veículos no Estado de Santa Catarina, no ano de 1954. Um dado que julgamos importante é aquele que se refere ao maior número de exames efetuados para os motoristas profissionais, que perfaz 3.200 (três mil e duzentos) exames. Esse número é, seguramente, bem maior do que aquele referente aos exames efetuados para os condutores amadores (1.373). Diante dos dados apresentados, temos que foi efetuado um acréscimo de cerca de 42,9\% para os exames de motoristas profissionais $^{1245}$. Tais elementos dão margem à especulação de que a atividade exercida por chauffeurs profissionais ou taxistas não deixou de ser praticada, mesmo após a popularização do automóvel, verificada com maior nitidez a partir das décadas de 1950 e 1960; aspecto este, aliás, que já vinha sendo progressivamente gestado desde os anos 1920 e $1930^{1246}$. Além disso, devemos considerar que, frente às políticas de incentivo à rodoviação e ao melhoramento das estradas estaduais, verificadas, pelo menos, desde a década de 1930, é muito provável que condutores profissionais tenham obtido habilitação para conduzir caminhões ou outros veículos de transporte pelas estradas do Estado. Com isso, não buscamos uma elucidação completa dessa questão, mas, sem dúvida, auxilia-nos a compreender o maior montante de exames para condutores profissionais, em Santa Catarina.

Os exames efetuados para condutores amadores envolvem, como vimos, aqueles que seriam habilitados para conduzirem automóveis de passeio, de natureza particular. Em vista disso, é possível especularmos que os veículos motorizados de passeio foram sendo, gradualmente, adquiridos pelos habitantes do Estado de Santa Catarina e de sua Capital; pois devemos observar, nesse contexto, que, para o ano de 1960, foram expedidas, somente para a cidade de Florianópolis, o total de 5.091 (cinco mil e noventa e uma) carteiras para motoristas, entre profissionais e amadores ${ }^{1247}$, contra o total de 4.683 (quatro mil, seiscentos e oitenta e três) exames para condutores de veículos no Estado, verificado para o ano de $1954^{1248}$. Essa

\footnotetext{
1245 O Decreto-lei n. 9546, de 06 de agosto de 1946, que dispõe sobre a habilitação e o exercício da atividade de condutores de veículos automotores, expõe, no parágrafo único do seu artigo primeiro, que "Parágrafo Único - Os condutores de veículos a motor de explosão são classificados em amadores e profissionais. Os amadores só poderão dirigir veículos particulares de passeio; os profissionais poderão dirigir quaisquer dos veículos automotores referidos no artigo 43, ns. 1 e 2 do Código Nacional de Trânsito (Decreto-lei n. 3651 , de 25 de setembro de 1941)". (Lei n. 9545: dispõe sobre a habilitação e exercício da atividade de condutor de veículos automotores. Rio de Janeiro, 05 ago. 1946. Diário Oficial de 07 ago. 1946. In: Revista Forense: mensário nacional de doutrina, jurisprudência e legislação. Rio de Janeiro, out. de 1946. v. CVIII, ano XLIII, fascículo 520, n. 108. p. 219. Disponível também em $<$ http://www.senado.gov.br $>$ ). Conforme especificado, os condutores profissionais podem dirigir "Art. 43 - 1. Os automóveis, caminhões e auto-ônibus" e " 2 . As motocicletas, com ou sem side-car, ou similares". (Decreto-lei 3651: dá nova redação ao Código Nacional de Trânsito. Rio de Janeiro, 25 de setembro de 1941. In: Revista Forense: mensário nacional de doutrina, jurisprudência e legislação. Rio de Janeiro, out. 1941. v. LXXXVIII, ano XXXVIII, fascículo 461, n. 88. p. 583). Devemos, pois, ter em mente que, frente aos dados levantados pela tabela 07, os exames para condutores profissionais envolviam os motoristas de ônibus e caminhões, embora tais especificações não tenham sido apresentadas pelos dados pesquisados para a confecção da referida tabela. ${ }^{1246}$ Ver nota 1251 , a seguir.

${ }^{1247}$ Santa Catarina. Secretaria da Segurança Pública. Relatório das Atividades da Secretaria da Segurança Pública, durante o exercício de 1960. Florianópolis, mar. 1961 .

${ }^{1248}$ É importante esclarecermos que o Decreto-lei n. 9546, de 06 de agosto de 1946, expõe, em seu artigo primeiro, que "Art. 1. ${ }^{\circ}$ - A condução de veículos automotores sujeitos a legislação de trânsito depende de habilitação, verificada em exame prestado perante as repartições de trânsito do
} 
expressiva diferença pode ser atribuída ao claro incentivo ao incremento da indústria automobilísticas no país, ocorrido durante o governo de Juscelino Kubitschek, sobretudo a partir dos anos de 1956/57, conforme referimos em passagens anteriores deste texto.

Neste ponto do texto, devemos observar que, para os anos de 1922 e 1929, foi expedido, para todo o Estado de Santa Catarina, o total respectivo de setenta e sete e oitenta e sete cartas para chauffeurs ou condutores de veículos motorizados ${ }^{1249}$ - conforme já apontado no capítulo primeiro (seção Elementos Incipientes). Para um e outro ano, houve, portanto, um acréscimo de 12,9\% no número de cartas expedidas. Notamos, entretanto, que, para o ano de 1954, foi efetuado o total de 4.683 exames para condutores de veículos no Estado; ou seja, se, no ano de 1922, apenas setenta e sete chauffeurs obtiveram habilitação para conduzir veículos automotores, esse número se eleva a, aproximadamente, $4.600^{1250}$ no ano de 1954. Enfatizamos que houve, portanto, um acréscimo de cerca de 6.000 \%. Esse levantamento, se não nos permite ter uma ideia precisa sobre o crescimento do número de chauffeurs ou motoristas habilitados, durante todo o período, possibilita-nos, porém, considerar, sem qualquer sombra de dúvida, que, no espaço de 32 anos (1922-1954), o automóvel atingiu uma posição de primazia nas estradas do Estado e nas ruas do perímetro urbano da cidade de Florianópolis ${ }^{1251}$.

Esse aspecto é corroborado pela consideração de que, nos relatórios da Secretaria de Segurança Pública, pesquisados entre os anos de 1951 e 1960, percebemos, também, uma análise relativa à necessidade de instalação de sinalização elétrica (sinaleiras) nos cruzamentos das principais vias de circulação do espaço central de Florianópolis, especialmente nos relatórios dos anos de 1951 e 1954. Por outro lado, o relatório da Secretaria de Segurança Pública do ano de 1960 considera esse aspecto superado, mas registra que as sinaleiras elétricas representam

Mecanismo que vêm prestando ao trânsito eficientíssima colaboração, contribuindo, em grande parte, a deficiência do material humano. Urge, no entanto, supri-lo com o maior número de sinais luminosos, tendo em vista o crescente número verificado no que diz respeito ao número de veículos e da população. Para tornar este serviço mais eficiente e seguro, seria de bom alvitre adotar em nossa

Distrito Federal e das Capitais dos Estados e Territórios ou comissões por elas organizadas”. (Lei n. 9545: dispõe sobre a habilitação e exercício da atividade de condutor de veículos automotores. Rio de Janeiro, 05 ago. 1946. Diário Oficial de 07 ago. $1946 \ldots$ op. cit). Assim, podemos considerar que o número de carteiras de motorista, expedidas a partir desse momento, corresponde, grosso modo, ao número de condutores habilitados para guiarem veículos automotores.

1249 1922: Santa Catarina. Relatório Apresentado ao Exmo. Sr. Dr. Joë Luiz M. Colaço, Secretário do Interior e Justiça pelo Desembargador Antero de Assis, Chefe de Polícia. Florianópolis, 1922; 1929: Santa Catarina. Relatório da Chefatura de Polícia Apresentado ao Exmo. Sr. Dr. Secretário do Interior e Justiça. Florianópolis, 1929.

${ }^{1250}$ Devemos contemplar, nesse total, aqueles que, de fato, obtiveram habilitação para dirigir e os que, eventualmente não aprovados nos exames, estariam impedidos de guiar veículos automotores. A esse respeito, o referido Decreto-lei n. 9545, aponta, dentre outros elementos, que "Para prestar exame de habilitação", o candidato "requererá inscrição à repartição de trânsito" e apresentará, dentre outros, "carteira de identidade, expedida pelas repartições públicas, institutos ou gabinetes de identificação a elas subordinadas", "certidão de idade maior de 18 anos", "folha corrida, ou atestado de bons antecedentes", etc. Além disso, "Não será concedida inscrição ao candidato que não souber ler e escrever". Outro aspecto importante é que o candidato que pretendesse obter habilitação para condução de veículos motorizados deveria prestar os exames médico e de habilitação. Assim, "Art. 3. ${ }^{\circ}$ - O exame de habilitação compreende: 1 - exame médico; 2 - exame técnico" e "Art. $4 .^{\circ}-\mathrm{O}$ exame médico constará das seguintes provas: 1 - De capacidade física; 2 - De sanidade mental”. (Lei n. 9545: dispõe sobre a habilitação e exercício da atividade de condutor de veículos automotores. Rio de Janeiro, 05 ago. 1946. Diário Oficial de 07 ago. 1946... op. cit). Notamos, pois, que nem todos os candidatos, submetidos aos exames para a condução de veículos motorizados, estariam legalmente aptos ou habilitados para conduzi-los. ${ }^{1251}$ Corroborando com essas considerações, temos que durante as décadas de 1940, 1950 e 1960, a figura do chauffeur, que guia o automóvel para o indivíduo de considerável condição financeira, tornou-se, gradativamente, incomum, dando lugar à figura do motorista que, muitas vezes, configura-se como o próprio proprietário do automóvel. Isso demonstra o barateamento do custo dos veículos automotores, o que tornou sua aquisição acessível a maior número de pessoas. 
cidade, bolas de ferro ou "tartarugas", como são mais conhecidas nas esquinas de maior movimento $^{1252}$.

Os elementos discutidos até aqui dão conta de que o automóvel se fez presente nas ruas e estradas do Estado e, especialmente, de sua Capital. Percebemos, portanto, que, ao final da década de 1950 e início do decênio seguinte, o fluxo de automóveis pelas ruas do perímetro urbano da cidade de Florianópolis havia assumido um tal porte que exigiu, além da instalação de sinaleiras, a adoção de "bolas de ferro ou "tartarugas", notadamente nas esquinas e trechos de maior movimento de veículos. Nesse sentido, devemos considerar que os caminhos e trajetórias, trilhados neste estudo, permitem-nos elucidar que, de fato, os automóveis assumiram uma posição de inegável presença no meio urbano de Florianópolis que, gestada desde as décadas de 1910 e 1920, mostrou-se claramente irreversível nos decênios seguintes, mesmo ante os embates e as resistências expressos, desde o início, pelos personagens anônimos do cotidiano da cidade, elucidados por meio da análise dos processos criminais aqui estudados.

Enfatizamos, por fim, que as análises efetuadas, neste último capítulo, sobre as apreciações da imprensa local e órgãos governamentais do Estado quanto à dinâmica operada pela convivência simultânea dos bondes e ônibus, assim como quanto às discussões sobre o adensamento do fluxo de veículos automotores, sobretudo durante a década de 1950, não deixam dúvida quanto à primazia assumida pelo automóvel nas ruas da capital catarinense e, também, nas estradas e nas vias estaduais; processo este que continuou assumindo gradativo adensamento pelos anos e decênios seguintes. Apesar desse quadro, não devemos esquecer os embates e as lutas expressos pelos personagens anônimos da capital catarinense os quais, por meio de percepções e táticas específicas e singulares, mostraram-se capazes de plena atuação no meio urbano de Florianópolis, convertido em palco principal da desenvoltura e performance de seus atores; personagens comuns do cotidiano cujas especificidades de trajetórias e enredos ${ }^{1253}$ procuramos, com este estudo, trazer à superfície.

A elaboração de tão extenso estudo não foi, de maneira nenhuma, tarefa fácil. O caminho trilhado, desde o mês de janeiro de 2004, levou-nos a pesquisar textos e documentos variados; alguns dos quais, inéditos para a historiografia florianopolitana e catarinense. Ao nos propormos a investigar as percepções e as sensibilidades dos habitantes da cidade de Florianópolis frente à gradativa presença e à circulação dos veículos motorizados, objetivamos, ao certo, resgatar nuanças e aspectos específicos do cotidiano vivido por chauffeurs, passageiros e transeuntes.

\footnotetext{
${ }^{1252}$ Santa Catarina. Secretaria da Segurança Pública. Relatório das Atividades da Secretaria da Segurança Pública, durante o exercício de 1960. Florianópolis, mar. 1961. p. 30.

${ }^{1253}$ CERTEAU, M. de; GIARD, Luce; MAYOL, Pierre. A invenção do cotidiano 2: morar, cozinhar. 5. ed. Petrópolis: Vozes, 2003. p. 200.
} 
Antes de tudo, procuramos dar voz ao homem comum, personagem envolto em tramas e enredos diversos, muitas vezes ocultos, que permitem-nos refazer, diariamente, a paisagem urbana ${ }^{1254} \mathrm{e}$ que apenas podem ser revelados por meio da investigação de textos e documentos inéditos, como então se apresentam os processos criminais, cuja pesquisa e análise demandou demasiado tempo e esforço intelectual; no fim, recompensados.

Essa investigação objetivou, igualmente, discutir o aspecto dinâmico que envolve a correlação entre o aparato legal aplicado à cidade, que pretende ordenar seu espaço e os embates e os conflitos expressos por seus habitantes. Evidenciamos, pois, que estes, trilhando vivências e caminhos díspares e nãolineares, entram em conflito com as intenções colocadas pelo poder público; choque que se fez refletir, também, em artigos de periódicos locais e em apreciações elaboradas nos textos dos próprios órgãos governamentais. Essas discussões denunciaram, pois, o caráter eminentemente político que está por trás de todo e qualquer jogo de interesses. Nesse sentido, observamos que o que "[...] torna a cidade habitável não é tanto sua transparência utilitária e tecnocrática, mas antes a opaca ambivalência de suas estranhezas" ${ }^{255}$.

Devemos observar que a investigação aqui proposta pretendeu estudar a fundo, dentro dos objetivos traçados, alguns aspectos que compunham o viver urbano daqueles envolvidos em atropelamentos e colisões dentro do perímetro urbano da capital catarinense, sobretudo durante as décadas de 1920 e 1930. Em vista disso, debruçamo-nos sobre os processos criminais pesquisados, para, dentre outros aspectos, tecer análises sobre o seu desenrolar, discutindo as tramas e intenções envoltas na elaboração de inquéritos e na aplicação de penas e valores afiançáveis.

Pretendemos, desse modo, discutir, por exemplo, a conjugação dos poderes judiciário e financeiro como forma de apresentar correlações com o encaminhamento dos processos; os quais, via de regra, culminavam com a absolvição dos réus - estes, na quase totalidade dos casos estudados, eram os próprios chauffeurs; apontados, muitas vezes, como responsáveis pela ocorrência dos atropelamentos ou colisões. Constatamos, entretanto, no processo n. 96, de 19 de dezembro de 1928, analisado no quarto capítulo da tese, por exemplo, que o transeunte, Romão Antônio Gonçalves, foi deliberadamente apontado como culpado por seu próprio atropelamento - posição defendida, inclusive, pelo então delegado de polícia da Capital, que considerou que ele procurou atravessar a rua de maneira imprudente ${ }^{1256}$. Nesse processo, o chauffeur, José Correia Dias, não foi responsabilizado pelo ocorrido. Devemos, todavia, destacar a rapidez com que o caso foi julgado, pois foi, segundo apontado, concluído no dia 22 de janeiro de 1929; deu-se,

\footnotetext{
${ }^{1254}$ CERTEAU, Michel de; GIARD, Luce; MAYOL, Pierre. A invenção do cotidiano 2: morar, cozinhar. 5. ed. Petrópolis: Vozes, 2003. p. 200.

${ }_{1255}$ Ibidem, p. 191

${ }^{1256}$ Processo n. 96, 19 dez. 1928. Caixa 02.
} 
portanto, pouco mais de um mês após a ocorrência do sinistro, ocasião em que o Juiz da Segunda Vara da Comarca da Capital ordena que se arquive o processo ${ }^{1257}$.

Outro episódio de atropelamento, apresentado no processo n. 239, de 21 de janeiro de 1932 - também analisado no quarto capítulo -, destaca que ao chauffeur Hélio Souza Silva, apontado como responsável pelo atropelamento da menor Alice Grumiché, de seis anos de idade, foi concedida suspensão condicional de sua pena, após o pagamento da respectiva fiança. Esse aspecto foi observado mesmo tendo sido efetuada a prisão em flagrante do referido chauffeur; e, também, após ter sido constatado o falecimento da vítima, em função dos ferimentos causados pelo atropelamento ${ }^{1258}$. Tais agravantes, não impediram, porém, que, sob a influência de fiadores "bastante conhecidos e abonados"1259, fosse concedida a Hélio Souza Silva, a "suspensão condicional da pena", registrada nos termos finais do processo ${ }^{1260}$. Esses elementos evidenciam, uma vez mais, a conjugação dos poderes judiciário e financeiro, como forma de operar-se a suspensão condicional das penas impostas aos apontados como diretamente responsáveis pelos crimes de atropelamento ou colisão, verificados nas ruas do perímetro urbano da cidade de Florianópolis, no período em estudo.

A análise dos casos aqui apontados, que perpassam as décadas de 1920 e 1930, objetivou, portanto, demonstrar que a conjugação dos poderes judiciário e financeiro, como fator condicionante para a soltura de chauffeurs, ou, mesmo, para o indiciamento de transeuntes, é um aspecto que se fez presente, durante todo o período analisado na tese, e que está imbricado na própria maneira de se elaborarem e de se aplicarem leis.

É importante destacarmos que a ocorrência de atropelamentos e colisões e a convivência diária entre automóveis, chauffeurs e transeuntes não foram, de maneira alguma, exclusividade de Florianópolis. Esses episódios estiveram, ao certo, presentes em outros contextos urbanos nacionais e, também, internacionais. Assim, buscamos relacionar os processos de adaptação da população florianopolitana frente à presença e à circulação dos veículos motorizados com situações semelhantes atestadas, principalmente, em outras cidades do País e da Europa Ocidental. Com isso, objetivamos dar à tese um enfoque mais amplo e diversificado, apontando outras situações e contextos nos quais o automóvel se fazia presente. As situações de atropelamentos e de colisões, verificadas em outros contextos urbanos, são ilustrativas de que o automóvel suscitou, em várias ocasiões, percepções e posicionamentos quanto à sua presença e circulação. Salientamos, entretanto, que a especificidade deste estudo está, justamente, na

\footnotetext{
${ }^{1257}$ Processo n. 96, 19 dez. 1928. Caixa 02.

${ }^{1258}$ Processo n. 239, 21 jan. 1932. Caixa 26. Este processo foi analisado, igualmente, no primeiro capítulo; porém, sob outros enfoques e perspectivas.

${ }_{1259}$ Processo n. 239, 21 jan. 1932. Caixa 26.

${ }^{1260}$ Idem.
} 
tentativa de trazer à tona impressões e anseios de personagens anônimos do cotidiano de uma cidade que viu surgir, com maior força, o automóvel apenas na década de 1920; impressões estas que apenas foram passíveis de investigação por meio da análise de textos e materiais inéditos, pesquisados no Arquivo Central do Tribunal de Justiça do Estado de Santa Catarina.

Outro objetivo a que nos propusemos, ao investigar os processos criminais, foi vê-los como disputas discursivas, em que a participação dos chauffeurs, vítimas e testemunhas nos trâmites legais dos processos é interpretada como uma forma de aprendizado, cujo aspecto pedagógico envolve o conhecimento "por ouvir dizer" dos sinistros ocorridos. Nesse sentido, procuramos ver que cada testemunha ou depoente responde, em síntese, perguntas muito bem definidas, e sua fala propõe um julgamento antecipado do réu, o que contribui para a construção de discursos, muitas vezes, orientados para a condenação ou não dos próprios chauffeurs, condutores dos automóveis $^{1261}$.

A investigação proposta envolveu, também, análises quanto ao crescente tráfego de automóveis pelas estradas de Santa Catarina e pelas ruas de sua Capital, por meio das quais verificamos o progressivo adensamento do fluxo desses veículos que, já na década de 1950, apresentava, nas ruas do espaço central da cidade de Florianópolis, claros sinais de saturação. Dentro desse quadro, as discussões sobre a convivência simultânea entre bondes e ônibus atestaram, por fim - a par de conflitos e resistências expressos em artigos de jornal e textos oficiais sobre a preferência a um ou outro meio de transporte -, a clara opção pela utilização diária dos ônibus. Esse aspecto denuncia ou está atrelado a um contexto de maior envergadura; pois, na esfera federal, observamos, já durante a década de 1930 e com maior nitidez nos decênios seguintes, os fortes incentivos dados, no país, ao transporte rodoviário, em detrimento do marítimo e ferroviário.

O caminho que nos leva à elaboração de uma tese é, sem dúvida, cheio de percalços e surpresas, como assim deve ser todo e qualquer trabalho de pesquisa. Para o historiador em especial, a pesquisa só adquire profundo sentido e riqueza quando ele se depara com dificuldades e, ao mesmo tempo, com achados inéditos; os quais, muitas vezes, são encontrados ocasionalmente. Isso é, sem dúvida, o que compõe o trabalho de pesquisa: lidar com a diversidade de fontes e informações, nem sempre fáceis de serem buscadas. A trajetória de pesquisa e de investigação percorrida pode, de maneira análoga, ser comparada à própria natureza do estudo aqui proposto. Assim, as percepções e as sensibilidades, expressas pelos habitantes da capital catarinense sobre a circulação e presença dos veículos motorizados,

${ }^{1261}$ PEDRO, Joana Maria; NECKEL, Roselane; HAWERROTH, Eliana Izabel; MACHADO, Vanderlei. Aborto e Infanticídio nos Códigos Penais e nos Processos Judiciais: a pedagogia de condutas femininas. In: PEDRO, Joana Maria. (Org). Práticas Proibidas: práticas costumeiras de aborto de infanticídio no século XIX. Florianópolis: Cidade Futura, 2003. p. 93. 
denunciam facetas específicas do homem comum da cidade de Florianópolis, levados a falar por meio das investigações aplicadas aos textos processuais aqui analisados. Desse modo, chauffeurs, passageiros e transeuntes compõem, pois, personagens do cotidiano, envoltos em tramas e vivências diversas, ricas em possibilidades e interações, algumas das quais trazidas à emergência por meio dos trabalhos de pesquisa e de intervenção do historiador.

A História é, assim, edificada em sua elaboração penosa e desgastante e, no fundo, é composta por histórias várias, vividas por homens e personagens comuns, cujos enredos são mesclados ao cotidiano. Alguns aspectos do cotidiano de personagens específicos da capital catarinense foram, sem dúvida, aqui elucidados; outros enredos e especificidades desses mesmos personagens ou, quem sabe, de outros atores do mesmo palco urbano podem ser, entretanto, dados e ler e a ver, pois talvez estejam presentes em outras fontes e textos ainda não elucidados, esperando o momento para que sejam, então, revelados. 


\section{CONSIDERAÇÕES FINAIS}

A investigação proposta nesta pesquisa objetivou analisar as percepções e sensibilidades cotidianas expressas pelo homem comum da cidade de Florianópolis, frente à presença e à circulação dos veículos automotores no seu perímetro urbano. Dificuldades e contratempos fizeram parte do exaustivo trabalho de pesquisa ao qual nos propusemos. Assim, a seleção e a coleta dos dezoito processos criminais, analisados durante todo o transcorrer da tese e que constituem o principal corpus documental deste estudo, envolveram, igualmente, um longo e cansativo trabalho de investigação. Este trabalho permitiu, ao certo, revelarmos muitas facetas do cotidiano de personagens anônimos da capital catarinense, de modo especial entre os chauffeurs, passageiros e transeuntes que viveram e habitaram a cidade entre os anos de 1920 e 1941.

Os capítulos foram organizados objetivando elaborar um estudo rico e diversificado sobre alguns aspectos que envolveram a circulação automobilística pelas ruas da capital catarinense, no período em estudo. Desse modo, procuramos, em linhas gerais, elucidar aspectos quanto à incipiente presença e circulação dos automóveis pelas ruas do perímetro urbano da cidade de Florianópolis, e constatamos que, pelo menos desde a segunda metade da década de 10 do século passado, esses veículos já se faziam presentes em algumas cidades do Estado de Santa Catarina, como Florianópolis e Lages ${ }^{1262}$. Analisamos, também, as percepções e sensibilidades expressas por chauffeurs, passageiros, transeuntes e testemunhas dos atropelamentos e colisões ocorridos na cidade de Florianópolis, pelo menos desde o ano de 1923, e enfatizamos suas impressões quanto às velocidades atingidas pelos automóveis ao circularem pelas ruas do perímetro urbano da Capital, durante as décadas de 1920 e 1930 do século passado. Tecemos, igualmente, uma análise sobre as relações de poder estabelecidas entre o conjunto automóvel/chauffeur e os pedestres, e as táticas e recursos emergenciais utilizados por estes últimos para se esquivarem e/ou se protegerem das investidas operadas pelos veículos motorizados. Neste ponto, pudemos verificar que chauffeurs e transeuntes operaram, de modo especial, comportamentos alinhados ou dissonantes frente às normas legislativas implementadas, à época, na cidade de Florianópolis, e esse caminho envolveu táticas e resistências que foram expressas sem que para isso fossem obedecidas regras pré-definidas, mas, antes, circunstâncias postas pelo cotidiano da urbe.

Estendendo um pouco mais esta análise, contemplamos também, na tese, uma investigação sobre as características do ambiente urbano moderno, especialmente quanto às grandes cidades brasileiras e da Europa Ocidental. O que queremos assinalar foi a circulação e o comportamento dos indivíduos diante da velocidade, agitação e aceleração do tempo; características próprias dos

\footnotetext{
${ }^{1262}$ Santa Catarina. Relatório Apresentado ao Exmo. Sr. Secretário Geral do Estado pelo Chefe de Polícia Ulysses Gerson Alves da Costa. Florianópolis, 14 maio de 1915.
} 
grandes centros urbanos do período, que são pautadas, igualmente, pela perda de experiências vivenciadas na cidade. Objetivamos, pois, analisar as situações de atropelamentos e colisões verificadas nas ruas do perímetro urbano da capital catarinense, como aspectos inseridos num contexto mais amplo, obedecendo, logicamente, a certo distanciamento temporal e espacial.

Discutimos, igualmente, o aprimoramento do aparato legislativo implantado no Estado de Santa Catarina e em sua Capital, especialmente durante as décadas de 10 e 20 do século passado; dispositivo este que pretendeu melhor organizar e controlar o deslocamento dos veículos motorizados e/ou operados por força motriz animal - pelas vias intermunicipais e, igualmente, pelas ruas do perímetro urbano da cidade de Florianópolis. Além disso, atentamos para as discussões ocorridas na esfera do poder público municipal - especialmente por meio da análise do conteúdo dos códigos de posturas municipais, datados de 1889, 1896 e 1898, assim como do Regulamento para o serviço policial do Estado (1920) - para a implementação de medidas que visavam à ordenação e à disciplinarização do espaço público da capital catarinense, com o objetivo de melhor equacionar o nivelamento e o calçamento de ruas e prover melhores condições de saneamento e higienização do seu espaço central.

Assim, os artigos e os respectivos parágrafos assinalados nos códigos de posturas municipais da Capital, aqui estudados, permitem-nos verificar, com maior clareza, a partir do final do século XIX, proibições quanto às ações de despejo de materiais e elementos que provocariam odores ou depreciações à plástica urbana; deviam-se, portanto, conservar limpos, dentre outros locais, os "quintais, praças, ruas e os terrenos compreendidos no perímetro da cidade e povoações". Além disso, conferimos especial atenção à livre fluência do trânsito público. Nos textos aqui registrados, é possível percebermos, igualmente, que o conjunto de determinações municipais pretendeu penetrar nas sociabilidades e valores do povo. Assim, foram estipuladas proibições aos hábitos e costumes populares, pois, dentre outros aspectos, "os sambas e batuques" foram impedidos de serem praticados "nas ruas e povoações da cidade"1263. Desse modo, já a partir do final do oitocentos, havia preocupações, por parte do poder público da Capital, em conferir à cidade um aspecto higienizado e aprazível.

Neste ponto, devemos observar que o ano de 1889 - data do primeiro código de posturas municipais de Desterro (Florianópolis) analisado neste estudo - marca o início do regime republicano no País. A par da consideração de que a proclamação de 1889 apenas assinalou o findar de regime monárquico que, desde pelo menos a década de 70 do século XIX, já mostrava claros sinais de saturação e esgotamento, podemos assinalar que a organização e a publicação do código de posturas municipal da cidade de Florianópolis (Desterro), datado daquele ano,

\footnotetext{
${ }^{1263}$ Câmara Municipal da Cidade do Desterro. Código de Posturas. Lei n. 1238, de 22 out. 1888. Desterro: Tip. da Regeneração, 1889. p. 25.
} 
envolveram, dentre outros elementos, a preocupação em elaborar ou, ao menos, reordenar artigos e dispositivos legais relativos aos principais procedimentos quanto à disciplinarização do espaço urbano e das práticas e vivências populares. Neste ponto, devemos sublinhar, também, que as medidas de higienização e de ordenamento do espaço central da capital catarinense envolveram embates políticos e teóricos ocorridos na imprensa local e nos principais órgãos dos poderes públicos municipal e estadual, o que nos permite considerar que as medidas aqui adotadas, assim como em outros centros urbanos do país, não foram simples adaptações de modelos urbanísticos aplicados em centros urbanos europeus, notadamente quanto àqueles adotados na cidade de Paris, sob inspiração haussmaniana.

Vale observarmos, ainda, que os artigos e parágrafos dos códigos de posturas municipais, analisados neste estudo não contemplam os termos chauffeur e automóvel. Esses termos são, com efeito, encontrados em leis e regulamentos municipais e estaduais de trânsito organizados nos anos posteriores, especialmente no Regulamento para o serviço policial do Estado, de 1920. Assim, esse regulamento objetivou atender, também, ao trânsito de veículos motorizados; e é esse, precisamente, o principal avanço dessa publicação em relação ao conteúdo apresentado pelos códigos de posturas municipais de Florianópolis, anteriormente referenciados.

No presente estudo nos debruçamos, também, sobre uma discussão a respeito da evolução e/ou adaptação dos regulamentos disciplinares de trânsito que se tentaram aplicar nas estradas intermunicipais do Estado de Santa Catarina e nas ruas e vias públicas da cidade de Florianópolis, durante as décadas de 20 e 30 do século passado. Procuramos verificar, dentre outros elementos, em que medida as legislações de trânsito aplicadas nos espaços supracitados atenderam à circulação automobilística e àquela operada por pedestres e veículos não motorizados. Neste ponto, observamos que os comportamentos e práticas exercidos pelos usuários cotidianos da cidade - especialmente chauffeurs e transeuntes - estavam, muitas vezes, em dissonância com os objetivos traçados pelas autoridades governamentais locais, voltados para o controle e fiscalização de comportamentos indevidos ou transgressores no trânsito, por meio da instituição de normas e dispositivos disciplinares de trânsito. Vimos, também, que o maior controle estatal exercido pelo governo de Getúlio Vargas sobre uma vasta gama de atividades e setores nacionais e estaduais - planejamento urbano, obras de infraestrutura, políticas educacionais voltadas para a valorização da língua portuguesa, especialmente em regiões onde línguas e costumes estrangeiros estavam fortemente arraigados, como então se constituía o Sul do Brasil ${ }^{1264}$ - proporcionou um incremento significativo dos quadros burocrático e legislativo no país e, especialmente, no Estado de Santa Catarina, o que implicou investimentos diretos no

\footnotetext{
${ }^{1264}$ CAMPOS, Cynthia M. A Política da Língua na Era Vargas: proibição de falar alemão e resistências no Sul do Brasil... op. cit., p. 103.
} 
aperfeiçoamento e na melhoria das estradas de rodagem intermunicipais e naquelas circunscritas ao perímetro urbano da capital catarinense, sinalizando para a clara opção pelo transporte rodoviário, em detrimento do marítimo e ferroviário.

Outra discussão a qual nos propusemos é aplicada sobre os procedimentos e falas proferidas pelos envolvidos na participação e na elaboração dos inquéritos policiais e processos judiciais relativos ao julgamento daqueles entendidos como responsáveis pelos atropelamentos e colisões ocorridos no perímetro urbano da cidade de Florianópolis, durante os anos de 1923 e 1934. Analisamos, portanto, posicionamentos e falas proferidos por chauffeurs, passageiros, transeuntes; mas também, por juízes, promotores públicos e advogados de defesa e acusação. Nesse sentido, enxergamos essas falas como elementos discursivos que envolveram, naturalmente, tendências e pontos de vista diferenciados sobre um mesmo aspecto. Objetivamos, pois, realçar o aspecto político e discursivo dessas falas e apontar posicionamentos tendenciosos que, por um lado, evidenciavam enfoques pedagógicos, uma vez que a participação nos inquéritos e nos julgamentos daqueles envolvidos nos episódios de atropelamentos e colisões configurava-se como um aprendizado, especialmente no instante em que o ato de "ouvir dizer" a respeito de determinado sinistro ou ocorrência revela seu caráter instrutivo quanto aos comportamentos considerados indevidos no trânsito, ou também no momento em que as autoridades judiciárias - notadamente o juiz de direito - determinavam e aplicavam as penas julgadas como cabíveis, segundo a avaliação das circunstâncias envoltas em cada episódio de atropelamento o colisão analisado. A análise dos processos criminais também permitiu verificarmos o teor discursivo de falas e pareceres que envolveram as tentativas de proceder-se à deliberada intenção de punir os transeuntes e inocentar os chauffeurs pelos atropelamentos e colisões ocorridos, o que realça um claro jogo político que envolve a conjugação de interesses em torno dos poderes judiciário e financeiro.

O trabalho de elaboração da presente tese também permitiu analisamos os posicionamentos da imprensa local sobre a circulação simultânea dos ônibus e bondes pelas ruas do perímetro urbano de Florianópolis. A intenção com esse enfoque foi oferecer ao leitor uma discussão em torno dos transportes coletivos na cidade, a fim de evidenciar imposições e conflitos enfatizados, especialmente, nos artigos jornalísticos locais - junto à preferência pelo uso público do bonde e, a partir da segunda metade da década de 1920, pelos coletivos motorizados: os ônibus. Dessa discussão, o que pudemos observar, com maior clareza, foi que as notas da imprensa local expressaram, a partir da segunda metade dos anos 1920, nítida preferência pelo uso público dos coletivos motorizados, posição esta que não foi assinalada sem que fossem observadas, paralelamente, críticas quanto ao estado de conservação dos ônibus e, mesmo, 
quanto ao progressivo adensamento de seu fluxo diário. Na seção Epílogo, discutimos o processo inicial de implementação dos semáforos nos principais cruzamentos de ruas da capital catarinense, a partir da década de 1950. A partir desse período, observamos, também, um claro processo de adensamento do fluxo de veículos motorizados pelas ruas do espaço central da cidade de Florianópolis; processo que evidenciou a preferência ao transporte rodoviário, em detrimento do marítimo e ferroviário, verificada, igualmente, nas esferas estadual e federal.

Em linhas gerais, o trabalho de elaboração da presente tese permitiu, ao certo, investigarmos aspectos específicos do cotidiano da capital catarinense que, de outra forma, seriam muito difíceis de ser revelados. E este é, talvez, a sua principal característica diferencial. Nesse sentido, deve ficar claro que o palco específico apresentado, neste estudo, constituiu-se no perímetro urbano da capital catarinense e nas vivências cotidianas operadas por seus habitantes. Personagens anônimos, heróis comuns, cidadãos vários ${ }^{1265}$, imersos no cotidiano da cidade; chauffeurs, passageiros e transeuntes converteram-se, desde o início de nossa investigação, nos atores principais das histórias narradas no transcorrer da tese; histórias estas marcadas por embates, discussões e vivências várias, envoltas em cada episódio de atropelamento e colisão analisado. Algumas facetas das falas e posicionamentos, expressas por esses personagens ante à presença e a circulação dos veículos motorizados, foram, pois, aqui reveladas, e tal procedimento só foi possível graças à natureza do presente estudo e das fontes nele investigadas, que nos permitiram discutir os pequenos enredos e vivências cotidianas operados por personagens do cotidiano da cidade de Florianópolis, pois que fizeram ler e falar a cidade; personagens estes que, agora, são conhecidos daqueles que se aventuraram a ler estas páginas. Indagamos, contudo, que outros atores, histórias e personagens dessa mesma cidade, envolvidos em textos possivelmente ainda ocultos, estão à espera de serem elucidados pelo trabalho árduo, mas sempre gratificante que a História impõe àqueles que se dedicam ao seu ofício? ${ }^{1266}$

\footnotetext{
${ }^{1265}$ CERTEAU, Michel de. A invenção do cotidiano 1: artes de fazer. 8. ed. Petrópolis: Vozes, 2002. p. 57.

${ }^{1266}$ GINZBURG, Carlo. O queijo e os vermes: o cotidiano e as idéias de um moleiro perseguido pela Inquisição. 3. ed. São Paulo: Companhia das Letras, 2003. p. 203.
} 
$\underline{\text { ANEXOS }}$ 
Anexo 01: Atropelamento - Processo n. 30, 05 mar. 1923. Caixa $03(*)$

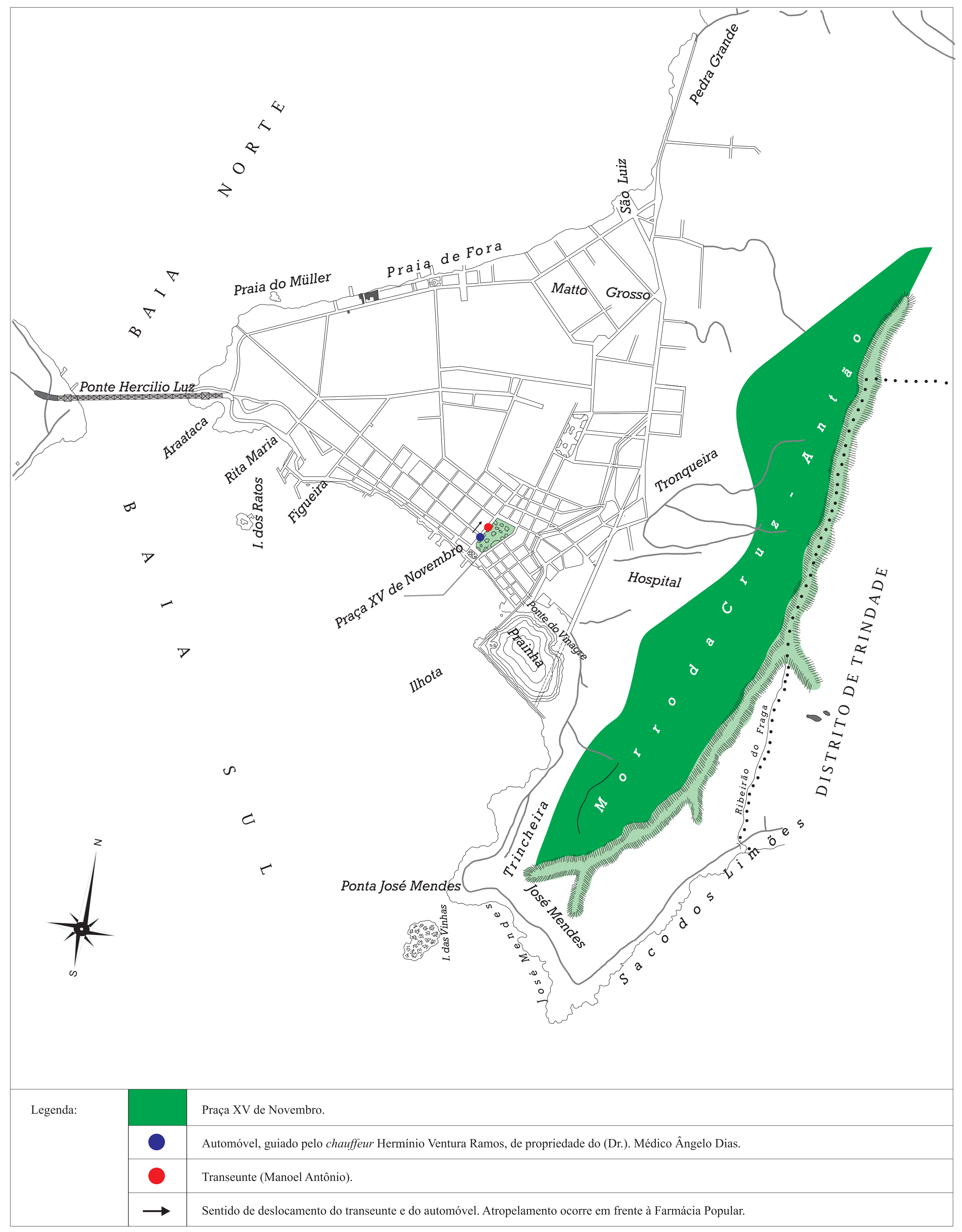

(*) Mapa do perímetro urbano da cidade de Florianópolis - 1940. Fonte: Centro Administrativo do Estado de Santa Catarina-Secretaria de Planejamento/Diretoria de Estatística e Cartografia -Florianópolis-Santa Catarina. Criação e Diagramação: Duplic Digital Copiadora-Florianópolis-Santa Catarina.

Adaptações feitas pelo autor, conforme informações constantes no processo n. 30, de 05 de março de 1923 . Caixa 03 . 
Anexo 02: Desastre/Colisão - Processo n. 52, 05 nov. 1925. Caixa 05 (*)

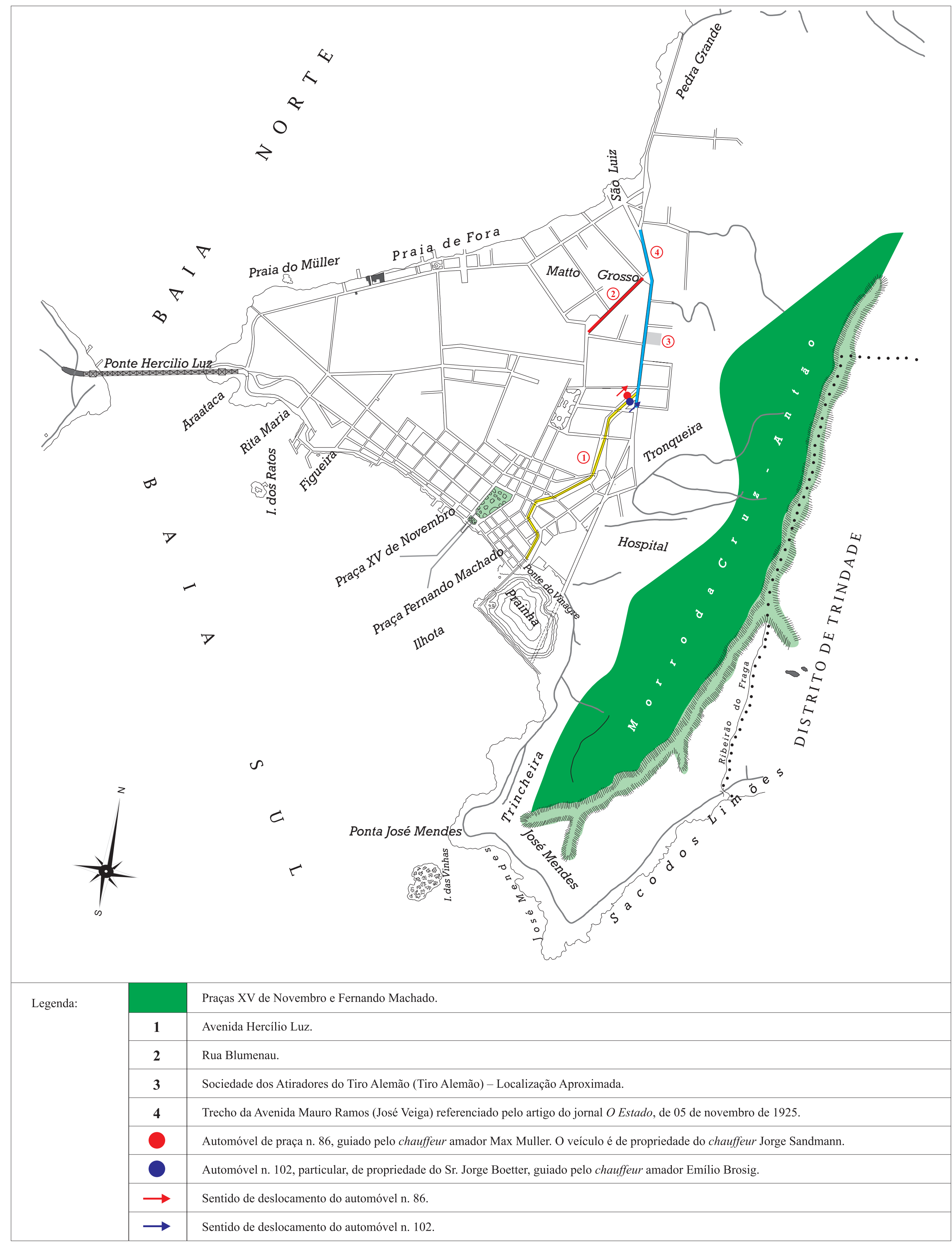

(*) Mapa do perímetro urbano da cidade de Florianópolis - 1940. Fonte: Centro Administrativo do Estado de Santa Catarina-Secretaria de Planejamento/Diretoria de Estatística e Cartografia - Florianópolis - Santa Catarina Criação e Diagramação: Duplic Digital Copiadora - Florianópolis - Santa Catarina.

Adaptações feitas pelo autor, conforme informações constantes no processo n. 52 , de 05 de novembro de 1925 . Caixa 05. 
Anexo 03: Colisão - Processo n. 95, 05 jul. 1926. Caixa $09\left(^{*}\right)$

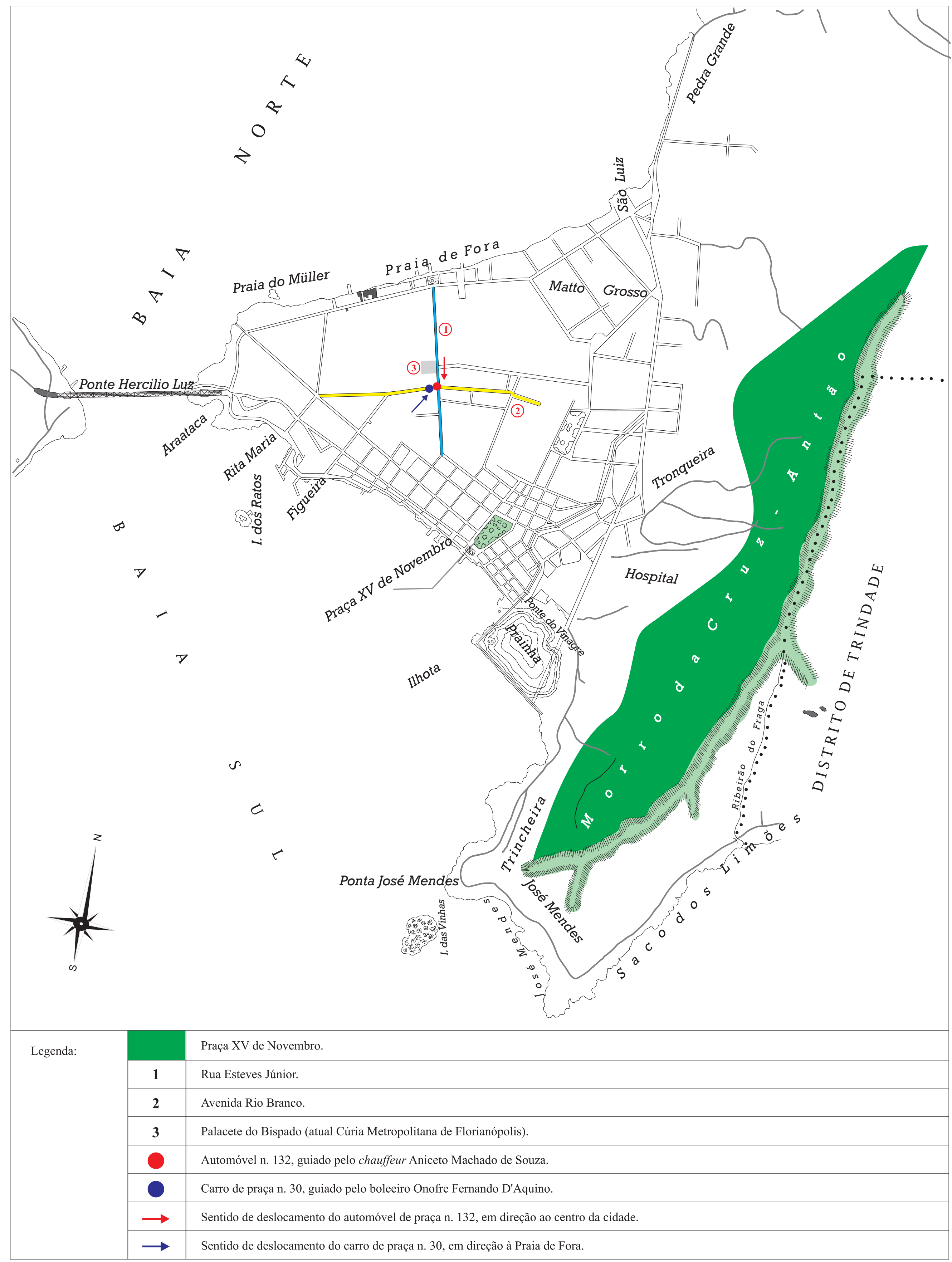

(*) Mapa do perímetro urbano da cidade de Florianópolis - 1940. Fonte: Centro Administrativo do Estado de Santa Catarina - Secretaria de Planejamento/Diretoria de Estatística e Cartografia - Florianópolis - Santa Catarina Adaptações feitas pelo autor, conforme informações constantes no processo n. 95 , de 05 de julho de 1926. Caixa 09 
Anexo 04: Atropelamento - Processo n. 239, 21 jan. 1934. Caixa $26(*)$

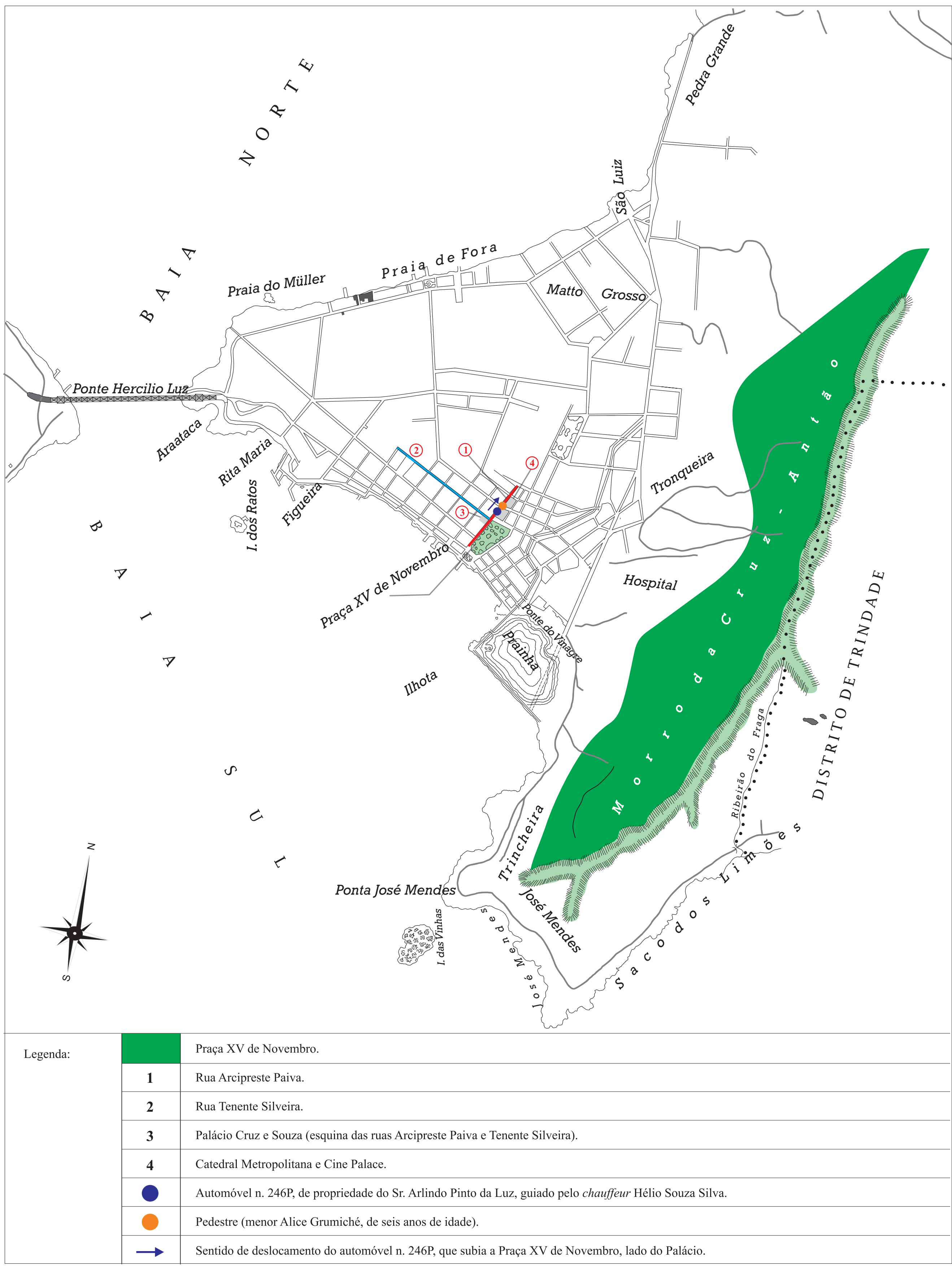

(*) Mapa do perímetro urbano da cidade de Florianópolis - 1940. Fonte: Centro Administrativo do Estado de Santa Catarina - Secretaria de Planejamento/Diretoria de Estatística e Cartografia - Florianópolis - Santa Catarina. Adaptações feitas pelo autor, conforme informações constantes no processo n. 239, de 21 de janeiro de 1934. Caixa 26 
Anexo 05: Atropelamento - Processo n. 45, 04 ago. 1923. Caixa $06\left(^{*}\right)$

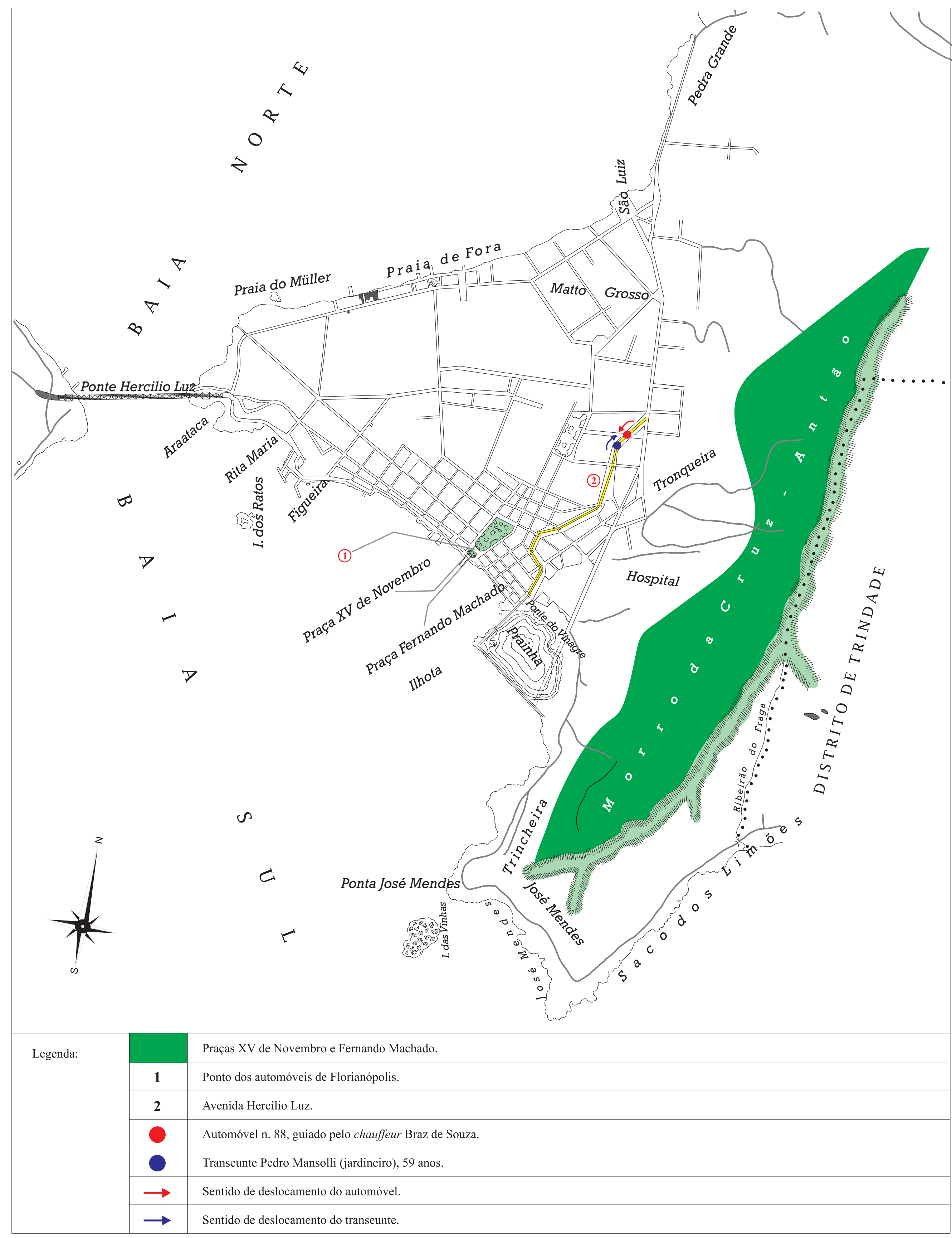

(*) Mapa do perímetro urbano da cidade de Florianópolis - 1940. Fonte: Centro Administrativo do Estado de Santa Catarina - Secretaria de Planejamento/Diretoria de Estatística e Cartografia - Florianópolis - Santa Catarina.

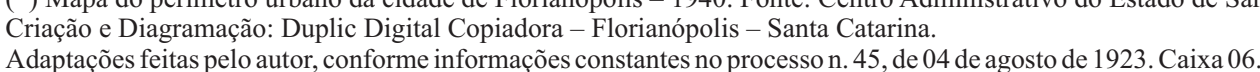


Anexo 06: Colisão - Processo n. 171, 27 dez. 1931. Caixa $16\left(^{*}\right)$

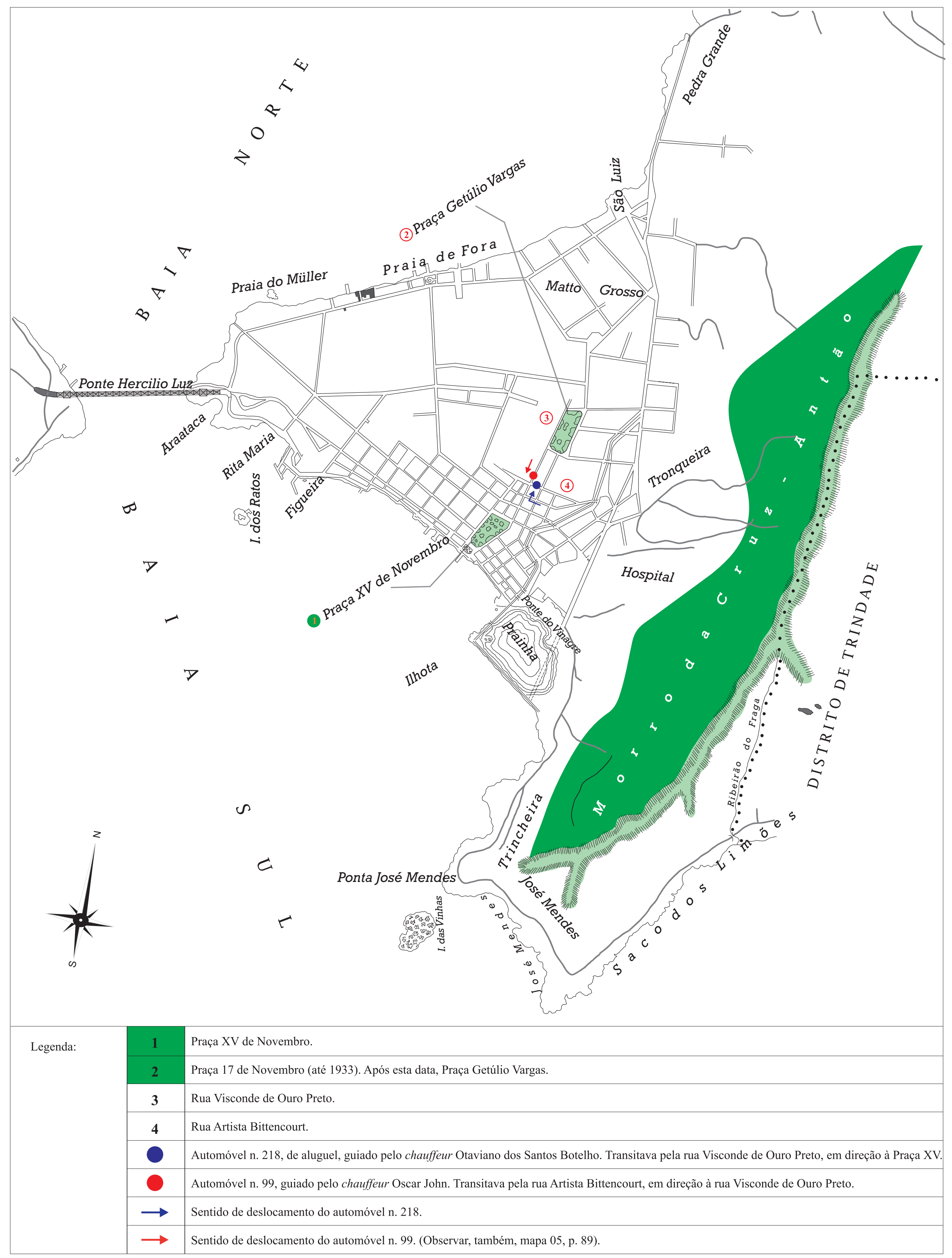

(*) Mapa do perímetro urbano da cidade de Florianópolis - 1940. Fonte: Centro Administrativo do Estado de Santa Catarina-Secretaria de Planejamento/Diretoria de Estatística e Cartografia -Florianópolis - Santa Catarina. Criação e Diagramação: Duplic Digital Copiadora -Florianópolis-Santa Catarina.

Adaptações feitas pelo autor, conforme informações constantes no processo n. 171, de 27 de dezembro de 1931. Caixa 16. 
Anexo 07: Atropelamento - Processo n. 29, 21 nov. 1923. Caixa $03\left(^{*}\right)$

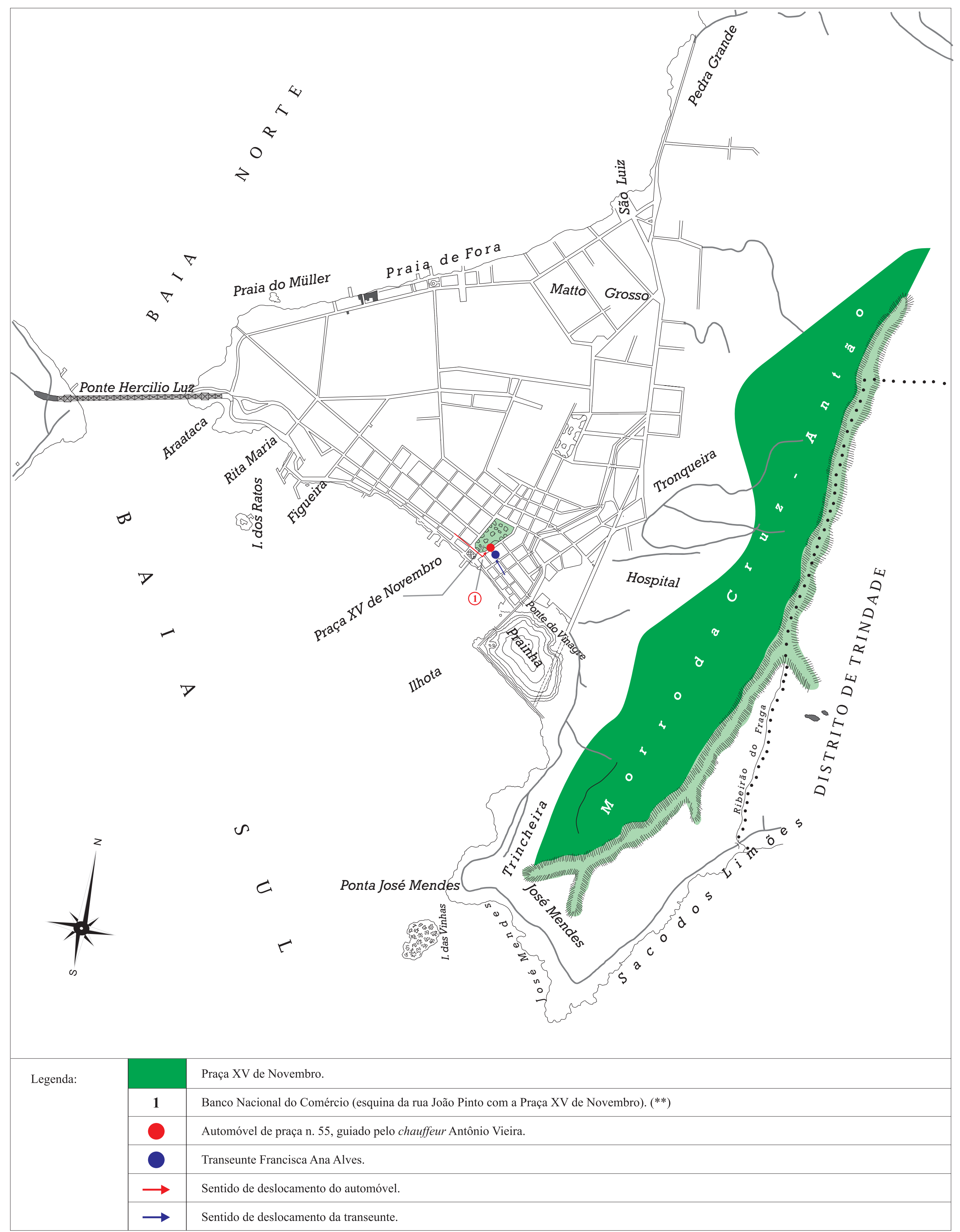

(*) Mapa do perímetro urbano da cidade de Florianópolis - 1940. Fonte: Centro Administrativo do Estado de Santa Catarina-Secretaria de Planejamento/Diretoria de Estatística e Cartografia -Florianópolis - Santa Catarina. (**) Referência obtida junto à seguinte publicação: SILVA, Adolfo Nicolich da. Ruas de Florianópolis: resenha histórica. Florianópolis: Fundação Franklin Cascaes. p. 39 ; p. 46 e p. 49.

Criação e Diagramação: Duplic Digital Copiadora-Florianópolis-Santa Catarina. 21 de novembro de 1923. Caixa 03. 
Anexo 08: Atropelamento - Processo n. 45, 13 abr. 1925. Caixa $05\left(^{*}\right)$

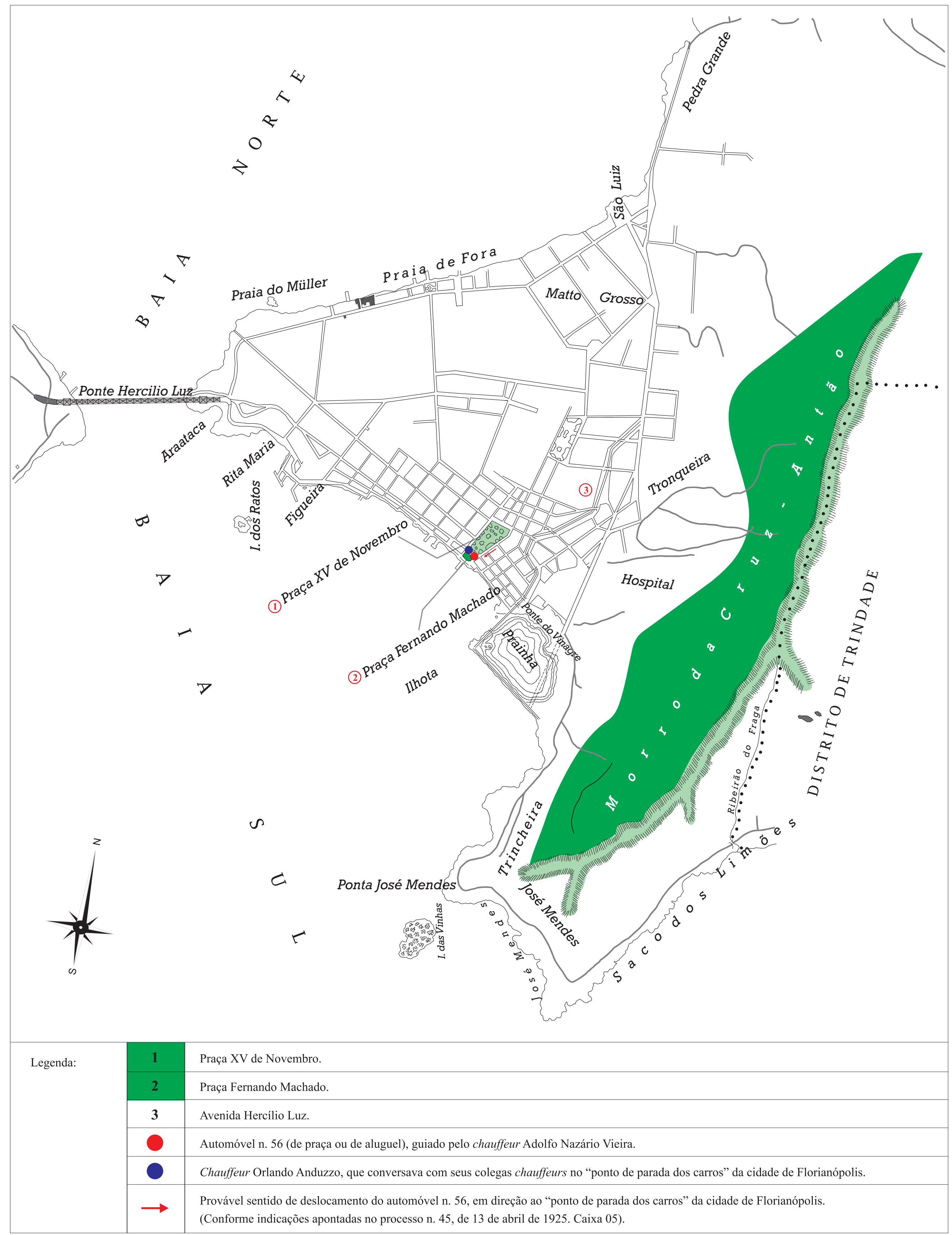

(*) Mapa do perímetro urbano da cidade de Florianópolis - 1940. Fonte: Centro Administrativo do Estado de Santa Catarina -Secretaria de Planejamento/Diretoria de Estatística e Cartografia - Florianópolis - Santa Catarina. $\left({ }^{* *}\right)$ Referência obtida junto à seguinte publicação: SILVA, Adolfo Nicolich da. Ruas de Florianópolis: resenha histórica. Florianópolis: Fundação Franklin Cascaes; p. 39 ; p. 46 ep. 49. 
Anexo 09: Colisão/Queda - Processo n. 76, 21 mar. 1926. Caixa $07(*)$

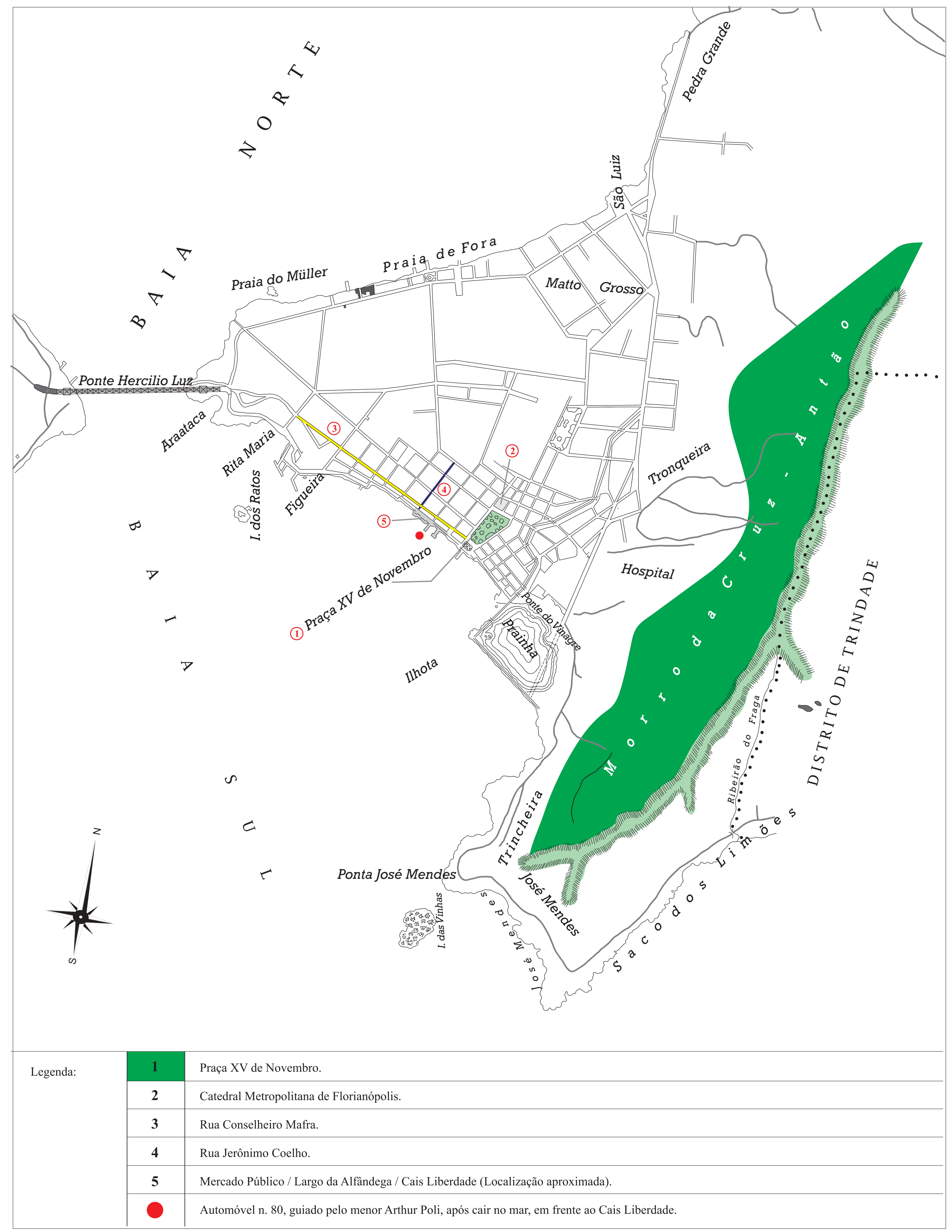

(*) Mapa do perímetro urbano da cidade de Florianópolis - 1940. Fonte: Centro Administrativo do Estado de Santa Catarina-Secretaria de Planejamento/Diretoria de Estatística e Cartografia - Florianópolis - Santa Catarina. Criação e Diagramação: Duplic Digital Copiadora-Florianópolis - Santa Catarina.

Adaptações feitas pelo autor, conforme informações constantes no processo n. 76, de 21 de março de 1926. Caixa 07. 
Anexo 10: Colisão/Atropelamento - Processo n. 77, 25 mar. 1926. Caixa $07\left(^{*}\right)$

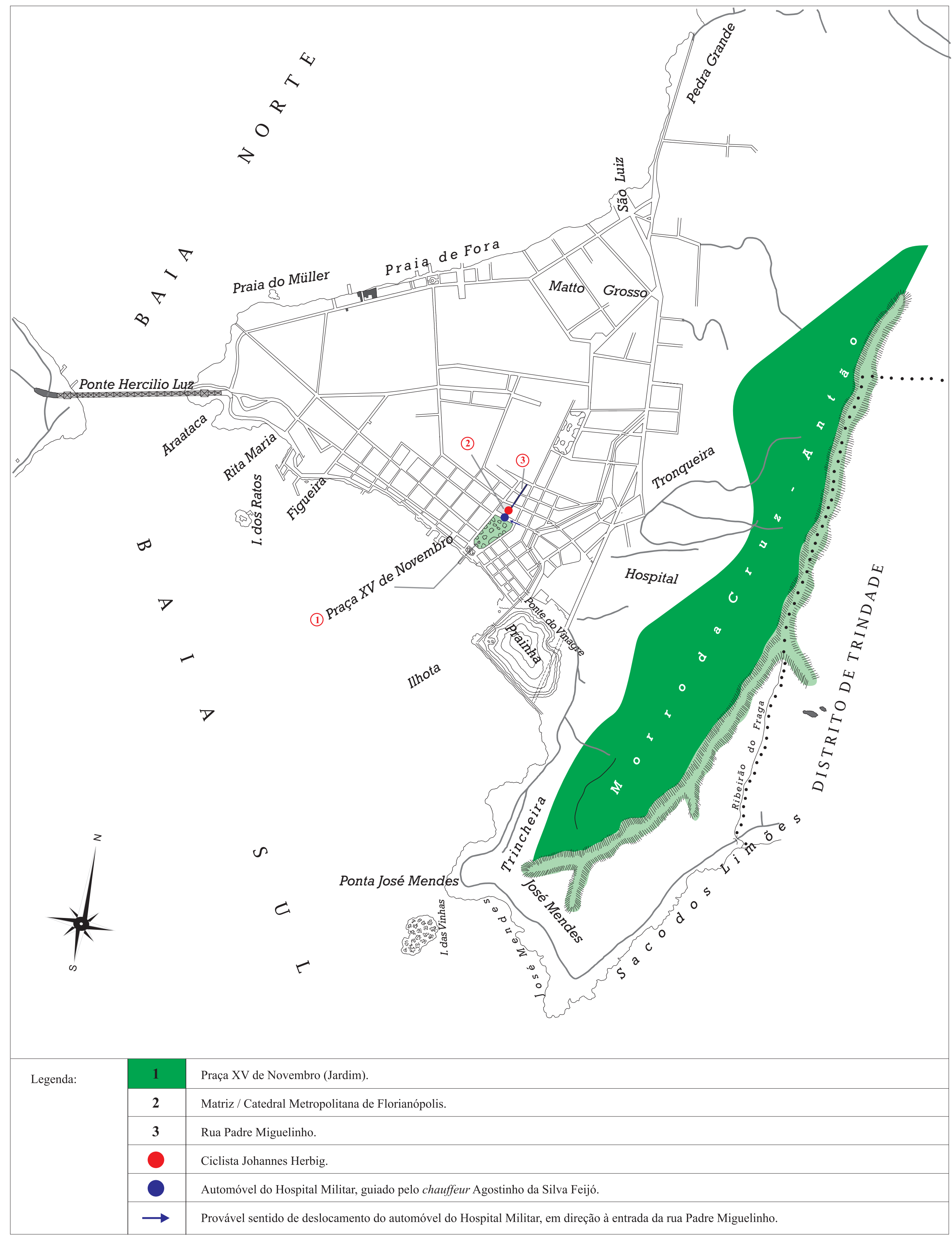
(*) Mapa do perímetro urbano da cidade de Florianópolis - 1940. Fonte: Centro Administrativo do Estado de Santa Catarina -Secretaria de Planejamento/Diretoria de Estatística e Cartografia - Florianópolis -Santa Catarina.
Criação e Diagramação: Duplic Digital Copiadora - Florianópolis - Santa Catarina.

Adaptações feitas pelo autor, conforme informações constantes no processon. 77 , de 25 de março de 1926 . Caixa 07. 
Anexo 11: Atropelamento - Processo n. 62, 03 abr. 1926. Caixa $06\left(^{*}\right)$

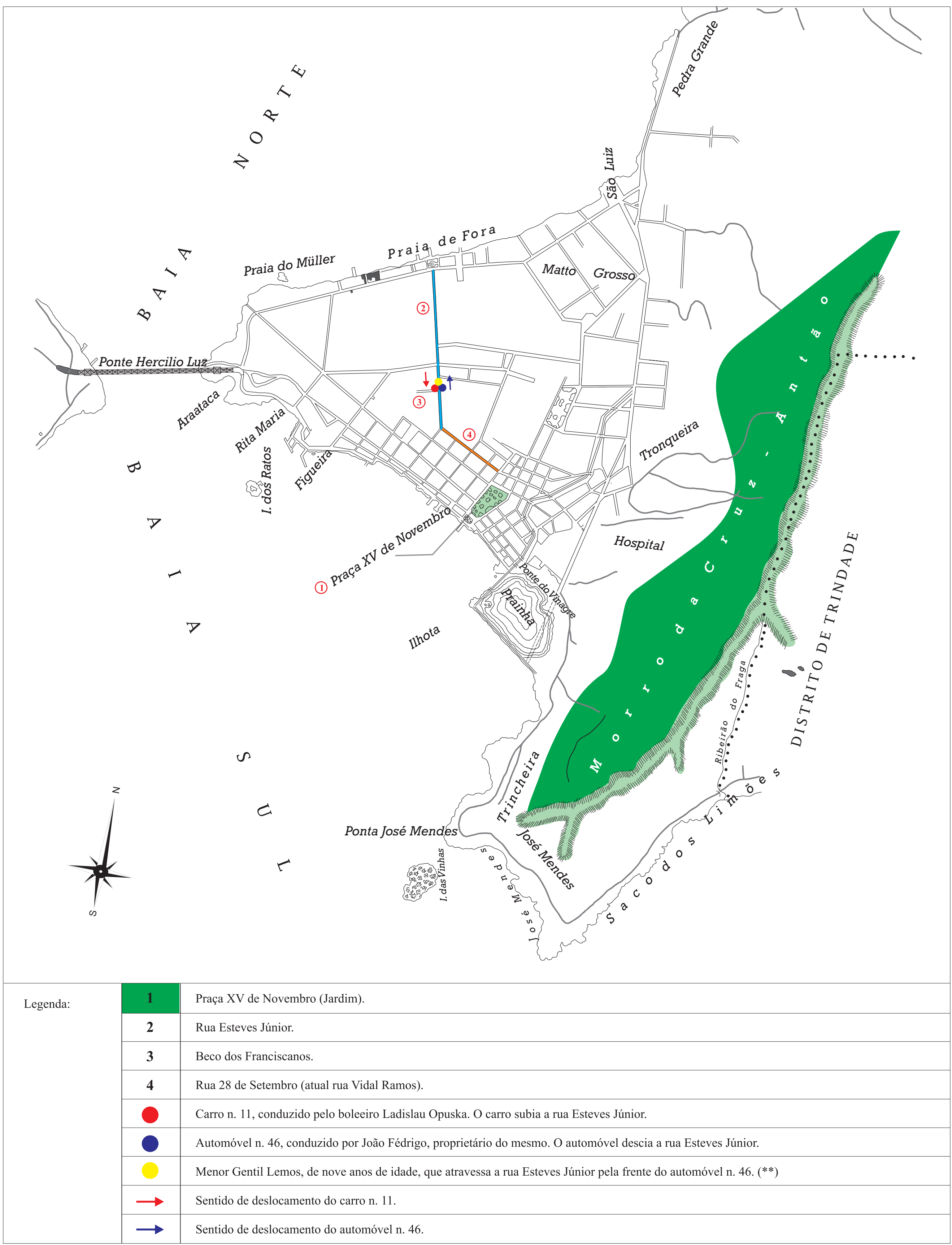

$\left(^{*}\right)$ Mapa do perímetro urbano da cidade de Florianópolis - 1940. Fonte: Centro Administrativo do Estado de Santa Catarina-Secretaria de Planejamento/Diretoria de Estatística e Cartografia -Florianópolis - Santa Catarina. $\left(*^{*}\right)$ Nesse mapa está representado o momento imediatamente anterior ao atropelamento do transeunte em questão. 
Anexo 12: Atropelamento - Processo n. 173, 20 ago. 1931. Caixa $17(*)$

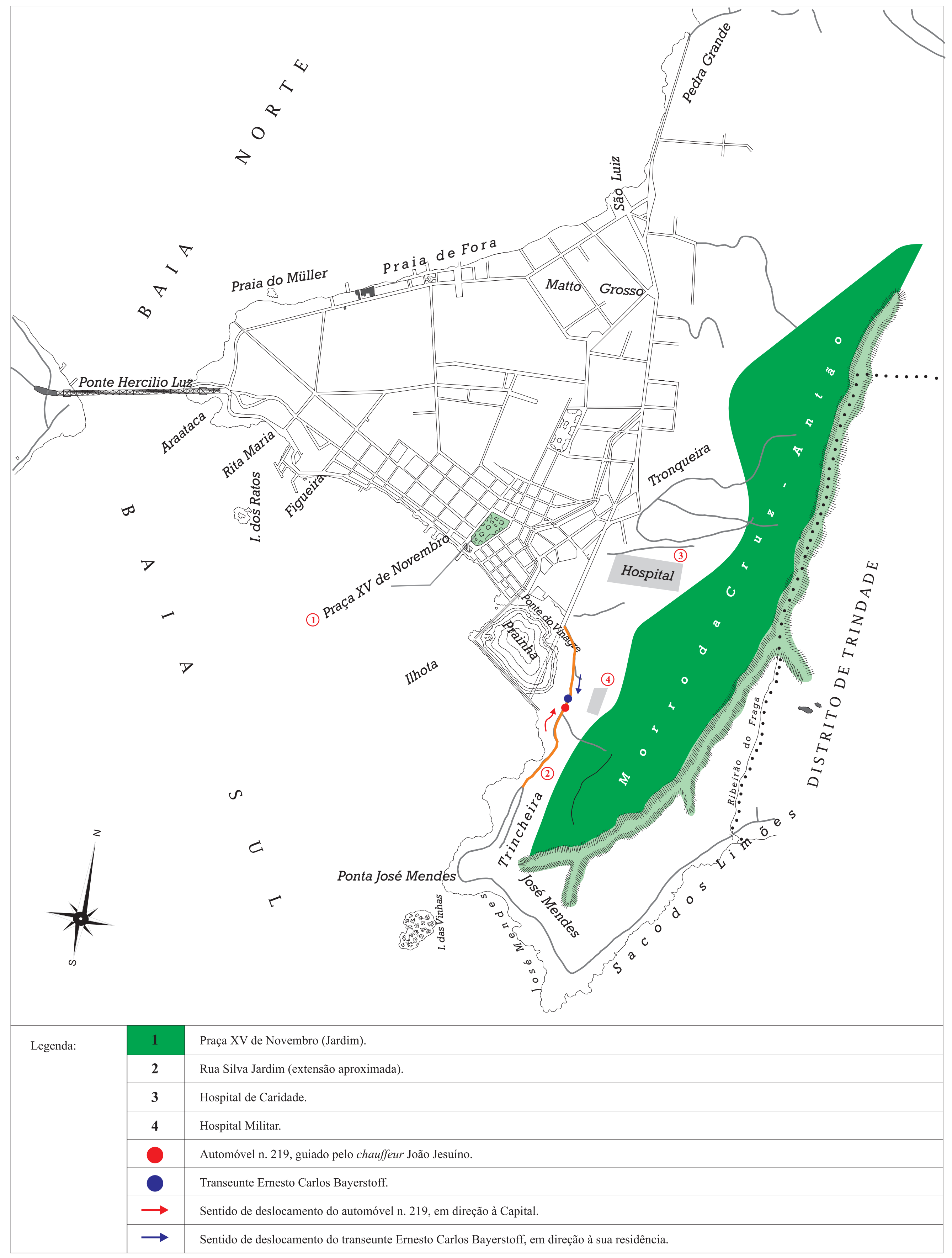

(*) Mapa do perímetro urbano da cidade de Florianópolis - 1940. Fonte: Centro Administrativo do Estado de Santa Catarina - Secretaria de Planejamento/Diretoria de Estatística e Cartografia - Florianópolis - Santa Catarina. Adaptações feitas pelo autor, conforme informações constantes no processo n. 173, de 20 de agosto de 1931. Caixa 17. 
Anexo 13: Colisão/Atropelamento - Processo n. 194, 21 jan. 1932. Caixa $20\left(^{*}\right)$

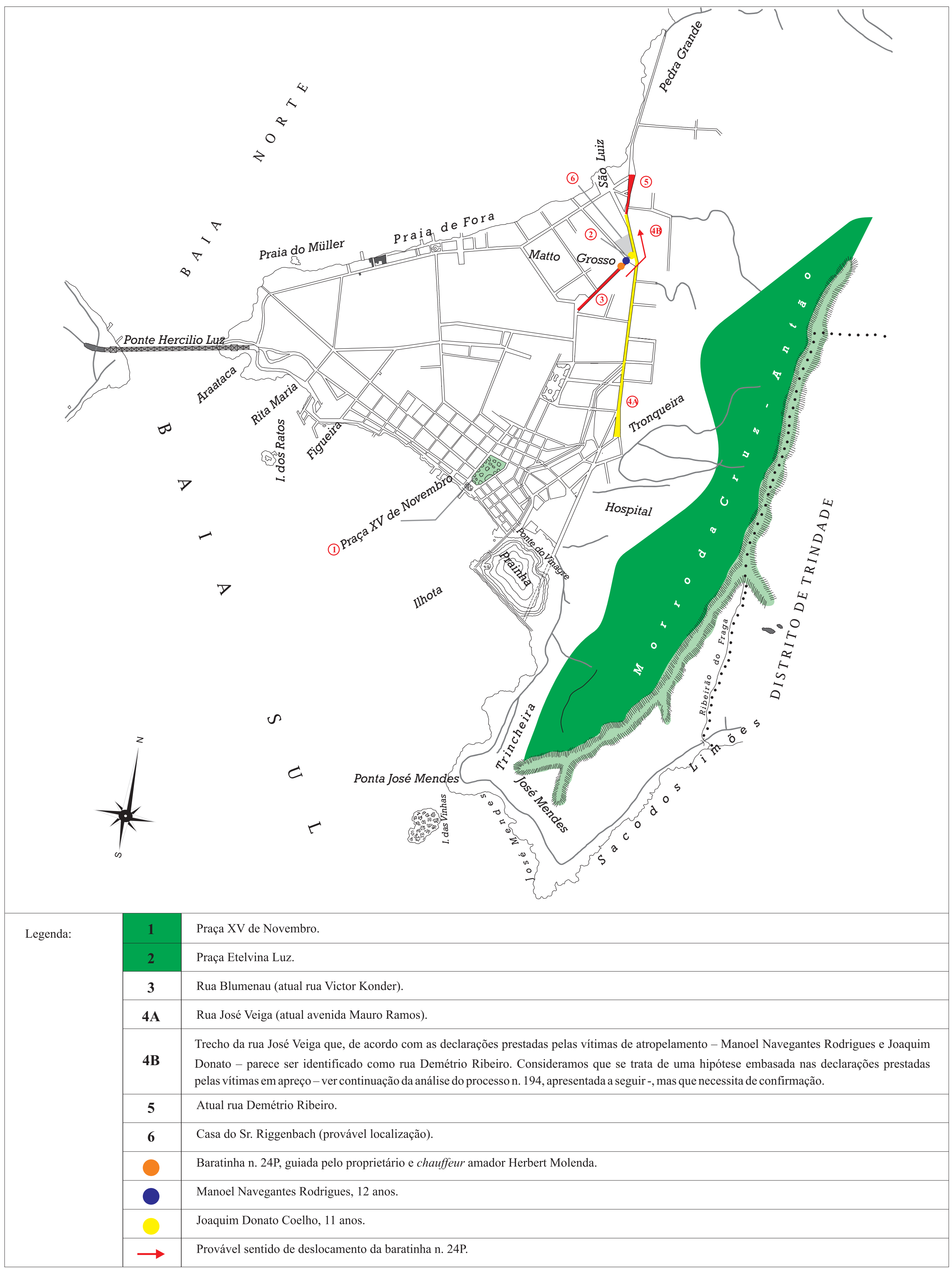

$\left(^{*}\right)$ Mapa do perímetro urbano da cidade de Florianópolis - 1940. Fonte: Centro Administrativo do Estado de Santa Catarina - Secretaria de Planejamento/Diretoria de Estatística e Cartografia - Florianópolis - Santa Catarina. Criação e Diagramação: Duplic Digital Copiadora - Florianópolis - Santa Catarina.

Adaptações feitas pelo autor, conforme informações constantes no processo n. 194, de 21 de janeiro de 1932. Caixa 20. 
Anexo 14: Atropelamento - Processo n. 351, 09 ago. 1937. Caixa $38(*)$

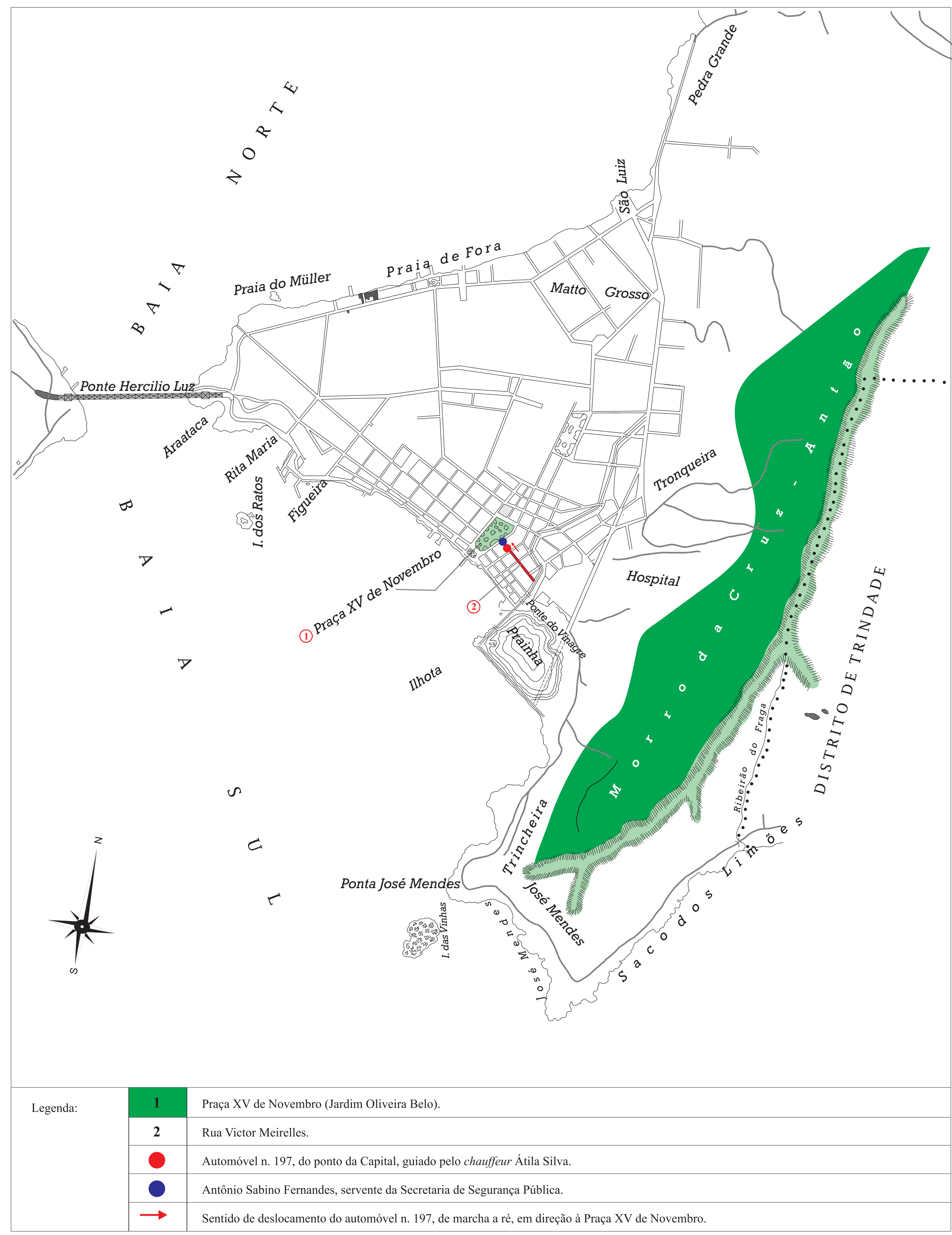

(*) Mapa do perímetro urbano da cidade de Florianópolis - 1940. Fonte: Centro Administrativo do Estado de Santa Catarina - Secretaria de Planejamento/Diretoria de Estatística e Cartografia - Florianópolis - Santa Catarina.

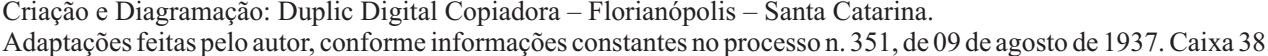


Anexo 15: Colisão - Processo n. 373, 27 jan. 1938. Caixa $41\left(^{*}\right)$

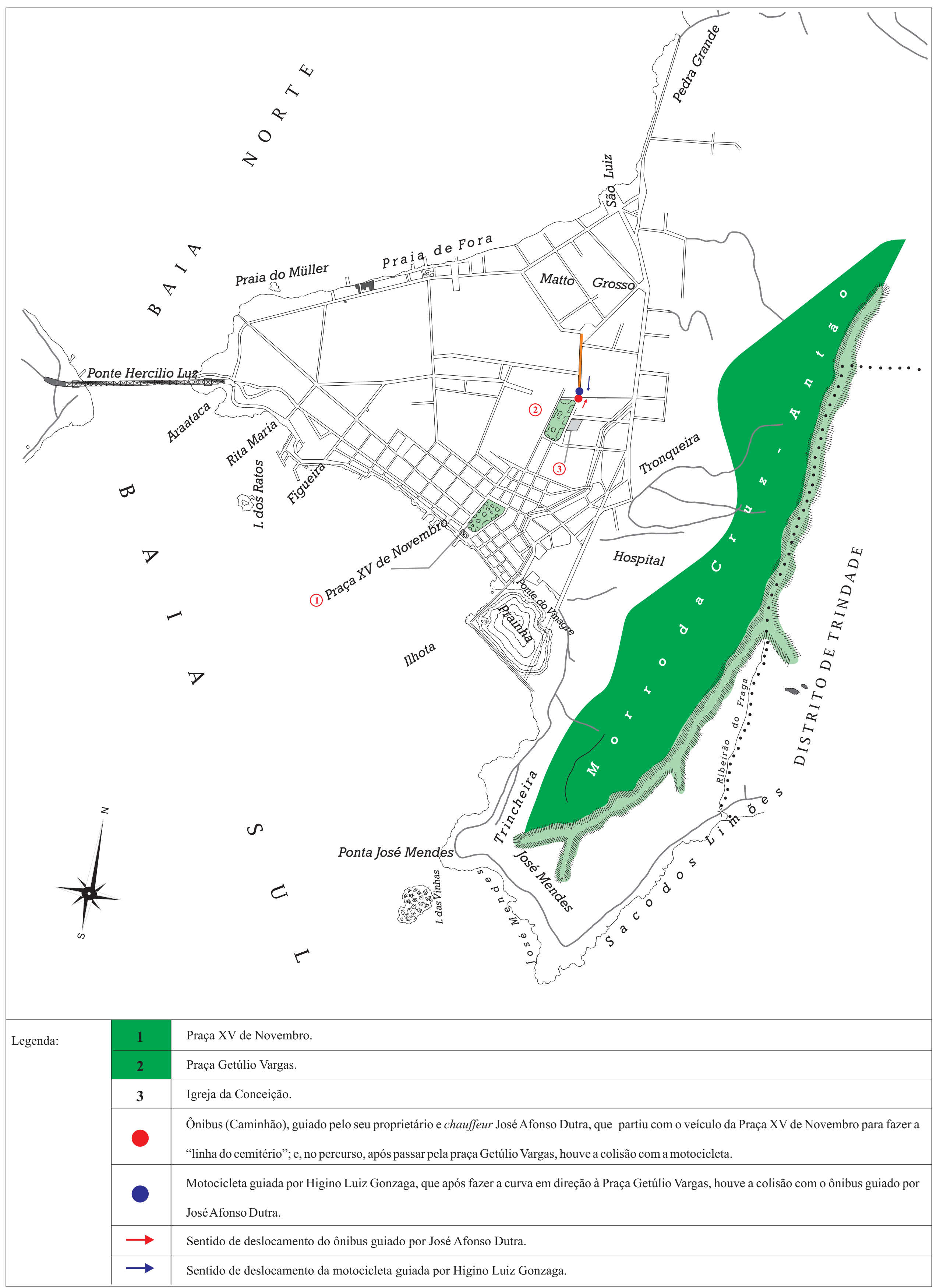

(*) Mapa do perímetro urbano da cidade de Florianópolis - 1940. Fonte: Centro Administrativo do Estado de Santa Catarina - Secretaria de Planejamento/Diretoria de Estatística e Cartografia - Florianópolis - Santa Catarina Criação e Diagramação: Duplic Digital Copiadora - Florianópolis - Santa Catarina.

Adaptações feitas pelo autor, conforme informações constantes no processo n. 373, de 27 de janeiro de 1938. Caixa 41. 
Anexo 16: Atropelamento - Processo n. 73, 17 dez. 1926. Caixa 07(*)

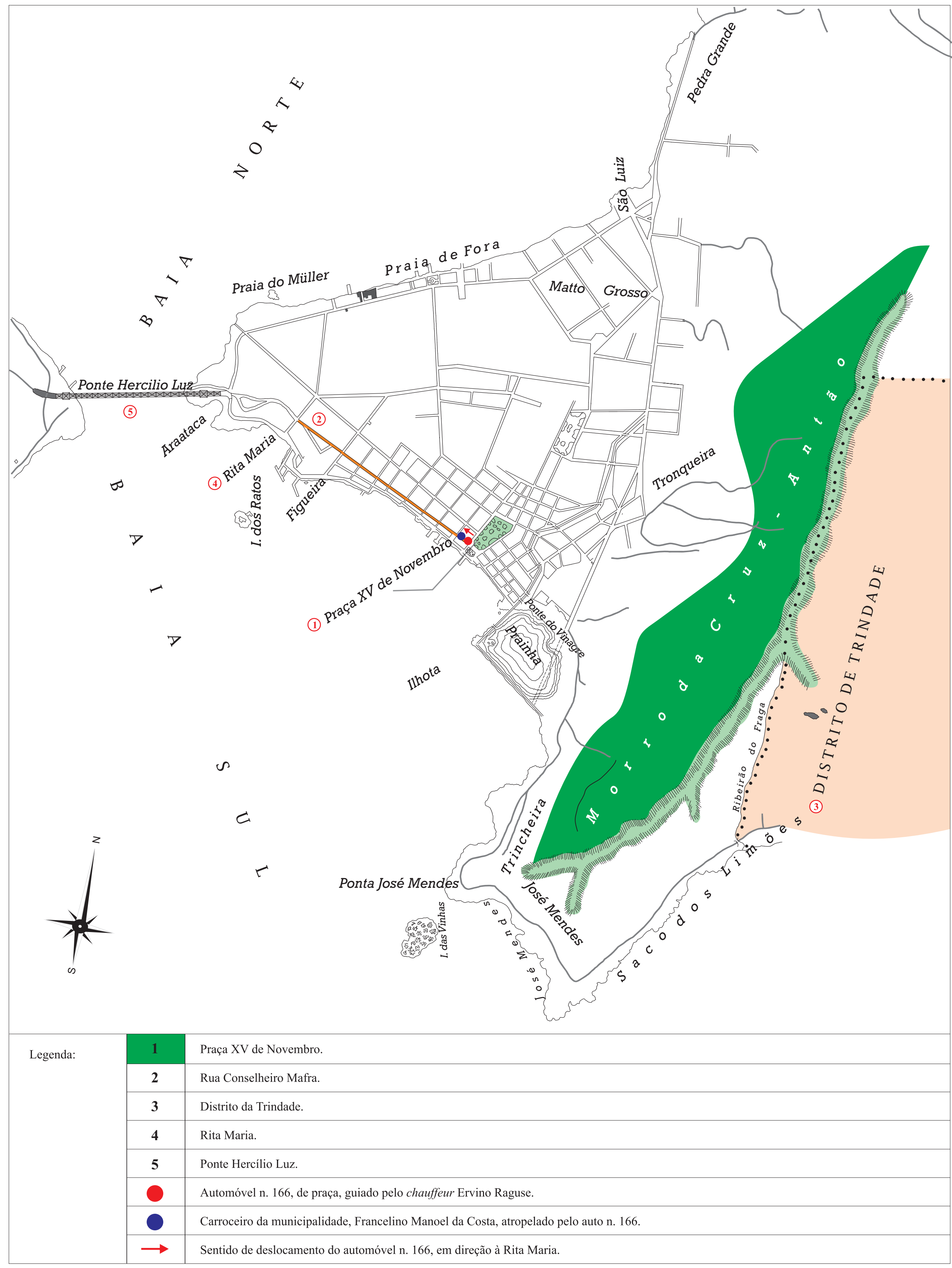

(*) Mapa do perímetro urbano da cidade de Florianópolis - 1940. Fonte: Centro Administrativo do Estado de Santa Catarina - Secretaria de Planejamento/Diretoria de Estatística e Cartografia - Florianópolis - Santa Catarina. 
Anexo 17: Atropelamento - Processo n. 96, 19 dez. 1928. Caixa $02(*)$

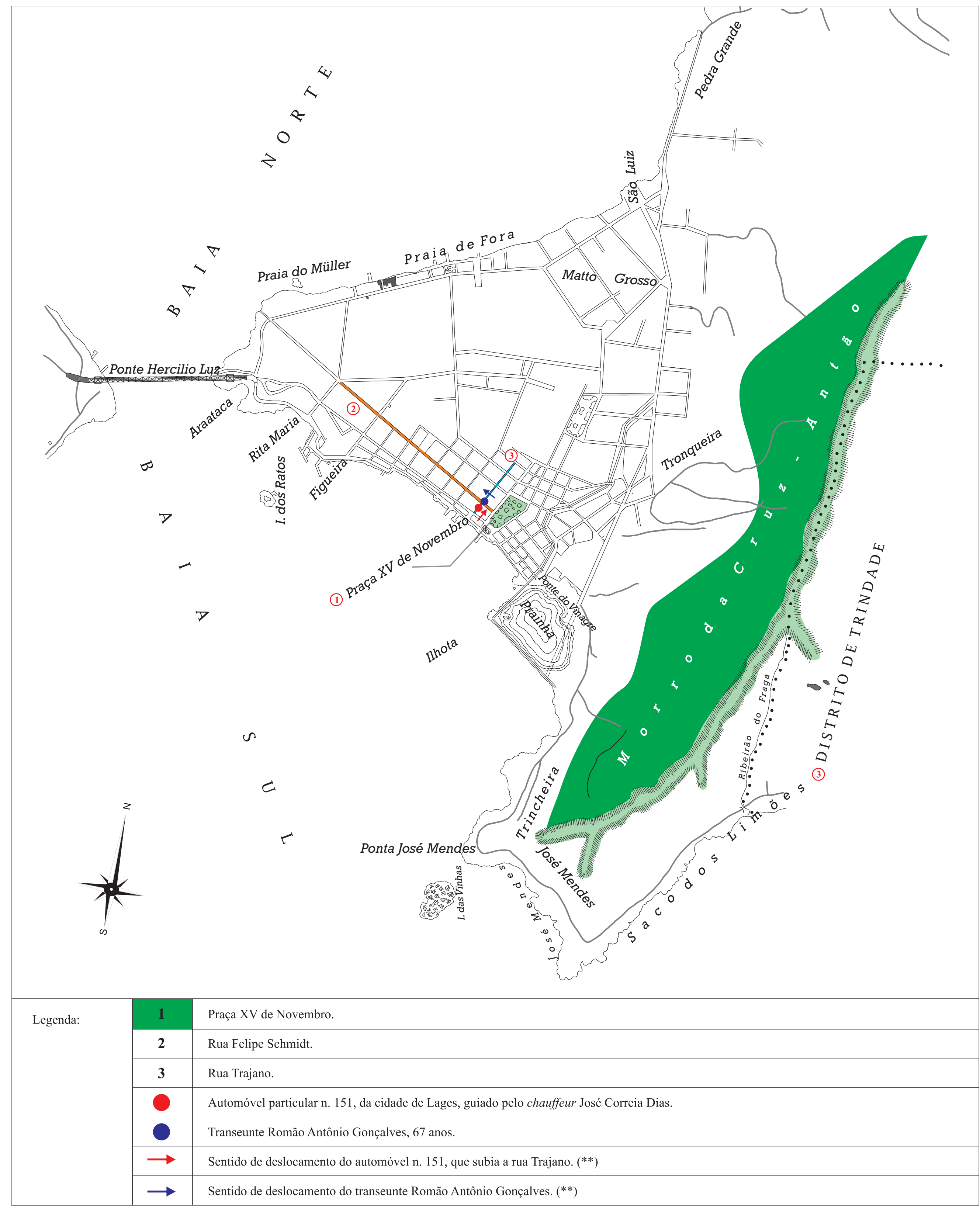

(*) Mapa do perímetro urbano da cidade de Florianópolis - 1940. Fonte: Centro Administrativo do Estado de Santa Catarina - Secretaria de Planejamento/Diretoria de Estatística e Cartografia - Florianópolis - Santa Catarina.

(**) Informações obtidas nas declarações prestadas pela testemunha Cyrillo Manoel da Cunha, no dia 22 de dezembro de 1928. De acordo com essa testemunha, " no dia dezenove do corrente às quinze horas, mais ou menos, o depoente achava-se na porta do Café 'Rio Branco', onde é empregado; que nessa ocasião, viu um automóvel que vinha subindo a rua Trajano, e ao chegar à esquina da rua Felipe Schmidt, um homem que atravessava a rua naquele momento, foi de encontro ao respectivo automóvel, ferindo a perna esquerda". (Processo n. 96, 19 dez. 1928. Caixa 02).

Criação e Diagramação: Duplic Digital Copiadora - Florianópolis - Santa Catarina.

Adaptações feitas pelo autor, conforme informações constantes no processo n. 96 , de 19 de dezembro de 1928. Caixa 02. 
Anexo 18: Atropelamento - Processo n. 183, 11 jan. 1932. Caixa $19(*)$

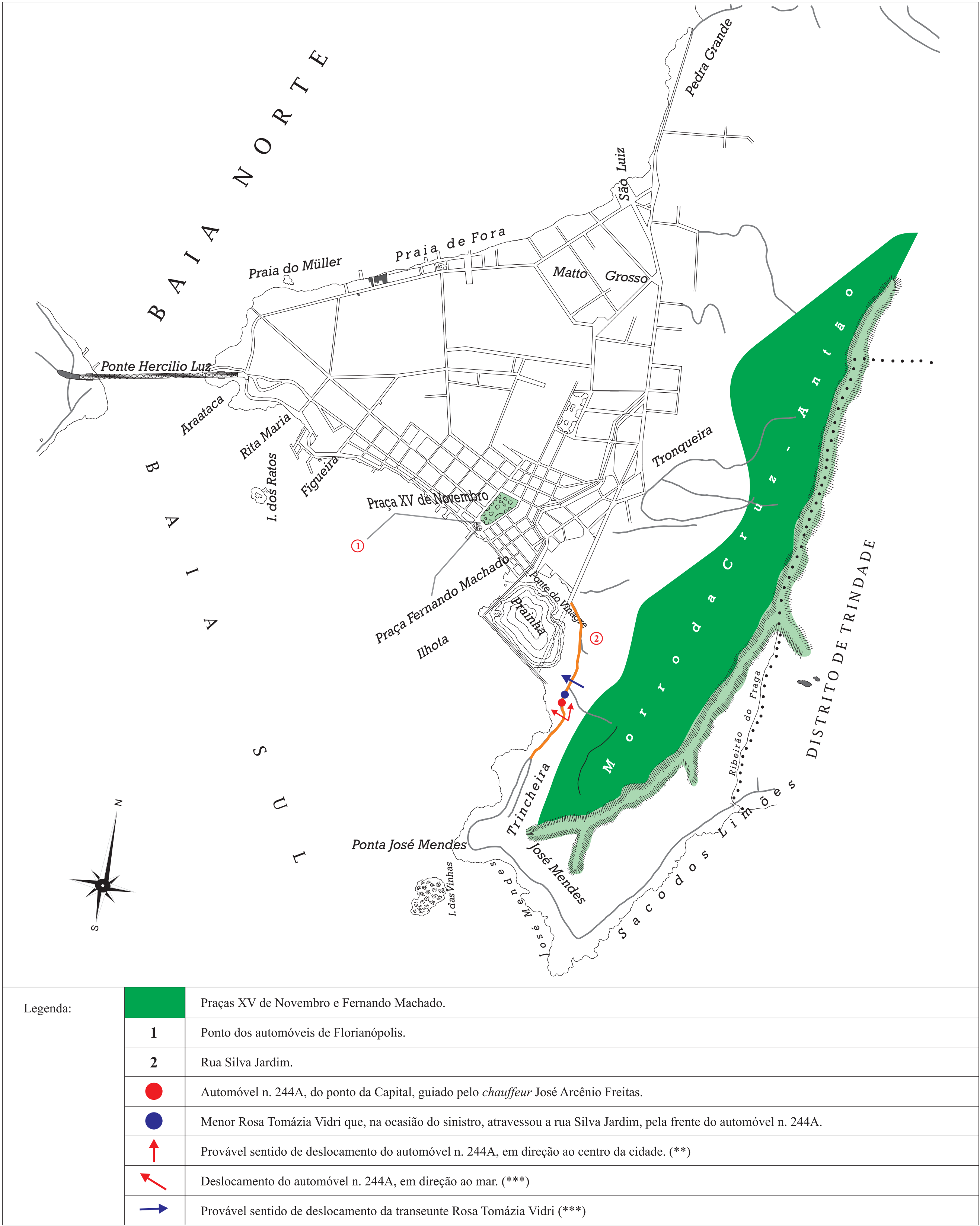

(*) Mapa do perímetro urbano da cidade de Florianópolis - 1940. Fonte: Centro Administrativo do Estado de Santa Catarina - Secretaria de Planejamento/Diretoria de Estatística e Cartografia - Florianópolis - Santa Catarina. Criação e Diagramação: Duplic Digital Copiadora - Florianópolis - Santa Catarina.

Adaptações feitas pelo autor, conforme informações constantes no processo n. 183, de 11 de janeiro de 1932. Caixa 19.

(**) Informação obtida no depoimento prestado pela testemunha Orlando Silvio Damiani, no dia 12 de janeiro de 1932. Conforme essa testemunha, "ontem, às treze e meia horas estava no portão da sua residência, quando por ali viu passar o automóvel n. 244A, guiado pelo chauffeur José Arcênio Freitas [...]; que sem muita demora foi a sua atenção despertada pelo rumor que fazia o motor do aludido automóvel, que olhando para o lado de tal rumor, viu que se tratava do automóvel acima descrito, que atropelava uma menor residente à rua referida; que pôde ver as rodas do citado veículo passarem por cima da menor, estando nessa ocasião o veículo aludido contramão, ou seja, encostado para o lado esquerdo da rua, pois o automóvel caminhava em rumo ao centro da Capital". (Processo n. 183, 11 jan. 1932. Caixa 19).

(***) Informações obtidas nas declarações prestadas por Germano de Oliveira, advogado de defesa do réu José Arcênio Freitas, no dia 29 de fevereiro de 1932, pois, nessa ocasião, o referido advogado argumenta que a testemunha Manoel Alexandre da Silveira alega que "achava-se em uma quitanda, à rua Silva Jardim, no dia e hora referidos na denúncia, 'quando ouviu o grito dado por seu filho que estacionava à porta de uma barbearia, ao lado da venda'; que, despertado pelo grito, voltou-se, e viu a ofendida atravessando a rua, correndo, na frente do automóvel guiado pelo denunciado; que observou quando a roda traseira do lado esquerdo do veículo passou sobre Rosa Tomázia Vidri; que o 'chauffeur' paro 
Anexo 19: Preços para comercialização e/ou venda de automóveis - 1919-1928

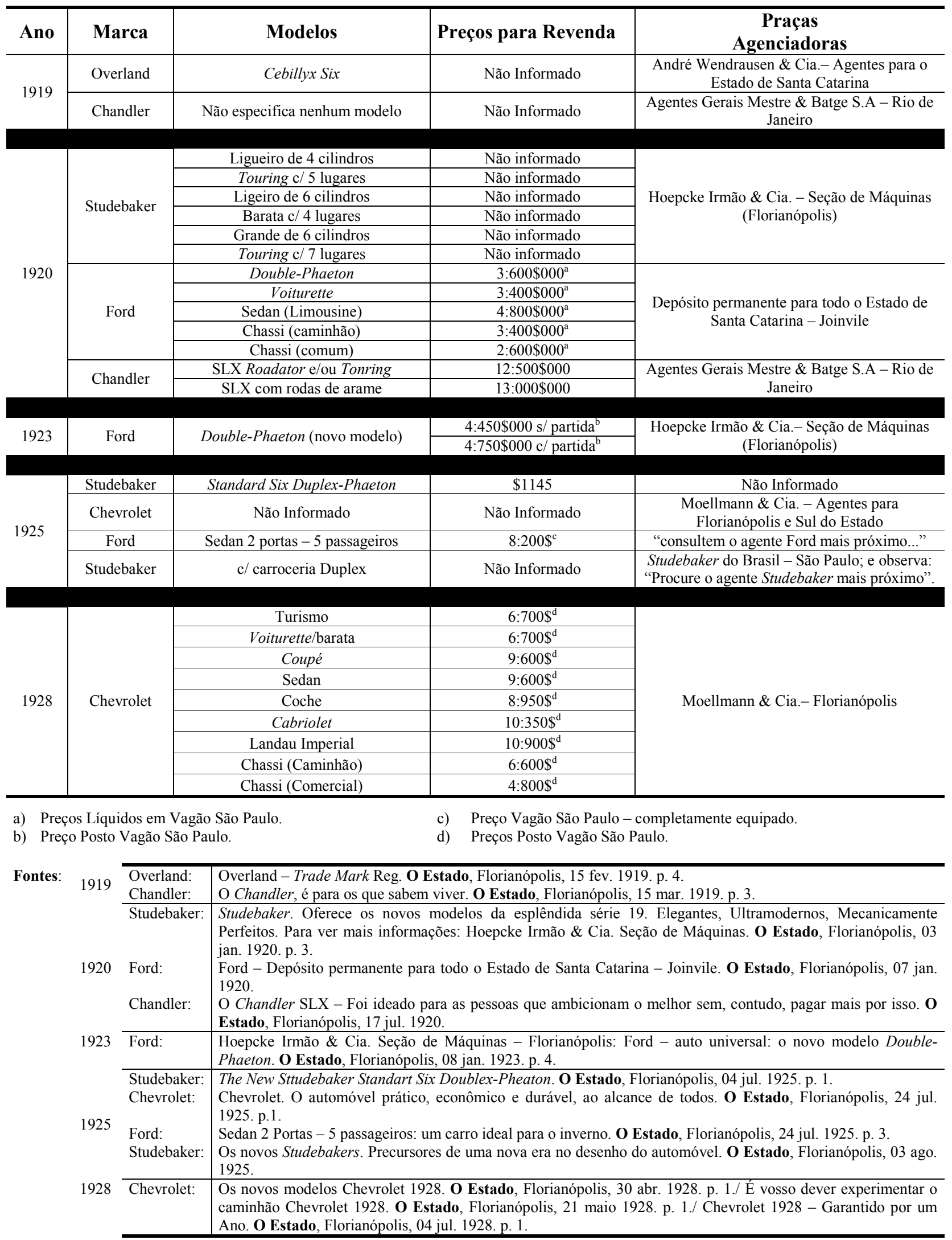




\title{
Banco de Dados:
}

Processos criminais envolvendo atropelamentos e colisões em Florianópolis (1923-1941)

\author{
Estado de Santa Catarina \\ Tribunal de Justiça do Estado de Santa Catarina \\ Arquivo Central - São José
}

Processos criminais envolvendo atropelamentos e colisões em Florianópolis (1923-1941)

\section{1) Primeira Vara Criminal - Estante 01}

\author{
A) Década de 20 \\ VENTURA, Hermínio Ramos. Processo n. 30, 05 mar. 1923. Caixa $03^{1267}$. \\ SOUZA, Braz de. Processo n. 45, 04 ago. 1923. Caixa 06. \\ VIEIRA, Antônio. Processo n. 29, 21 nov. 1923. Caixa 03. \\ VIEIRA, Adolfo Nazário. Processo n. 45, 13 abr. 1925. Caixa 05. \\ MULLER, Max. Processo n. 52, 05 nov. 1925. Caixa 05. \\ FURTADO, Euclydes. Processo n. 76, 21 mar. 1926. Caixa 07. \\ FEIJÓ, Agostinho da Silva. Processo n. 77, 25 mar. 1926. Caixa 07. \\ FÉDRIGO, João. Processo n. 62, 03 abr. 1926. Caixa 06. \\ SOUZA, Aniceto Machado de. Processo n. 95, 05 jul. 1926. Caixa 09. \\ RAGUSE, Ervino. Processo n. 73, 17 dez. 1926. Caixa 07. \\ DIAS, José Correia. Processo n. 96, 19 dez 1928. Caixa 02.
}

\section{B) Década de 30}

SOUZA, João Jesuíno de. Processo n. 173, 20 ago. 1931. Caixa 17.

JOHN, Oscar. Processo n. 171, 27 dez. 1931. Caixa 16.

FREITAS, José Arcênio. Processo n. 183, 11 jan. 1932. Caixa 19.

MOLENDA, Herbert. Processo n. 194, 21 nov. 1932. Caixa 20.

SILVA, Hélio Souza. Processo n. 239, 21 jan. 1934. Caixa 26.

SILVA, Átila. Processo n. 351, 09 ago. 1937. Caixa 38.

DUTRA, José Afonso. Processo n. 373, 23 jan. 1938. Caixa 41.

\footnotetext{
${ }^{1267}$ A ordenação dos processos aqui apresentada obedece à numeração dos mesmos. Esta foi organizada pelo Fórum Municipal da cidade de Florianópolis por ocasião da transferência da referida documentação para o Arquivo Central do Tribunal de Justiça do Estado, localizado no município de São José (BR - 101, km. 209 - Picadas do Sul - Forquilhinha).
} 


\section{Banco de Dados:}

\section{Processos criminais envolvendo atropelamentos e colisões em Florianópolis (1923-1941)}

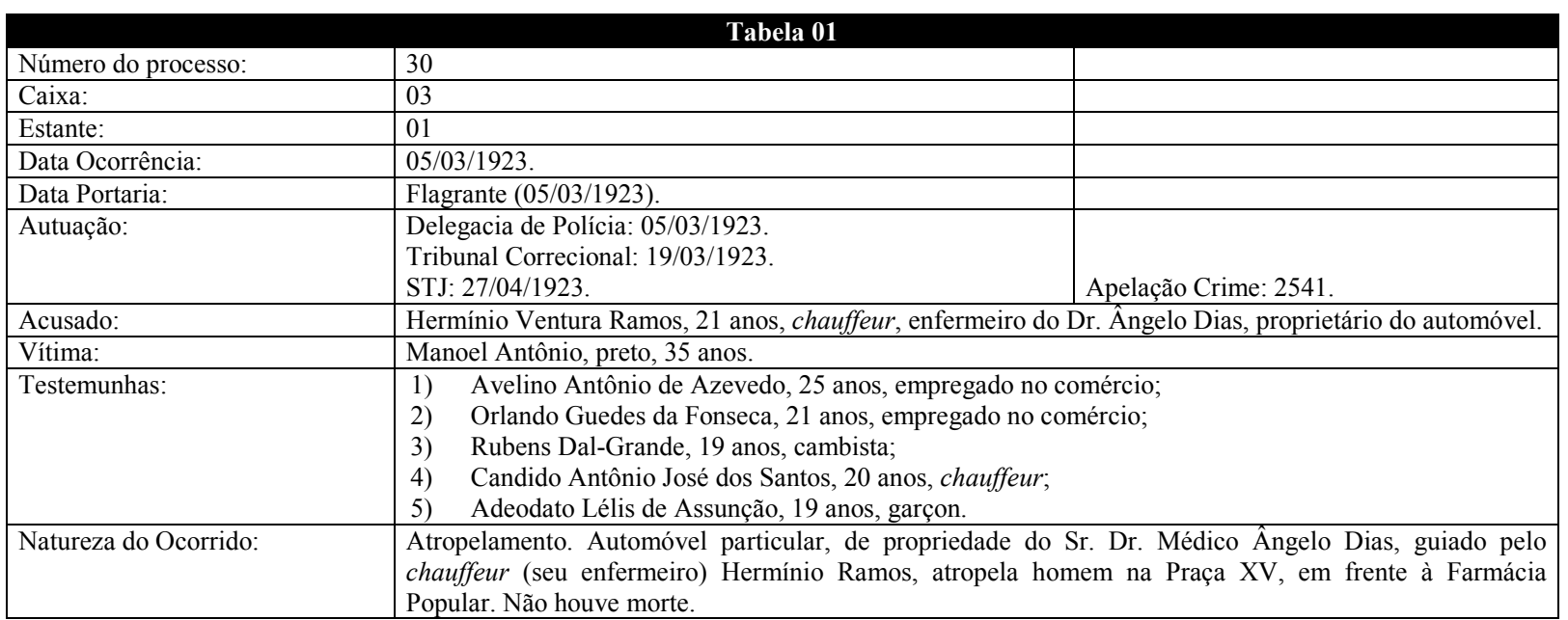

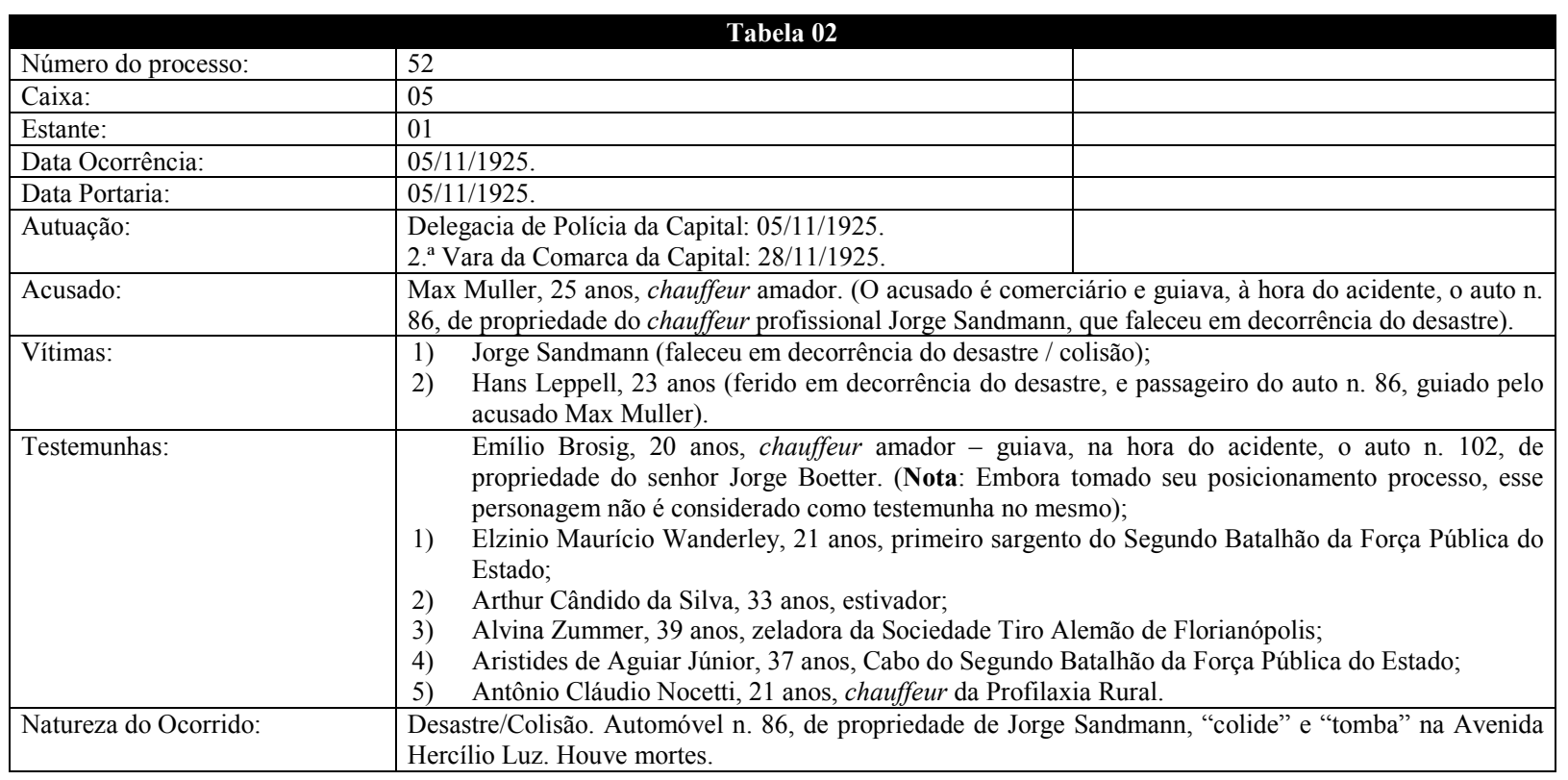




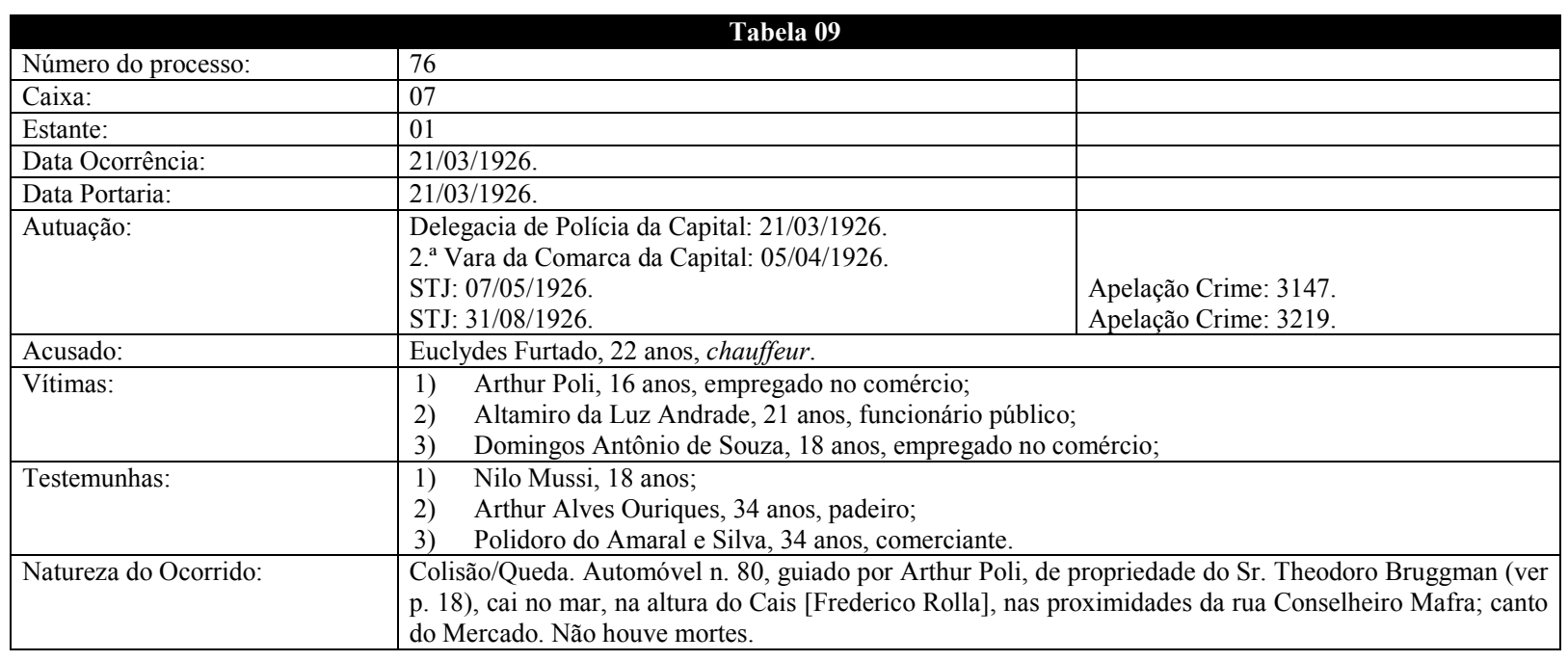

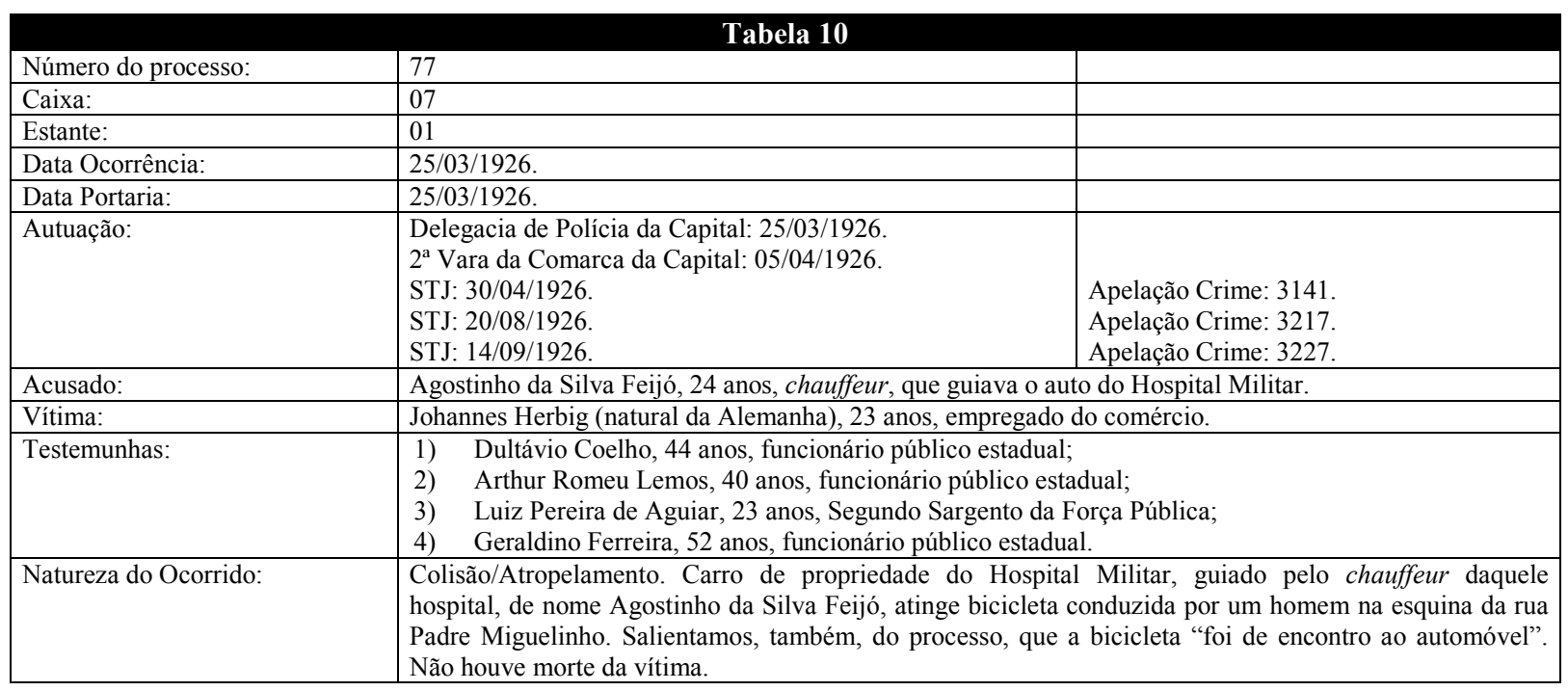

\begin{tabular}{|c|c|}
\hline Número do processo: & 62 \\
\hline Caixa: & 06 \\
\hline Estante: & 01 \\
\hline Data Ocorrência: & 03/04/1926. \\
\hline Data Portaria: & $03 / 04 / 1926$ \\
\hline Autuação: & $\begin{array}{l}\text { Delegacia de Polícia da Capital: 03/04/1926. } \\
\text { 2. }{ }^{\text {a }} \text { Vara Criminal da Comarca da Capital: 12/04/1926. }\end{array}$ \\
\hline Acusado: & João Fédrigo, 33 anos, mecânico. \\
\hline Vítima: & O menor Gentil Lemos, de nove anos de idade. \\
\hline Testemunhas: & $\begin{array}{l}\text { 1) Ladislau Opuska, } 28 \text { anos, boleeiro, proprietário de carro de praça; } \\
\text { 2) Joaquim Marcelino Coelho, } 43 \text { anos, Capitão Farmacêutico do Exército; } \\
\text { 3) Jesuino Coelho Pinto, } 41 \text { anos, empregado público; } \\
\text { 4) Antônio Augusto Schorcht, } 43 \text { anos, Oficial de Marinha; } \\
\text { 5) Odílio Pinto da Luz, } 22 \text { anos, Praça do } 14 .^{\circ} \text { Batalhão; } \\
\text { 6) Oscar Pinto da Luz, } 26 \text { anos, farmacêutico; } \\
\text { 7) José Meira, } 16 \text { anos, empregado no comércio. }\end{array}$ \\
\hline Natureza do Ocorrido: & $\begin{array}{l}\text { Atropelamento. Carro n. } 46 \text {, de propriedade do acusado, João Fédrigo, e por ele guiado, atropela, fere e } \\
\text { mata o menor Gentil Lemos, de nove anos de idade, na rua Esteves Júnior. O menor faleceu na } \\
\text { madrugada do dia } 04 \text { de abril de } 1926 \text {. }\end{array}$ \\
\hline
\end{tabular}




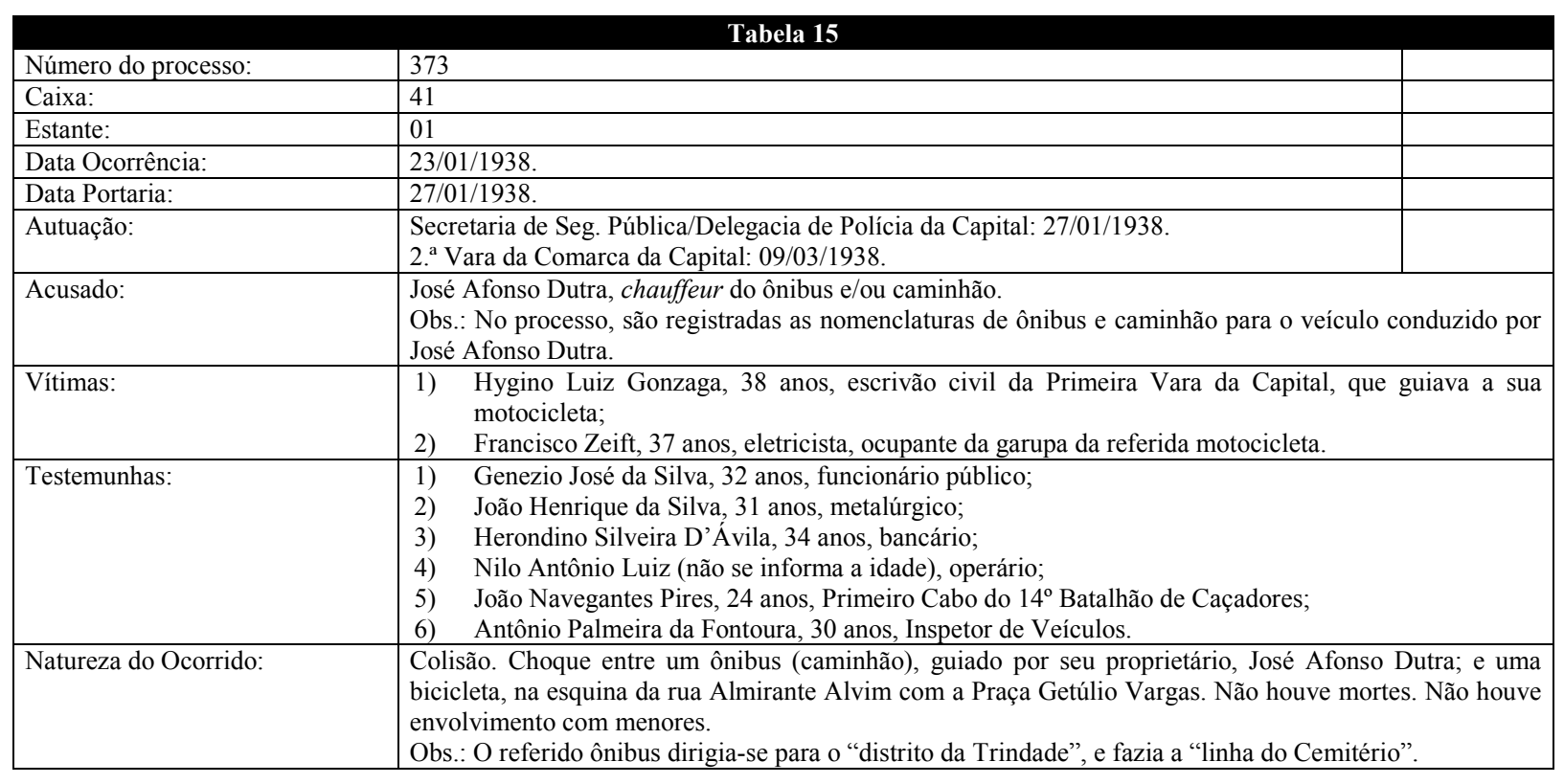

\begin{tabular}{|l|l|l|}
\hline \multicolumn{2}{|c|}{ Tabela 16 } \\
\hline Número do processo: & 73 & \\
\hline Caixa: & 07 & \\
\hline Estante: & 01 & \\
\hline Data Ocorrência: & $17 / 12 / 1926$. & \\
\hline Data Portaria: & $17 / 12 / 1926$. & \\
\hline Autuação: & Delegacia de Polícia da Capital: $17 / 12 / 1926$. \\
& $2 .{ }^{a}$ Vara da Comarca da Capital: 22/12/1926. & \\
\hline Acusado: & Ervino Raguse, 22 anos, chauffeur. \\
\hline Vítima: & Francelino Manoel da Costa, 44 anos, carroceiro da municipalidade. \\
\hline Testemunhas: & $1) \quad$ Pantaleão Aphanasio, 34 anos, negociante; \\
& 2) João Elyseu di Bernardi, 36 anos, negociante; \\
& $3) \quad$ João Farias dos Passos, 25 anos, trabalhador da municipalidade; \\
& 4) João di Bernardi, 34 anos, farmacêutico; irmão de João Elyseu di Bernardi. \\
\hline Natureza do Ocorrido: & $\begin{array}{l}\text { Atropelamento. Automóvel de praça, n. 166, guiado pelo chauffeur Ervino Raguse, atropela carroceiro da } \\
\text { municipalidade no princípio da rua Conselheiro Mafra. }\end{array}$ \\
\hline
\end{tabular}

\begin{tabular}{|l|l|l|}
\hline \multicolumn{2}{|c|}{ Tabela 17 } \\
\hline Número do processo: & 96 & \\
\hline Caixa: & 02 & \\
\hline Estante: & 01 & \\
\hline Data Ocorrência: & $19 / 12 / 1928$. & \\
\hline Data Portaria: & $19 / 12 / 1928$. & \\
\hline Autuação: & Delegacia de Polícia da Capital: 19/12/1928. \\
\hline Acusado: & José Correia Dias, 22 anos, chauffeur. & \\
\hline Vítima: & Romão Antônio Gonçalves, 67 anos, operário. \\
\hline Testemunhas: & $1) \quad$ Jorge Suint, 39 anos, funcionário público; \\
& $2) \quad$ Cyrillo Manoel Cunha, 19 anos, empregado no comércio; \\
& 3) Manoel Antônio Ferreira, 54 anos, empregado público federal. \\
\hline Natureza do Ocorrido: & $\begin{array}{l}\text { Atropelamento. Senhor de 67 anos é atropelado na esquina das ruas Trajano e Felipe Schmidt, pelo } \\
\text { automóvel n. 151, da cidade de Lages, guiado pelo chauffeur José Correia Dias. Não houve morte. }\end{array}$ \\
\hline
\end{tabular}

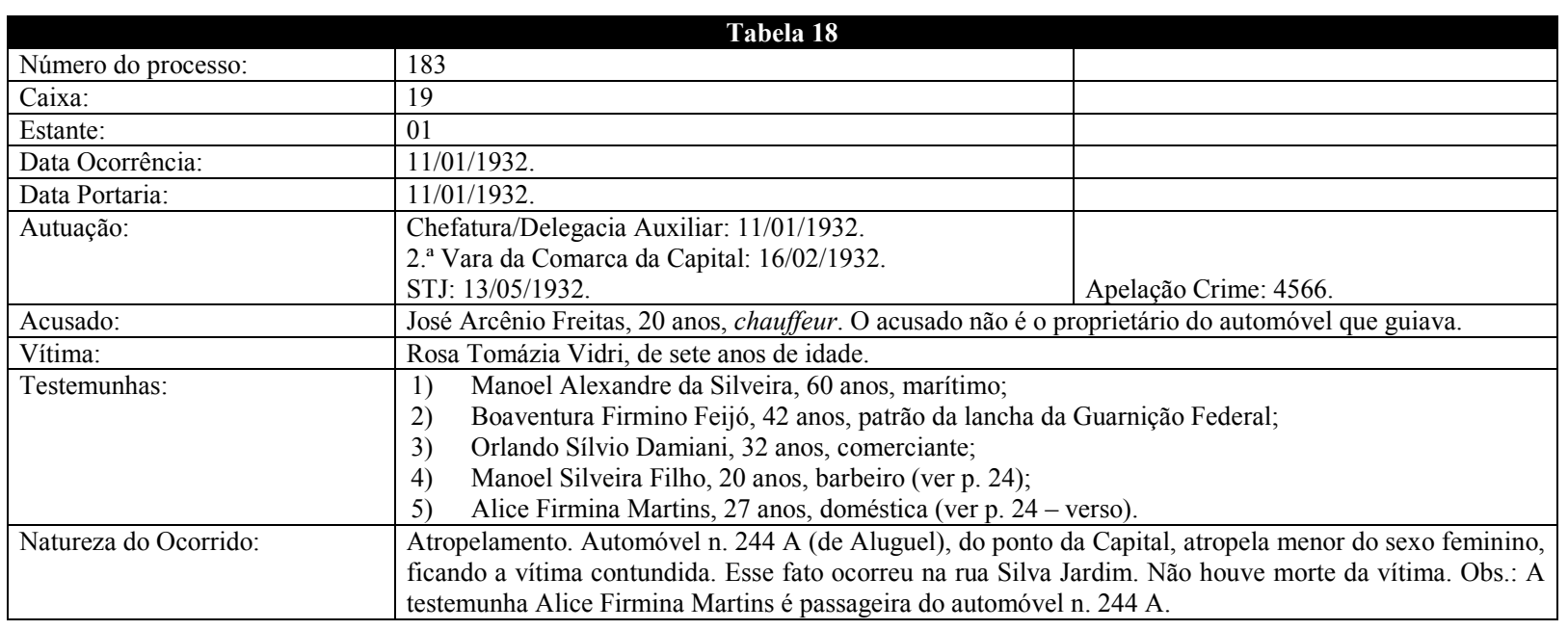




\section{Banco de Dados}

\section{Processos criminais envolvendo atropelamentos e colisões em Florianópolis (1923-1941)}

\begin{tabular}{|c|c|c|c|c|c|c|c|}
\hline Períodos & 茪 & 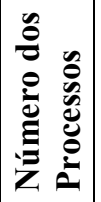 & $\stackrel{\varrho}{\gtrless}$ & Oِّ & 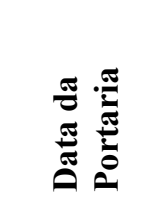 & 号 & 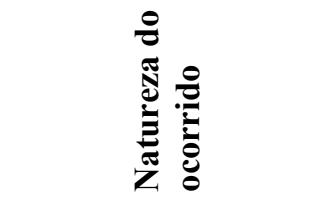 \\
\hline \multicolumn{8}{|c|}{ Década de 1920} \\
\hline & 01 & 30 & 1923 & $05 / 03 / 1923$ & Flagrante & $05 / 03 / 1923$ & Atropelamento \\
\hline & 01 & 45 & 1923 & $04 / 08 / 1923$ & $04 / 08 / 1923$ & $04 / 08 / 1923$ & Atropelamento \\
\hline & 01 & 29 & 1923 & $16 / 11 / 1923$ & $21 / 11 / 1923$ & $21 / 11 / 1923$ & Atropelamento \\
\hline & 01 & 45 & 1925 & 13/04/1925 & 13/04/1925 & 13/04/1925 & Atropelamento \\
\hline & 01 & 52 & 1925 & 05/11/1925 & $05 / 11 / 1925$ & $05 / 11 / 1925$ & Desastre/Colisão \\
\hline & 01 & 76 & 1926 & $21 / 03 / 1926$ & $21 / 03 / 1926$ & $21 / 03 / 1926$ & Colisão/Queda \\
\hline & 01 & 77 & 1926 & 25/03/1926 & $25 / 03 / 1926$ & $25 / 03 / 1926$ & Colisão/Atropelamento \\
\hline & 01 & 62 & 1926 & 03/04/1926 & $03 / 04 / 1926$ & 03/04/1926 & Atropelamento \\
\hline & 01 & 95 & 1926 & $05 / 07 / 1926$ & $05 / 07 / 1926$ & $05 / 07 / 1926$ & Colisão \\
\hline & 01 & 73 & 1926 & $17 / 12 / 1926$ & $17 / 12 / 1926$ & $17 / 12 / 1926$ & Atropelamento \\
\hline & 01 & 96 & 1928 & 19/12/1928 & $19 / 12 / 1928$ & $19 / 12 / 1928$ & Atropelamento \\
\hline \multicolumn{8}{|c|}{ Década de 1930} \\
\hline & 01 & 173 & 1931 & 19/08/1931 & $20 / 08 / 1931$ & $20 / 08 / 1931$ & Atropelamento \\
\hline & 01 & 171 & 1931 & $27 / 12 / 1931$ & $27 / 12 / 1931$ & $27 / 12 / 1931$ & Colisão \\
\hline & 01 & 183 & 1932 & 11/01/1932 & 11/01/1932 & 11/01/1932 & Atropelamento \\
\hline & 01 & 194 & 1932 & 21/11/1932 & 21/11/1932 & 21/11/1932 & Colisão/Atropelamento \\
\hline & 01 & 239 & 1934 & $21 / 01 / 1934$ & Flagrante & $21 / 01 / 1934$ & Atropelamento \\
\hline & 01 & 351 & 1937 & 08/08/1937 & $09 / 08 / 1937$ & 09/08/1937 & Atropelamento \\
\hline & 01 & 373 & 1938 & 23/01/1938 & 27/01/1938 & 27/01/1938 & Colisão \\
\hline Década de 1920: & \multicolumn{6}{|c|}{ Número total de processos envolvendo atropelamentos: } & 07 \\
\hline & \multicolumn{6}{|c|}{ Número total de processos envolvendo colisões: } & 02 \\
\hline & \multicolumn{6}{|c|}{ Número total de processos envolvendo queda c/ colisão: } & 01 \\
\hline & \multicolumn{6}{|c|}{ Número total de processos envolvendo colisão c/ atropelamentos: } & 01 \\
\hline & \multicolumn{6}{|c|}{ Número total de processos: } & 11 \\
\hline Década de 1930: & \multicolumn{6}{|c|}{ Numero total de processos envolvendo atropelamentos: } & 04 \\
\hline & \multicolumn{6}{|c|}{ Número total de processos envolvendo colisões: } & 02 \\
\hline & \multicolumn{6}{|c|}{ Número total de processos envolvendo queda c/ colisão: } & --- \\
\hline & \multicolumn{6}{|c|}{ Número total de processos envolvendo colisão c/ atropelamentos: } & 01 \\
\hline & \multicolumn{6}{|c|}{ Número total de processos: } & 07 \\
\hline & \multicolumn{6}{|c|}{ Totais } & \\
\hline & \multicolumn{6}{|c|}{ Número total de processos envolvendo atropelamentos: } & 11 \\
\hline & \multicolumn{6}{|c|}{ Número total de processos envolvendo colisões: } & 04 \\
\hline & \multicolumn{6}{|c|}{ Número total de processos envolvendo queda c/ colisão: } & 01 \\
\hline & \multicolumn{6}{|c|}{ Número total de processos envolvendo colisão c/ atropelamentos: } & 02 \\
\hline & \multicolumn{6}{|c|}{ Número Total de Processos: } & 18 \\
\hline
\end{tabular}




\section{Fontes e Bibliografia Utilizadas e Referenciadas na Tese}

\section{1) Bibliográficas}

\section{Bibliografia Geral}

ARAÚJO, Hermetes Reis de. O mercado, a floresta e a ciência do mundo industrial. In: (Org). Tecnologia e Cultura: ensaios sobre o tempo presente. São Paulo: Estação Liberdade, 1998. p. 65-90.

; Sant'Anna, Denise Bernuzzi de. Os motores da história: entrevista com Paul Virgílio (22 fev. 1994). In: (Org). Tecnologia e Cultura: ensaios sobre o tempo presente. São Paulo: Estação Liberdade, 1998. p. 127-147.

ARENDT, Hannah. A condição humana. 10 ed. Rio de Janeiro: Forense Universitária, 2004.

ASSIS, Joaquim Maria Machado de. A Semana (Crônica). In: Obra Completa. Rio de Janeiro. Nova Aguilar, v. III, 1994, n. 98-210. Disponível em: <www.cce.ufsc.br/ nupill/literatura/semana.html>.

BARREIRA, Irlys Alencar F. A cidade no fluxo do tempo: invenção do passado e patrimônio. Sociologias, Porto Alegre, n. 9 , jan./jun. 2003. Versão Impressa.

BAUDELAIRE, Charles. As flores do mal. São Paulo: Martin Claret, 2001. (Col. A Obra Prima de Cada Autor, n. 52).

BAUMAN, Zygmund. Identidade: entrevista a Benedetto Vecchi. Rio de Janeiro: Jorge Zahar, 2005.

Modernidade Líquida. Rio de Janeiro: Jorge Zahar, 2001.

BAUMAN, Zygmund. Modernidade e ambivalência. In: FEATHERSTONE, Mike (Coord.). Cultura global: nacionalismo, globalização e modernidade. Petrópolis: Vozes, 1994. p. 155-159.

O mal-estar da pós-modernidade. Rio de Janeiro: Jorge Zahar, 1998.

BENJAMIN, Walter. Paris: capital do século XIX. In: KOTHE, Flávio R. (Org.). Walter Benjamin: sociologia. 2. ed. São Paulo: Ática, 1991. p. 30-43. (Col. Grandes Cientistas Sociais, n. 50).

. A Paris do Segundo Império em Baudelaire. In: KOTHE, Flávio R. (Org.). Walter Benjamin: sociologia. 2. ed. São Paulo: Ática, 1991. p. 44-122. (Col. Grandes Cientistas Sociais, n. 50). Escolhidas).

Charles Baudelaire: um lírico no auge do capitalismo. 2. ${ }^{a}$ reimpressão. São Paulo: Brasiliense, 2000. v. 3. (Obras

Rua de mão única. 3. ${ }^{a}$ reimpressão. São Paulo: Brasiliense, 2000. v. 2. (Obras Escolhidas).

A Modernidade e os Modernos. Rio de Janeiro: Tempo Brasileiro, 1975.

Magia e técnica, arte e política: ensaios sobre literatura e história da cultura. 3. ed. São Paulo: Brasiliense, 1987. p. $\overline{21-49}$ e p. 222-232. (Obras Escolhidas, v. 1).

BENSA, Alban. Da micro-história a uma antropologia crítica. In: REVEL, Jacques. Jogos de Escalas: a experiência da microanálise. Rio de Janeiro: FGV, 1998. p. 39-76.

BIVAR, Antônio. James Dean: o moço da capa. São Paulo: Brasiliense, 2002. (Col. Encanto Radical, n. 38).

BOURDIEU, Pierre. Esboço de uma teoria da prática. In: ORTIZ, Renato (Org.). Pierre Bourdieu: sociologia. 2. ed. São Paulo: Ática, 1994. p. 46-81. (Col. Grandes Cientistas Sociais, n. 39).

A economia das trocas lingüísticas. In: ORTIZ, Renato (Org.). Pierre Bourdieu: sociologia. 2. ed. São Paulo: Ática, 1994. p. 156-183. (Col. Grandes Cientistas Sociais, n. 39).

BRESCIANNI, Maria Stella Martins. Imagens de São Paulo: Estética e Cidadania. In: Anais do IV Seminário de História da Cidade e do Urbanismo. Rio de Janeiro, v. 1, p. 465-474, nov. 1996.

Nas Ruas, os Caminhos da Cidade. In: Cadernos de História de São Paulo / A cidade e a rua. São Paulo, n. 2, p. 27-38, jan./dez. 1993.

Século XIX: A Elaboração de um Mito Literário. In: História: Questões \& Debates. Curitiba, p. 209-244, dez. 1986.

História e Historiografia das Cidades: um percurso. In: FREITAS, Marcos Cezar. (Org.). Historiografia brasileira em perspectiva. São Paulo: Contexto, 1998.

(Org.). Palavras da cidade. Porto Alegre: UFRGS, 2001.

A Cidade: objeto de estudo e experiência vivenciada. In: Revista Brasileira de Estudos Urbanos e Regionais. São Paulo: ANPUR, v. 6, n. 2, nov. 2004. p. 9-26. 
Cidade e História. In: OLIVEIRA, Lúcia Lippi (Org.). Cidade: história e desafios. Rio de Janeiro: FGV, 2002. p. 16-35.

BURKE, Peter. O que é história cultural? Rio de Janeiro: Jorge Zahar, 2005.

CALVINO, Ítalo. As cidades invisíveis. São Paulo: Companhias das Letras, 1990.

CAMPOS, Cândido Malta. Os Rumos da Cidade: Urbanismo e Modernização em São Paulo. São Paulo: Senac, 2002.

CARVAlHO, José Murilo de. A formação das almas: o imaginário da República no Brasil. São Paulo: Companhia das Letras, 1990.

CASTORIADIS, Cornélius. A Instituição Imaginária da Sociedade. Rio de Janeiro: Paz e Terra, 1982.

CERTEAU, Michel de. A invenção do cotidiano 1: artes de fazer. 8. ed. Petrópolis: Vozes, 2002.

CERTEAU, Michel de; GIARD, Luce; MAYOL, Pierre. A invenção do cotidiano 2: morar, cozinhar. 5. ed. Petrópolis: Vozes, 2003.

CERUTTI, Simona. Processo e experiência: indivíduos, grupos e identidades em Turim no século XVII. In: REVEL, Jacques. Jogos de Escalas: a experiência da microanálise. Rio de Janeiro: FGV, 1998. p. 173-201.

CHALHOUB, Sidney. Trabalho, lar e botequim: o cotidiano dos trabalhadores no Rio de Janeiro da belle époque. 2. ed. Campinas: Unicamp, 2001.

Machado de Assis Historiador. São Paulo: Companhia das Letras, 2003.

Cidade Febril: cortiços e epidemias na Corte Imperial. São Paulo: Companhia das Letras, 1996.

CHARTIER, Roger. O mundo como representação. Estudos Avançados, São Paulo: IEA/USP, v. 5, n. 11, 1991. p. $173-191$.

. À Beira da Falésia: a história entre incertezas e inquietudes. Porto Alegre: UFRGS, 2002.

CORREIA, Telma de Barros. Os Rumos da Cidade: Urbanismo e Modernização em São Paulo. Resenha. São Paulo: Senac, 2002. In: Revista Brasileira de Estudos Urbanos e Regionais. São Paulo: ANPUR, n. 5, maio 2002. p. 119-120.

EAGLETON, Terry. Depois da Teoria: um olhar sobre os Estudos Culturais e pós-modernismo. Rio de Janeiro: Civilização Brasileira, 2005. p. 13-66.

FAORO, Raimundo. Machado de Assis: a pirâmide e o trapézio. 4. ed. São Paulo: Globo, 2001.

FAUSTO, Boris. (Org.). História Geral da Civilização Brasileira. 9. ed. Rio de Janeiro: Bertrand Brasil, 2001. Tomo III: O Brasil Republicano. v. 3: Sociedade e Política (1930-1964).

(Org.). História Geral da Civilização Brasileira. 9. ed. Rio de Janeiro: Bertrand Brasil, 2001. Tomo III: O Brasil Republicano. v. 4: Economia e Cultura (1930-1964).

FÉLIX, Guattari \& ROLNIK, Suely. Micropolítica - Cartografias: Cartografias do Desejo. 3. ed. Rio de Janeiro: Vozes, 1993. p. 25-126.

FILHO, Dilermando Brito. Toxicologia Humana e Geral. 2. ed. Rio de Janeiro/São Paulo: Atheneu, 1988.

FORTES, José Roberto de Albuquerque. Alcoolismo: diagnóstico e tratamento. São Paulo: Sarvier, 1991.

FOUCAULT, Michel. Microfísica do Poder. 17 ed. Rio de Janeiro: Graal, 2002.

Vigiar e Punir: nascimento da prisão. 16 ed. Petrópolis: Vozes, 1987.

História da Sexualidade I: A vontade de saber. 12 ed. Rio de Janeiro: Graal, 1997.

Sexo, Poder e Indivíduo. Florianópolis: Nefelibata, 2003.

Ditos e Escritos: estratégia, poder-saber. 1 ed. Rio de Janeiro: Forense Universitária, 2003. v. 4.

Ditos e Escritos: ética, sexualidade, política. 1 ed. Rio de Janeiro: Forense Universitária, 2004. v. 5.

“Omnes et singulatim”: para uma crítica da razão política. In: Dits et Écrits 1954-1988. Paris: Gallimard, 1994. v. IV. P. 134-161. Trad.: Selvino José Assmann.

Entrevista com Michel Foucault. In:

Ditos e Escritos: Problematização do Sujeito: Psicologia, Psiquiatria e Psicanálise. Rio de Janeiro: Forense Universitária. v. 1. p. 300-312.

FRAGOSO, João \& FLORENTINO, Manolo. O arcaísmo como projeto. 4. ed. Rio de Janeiro: Civilização Brasileira, 2001.

FREUD, Sigmund. O Mal-Estar na Civilização. São Paulo: Abril Cultural. p. 131-194.

GARBER, Klaus; GAGNEBIN, Jeanne-Marie. Por que um mundo todo nos detalhes do cotidiano? In: ASCHER, Nelson. (Org). Dossiê Walter Benjamin. Revista USP. São Paulo: CCS/USP, n. 15, p. 38-47, set./nov. 1992.

GALIMBERTI, Umberto. Técnica e Natureza: a inversão de uma relação. In: Psiche e techne. L'uomo nell' età della técnica. 2. ed. Milano: Feltrinelli, 2003. (Parte VI, cap. 45. p. 474-487) 
GINZBURG, Carlo. O queijo e os vermes: o cotidiano e as idéias de um moleiro perseguido pela Inquisição. 3. ed. São Paulo: Companhia das Letras, 2003.

GONDRA, José G. Medicina, Higiene e Educação Escolar. In: LOPES, Eliane Marta Teixeira; FILHO, Luciano Mendes Faria; VEIGA, Cynthia Greive. (Org). 500 anos de educação no Brasil. 3. ed. Belo Horizonte: Autêntica, 2003.

GONÇALVES FILHO, José Moura. Memória e Sociedade. Memória e ação cultural. Revista do Arquivo Municipal. São Paulo: Departamento do Patrimônio Histórico Municipal, 1992. p. 5-63.

GORDINHO, Margarida Cintra. Transportes no Brasil: a opção rodoviária. São Paulo: Marca D’Água, 2003.

GORZ, André. A ideologia social do carro a motor. ComCiência: revista eletrônica de jornalismo científico - Transportes. São Paulo: SBPC/Labjor, n. 53, abr. 2004. Disponível em: < http://www.comciencia.br/200404/reportagens/02.shtml > .

HALL, Stuart. A identidade cultural na pós-modernidade. Rio de Janeiro: DP\&A, 2003.p. 07-97.

HART, Michael H. As 100 maiores personalidades da história. 8. ed. Rio de Janeiro: DIFEL, 2003.

HERSCHMANN, Micael M; PEREIRA, Carlos Alberto M. O imaginário moderno no Brasil. In: Brasil Moderno: medicina, educação e engenharia nos anos 20 e 30. Rio de Janeiro: Rocco, 1994. (Org.). A invenção do

HORKHEIMER, Max \& ADORNO, Th. W. Dialética do Esclarecimento. Rio de Janeiro: Jorge Zahar, 1985. p. 19-52.

HORKHEIMER, Max. Eclipse da razão. 5. ed. São Paulo: Centauro, 2002.

JÚNIOR, Durval Muniz de Albuquerque. História: a arte de inventar o passado: ensaios de teoria da História. Bauru: EDUSC, 2007.

LARINI, Lourival. Toxicologia. 3. ed. São Paulo: Manole, 1998.

LATOUR, Bruno. Jamais fomos modernos: ensaio de antropologia simétrica. Rio de Janeiro: Ed. 34, 1994.

; SCHARTZ, Cécile; CHARVOLIN, Florian. Crises dos meios ambientes: desafios às ciências humanas. In: ARAÚJO, Hermetes R. de. (Org). Tecnologia e Cultura: ensaios sobre o tempo presente. São Paulo: Estação Liberdade, 1998. p. 91-125.

Le Corbusier. Urbanismo. São Paulo: Martins Fontes, 1992.

Planejamento Urbano. 3. ed. São Paulo: Perspectiva, 1984. (Col. Debates, n. 37).

La Ciudad del Futuro. 2. ed. Buenos Aires: Infinito, 1971.

LE GOFF, Jacques. L'imaginaire médiéval. Paris: Gallimard, 1985.

Por amor às cidades: conversações com Jean Lebrun. São Paulo: UNESP, 1998.

LEVI, Giovanni. Sobre a micro-história. In: BURKE, Peter. (Org). A Escrita da História: novas perspectivas. São Paulo: UNESP, 1992. p. 133-161.

A herança imaterial: carreira de um exorcista no século XVII. Rio de Janeiro: Civilização Brasileira, 2000.

LIMA, Henrique Espada. A micro-história italiana: Escalas, Indícios e Singularidades. 1. ed. Rio de Janeiro: Civilização Brasileira, 2006.

. E. P. Thompson e a micro-história: trocas historiográficas na seara da história social. Esboços - Revista do Programa de Pós-Graduação em História da UFSC. Florianópolis: UFSC, n. 12, p. 53-74, 2004.

LOPES, Eliane Marta Teixeira; FILHO, Luciano Mendes Faria; VEIGA, Cynthia Greive. (Org.). 500 Anos de Educação do Brasil. 3. ed. Belo Horizonte: Autêntica, 2003.

LOPEZ, Antonio Herculano; VELloSO, Mônica Pimenta; PESAVENTO, Sandra J. (Org.). História e Linguagens: texto, imagem, oralidade e representações. Rio de Janeiro: Edições Casa Rui Barbosa/7Letras, 2006.

LOWI, Michael. Redenção e Utopia: o judaísmo libertário na Europa Central. São Paulo: Companhia das Letras, 1989.

Walter Benjamin: uma leitura das teses "Sobre o conceito de história". São Paulo: Boitempo, 2005.

MANFIO, Diléia. (Org.). Poesias Completas / Mário de Andrade. Belo Horizonte: Itatiaia, 2005.

MARICATO, Ermínia. Metrópole, legislação e desigualdade. Estudos Avançados, v. 17, n. 48, p. 151-166, 2003.

MARX, Murilo. Cidade Brasileira. São Paulo: Melhoramentos/USP, 1980.

MATOS, Olgária C. F. A Escola de Frankfurt: luzes e sombras do iluminismo. São Paulo: Moderna, 1993.

MORAES, José Geraldo Vinci de. Cidade e cultura urbana na Primeira República. São Paulo: Atual, 1994.

MOURA, Ana Maria da Silva. Cocheiros e Carroceiros: homens livres no Rio de senhores e escravos. São Paulo: Hucitec, 1988. (Col. Estudos Históricos).

NEVES, Margarida de Souza. História, memória e memorialística. Esboços - Revista do Programa de Pós-Graduação em História da UFSC. Florianópolis: UFSC, n. 11, p. 11-24, 2004. 
NIETZSCHE, Friedrich. Para a Genealogia da Moral (1887). In: LEBRUN, Gerard. (Org.). Friedrich Nietzsche - Obras Incompletas. São Paulo: Abril Cultural, 1978. p. 299-325. (Col. Os Pensadores).

PESAVENTO, Sandra Jatahy. O Imaginário da Cidade: visões literárias do urbano - Paris, Rio de Janeiro, Porto Alegre. Porto Alegre: UFRGS, 1999.

Em busca de uma outra história: imaginando o imaginário. Revista Brasileira de História. São Paulo:

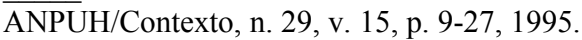

Muito além do espaço: por uma história cultural do urbano. Estudos Históricos - Cultura e História urbana. Rio de Janeiro, v. 8, n.16, p. 279-290, jul./dez. 1995.

A cidade como palimpsesto. Esboços - Revista do Programa de Pós-Graduação em História da UFSC. Florianópolis: UFSC, n. 11, p. 25-30, 2004.

História, memória e centralidade urbana. Novos Mundos - Mundos Novos. História Cultural no Brasil, n. 7, 2007.

Cidades visíveis; cidades sensíveis, cidades imaginárias. In: Revista Brasileira de História. São Paulo, v. 27, n. 53,

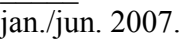

PIERANGELI, José Henrique. Códigos Penais do Brasil: evolução histórica. 2. ed. São Paulo: Revista dos Tribunais, 2004.

POE, Edgard Allan. O homem na multidão. Disponível em: http://www.alfredo-braga.pro.br/biblioteca/homemnamultidao.html.

RABINOW, Paul. Michel Foucault: Naturaleza Humana: Justicia versus poder. Disponível em: $<\underline{\text { http:/herejia.com.tripod.com/Naturaleza.htm }>}$

RAGO, Margareth. Do cabaré ao lar: a utopia da cidade disciplinar: Brasil 1890-1930. 3. ed. Rio de Janeiro: Paz \& Terra, 1997.

O efeito-Foucault na historiografia brasileira. Revista Tempo Social. São Paulo: USP, n. 7, p. 67-82, 1995.

REBELO, Fernanda; CAPONI, Sandra. O gabinete do doutor Edelvito Campelo D'Araújo: a Penitenciária Pedra Grande como espaço de construção de um saber (1933-1945). In: História; Ciências; Saúde-Manguinhos. Rio de Janeiro, v. 14, n. 4, out./dez. 2007. Disponível em: $<$ http://www.scielo.br/scielo.php?script=sci_arttext\&pid=S0104-59702007000400007>

REIS, Nestor Goulart. Imagens de Vilas e Cidades do Brasil Colonial. São Paulo: EDUSP/Imprensa Oficial do Estado/Fapesp, 2000. (Estande USP - Brasil 500 Anos).

REVEL, Jacques. Microanálise e construção do social. In: Janeiro: FGV, 1998. p. 15-38. Jogos de escalas: a experiência da microanálise. Rio de

. A História ao rés do chão (Prefácio). In: LEVI, Giovanni. A herança imaterial: carreira de um exorcista no século XVII. Rio de Janeiro: Civilização Brasileira, 2000. p. 7-37.

REZENDE, Maria José de. Teorias da mudança social: as mudanças lineares e as cíclicas. Revista de Ciências Humanas. Florianópolis: EDUSC, n. 32, p. 349-378, 2002.

RIO, João do. A Alma encantadora das ruas: crônicas. São Paulo: Companhia das Letras, 2008. ((Org.). Raúl Antelo).

Os melhores contos de João do Rio. São Paulo: Global, 1990. (Seleção de Helena Parente Cunha).

Rodovias são obras de grande impacto. ComCiência: revista eletrônica de jornalismo científico - Transportes. São Paulo: SBPC/Labjor, n. 53, abr. 2004. <Disponível em: http://www.comciencia.br/200404/reportagens/08.shtml>.

ROUANET, Sérgio Paulo e PEIXOTO, Nelson B. É a cidade que habita os homens ou são eles que moram nela? In: ASCHER, Nelson. (Org). Dossiê Walter Benjamin. Revista USP. São Paulo: CCS/USP, n. 15, p. 49-75, set./nov. 1992.

e WITTE, Bernd. Por que o moderno envelhece tão rápido? In: ASCHER, Nelson. (org). Dossiê Walter Benjamin. Revista USP. São Paulo: CCS/USP, n. 15, p. 102-117, set./nov. 1992.

SANTOS, Laymert Garcia dos. Tempo de Ensaio. São Paulo: Companhia das Letras, 1989.

SÁVIO, Marco Antônio Cornacioni. A Modernidade sobre Rodas. São Paulo: EDUC, 2002.

SCHPUN, Mônica Raisa. Luzes e sombras da cidade - São Paulo na obra de Mário de Andrade. In: Revista Brasileira de História, v. 23, n. 46, São Paulo, 2003. (Dossiê Experiências Urbanas).

SENNET, Richard. O declínio do homem público: as tiranias da intimidade. São Paulo: Companhia das Letras, 1998.

Carne e Pedra: o corpo e a cidade na civilização ocidental. 2. ed. Rio de Janeiro: Record, 2001.

SEVCENKO, Nicolau. A capital irradiante: técnica, ritmos e ritos do rio. In: (Org.). História da vida privada no Brasil - República: da Belle Èpoque à Era do Rádio. 5. ed. São Paulo: Companhia das Letras, 2002. p. 513-619.

Orfeu extático na metrópole: São Paulo, sociedade e cultura nos frementes anos 20. São Paulo: Companhia das Letras, 1992. 
Literatura como Missão: tensões sociais e criação cultural na Primeira República. 2. ed. São Paulo: Companhia das $\overline{\text { Letras, }} 2003$.

SILVA, Luis Octávio. História Urbana: uma área de conhecimento. Revista de Ciências Humanas. Florianópolis: EDUFSC, $\mathrm{n}$. 29, abr. 2001.

SKIDMORE, Thomas. Brasil: de Getúlio a Castelo (1930-1964). 12. ed. Rio de Janeiro: Paz e Terra, 2000.

THOMPSON, Edward Pawmer. Tempo, Disciplina de Trabalho e Capitalismo Industrial. In: Costumes em Comum. São Paulo: Companhia das Letras, 1998. p. 267-304.

. A Formação da Classe Operária Inglesa (Prefácio). Rio de Janeiro: Paz \& Terra, 1987.

VAINFAS, Ronaldo. Os protagonistas anônimos da história: micro-história. Rio de Janeiro: Campus, 2002.

VIEIRA, José Luiz. A história do automóvel: a evolução da mobilidade. São Paulo: Alaúde Editorial, 2008. (v. 1. da Préhistória a 1908).

VIEIRA, Priscila Piazentini. Michel Foucault e a História Genealógica em Vigiar e Punir. (Monografia). Campinas: IFCH/UNICAMP, 2006.

VEYNE, Paul. Foucault Revoluciona a História. In: Como se Escreve a História. Brasília: UNB, 1982.

WEBER, Max. A Ética Protestante o e Espírito do Capitalismo. 12. ed. São Paulo: Pioneira, 2001.

WILLIAMS, Raymond. O Campo e a Cidade: na história e na literatura. São Paulo: Companhia das Letras, 1989.

Bibliografia Específica

ARAÚJO, Hermetes Reis de. A invenção do litoral: Reformas urbanas e reajustamento social em Florianópolis na Primeira República. Dissertação (Mestrado em História). São Paulo: PUC, 1989

Fronteiras Internas: Urbanização e Saúde Pública em Florianópolis nos anos 20. In: BRANCHER, Ana (Org.). História de Santa Catarina: estudos contemporâneos. Florianópolis: Letras Contemporâneas, 1999.

CABRAL, Oswaldo Rodrigues. Nossa Senhora do Desterro: Notícia 1. Florianópolis: Lunardelli, 1990.

História de Santa Catarina. 4. ed. Florianópolis: Lunardelli, 1994.

CAMPOS, Cynthia Machado. A Política da Língua na Era Vargas: proibição de falar alemão e resistências no Sul do Brasil. Campinas: UNICAMP, 2006.

Santa Catarina, 1930: da degenerescência à regeneração. Florianópolis: EDUSC, 2008.

(Org.). Esboços - Revista do Programa de Pós-Graduação em História da UFSC. Florianópolis: UFSC, n. 11, 2004. (Dossiê Cidade e Memória).

CHEREM, Rosângela Miranda. Heterotopias de uma cidade chamada Desterro. Esboços - Revista do Programa de PósGraduação em História da UFSC. Florianópolis: UFSC, n. 11, p. 31-50, 2004.

CORADINI, Lisabete. Praça XV: Espaço e Sociabilidade. Florianópolis: Letras Contemporâneas, 1995.

COSTA, Sandro da Silveira. Ponte Hercílio Luz: mutações urbanas em uma cidade insular (1890-1960). Dissertação (Mestrado em História). Florianópolis: UFSC, 2002.

DIAS, Wilmar. Florianópolis, Ensaio de Geografia Urbana. Boletim Geográfico do Departamento Estadual de Geografia e Cartografia - DEGC, Florianópolis, ano 1, n. 1, jan. 1947.

Florianópolis, Ensaio de Geografia Urbana. Boletim Geográfico do Departamento Estadual de Geografia e Cartografia - DEGC, Florianópolis, ano 1, n. 2, jul. 1947.

FARIAS, Vilson Francisco de. São José: 250 anos: natureza, história e cultura. São José: ed. do autor, 1999.

FROTSCHER, Méri; VEDANA, Lea Maria Ferreira. Viagens pela Cidade: o transporte coletivo de Blumenau. Florianópolis: Insular, 1999.

MEIRINHO, Jali. República e Oliguarquias: subsídios para a história catarinense - 1889-1930. Florianópolis: Insular, 1997.

NECKEL, Roselane. A República em Santa Catarina: modernidade e exclusão (1889-1920). Florianópolis: UFSC, 2003.

. Tensões e Imagens do Viver Urbano em Florianópolis (1910-1930). Dissertação (Mestrado em História). São Paulo: PUC, 1993.

PAULI, Evaldo. Hercílio Luz: governador inconfundível. Florianópolis: IOESC/Governo do Estado de Santa Catarina, 1976.

PEDRO, Joana Maria. A Repercussão das Disputas Legislativas: a legislação sobre o aborto e a imprensa. In:

Práticas Proibidas: práticas costumeiras de aborto de infanticídio no século XIX. Florianópolis: Cidade Futura, $\overline{2003 .}$

(Org). 
PEDRO, Joana Maria; NECKEL, Roselane; HAWERROTH, Eliana Izabel; MACHADO, Vanderlei. Aborto e Infanticídio nos Códigos Penais e nos Processos Judiciais: a pedagogia de condutas femininas. In: PEDRO, Joana Maria. (Org). Práticas Proibidas: práticas costumeiras de aborto de infanticídio no século XIX. Florianópolis: Cidade Futura, 2003.

PELUSO JUNIOR, Victor Antônio. O crescimento de Florianópolis e suas repercussões no plano e na estrutura da cidade. In: Estudos de geografia urbana de Santa Catarina. Florianópolis: UFSC / Secretaria de Estado da Cultura e do Esporte, p. 311-354, 1983.

. Tradição e Plano Urbano. In:

Estudos de geografia urbana de Santa Catarina, Florianópolis: UFSC / Secretaria

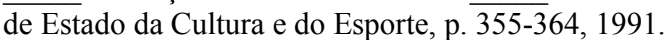

RAMOS, Átila Alcides. Memória do Saneamento Desterrense. Florianópolis: CASAN, 1986.

O Saneamento em Dois Tempos: Desterro e Florianópolis. Florianópolis: ARTGRAF, 1984.

SANTOS, Sílvio Coelho dos. (Org.). Santa Catarina no século XX: ensaios e memória fotográfica. Florianópolis: UFSC/UNIVALI/FCC, 2000.

SILVA, Adolfo Nicolich. Ruas de Florianópolis: resenha histórica. Florianópolis: Fundação Franklin Cascaes, 1999.

SUGAI, Maria Inês. As Intervenções Viárias e as Transformações do Espaço Urbano: A Via de Contorno Norte-Ilha. Dissertação (Mestrado em Arquitetura e Urbanismo) - Programa de Pós-Graduação da USP, São Paulo, 1994.

VÁRZEA, Virgílio. Santa Catarina: A Ilha. Florianópolis: Lunardelli, 1985.

VEIGA, Eliane. Transporte Coletivo em Florianópolis: origens e destino de uma cidade à beira-mar. Florianópolis: Insular, 2004.

VEIGA, Eliane Veras da. Florianópolis: memória urbana. Florianópolis: UFSC / Fundação Franklin Cascaes, 1993.

\section{2) Periódicas}

\section{Jornal O ESTADO - Biblioteca Pública de Santa Catarina (BIPESC)}

O caso dos conductores de vehiculos: A policia prende uma carroça da Empreza de Electricidade. O Estado. Florianópolis, 04 mar. 1920. p. 1 .

Registro de conductores de vehiculos. O Estado. Florianópolis, 18 mar. 1920. p. 1.

Bondes para o continente. O Estado. Florianópolis, 12 abr. 1920. p. 8

O contracto para Viação Electrica no Continente: As manifestações do jubilo popular. O Estado. Florianópolis, 20 maio 1920.

Regulamento para o transito de vehiculos. O Estado. Florianópolis, 25 maio 1920. p. 1.

Florianopolis vai ter 'auto omnibus'. O Estado. Florianopolis, 11 jun. 1920. p. 1.

Florianópolis vai ter 'autos-omnibus'. O Estado. Florianópolis, 8 jul. 1920. p. 6.

Um beijo... de vehiculos. O Estado. Florianópolis, 31 ago. 1920. p. 1.

Serviço de "auto-omnibus". O Estado. Florianópolis, 13 set. 1920. p. 6.

Empreza de Auto-Omnibus. O Estado. Florianópolis, 13 maio 1921. p. 11.

E' preciso acabar com os "matchs" nas ruas. O Estado. Florianópolis, 20 jul. 1921. p. 2.

Foi victima de um desastre. O Estado. Florianópolis, 29 jul. 1921. p. 5.

Encontro entre um bonde e um auto. O Estado. Florianópolis, 10 ago. 1921. p. 2.

O Brasil encommendou 50 auto-caminhões. O Estado. Florianópolis, 22 set. 1921. p. 2.

Um "chauffeur" punido. O Estado. Florianópolis, 26 nov. 1921. p. 3.

O anno de 1922 foi menos activo que o anno de 1920 para os fabricantes de automóveis. O Estado. Florianópolis, 18 mar. 1922.

p. 3 .

Já embarcaram os rodados para os bondes. O Estado. Florianópolis, 25 mar. 1922. p. 2.

Os bondes. O Estado. Florianópolis, 18 abr. 1922. p. 2.

Os automoveis vão uzar salva-vidas nos E. Unidos. O Estado. Florianópolis, 04 ago. 1922. p. 3.

Dos autos que se chocam. O Estado. Florianópolis, 16 dez. 1922. p. 2.

Nova linha de bonds. O Estado. Florianópolis, 05 mar. 1923. p. 2.

Um carro que se encontra com o auto n. 10. O Estado. Florianpolis, 04 ago. 1923. p. 2.

Auto-Omnibus. O Estado. Florianopolis, 21 ago. 1923. p. 3.

Os bondes. O Estado. Florianópolis, 26 mar. 1924. p. 3.

Dois Desastres: a morte de um estivador. O Estado. Florianópolis, 16 abr. 1924. p. 3.

Os bondes de Florianópolis. O Estado. Florianópolis, 10 jan. 1925. p. 5

Um bond supplicio. O Estado. Florianópolis, 09 set. 1925. s/p.

Desastre de automóvel: o carro 86 virou. O Estado. Florianópolis, 05 nov. 1925. p. 1.

O menor Gentil, atropelado por um auto, morre horas depois. O Estado. Florianópolis, 05 abr. 1926.

A inauguração official da Ponte Hercilio Luz. O Estado. Florianopolis, 13 maio 1926. p. 1.

Quatro carros de luxo para o serviço da Empresa Corsini. O Estado. Florianopolis, 21 maio 1926. p. 1.

Os novos carros da Empresa Auto-Viação Corsini. O Estado. Florianopolis, 22 maio 1926.

Empresa Catharinense de Auto-ominbus. O Estado. Florianopolis, 31 maio 1926.

Os autos, sempre os autos! O Estado. Florianópolis, 6 jul. 1926. p. 1.

O auto 166 atropelou, hontem, um lixeiro. O Estado. Florianópolis, 18 dez. 1926. p. 2.

Ruas em máu estado. O Estado. Florianopolis, 9 mar. 1927. p. 1.

Os trilhos 'mortos'. O Estado. Florianopolis, 14 mar. 1927. p. 2. 
Aviso. O Estado. Florianópolis, 15 jun. 1927.

Um novo meio de tracção para os bondes. O Estado. Florianópolis, 11 abr. 1928. p. 1.

Um omnibus contra um auto. O Estado. Florianópolis, 30 abr. 1928. p. 1.

Victima de um Omnibus. O Estado. Florianópolis, 30 abr. 1928. p. 2.

Nova Empresa de Auto-Omnibus. O Estado. 04 maio 1928.

O omnibus da "Estação Agronômica" perdeu a direcção. O Estado. Florianópolis, 04 jul. 1928.

Novo omnibus 'Circular'. O Estado. Florianopolis, 28 jul. 1928.

V.S. já notou que não sabe andar na rua?... O Estado. Florianópolis, 19 dez. 1928. p. 1.

Choque de Vehiculos. O Estado. Florianópolis, 11 jan. 1932. p. 6.

A baratinha 24 P. apanha dois menores. O Estado. Florianópolis, 22 nov. 1932. p. 5.

Um automóvel: atropela e fere u'a menina. O Estado. Florianópolis, 22 jan. 1934. p. 8.

Atropelados por um caminhão da Prefeitura. O Estado. Florianópolis, 01 fev. 1934. p. 6.

Um bonde destruido por populares. O Estado. Florianopolis, 26 set. 1934. p. 6.

Mais um desastre causado por Ônibus da Base de Aviação Naval. O Estado. Florianópolis, 07 jul.1937. p. 6.

Omnibus contra moto. O Estado. Florianópolis, 24 jun. 1938. p. 6.

Sindicato dos Condutores de Veículos de Florianópolis. O Estado. Florianópolis, 22 maio 1942. p. 4.

Capotou o Carro n. 1520. O Estado. Florianópolis, 30 mar. 1942. p. 6.

Chácara. O Estado. Florianópolis, 15 abr. 1942. p. 4.

Ônibus matou-o. O Estado. 27 abr. 1944. p. 8.

Morreu debaixo de um ônibus. O Estado. Florianópolis, 04 jun. 1945. p. 8.

Registro necessário. O Estado. Florianópolis, 13 nov. 1946. p. 8.

Inspetoria de Veículos. O Estado. Florianópolis, 24 dez. 1946. p. 2.

Com a Inspetoria de Veículos. O Estado. Florianópolis, 25 nov. 1949. p. 8.

Abandonou a Vítima que se Esvaia em Sangue! O Estado. Florianópolis, 24 jun. 1952. p. 8.

Atropelamento: Marido e Mulher, á rua João Pinto, feridos por um caminhão. O Estado. Florianópolis, 8 abr. 1953. p. 8.

Notas \& Comentários - sinaleiras coloridas. O Estado. Florianópolis, 27 jun. 1954. p. 1.

Doloroso desastre, ontem, às primeiras horas da noite à rua Felipe Schmidt. O Estado. Florianópolis, 15 jul. 1954. p. 12.

\section{Jornal REPUBLICA - Biblioteca Pública de Santa Catarina (BIPESC)}

O novo governo de Santa Catharina: posse do Exmo. Sr. Hercílio Luz. Republica. Florianópolis, 29 set. 1918. p. 1-2.

Victima de um auto. Republica. Florianópolis, 17 nov. 1923. p. 2.

Uma Penitenciária. República. Florianópolis, 07 out. 1926.

Diversas. Republica. Florianópolis, 17 dez. 1926. p.3.

Desastres de automóveis. Republica. Florianópolis, 1 maio 1928. p. 1-2.

Nosso Progresso Ferroviário. Republica. Florianópolis, 19 ago. 1931. p. 3.

O Auto Atropelou a Creança. Republica. Florianópolis, 27 dez. 1931. p. 4.

\section{Jornal A Gazeta - Biblioteca Pública de Santa Catarina - (BIPESC)}

Alargamento da rua 7 de Setembro. A Gazeta. Florianópolis, 18 jun. 1939. p. 1.

Carteiro Atropelado. A Gazeta. Florianópolis, 27 fev. 1941. p. 2.

Inspetoria de Veículos. A Gazeta. Florianópolis, 8 jan. 1942. p. 2.

O Brasil fabricará automóveis. A Gazeta. Florianópolis, 5 nov. 1946.

Atropelada por um automóvel. A Gazeta. Florianópolis, 03 jun. 1948. p. 7.

Morte pela Caminhonete quando retornava do baile. A Gazeta. Florianópolis, 24 jun. 1952.

RIBEIRO, Aôr. Malandro! A Gazeta. Florianópolis, 22 jul. 1952.

MELO, Osvaldo. Embelezemos a Capital. A Gazeta. Florianópolis, 25 nov. 1952. p. 2.

Problemas de Trânsito em Florianópolis. A Gazeta. Florianópolis, 26 mar. 1953. s/p.

\section{Jornal Diário da Tarde - Biblioteca Pública de Santa Catarina - (BIPESC)}

A representação da classe dos motoristas no Conselho Nacional de Trânsito. Diário da Tarde. Florianópolis, 6 jan.1942.

A nova sinalização do Tráfego. Diário da Tarde. Florianópolis, 7 jan. 1942. p. 4.

O racionamento da gasolina. Diário da Tarde. Florianópolis, 28 mar. 1942. p. 1.

Estimulando a produção do carvão na América do Sul. Diário da Tarde. Florianópolis, 11 abr, 1942. p. 2.

A redução de 10\% da gasolina. Diário da Tarde. Florianópolis, 20 abr. 1942. p. 1.

\section{Jornal O Dia - Biblioteca Pública de Santa Catarina - (BIPESC)}

O Bond n. 19. O Dia. Florianópolis, 14 jan. 1910. p. 1.

RAMOS, Vidal de Oliveira. MENSAGEM lida hoje pelo exmo. sr. coronel Vidal Ramos, digno Governador do Estado, por occasião da secção inaugural do Congresso Representativo do Estado. In: O Dia. Florianópolis, 23 jul. 1911. pp. 1-6.

Automovel. O Dia. Florianópolis, 11 jan. 1913. p. 2.

$\mathrm{Na}$ Pedra Grande: choque de um automóvel com um bond. O Dia. Florianópolis, 16 mar. 1913. p. 1.

Supplemento D' “O Dia”. Companhia Carris Urbanos e Suburbanos - Relatório apresentado á Assembléa Geral Ordinária, convocada para 9 de Outubro de 1915. In: O Dia. Florianópolis, 07 out. 1915. p. 5.

Imponente Recepção. O Dia. Florianópolis, 04 jun. 1918. p. 1. 
Jornal O Clarão - Biblioteca Pública de Santa Catarina - (BIPESC)

Apelar?!! Para quem?!!. O Clarão. Florianópolis, 29 nov. 1913.

Alerta Srs. Proprietários. O Clarão. Florianópolis, 07 jul. 1915.

Ilha dos casos raros. O Clarão. Florianópolis, 27 nov. 1915.

Jornal FOLHA NOVA - Biblioteca Pública de Santa Catarina - (BIPESC)

Os Cocheiros de Florianópolis defendem seu antigo posto de honra - Palestra com o cocheiro Pepino. Folha Nova. Florianópolis, 18 nov. 1926. p. 1.

Aos nossos melhores amigos - Gente do povo, de mãos calejadas e coração nobilíssimo. Folha Nova. Florianópolis, 17 nov. 1927. p. 3.

Jornal A SEMANA - Biblioteca Pública de Santa Catarina - (BIPESC)

Os Automoveis. A Semana. Florianopolis, n. 11, 24 jan. 1915. p. 2.

Jornal Folha de São Paulo - Biblioteca Particular do Autor

BIVAR, Antônio. A Invenção da Velocidade. Folha de São Paulo. São Paulo, 25 set. 2005. p. 4. (Caderno Mais!).

TERRON, Joça Reiners. Por Todos os Rumos. Folha de São Paulo. São Paulo, 25 set. 2005. p. 6. (Caderno Mais!).

Revista O Olho - Biblioteca Pública de Santa Catarina - (BIPESC)

O calçamento da nossa capital. O Olho. Florianopolis, 18 jun. 1916. p. 8.

D’Orlac. Habitos e Costumes. O Olho. Florianopolis, 2 jul. 1916. p. 7.

\section{Revista Veja}

BOSCOV, Isabela. O que fazer quando acabar: o mundo do século XX nasceu de uma união indissolúvel como o óleo. E ele terá de mudar no século XXI. Veja. São Paulo: Abril, n. 23, ano 37, 9 Jun. 2004. (Edição 1857).

\section{3) Documentação Oficial}

\section{A) Tribunal de Justiça do Estado de Santa Catarina - (T.J.) - Florianópolis}

\section{Leis; Códigos Penais \& Códigos de Trânsito Brasileiros}

Decreto n. 847, de 11 de outubro de 1890. Codigo Penal do Brazil - 1890. Rio de Janeiro, jan. 1905.

Lei n. 897, de 29 de agosto de 1911. Estabelece os prazos em que as leis e decretos do Governo, com força de lei, abrigam em todo o Estado. In: Santa Catarina. Colecção de Leis - 1910. Joinville: Typ. Boehm, 1910.

Decreto n. 17943A: consolida as leis de Assistência e Proteção aos Menores. Rio de Janeiro, 12 out. 1927. Disponível também em $<$ http://www.senado.gov.br $>$

MINEIRO, Beatriz Sofia. Código dos Menores dos Estados Unidos do Brasil Comentado. São Paulo: Companhia Editora Nacional, 1929.

Decreto-lei n. 2994, de 28 de janeiro de 1941. Código Nacional de Trânsito. In: Revista dos Tribunais. Rio de Janeiro, ano XXX, v. CXXX, fascículo 491, n. 130, p. 783-843, mar. 1941.

Decreto-lei 3651: dá nova redação ao Código Nacional de Trânsito. Rio de Janeiro, 25 de setembro de 1941. In: Revista Forense: mensário nacional de doutrina, jurisprudência e legislação. Rio de Janeiro, out. 1941. v. LXXXVIII, ano XXXVIII, fascículo 461, n. 88 .

Decreto-lei n. 4791: institui o cruzeiro como unidade monetária brasileira e dá outras providências. Rio de Janeiro, 05 de outubro de 1942. In: Revista Forense: mensário nacional de doutrina, jurisprudência e legislação. Rio de Janeiro, dez. 1942. v. XCI, ano XXXIX, fascículo 474, n. 92. p. 831. (Diário Oficial de 06 out. 1942).

Lei n. 5108: institui o Código Nacional de Trânsito ${ }^{1268}$. Brasília, 21 set. 1966. (Diário Oficial de 22 set. 1966).

Lei n. 9545: dispõe sobre a habilitação e exercício da atividade de condutor de veículos automotores. Rio de Janeiro, 05 ago. 1946. Diário Oficial de 07 ago. 1946. In: Revista Forense: mensário nacional de doutrina, jurisprudência e legislação. Rio de Janeiro, out. de 1946. v. CVIII, ano XLIII, fascículo 520, n. 108. p. 219. Disponível também em <http://www.senado.gov.br>

\section{Códigos Judiciários Estaduais}

Código Judiciário do Estado de Santa Catarina. Lei n. 1526, de 14 de novembro de 1925. Florianópolis: Oficinas à Eletricidade da Imprensa Oficial, 1925, 352 p.

Código Judiciário do Estado de Santa Catharina. Lei n. 1640, de 3 de novembro de 1928. Florianópolis: Imprensa Official, 1928.

B) Tribunal de Justiça do Estado de Santa Catarina - Arquivo Central - São José

Processos envolvendo atropelamentos e colisões na cidade de Florianópolis (1920-1938)

\section{A) Década de 20}

VENTURA, Hermínio RAMOS. Processo n. 30, 05 mar. 1923. Caixa 03.

\footnotetext{
${ }^{1268}$ Regulamentada pelo Decreto n. 62127, de 16 jan. 1968.
} 
SOUZA, Braz de. Processo n. 45, 04 ago. 1923. Caixa 06.

VIEIRA, Antônio. Processo n. 29, 21 nov. 1923. Caixa 03.

VIEIRA, Adolfo Nazário. Processo n. 45, 13 abr. 1925. Caixa 05.

MÜLLER, Max. Processo n. 52, 05 nov. 1925. Caixa 05.

FURTADO, Euclydes. Processo n. 76, 21 mar. 1926. Caixa 07.

FEIJÓ, Agostinho da Silva. Processo n. 77, 25 mar. 1926. Caixa 07.

FÉDRIGO, João. Processo n. 62, 03 abr. 1926. Caixa 06.

SOUZA, Aniceto Machado de. Processo n. 95, 05 jul. 1926. Caixa 09.

RAGUSE, Ervino. Processo n. 73, 17 dez. 1926. Caixa 07.

DIAS, José Correia. Processo n. 96, 19 dez 1928. Caixa 02.

\section{B) Década de 30}

SOUZA, João Jesuíno de. Processo n. 173, 20 ago. 1931. Caixa 17.

JOHN, Oscar. Processo n. 171, 27 dez. 1931. Caixa 16.

FREITAS, José Arcênio. Processo n. 183, 11 jan. 1932. Caixa 19.

MOLENDA, Herbert. Processo n. 194, 21 nov. 1932. Caixa 20.

SILVA, Hélio Souza. Processo n. 239, 21 jan. 1934. Caixa 26.

SILVA, Átila. Processo n. 351, 09 ago. 1937. Caixa 38.

DUTRA, José Afonso. Processo n. 373, 27 jan. 1938. Caixa 41.

\section{Documentos Diversos}

Decreto n. 2075. Aprova as instrucções para a Inspectoria de Vehiculos. Palácio do Governo. Florianópolis, 28 jun. 1927. Santa Catharina. Instrucções Regulamentares para o serviço de transito publico. Florianópolis: Imprensa Official, 1928.

\section{C) Arquivo Público Estadual de Santa Catarina (A.P.S.C.)}

\section{Relatórios; Regulamentos; Falas \& Código de Posturas}

COUTINHO, João José. Relatório Apresentado à Assembléa Provincial de Santa Catharina. Desterro, 19 abr. 1854.

ROCHA, Francisco José da. Relatório Apresentado à Assembléa Legislativa Provincial de Santa Catharina. Rio de Janeiro, 1888.

Camara Municipal da Cidade do Desterro. Código de Posturas. Lei n. 1238, de 22 out. 1888. Desterro: Typographia da Regeneração, 1889.

Santa Catharina. Código de Posturas Municipais de Florianópolis. Florianópolis: Typ. da República, 1896.

Santa Catharina. Relatório Apresentado ao Exmo. Sr. Coronel Vidal Jose' de Oliveira Ramos, digníssimo Governador do Estado pelo Desembargador Sílvio de Sa' Gonzaga, Chefe de Polícia, em 1 de Junho de 1911. Florianópolis: Gab. Typ. D’ O Dia, 1911.

Santa Catharina. Relatório Apresentado ao Exmo. Sr. Secretário Geral do Estado pelo Chefe de Polícia Ulysses Gerson Alves da Costa. Florianópolis, 14 maio de 1915.

Santa Catharina. Relatório apresentado ao Exmo. Sr. Dr. Governador do Estado, pelo Juiz de Direito Dr. Gil Costa, Chefe de Polícia do Estado. Florianópolis, 1919.

Santa Catharina. Regulamento para o serviço policial do Estado. Florianópolis: Typ. da Livraria Central, 1920.

Santa Catharina. Secretaria da Fazenda, Viação, Obras Públicas e Agricultura. Relatório Exercício 1919. Florianópolis, 1 maio 1920.

Santa Catharina. Relatório Apresentado ao Exmo. Sr. Dr. Joë Luiz M. Collaço, Secretário do Interior e Justiça pelo Desembargador Antero de Assis, Chefe de Polícia. Florianópolis, 1922.

Santa Catharina - Palácio do Governo em Florianópolis. Relatório da Directoria do Interior e Justiça referente ao exercício de 1926. Florianópolis, 1926.

Ponte Hercílio Luz. Relatório. Apresentado ao Governo do Estado de Santa Catharina pelos Engenheiros Oscar Machado da Costa e Mário de Faria Bello. Rio de Janeiro, 23 abr. 1926.

Santa Catharina. Relatório apresentado ao Ex. ${ }^{\mathrm{mo}} \mathrm{Sr}$. Dr. Adolpho Konder, Governador do Estado de Santa Catharina pelo Dr. Cid Campos, Secretário do Interior e Justiça em 24 de Agosto de 1927. Florianópolis: Of. Graph. da Escola de Aprendizes Artífices, 1927.

Directoria de Obras Publicas. Relatório de Atividades 1927. Florianópolis, 1927.

Directoria de Obras Publicas. Relatório de Atividades 1928. Florianópolis, 1928.

Santa Catharina. Relatório apresentado ao Exm. ${ }^{\circ}$ Sr. Dr. Adolpho Konder, Governador do Estado, pelo Dr. Cid Campos, Santa Catharina. Secretário do Interior e Justiça, em 24 de maio de 1928. Florianópolis: Typ. São José, 1928.

Santa Catarina. Secretaria do Interior e Justiça. Relatório apresentado ao Presidente do Estado de Santa Catharina, Exmo. Sr. Dr. Adolpho Konder, pelo Secretário do Interior e Justiça Dr. Cid Campos, anno de 1928. Florianópolis: Gab. Typ. Brasil, 1930. 
Santa Catharina. Relatório da Chefatura de Polícia Apresentado ao Exmo. Sr. Dr. Secretário do Interior e Justiça. Florianópolis, 1929.

BLUM, Heitor. Relatório do exercício de 1929. Apresentado ao snr. Prefeito Municipal, dr. José da Costa Moellmann. Florianópolis, 1935. (Cópia entregue em 9 de Agosto de 1935 ao Prefeito Municipal snr. Olivio J. de Amorim, por se haver extraviado o original entregue ao então Prefeito em 31 de Janeiro de 1931). Florianópolis: Imprensa Oficial do Estado, 1935.

Diretoria do Interior e Justiça. Relatório apresentado ao Secretário d'Estado dos Negócios do Interior e Justiça, Exmo. Sr. Dr. Manoel Pedro Silveira pelo Diretor do Interior e Justiça Sr. José Rodrigues Fernandes. Período 25 nov. 1930 a 29 out. 1931. Florianópolis, 1931.

Santa Catarina. Relatório apresentado ao Exmo. Sr. General Ptolomeu de Assis Brasil, Interventor Federal, pelo Dr. Manoel Pedro Silveira, Secretário d'Estado dos Negócios do Interior e Justiça. Florianópolis, nov. 1931.

BOTTINI, Antônio. Diretor de Higiene do Estado. Relatorio sobre a Febre Tifoide em Florianopolis. Apresentado ao Exm. ${ }^{\circ}$ SR Interventor Federal General Assis Brasil, jun. 1932.

MELLO, Renato Tavares da Cunha. Tem. Cel. Cmt. Geral da Fôrça Pública. Relatório da Fôrça Pública - ano de 1933. Apresentado ao Exmo. Sr. Dr. Secretário de Estado dos Negócios do Interior e Justiça. Florianópolis, set. 1934.

RAMOS, Mauro. Relatório. Apresentado ao Sr. Interventor Federal no Estado. Florianópolis, 1937. 1940.

Relatório da Prefeitura Municipal de Florianópolis. Apresentado ao Sr. Interventor Federal no Estado. Florianópolis,

Santa Catarina. Departamento Estadual de Estatística. Santa Catarina: vida econômica e ensino - aspectos. Florianópolis, 1948.

Santa Catarina. Secretaria da Segurança Pública. Relatório das Atividades desta Secretaria no ano de 1951. Apresentado ao Exmo. Sr. Governador Irineu Bornhausen, pelo Secretário da Segurança Pública, Dr. Luiz de Souza. Florianópolis, 29 fev. 1952. Santa Catarina. Secretaria da Segurança Pública. Relatório do Exercício de 1954. Apresentado ao Excelentíssimo Senhor Irineu Bornhausen, DD. Governador do Estado, pelo Snr. Desenbargador Dr. Nelson Nunes de Souza Guimarães, Secretário de Estado dos Negócios da Segurança Pública. Florianópolis, 24 mar. 1955.

Santa Catarina. Secretaria da Segurança Pública. Relatório das Atividades da Secretaria da Segurança Pública, durante o exercício de 1960. Florianópolis, mar. 1961.

\section{Mensagens}

OLIVEIRA, Antônio Pereira da Silva e. Superintendente Municipal. MENSAGEM dirigida ao Conselho Municipal em $1^{\circ}$ de abril. Florianópolis, Gazeta Oficial, 15 abr. 1905.

RICHARD, Gustavo. MENSAGEM lida na Sessão de Abertura do Congresso Representativo. Florianopolis, 5 ago. 1907. MENSAGEM lida na $2^{\text {a }}$ Sessão da $7^{\text {a }}$ Legislatura do Congresso Representativo. Florianópolis, 2 ago. 1908.

MENSAGEM lida na $1^{a}$ Sessão Ordinária da $\mathbf{8}^{\text {a }}$ Legislatura do Congresso Representativo. Florianópolis, 17 set. 1910.

RAMOS, Vidal de Oliveira. MENSAGEM apresentada ao Congresso Representativo do Estado. Florianópolis, 23 jul. 1911. MENSAGEM apresentada ao Congresso Representativo do Estado. Florianópolis, 24 jul. 1913.

$\overline{\mathrm{PINH}}$, João Guimarães. [Presidente do Congresso Representativo, no exercício do cargo de Governador]. MENSAGEM apresentada ao Congresso Representativo do Estado. Florianópolis: Gab. Typ. D’ O Dia, 29 jul. 1915.

LUZ, Hercílio Pedro da. Vice-Governador, no exercício do cargo de Governador do Estado de Santa Catharina. MENSAGEM apresentada ao Congresso Representativo do Estado. Florianópolis, 22 jul. 1920.

HORN, Raulino Julio Adolpho. Presidente do mesmo Congresso, no exercicio do cargo de Governador do Estado de Santa Catharina. MENSAGEM apresentada ao Congresso Representativo do Estado. Florianópolis, 16 ago. 1922.

OLIVEIRA, Antonio Pereira da Silva. Vice-Governador no exercicio do cargo de Governador do Estado de Santa Catharina. MENSAGEM apresentada ao Congresso Representativo do Estado. Florianópolis, 22 jul. 1924.

VIANNA, Antonio Vicente Bulcão. Presidente do mesmo Congresso, no exercício do cargo de Governador do Estado de Santa Catharina. MENSAGEM apresentada ao Congresso Representativo do Estado. Florianópolis, 22 jul. 1926.

Presidente do mesmo Congresso, no exercicio do cargo de Governador do Estado de Santa Catharina. MENSAGEM apresentada ao Congresso Representativo do Estado. Florianópolis, 21 ago. 1926.

KONDER, Adolpho. Governador do Estado de Santa Catharina. MENSAGEM apresentada ao Congresso Representativo do Estado. Florianópolis, 22 jul. 1927.

KONDER, Adolpho. Presidente do Estado de Santa Catharina. MENSAGEM apresentada á Assembléia Legislativa. Florianópolis, 29 jul. 1928.

RAMOS, Nereu. MENSAGEM apresentada á Assembléia Legislativa de Santa Catarina. Florianópolis, 16 jul. 1937.

SILVA, Aderbal Ramos da. Mensagem apresentada à Assembléia Legislativa. Florianópolis: Imprensa Oficial do Estado, 15 abr. 1948.

BORNHAUSEN, Irineu. Mensagem à Assembléia Legislativa: apresentada pelo Governador do Estado por ocasião da abertura da Sessão Legislativa de 1954. Florianópolis, 15 abr. 1954.

\section{Leis \& Resoluções}

Lei n. 137 de 22 de abril de 1840. Collecção de Leis, 1835-1840. Desterro, 1840.

Lei n. 1.238, de 22 out. 1888. Approva o Codigo de Posturas da Camara Municipal da Capital. In: Camara Municipal da Cidade do Desterro. Código de Posturas. Desterro, 1889.

Lei n. 1.084, de 4 de out. 1915. Orçando a Receita e fixando a Despesa do Estado para o exercício de 1916. In: Santa Catharina. Collecção de Leis, Decretos e Resoluções de 1915. Florianópolis: Imprensa Official, 1915. p. 66-116.

Lei n. 1.143, de 6 de outubro de 1916. Orça a Receita e fixa a despeza do Estado para o exercício de 1917. In: Collecção de Leis, Decretos e Resoluções de 1916. Florianópolis: Imprensa Official, 1916, pp. 81-109.

Lei n. 1524, de 7 de nov. 1925. Creando o pedágio para o trânsito na ponte 'Hercilio Luz'. Santa Catharina. Collecção de Leis, Decretos e Resoluções de 1925. Florianópolis, 1925. 
Lei n. 582, de 19 de abr. de 1927. Autorisando o Superintendente Municipal a regulamentar o transito de carros de bois na zona permittida. Santa Catharina - Município de Florianópolis. Colleç̧ão de Leis e Resoluções de 1927. Florianópolis, 1928.

Resolução n. 23. Santa Catarina - Município de Florianópolis. Coleção de Resoluções do ano de 1933. Florianópolis: Imprensa Oficial do Estado, 1935. p. 16-17.

Resolução n. 37. Santa Catarina - Município de Florianópolis. Coleção de Resoluções do ano de 1935. Florianópolis: Imprensa Oficial do Estado, 1935. p. 33-34.

Decreto-lei n. 54. Cria a Inspetoria de Veículos e Trânsito Público e dá outras providências. In: Santa Catarina. Coleção de Decretos-Leis de 1938. Florianópolis: Imprensa Oficial do Estado, 1939. p. 35-37.

Decreto-lei n. 261. Cria a Guarda de Trânsito da Capital do Estado e o cargo de sub-Inspetor Geral de Veículos e Trânsito Público. In: Santa Catarina. Coleção de Decretos-Leis de 1938. Florianópolis: Imprensa Oficial do Estado, 1939. p. 435-436. Esse decreto-lei é, igualmente, encontrado no seguinte documento: Decretos-Leis, nov./dez. 1938, s/p. (Decreto-Lei "Publicado em 28-12-1938”).

Decreto n. 271, de 27 jun. 1942. Raciona o uso do petróleo e seus derivados líquidos. In: Santa Catarina. Ofícios Recebidos da Secretaria de Segurança Pública. Florianópolis, 1942.

Lei 246, 15 nov. 1955. Diário Oficial. Estado de Santa Catarina. Ano III, n. 5.495, Florianópolis, 21 nov. 1955.

\section{Ofícios \& Portarias}

RIBEIRO, João Alberto Miranda. Ofícios Recebidos Pela Câmara do Governador João Alberto Miranda Ribeiro. Desterro, 26 jun. 1794.

THIAGO, Polydoro Olavo de São. (Eng. ${ }^{\text {ro }}$ ). Ofício. Encaminhado ao Presidente da Província João Rodrigues Chaves. Desterro, 3 nov. 1880.

Santa Catarina. Secretaria dos Negócios do Interior e Justiça. In: Ofícios Recebidos - Secretaria de Justiça, 1939/1940. p. 139.

Santa Catarina. Secretaria de Estado dos Negócios do Interior e Justiça. In: Ofícios à Secretaria de Segurança Pública. Florianópolis, 9 de agôsto de 1939. p. 198.

Portaria n. 37, de 18 abr. 1939. In: Circulares do ano de 1939, p. 91. (Circulares e Portarias da Secretaria de Estado dos Negócios da Segurança Pública encaminhados à Delegacia de Polícia de Florianópolis).

Santa Catarina. Secretaria da Segurança Pública. Ofício n. 1.083, expedido pela Inspetoria de Veículos e Trânsito Público ao Capitão Antônio de Lara Ribas, Responsável pelo Expediente da Secretaria de Segurança Pública. Florianópolis, 11 dez. 1941. p. 11.

Santa Catarina. Secretaria da Segurança Pública. Ofício n. 279, expedido pela Inspetoria de Veículos e Trânsito Público ao Capitão Antônio de Lara Ribas, Responsável pelo Expediente da Secretaria de Segurança Pública. Florianópolis, 27 abr. 1942. p. 144.

Santa Catarina. Secretaria da Segurança Pública. Ofício expedido pelo Inspetor Geral de Trânsito em Florianópolis, Raimundo Vieira, à Secretaria de Segurança Pública. Florianópolis, 27 maio 1942. p. 118-119.

\section{Códigos Municipais}

CUNHA, Osmar. (Prefeito Municipal). Código Municipal de Florianópolis. Florianópolis, 21 nov. $1955^{1269}$.

\section{Planos Diretores}

PAIVA, Edvaldo Pereira; RIBEIRO, Demétrio; GRAEFF, Edgar A. FLORIANÓPOLIS: Plano Diretor. Florianópolis: Imprensa Oficial do Estado do Rio Grande do Sul, 1952. (Administração do Prefeito Dr. Paulo de Tarso da Luz Fontes).

Guias \& Anuários ${ }^{1270}$

Guia do Estado de Santa Catharina. Rio de Janeiro, 5 set. 1927.

Guia do Estado de Sta. Catharina: Suplemento para o anno de 1937. Florianópolis: Livraria Central de Alberto Entres, 1937. Anuário Catarinense. Ano II, n. 2. Florianópolis, jan. 1949.

No 4. ${ }^{\circ}$ Aniversário do Governo Estadual: Damos, a seguir, a íntegra do importante discurso proferido pelo Exmo. Sr. Governador Irineu Bornhausen, do dia 31 de janeiro de 1955, no ensejo do transcurso do $4 .^{\circ}$ aniversário de sua profícua administração. In: Anuário Catarinense. Ano VIII, n. 8. Florianópolis, 1955. p.169-180.

\section{D) Arquivo Histórico da Prefeitura Municipal de Florianópolis (A .H .P .M .F)}

Câmara Municipal de Florianópolis. Projecto n. 4 (Redacção final). Concede à empresa que organizarem os cidadãos Eduardo Horn, José Bueno Villela, Emílio Blum e outros a permissão de uso, por espaço de 60 annos, de uma linha de bonds a tracção animal, a vapor ou electrica, para conducção de passageiros e cargas na Capital. Florianópolis, 20 fev. 1907. Caixa 03.

Câmara Municipal de Florianópolis. Redacção final do Projeto n. 21. Autoriza o Superintendente Municipal da Capital a abrir crédito para efetuctuação das obras para o assentamento de trilhos nas ruas compreendidas pela primeira linha da Companhia Carris Urbanos e Suburbanos de Florianópolis. Florianópolis, 9 nov. 1907. Caixa 03.

Câmara Municipal de Florianópolis. Série: Documentos, Ofícios, Projetos, Pareceres. Projeto n. 13. Concede à Sociedade organizada pelos Srs. Antonio Babitonga Linhares e Julio Nicolau de Moura o direito de uso e gozo, pelo espaço de cinco anos, do serviço de transporte por meio de 'auto-ônibus', dentro do perímetro urbano da Capital. Florianópolis, jul. 1920. Caixa 03 Comissão de Leis e Posturas. Emenda ao Projeto n. 13. Autoriza o estabelecimento da primeira linha de ônibus da cidade de Florianópolis e concede isenção de impostos à sociedade organizada para este fim pelo prazo de 03 anos. Florianópolis, 05 jul. 1920.

\footnotetext{
${ }^{1269}$ Esse documento é, igualmente, encontrado nas seguintes instituições: a) Arquivo Histórico da Prefeitura Municipal de Florianópolis; b) Câmara Municipal de Florianópolis.

${ }^{1270}$ Esses documentos estão, igualmente, disponíveis à consulta na Biblioteca Pública do Estado de Santa Catarina (BIPESC).
} 


\section{E) Biblioteca Pública do Estado de Santa Catarina (BIPESC)}

Lei n. 919, de 22 set. 1911. Organização Judiciária [do Estado de Santa Catarina]. In: Santa Catharina. Collecção de Leis do Estado de Santa Catharina Relativo ao Anno de 1911. Florianópolis: Officinas à Elect. da Imprensa Official, 1925. p. 85-199. Decreto n. 846, de 29 dez. 1914. Expedindo o Regulamento das estradas estadoais e respectivo imposto de transito. In: Leis, Decretos, Resoluções e Portarias de 1914. Florianópolis: Gab. Typ. d'O Dia, 1915. p. 86.

Regulamento das estradas estadoais e respectivo imposto de transito a que se refere o Decreto n. 846, de 29 dez. 1914. In: Leis, Decretos, Resoluções e Portarias de 1914. Florianópolis: Gab. Typ. d' O Dia, 1915. p. 187-210

Lei n. 1.180, de 4 out. 1917. Prorrogando por 5 annos, o prazo estabelecido pela Lei n. 761, de 1907, e estabelecendo favores ás Companhias Ferro Carris da Capital e Joinville. In: Leis, Decretos e Resoluções de 1917. Florianópolis: Gab. Typ. d' O Dia, 1918. p. 66-67.

Decreto n. 1.116, de 10 abr. 1918: approvando o regulamento para as estradas de rodagem estadoaes. In: Santa Catharina. Collecção de Leis, Decretos e Resoluções de 1918. Florianópolis: Imprensa Official, 1919. p. 161.

Regulamento para estradas estadoaes a que se refere o Decreto 1.116 d'esta data. In: O Dia. Florianópolis, 16 e 17 abr. 1918 . p. 2.

Decreto n. 1.285, de 27 set. 1919. In: Santa Catharina. Colleç̧ão de Leis, Decretos e Resoluções - Anno de 1919. Florianópolis: Officinas á Elect. da Imprensa Official, 1922. p. 71-77.

Lei n. 1.303, de 17 set. 1919. Autorizando o Poder Executivo a subvencionar a empreza de automóveis que se fundar para o serviço de transporte entre o Estreito e Lages. In: Collecção de Leis, Decretos e Resoluções - Anno de 1919. Florianópolis: Imprensa Official, 1922. p. 105.

Decreto n. 1.305, de 15 dez. 1919. Reorganizando o serviço policial do Estado e baixando regulamento para este fim. In: Collecção de Leis, Decretos e Resoluções - Anno de 1919. Florianópolis: Officinas à Elect. da Imprensa Official, 1922. p. 94. Lei n. 1.325, de 18 ago. 1920. Dispondo sobre o exame de habilitação para conductores de automóveis. In: Collecção de Leis, Decretos, Resoluções e Portarias de 1920. Florianópolis: Imprensa Official, 1920. p. 13-14.

Lei n. 1.340, de 20 ago. 1920. Concedendo isenção de imposto a prazo a empreza de auto-omnibus organizada por Julio Nicolau de Moura e Antonio B. Linhares. In: Collecção de Leis, Decretos, Resoluções e Portarias de 1920. Florianópolis: Imprensa Official, 1920. p. 34-35.

Lei n. 1.341, de 25 ago. 1920. Orça a receita e fixa a despesa para o exercício de 1921. In: Collecção de Leis, Decretos, Resoluções e Portarias de 1920. Florianópolis: Imprensa Official, 1920. p. 35-73.

Decreto n. 1.465A, de 17 maio 1921. Creando na Força Publica uma secção para serviços especiaes de automóveis. In: Collecção de Leis, Decretos e Resoluções de 1921. Florianópolis: Imprensa Official, 1921. p. 46.

Lei n. 1.381, de 21 set. 1921. Orçando a Receita e fixando a Despesa para o exercício de 1922. In: Collecção de Leis, Decretos e Resoluções de 1921. Florianópolis: Imprensa Official, 1921. p. 80.

Decreto n. 1.545, de 11 abr. 1922. Alterando o fardamento dos chauffeurs da Secção para serviços de automóveis annexa á Força Pública. In: Colleç̧ão de Leis, Decretos e Resoluções - 1922. Florianópolis: Imprensa Official, 1922. p. 68-69.

Lei n. 1.539, de 8 out. 1926. Creando a Inspectoria de Estradas de Rodagem e de Minas e dando outras providências. In: Collecção de Decretos, Resoluções e Portarias do Anno de 1926. Florianópolis: Imprensa Official, 1927. p. 16-20.

Lei n. 1.556, de 28 out. 1926. Abolindo os Impostos de Industria e profissão e de capital sobre os alugadores e os proprietários de carros e outros vehiculos e creando a taxa de Viação Terrestre. In: Collecção de Leis, Decretos, Resoluções e Portarias do Anno de 1926. Florianópolis: Imprensa Official, 1927. p. 50-52.

Lei n. 12, de 12 de novembro de 1935. Cria a Secretaria de Segurança Pública. In: Santa Catharina. Coleção de Leis, Decretos, Resoluções e Portarias de 1935. Florianópolis: Livraria Central de Alberto Entres, 1936. p. 13-14.

Lei n. 53, de 30 de dezembro de 1935. Fixa a Fôrça Pública para a atual legislatura. In: Santa Catharina. Coleção de Leis, Decretos, Resoluções e Portarias de 1935. Florianópolis: Livraria Central de Alberto Entres, 1936. p. 51-62.

Lei n. 72, de 20 de abril de 1936. Autoriza o Poder Executivo a baixar o Regulamento da Secretaria de Viação e Obras Públicas. In: Estado de Santa Catarina. Coleção de Leis de 1936. Florianópolis: Imprensa Oficial do Estado, 1936. p. 10-11.

Lei n. 84, de 14 de setembro de 1936. Cria o posto de major no quadro "A" da Fôrça Pública, estabelece gratificações para oficiais e sargentos, fixa vencimentos dos oficiais e praças da mesma corporação e dá outras providências. In: Coleção de Leis de 1936. Florianópolis: Imprensa Oficial do Estado, 1936. p. 21.

Lei n. 85, de 15 de setembro de 1936. Cria o serviço de cadastro das estradas de rodagem, obras de arte, etc. e os cargos de engenheiro-inspetor, auxiliar técnico e desenhista. In: Santa Catarina. Coleção de Leis de 1936. Florianópolis: Imprensa Oficial do Estado, 1936. p. 23-24.

Lei n. 105, de 22 de outubro de 1936. Cria a taxa de serviço de conservação e melhoria de estradas de rodagem estaduais e de serviços de registro e fiscalização de veículos. In: Coleção de Leis de 1936. Florianópolis: Imprensa Oficial do Estado, 1936. p. $68-73$.

Lei n. 123, de 10 de novembro de 1936. Estabelece o plano rodoviário do Estado. In: Coleção de Leis de 1936. Florianópolis: Imprensa Oficial. p. 92-93.

Decreto-lei n. 5. Altera a fixação da Fôrça Pública e dá outras providências. In: Santa Catarina. Decretos-Leis de 1937. Florianópolis: Imprensa Oficial. p. 56-57.

Decreto n. 7. Decretos da Secretaria da Viação e Obras Públicas, 1937. In: Coleção de Decretos, Resoluções e Portarias de 1937. Florianópolis: Imprensa Oficial do Estado, 1939. p. 301-304.

Decreto n. 8. Decretos da Secretaria de Viação e Obras Públicas, 1937. In: Coleção de Decretos, Resoluções e Portarias de 1937. Florianópolis: Imprensa Oficial do Estado, 1939. p. 304-312.

Decreto-lei n. 24, de 7 jan. 1938. Atribuindo à Secretaria de Segurança a orientação e fiscalização do trânsito nas vias públicas. In: Santa Catarina. Coleção de Decretos-Leis de 1938. Florianópolis: Imprensa Oficial do Estado, 1939. p. 6-10.

Decreto-lei n. 254, de 23 de dez. de 1938. Dispõe sobre as taxas a serem cobradas pelo emplacamento de veículos. In: Santa Catarina. Coleção de Decretos, Resoluções e Portarias de 1938. Florianópolis: Imprensa Ofic. do Estado, 1939. p. 428-429. Decreto-lei n. 343, de 6 de jun. de 1939. Dispõe sobre fiscais de estradas de rodagem. In: Santa Catarina. Coleção de DecretosLeis de 1939. Florianópolis: Imprensa Oficial do Estado, 1939. p. 110. 
Decreto-Lei n. 401, de 26 de dez. de 1939. Fixa a Fôrça Policial do Estado para o exercício financeiro de 1940. In: Santa Catarina. Coleção de Decretos-Leis de 1939. Florianópolis: Imprensa Oficial do Estado, 1939. p. 249.

Santa Catarina. Legislação Estadual. Decreto n. 14, 03 nov. 1939. In: Decretos-Leis, Decretos, Resoluções e Portarias. Janeiro a junho de 1940. Imprensa Oficial do Estado, jan. 1940. p. 74-79.

Decreto-Lei n. 462, de 12 de jul. de 1940. Dispõe sobre as regiões policiais. In: Santa Catarina. Coleção de Decretos-Leis, Decretos, Resoluções e Portarias, jan. 1940. p. 4.

Decreto-Lei n. 489, de 24 de out. de 1940. Dispõe sôbre emplacamento de veículos. In: Santa Catarina. Coleção de DecretosLeis, Decretos, Resoluções e Portarias, jun. 1940. p. 203-204.

Secretaria da Segurança Pública. Decreto n. 26. In: Santa Catarina. Coleção de Decretos-Leis, Decretos, Resoluções e Portarias, jan-jun. 1941. p. 98-99.

Secretaria da Segurança Pública. Decreto n. 271. In: Santa Catarina. Legislação Primeiro Semestre de 1942. Florianópolis: Imprensa Oficial do Estado, 1943. p. 130-133.

Decreto-Lei n. 1.320, de 17 de maio de 1945. Dispõe sobre emplacamento de veículos. In: Santa Catarina. Legislação Primeiro Semestre de 1945. Florianópolis: Imprensa Oficial do Estado, 1945. p. 43-44.

Decreto-Lei n. 217, de 12 de set. de 1946. Reorganiza a Diretoria de Estradas de Rodagem do Estado, nos moldes do Decreto-lei federal n. 8.463, de 27 de dezembro de 1945. In: Santa Catarina. Legislação 1946. Florianópolis: Imprensa Oficial do Estado, 1946. p. 70-76.

Decreto-Lei n. 300, 18 de nov. de 1946. Modifica e amplia o Plano Rodoviário Estadual, aprovado pelo Decreto n. 7, de 6 de janeiro de 1937. In: Santa Catarina. Legislação 1946. Florianópolis: Imprensa Oficial do Estado, 1946. p. 134-136.

Lei n. 802, de $1 .^{\circ}$ de dez. de 1952. Dispõe sobre as concessões dos serviços de transporte de passageiros em auto-ônibus, autolotação, jardineiras e outros veículos, em todo o Estado de Santa Catarina, em linhas intermunicipais. In: Santa Catarina. Legislação 1952. Florianópolis: Imprensa Oficial do Estado, 1952. p. 103-108.

Lei n. 1.365, de 4 de novembro de 1955. Aprova o Plano de Obras e Equipamentos e dá outras providências. In: Santa Catarina. Legislação 1955. Florianópolis: Imprensa Oficial do Estado, 1955. p. 55-58.

ROSA, Vieira da. Choreographia de Santa Catharina. Florianópolis: Typ. da Livraria Moderna, 1905. MIRA, Crispim. Terra Catharinense. Florianópolis: Typ. da Livraria Moderna, 1920.

\section{F) Biblioteca Universitária (BU) - Universidade Federal de Santa Catarina}

NETO, Alvarenga. Código Penal Brasileiro e [leis penais subseqüentes]. Rio de Janeiro: Leite Ribeiro, 1929. p. 207. (Col. Biblioteca Jurídica, v. 4).

Diretoria Geral de Estatística. Recenseamento do Brasil, v. IV, Rio de Janeiro, 1 set. 1920, 1926.

Grande Dicionário Enciclopédico Brasileiro Ilustrado. São Paulo: Novo Brasil. v. IV e V, 1979. (“Ortografia de acordo com as Instruções para a Organização do Vocabulário Ortográfico da Língua Nacional, aprovadas pela Academia Brasileira de Letras").

\section{G) Instituto Brasileiro de Geografia e Estatística (IBGE)}

Anuário Estatístico do Brasil, ano II, Rio de Janeiro, 1936. Anuário Estatístico do Brasil, ano III, Rio de Janeiro, 1937. Anuário Estatístico do Brasil, ano IV, Rio de Janeiro, 1938. Anuário Estatístico do Brasil, ano V, Rio de Janeiro, 1940. Anuário Estatístico do Brasil, ano VI, Rio de Janeiro, 1946. Anuário Estatístico do Brasil, ano VII, Rio de Janeiro, 1947. Anuário Estatístico do Brasil, ano XII, Rio de Janeiro, 1952. Anuário Estatístico do Brasil, ano XXI, Rio de Janeiro, 1960. Anuário Estatístico do Brasil, ano XXII, Rio de Janeiro, 1961. Anuário Estatístico do Brasil, v. 32. Rio de Janeiro, 1971. Anuário Estatístico do Brasil, v. 59. Rio de Janeiro, 1999. FERREIRA, Juradyr Pires (Org.). Enciclopédia dos Municípios Brasileiros. Rio de Janeiro, v. XXXII, 1959. IBGE/CNI (Confederação Nacional da Indústria). Séries Estatísticas Retrospectivas. Rio de Janeiro, 1986. Tomo 3 - Indústria de Transportes, Indústria Fabril. v. 2 - O Brasil, suas riquezas naturais, suas indústrias.

\section{H) Documentação On-line}

Decreto-Lei n. 3.689, 3 de outubro de 1941. Código de Processo Penal - 1941. Rio de Janeiro, 1941. Disponível em: <www.planalto.gov.br/ccivil 03/Decreto-Lei/Del3689.htm>.

Ato n. 146, de 26 fev. 1903. (Primeira Lei - Regulamenta o trânsito de automóveis na cidade de São Paulo)”. In: História do Detran. Disponível em: < www.detran.sp.gov.br/conheca/01 historia.asp $>$ ).

Código de Trânsito Brasileiro - CTB (Lei Federal 9.503, de 23 de setembro de 1997). Disponível em: <www.br.com.br/portalbr/calandra.nsf\#http://www.br.com.br/portalbr/calandra.nsf $>$.

\section{4) Encarte: São Paulo: 110 anos de industrialização}

GODOY, Roberto. (1937-1945). São Paulo: 110 anos de industrialização. São Paulo: Isto É Senhor/Banespa, 1990.

WERNECK, Humberto. (1955-1961). São Paulo: 110 anos de industrialização. São Paulo: Isto É Senhor/Banespa, 1990. 


\section{5) Entrevistas Orais}

AMANTE, Francisco Hegídio. Entrevista concedida a Sandro da Silveira Costa. (Impressa). Florianópolis, Santa Catarina, 11 maio 2001. Transcrita por Sandro da Silveira Costa. Biblioteca particular do autor.

CAMINHA, Paulo Ricardo. Entrevista concedida a Sandro da Silveira Costa. (Impressa). Florianópolis, Santa Catarina, 14 maio 2002. Transcrita por Sandro da Silveira Costa. Biblioteca particular do autor.

\section{6) Iconográficas}

\section{Banco de Imagens da Fundação Franklin Cascaes ${ }^{1271}$.}

1. Exemplo das lanchas motorizadas na passagem do Estreito entre a Ilha e o Continente, no primeiro quartel do século XX.

2. Construção da Avenida Hercílio Luz - 1922. (mesmo ângulo da foto anterior).

3. Rua Conselheiro Mafra - Esquina com rua Padre Roma - 1913.

4. Rua Felipe Schmidt - 1938.

5. Rua Trajano - c. 1935.

6. Rua Felipe Schmidt - 1940.

7. Rua Bocaiúva - 1912. Antiga Praia de Fora.

8. Rua Vidal Ramos - c. 1925.

9. Praça XV de Novembro - Início do século XX.

10. Rua Felipe Schmidt - depois de 1912. Abertura do trecho final, entre as ruas Padre Roma e Bento Gonçalves.

11. Ponte Hercílio Luz (concluída). Florianópolis - Santa Catarina.

\section{Arquivo Histórico da Prefeitura Municipal de Florianópolis 1272}

1. Foto Ilustrando o primeiro ônibus de Florianópolis no momento de sua inauguração - 1920 (parte frontal).

2. Foto Ilustrando o primeiro ônibus de Florianópolis no momento de sua inauguração - 1920 (parte lateral).

3. Foto Ilustrando o primeiro ônibus de Florianópolis no momento de sua inauguração - 1920 (parte traseira).

\section{Centro Administrativo do Estado de Santa Catarina - (Secretaria de Planejamento / Diretoria de Estatística e Cartografia).}

Mapa do Perímetro Urbano da Cidade de Florianópolis - 1940.

\section{Ilustrações Jornal O Estado - Biblioteca Pública de Santa Catarina - (BIPESC).}

1. Empresa de Automóveis - Lages/Florianópolis. O Estado, Florianópolis, 06 ago. 1918.

2. Overland - Trade Mark Reg. O Estado, Florianópolis, 15 fev. 1919. p. 4.

3. Viver, todos vivem! Quantos, porém, saberão viver? O Chandler, é para os que sabem viver. O Estado, Florianópolis, 15 mar. 1919. p. 3.

4. Studebaker. Offerece os novos modelos da esplendida série 19. Ellegantes, Ultramodernos, Mecanicamente perfeitos. Para ver mais informações: Hoepcke Irmão \& Cia. Secção de Machinas. O Estado, Florianópolis, 03 jan. 1920. p. 3.

5. Ford - Depósito permanente para todo o Estado de Santa Catharina - Joinville. O Estado, Florianópolis, 07 jan. 1920.

6. Ford: Terry \& Fullen: agentes geraes no Estado de Santa Catharina - Joinville. Sub-agentes no Sul do Estado, Hoepcke Irmão \& Cia. Secção de Machinas. O Estado, Florianópolis, 08 jul. 1920. p. 3.

7. Studebaker. Offerece os novos modelos da esplendida série 19. Ellegantes, Ultramodernos, Mecanicamente perfeitos. Para ver mais informações: Hoepcke Irmão \& Cia. Secção de Machinas. O Estado, Florianópolis, 08 jul. 1920. p. 5.

8. O Chandler SLX - Foi ideado para as pessoas que ambicionam o melhor sem, contudo, pagar mais por isso. O Estado, Florianópolis, 17 jul. 1920.

9. Hoepcke Irmão \& Cia. Seç̧ão de Machinas - Florianópolis: Ford - auto universal: o novo modelo Double-Phaeton. O Estado, Florianópolis, 08 jan. 1923. p. 4.

10. Caminhões Ford: eficiência, economia, rapidez. O Estado, Florianópolis, 03 jul. 1925. p. 2.

11. The New Sttudebaker Standart Six Doublex-Pheaton. O Estado, Florianópolis, 04 jul. 1925. p. 1.

12. Chevrolet. O automóvel prático, econômico e durável, ao alcance de todos. O Estado, Florianópolis, 24 jul. 1925. p. 1.

13. Sedan 2 Portas - 5 passageiros: um carro ideal para o inverno. O Estado, Florianópolis, 24 jul. 1925. p. 3.

14. Ford - Já estão à venda os novos modelos com rodas "balão". O Estado, Florianópolis, 05 ago. 1925.

15. Os novos Studebakers - Precursores de uma nova era no desenho do automóvel. O Estado, Florianópolis, 03 ago. 1925.

16. Grandes reduções nos preços dos carros Ford. O Estado, Florianópolis, 13 ago. 1925.

17. Os novos modelos Chevrolet 1928. O Estado, Florianópolis, 30 abr. 1928. p. 1.

18. E' vosso dever experimentar o caminhão Chevrolet 1928. O Estado, Florianópolis, 21 maio 1928. p. 1.

19. Chevrolet 1928 - Garantido por um Anno. O Estado, Florianópolis, 04 jul. 1928. p. 1.

20. Há uma história em cada gotta de TEXACO MOTOR OIL F. - Dourado e Transparente. O Estado, Florianópolis, 05 jun. 1930. p. 3.

\footnotetext{
${ }^{1271}$ O Banco de Imagens da Fundação Franklin Cascaes / Casa da Memória (Núcleo Audiovisual) está localizado na rua Padre Miguelinho, n. 58, Centro, Florianópolis. A aquisição de material fotográfico, nessa instituição, foi efetuada através de compra; condicionada à especificação do título e objetivos do presente estudo.

${ }^{1272}$ Em todas as ilustrações observamos o considerável número de pessoas presentes à solenidade de inauguração. Observamos, igualmente, bandeiras (provavelmente do Brasil e do Estado de Santa Catarina) e arranjos florais adornando o veículo.
} 
21. Não ha duvida: os motoristas preferem "Standard” Motor Oil. O Estado, Florianópolis, 13 jun. 1930. p. 3.

22. Os Pierre-Arrows Exemplificam a evolução do automóvel. O Estado, Florianópolis, 22 maio 1930. p. 1.

23. Ao público automobilista - Óleo lubrificante Swastika. O Estado, Florianópolis, 14 jan. 1935. p. 3.

24. ATLANTIC - Gazolina - lubrificação MOTOR OIL. O Estado, Florianópolis, 29 jan. 1938. p. 6.

25. ESTA LATA INVIOLÁVEL Essolube Offerece Três Vantagens. O Estado, Florianópolis, 06 abr. 1940. p. 3.

26. Essolube - ISTO é segurança para os automobilistas. O Estado, Florianópolis, 13 abr. 1940. p. 3.

27. Ford V-8 - O único caminhão com motor de 8 cilindros em V. O Estado, Florinópolis, 30 maio 1940. p. 4.

28. Goodyear - Indústria Brasileira. Distribuidores em Santa Catarina: Carlos Hoepcke S.A. O Estado, Florianópolis, 30 maio 1940.

29. Harmonia Esso... produzida por um motor bem cuidado. Esso Standard Oil Campany of Brazil. O Estado, Florianópolis, 26 jun. 1944. p. 5.

30. Quando o Brasil tinha apenas 3.000 automóveis... ou agora que tem mais de 500.000 veículos... Esso Standard Oil of Brazil. Há 40 anos participa do progresso do Brasil. O Estado, Florianópolis, 04 maio 1952. p. 5. 